\title{
Het dagblad onderscheidt zich : redactiestatuten voor dagbladen in Nederland en Duitsland
}

Citation for published version (APA):

Teeuwen, W. J. M. (1993). Het dagblad onderscheidt zich : redactiestatuten voor dagbladen in Nederland en Duitsland. [Doctoral Thesis, Maastricht University]. Rijksuniversiteit Limburg. https://doi.org/10.26481/dis.19931203wt

Document status and date:

Published: 01/01/1993

DOI:

10.26481/dis.19931203wt

Document Version:

Publisher's PDF, also known as Version of record

\section{Please check the document version of this publication:}

- A submitted manuscript is the version of the article upon submission and before peer-review. There can be important differences between the submitted version and the official published version of record.

People interested in the research are advised to contact the author for the final version of the publication, or visit the DOI to the publisher's website.

- The final author version and the galley proof are versions of the publication after peer review.

- The final published version features the final layout of the paper including the volume, issue and page numbers.

Link to publication

\footnotetext{
General rights rights.

- You may freely distribute the URL identifying the publication in the public portal. please follow below link for the End User Agreement:

www.umlib.nl/taverne-license

Take down policy

If you believe that this document breaches copyright please contact us at:

repository@maastrichtuniversity.nl

providing details and we will investigate your claim.
}

Copyright and moral rights for the publications made accessible in the public portal are retained by the authors and/or other copyright owners and it is a condition of accessing publications that users recognise and abide by the legal requirements associated with these

- Users may download and print one copy of any publication from the public portal for the purpose of private study or research.

- You may not further distribute the material or use it for any profit-making activity or commercial gain

If the publication is distributed under the terms of Article $25 \mathrm{fa}$ of the Dutch Copyright Act, indicated by the "Taverne" license above, 


\title{
HET DAGBLAD ONDERSCHEIDT ZICH
}

\author{
Redactiestatuten voor dagbladen in Nederland \\ en Duitsland
}

PROEFSCHRIFT

ter verkrijging van de graad van doctor aan de Rijksuniversiteit Limburg te Maastricht, op gezag van de Rector Magnificus, Prof. dr. H. Philipsen, volgens het besluit van het College van Dekanen, in het openbaar te verdedigen op vrijdag 3 december 1993 om 16.00 uur

door

Wilhelmus Josephus Maria Teeuwen 



\section{VOORWOORD}

Deze dissertatie over het redactiestatuut bij dagbladen heeft een lange voorgeschiedenis. Al sinds de beginjaren zeventig houd ik mij zeer intensief met het onderwerp bezig. Onder andere als afgevaardigde voor Brabant in de Verenigingsraad van de Nederlandse Vereniging van Journalisten (NVJ) maakte ik de moeizame totstandkoming van het Modelstatuut voor hoofdredactie en redactie mee en als lid van de (voorlopige) redactieraad was ik betrokken bij de opstelling van het statuut van Brabant Pers. In 1981 was "Het redactiestatuut en art. 7 van de Grondwet" onderwerp van een van mijn doctoraalscripties.

Dit proefschrift is daar slechts gedeeltelijk een vervolg op. Toen ik mijn doctoraalscriptie schreef was in het kader van het wetenschappelijke en politieke debat over het nieuwe grondrechtenhoofdstuk in de Grondwet het leerstuk van de horizontale werking ("derdenwerking") van grondrechten sterk in de belangstelling gekomen. In mijn scriptie probeerde ik het redactiestatuut in deze discussie te plaatsen. Achteraf moet geconstateerd worden dat de gedachte dat grondrechten in het algemeen - en dat van de uitingsvrijheid in het bijzonder - ook in de rechtsverhoudingen tussen burgers onderling (moeten) doorwerken niet op die wijze heeft doorgezet als indertijd verwacht mocht worden. Het leerstuk is te controversieel gebleken om het opnieuw als basis voor een grondrechtelijke benadering van het redactiestatuut te gebruiken.

In één opzicht is de lijn uit 1981 wel doorgetrokken: in dit proefschrift neemt de Duitse discussie over de interne verhouding tussen uitgever en (hoofd)redactie een belangrijke plaats in. In Duitsland was tot voor kort de "innere Pressefreiheit", zoals deze verhouding genoemd wordt eines der meistdebattierten Reformvorhaben im kommunikationsrechtlichen Bereich (Herbert Bettge in Zur Problematik von Grundrechtskollisionen).

Deze dissertatie is geschreven op basis van een langdurige journalistieke praktijk, maar buiten de universitaire ambiance en zonder de daarbijbehorende faciliteiten, welk laatste ongetwijfeld een handicap is. Dat werd echter ruimschoots gecompenseerd door de royale aandacht die ik mocht ontvangen van mijn promotor prof. mr. Erik Jurgens, die ondanks zijn overladen agenda steeds tijd gevonden heeft om "geraadpleegd te worden, aan te moedigen en te waarschwwen", om 
Bagehot's definitie van "royale" aandacht te lenen. Na elk van onze gesprekken het eerste was op de voor dit proefschrift historische dag dat de Perscombinatie en de Nederlandse Dagbladunie hun voorgenomen (maar niet geëffectueerde) fusie aankondigden - voelde ik me weer extra gestimuleerd om door te gaan. Erik, ik ben je heel dankbaar voor deze inspirerende sessies en voor de grote vrijheid die je me gelaten hebt bij opzet en uitwerking van dit proefschrift.

Vrijwel alle voorzitters van redactieraden van de dagbladen in ons land hebben mij hun redactiestatuten ter beschikking gesteld en mij later op de hoogte gebracht van eventuele wijzigingen. Bij dezen zeg ik hun dank voor hun medewerking. Ik ben ook dank verschuldigd aan het NVJ-bestuur en het Nederlands Genootschap van Hoofdredacteuren, die inzage verleenden in de archieven, en aan het altijd behulpzame personeel van de persbibliotheken van de Universiteit van Amsterdam en van de sectie "Publizistik" van de Ruhr Universität in Bochum, waar ik enkele weken gastvrijheid genoot.

Van alle collega's uit de journalistiek is er een die ik met bijzondere dankbaarheid gedenk: mijn vroegere hoofdredacteur wijlen Ton Brouwers. Hij heeft heel veel voor mij betekend. Het persrecht had zijn bijzondere belangstelling, vooral het Angelsaksische. Bovenal was hij een voortreffelijk journalist, die ook als hoofdredacteur uitstraalde dat hij altijd de teamsporter uit zijn jonge jaren gebleven is.

Een bijzonder woord van dank geldt uiteraard mijn fantastisch "Dreimädelhaus": Isabel, Rosalie en Claartje, jullie hebben je de afgelopen jaren veel van mijn aandacht en zelfs wan de zomervakanties moeten ontzeggen, maar jullie hebben daar nooit over geklaagd. Integendeel. Aan jullie is het boek opgedragen. 


\section{Inhoudsopgave}

\section{Hoofdstuk 1}

Inleiding, object van onderzoek en probleemstelling

1.1. Inleiding

1.2 Object van onderzoek

1.3 Probleemsstelling

1.4 Methode van onderzoek

\section{Hoofdstuk 2}

Redactionele medezeggenschap in Nederland:

het rapport van de Commissie-Van Blom

$2.1 \quad$ Inleiding 8

2.2 Nederlandse dagbladpers in de jaren 20

$2.3 \quad$ NJK: van vriendenkring tot belangenbehartiger 13

2.4 Rapport van de commissie-Van Blom $\quad 15$

2.4.1 Aanleiding 15

2.4.2 Resolutie van het NJK-bestuur 15

2.4.3 Enquête van de commissie-Van Blom 18

2.4.4 Conclusies en aanbevelingen van de $\quad 19$ commissie-Van Blom

2.4.5 Ontwerp voor een CAO van de commissie-Van Blom 22

2.4.6 Resultaten van het rapport van de commissie-Van Blom 25

$\begin{array}{lll}2.5 & \text { Samenvatting } & 28\end{array}$

\section{Hoofdstuk 3}

\section{"Innere Pressefreiheit" in Duitsland (1920-1933)}

3.1 Inleiding

3.2 Historisch overzicht

3.3 Artikel 118 van de Weimarer Verfassung 34

3.4 "Die öffentliche Aufgabe der Presse"

$3.5 \quad$ "Innere Pressefreiheit" 36

3.6 Concrete voorstellen $1920-1933 \quad 37$

3.6.1 De "Reichstarifentwurf" van de RDP uit 1920 
3.6.2 De "Reichsarbeitsgemeinschaft" 40

3.6.3 De drie ontwerpen uit 1924

3.6.4 De "Tarifvertrag" uit 1926 als compromis 45

3.6.5 Naar de "Schriftleitergesetz" van 1933

3.7 Samenvatting 49

\section{Hoofdstuk 4}

Van CAO tot modelstatuut voor hoofdredactie en redactie

4.1 Het ontwerp Wet op de journalistieke

42 verantwoordelijkheid 51

4.3 Verhouding (hoofd)redactie-directie in latere CAO's 56

4.4 CAO en persconcentratie $\quad 57$

4.5 De opvattingen van Rooij 58

4.6 "Paper" van de Sectie Hoofdredacteuren 60

4.7 Naar een Statuut voor de Hoofdredactie 62

4.8 Naar een modelstatuut voor hoofdredactie en redactie 65

4.8.1 Rapport van de Studiecommissie Dagbladconcentraties

4.8.2 Discussie binnen de NVJ 69

4.8.3 Akkoord over het Modelstatuut $\quad 70$

4.9 Redactiestatuut en Ondernemingsraad 72

4.9.1 Art. 5.4.1 van het Modelstatuut 72

4.9.2 Poging tot herformulering relatie OR-redactieraad 74

$\begin{array}{lll}4.9 .3 & \text { De opvatting van Schuijt } & 75\end{array}$

4.9.4 De opvatting van Rooij $\quad 77$

4.10 De verhouding hoofdredactie - redactie 79

4.10.1 "Verlengstuk van die feodale directies" 79

4.10.2 Het Genootschap van Hoofdredacteuren 81

4.11 Samenvatting 84

\section{Hoofdstuk 5}

Het Modelstatuut voor hoofdredactie en redactie

5.1 Hoofdlijnen van het Modelstatuut 86

$\begin{array}{lll}5.2 & \text { De inspraakmodaliteiten } & 87\end{array}$

5.3 Artikelsgewijze behandeling $\quad 88$

5.3.1 Considerans $\quad 89$

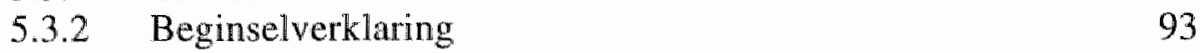

$\begin{array}{lll}5.3 .3 & \text { De organen } & 98\end{array}$ 
5.3.4 Benoeming/verkiezing en werkwijze organen

$\begin{array}{ll}\text { 5.3.4.1 Benoeming van de hoofdredactie } & 103\end{array}$

$\begin{array}{ll}\text { 5.3.4.2 Redactievergadering } & 104\end{array}$

$\begin{array}{lll}\text { 5.3.4.3 Redactieraad } & 106\end{array}$

$\begin{array}{ll}\text { 5.3.5 Bevoegdheden van de organen } & 108\end{array}$

$\begin{array}{ll}\text { 5.3.5.1 Hoofdredactie } & 108\end{array}$

5.3.5.2 Redactievergadering $\quad 112$

5.3.5.3 De redactieraad 113

$\begin{array}{lll}\text { 5.3.5.4 Verhouding tot ondernemingsraad } & \\ \text { en redactiecommissie } & 114\end{array}$

$\begin{array}{lll}5.3 .6 & \text { Personeelsbeleid } & 115\end{array}$

5.3.7 Persoonlijke verantwoordelijkheid 116

$\begin{array}{lll}5.3 .8 & \text { Redactiebudget } & 119\end{array}$

$\begin{array}{ll}\text { 5.3.9 Structuurwijzigingen } & 119\end{array}$

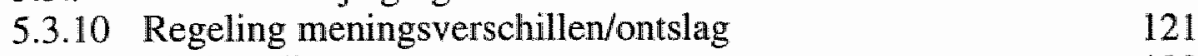

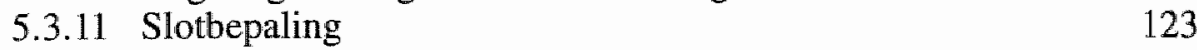

$\begin{array}{lll}5.4 & \text { Samenvatting } & 123\end{array}$

\section{Hoofdstuk 6}

\section{De naoorlogse Duitse ontwikkeling}

6.1 Inleiding

6.2 "Innere Pressefreiheit" in grondrechtelijk perspectief 125

6.2.1 Persvrijheid: institutioneel of "Jedermann-Recht"? 127

6.2.2 "Die öffentlliche Aufgabe der Presse" 130

6.3 "Pressefreiheit" en "Verlegerfreiheit" 132

6.3.1 De opvattingen van Mallmann 132

6.3.2 De opvattingen van Hoffmann-Riem 133

6.4 Medezeggenschap en

$\S 118$ Betriebsverfassungsgesetz (BetrVG) 135

6.4.1 Redactiestatuut via Tarifvertrag

6.4.2 Statuten tussen redacties en dagbladuitgevers 141

6.5 Zes Duitse dagbladstatuten 143

$\begin{array}{lll}6.5 .1 & \text { Rhein-Zeitung } & 143\end{array}$

$\begin{array}{lll}\text { 6.5.2 Saarbrücker Zeitung } & 144\end{array}$

$\begin{array}{lll}\text { 6.5.3 Süddeutsche Zeitung } & 147\end{array}$

6.5.4 Abendzeitung (München) 149

6.5.5 Mannheimer Morgen $\quad 152$

6.5.6 Südwest Presse Ulm 153

6.7 Het ontwerp uit 1974 voor een nieuwe perswet 155

6.7.1 De voorgeschiedenis $\quad 155$

6.7.2 De "Begründung" van het PRRG-ontwerp 157

6.7.3 Hoofdlijnen van het ontwerp-PRRG van 25 juli 1974 


\section{Hoofdstuk 7}

\section{Nederlandse redactiestatuten}

7.1 Inleiding

7.2 "Model" of minimumregeling

162

7.3 Redactiestatuten bij andere media

164

7.3.1 Schrijvende Pers (niet dagbladen); de zaak "Voorwaarts"

164

7.3.2 De programmastatuten van de omroepen 166

$\begin{array}{lll}7.4 & \text { Korte beschrijving van de Nederlandse dagbladstatuten } & 169\end{array}$

7.4.1 Holdingmaatschappij De Telegraaf 169

7.4.1.1 De Telegraaf/De Courant Nieuws van de Dag 169

$\begin{array}{ll}\text { 7.4.1.2 Limburgs Dagblad } & 171\end{array}$

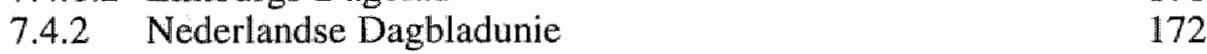

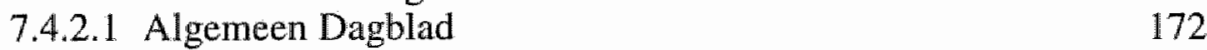

7.4.2.2 Rijn en Gouwe $\quad 173$

7.4.2.3 De Dordtenaar 173

7.4.2.4 NRC Handelsblad 174

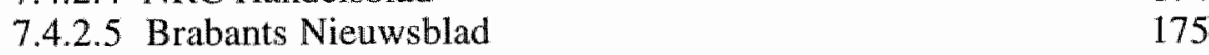

7.4.3 VNU Dagbladengroep 176

7.4.3.1 v/h AUDET: (De Gelderlander; De Limburger; De Stem; Dagblad voor Noord-Limburg) $\quad \cdots 176$

7.4.3.2 Brabant Pers: (Eindhovens Dagblad, Brabants

Dagblad, Het Nieuwsblad) 177

7.4.4 Wegener-Tijl-Oostelijke Dagbladen Combinatie 179

$\begin{array}{ll}\text { 7.4.4.1 Utrechts Nieuwsblad } & 179\end{array}$

$\begin{array}{ll}\text { 7.4.4.2 Wegener-Dagbladen } & 180\end{array}$

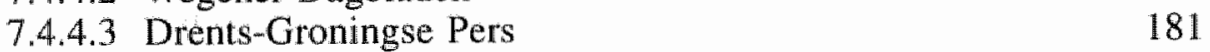

$\begin{array}{ll}7.4 .4 .4 \text { Zwolse Courant } & 182\end{array}$

7.4.4.5 Dagblad Tubantia $\quad 182$

$\begin{array}{lr}\text { 7.4.4.6 Arnhemse Courant } & 182\end{array}$

7.4.4.7 Deventer Dagblad Combinatie $\quad 183$

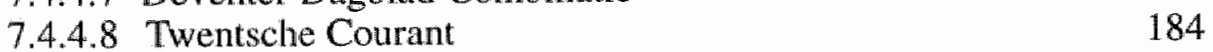

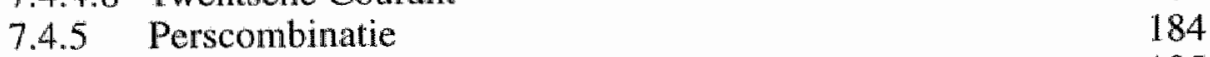

7.4.5.I. De Volkskrant 185

$\begin{array}{ll}7.4 .5 .2 \text { Het Parool } & 186\end{array}$

$\begin{array}{ll}\text { 7.4.5.3 Trouw } & 187\end{array}$

$\begin{array}{lll}7.4 .6 & \text { Hollandse Dagbladen Combinatie } & 189\end{array}$

$\begin{array}{ll}\text { 7.4.6.1 Haarlems Dagblad } & 189\end{array}$

7.4.6.2 Verenigde Noordhollandse Dagbladen (VND) 189

7.4.7 Noordelijke Dagbladen Combinatie 190 
7.4.7.1 Nieuwsblad van het Noorden

7.4.7.2 Leeuwarder Courant

7.4.8 Haagsche Courant/Dagblad Het Binnenhof

7.4.9 Rotterdams Dagblad

7.4.10 Provinciale Zeeuwse Courant (PZC)

7.4.11 De Gooi- en Eemlander

7.4.12 Nederlands Dagblad

7.4.13 Friesch Dagblad

7.5 Samenvatting

\section{Hoofdstuk 8}

\section{Het rechtskarakter van het redactiestatuut}

8.1 Grondrechtelijke aspecten van de verhouding

uitgever - (hoofd)redactie

8.1.1 Inleiding

8.1.2 Het grondrecht als afweerfunctie én zorgplicht

200

8.1.3 Tussenconclusie

204

8.1.4 Het redactiestatuut als voorbeeld van de horizontale werking (derdenwerking) van het grondrecht

8.1.5 Wie is "drager van het grondrecht"?

208

8.1.5.1 Inleiding

208

8.1.5.2 "Openbaren" en "hulphandelingen"

210

8.1.5.3 Tussenconclusie

8.1.5.4 Uitgever en identiteit

8.1.5.5 "Träger der Pressefreiheit"

8.1.5.6 De "zware procedure" volgens Hoffmann-Riem

8.1.5.7 Tussenconclusie

8.2 Redactiestatuut en arbeidsrecht 223

8.2.1 Redlactiestatuut en CAO 223

$\begin{array}{ll}\text { 8.2.2 Eigen opvatting } & 224\end{array}$

8.3 Verantwoordelijkheid en aansprakelijkheid voor de redactionele inhoud

$\begin{array}{lll}8.3 .1 & \text { Inleiding } & 225\end{array}$

$\begin{array}{ll}\text { 8.3.2 Verantwoordelijkheid en aansprakelijkheid } & 226\end{array}$

8.3.3 De strafrechtelijke aansprakeli.jkheid 228

8.3.4 De civielrechtelijke ansprakelijkheid 23॥

8.3.5 De hoofdredactie aansprakelijk? 235

8.3.5.1 De zaak Diekstra - Het Parool BV 235

8.3.5.2 Hof Leeuwarden (Rauwerda-Schuurmans); Rb.

Rotterdam (Frank Hubert Croes e.a.-BV NDU); Pres. $\mathrm{Rb}$. Arnhem (Lamers-De Gelderlander); Hof Arnhem (De Gelderlander-Lamers) 
8.3.5.3 Maatschappelijke verkeersopvattingen

en het redactiestatuut

8.3.5.4 De hoofdredacteur vrijwillig aansprakelijk 242

8.3.5.5 Conclusie bij 8.3 245

$\begin{array}{lll}\text { Bijlage } 1 & \text { Statuut voor de hoofdredactie } & 247\end{array}$

Bijlage 2 Model voor een redactiestatuut (NVJ-concept) 251

Bijlage $3 \quad$ Modelstatuut voor hoofdredactie en redactie 257

Bijlage 4 Entwurf eines Gesetzes über die allgemeinen Rechtsverhältnisse der Presse 264

$\begin{array}{ll}\text { Kurzfassung } & 269\end{array}$

$\begin{array}{ll}\text { Lijst van geraadpleegde literatuur } & 272\end{array}$

$\begin{array}{ll}\text { Curriculum vitae van de auteur } & 279\end{array}$ 


\section{Inleiding, object van onderzoek en probleemstelling}

\subsection{Inleiding}

Wie vanuit de journalistiek in het algemeen - en de dagbladjournalistiek in het bijzonder - de juridische betekenis van het begrip "uitingsvrijheid" bestudeert, wordt onvermijdelijk geconfronteerd met een weerbarstige paradox. De formulering van het grondrecht van de vrijheid van meningsuiting in onze Grondwet noch in art. 10 van de Europese Conventie tot Bescherming van de Rechten van de Mens (ECRM) biedt ruimte voor een bevoorrechte positie van de pers. De bewoordingen uit 1848 van het huidige artikel 7 lid $1 \mathrm{Gw}$, in 1983 nadrukkelijk opnieuw bevestigd, laten, ondanks de cryptische en negatieve formulering ("Niemand heeft voorafgaand verlof nodig om door de drukpers gedachten of gevoelens te openbaren.......") slechts één conclusie toe: het grondrecht tot ongecensureerde openbare communicatie via de drukpers is primair voor het individu geschreven, voor eenieder die zich op Nederlands grondgebied bevindt. Bij de uitingsvrijheid gaat het allereerst om een individueel vrijheidsrecht. Pas daarna mogen we opmerken dat eerbiediging van dat recht en vooral het vrijmoedige gebruik ervan ook onmisbaar zijn in een gemeenschap die hecht aan een democratisch bestel en aan invloed, ook van minderheidsgroepen, op de publieke besluitvorming. Vrije en mondige burgers die zich van dit grondrecht bewust zijn richten zich door middel van de drukpers en andere verspreidingsmedia ongehinderd tot hun medeburgers, informeren hen, stellen misstanden aan de kaak, ijveren voor een democratische inrichting van stat en maatschappij en verdrijven zo nodig de tirannie.

Kijken we naar de feitelijke betekenis van het vrijheidsrecht om "door de drukpers gedachten of gevoelens te openbaren", dan zien we een heel ander beeld. Het individu is in de dagelijkse praktijk vrijwel uit de openbare communicatie via de pers verdwenen. Wie zich bij art. $7 \mathrm{Gw}$ iets en iemand voor de geest probeert te halen, ziet media-organisaties van soms zeer grote omvang en met vele honderden medewerkers, die binnen deze organisaties, meestal in ondergeschiktheid, een beroep uitoefenen.

Het grondrecht daarentegen lijkt uitsluitend geschreven te zijn voor wat nu de randfiguren zijn van de mediawereld: de brochureschrijvers, de pamflettisten, de anonieme redactie van de muurkrant, de ingezonden-brievenschrijvers, de "plakkers" op muren, schuttingen en lantaarnpalen. Ook wanneer we deze paradox opheffen met de feitelijke erkenning van een institutionele uitingsvrijheid (persvrij- 
heid) naast het recht van de individuele burger om zich via de drukpers te uiten, ontkomen we niet aan de vraag wie binnen een media-organisatie zoals een dagbladonderneming "drager van het grondrecht" is. Is dat de individuele journalist? De uitgever? De hoofdredactie? Hoofdredactie en redactie samen? Ook het grafisch en administratief personeel? Of misschien allemaal, maar in verschillende mate?

Het redactiestatuut bij dagbladen, onderwerp van dit onderzoek, is aanleiding geweest naar antwoorden op deze vragen te zoeken.

\subsection{Object van onderzoek}

Sinds 1 januari 1977 is een dagbladonderneming per dagbladuitgave met vijftien of meer journalisten in vaste dienst, op grond van de CAO voor Dagbladjournalisten (art. 14), gehouden een statuut vast te stellen dat zowel de positie van de hoofdredactie als die wan de redactie regelt. Vrijwel alle dagbladen hebben sinds eind jaren zeventig een eigen redactiestatuut. Bij de meeste kranten lieten de drie contractpartijen (directie, hoofdredactie en redactievertegenwoordigers) zich bij het opstellen van de tekst leiden door het "Modelstatuut voor hoofdredactie en redactie", waarover de vereniging De Nederlandse Dagbladpers (NDP) (werkgevers) en de Nederlandse Vereniging van Journalisten (NVJ) in april 1976 overeenstemming hadden bereikt en dat in de toelichting bij het $\mathrm{CAO}$-artikel als "referentiekader" werd genoemd. Aan dit "modelstatuut" was een model voor een hoofdredactiestatuut voorafgegaan, waarover NVJ en NDP het al in 1972 eens waren geworden. De positie van de hoofdredacteur zoals in de overeenkomst van 1972 beschreven zou in de tekst van het latere "Modelstatuut" geintegreerd worden.

In de juridische literatuur en in de jurisprudentie hebben deze contracten slechts in een beperkte kring de aandacht gekregen die ze verdienen. Als ze in juridische kring al bekend waren, werden ze beschouwd als bijzondere overeenkomsten van arbeidsrechtelijke aard, die uitsluitend de interne verhoudingen binnen een dagbladonderneming regelen en waar derden geen boodschap aan hebben. Rechterlijke uitspraken waarin het redactiestatuut een rol speelt lijken de opvatting te bevestigen, dat dit laatste ook maar zo moet blijven.

Het redactiestatuut staat incidenteel in de belangstelling van de politiek. In het kader van de discussie over het al dan niet instellen van een persfusie-controleregeling ter voorkoming van een nog verdergaande persconcentratie is onder meer versterking van de positie van de redactie door middel van een redactiestatuut op wettelijke basis voorgesteld. In Duitsland, waar eerder dan in ons land "Redaktionsstatuten" tot stand waren gekomen, is medio jaren zeventig opnieuw een poging ondernomen om een federale perswet te formuleren, waarin opgenomen een hoofdstuk dat de interne verhouding tussen uitgever en redactie bij een krant of tijdschrift zou regelen.

De relatie tussen persconcentratie en redactiestatuut is overigens niet toevallig. Zowel in Nederland als in (West-)Duitsland is de opkomst van de statuten een 
(late) reactie geweest op de eerste grote concentratiegolf van de jaren zestig. Er zijn tussen beide landen ook opvallende verschillen. In ons land heeft de georganiseerde journalistiek energiek het voortouw genomen bij het formuleren van de bezwaren tegen het verdwijnen van steeds meer kranten zonder inspraak van de redacties. De redactiestatuten, waarvoor de NVJ samen met de NDP modellen aanleverde, moesten de (hoofd)redacties deze inspraak bieden bij alle beslissingen van de uitgever die van rechtstreekse invloed konden zijn op de positie en het functioneren van hoofdredactie en redactie, en daarbij dacht men uiteraard ook aan beslissingen over het voortbestaan van de krant.

De "Statutenbewegung" in Duitsland laat een andere ontwikkeling zien. In dit land heeft vooral de rechtswetenschap zich al vóor "das große Zeitungsstirben" van de jaren zestig en zeventig intens beziggehouden met de "innere Pressefreiheit". Met dit begrip, dat uit de jaren twintig stamt, duidt men in Duitsland aan dat persvrijheid niet alleen opgevat moet worden als afweerrecht tegen de overheid ("äußere Pressefreiheit"), maar dat ook binnen de media krachten aan het werk zijn, waartegen de redactie zich dient te weren.

Redactiestatuten zijn in Duitsland altijd met het begrip "innere Pressefreiheit" geassocieerd. De eerste Duitse statuten ontstonden bij bladen, waar een redactie zich bedreigd voelde. Zij nam in de regel het initiatief tot een interne regeling van bevoegdheden en kreeg daarbij in enkelle gevallen de steun van een sympathiserende uitgever. De georganiseerde journalistiek, die in Duitsland verdeeld is over drie bonden, speelde aanvankelijk helemaal geen rol bij de totstandkoming van redactiestatuten.

\subsection{Probleemstelling}

Sinds een aantal jaren is in journalistieke kring de belangstelling voor het redactiestatuut aan het tanen. Dat geldt niet alleen voor ons land. Ook in WestDuitsland, dat als bakermat van deze overeenkomst mag gelden, is het sinds het mislukken van een wettelijke regeling van de verhouding tussen uitgever en redactie, stil geworden. Een aantal factoren heeft in beide landen een rol gespeeld. Ook voor ons land geldt de constatering van Ronneberger uit 1987: (......) Darüber hinaus muß man sich vergegenwärtigen, daß die Statutenbewegung mehr oder weniger ein Kind der Studentenbewegung der 70er Jahre war, die sich durch hochgesteckte, ja utopische Erwartungen auszeichnete. Demgegenüber erweist sich die Realitat stets als banal, Resignation stellt sich ein. De solidariteit, aldus deze auteur, is ook niet meer die van twintig jaar geleden. Wie kann es auch anders sein: Wenn ein Beruf vorwiegend Individualisten anzieht und prämiert, dann ist es doch wohl der journalistische. Neue Themen tauchen auf und werden wichtiger. (1)

Tussen Nederlandse en (West-)Duitse redactiestatuten bij dagbladen - en daar beperkt dit onderzoek zich hoofdzakelijk toe - is er nog een zeer in het oog springend verschil. In Nederland hadden bijna alle dagbladen binnen een paar jaar, nadat werkgevers en werknemers het eens waren geworden over een model, hun 
eigen redactiestatuut en is het nog niet voorgekomen dat er een is opgezegd. In Duitsland daarentegen hebben nog slechts enkele kranten een statuut. In de Bondsrepubliek zijn gedurende de 24 jaar sinds de ondertekening van het eerste redactiestatuut (bij de Rhein-Zeitung in Koblenz - 1 april 1969) in totaal slechts twaalf statuten bij dagbladen tot stand gekomen. Daarvan zijn er anno 1993 nog slechts zes van kracht; in de overige gevallen is de krant inmiddels ter ziele, overgenomen door een andere onderneming of werd het statuut door de uitgever opgezegd.

Eerste object van onderzoek was dan ook de verklaring voor deze paradox: hoe kan het dat in Duitsland, waar "innere Pressefreiheit" al zo lang en zo gedegen bestudeerd is, zo weinig overeenkomsten tussen uitgevers en (hoofd)redacties tot stand zijn gekomen, en in ons land kennelijk moeiteloos zoveel? Bestaat er - was een veronderstelling - wellicht een relatie tussen de langdurige en vruchtbare Duitse wetenschappelijke belangstelling en traditie op het gebied van "Presserecht" en "Publizistik" en het moeizaam tot stand komen van redactiestatuten? En is het kennelijk moeiteloos tot stand komen van zoveel redactiestatuten in Nederland wellicht mede te verklaren uit het tot dan toe (eind jaren zestig) vrijwel ontbreken van aandacht voor de interne verhoudingen binnen de media? Met andere woorden: was het in Duitsland zo moeilijk en in ons land zo gemakkelijk om redactiestatuten overeen te komen, omdat er in het ene land al langer en grondiger dan in het andere over de interne verhouding van bevoegdheden is nagedacht?

Bij een vergelijking van het Duitse en het Nederlandse denken over de verhouding uitgever - hoofdredactie - redactie valt op, dat de Duitse doctrine en wetgeving het thema consequent in de sleutel van de grondrechten geplaatst hebben. Medezeggenschap van de redactie in belangrijke beslissingen over haar eigen krant geldt in Duitsland als een inbreuk op verscheidene grondrechten van de uitgever, wiens "Grundsatzkompetenz" niet alleen onomstreden is, maar ook nadrukkelijk opgeëist: de "Verleger" (uitgever) wordt verondersteld zeer betrokken te zijin bij de redactionele beginselen van krant of tijdschrift en ontleent daar rechten aan. Een zeer in het oog springend voorbeeld van zo'n recht is de "Tendenzschutz": een bedrijf dat een ideëel produkt vervaardigt - en ook de media ondernemingen worden daartoe gerekend - mag op bijzondere bescherming van dat ideële aspect rekenen. In wetgeving die teruggaat tot de jaren twintig wordt de "Tendenzschutz" van de media-onderneming ook nadrukkelijk beschermd tegen elke vorm van werknemersinspraak die het grondrecht van de uitgever zou kunnen aantasten. Dit blijkt een formidabele hindernis voor de totstandkoming van redactiestatuten te zijn.

De beginzin van de considerans van de beide "modelstatuten" die begin jaren zeventig tot stand zijn gekomen verwijst nadrukkelijk naar het grondrechtelijk kader waarbinnen het dagblad vervaardigd wordt: Het dagblad onderscheidt zich van andere industriele produkten:

- doondat het gestalte geeft aan het in Nederland geldende grondrecht wan vrijheid van meningsuiting, informatieverwerving, -vermeningvuldiging en -ver- 
strekking, zoals vastgelegd in onder meer artikel 7 van de Grondwet en artikel 10 van het Verdrag van Rome; (.....). Deze constatering, die met instemming aan de basis van dit onderzoek ligt, heeft tot de volgende vragen geleid die als probleemstellingen bij dit onderzoek kunnen gelden:

- Is een generieke regeling van het redactiestatuut - hetzij bij wet of bij CAO waarbij ook inhoudelijke eisen aan een dergelijk statuut worden gesteld, grondrechtelijk geoorloofd?

- Op welke wijze is het redactiestatuut als regeling van de verhouding uitgever hoofdredactie - redactie in te passen in het grondrechtelijke kader waar de considerans van de beide model-statuten naar verwijst?

- Behoort ook de wijze waarop de uitgever feitelijk omgaat met de identiteit van een dagblad een rol te spelen bij de beoordeling van zijn aandeel in de uitoefening van een grondrecht?

- Welke consequenties behoort dit feitelijk gedrag van de uitgever te hebben ten aanzien van de gepretendeerde zeggenschap in voor de redactie belangrijke beslissingen?

- Is de gepretendeerde exclusieve verantwoordelijkheid van de hoofdredacteur voor de redactionele inhoud van de krant voldoende geloofwaardig zonder de bereidheid ook de civielrechtelijke aansprakelijkheid ervoor te accepteren?

(1) Franz Ronneberger in de bespreking van Christina Holtz-Bacha Mitspracherechte für Joumalisten in: Publizistik, 1987, Heft 3, blz. 382.

\subsection{Methode van onderzoek}

Dit onderzoek is een verdere uitwerking van mijn afstudeerscriptie "Het redactiestatuut en artikel 7 van de Grondwet" (Katholieke Hogeschool Tilburg, 1981), waarin vooral de leer van de derdenwerking van grondrechten en haar mogelijke toepasbaarheid op het redactiestatuut centraal stond. Ook daarin speelde de Duitse doctrine al een belangrijke rol. Onmiddellijk na aanvang van dit hernieuwde onderzoek was het duidelijk dat bij een studie naar de totstandkoming en betekenis van de Nederlandse redactiestatuten opnieuw gekeken moest worden naar parallelle ontwikkelingen in zowel het vooroorlogse als het naoorlogse Duitsland. Een van de belangrijkste Nederlandse documenten van vóór de tweede wereldoorlog, het rapport van de Commissie-Van Blom uit 1924, doet dat expliciet. En hoewel er in de jaren zestig en zeventig maar weinig Nederlandse verwijzingen te vinden zijn naar de al eerder begonnen "Statutenbewegung" in de Bondsrepubliek, ligt vergelijking des te meer voor de hand omdat in dit onderzoek, zoals in Duitsland, de grondrechtelijke invalshoek gekozen wordt.

$\mathrm{Bij}$ het onderzoek heb ik mij vooral beziggehouden met de juridisch relevante teksten die in de discussie rond de statuten een rol gespeeld hebben. In Duitsland 
zijn dat hoofdzakelijk de zeer vele ontwerpen voor collectieve arbeidsovereenkomsten, perswetten en journalistenwetten geweest, in Nederland in het bijzonder het "modelstatuut voor hoofdredactie en redactie" en de voorontwerpen ervan. Bij de naoorlogse Nederlandse en Duitse literatuur naar aanleiding van bepaalde teksten is vervolgens vooral bekeken vanuit welke juridische vóóronderstellingen geschreven is. In de Duitse literatuur is het dan veelal noodzakelijk te weten of de auteur vanuit de uitgevers- of de journalistenoptiek schrijft of vanuit de staatsrechtelijke of de arbeidsrechtelijke gezichtshoek. Wat de Duitse literatuur betreft zal opvallen dat relatief vaak verwezen word naar het oudere werk van Wolfgang Hoffmann-Riem, soms in samenwerking met Harro Plander en Udo Branahl. Hoffmann-Riem, verbonden aan het Hans-Bredow-Institut für Rundfunk und Fernsehen van de universiteit van Hamburg, is in ons land vooral bekend door zijn publicaties over het omroep-recht. In de jaren zeventig heeft hij zich zeer intensief beziggehouden met het redactiestatuut als praktische verwezenlijking van de "innere Pressefreiheit". Wanneer in dit onderzoek de indruk zou worden gewekt dat de auteur zich in sterke mate door de ideeën van HoffmannRiem voelt aangesproken, is die indruk juist.

Waar dat ter verduidelijking nodig was zijn de teksten in een historische context geplaatst. Het onderzoek heeft echter niet de pretentie de geschiedenis van de Nederlandse en Duitse redactiestatuten te beschrijven. Evenmin is per dagblad onderzocht of en in hoeverre het redactiestatuut bij belangrijke beslissingen een rol heeft gespeeld en hoe directies, hoofdredacties en redacties oordelen over hun statuten. Een dergelijk empirisch onderzoek is waarschijnlijk pas zinvol na de totstandkoming van "tweede-generatiestatuten", waartoe dit onderzoek hopelijk aanleiding geeft.

Het onderzoek is eveneens met opzet beperkt tot Nederland en West-Duitsland. Dat is vooral om praktische redenen gedaan. Uitbreiding tot andere landen zou allereerst een studie vergen naar de mate van vergelijkbaarheid van de verhouding uitgever - (hoofd)redactie in landen met een geheel verschillende traditie op dit gebied. De noodzakelijke beperking van het aantal landen dat in zo'n onderzoek betrokken wordt zou bovendien tot een arbitraire keuze nopen.

$\mathrm{Na}$ deze inleiding volgen een zevental hoofdstukken, die gedeeltelijk een Nederlands - Duitse parallellie vertonen en een viertal bijlagen.

De hoofdstukken 2 en 3 laten zien hoe de verhouding uitgever - redactie vór de oorlog in respectievelijk Nederland en Duitsland ter discussie kwam en hoe partijen in beide landen vanuit geheel andere invalshoeken aanvankelijk dezelfde korte-termijnoplossing kozen: verbetering van arbeidsvoorwaarden in ruil voor echte medezeggenschap. De Duitse journalistiek moest tenslotte zelfs ervaren hoe de eerste aanzetten tot "innere Pressefreiheit" misbruikt werden om de nationaalsocialistische "Schriftleitergesetz" van 1933 te onderbouwen.

In de hoofdstukken 4 en 5 staan het totstandkomen en de inhoud van het Nederlandse "model-statuut" centraal. Dit contract wordt kritisch vergeleken met het modelstatuut voor de hoofdredactie en vooral met het concept voor een redactiestatuut uit 1973 waarmee een NVJ-delegatie de onderhandelingen met de 
uitgevers is ingegaan. Hoofdstuk 6 volgt de moeizame Duitse worsteling met de grondrechtelijke vragen rond "innere Pressefreiheit" en de mislukte pogingen om deze via de CAO en een nieuwe federale perswet te regelen. Aan het slot van dit hoofdstuk worden de zes dagbladstatuten die nog bij Duitse kranten van kracht zijn besproken.

Hoofdstuk 7 bevat een korte, hier en daar kritische, beschrijving van alle Nederlandse dagbladstatuten die voor dit onderzoek ter beschikking werden gesteld en een aantal positief in het oog springende varianten op het "modelstatuut". Bovendien wordt in hoofdstuk 7 summier aandacht geschonken aan redactiestatuten respectievelijk programmastatuten bij andere geschreven periodieken dan het dagblad en bij de omroepen.

Het afsluitende hoofdstuk 8 is te beschouwen als uitwerking van de gemotiveerde eigen opvattingen naar aanleiding van de bij de probleemstelling opgeworpen vragen en daarmee als samenvatting en conclusie van alle voorgaande hoofdstukken. De probleemstellingen keren er in de hierboven aangegeven volgorde in terug, telkens afgesloten met een "tussenconclusie". Dit slothoofdstuk heet "Het rechtskarakter van het redactiestatuut" en probeert dit contract tussen uitgever, hoofdredactie en redactie een plaats te geven binnen de discussie over grondrechten in het algemeen en dat van de uitingsvrijheid in het bijzonder. Tevens komt de verhouding tussen $\mathrm{CAO}$ en het redactiestatuut aan de orde. Het hoofdstuk schenkt ook kritische aandacht aan de jurisprudentie waarbij het redactiestatuut direct of indirect betrokken was. Daaruit is een voorstel afgeleid om hoofdredacteuren die hun exclusieve verantwoordelijkheid voor het redactionele gedeelte van de krant opeisen deze claim geloofwaardiger te laten maken door vrijwillig ook de civielrechtelijke pendant ervan, de civielrechtelijke aansprakelijkheid, te aanvaarden. 


\section{Redactionele medezeggenschap in Nederland: het rapport van de Commissie-Van Blom}

\subsection{Inleiding}

Dit onderzoek naar de redactionele medezeggenschap bij Nederlandse dagbladen begint in de jaren twintig. Rond deze tijd hebben journalisten van dagbladen in Nederland die medezeggenschap in voor hen belangrijke beslissingen, zoals de verkoop van hun krant, voor het eerst opgeëist.

Een voor dit onderzoek belangrijk document is gedateerd 9 juni 1923. Op die zaterdag nam het bestuur van de Nederlandsche Journalisten-Kring (NJK) een resolutie aan, waarin het recht van medezeggenschap voor journalisten werd opgeëist bij de vervreemding van een krant. (1) Deze resolutie heeft anderhalf jaar later geleid tot een belangwekkende studie: het Rapport der Commissie voor de Medezeggenschap (de Commissie-Van Blom). Dit rapport was zijn tijd ver vooruit, waarschijnlijk zelfs te ver. Het bevatte zelfs al een ontwerp voor een eerste $\mathrm{CAO}$ voor dagbladjournalisten. Het is bij een ontwerp gebleven; de eerste journalisten-CAO zou er pas in 1948 komen. Het rapport bevat elementen die nog veel later (begin jaren zeventig) terug zullen keren in twee "modelstatuten", modelovereenkomsten die de bevoegdheden van directie, hoofdredactie en redactie bij een dagblad nader regelen.

Een tweede reden om dit onderzoek rond deze tijd te laten starten is dat eveneens in het begin van de jaren twintig in Duitsland het pregnante begrip "innere Pressefreiheit" zijn intrede deed, mede onder invloed van een nieuwe grondwet, de Weimarer (Reichs) Verfassung (WV) van 11 augustus 1919, die in het nog steeds opmerkelijke artikel 118 niet alleen voor het eerst de vrijheid van meningsuiting en de persvrijheid in Duitsland grondwettelijk beschermde, maar in zijn zeer royale formulering ook de vrijheid van meningsuiting binnen arbeidscontract garandeerde. De juridische basis onder de Duitse Statutenbewegung" uit de jaren zestig en zeventig steunt mede op de pogingen in de jaren twintig om de verhouding uitgever - redactie zodanig in wetgeving en/of collectief arbeidscontract vast te leggen, dat deze binnen de grondwettelijke regeling van $118 \mathrm{WV}$ paste. De Commissie-Van Blom was blijkens haar eigen rapportage op de hoogte van de Duitse ontwikkelingen op dit gebied. Zij nam in haar ontwerp-CAO zelfs belangrijke elementen uit Duitse wetsvoorstellen en ontwerp-CAO's over.

(1) Voor de tekst van deze resolutie zie 2.4.2.88 


\subsection{Nederlandse dagbladpers in de jaren " 20}

Hoewel de aanleiding tot de instelling van de Commissie-Van Blom (de verkoop kort na elkaar van twee kranten) anders doet vermoeden, was deze periode voor wat we thans de pluriformiteit van het dagbladwezen noemen, een betrekkelijk gunstige. Er waren al veel redactioneel zelfstandige kranten (66 in 1917), en ondanks de zeer aanzienlijke verhoging van de kostprijs door de verdrievoudiging van de papierprijs na de eerste wereldoorlog, forse loonsverhogingen en verdubbeling van de portokosten voor dag-en weekbladen, en ondanks de economische malaise van 1920 tot $1923 \mathrm{kwamen}$ er nog veel kranten bij. In 1931 was hun aantal opgelopen tot 95, waarvan negen in Amsterdam, ook negen in Den Haag en zeven in Rotterdam.

Tal van factoren hadden al sinds de eeuwwisseling de vraag naar kranten en dientengevolge de groei van de dagbladpers bevorderd. Hemels (1) noemt in dit verband onder meer de toeneming van de bevolking, de stijging van de koopkracht, het afnemen van het analfabetisme, de deelname van meer mensen aan vormen van uitgebreider onderwijs, de toenemende belangstelling voor binnen- en buitenlandse politieke gebeurtenissen, het bewustwordingsproces van het katholieke volksdeel en de opkomst van de arbeidersbeweging. Na 1918 was de aanhang van de SDAP, met name in de steden, aanzienlijk versterkt, wat de basis legde voor uitbreiding van de sociaal-democratische partijpers, in het bijzonder na de oprichting door de SDAP en het NVV van de NV De Arbeiderspers.

De politieke en godsdienstige verscheidenheid in ons land werd weerspiegeld in een gevarieerd dagbladwezen. Of, negatiever uitgedrukt: "verzuiling", hoewel het woord toen nog niet bestond, was het kenmerk van het dagbladwezen. Vrijwel alle kranten hadden een uitgesproken politieke en/of godsdienstige signatuur (katholiek, liberaal, nationaal-liberaal, sociaal-democratisch of anti-revolutionair), hoewel slechts een minderheid die signatuur ook in de ondernemingsstatuten had opgenomen. (2) Behalve door kerkelijke en godsdienstige verschillen was de vooroorlogse samenleving in subculturele bevolkingsgroepen gesegmenteerd door traditionele klasse- en standsonderscheidingen, een betrekkelijk sterk regionalisme en een krachtig leidende elite van politici, vakbewegingsleiders en staatslieden. (3) "Verzuiling" heeft tegenwoordig een zo negatieve connotatie dat men de conclusie zou kunnen trekken dat de vooroorlogse pers op een kwalitatief laag niveau zou staan. Die gevolgtrekking is - zeker wat de landelijke bladen betreft onjuist; behalve kwantitatief stond de Nederlandse dagbladpers ook kwalitatief op een hoog peil. De Nijmeegse historicus Rogier (4) sprak in 1954 met onverholen weemoed over de dagbladen uit de jaren mijner jongelingschap. (...........) De jongste oorlog heeft in de ontwikkeling van de pers in dit veelszins bevoorrechte land een breuk teweegebracht. Geen van onze te goeder naam en faam bekende bladen heeft het oude peil bereikt en als het waar is, dat de gunst van een steeds groter kring zich tegenwoordig wan de landelijke naar de regionale bladen verplaatst, valt te vragen, of dit een gevolg is van een onmiskenbare nivellering ten nadele van de enkele corypheeën van vroeger. Men vergelijke de Zaterdagavond- 
edities van sommige grote bladen maar met die van vóór de oorlog. Rogier veronderstelde dat de weekbladen de opinievormende taak van de kranten gedeeltelijk hadden overgenomen.

Rond de jaren twintig hadden de toonaangevende dagbladondernemingen reeds de juridische organisatievormen die we thans in deze bedriffstak kennen. De uitgeverijen van de grote kranten waren rechtspersonen (naamloze vennootschap, stichting of vereniging). Bij de kleinere dagbladen kwamen ook de vennootschap onder firma, de commanditaire vennootschap en de persoonlijke onderneming nog voor.

De oplagen van de kranten waren, naar huidige begrippen, klein, evenals de meeste redacties. De Volkskrant bij voorbeeld, op 2 oktober 1919 als weekblad begonnen, werd op 1 oktober 1921 "dagblad voor het katholieke volk" met een part time hoofdredacteur, J.B. Vesters, die van 1920 tot 1934 ook hoofdredacteur van het in Den Bosch verschijnende dagblad Het Huisgezin was. Pas in 1936 kwam bij de Volkskrant de zevende redacteur in dienst. (5) De organisatie van het huidige dagblad met een directeur en een hoofdredacteur was begin jaren twintig bij de landelijke kranten al regel, zij het dat bij een aantal dagbladen de combinatie directeur-hoofdredacteur niet ongebruikelijk was. Soms ontbrak een hoofdredacteur en was de "algemeen redactiechef" de hoogste journalistieke functionaris. Bij de grotere kranten was de commerciële en de redactionele leiding reeds in aparte handen en bij de meeste van deze bladen was het een weliswaar ongeschreven, maar onbetwiste regel dat de directie zich niet rechtstreeks met het redactionele beleid zou bemoeien, terwijl de redactie van haar kant accepteerde dat zij de directie bij zakelijke beslissingen niet voor de voeten mocht lopen. Bij de kleinere kranten kwam het volgens tijdgenoten wel voor dat de directeur zich direct met de inhoud van de krant bezighield. Bij directionele bemoeienis met de redactie dacht men echter niet zozeer aan inmenging in de politieke en/of godsdienstige richting van de krant, maar vooral aan invloed, via de directie, van de adverteerders. De Nederlandsche journalist is opgevoed in de vreeze voor den invloed der directies. Niets brengt men hem eerder aan zijn verstand dan dat de directeur de man is van het geld, wiens invloed op de redactie gelijk nul behoort te zijn en die zich te bemoeien heeft met de advertenties en de abonnementen. En zeker is de absolute scheiding russchen redactie en administratie een uitnemend ding, omdat zij de onafhankelijkheid van de courant waarborgt en zelfs zoover gaat, dat de redacteuren in het algemeen onkundig zijn van de advertentiën, die in de courant worden opgenomen constateert in 1924 L.J. Plemp van Duiveland, toen ex-hoofdredacteur van de Nieuwe Courant. (6) Bij de Duitse kranten was dat in de jaren twintig wezenlijk anders, zoals het bestuur van de NDP, de vereniging van dagbladuitgevers, na een bezoek in 1926 aan de Duitse zusterorganisatie Verein Deutscher Zeitungsverleger rapporteerde. Daar was het de NDP-delegatie opgevallen datde directies van Duitse dagbladen onder alle omstandigheden de leiding van het hele dagbladbedrijf voor zich opeisten, ook op redactioneel gebied. (7)

Zo afstandelijk als volgens Plemp van Duiveland de verhouding van de uitgever 
(directeur) met zijn (hoofd)redactie zou behoren te zijn was zij in de praktijk echter niet. De uitgever had, zonder inspraak van wie dan ook, zelf de hoofdredacteur van zijn keuze benoemd, met wie de directeur dagelijks de lopende zaken besprak. Tot die lopende zaken rekent Plemp van Duiveland niet alleen het budget en het aantal pagina's dat de redactie ter beschikking krijgt, maar ook uitbreiding van het correspondentennet en de redenen waarom abonnees de krant opzeggen, terwijl ook aan de opinie van de directie over de aandacht die de hoofdredacteur aan een bepaald onderwerp moet wijden in sommige gevallen een groote waarde zal moeten worden gehecht. (8) De hoofdredacteur stond dan ook heel wat dichter bij de directie dan bij de redactie en binnen deze redactie was hij heel nadrukkelijk de baas. Zo ergens, dan geldt voor een courant dat één de meester behoort te zijn aldus Plemp, nadat hij het experiment bij Het Volk met een republikeinsche redactie, zonder hoofdredacteur als volstrekt ondeugdelijk had afgewezen. Ook een tweehoofdige hoofdredactie was volgens Plemp ongewenst. Want er ligt in de dagelijksche gezamenlijke leiding van het krantenbedrijf, met zijn enerveerende werking op het gemoed en den geest, een bron van conflicten opgesloten, die slechts door een volmaakte harmonie der geesten, door een elkander volkomen begrijpen en waarderen kan worden belet tot uitbarsting te komen. (9) Bij kleine bladen en bij kranten waar de directeur tevens hoofdredacteur is (Plemp noemt hier het Algemeen Handelsblad met name) is de situatie minder ideaal, omdat de directeur er te veel te zeggen heeft. Zelfs bij de Nieuwe Rotterdamsche Courant, waarover Plemp kritisch, maar zeer bewonderend schrijft, en zijn hoofdredacteur mr. G.G. van der Hoeven signaleert hij een grote mate van invloed ook over den redactioneelen inhoud van directeur $\mathrm{H}$. Nijgh door de feitelijke macht, waarover hij beschikt - de financieele. (10)

Bij teruminste één krant - de Telegraaf - bemoeide de uitgever zich heel nadrukkelijk met de redactie. Zijn oprichter Henry Tindal (1852 - 1902) was een typische "courantier", uitgever en zakenman met een journalistieke boodschap. Volgens R.E.M. van den Brink was Tindal meer gericht op de progressief - liberale inhoud van De Telegraaf dan op het exploitatieresultaat en werd hij dan ook "een verliesmagnaat". (11) H.M.C. (Hak) Holdert, sedert 1902 (mede-)eigenaar van De Telegraaf, was tot zijn dood in 1944 tevens de feitelijke hoofdredacteur, ook nadat Holdert zich in 1914 in Parijs had gevestigd. De eigenlijke hoofdredacteur J.C. Schröder (onder de nom de plume "Barbarossa" schreef hij ook gevreesde toneelkritieken) werd in het overzicht van het personeel in 1902 genoemd als secretaris van de redactie, een omschrijving die meer met de werkelijkheid overeenstemde, dan de benaming hoofdredacteur. Schröder had in 1914 over principiële aangelegenheden weinig meer te vertellen dan toen hij in 1902 werd aangesteld: H.M.C. Holdert blijft ook nu heer en meester over het redactionele deel van De Telegraaf en De Courant. Medewerkers die hij waardeert wor-den goed betaald en degene die zijn gunst verspeelt, loopt kans op staande voet te worden ontslagen. (......) Hij is het die de fel anti-Duitse houding van De Telegraaf in de Eerste Wereldoorlog decreteert en er voor verantwoordelijk is dat De Telegraaf en De Courant in de befaamde novemberweek van 1918 aanbieden de 
Nederlandse revolutionairen te steunen. (12)

Dat de verhouding directeur - hoofdredacteur heel wat inniger was dan we thans gewend zijn had ook een historische achtergrond. Tot 1918 waren zowel directeuren als redacteuren lid geweest van de oudste journalistenvereniging in ons land - opgericht op 1 februari 1884 - de Nederlandsche Journalisten-Kring (NJK). In oktober 1918 nam de NJK het besluit dat voortaan uitsluitend beroepsjournalisten gewoon lid van de NKJ konden zijn en dat de dagbladdirecteuren de NJK dienden te verlaten. Hoofdredacteuren die tevens directeur waren konden alleen buitengewoon lid, zonder stemrecht, van de NJK worden, een besluit dat overigens later herroepen werd.

De directeuren kenden hun eigen Vereniging "De Nederlandse Dagbladpers" (NDP). Van deze vereniging van directeuren en uitgevers van dagbladen, opgericht op 21 december 1908 , konden hoofdredacteur-directeuren wel lid zijn. Het was een vereniging van personen, niet van ondernemingen, en zij kon dus geen collectieve overeenkomsten sluiten. (13) Aanleiding tot de oprichting van de NDP was eerder pragmatisch dan ideëel, zoals uit de circulaire aan de toekomstige leden ("eigenaars en directeuren van dagbladen") blijkt. Daarin stond een achttal dringende aandachtspunten opgesomd. De eerste twee hadden betrekking op het gezamenlijk optreden tegen malafide adverteerders en advertentiebureaus en tegen sluikreclame. Andere punten waren onder meer verlaging van het telegram- en posttarief, praktischer vertrektijden van treinen voor de verzending van kranten en overleg bij het regelen van contracten met $0 . m$. de leverancier van de Amsterdamse beursnoteringen. Ook overleg en samenwerking met de journalistenvereniging en het vaststellen van de hoofdlijnen van arbeidscontracten werden genoemd.

Nederland heeft, constateert Hemels in zijn jubileumboek bij gelegenheid van het 75-jarig bestaan van de NDP, geen persbaronnen wan het type William Randolph Hearst ("Citizen Kane"), baron Beaverbrook, Leopold Ullstein en Alfred Hugenberg gekend. De Nederlandse uitgever was niet belust op politieke macht. Het merendeel gaf kranten uit om louter commerciële, niet om ideële motieven. Velen waren boek- en handelsdrukkers die hun onbenutte zet- en drukcapaciteit gebruikten om een plaatselijk blad op de markt te brengen. Volgens Hemels was bij een deel van de richtingbladen (kranten met een godsdienstige en/of politieke boodschap) het ideële motief wel degelijk aanwezig, soms zelfs sterker dan het commercièle. (14)

(1) Joan Hemels De krant in bedrijf, pag. 24 e.v.

(2) Bronnen: Dr. Maarten Schneider i.s.m. dr. Joan Hemels De Nederlandse krant 1618-1978, pag. 471; M. Rooij Het econonisch-sociale beleid van het dagbladbedriff in Nederland, pag. 45 e.v; idem, Kranten-Dagbladpers en maatschappij, pag. 91 en 92.

(3) J.J. van Cuilenburg et al. De redactionele zelfstandigheid van dagbladen, Publicatie van hetBedrijfsfonds voor de Pers, (1990) pag. 193.

(4) L.J. Rogier De Nederlandse pers van gisteren en heden, Perswetenschappelijke bijdragen van het Katholiek Instituut voor de Journalistiek, Nijmegen (1954), pag. 14 en 15.

(5) Joan Hemels De emancipatie van een dagblad-Geschiedenis van De Volkskrant pag. 132 e.v.

(6) Mr. L.J. Plemp van Duiveland Journalistiek in Nederland, pag. 76 e.v. 
(7) Joan Hemels De krami in bedriff, pag. $112 / 113$.

(8) Mr. L.J. Plemp van Duiveland Joumalistiek in Nederland, pag. 78.

(9) Idem pag. 79, resp. 92.

(10) Ower de verhouding directie-hoofdredactie in de jaren dertig bij het Algemeen Handelsblad en bij de Nieuwe Rotterdamsche Courant naar aanleiding van de affaires rond respectievelijk von Balluseck en Van Blankenstein zie H.J. Scheffer De Dagbladondememing - historische verken. ningen (1986), pag. 53 e.v. Bij beide kranten, aldus Scheffer, bemoeide de directie zich met de in houd van de krant. Bij de NRC gebeurde dat "voorzichtig en indirect", bij het Handelsblad "zonder aarzeling en rechtstreeks".

(11) R. E.M. van den Brink Informatie over infornatie, Handboek van de informatiemedia in Nederland 1938-1985, pag. 51 .

(12) H.J. Scheffer Henry Tindal. Een ongewoon heer met ongewone besognes, pag. 320 - 326; noot 50 , pag. 65 in motenbijlage.

(13) M. Rooij Het dagbladbedrijf in Nederland, pag. 272; Joan Hemels De krant in bedriff. pag. 35 e.v. en pag. 78 .

(14) Joan Hemels De krant in bedrijf. pag. 26 en 37 e.v.

\subsection{NJK: van vriendenkring tot belangenbehartiger}

Het begin van de jaren twintig bracht de Nederlandse Journalisten-Kring in een identiteitsconflict, dat tot de dag van vandaag de georganiseerde journalistiek parten speelt: moet een vereniging van journalisten zich vooral bezighouden met de ideële kanten van het beroep, de beroepsethiek en de verheffing van het vak of moet zij zich in de eerste plaats als vakbond opstellen?

Tot begin van de jaren twintig was de in de NJK georganiseerde journalistiek een typische standsorganisatie; eerder een veredelde gezelligheidsvereniging dan een vakorganisatie, met steeds een prominente, academisch gevormde, hoofdredacteur van een Amsterdamse of Haagse krant als voorzitter. Een van de meest prominente was zonder twijfel dr. Abraham Kuyper, hoofdredacteur en oprichter van De Standaard, die het NJK-voorzitterschap in 1901 neerlegde, toen hij tot minister-president werd benoemd. Journalisten uit de lagere eche-lons ontbraken aanvankelijk in de "vriendenkring".

In 1912, toen het zwaartepunt in de Kring zich naar de "gewone journalisten" begon te verplaatsen, klaagde de in dat jaar aangetreden NJK-voorzitter Plemp van Duiveland over hun aantal. Het is overdreven te zeggen dat onze Kring tegenwoordig voornamelijk een vereniging is van verslaggevers, maar wel moet erkend worden dat in ons Kringleven en onze vergaderingen het element van de in ons vak leiding gevende journalisten te weinig van zich laat horen.

Hoofdredacteuren en directeur-hoofdredacteuren hebben zich in 1920 zelfs in een aparte vereniging georganiseerd, in zekere zin een voorloper van het latere Genootschap van Hoofdredacteuren. De secretaris ervan, J.W. Henny, directeurhoofdredacteur van het Leidsch Dagblad, zou later voorzitter van de NDP worden. Volgens Joan Hemels was het wel duidelijk waarom een aantal hoofdredacteuren in deze situatie tóch behoefte had aan een eigen organisatie: De journalisten streefden naar een regeling van de arbeidstijd en er was volop discussie en overleg over de salarisregeling, waartoe in 1919 een Commissie van Advies bestaande uit journalisten en directeuren was ingesteld. De vakbondachtige op- 
stelling van de NJK moet een aantal hoofdredacteuren hebben doen besluiten tot het oprichten wan een eigen vereniging. (1) Pas in 1920 - de NJK telde toen 410 leden - zou een "gewone" redacteur, de Haagse Kamerverslaggever van De Telegraaf D. (Doe) Hans, het voorzitterschap overnemen. Hij bleef het twintig jaar Onder zijn leiding kwamen belangrijke verbeteringen tot stand in "de economische positie van de geestelijke werker", zoals een van de thema's luidde van het Eerste Journalistiek Congres, dat in 1920 werd gehouden in de aula van de "Rotterdamse Handelshoogschool". Dit debat over de materiële positie van de journalist, waarvan zelfs de NDP had erkend dat de belangen dergenen die in onze redactiebureaus voor ons en met ons arbeiden wel wat ver op de achtergrond zijn geraakt, mondde uit in een resolutie, waarin werd gesteld dat de behartiging van materiêle belangen der intellectuelen zo onvoldoende was dat zij in de maatschappelijke strijd der volksgroepen meer en meer ten achter kwamen. (2) Onder het voorzitterschap van Hans heeft de NJK belangwekkende aanzetten gegeven tot verbetering van de rechtspositie van de journalisten in het algemeen en van hen die slachtoffer werden van een nieuw fenomeen, de handel in kranten, in het bijzonder. In de woorden van oud-secretaris van de NJK, C.K. Elout (parlementair redacteur van het liberale Algemeen Handelsblad) was bij dit laatste sprake van moreelen smaad dat een journalist op zekeren dag hoort, dat hij, met de zetmachines en de bureaustoelen (al of niet), is overgedaan als een hond, die aan een andere baas is versjacherd en deze smaad was volgens Elout nog erger dan de nadelige materiële kant van de zaak. (3)

Het belangrijkste initiatief van het NJK-bestuur is de instelling op 9 juni 1923 geweest van een commissie die tot taak kreeg de mogelijkheden tot medezeggenschap van journalisten te bestuderen bij vervreemding van hun krant. Deze negen leden tellende Commissie voor de Medezeggenschap werd voorgezeten door de Leidse hoogleraar in de Staathuishoudkunde en Statistiek prof. mr. D. van Blom, "een bevoegd buitenstaander" , aldus NJK-voorzitter Hans bij de installatie van de commissie op 24 november 1923 , daarbij refererend aan het journalistieke verleden van Van Blom, die parlementair journalist en hoofdredacteur van Het Vaderland was geweest. (4)

De opdracht aan de commissie was Te onderzoeken:

1. op welke wijze, bij voorgenomen verkoop van een dagblad, de medezeggenschap van de berrokken journalisten, of van de organisatie(s) waartoe zij behooren, het best ware te regelen en te verwezenlijken:

2. op welke wijze, voor genoemd geval, de materieele belangen der betrokken joumalisten zoo goed mogelijk verzekerd kunnen worden;

3. of, ook buiten het geval in de vorige punten genoemd, medezeggenschap der journalisten in de leiding wan het dagblad als onderneming wenschelijk en mogelijk is, en zoo ja, op welke wijze.

(1) Joan Hemels De krant in bedriff, pag. 55 .

(2) M. Rooij Het Dagbladbedriff in Nederland pag. 279; Joop Bartman De Kring: hoe eindelijk vakbelangen het wonnen van het autoritje, in het herdenkingsnummer van De Journalist van 1 
februari 1984 t.g.v. 100 jaar georganiseerde joumalistiek.

(3) Geciteerd in Rapport van de werkgroep Redactionele Medezeggenschap, deel $2, \mathrm{pag} .25$.

(4) De overige leden van de redactie waren mr. Gerbert Scholten, secretaris wan de hoofdredactie van het Algemeen Handelsblad; hij bedankte voor de benoeming en werd opgevolgd door Herm. H.J. van de Pol, hoofdredacteur van de Deltsche Courant, die als secretaris zou optreden; mr. Joh. $J$. Belinfante, directeur van het Nederlandsch Correspondentiebureau (ondervoorzitter); $\mathrm{S}$. Bruysten, hoofdredacteur van de Residentiebode; $\vec{F}$. Th. Holsboer, hoofdredacteur van het Deventer Dagblad; W.N. van der Hout, secretaris van de Nederlandsche Journalisten-Kring, redacteur van Het Vaderland; J.K. van Loon, redacteur van De Standaard; Ed. Polak, wethouder van Amsterdam en oud-redacteur wan Het Volk; L.M. Weterings, hoofdredacteur van de Nieuwe Haarlemsche Courant. De woorzitter van de NDP, Chr. A. Vieweg (directeur van de Provinciale Geldersche en Nijmeegsche Courant), die ook voor de commissie - Van Blom was aangezocht, weigerde lid te worden. Hij wilde geheel vrij tegenover het rapport staan.

\subsection{Rapport van de commissie-Van Blom}

\subsubsection{Aanleiding}

Directe aanleiding tot de instelling van de commissie was de verkoop in 1922 van de Nieuwe Courant in Den Haag aan de Nieuwe Rotterdamsche Courant, een verkoop die kort daarop - 5 mei 1923 - gevolgd werd door de overgang van het Nieuws van den Dag naar De Telegraaf, gebeurtenissen, die ook buiten den journalistieke kring aller aandacht in den lande hebben gehad. Algemeen en onverdeeld was de afkeuring, welke in de commissie is tot uiting gekomen over het feit, dat bij de onderhandelingen over den verkoop van de genoemde bladen de belangen der journalisten geen oogenblik zijn ter sprake geweest. De werkelijke positie van het redactioneele personeel van het dagblad, zoals sommige ondernemers die gevoelen en bepalen: in geen enkel opzicht afwijkende van die der andere personeelsgroepen, is daardoor volkomen blootgelegd. (1)

Later zouden zowel de commissie-Van Blom als het NJK-bestuur de beschuldiging aan het adres van de oude en nieuwe eigenaar van Nieuwe Courant gedeeltelijk terugnemen. Ook ten aanzien van de overgang van Het Nieuws van den Dag naar de Telegraaf kwam de commissie tot de erkenning dat zij foute informatie had gekregen. (2)

(1) Rapport der Commissie voor de Medezeggenschap van 29 september 1924, pag. 13. Over de commotie in journalistieke kring rond de verkoop van Het Nieuws van den Dag aan de Vereenigde Drukkerijen, die het blad onmiddellijk doorverkocht aan H.M.C. Holdert, eigenaar van de Telegraaf en De Courant, zie H.J. Scheffer Hewry Tindal. Een ongewoon heer met ongewone bes ognes, pag. $335-359.15(2)$ De Journalist van 1 september en 25 november 1925 , geciteerd in Rapport van de werkgroep Redactionele medezeggenschap, deel 2, pag. 28-30. Zie ook de kritische opmerkingen over beide transacties bij Joan Hemels in De krant in bedrijf, pag. 92.

\subsubsection{Resolutie van het NJK-bestuur}

De reeds gememoreerde commotie in journalistiek Nederland over de verkoop van twee prominente bladen had er in het voorjaar van 1923 al toe geleid dat het bestuur van de Nederlandsche Journalisten-Kring een resolutie aannam, waarin 
zowel op de ideẻle als de materiële aspecten van de krant gewezen werd. Het is de eerste formele uitspraak van de georganiseerde journalistiek over het bijzondere karakter van het industriële produkt "krant". De resolutie luidde:

1. Het uitgeven van een dagblad, hoezeer mede een commercieele onderneming, kan niet op een lijn worden gesteld met eenige andere onderneming, waaraan het maken van geldelijke winst ten grondslag ligt.

2. Een dagblad is een ideeel en cultureel goed, dat, al moge zijn karakter als nieuwsorgaan vaak en terecht de overhand hebben, beschouwd dient te worden als een middel voor de geestelijke, intellectueele en sociale scholing van het publiek.

3. De verkoop van een dagblad, eenvoudig als handelsobject, zonder dat men weet wie eigenlijk het blad koopt, wat er mee gebeuren zal, en in welke richting het verder zal worden geleid, dient scherp te worden veroordeeld.

4. Elke verkoop, waarbij de journalisten, die de geestelijke en intellectueele betekenis van het dagblad hebben bepaald, het slachtoffer dreigen te worden, is reeds uit dien hoofde immoreel. In elk geval dienen voor de verzekering van het belang der betrokken journalisten afdoende maatregelen te worden genomen.

5. Geijverd moet worden voor een zoodanige regeling, waarbij, indien van verkoop van een dagblad sprake is, aan de betrokken journalisten of de organisatie waartoe zij behoren, recht van medezeggenschap wordt gegeven. Deze regeling worde desnoods wettelijk vastgelegd.

In de resolutie vallen vier punten op. Allereerst de prominente positie, namelijk als eerste en tweede lid, van de vaststelling dat een krant geen gewoon produkt is, maar een ideëel en cultureel goed.

Ten tweede is het opmerkelijk dat de resolutie de redactionele medezeggenschap kennelijk beperkt tot het moment van vervreemding van de krant. Dat lag, gezien de directe aanleiding tot de resolutie, ook voor de hand. Bij de installatie van de Commissie-Van Blom gaf NJK-voorzitter Hans echter in overweging te bestuderen of ook overigens - dus buiten het moment van verkoop - medezeggenschap van journalisten in de onderneming als zoodanig mogelijk en wenschelijk is. (1)

Ten derde valt op dat de ideële functie van de krant in de resolutie vrijwel beperkt blijft tot haar culturele betekenis: de krant als middel voor de geestelijkeen intellectuele scholing van het publiek. Dat doet denken aan de allereerste vermelding van de vrijheid van drukpers als grondrecht, i.c. an artikel 227 van de Grondwet van 1815, dat deze vrijheid beschreef als een doelmatig middel tot uitbreiding van kennis en voortgang van verligting. Alleen de vermelding in de NJK-resolutie van het dagblad als middel voor de sociale scholing van het publiek herinnert indirect - de nadruk ligt immers op scholing - aan zijn politieke betekenis en functie. Duitse documenten uit dezelfde tijd, zoals de "Reichstarifentwurf" uit 1920, spreken steeds van de allgemeine politische, wirtschafiliche und kulturelle Richtung van een blad. Geen expliciete verwijzing dus naar een mogelijk negatief effect van de verkoop van de krant op de pluriformiteit van de pers. Zoals hiervoor al vermeld, was in de jaren twintig de kwantitatieve pluriformiteit in de Nederlandse krantenwereld nog geen probleem. De ge- 
dachte van de "waakhondfunctie" van de journalistiek is zelfs bij haar beoefenaren lange tijd onderontwikkeld gebleven. Als de commissie- Van Blom later in haar rapport op de "publieke taak" van de krant zal wijzen, doelt ze daarmee niet op de journalistieke taak om de overheid kritisch te volgen, maar op de hartelijke samenwerking tussen overheid en pers: (....) de overheid erkent de waarde der courant als zoodanig op tallooze wijzen. De journalist, die in den buitendienst werkt, vindt de overheid voorkomend en behulpzaam, de journalist, die zijn be. schouwend werk in de courant levert, kan de beschikking krijgen over allerlei gegevens, welke hij van haar vraagt. (2) Het is dan ook veelzeggend dat pas in 1939 in de NJK-statuten een verwijzing kwam naar de grondwettelijke vrijheid van meningsuiting als grondslag van de Kring. En zelfs toen was niet iedereen van de noodzaak daarvan overtuigd. Volgens sommige leden zou het opnemen van een artikel over de persvrijheid het algemene (niet-politieke) karakter van de NJK aantasten. (3)

Tenslotte laat de resolutie er geen misverstand over bestaan dat de medezeggenschapsclaim in de dagbladonderneming uitsluitend gereserveerd dient te zijn voor de redactie en niet voor de overige werknemers van het dagbladbedrijf. De commissie zou deze claim in haar rapport krachtig onderschrijven. Dit standpunt past bovendien geheel in de controverse die in deze tijd was ontstaan met de "directeurenvereniging", de Nederlandse Dagbladpers. Deze had de NJK onder voorzitter Hans ervan beschuldigd steeds dichter op te schuiven naar een gewone vakbond en zelfs het stakingswapen niet te schuwen, een voorstelling van zaken waar Hans zich krachtig tegen heeft verweerd: Wie de geschiedenis van onzen Kring uit de laatste jaren onbevooroordeeld nagaat, beseft, hoe wij met succes een economische actie hebben gevoerd, maar hoe wij niettemin hebben weten te vermijden, dat onze vereeniging de allures en de methode van een pure economische vakvereeniging aannam. (4)

De al genoemde C.K. Elout, hoewel al vóór de eeuwwisseling binnen de NJK een van de voorvechters van de evolutie van nette-herensociëteit tot volwaardige vakbond (Bartman), schreef an commissie-secretaris Herm. van de Pol over de verhouding journalisten en "arbeiders": Ik acht medezeggenschap inde journalis tiek zeer wenschelijk en beter mogelijk dan in de arbeiderswereld, omdat men bij ons te doen heeft met intellectueelen en dus met menschen, die veel minder licht dan arbeiders ( $i k$ wil niet zeggen: nooit) zich laten meesleepen door leuzen en leiders van buiten. Het vaak geuite bezwaar tegen medezeggenschap: dat de wantrouwen-propaganda der agitatoren toch alles zou fnuiken, geldt dus niet voor de journalistiek. (5) De reactie van de NDP op de resolutie was vrij schamper. De tekst ervan werd anderhalve maand later in het mededelingenblad (MNDP) afgedrukt "als curiositeit" voor het nageslacht over hoe er anno 1923 over de Nederlandse dagbladpers werd gedacht. (6)

(1) Rapport der Commissie voor de Medezeggenschap, pag. 5 .

(2) idem pag. 14.

(3) Dr. N. Cramer 75 jaar in het nieuws; 1884 - 1959; Kroniek van de Nederlandse JournalistenKring. pag. 65/66; Joop Bartman in De Journalist van I februari 1984, pag. 28-29. 
(4) D. Hans in De Journalist van 8 april 1925, geciteerd in Redactionele Medezeggenschap, deel $2, \mathrm{pag}, 26$

(5) Geciteerd in Rapport van de werkgroep Redactionele Medezeggenschap deel 2, pag. 27 en 24.

(6) Joan Hemels De krant in bedriff, pag. 89.

\subsubsection{Enquête van de Commissie-Van Blom}

De commissie, die ruim tien maanden later reeds haar eindrapport afleverde, was begonnen met een nationaal en internationaal onderzoek naar de mate van medezeggenschap bij dagbladbedrijven. Voor dat doel had zij een enquête gehouden onder 42 Nederlandse kranten, waarvan telkens een lid van de redactie en van de directie waren aangeschreven. Over de respons was de commissie teleurgesteld. Van de 42 directies gaven er 17 in het geheel geen antwoord en van de overige weigerden er zeven de vragenlijst in te vullen. Drie antwoorden kwamen binnen van directeuren die tevens hoofdredacteur waren. Dat van de 42 redacties er twaalf helemaal niets van zich lieten horen en twee ervan duidelijke antwoorden op de vragen ontweken, was voor de commissie het meest teleurstellend. De belangrijkste conclusies uit de enquête waren:

1. Van medezeggenschap van de redactie, in de zin van medebeslissingsrecht, is in ons land, zoals de commissie ook wel verwacht had, zo goed als geen sprake. De situatie is nog het gunstigst bij de kranten waarvan de hoofdredacteur tevens directeur is. De commissie meent dat bij deze bladen de belangen der journalistiek (ideèel) en der journalisten (materieel) beter dan anders kunnen worden behartigd. (1) Bij vier bladen bleek de hoofdredactie het recht te hebben tot het bijwonen van de vergaderingen van het college (de raad) van commissarissen dan well van de aandeelhouders.

2. Van "enige medezeggenschap" is sprake bij verschillende dagbladen waar "leidende redacteuren" het recht hebben advertenties te weigeren. Verder signaleert de commissie ến dagblad waar het gebruik schijnt te bestaan, de hoofdredacteur de beschikking te geven over een vaste som per jaar, waaruit hij, geheel naar eigen inzicht, de kosten der redactie kan bestrijden. Op deze wijze zijn de grenzen tussen de bemoeiingen van directie en redactie scherper getrokken en wordt de redactioneele zelfstandigheid verg root. (2)

3. Een vergelijking met de medezeggenschap binnen de dagbladpers in dertien andere landen leert dat Oostenrijk en Duitsland het verst gevorderd zijn. In Duitsland kunnen de journalisten krachtens de bepalingen van de Betriebsrätegesetz uit 1920 als leden van het personeel, door den Bedrijfsraad een inzicht verkrijgen in den commercieelen toestand van de dagbladen, waaraan zij werkzaam zijn. Wat Duitsland betreft wijst de commissie ook op de vorming van een samenwerkingsverband van de organisaties van werkgevers en journalisten (Reichsarbeitsgemeinschaft der deutschen Presse) en op een wetsontwerp (Gesetz betreffend die Rechtsverhältnisse der Redakteure - Entwurf des Reichsverbandes der Deutschen Presse (RDP). Dit wetsontwerp, alsmede het statuut van de Reichsarbeitsgemeinschaft, voegde de commissie als bijlagen toe aan haar rapport. (3) 
Oostenrijk was het verst gevorderd met regelingen waarin de rechtspositie van de journalist was vastgelegd. Er was de Gesetz von 11 Februar 1920 über die Rechtsverhälmisse der Journalisten (Journalistengesetz) die de basis vormde voor collectieve overeenkomsten tussen de Oostenrijkse dagbladuitgevers en hun journalisten. In deze overeenkomsten is de rechtspositie van de journalisten, ook ingeval van opheffing, verkoop of verandering van richting van de courant, geheel bevredigend geregeld. (4)

De commissie zal later dankbaar gebruik maken van deze reeds bestaande regelingen. Zij maakt er geen geheim van dat haar ontwerp voor een collectieve arbeidsovereenkomst naar Duitse en Oostenrijkse voorbeelden is samengesteld. Een van haar belangrijkste aanbevelingen - prohibitief hoge schadevergoedingen voor journalisten bij verkoop, opheffing of verandering van richting van de krant neemt de commissie rechtstreeks over uit de Duitse en Oostenrijkse voorstellen, evenals de vorming van redactiecommissies, zoals reeds in Oostenrijkse wetgeving gerealiseerd.

Geen enkel ander land heeft op medezeggenschapsgebied iets belangrijks te bieden, rapporteert de commissie. In Engeland heeft zij slechts vernomen dat bij enkele kranten een "suggestions-box" aanwezig is (de commissie suggereerde: een wenkenbus mag wellicht het Nederlandsche woord zijn) waarin journalisten die zich ook interesseren voor het commerciële aspect van hun krant wenken en raadgevingen aan de directie kunnen stoppen. (5)

(1) Rapport der Commissie voor de Medezeggenschap.

(2) Idem pag. 9.

(3) Idem pag. $3 \rrbracket-35$.

(4) Idem pag. 12

(5) Idem pag. 10 en 18 .

\subsubsection{Conclusies en aanbevelingen van de commissie-Van Blom}

Het eigenlijke rapport begint met een hoofdstuk Algemeene beschouwingen waarin de commissie nadrukkelijk het tweeledige karakter van de krant onderschrijft: enerzijds een commercieel produkt, anderzijds een cultureel goed. De journalisten die eraan werken zijn niet te vergelijken met andere personeelsleden, al denken veel ondernemers, die hun krant uitsluitend als winstobject zien, dat wel. Op zichzelf, aldus de commissie, is er niets ongeoorloofds aan de verkoop van een krant. Ongeoorloofd acht zij slechts dat ondernemers zich van hun krant ontdoen zonder zich te vergewissen, dat het cultureele goed, hetwelk door den arbeid der redactie in hunne courant is belichaamd geworden, in stand blijft en de journalisten, die vaak hun leven er aan hebben gewijd, eraan verbonden blijven, of op andere wijze dan met eenvoudig ontslag op korten termijn worden beloond voor de jarenlange vervulling van hun taak. Het moet, voorzoover dat niet reeds is geschied, doordringen tot de kringen van aandeelhouders van couranten, dat een courant sinds jaren niet meer een gewoon handelsobject is als zoovele andere. 
De joumalisten zijn de geestelijke verzorgers van hun krant; welke juist commerciel bijzondere voordeelen geniet van de wijze van behartiging van de publieke zaak door de aan haar verbonden journalisten, van de standing welke haar door den bijzonderen arbeid der journalisten wordt gegeven. (1)

De behartiging van de publieke zaak vloeit volgens de commissie voort uit de "publieke taak" van de redactie. De commissie introduceert dit nieuwe begrip van welke de belangrijkheid door niemand kan worden ontkend. Waar dit zoo is, behooren verouderde begrippen baan te maken woor nieuwe: Onder "publieke taak" verstaat zij de dienst die de redactie bewijst aan zowel het publiek, dat de krant als leider van zijn opinie aanvaardt, als aan de overheid. De krant kan, als voorlichtster van het publiek, haar publieke taak alleen goed vervullen, wanneer de commerciële en redactionele zaken gescheiden zijn. (2) Het voor Nederland kennelijk nieuwe begrip "publieke taak" was de vertaling van "öffentliche Aufgabe", een term die in Duitsland sinds het begin van de jaren twintig opgang begon te doen om de bijzondere functie van de pers te beschrijven.(3) De commissie moest vervolgens het begrip "medezeggenschap" uit haar opdracht nauwkeurig formuleren. Daar was namelijk geen eenstemmigheid over. Een radicale minderheid was van mening dat medezeggenschap uitsluitend in den gangbaren politieken zin moest worden verstaan, namelijk in de betekenis van medebeslissingsrecht van de journalisten in de leiding van het dagblad.

De commissie als geheel kwam echter tot de conclusie dat medebeslissingsrecht wel mogelijk, maar niet wenselijk is en afgezien nog van de bezwaren voor de onderneming, bezien van economisch standpunt, daaruit voortvloeiend, voor de journalisten zelf eer een achteruitgang dan een vooruitgang zou wezen. Zij streven altij, en terecht, naar een zoo groot mogelijke zelfstandigheid en onafhankelijkheid op hun eigen, redactioneel terrein. Hoe zou daarmee overeen zijn te brengen een ander streven, dat hen middenin de commercieele beslommeringen wan het bedrijf zou trekken? Zij moeten, consequent zijnde, zich daarvan integendeel volkomen vrijhouden. De commissiemeerderheid werd nog in haar standpunt versterkt door een brief van het bestuur van de NJK waarin dit bevestigde dat er voor de journalisten geen aanleiding is voor een actie, om ook "op den stoel der directie" een platats te krijgen. (4) De commissie vindt permanent overleg van de redactie met de directie noodzakelijk over alle aangelegenheden van commerciële aard die ook de belangen van de redactie of de ideële belangen van de onderneming raken. Als voorbeeld van hoe het niet moet noemt de commissie een genoegzaam bekend geval van de wens van een directie om op de achterpagina van de krant, die tot nu toe steeds voor redactionele bijdragen was gereserveerd, een rubriek op te nemen met mededelingen over adverteerders en hun produkten. Zo'n rubriek mag dan commercieel aantrekkelijk zijn, zij sticht echter, volgens de commissie, verwarring bij de lezers, die vaak denken dat de rubriek van de redactie afkomstig is.

Wat de vorm van het permanent overleg van de redactie met de directie betreft doet de commissie vervolgens een stoutmoedig voorstel: een vertegenwoordiger 
van de redactie zou toegelaten moeten worden tot het college (de raad) van commissarissen, waarin dit redactielid een adviserende stem zou hebben. Als het dagblad wordt uitgegeven door een vereniging, een vennootschap onder firma of door een of meer particuliere personen zou de redactievertegenwoordiger de vergaderingen van het bestuur, van de vennoten of de eigenaren moeten bijwonen. De journalisten zouden via hun redactievertegenwoordiger een permanente uitkijkpost in de leiding van de krant krijgen, waardoor ze een goed inzicht zouden krijgen in de commerciële toestand van de krant. Ze zijn wel niet verantwoordelijk voor de commerciële gang van zaken, maar het eenvoudig kennisnemen van die zaken hoeft hun ook niet onmogelijk te worden gemaakt. In het "college van commissarissen" zal de redactievertegenwoordiger de gelegenheid hebben krachtig te pleiten voor de redactionele belangen, temeer omdat, aldus de commissie, bij lang niet alle kranten de commerciële leiding die behoeften begrijpt. De vertegenwoordiger moet vanaf het begin tot het eind op de hoogte gehouden worden van onderhandelingen over de opheffing of verkoop van de krant en het recht hebben, in de vergaderingen waarin beslist wordt over verkoop of opheffing, de belangen van de redactie te bepleiten. De vertegenwoordiger is verplicht tot geheimhouding tegenover iedereen, waar de directie hem deze heeft opgelegd, maar niet tegenover de redactie terzake van omstandigheden, welker verzwijging overwegend nadeel voor leden der redactie moet tengevolge hebben.. De gekozen redactievertegenwoordiger zou eigenlijk altijd de hoofdredacteur moeten zijn, vindt de commissie, maar zij heeft er begrip voor wanneer de redactie liever iemand anders kiest, omdat de redactie dien titularis niet altijd beschouwt als haar natuurlijken vertegenwoordiger. Wanneer de hoofdredacteur niet gekozen wordt pleit de commissie er voor hem qualitate qua in het "college van commissarissen" toe te laten. Dit laatste heeft zij echter niet in haar ontwerpCAO opgenomen.

Dat uitsluitend de redactie recht heeft op een plaats in het college van commissarissen vloeit voor de commissie voort uit het ideële en culturele karakter van de krant. De redactie maakt den naam en het karakter der courant. Neemt men haar, met haar hoofdredacteur, collectief van de courant weg, vervangt men haar dan door een gelijkheid van getal, dan is de courant dezelfde courant niet meer. (......) Een zetter, een boekhouder, kan een hoogst verdienstelijk man voor de onderneming wezen, hij en de zijnen kunnen evengoed aan een andere onderneming tewerk gesteld worden, zonder dat het karakter der courant naar buiten daardoor een wijziging zal ondergaan.

De commissie verheelt niet dat zij ook wel problemen met haar voorstel voorziet. Zij vermoedt zelfs dat de meeste dagbladondernemers het nut van een redactielid in het "college van commissarissen" niet zullen erkennen. Het belangrijkste bezwaar blijft dat een redactievertegenwoordiger met slechts adviserende stem in de leiding van het bedrijf een voor de redactie ongewenste vervreemding, opheffing of richtingverandering van de krant niet kan verhinderen. Hoeveel voordeelen ook aan den permanenten uitkijkpost der redactie in het college van commissarissen zijn verbonden, bij voorgenomen verkoop verschaft hij geen zekerheid, 
dat de materieele belangen der journalisten voldoende zullen worden verzorgd. Dé commissie meent die zekerheid op andere wijze te kunnen verkrijgen. Zij zou de verzorging der materieele belangen van de journalisten in zoo'n geval willen zien opgenomen in een algeheele regeling der rechtspositie. (5) Met dit laatste doelde de commissie op een regeling door middel van een $\mathrm{CAO}$.

(1) Rapport der Commissie voor de Medezeggenschap, pag. 14 en 15.

(2) Idem pag. 14 en 15.

(3) Zie 3.4 "Die öffentliche Aufgabe der Presse" in de jaren '20.

(4) Rapport der Commissie voor de Medezeggenschap, pag. 17.

(5) Idem pag. 24.

\subsubsection{Ontwerp voor een CAO van de commissie-Van Blom}

De algehele regeling der rechtspositie, die de commissie-Van Blom gewenst achtte, bestaat uit een ontwerp voor een (eerste) collectieve arbeidsovereenkomst voor dagbladjournalisten, naar voorbeelden uit Duitsland en Oostenrijk. In tegenstelling tot de typografen, die reeds in 1914 een CAO hadden afgedwongen, kenden de journalisten, die zich in georganiseerd verband aanvankelijk slechts schoorvoetend met materiële zaken wensten bezig te houden, sinds oktober 1919 een salarisregeling van de NJK en de in 1903 opgerichte (katholieke) RKJV met de NDP, waaraan de individuele leden van de NDP weliswaar niet gehouden waren, maar die toch vrij algemeen werd nagekomen. (1) Deze salarisregeling bevatte o.a. getalsverhoudingen, drie jaarweddeklassen, oplopend van $C$ naar $A$ (maximaal 4.000 gulden per jaar), zonder functie-omschrijving, waarin overigens de hoofdredacteuren niet ingepast waren, en vier gemeenteklassen, afhankelijk van de vestigingsplaats van de krant. Dit leidde tot aanzienlijke salarisverschillen: een leerling in Eindhoven kreeg 600 gulden per jaar; in Amsterdam begonnen leerlingen met 800 gulden. Na afsluiting van de leerlingentijd werd het verschil nog groter: 1.000 gulden per jaar en 1.500 gulden. (2)

Een opvallend onderdeel in het ontwerp voor de CAO is hoofdstuk IV, met daarin de reeds aangekondigde regeling van de rechtspositie van journalisten wanneer hun krant van richting zou veranderen, dan wel verkocht of opgeheven wordt. De grondgedachte is deze: wanneer het ongewenst is de redactie een medebeslissingsrecht te geven in geval van richtingverandering of verkoop, waarbij journalisten hun baan zouden verliezen, dan moeten de gedupeerden financiële schadeloosstellingen krijgen die voldoende zijn om een tijdelijke verzorging der getroffen journalisten te verzekeren. (3) De uitkeringen zouden bovendien zo royaal dienen te zijn dat ze een prohibitief effect zouden hebben. Op dat element wees ook C.K. Elout in een persoonlijke reactie op het rapport van de commissie: (...) Overigens komt het mij voor, dat de artikelen 15, 16 en 17 een gelukkige oplossing bieden voor de moeilijkheden op dit punt en dat daarin, doordien de verplichting tot schadevergoeding remmend zal werken op verkoopers, ook het moreele element voldoende is beschermd. (4) De betreffende bepalingen in de con- 
cept-CAO van de commissie luiden:

Art. 15 Verandering van richting: 1. Wanneer een courant van richting verandert, heeft een journalist (.....) die zijn werkzaamheden aan die courant niet zou kunnen voortzetten zonder zijn overtuiging geweld aan te doen, het recht zijn dienstverband te verbreken zonder inachtneming van de opzeggingstermijnen, in deze collectieve overeenkomst vastgelegd.

Art. 16 Verkoop: 1. Wanneer een courant wordt verkocht, moet de kooper binnen een maand na den koop den journalisten (....) hoofdelijk mededeelen, of hij hun dienstverband met de onderneming al dan niet wenscht over te nemen. Indien hij deze mededeeling achterwege heeft gelaten of heeft medegedeeld, dat hij het dienstverband der journalisten met de onderneming handhaaft, dan heeft hij niet het recht hun binnen twee jaren na den koop ontslag aan te zeggen. In de voorwaarden van het dienstverband der journalisten mag bij verkoop geen wijziging ten ongunste worden gebracht.

2. Een journalist (....) heeft het recht zonder inachtneming van de opzeggings -

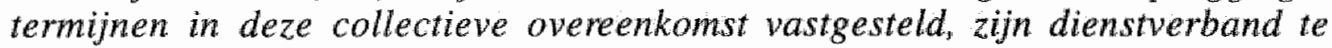
verbreken, indien hij meent, dat door de handhaving van zijn dienstverband met den nieuwen eigenaar het aanzien, dat hij in het vak geniet, wordt geschaad. Is de nieuwe eigenaar van oordeel, dat de verbreking van het dienstverband zonder geldige reden is geschied, dan kan hij de beslissing van het scheidsgericht inroepen, ( .........)

Artikel 17 Uitkeeringen: 1 . In de gevallen bedoeld in de artikelen 15 en 16 alsmede in geval van opheffing der courant, ontvangen de journalisten (.......) wier dienstverband eindigt een uitkeering van een jaar salaris, indien zij minder dan zes jaar, benevens twee maanden salaris voor elk jaar, dat zij meer dan zes jaar aan de courant verbonden zijn geweest. (.....)

2. De leerlingen (.......) ontvangen in deze gevallen drie maanden salaris.

De afkooptermijnen van de commissie-Van Blom komen vrijwel overeen met die uit de Oostenrijkse Gesetz von 11 Februar 1920 über die Rechtsverhältnise der Journalisten (Journalistengesetz). (5) Vergeleken met Duitse ontwerp-regelingen uit dezelfde tijd, zoals de in het volgende hoofdstuk nader te bespreken Reichstarifentwurf: van de Reichsverband der deutschen Presse (RDP) uit 1920 en het ontwerp voor een Gesetz betreffend die Rechtsverhältnisse der Redakteure van dezelfde journalistenorganisatie uit 1924, hanteert de commissie-Van Blom afkooptermijnen die ongeveer twee keer zo royaal zijn. Een ander opvallend verschil met Duitse en Oostenrijkse regelingen is dat het commissie-ontwerp in artikel 15 weliswaar de mogelijkheid oppert dat een krant van richting kan veranderen, maar dat het in het geheel niet aangeeft wie daartoe in de regel bevoegd is. In elke Duitse en Oostenrijkse ontwerp-regeling - ook wanneer een journalistenorganisatie als de RDP daartoe het initiatief nam - was de Grundsatzkompetenz (de bevoegdheid om de redactionele beginselen vast te leggen) nadrukkelijk genoemd als prerogatief van de uitgever.

Het CAO-ontwerp van de commissie bevat eveneens enkele voor dit onderzoek 
belangrijke bepalingen over verhouding directie-hoofdredacteur-redactie. Bijna vijftig jaar later zullen de model-redactiestatuten bepalingen bevatten die inhoudelijk en hier en daar zelfs tekstueel overgenomen zouden kunnen zijn uit dit ontwerp. De belangrijkste zijn:

Art. 9 Taakverdeeling: 1. De hoofdredacteur van eene courant wijst elk zijner redactioneele medewerkers, in overleg met de redactiecommissie, bedoeld in art. 12.1 hum taak aan. Hij kan in deze taakverdeeling; in overleg met de redactiecommissie en met toestemming der betrokken medewerkers, verandering aanbrengen. (.......)

Art. 11 De leiding der courant: De hoofdredacteur of zijn plaatsvervanger heeft de journalistieke leiding der courant. Hij is verantwoordelijk voor den redactioneelen inhoud, voor zoover die verantwoordelijkheid niet blijkens de onderteekening of aanduiding op andere wijze van bijdragen door anderen wordt verkregen.

Het laatste artikel is niet alleen de bevestiging van het tweeledige karakter (journalistiek en commercieel) van de krant, maar vooral een formele profilering en opwaardering van de functie van hoofdredacteur ten opzichte van de directie: over het journalistieke gedeelte van de krant is niet de directeur maar de hoofdredacteur de baas. Impliciet was het artikel tevens een afkeuring van de combinatie directeur-hoofdredacteur en van de situatie bij sommige kranten, waar in het geheel geen hoofdredacteur in functie was.

In artikel 9 is neergelegd op welke wijze de hoofdredacteur zijn verantwoordelijkheid uitoefent: hij alleen geeft de journalisten aanwijzingen omtrent het werk dat zij moeten doen. Deze bevoegdheid kan echter gecorrigeerd worden door een vergaande vorm van redactionele inspraak. Wanneer de hoofdredacteur de taak van een ondergeschikte wil veranderen, heeft hij namelijk de instemming van de redactiecommissie en de betrokkene nodig. Bij verschil van mening beslist een extern orgaan, het permanent scheidsgerecht, bestaande uit zeven personen: drie aangewezen door de NJK, drie door de NDP en een door deze zes gekozen neutrale voorzitter.

De Oostenrijkse Journalistengesetz kende eveneens een paritair samengesteld Schiedsgericht $(\$ 12)$, doch van vijf personen, twee van elk der partijen en een Mitglied der Nationalversammlung als Obman. Het Duitse $\mathbb{R D P}$-ontwerp voor een Geserz betreffend die Rechtsverhältnisse der Redakteure uit 1924, eveneens als bijlage bij het rapport gevoegd, gaat uit van de instelling van een Pressekammer bij elk Oberlandesgericht. ( $\$ \$ 16$ en 17).

Art. 12 De redactiecommissie: 1. Aan elke courant, waaraan meer dan vier journalisten verbonden zijn, bestaat een redactiecommissie van ten hoogste drie leden. Zij draagt zorg voor de nakoming van de bepalingen van deze collectieve overeenkomst en behartigt de belangen der journalisten, aan de courant verbonden. $(\ldots . . .$.

5. De hoofdredacteur kan geen lid van de redactiecommissie zijn. Hij heeft wel het actieve kiesrecht.

De commissie-Van Blom was zo'n redactiecommissie ook tegengekomen in para- 
graaf 5 van de collectieve overeenkomst tussen de Oostenrijkse vereniging van dagbladuitgevers en de organisatie van Weense journalisten. Zij ontbreekt in het RDP-ontwerp voor een Gesetz betreffend die Rechtsverhälmisse der Redakteure. De Duitse Reichstarifentwurf uit 1920 voorziet wel in een Redaktionsausschuß (\$ 24) voor toezicht op naleving van de $\mathrm{CAO}$, doch naast een Redaktionskonferenz $(\$ 25)$ die er is voor overleg met de hoofdredacteur.

Uit de Memorie van Toeliching bij haar rapport (pag. 80) blijkt dat de commissie-Van Blom nog een reden had om een redactiecommissie gewenst te vinden, en wel omdat zij, zoals uit haar rapport is gebleken, zich op het siandpunt heeft ge steld, dat de hoofdredacteur niet steeds is de natuarlijke vertegenwoordiger der journalisten. Redactievergaderingen mogen in de meeste gevallen, dat zij zijn ingevoerd, een mislukking zijn geweest, een redactiecommissie heeft krachtens deze collectieve overeenkomst zoo"n belangrijke positieve taak, dat zij geen mislukking worden kan.

Art. 13 Redactie en directie: 1. De behandeling van aangelegenheden van zuiver redactioneelen aard berust uitsluitend bij den hoofdredacteur en de redactiecommissie. De directie onthoudt zich van inmenging in deze aangelegenheden. Ingeval deze bij haar worden aangebracht, stelt zij de afdoening ervan in handen van den hoofdredacteur.

2. In aangelegenheden, welke zowel de redactie als de directie betreffen, handelt de directie niet dan na gepleegd overleg met den hoofdredacteur en, waar zulks in het belang van de courant wenschelijk is of uit deze collectieve overeenkomst voortvloeit, ook met de redactiecommissie.

Lid 1 van dit artikel is een nadere uitwerking van het in art. 11 neergelegde beginsel dat de hoofdredacteur de leiding heeft over het redactionele deel van de krant. Lid 2 geeft een regeling voor de, vaak voorkomende, gevallen, dat een directionele beslissing direct of indirect gevolgen kan hebben voor de redactie. Het zal in de latere redactiestatuten, verder uitgewerkt en gecomplementeerd door een overlegplicht van de hoofdredacteur met de directeur, terugkeren.

(1) In het ontwerp van de commissie-Van Blom zat een opvallende overeenkomst met de typografen-CAO, namelijk het closed-shopbeding. Werkgevers verenigd in de NDP moesten zich volgens het ontwerp verplichten geen journalisten in dienst te nemen die geen lid waren van de Nederlandsche Journalisten-Kring, terwij] NJK-leden zich zouden verplichten alleen bij NDP. leden in dienst te treden. (Art. I "Rechtskracht der overeenkomst"). Ditzelfde closed-shopbeding was aanvanke lijk ook opgenomen in de eerste journallisten-CAO van 1948, maar werd er uit verwijderd omdat het College van Rijksbemiddelaars er anders zijn goedkeuring aan zou onthouden.

(2) Bartman in De Journalist van 1 februari 1984, pag. 27; Schuijt Werkers van het woord. pag.

227; Joan Henels De krant in bedrijf pag. 79 e.v.

(3) Rapport der Commissie voor de Medezeggenschap, pag. 25.

(4) Geciteerd in Rapport van de werkroep Redactionele Medezeggenschap, deel 2, pag. 25.

(5) $\$ 88$ tot en met 11 , opgenomen in het Rapport der Commissie, pag. 43 en 44

\subsubsection{Resultaten van het rapport van de commissie-Van Blom}

Het bestuur van de NJK, hoewel met groote waardering kennis genomen heb- 
bend van den belangrijken arbeid, verricht door de commissie-Van Blom, vond dat de $\mathrm{CAO}$-voorstellen die de commissie in haar rapport ten beste had gegeven voorlopig te hoog gegrepen waren voor de meerderheid van de leden van de Kring. Op de buitengewone algemene ledenvergadering van (zondag) 17 mei 1925 herinnerde het bestuur eraan dat de belangrijkste opdracht van de commissie was geweest om een regeling te treffen voor de journalisten bij de verkoop van hun krant. Dit punt, aldus het bestuur, is het meest urgent.

Het bestuur nam in een concept-motie zelfs afstand van een van de meest essentiẻle onderdelen van het commissierapport, namelijk het voorstel van de permanente vertegenwoordiging van de redactie in de raad wan commissarissen. De motie nam er al genoegen mee dat een redactielid bij de verkoop van een blad via de commissarissen geinformeerd zou worden over de gang van zaken. De algemene ledenvergadering wilde zover zelfs niet gaan. Zij nam slechts één onderdeel van een door het bestuur voorgestelde motie aan: allereerst te streven naar verbetering van de positie der journalisten bij den verkoop van bladen. Daarbij moest de nadruk liggen op de financiële uitkering aan journalisten die bij de verkoop van de krant hun baan zouden verliezen.

Het NJK-bestuur, dat met de NDP over deze wens van de leden heeft onderhandeld, bereikte niet veel. De NDP, die zich bijzonder boos had gemaakt over de beschuldigingen in het rapport van de commissie-Van Blom dat bij de overname van Het Nieuws van den Dag en van de Nieuwe Courant geen rekening was gehouden met de belangen van de betrokken journalisten, was evenmin ingenomen met de vergaande voorstellen van de commissie. "Weltfremd" en "kleurige fantasieën" werden ze in het NDP-orgaan genoemd. Over het voorstel van de commissie-Van Blom om een redactievertegenwoordiger in de raad van commissarissen toe te laten deed het artikel in het NDP-blad zeer laatdunkend. Niet alleen werd betwijfeld of zo'n redacteur wel voldoende commercieel inzicht zou bezitten (Het is immers niet ongewoon, dat journalisten zekeren afkeer aan den dag leggen voor advertentiën en abonnementen en alles wat daarmede in verband staat ......) het risico was volgens de (anonieme) NDP-auteur ook groot dat aandeelhouders bij verwezenlijking van het voorstel hun bezit van de hand zouden doen en dat nieuwe kapitaalverschaffers niet meer gevonden zouden worden. En van een collectieve arbeidsovereenkomst ("de strijdmethode van den arbeider") wilde de NDP helemaal niets weten.

De enige "concessie" die de NJK binnenhaalde was het uitspreken van de wenselijkheid door de NDP-leden om na de verkoop van een krant overleg te plegen met de NIK ten einde, voor zooveel nog noodig, inlichtingen te ontvangen, opdat de behartiging der personeelsbelangen geschiede op de meest redelijke wijze. (1) Dat was wel heel ver verwijderd van wat de commissie-Van Blom had voorgesteld.

Achteraf kan men zich de vraag stellen waarom de NJK zo weinig met de uitkomsten van het rapport van de commissie-Van Blom heeft gedaan en zelfs genoegen heeft genomen met een zeer vage toezegging over de belangenbehartiging van journalisten bij verkoop van een krant. Twee factoren hebben daarbij een rol 
gespeeld:

1. Het NJK-bestuur, aangevallen door de NDP op het punt van het beweerde vakbondskarakter van de Kring, had zich daar zo sterk tegen verzet, onder meer door al bij voorbaat het stakingswapen uit te sluiten, dat de journalisten slechts symbolisch "economische actie" hadden kunmen voeren. De NDP aan de andere kant was vastbesloten geen collectieve arbeidsovereenkomst te sluiten, laat staan journalisten in de bedrijfsleiding mee te laten praten. Dat de commissie-Van Blom beide zaken, de CAO en de medezeggenschap van journalisten in de raad van commissarissen, met elkaar verbonden had, speelde volgens Hemels (2) de NDP in de kaart. Elke actie van de NJK zou bij voorbaat verloren zijn.

2. Vooral sinds 1923 , toen het weer wat beter ging met de kranten, waren de arbeidsvoorwaarden van de journalisten geleidelijk verbeterd. Per 1 januari 1923 werd bij 28 dagbladen de eerste pensioenovereenkomst voor journalisten van kracht. In 1927 noemde NJK-voorzitter Hans de situatatie van de journalisten wat betreft hun salaris en pensioen over het algemeen niet onbevredigend. Mede daardoor zou de eens levendige discussie over inspraak- en medezeggenschapsregelingen verflauwd zijn. (3)

Zolang de NDP niet bereid was over een collectieve arbeidsovereenkomst te praten, streefde de NJK ernaar, samen met de directeurenvereniging, ten minste een modelcontract op te stellen, waarvan de nakoming weliswaar niet bij de individuele werkgevers kon worden afgedwongen, maar waarvan toch een moreel dwingend effect zou uitgaan. Pas in 1931 is zo'n model-arbeidscontract, dat als, niet verplichte, algemene norm zou gelden, tot stand gekomen. (4) De NJK besloot het model als minimum te aanvaarden, omdat het beschouwd kan worden als een eerste stap naar een volkomen bevredigende regeling der rechtspositie. (5) De belangrijkste winst voor de (hoofd)redactie was de nieuwe bepaling, dat de directie pas journalisten zou benoemen en ontslaan na overleg met de hoofdredacteur. Ten aanzien van de positie van journalisten bij de verkoop van een krant werd afgesproken:

- dat in het algemeen de voorwaarden van de dienstbetrekking ongewijzigd zouden blijven;

- dat bij ontslag de journalist een uitkering zou krijgen waarvan het bedrag afhankelijk is van de omstandigheden. Tot die omstandigheden behoren de financiële toestand van het blad en diensttijd, leeftijd en salaris van de journalist.

De commissie-Van Blom heeft zich niet gewaagd aan adviezen in de richting van een wettelijke regeling van de rechtspositie van de journalist. De NJK-resolutie van 9 juni 1923, waarop haar opdracht was gebaseerd, zinspeelde wel op die mogelijkheid. Lid 5 van de hiervoor $(\$ 2.4 .2)$ geciteerde resolutie vroeg daar immers om. De commissie had ook via de beschikbare Duitse literatuur aan een wettelijke regeling kunnen denken. Zij heeft er, om niet meer te achterhalen redenen, van afgezien. (6)

(1) Geciteerd in Joan Hemels Krant in bedrijf, pag. 92.

(2)Joan Hemels Krant in bedriff, pag. 91.

(3) Idem, pag. 93 
(4) Over de achtergrond van de aanzienlijk verbeterde rellaties tussen de NJK en de NDP zie Joan Henels De kran in bedriff, pag. 108 e.v.

(5) De Journalist van 31 augustus 1931 , geciteerd in Rapport wan de werkgroep Redactionele we dezeggenschap, deel 2, pag. 38, zie ook Hemels De krant in bedrif, pag. 112.

(6) Pas midden jaren dertig zou in ons land "perswetgeving" - dit keer echter de invoering van aanvullende strafrechtelijke bepalingen - serieus in overweging worden genomen. Bij de algemene beschouwingen over de begroting van 1936 werd aangedrongen op wijziging van artikel $7 \mathrm{Gw}_{*}$ teneinde "persexcessen" met een wettelijk geregelde preventieve censuur te kunnen bestrijden. Het is bij plannen van een statscommissie gebleven. De aandacht van regering en parlement voor de pers hing naw samen met de politieke situatie in die jaren, in het bijzonder met de opkomst van de NSB. Over de vooroorlogse discussie over verschijningsverboden zie de gelijknamige paragraaf in J.M. de Meij Uitingsyrijheid, pag. 19; over de Nederlandse pers aan de vooravond van de Tweede Werelloorlog zie de Leidse dissertatie van René Vos Niet voor" Publicatie (1988), pag. 35 - 49.

\subsection{Samenvatting}

Een krant is een ideëel bezit. Een brok geestelijke arbeid. De krant is, financieel, economisch, van zijn eigenaar. De krant is geestelijk van ons. Wij maken haar. Haar waarde, haar betekenis, haar invloed, haar rechtschapenheid als orgaan der publieke opinie wordt bepaald door ons. Met deze woorden reageerde NJKvoorzitter D. Hans begin 1922 in het verenigingsorgaan De Journalist op de overneming door de Nieuwe Rotterdamsche Courant van de Nieuwe Courant zonder dat de redacteuren in de verkoop gekend waren. Een jaar later kreeg De Telegraaf het Nieuws van den Dag in handen, wat neerkwam op het verdwijnen van het Nieuws van den Dag als zelfstandige krant. Beide transacties, die in journalistieke kringen grote onrust hadden veroorzaakt, leidden tot de instelling van een commissie onder leiding van de Leidse hoogleraar prof. mr. D. van Blom, die een rapport uitbracht over medezeggenschap van journalisten bij voor de redactie belangrijke beslissingen van de uitgever, zoals opheffing of vervreemding van de krant.

De commissie, die zich duidelijk liet inspireren door ontwikkelingen in Duitsland en Oostenrijk, kwam tot vier conclusies:

A. Het dagblad is geen gewoon handelsobject, maar een cultureel goed van de redactie. Deze gedachte was geen gedurfde theorie van bevlogen kamergeleerden, maar drukte het algemene gevoelen uit van de journalistiek in de jaren twintig. De gedachte leeft nog steeds, zij het dat thans de informerende en meningvormende functie van de krant sterker benadrukt wordt dan de culturele betekenis ervan.

B. Bij verkoop van de krant moet de nieuwe eigenaar rekening houden met de belangen van de journalisten. Prohibitief hoge uitkeringen aan journalisten bij verkoop van de krant of verandering van richting moeten die belangen beschermen.

C. De redactie kan als voorlichtster van het publiek haar "publieke taak" alleen dan goed vervullen, wanneer zij permanent overleg kan voeren met de directie. Daarvoor dient een redactievertegenwoordiger een adviserende stem te krijgen in de raad van commissarissen.

D. De rechtspositie van journalisten, inclusief de taakverdeling tussen hoofdre- 
dactie en directie, dient geregeld te worden in een collectieve arbeidsovereenkomst.

Achteraf kan men concluderen dat de commissie-Van Blom, die toch moet hebben geweten dat een collectieve arbeidsovereenkomst onhaalbaar was, een rapport heeft afgeleverd dat voor de praktische uitvoerbaarheid teveel de geest van de studeerkamer ademde. Het rapport van de commissie heeft dan ook nauwelijks effect gesorteerd. De aanbevelingen bleken te hoog gegrepen voor de georganiseerde journalistiek, die niet bereid en ook niet in staat was ze bij de werkgevers af te dwingen. De werkgeversvereniging, die overigens zelf geen collectieve arbeidsovereenkomst kon afsluiten, werkte vanaf het begin van de jaren twintig mee aan het verbeteren van de arbeidsvoorwaarden van de journalisten en aan een pensioenvoorziening. Dit heeft de discussie over inspraak in de loop der jaren doen verstommen.

Het volgende hoofdstuk zal overigens een parallelle ontwikkeling in het Duitsland van de jaren twintig tonen: ook hier ruilden journalisten hun aanspraak op medezeggenschap in voor betere salarissen en pensioenen. 


\section{Hoofdstuk 3}

\section{"Innere Pressefreiheit" in Duitsland $(1920$ - 1933)}

\subsection{Inleiding}

Het rapport van de Nederlandse commissie-Van Blom van 29 september 1924 over de medezeggenschap constateerde reeds dat alleen in Duitsland en Oostenrijk vorderingen waren gemaakt met (ontwerp)wetgeving die het institutionaliseren van de redactionele medezeggenschap ten doel moest hebben. De comnissie viel, wat Duitsland betreft, midden in een levendige en achteraf gezien zeer vruchtbare discussie over dit onderwerp, waaraan uitgevers, journalisten, juristen, vertegenwoordigers van de opkomende wetenschap der "Publizistik" en hoge ambtenaren van het ministerie van binnenlandse zaken deelnamen. Deze discussie werd mede beïnvloed door de wetgeving ten behoeve van de pers in het algemeen en de journalisten in het bijzonder die in Oostenrijk reeds tot stand was gebracht. (1)

De "Weimarer Republik" kenmerkte zich niet uitsluitend door politieke en economische chaos, die uiteindelijk zou leiden tot de katastrofe van de Hitler-dictatuur. Vooral onder invloed van een nieuwe grondwet is de Weimarperiode onder meer op het gebied van de theoretische onderbouwing van de redactionele onafhankelijkheid, niet alleen tegenover de staat, maar ook tegenover uitgevers en andere economische belangengroepen, buitengewoon inspirerend geweest. Volgens Walter Jänecke, die in de jaren twintig (aan werkgeverszijde) een rol speelde bij de totstandkoming van de eerste arbeidsovereenkomsten in de dagbladpers, dwongen de problemen rond de wederopbouw van staat, economie en pers alle betrokkenen tot extra inspanningen. Ungeachtet der bestehenden tiefen politischen Gegensätze und der daraus folgernden Meinungsverschiedenheit über die der Presse gestellten Aufgaben fanden sich Verleger und Journalisten mit dem klaren Willen zusammen, dieser wieder erneuerten Presse die festen ethischen, sozialen und wirtschaftlichen Grundlagen zu geben, dever sie zur Erfullung ihrer Aufgaben damals besonders bedurfte. (2) In het begin van de jaren twintig hebben journalisten en uitgevers, apart en soms samen, of in nauw overleg met de Pressereferat in het rijksministerie van binnenlandse zaken (RMI) onder leiding van de, volgens Jänecke, an Pressefragen (.....) auch als Persönlichkeit leidenschaftich interessierten Ministerialdirektors $\mathrm{d} r$. Kurt Haentzschel, wetsontwerpen en collectieve arbeidsovereenkomsten op papier gezet die manchmal ( ...) den Einfluß der Stunde allzudeutlich erkennen lassen, die aber auch zu Lösungen kommen, die Bausteine des neuen Presserechts werden können.

(1) Deutsche Presse, Jg. 1920/ Nr. 37, Pag. 6, geciteerd door Rudolf Stöber in: Kontroversen um ein Joumalistengesetz in: Publizistik 1990, Heft 3, pag. 268. Over de "Pionierstellung" van Oostenrijk "bis in die juingste Vergangenheit" zie ook de uitgebreide noot in Edwin Kau Die 
Mitbestimmung in Presseuntemehnen. 1980, pag. 50.

(2) Walter Jänecke Verleger-Redakteur. Die Rechtslage und die Wirklichkeit; in: Festschrift fitr Anton Betz (1963), pag. 53 e.v.

(3) Karl Bringmann: Die Presse und ih Recht-Refornentwüre als Dokwment und Selbstzeugnis (1924-1933) in: Fesischrift für Anton Betz, pag. 118.

\subsection{Historisch overzicht}

De Weimarer Verfassung van 11 augustus 1919 erkende voor het eerst in de Duitse geschiedenis de vrijheid van meningsuiting als grondrecht. Zeventig jaar eerder had de Nationalversammlung van de "Deutsche Bund" in maart van het revolutiejaar 1848 in de Paulskirche van Frankfurt een Reichsverfassung aangenomen die in artikel 4 de vrijheid van meningsuiting en de persvrijheid beschermde (1) maar de liberale beweging, die deze en andere politieke eisen had afgedwongen, werd een jaar later met wapengeweld onderdrukt. In de Reichsverfassung van 16 april 1871 van het onder Bismarck tot stand gekomen keizerrijk ontbreekt de grondwettelijke bescherming van de uitingsvrijheid en de persvrijheid. De pers wordt slechts genoemd als een van de onderwerpen, waarvan de regeling uitsluitend onder de competentie van de rijksoverheid zou vallen. (2)

Op basis van artikel 4 van de Reichsverfassung nam de rijksdag op 25 april 1874 de voor die tijd zeer moderne "Reichspreßgesetz" (RPG) aan, die bijna honderd jaar van kracht is gebleven. (3) De censuur en alle andere preventieve maatregelen tegen de pers werden opgeheven, de uitoefening van het persbedrijf was voortaan vrij. ( $\$ 4$ RPG).

Volgens Löffler kon de pers over het algemeen (zo ontbrak bijvoorbeeld een regeling van het verschoningsrecht) met de wet tevreden zijn. (4) Zoals hiervoor reeds opgemerkt was de RPG voor zijn tijd zeer modern. De wet had echter ook inherente nadelen. Het belangrijkste ervan was dat ze als gewone wet eenvoudig te wijzigen was en daarmee feitelijk buiten werking te stellen. Kanselier Bismarck heeft dat zwakke punt verscheidene keren uitgebuit. Zo werd via een lex specialis, zoals de "Gesetz gegen die gemeingefährlichen Bestrebungen der Sozialdemokratie" (1878-1890), die alle publicaties verbood die het socialisme bepleitten, de persvrijheid die de RPG moest garanderen grotendeels illusoir gemaakt.

De RPG, die het economisch risico om een krant uit te geven aanzienlijk heeft verminderd, luidde de stormachtige groei in, die het Duitse krantenbedrijf op het eind van de vorige en het begin van deze eeuw kenmerkte. Van de 2913 dagbladen die Duitsland in 1917 telde waren er $100(3,4 \%)$ gesticht in de periode 1701 - $1800 ; 982(33,7 \%)$ tussen 1801 en $1870 ; 1376(47,3 \%)$ tussen 1871 en 1900 en $455(15,6 \%)$ tussen 1901 en 1916. De oplagen van de kranten waren voor huidige begrippen klein; twee van de drie $(67,8 \%)$ verkochten minder dan 5.000 exemplaren. (5) De bloeiperiode van het dagbladwezen tot de eerste wereldoorlog tijdens de oorlog en de economische chaos vlak erna verdwenen ruim duizend kranten - ging gepaard met twee ontwikkelingen die voor de verhouding uitgever - redactie van groot belang zijn geweest. 
A. Op het eind van de vorige eeuw was, vooral in de grote steden, naast de tot dan toe vrij algemene "Meinungspresse" (politische Zeitungen) een nieuw type krant ontstaan: de "Generalanzeigerpresse" of, zoals Dovifat ze noemt "Geschäftszeitungen" (6) $\mathrm{Bij}$ dit laatste type krant ging het niet om het nastreven van een partijpolitiek of ander ideaal, maar vooral om het commerciële resultaat via grote oplagen. Egloff (7) berekende het aandeel van niet-partijgebonden en politiek-neutrale kranten in 1898 all op 45 procent en in 1926 op 51,7 procent. Mit dem Aufkommen der Generalanzeiger (................) war ein anderer Verlegertyp entstanden. Ohne bestimmte politische Zielsetzung liegt seine Aufgabe in der bestmöglichen Anpassung an die Bedürfnisse der großen Masse. Nicht die offentliche Meinung zu beeinflüssen, sie in bestimmte politische Richtung zu lenken, sondern sie vorauszufühlen, ihre Wandlungen zu erspüren und sich ihnen anzupassen ist hier das Problem, dessen richtige Lösung in der Massenauflage und den damit gegebenen Chancen für ein blïhendes Inseratengeschäft sich offenbart. (8)

B. "Inseratengeschäft" is het trefwoord voor de tweede ontwikkeling die gelijktijdig plaatsvond. In een weer oplevende economie ontdekten de handel en het bedrijfsleven de mogelijkheden van reclame, vooral via de periodieke pers. Kostbare technische voorzieningen, zoals nieuwe zettechnieken en vooral de rotatiedruk, maakten het mogelijk (maar ook noodzakelijk) grotere kranten te vervaardigen, waarin de advertentiepagina's spoedig voor meer inkomsten zorgden dan de bijdragen van de lezers. De uitgever Egloff berekent de verhouding in 1922 bij de kleine kranten al op 32 procent inkomsten uit abonnementsgeld en 68 procent uit advertenties. (9) Naarmate de pers commerciëler werd veranderde de verhouding uitgever-redactie. De uitgevers, die zich vroeger als die kaufmännischen Helfer, die Geschäftsbesorger der Publizisten fühlten, selbst auch nicht selten mehr Publizisten als Kaufleute waren gingen zich in sterkere mate met de inhoud van de krant bemoeien dan voorheen. Als die Presse kommerzialisiert wurde wandelte sich (das früher ausbalanzierte Verhältnis Verleger-Journalist): der Verleger wurde zum "Herm im Hause" und zum Herrn des Journals, der nicht nur die Linie der Zeitung durch generelle Richtlinien bestimmt, sondern auch mit Einzelweisungen in die publizistische Arbeit eingreift. Die Pressefreiheit, einst Publizistenfreiheit, ist weithin zur Presseverlegerfreiheit geworden. (10) Volgens Otto Groth (11) maakten de veranderingen in de periodieke pers, zoals de toegenomen lezersmassa, uitbreiding van het aantal advertenties en de belangrijker plaats van het nieuwsbericht (mogelijk gemaakt door de telegraaf) de uitgever en niet de journalist tot degene die de belangrijke beslissingen nam, niet alleen op materieel, maar ook op ideëel gebied. Volgens Klaus-Detlev Funke zette deze tendens al in de jaren zeventig van de vorige eeuw in. Zij was volgens hem in strijd met letter en geest van de Reichspreßgesetz, die de persvrijheid niet primair met de uitgever identificeerde, maar met de journalist. Funke wijst er in dit verband op dat de RPG de functie van de "verantwoordelijke redacteur" heeft geîntroduceerd, die door de uitgever als zodanig moet 
worden aangewezen en van wie de naam in het impressum behoort te staan. Ook Mallmann stelt dat volgens de Reichspreßgesetz niet de uitgever de centrale figuur is in de dagbladonderneming. Das zeigt am deutlichsten das Rechtsinstitut des verantwortlichen Redakteurs, den das Gesetz zum Angelpunkt seines gesamten Haftungssystems gemacht hat und der gewiss nicht nur als Strohman des Verlegers gedacht ist. In $\$ 6$ van de RPG kreeg de "verantwoordelijke redacteur" een vetorecht - ook tegenover de uitgever - ten aanzien van de publicatie van strafrechtelijk verboden teksten. Daarnaast bevatte de RPG in $\$ 4$ bijzondere regels omtrent de Pressegewerbefreiheit van de uitgever. (12)

(1) Dit artikel 4 luidde: 1. Jeder Deursche hat das Recht durch Wort, Schrift. Druck und bilaliche Darstellung seine Meinung frei zu äussem. 2. Die Pressefreiheit darf wnter keinen Umständen und in keiner Weise durch vorbeugende Maßnahmen, namentlich Zensur Konzession. Sicherheitsbestellungen, Staatsaufagen. Beschränkungen der Druckereien oder des Buchhandels, Postverbote oder andere Hemmungen des freien Verkehrs beschränkt, suspendiert oder aufgehoben werden. 3. Über Pressevergehen, welche von Amts wegen verfolgt werden, wird durch Schwurgerichte geurteilt. 4. Ein Pressegesetz wird vom Reiche erlassen werden. NB: ook hier reeds de aparte vermelding van vrijheid voor het "instituut" pers.

(2) Art. 4. Der Beaufsichtigung seitens des Reichs und der Gesetzgebung derselben anterliegen die nachstehenden Angelegenheiten: (.....) 16. Die Bestimmungen ubber die Presse und das Vereinswesen.

(3) Pas op 1 juli 1966 werd de RPG formeel geheel buiten werking gesteld, toen in de naoorlogse Bondsrepubliek de deelstaat Noordrijn-Westfalen als laatste zijn eigen Landespressegesetz afkondigde. De andere negen deelstaten en Berlijn hadden al eerder een eigen perswet.

(4) Over de mate van vrijheid die de wet bood zie Löffler/Ricker, 4. Kap. Rdz. 22. In $1926 \mathrm{kwam}$ een beperkte vorm van verschoningsrecht in het wetboek van strafvordering ( $\$ 53$ StPO). Zie ook Loffler Presserecht Band I, 3. Aufl. (1983) \$23 Rdz. 21.

(5) Helmut Egloff Arbeits- und Berufsorganisation in dentschen Zeitungsgewerbe - pag. 62, noot 78.

(6) $\mathrm{E}_{\mathrm{e}}$ Dovifat Die Zeitungen in: Die Deutsche Wirtschafi und thre Fuhrer pag. 89.

(7) Helmut Egloff Arbeits- und Berufsorganisation im deutschen Zeitungsgewerbe, pag. 27.

(8) Helmut Egloff, idem pag. 27-28.

(9) Helmut Eg॥off, idem, pag. 25.

(10) Walter Mallmann Pressefreiheit und Journalistenrecht in: Es geht nicht nur um Springer. Material und Meinungen zur inneren Pressefreiheit; 1968 , pag. 14-15.

(11) Otto Groth Die wnerkannte Kulturmachs, Band IV, pag. 129.

(12) "Verantwoordelijke redacteur"' is nog steeds de enige journalistieke functie die het formele Duitse mediarecht kent; de aanduiding "Chefredakteur" (hoofdredacteur) heeft dus geen externwerkende juridische status. In de huidige "Landespressegesetze" is de verantwoordelijke redacteur degene die altijd aansprakelijk gesteld kan worden voor elke strafbare publikatie, waartegen hij geen veto uitgesproken heeft. Löffler/Ricker noemt de functie van de verantwoordelijke redacteur "eine juristische Erfindung".

Het onderscheid tussen het redactionele deel van de krant en het commerciële deel blijkt in de "Landespressegesetze" nog steeds uit de verplichting om ook voor het advertentiedeel een eigenverantwoordelijke functionaris aan te wijzen. Vgl. \& " "Impressum" van LPG NordrheinWestfalen. (lid 2) Auf den periodischen Druckwerken sind ferner der Name und die Anschrift des verantworlichen Redakteurs anzugeben. Sind mehrere Redakteure verantwortlich, so muk das Impressum die in Satz I geforderten Angaben fü jeden von ihnen enthalten. Hierbei ist kenntich zu machen, für welchen Tell oder sachlichen Bereich des Druckwerks jeder einzelme werantwortlich ist. Für den Anzeigenteil ist ein Verantwortlicher zu benennen; fü diesen gelten die Vorschriften über den verantwortichen Redakteur entsprechend. Vgl. ook Klaus-Detlew Funke Innere Pressefreiheit - Zu Problemen der Organisation von Journalisten, 1972, pag. 14 e.v. en 
Walter Mallmann Pressefreiheit und Joumalistenrecht pag. 17.) Over de functie wan de verantwoordelijke redacteur volgens huidig recht zie Löfler-Ricker Handbuch des Presserechts, 13. Kap. Rz. $24 \mathrm{ff}$.

\subsection{Artikel 118 van de Weimarer Verfassung}

Na de ondergang van het Duitse keizerrijk als gevolg van de verloren eerste wereldoorlog blijft de Reichspreßgesetz van kracht. In de nieuwe grondwet, de Weimarer Verfassung (WV) van 11 augustus 1919, komt in het hoofdstuk over de "Grundrechte und Grundpflichten der Deutschen" het opmerkelijke artikel 118, dat het grondrecht van de vrijheid van meningsuiting (en impliciet, hoewel het woord "pers" er niet in genoemd wordt, ook van de persvrijheid) garandeert. Artikel $118 \mathrm{WV}$ luidt:

1: Jeder Deutsche hat das Recht, innerhalb der Schranken der allgemeinen Gesetze seine Meinung durch Wort, Schrift, Druck, Bild oder in sonstiger Weise frei zu äußern. An diesem Recht darf ihn kein Arbeits- oder Anstellungsverhaltnis hindern und niemand darf ihn benachteiligen, wenn er von diesem Rechte Gebrauch macht.

2: Eine Zensur findet nicht statt, doch können für Lichtspiele durch Gesetz abweichende Bestimmungen getroffen werden. Auch sind zur Bekämpfung der Schund- und Schmutzliteratur sowie zum Schutze der Jugend bei öffentlichen Schaustellungen und Darbietungen gesetzliche Maßnahmen zulässig.

De tweede zin van lid 1 geldt algemeen als de formele erkenning dat het niet alleen de staat is, die de vrije meningsuiting van de burgers bedreigt, maar dat ook andere machtige groepen in de maatschappij de burgers kunnen verhinderen van dit grondrecht gebruik te maken - en dat ze dat ook feitelijk doen, onder meer in de werkgever-werknemerverhouding. Artikel 118 WV wordt dan ook vaak geciteerd in samenhang met de discussie over de derdenwerking van het grondrecht van de vrijheid van meningsuiting. Meo-Michaela Hahne noemt de artikelen 118 en 159 (Versammlungsfreiheit) van de grondwet van de Weimarrepubliek die erste ausdrickliche Erwänung der verpflichtenden Wirkung von Grundrechten auch gegenuber Privaten. (1) Reinowski brengt de formulering van art. $118 \mathrm{WV}$ in direct verband met het sinds de jaren twintig bijna permanent gevoerde overleg tussen organisaties van uitgevers en journalisten samen om eine gemeinsame Grundlage für die künftige, möglichst reibungslose beiderseitige Zusammenarbeit zu schaffen. (2)

Met de formulering dat de vrijheid van meningsuiting durch Wort, Schrift,Druck, Bild oder in sonstiger Weise (.....) innerhalb der Schranken der allgemeinen Gesetze grondwettelijk gegarandeerd is, beperkte artikel $118 \mathrm{WV}$ de bescherming tot uitsluitend de materiële, de "actieve" persvrijheid, waaronder verstaan wordt de vrijheid van de pers om informatie in te winnen, deze informatie te publiceren en te verspreiden en op deze wijze aan de publieke meningsvorming mee te werken. De formele persvrijheid - de processuele bescherming tegen beperkingen in de uitoefening van de persvrijheid ("Abwehrrecht") - viel 
buiten de grondwettelijke garantie. Wat de formele persvrijheid betreft bleef de pers aangewezen op de Reichspreßgesetz, die als gewone wet, net als onder Bismarck, zo nodig aan politiek instabiele omstandigheden kon worden aangepast. Dat zou in de jaren twintig ook gebeuren, onder meer via de "Gesetzgebung zum Schutz der Republik" van 21 juli 1922 en 25 maart 1930 en door het gebruik van bijzondere volmachten door de Reichspräsident, op basis van artikel 48 van degrondwet. Het was echter niet de repressie van de overheid, maar de hiervoor reeds aangeduide vercommercialisering van de dagbladpers, die de georganiseerde Duitse journalistiek (3) in de jaren twintig in actie bracht tegen wat zij zag als een ondermijning van het ideële karakter van de krant. Net als de georganiseerde journalistiek in Nederland uit die tijd benadrukten de Duitse journalisten vooral het ideële karakter van het produkt dagblad. Er is echter ook een belangrijk verschil: waar de Nederlandse journalisten in de jaren twintig het culturele karakter van de krant onderstreepten, zien de Duitsers de krant toch vooral als medium met een politieke boodschap.

Sindsdien hebben twee begrippen de Duitse discussie over de media tot de dag van vandaag beheerst: "die öffentliche Aufgabe" van de pers en de "innere Pressefreiheit". Zij zullen voortaan kernbegrippen (en strijdpunten) worden van het Duitse mediarecht in het algemeen en van de redactionele medezeggenschap in het bijzonder. Beide begrippen hadden in de jaren twintig echter een andere betekenis dan ze later zouden krijgen.

(1) Meo-Michaela Hahne Das Drittwirkungsproblem in der europäischen Konvention zum Schutz der Menschenrechte und Grundfreiheiten, diss. Heidelberg, 1973, pag. 12 e.v. Dat ook het huidige artikel $5 \mathrm{GG}$ impliciet de indirecte derdenwerking van het grondrecht mogelijk maakt wordt afgelezen uit de naoorlogse jurisprudentie o.a. BVerfGE 25, blz. 256 e.v. (Blinkfüer); BVerfGE 30 , blz. 173 (Mephisto); BVerfGE 35, blz. 202 (Lebach); vgl. ook Albert Bleckmann Allgemeine Grundrechtslehre (1979), pag. 138/139; Löffler/Ricker 6. Kap., Rdz. 2 en Kap. 11 Rdz. 28, 29 en 30 .

(2) Hans J. Reinowski Innere Pressefreiheit-ein Grundrecht für Verleger und Redakteure, pag. 30 .

(3) In 1909 werd de "Bund deutscher Redakteure" opgericht, in 1910 de "Reichsverband der deutschen Presse". De journalisten waren daarmee een van de laatste georganiseerde beroepsgroepen; de grafici in Duitsland waren al sinds 1848 in een wakbond verenigd . De werkgeversorganjsatie "Verein deutscher Zeitungsverleger" dateert uit 1894.

\section{4 "Die öffentliche Aufgabe der Presse"}

De idee dat de pers een publieke taak, een "öffentliche Aufgabe" zou vervullen stamt al uit het midden van de vorige eeuw. Volgens Oertel ligt de oorsprong ervan in het vroegliberalisme en het belang dat dit hechtte aan de "öffentliche Meinung". Als staatspolitisches Prinzip lag ihm (dem Frühliberalismus) die Idee der "Volkssouveränität" zugrunde, wonach das souverän gewordene oder seine Souveränität beanspruchende Volk zur Sicherung seiner Rechte und zum Ausdruck seines politischen Willens der freien Presse bedurfte, so daß dieser infolgedessen ein besonderer Rang innerhalb des Gemeinwesens zukommen sollte. 
(1) Czajka (2) citeert eind $19 \mathrm{de}$ - begin 20ste-eeuwse auteurs als Wutke (Die deutschen Zeitungen und die Entstehung der öfentlichen Meinung - Leipzig 1875) en Ernst Posse (Über Wesen und Aufgabe der Presse, Tübingen 1917), die daarentegen meenden dat de pers reeds een zo grote politieke invloed uitoefende dat zij als semi-overheidsorgaan beschouwd (en gereglementeerd) diende te worden, een gedachte die na de oorlog zou herleven.

In de jaren twintig claimen de journalisten dat vooral zij het zijn die als "Vertreter der offentlichen Meinung" een publieke taak vervullen. In de statuten van de Reichsverband der deutschen Presse (RDP) uit 1920 wordt de term "öffentliche Aufgabe" gebrukt in de doelomschrijving van de organisatie, namelijk tatkräftige Vertretung der beruflichen, der öffentlich-rechtlichen wie privatrechtlichen Interessen des Journalistenstandes innerhalb der Zeitungsbetriebe, in der Öffentlichkeit, in der Gesetzgebung und Verwaltung, insbesondere durch Förderung eines neuen deutschen Presserechts, durch Abwehr aller Angriffe auf die Pressefreiheit und überhaupt aller Versuche und Bestrebungen, die Presse an der Erfüllung ihrer öffentlichen Aufgabe zu verhindern und zu beschränken. (3) In vrijwel alle hierna volgende ontwerpen voor wetgeving en arbeidsovereenkomsten zal de "öffentliche Aufgabe" een rol spelen, tot de grondgedachte (maar dan geperverteerd in nationaal-socialistische zin) een wettelijke basis zal vinden de beruchte Schriftleitergesetz van 4 oktober 1933.

(1) Reinhold Oertel Das Verhälmis Verleger - Redakteur im Hinblick auf die Sicherung der "Inneren Pressefreiheit, Würzburg (1971), pag. 7/8.

(2) D. Czajka Pressefreiheit und" "offentiche Aufgabe der Presse", Stuttgart 1968, pag. 58.

(3) Marie Matthies Joumalisten in eigener Sache. Zur Geschichte des Reichsverbandes der Deutschen Presse. Berlin 1969, blz. 149.

\section{5 "Innere Pressefreiheit"}

Onder de benaming "Innere Freiheit der Presse" komt de term volgens Werner Breede voor het eerst voor in W. Bauer's Die öffentliche Meinung und ihre geschichtlichen Grundlagen. Ein Versuch. Tübingen 1914. Vanaf de jaren twintig raakte het begrip onder de benaming "Innere Pressefreiheit" ingeburgerd. "Innere Pressefreiheit" staat naast en tegenover "äußere Pressefreiheit", het recht van de pers verschoond te blijwen van onderdrukking door de overheid. Innere Pressefreiheit daarentegen betreft de redactionele "Kompetenzabgrenzung" binnen de personderneming zelf tussen (hoofd)redactie en uitgever, in die zin dat uitsluitend de redactie en niet de uitgever of een andere belangengroep bepaalt wat er in de krant komt binnen de door de uitgever aangegeven "Richtung der Druckschrift".

De georganiseerde journalistiek uit de jaren twintig, met een sterk besef van haar "öffentliche Aufgabe", zag de gevaarlijkste dreiging niet komen van de kant van de uitgever, maar van de adverteerders en andere economische belangengroepen. Dit hield uiteraard ook verband met de hiervoor reeds genoemde wijzigingen in de verhouding uitgever - journalist als gevolg van de opkomst van de kranten met 
zeer grote oplagen en daarmee van de krant als advertentiemedium. (1)

Vanaf 1920 tot aan de vooravond van de nationaal-socialistische machtsovername zijn in Duitsland verscheidene pogingen ondernomen om de bevoegdheden van uitgever en redacteur af te palen, zowel via collectieve arbeidsovereenkomsten als via een geheel nieuwe "Reichspressegesetz" dan wel via een beperkter regeling in de vorm van een "Journalistengesetz". De concrete voorstellen gaan alle van de volgende premissen uit:1. De uitgever bepaalt de algemene politieke, economische en culturele richting van de krant ("Grundsatz- und Richtlinienkompetenz"). Dat de uitgever ook nadere richtlijnen mag geven over de toepassing van de redactionele uitgangspunten ("Richtlinienkompetenz") wordt gezien als een nieuw element in het Duitse persrecht, deGeburtsstunde der Richtlinienkompetenz des Verlegers (Schmidt-Osten). De "Reichspressegesetz" van 1874 en de rechtspraak gingen volgens Kau (2) tot nu toe uit van de redacteur als uitsluitende Verantwortungsträger voor de inhoud van de krant.

2. Binnen die uitgangspunten voert de redactie een zelfstandig beleid, zonder inmenging van welke belangengroep dan ook.

3. Deze taakafbakening tussen uitgever en redactie vloeit voort uit de "öffentliche Aufgabe der Presse".

4. Een redacteur kan nooit gedwongen worden tegen zijn overtuiging te schrijven. Wanneer de uitgever de richting van zijn krant verandert, kan de redacteur ontslag nemen zonder inachtneming van een opzeggingstermijn en heeft hij recht op een afkoopsom die gerelateerd is aan het aantal dienstjaren.

(1) Christina Holtz-Bacha Mitspracherechte für Journalisten, pag. 14; Rudolf Stöber Kontroversen um ein Joumalistengesetz, in Publizistik 1990, Heft 3, pag. 267 e.v.

(2) Edwin Kau Die Mitbestimmung in Presseunternehmen, pag. 50.

\subsection{Concrete voorstellen $1920-1933$}

De diverse voorstellen zijn te onderscheiden in ontwerpen voor arbeidsovereenkomsten en in ontwerpen voor een wettelijke regeling van de rechtspositie van de journalist. De journalisten gaven de voorkeur aan een wettelijke regeling. De uitgevers waren bang voor wetgeving, wegens het generieke karakter ervan, en gaven er de voorkeur aan de afbakening van bevoegdheden binnen een "(Reichs)tarifvertrag" onder te brengen; dat contract konden ze, indien nodig, na de overeengekomen looptijd zelf opzeggen. (1) Een niet te onderschatten voordeel voor de uitgevers, zoals later zal blijken, is bovendien dat een afbakening van bevoegdheden door middel van een "Tarifvertrag" moet passen binnen - en daarmee beperkt wordt door - het vigerende arbeidsrecht.

(1) Aldus ook de uitgever Walther Jänecke Verleger - Redakteur. Die Rechtslage und die Wirklichkeit, pag. 56. 


\subsubsection{De "Reichstarifentwurf" van de RDP uit 1920}

Het concept voor een arbeidsovereenkomst dat de "Reichsverband der deutschen Presse ${ }^{\text {ti }}$ in 1920 uitbracht geldt nog steeds als een van de eerste en belangrijkste Duitse documenten over de verhouding uitgever - redactie. Het stuk is nooit verder is gekomen dan de ontwerpfase, omdat de uitgevers het op essentielle punten onaanvaardbaar achtten. Steen des aanstoots voor hen in het ontwerp was de in $\$$ 25 neergelegde regeling van de verhouding uitgever - redactie die ten aanzien van de redactionele inhoud van de krant inderdaad zeer ver gaat. Bovendien verplicht $\$ 25$ tot inspraak van de redactie in het beleid van de hoofdredacteur. Kau merkt zestig jaar later naar aanleiding van deze paragraaf en de $\$ \$ 20,21$ en 22 , die tot zeer hoge afkoopsommen verplichten bij verkoop, verandering van politieke richting en opheffing van de krant, op daß die derzeitigen Bestrebungen, Redaktionsstatute und -ausschüsse zu errichten, keineswegs revolutionären Charakter tragen. (1) (Uitgever)Karl Bringmann daarentegen citeert in 1963 met instemming de kritiek van een tijdgenoot die in 1924 schreef dat $\$ 25$ neerkwam op een "Versuch der geistigen Expropriirung" van de uitgever. De omstreden paragraaf luidt:

\section{$\$ 25$. Fur die Redaktionsfiuhrung wird folgendes vereinbart:}

1. Im Rahmen der allgemeinen politischen, wirtschaftlichen und kulturellen Gesamthaltung der Zeitung ist die geistige Gestaltung der Zeitung ausschließlich Sache der Redaktion.

2. Die Redaktion ist verpflichtet, ïber die Behandlung von Fragen, die für die Richtung der Zeitung von entscheidender Bedeutung sind, sich vorher mit dem Verleger zu verständigen.

De regeling van lid 1 en 2 wijst op vergaande redactionele autonomie. Bij controversiële kwesties is contact met de uitgever voorgeschreven, maar de term "sich vorher verständigen" duidt eerder op een plicht om de uitgever te informeren dan op diens vetorecht. Het ontwerp zegt weliswaar nergens expliciet dat de uitgever de richting van de krant heeft vastgesteld, maar dat blijkt impliciet uit $\$ 21$ (Falls der Verleger die politische Richtung ändert ......)

De leden 3 en 4 schrijven een redactionele organisatie voor met een hoofdredacteur, die een heel bijzondere positie inneemt: wel verantwoording verschuldigd wan, maar geen vertegenwoordiger van de uitgever:

3. Ist von dem Verleger ein Chefredakteur bestellt, so ist dieser allein dem Verleger verantwortlich, während alle anderen Redakteure dem Chefredakteur gegenüber die Verantwortung tragen, soferm nicht Vertragsbestimmungen dem entgegenstehen. Der Chefredakteur ist nicht Vertreter des Verlegers, sondern Vertreter des Allgemeininteresses der Zeitung sowohl gegenüber dem Verleger alsauch gegenüber der Redaktion. Ungeachtet der Stellung und Verantwortung des Chefredakteurs besteht eine moralische Mitverantwortung aller Redaktionsmitglieder für den geistigen Inhalt der Zeitung vor der 
Öffentlichkeit. Der Chefredakteur fuhrt die Redaktion wnter Fuhhungnahme mit den Ressortredakteuren und, wo eine solche besteht, mit der Redaktionskonferenz.

Die Redaktionskonferenz besteht aus dem Chefredakteur als Vorsitzenden, dessen Stellvertreter oder dem dienstältesten Abteilungsleiter als stellvertretendem Vorsitzenden, den Ressortredakteuren und allen Redakteuren mit mindestens zehn Berufsjahren, sofern nicht auch anderen Redakteuren durch Vertrag oderÜbung die Teilnahme zusteht.

4. Ist kein Chefredakteur bestellt, so wird die Redaktion entsprechend Punkt 3 dieses Paragraphen durch die Redaktionskonferenz geführt.

Lid 5 legt het primaat over de redactionele pagina's opnieuw bij de (hoofd)redactie, zoals al in lid I beschreven. Dit primaat wordt nog versterkt door de uitgever te herinneren aan de "verantwoordelijke redacteur", de bij wet voorgeschreven (redactionele) functionaris die de inhoud van de krant moet bewaken. $\mathrm{Er}$ is ook een geste richting uitgever: hij mag onder eigen naam publiceren, wanneer hij het niet met de redactie eens is. (2)

De hoge afkoopsommen uit de reeds genoemde $\S \S 20,21$ en 22 wijzen op een taktiek die de journalistenorganisaties in de toekomst vaker zouden kiezen: een uitgever die een krant (ver)koopt, de politieke richting ervan tegen de wens van journalisten verandert of de uitgave ervan staakt, krijgt daar een rekening voor gepresenteerd. Een journalist die geen nieuw contract krijgt van een nieuwe eigenaar moet een "Gesamtabfindung" van tenminste een jaarsalaris ontvangen $(\$ 20)$; bij verandering van politieke richting $(\$ 21)$ kan een redacteur onmiddellijk ontslag nemen met doorbetaling tot de opzegtermijn, met extra-betaling van een half jaar of een heel jaar salaris, wanneer de ontslag nemende journalist vijf resp. tien jaar in dienst is geweest. Wanneer de krant ophoudt te bestaan moet nog een half jaar salaris doorbetaald worden. $(\$ 22)$. Zoals reeds in het vorige hoofdstuk (2.4.5) beschreven liet de commissie-Van Blom zich op dit punt door onder meer de "Reichstarifentwurf" inspireren met nog hogere afkoopsommen.

Paragraaf 24 voorziet in de geheime en schriftelijke verkiezing van een redactiecommissie (Redaktionsausschuß), die toeziet op de correcte uitvoering van deze overeenkomst. De commissie heeft een gedeeltelijk opschortend vetorecht bij al dan niet gedwongen ontslag van redactieleden. De uitgever kan dit veto-

recht negeren en toch een ontslag afdwingen door een extrabetaling van zes maanden salaris. Of dit vetorecht van de redactiecommissie ook geldt bij het ontslag van de Chefredakteur is niet duidelijk. Kau concludeert uit de formulering van dit artikel in samenhang met $\$ 25.3$, waar de positie van de Chefredakteur beschreven is als Vertreter des Allgemeininteresses der Zeitung sowohl gegenüber dem Verleger als auch gegenüber der Redaktion, dat deze als eigenständige Kraft innerhalb der Zeitungsstruktur, nicht nur als Redakteur besonderer Art te beschouwen is en dus buiten de regeling van $\$ 24$ valt. (3) 
Andere punten uit de "Reichstarifentwurf" zijn:

- Een absoluut verbod op enig concurrentiebeding (\$15), vast onderdeel van alle latere Duitse ontwerpen. De voorgestelde regeling anno 1920 is des te opmerkelijker, wanneer men bedenkt dat in ons land het verbod van een concurrentiebeding pas sinds 1972 in de $\mathrm{CAO}$ is opgenomen. (4)

- \&26: De aankondiging van een samenwerkingsverband tussen uitgevers en journalisten in de "Reichsarbeitsgemeinschaft der deutschen Presse", waarover in de volgende paragraaf meer.

- De oprichting van paritair samengestelde "Tarifschiedsgerichte" van drie leden (een uitgever, een journalist en een door beide gekozen onafhankelijke voorzitter) die bindende uitspraken doen over uitleg en toepassing van de overeenkomst ( $\$$ 27).

(1) Edwin Kau Die Mitbestimmung in Presseunternehmen, pag. 48.

(2) Voor de integrale tekst van de Reichstarifentwurf zie Marie Mathies Journalisten in eigener Sache (1969), pag. 154 e.v., gedeeltelijk geciteerd in Ansgar Skriver, pag. 32/33 en bij Edwin Kau Die Mibestimmung in Presseunternehmen, pag. 249 e.v.

(3) Edwin Kau Die Mitbestimmung in Presseunternehmen, pag. 48, met een interessante verwijzing naar het redactiestatuut van Stern.

(4) Art. 33 CAO voor dagbladjournalisten; Schuijt Werkers van het woord" pag. 300.

\subsubsection{De "Reichsarbeitsgemeinschaft"}

In juli 1921 besprak de algemene vergadering van de RDP een nieuwe versie van het wetsontwerp voor een Journalistengesetz die al uit 1918/19 stamde. Tevens werd besloten om samen met de Arbeitgeberverband für das deutsche Zeitungsgewerbe over te gaan tot oprichting van de Reichsarbeitsgemeinschaft der deutschen Presse (RAG), die als doelstelling kreeg enerzijds, naar buiten toe, zich te weren tegen alle pogingen om de pers te hinderen bij het uitoefenen van haar publieke taak en te ijveren voor een nieuw en modern persrecht en anderzijds, naar binnen toe, insbesondere durch eine Abgrenzung der Begriffe Verleger und Redakteur die gedeihliche Zusammenarbeit von Redakteur und Verleger in der Zeitung in Geiste der Reichsarbeitsgemeinschaft in einer den Rechten und der Würde beider Teile entsprechenden Weise zu fördern.

De werkgevers zagen in de Reichsarbeitsgemeinschaft een podium om de journalistieke claims op exclusieve zeggenschap over het redactionele deel van de krant de kop in te drukken. Egloff citeert met instemming zijn collega-uitgever Carbe om te verduidelijken waarom gerade die geistig führenden Persönlichkeiten (onder de uitgevers) zich tegen de journalistieke onafhankelijkheid verzetten: Der Handel mit bedrucktem Papier ist gewiß ein sehr ehrsames Gewerbe, aber wir Zeitungsverleger betreiben es nicht. Wir Zeitungsverleger sind auch nich lediglich die Abonnementsgeldkassierer zum Zwecke seiner Weiterleitung an Papierlieferanten und Redakteure; wir sind nicht lediglich die Leute, die Setzmaschinen kaufen, um sie den Setzern zur Verfügung zu stellen, damit sie die Artikel der Redakteure und Mitarbeiter den Zeitungsabonnenten zur 
Kenntnis bringen können; nein, nein und dreimal nein! De dagbladuitgevers gaven er de voorkeur aan die äußerst subtile Frage der Abgrenzung der Begriffe Verleger und Redakteur, (Carbe) in arbeidsovereenkomsten te regelen om een wettelijke regeling overbodig te maken. Zij waren bereid daarvoor grote concessies - vooral in materiële zin te doen. (1)

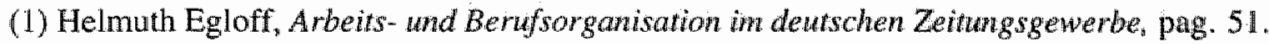

\subsubsection{De drie ontwerpen uit 1924}

\section{A. RDP-ontwerp}

De angst van uitgevers voor een wettelijke regeling van de verhouding uitgeverredactie verklaart mede de grote aandrang van journalistieke zijde om juist wel te ijveren voor wetgeving. In 1924 verschenen niet minder dan drie verschillende ontwerpen voor een "journalistenwet". Allereerst, in februari 1924, presenteerde de RDP buiten de Reichsarbeitsgemeinschaft om, opnieuw zijn reeds eerder genoemde ontwerp (Entwurf zu einem Gesetz betreffend die Rechtsverhältnisse der Redakteure). Het in de vorm van een wetsontwerp gegoten stuk hanteert ongeveer dezelfde afkoopsommen ingeval van vervreemding $(\$ 10)$, beëindiging van het blad $(\$ 11)$ en verandering van politieke richting $(\$ 12)$ als de Reichstarifentwurf uit 1920. Opvallend afwezig is de mogelijkheid tot vorming van een Redaktionsausschuß. Ook in latere ontwerpregelingen zal dit voor de medezeggenschap zo belangrijke instituut voortaan ontbreken, althans niet meer onder die naam genoemd worden. Volgens Bringmann (1) zagen de uitgevers in vergaande bevoegdheden voor een redactiecommissie of redactievergadering nicht ohne Grund Parallelen zu den Betriebsräten auch im geistigen Bereich derZeitung. Bringmann doelt hierbij op $\$ 67$ van de Betriebsrätegesetz (BRG) van 1920 , die als voorloper kan worden beschouwd van $\$ 118$ van de naoorlogse Betriebsverfassungsgesetz (BetrVG) en die inspraak van een ondernemingsraad beperkt in zogenaamde Tendenzbetriebe. (2)

Volgens Kau (3) is met het verdwijnen van de redactiecommissie ein entscheidender Bruch in dem Bemühen um Mitbestimmung bzw. Mitwirkung eingetreten. Aus dem Problemkreis "innere Pressefreiheit" wird die Regelung der Beziehungen zwischen Verleger und Redakteur ausgeklammert! Bringmann meent - op zwakke gronden - echter dat de Redaktionsausschuß in de nader te bespreken Referentenentwurf wel degelijk terugkeert. (4)

In de $\$ \$ 13$ en 14 van het ontwerp worden de verhouding uitgever - redactie en de öffentliche Aufgabe van de pers als volgt gecodificeerd:

\$13: Im Rahmen der festgelegten allgemeinen politischen, wirtschaftlichen und kulturellen Richtung der Druckschrift ist die Gestaltung und Vertretung ihres geistigen Inhalts Sache des Redakteurs. Gegen den ausdrücklichen Willen des Redakteurs darf keine Veröffentlichung im redaktionellen Teil der Zeitung vor- 
genommen werden. Eine Druckschrift verantwortlich zeichnen darf nur ein Redakteur, der mindestens drei Jahre im Beruf ist.

\$14: Da die Presse ihrem Wesen nach die Aufgabe und die Pflicht hat, öffentliche Interessen wahrzunehmen, so darf der Redakteur an deren pflichtgemäßer Wahrnehmung nicht gehindert werden.

Wer es unternimmt, den Redakteur zu nötigen, seine Berufspflicht zur Wahrnehmung offentlicher Interessen zu verletzen, wird mit Geldstrafe bis zu 10000 Mark bestraft. Ist die Nötigung vom Verleger ausgegangen, so ist der Redakteur berechtigt, das Vertragsverhältnis ohne Einhaltung einer Kündigungsfrist zo lösen. Der Verleger ist in diesem Falle verpflichtet, dem Redakteur das vereinbarte Gehalt für die ganze Dauer des Vertrages, mindestens aber für ein Jahr, zu zahlen.

Het wetsontwerp lokte heftige redacties uit van de uitgevers, die heel expliciet ook de Detailkompetenz opeisten, waarmee zij betrokken wensten te blijven bij het dagelijkse redactionele werk. Zij herhaalden dat het RDP-ontwerp beschouwd kon worden als een feitelijke Enteignung des Verlegers aus dem wichtigsten Teil seines Unternehmens - aus dem Teil, der der Verwirklichung des ureigentlichen Zweckes des gesamten Unternehmens dient (.......). . Diese Bestimmungen bedeuten in der Praxis nichts anderes, als daß dem Verleger jede tatsächliche Möglichkeit genommen wird, seine Schriftleiter vorkommendenfalls zu hindern, eine Einzelfrage in einer Art zu behandeln, die nach seiner Auffassung den Aufgaben und Zielen seiner Zeitung nicht entspricht. Den hierin liegenden Gefahren kann die Bestimmung der allgemeinen Richtung und Aufgabe der Zeitung und die Aufstellung allgemeiner Richtlinien durch den Verleger nicht vorbeugen. Es ist praktisch absolut un-möglich, die allgemeine Richtung und Aufgabe einer Zeitung so erschöpfend und andererseits so bis ins einzelne gehend festzulegen, daß damit auch die Stellungnahme der Zeitung $z u$ allen Einzelfragen unzweideutig klar präzisiert wird ganz abgesehen davon, daß in der uberwiegenden Anzahl der Fäle sich derartige Einzelfragen bei der Bestimmung der allgemeinen Richtung der Zeitung gar nicht haben voraussehen lassen. (5)

Funke (6) citeert het blad van de dagbladuitgevers (Zeitungsverlag, Jg. 25 (1924) nr. 8, Sp. 233): Es bleibt dabei, daß der Redakteur rechtlich Beauftragter des Verlegers ist. Dieser Auftrag ist unter selbstverständlicher Berücksïchtigung des abgeschlossenen Dienstvertrages widerrufbar. Der Redakteur ist in der Zeitung nichts aus eigenem Recht, alles aus Verlegers Recht. Bringmann (7) citeert van dezelfde (anonieme) uitgever diens variant op de omstreden $\$ 14$, namelijk daß die Zeitung ihrem Wesen nach die Aufgabe und die Pflicht hat, offentliche Interessen wahrzunehmen, und daß die Zeitung, deren berufener letztverantwortlicher Exponent ihr Herausgeber und Verleger ist, an deren pflichtgemäßer Wahrnehmung nicht gehindert werden darf. 


\section{B. De "Referentenentwurf"}

Eveneens in 1924 publiceerde het ministerie van binnenlandse zaken een ontwerp voor een Gesetz über die Rechte und Pflichten der Schriftleiter periodischer Druckschriften van de hand van de inmiddels tot Ministerialrat gepromoveerde Kurt Haentzschel, die daarvoor de instemming van zowel de uitgevers als de journalisten had gezocht. Dit stuk, dat als een juridisch nauwkeuriger bewerking van het RDP-ontwerp beschouwd wordt, staat bekend als de "Referentenentwurf" zum sogenannten Journalistengesetz. De voor de verhouding uitgever - redactie belangrijkste artikelen luiden: (8)

$\S$ 3. Der Schriftleitungsteil dient öffentlichen Interessen. Ein Schriftleiter, der ihn mißbraucht, um in einer zur Täuschung der Öffentlichkeit geeigneten Weise private mit öffentlichen Interessen zu verquicken oder um die Wahrheit, das Recht oder das öffentliche Wohl zugunsten privater Interessen zu verletzen, handelt pflichtwidrig. (..........)

$\$$ 4. Die allgemeine politische, wirtschaftliche und kulturelle Aufgabe und Richtung der Druckschrift bestimmt der Verleger. Diese Bestimmung soll vor Abschluß des Arbeitsvertrages erfolgen.

Jede nach Abschluß des Arbeitsvertrages erfolgende Bestimmung uber die Richtung der Druckschrift darf den Rahmen allgemeiner Richtlinien nicht uberschreiten. Sie gilt im Zweifel als Richtungsänderung.

Alle Bestimmungen über Aufgabe und Richtung der Druckschrift sind für den Schriftleiter nur insoweit verbindlich, als sie schriftlich erfolgt sind.

$\S 5$. Im Rahmen der festgelegten algemeinen politischen, wirtschaftlichen und kulturellen Richtung der Druckschrift ist die Gestaltung und Vertretung ihres geistigen Inhalts Aufgabe des Schriftleiters. Ihn trifft die berufliche Verantwortung für den Inhalt der Druckschrift ohne Rücksicht darauf, ob er auch die pressegesetzliche Verantwortung übernommen hat.

Bei Meinungsverschiedenheiten zwischen mehreren Schriftleitern entscheidet der Hauptschriftleiter, soweit nicht im Arbeitsvertrag die Entscheidung durch einen anderen Schriftleiter oder eine Mehrheit von Schriftleitern vorgesehen ist. (9) Das Recht des Verlegers als solchen, in Einzelfallen eine Veröffentlichung auch ohne Zustimmung des Schriftleiters vorzunehmen, bleibt unberïhrt; sie muß jedoch als eigene Veröffentlichung des Verlags deutlich gekennzeichnet sein. (...........)

§ 6: Der Schriftleiter soll im Rahmen seiner Berufspflichten auch auf die Erhaltung des Bestandes der Druckschrift und ihrer überlieferten Gepflogenheiten gebührende Rücksicht nehmen und den in dieser Beziehung an ihn gerichteten Wünschen des Verlegers insofern entsprechen, als nicht überwiegende offentliche Interessen dem entgegenstehen. Bestehen Zweifel, ob eine Veroffentlichung sich im Rahmen der festgelegten allgemeinen Richtung hält 
(....) so soll wich der Schriftleiter vorher mit dem Verleger ins Benehmen setzen. Das gleiche gilt, wenn eine Veröffentlichung eine Strafverfolgung oder Schadenshaftung des Verlegers zur Folge haben kann.

Kommt über eine Veroffentlichung zwischen dem Schriftleiter und dem Verleger eine Einigung nicht zustande und besteht der Schriftleiter auf der Veröffentlichung, so darf der Verleger unbeschadet seiner Rechte aus $\$ 19$ den Abdruck nur dann verweigern, wenn die Veröfentlichung eine Strafverfolgung oder eine Schadenshaftung für ihn zur Folge haben kann. (10)

In de $\$ \$ 8$ tot en met 14 is een minutieuze regeling opgenomen van de afkoopsommen en afkoopvoorwaarden bij ontslag van journalisten als gevolg van gehele of gedeeltelijke overname door een andere uitgever, van wijziging van de identiteit van het blad of bij beëlndiging van de publicatie. De regeling is minder genereus en op enkele punten wat gedetailleerder dan het RDP-ontwerp. Zo voorziet zij bijvoorbeeld ook in korting op de afkoopsommen ten bedrage van wat de ontslagen journalist die nog geen andere angemessene Anstellung gevonden had, intussen elders heeft verdiend oder zu erwerben schuldhaft unterläßt.

De "Referentenentwurf" heeft ook buiten de direct betrokkenen grote aandacht gekregen, tot in de hoogste regeringskringen toe. De toenmalige Reichskanzler dr. Wilhelm Marx sprak zich in een onderhoud met leidende persoonlijkheden van de "Reichsverband der deutschen Presse" uit voor een wettelijke regeling van het journalistieke beroep. (11) De uitgevers waren sterk gekant tegen de wet, die naar $\mathrm{zij}$ vreesden hun door de inflatie verzwakte ondernememingen nog meer schade zou toebrengen. Het omstreden ontwerp verdween al in 1925 in den Akten onder andere als gevolg van een regeringswisseling. Tot opluchting van de uitgevers namen de journalisten genoegen met een financieel gunstige "Tarifvertrag", die in 3.6.4 nader besproken wordt.

\section{Een herontdekt voorontwerp van de "Referentenentwurf"}

Stöber (12) maakte in het najaar van 1990 melding van een tot voor kort onbekend voorontwerp (Entwurf eines Gesetzes betreffend die Rechtsverhälnisse der Schriftleiter periodischer Druckschriften) van het ministerie van binnenlandse zaken, dat zich in het Centrale Staatsarchief in Postdam (voorheen DDR) bevond. Dit voorontwerp staat heel dicht bij het stuk dat de journalisten hadden ingediend, maar werd in zijn eindversie, de Referentenentwurf, sterk geamendeerd.

In het definitieve ontwerp kreeg de uitgever nadrukkelijk auch ohne Zustimmung des Schriftleiters ( $\$ 5$ ) toegang tot de redactionele kolommen. In het voorontwerp heeft een regeling gestaan die publicatie tegen de wens van de redactie aan nog striktere voorwaarden bond. (13) 
(1) Karl Bringmann Die Presse whd hr Recht, pag. 119.

(2) De Betriebsrätegesetz noemt in $\$ 67$ de persondernemingen niet met name, maar uit de parlementaire behandeling blijkt dat men ze eveneens begreep onder de Betriebe, die politischen ge $^{2}$ werkschaftlichen, militärischen, konfessionellen, wissenschaftlichen, künstlerischen whd ähilichen Bestrebungen dienen........

(3) Edwin Kau, a.w. pag. 51.

(4) Karl Bringmann Die Presse und ihr Recht, pag. 132.

(5) Denkschrift d.d. 28 mei 1925 van de Verein deutscher Zeitungs-Verleger (VDZV) aan het ministerie van binnenlandse zaken, geciteerd bij Helmut Egloff Arbeits- und Berufsorgamisation im deutschen Zeitungsgewerbe (1927), pag. 52, en Rudolf Stäber Kontroversen wm ein Joumalistengesetz, pag. 271. Vgl. ook Jänecke Verleger-Redakteur, pag. 56, volgens wie de uitgeversargumenten tenslotte de overhand kregen.

(6) Klaus-Detlev Funke Innere Pressefreiheit, pag. 21

(7) Karl Bringmann Die Presse und ihr Recht, pag. 124.

(8) Tekst ontleend aan Bringmann Die Presse und ihr Recht pag. 124 - 132. Bringmanns tekst is weer ontleend aan een getypte kopie in bezit van Emil Dovifat: Een van de bewerkingen in dit concept is de vervanging van de woorden Chefredakteur en Redakteur door de puristische schrijfwijze Hauptschriflleiter en Schriftleiter:

(9) Volgens Bringmann blijkt uit deze laatste bijzin de mogelijkheid tot vorming van een sowverïne Redaktionskonferenz, met inspraakmogelijkheden die in strijd zouden zijn met $\$ 67$ van de Betriebsrätegesetz van 1920 .

(10) $\$ 19$ maakt ontslag op staande voet mogelijk wegens zwaarwichtige redenen in drie gevallen, o.a. wegens een publicatie die tot een straf- of civielrechtelijke procedure aanleiding geeft zonder toestemming van de uitgever.

(11) Mondelinge informatie van Emil Dowifat an Karl Bringmann, id. pag. 133.

(12) Rudolf Stơber Kontroversen um ein Joumalistengesetz, Publizistik 1990, Heft 3, pag. 269

(13) Stöber, idem, pag. 276.

\subsubsection{De "Tarifvertrag" uit 1926 als compromis}

Geen enkele van de voorontwerpen van 1924 is ooit wet geworden. In 1925 kwamen dagbladuitgevers en journalisten tot een compromis in de vorm van de allereerste "Tarifvertrag", die per 25 januari 1926 is ingegaan met een looptijd van tien jaar en die, aldus Reinowski die innere Struktur der deutschen Tageszeitungen maßgeblich beeinflußt hat und der heute noch weitgehend praktiziert wird. Vooral onder uitgevers geldt de "Vertrag" als het beste wat uitgevers en journalisten over hun wederzijdse verhouding hebben geformuleerd. VolgensJänecke bevatten de naoorlogse arbeidsovereenkomsten van 1951 en 1960 een regeling van de verhouding uitgever - redactie die eine fast gleichlautende Formuliering is als die van 1926. Daraus folgt doch wohl, daß manche Ausfiuhrungen über "die Kompetenz des Redakteurs" eigentlich auch aus verlegerischem Denken stammen könnten. Bringmann citeert met instemming het orgaan van de RDP ("Deutsche Presse" van 13 januari 1926) dat over het document geschreven had dat het das vertrauensvolle Zusammenwirken der Redakteure und Verleger zum Segen der deutschen Presse und zur Erfullung ihrer öffenttichen Aufgabe dauernd sichern (soll). (1) Het eerste hoofdstuk van de overeenkomst heeft het karakter van een preambule, die de verhouding uitgever - redactie in neuer Form festlegt (Bringmann). De tekst ervan luidt: 
Die Zusammenarbeit von Verleger und Redakteur ist bedingt durch die Pflicht zur Wahrnehmung öffentlicher Interessen durch die Zeitung. (2) Es darf daher vom Verleger auf den Redakteur kein Gewissenszwang ausgeübt werden. Dem Redakteur wird im Rahmen der mit dem Verleger vereinbarten politischen oder wirtschaftlichen oder kulturellen Richtlinien für die Redaktionsführung die geistige Bewegungsfreiheit auch bei der Gestaltung des Textteils im einzelnen gewährleistet. Der Redakteur ist verpflichtet, das Gesamtinteresse und die Uberlieferung der Zeitung im Auge zu behalten. Die vertrauensvolle Zusammenarbeit von Verleger und Redakteur bedingt rechtzeitige gegenseitige Fühlungnahme, insbesondere in allen Zweifelsfällen. Über die Form dieser Fuhlungnahme sind vertragliche Abmachungen zulassig.

De preambule maakt duidelijk waarom uitgevers met deze formulering konden instemmen. De exclusieve zeggenschap van de redactie binnen de vooraf vastgelegde politieke, economische en culturele richting van de krant, die eerdere voorstellen voor een wettelijke regelling nog kenmerkten, is in de drie slotzinnen feitelijk weggeclausuleerd.

Waarom namen de journalisten in 1926 genoegen met deze overeenkomst? Volgens Stöber (3) heeft de leiding van de Duitse georganiseerde journalistiek in de jaren twintig ontwerpen voor "journalistenwetten" als drukmiddel gebruikt om verbetering van de arbeidsvoorwaarden en sociale voorzieningen bij overlijden en pensioen voor de journalisten in loondienst af te dwingen. Daarbij konden de journalisten ook rekenen op steun van Regierungsstellen bis hin zum Reichskanzler (Stöber). De economische positie van de journalist was immers onhoudbaar slecht; zijn reële inkomen bedroeg volgens Stöber nog slechts eenachtste van dat van vóór de oorlog. Alleen het dreigen met een wettelijke regeling van de verhouding uitgever-redactie, die de bevoegdheden van de uitgevers zou beperken, stond de RDP als pressiemiddel ter beschikking. Staken konden en wilden de journalisten niet; de statuten van de RDP voorzagen niet in een stakingskas. Verbetering van de sociale voorzieningen zou vooral de slechtst betaalde en zwaarst belaste groep, de journalisten van de "Kleinstpresse", ten goede komen. Diese hätten sich zugleich am wenigsten Hoffnung auf De-factoDurchsetzung einer De-jure-Regelung der redaktionellen Pressefreiheit machen könmen; sie mußten am ehesten mit dem Handel zwischen RDP-Spitze und Verlegern einverstanden sein, dürften aber vermutlich am wenigsten bereit gewesen sein, für die Chimäre der Gleichberechtigung zu streiken. (4)

De werknemers ruilden via de Tarifvertrag de redaktionelle Pressefreiheit in tegen pensioenrechten en arbeidsongeschiktheids-, weduwen- en wezenverzekeringen. Het was de prijs die de uitgevers bereid waren te betalen om hun invloed op de redactionele inhoud te behouden. Zij waren er, volgens Stöber, in geslaagd het begrip innere Pressefreiheit in twee stukken te breken: in redaktionelle Freiheit en wirtschaftliche Freiheit. Grotere sociale zekerheid voor de journalisten was de prijs die de uitgevers bereid waren te betalen om hun invloed op de 
redactionele inhoud van de krant veilig te stellen. Kau citeert met instemming Mallmann (5): Das Journalistenrecht war damit "auf das Gleis des Tarifiertrages abgeschoben worden".

(1) Hans J. Reinowski Innere Pressefreiheit - Ein Grundrech für Verleger und Redakteure pag. 32. Walther Jänecke Verleger-Redakteur, pag. 55; Kanl Bringmann Die Presse und ihr Recht, pag. 133/134. Over de arbeidsrechtelijke inhoud van de "Tarifvertrag" zie ook Kau Die Mitbestimmung in Presseuntemehmen, pag. 52.

(2) Deze variant op de term "öffentliche Aufgabe der Presse" stamt uit de Referentenentwurf van Haentzschel, \& 3, eerste zin: Der Schriftleitungsteil dient öffentlichen Imteressen.

(3) Rudolf Stöber Kontrowersen um ein Journalistengesetz, pag. 273 e.v.

(4) Rudolf Stöber, idem, pag. 274

(5) Walter Mallmann Pressefreiheit und Joumalistenrecht in: Es geht nicht nur um Springer, pag. 21 .

\subsubsection{Naar de "Schriftleitergesetz" van 1933}

\section{A. Ontwerp voor een nieuw "Reichspreßgesetz" uit 1932}

Zowel van de kant van journalisten als van uitgevers bleef men ook na 1926 aandringen op een wettelijke regeling, niet van de interne verhouding binnen de personderneming, maar van het journalistieke beroep, in een nieuwe perswet. Die was noodzakelijk, omdat de oude perswet uit 1874 niet meer zou vol-doen. (1) Al in 1925 hadden de uitgevers zich jegens de journalisten verplicht mee te werken aan een modernisering van de wet. In 1929 nam Haentzschel, inmiddels Ministerialrat en Leiter der Abteilung Presse in het ministerie van binnenlandse zaken, het initiatief tot vorming van een Sachverständigen-Kommission für die Beratung des neuen Preßgesetzes. Deze commissie, door Bringmann (1) omschreven als Versammlung führender Köpfe aus Presse und Wissenschaft, werkte vanuit het ministerie en publiceerde in september en november 1932 het eerste concept en een herziene versie die in hun onderlinge verschillen al de sporen droegen van het naderende politieke onheil. Zo werd in het eerste concept de äußere Pressefreiheit (hoewel niet zo genoemd) beschermd, doordat zowel wetgeving als bestuur alleen onder bijzondere voorwaarden tegen de pers konden optreden. In de tweede versie is bescherming tegen al te eenvoudig wetgevend ingrijpen (i.c. via machtigingswetten) verdwenen. Opvallend is eveneens dat in het stuk uit 1932 de bevoegdheid van de uitgever om exclusief de identiteit van het blad vast te stellen al geheel ontbreekt.

Paragraaf 10 van het stuk kreeg als titel mee Innere Freiheit der Presse. Unzulässige Bindungen der Textgestaltung. De omschrijving van het begrip in de tekst van $\$ 10$ is traditioneel: "innere Pressefreiheit" is bescherming tegen de ongewenste invloed van adverteerders op de redactionele inhoud. (3) Dit ontwerp voor een nieuwe perswet van de commissie onder leiding van Haentzschel, die in 1933 het ministerie zou verlaten (4) is volgens Bringmann (5) die vollständigste Neubearbeitung des Komplexes, die bisher (1963) gelungen ist. Volgens Schmidt-Osten (6) zou het ontwerp, wanneer het inderdaad wet geworden was, 
met recht kunnen claimen das beste und modernste Pressegesetz zu sein, das mit seiner Klarheit und umfassender Konzeption seiner Zeit weit voraus war. Het ontslag van het kabinet-von Papen was tevens het einde van dit wetsontwerp.

\section{B. RDP-Entwurf eines Pressegesetzes van april 1933}

In april 1933 (de nazi's waren reeds aan de macht, de eerste kranten waren al verboden en Joseph Goebbels was Reichsminister für Volksaufklärung und Propaganda) publiceerde de Reichsverband der deutschen Presse onder leiding van Paul Baecker, Chefredakteur van de Deutsche Tageszeitung (gelieerd an de Deutschnationale Volkspartei), een ontwerptekst, waarin de geest van de nationaal-socialistische Schriftleitergesetz van oktober van datzelfde jaar reeds aanwezig is. Dat blijkt al uit de tekst van $\& 1$ en in het bijzonder uit de onmiskenbaar ideologisch gekenmerkte toelichting:

\$. Die Presse dient öffentlichem Interesse. Ihre Freiheit ist durch die Grundlagen des nationalen Staates bestimmt. (....)

Begründang zu \& 1: Die Auffassung, daß die Presse öffentlichen Interessen zu dienen hat, ist vor allem von der Presse selber schon immer vertreten, ihre Durchsetzung aber namentlich durch die Praxis der Gerichte bis in die jüngste Zeit gehemmt worden. Der neue nationale Staat, der alle Volkskräfte in den Dienst der Gesamtheit stellen will, betrachtet die Wahrnehmung öffentlicher Interessen nicht nur als das Recht, sondern als selbstverständliche Pflicht der deutschen Presse: ihre gesamte Arbeit muß Dienst für die Nation sein. Da die Presse als Funktion des nationalen Lebens mit der Nation selber steht und fällt, so ist auch ihre Freiheit in die Lebensgesetze der Nation hineingestellt. So frei auch darum die Kritik der Presse grundsätzlich sein soll, zumal in einer Zeit, in der Staat und Nation in entscheidenden Kämpfen um Freiheit und Dasein stehen, wäre eine Kritik, die Grundlagen des nationalen Staates, die religiösen und sittlichen Fundamente des deutschen Volkslebens zu zersetzen sucht, oder die den Staat durch Beschimpfung seiner Symbole, seiner tragenden Einrichtungen oder Persönlichkeiten herabwürdigt, mit der Grundpflicht der Presse zum Dienst an der Nation unvereinbar.

De nationaal-socialistische Schriftleitergesetz van 4 oktober 1933 maakte een dankbaar en pervers gebruik van de gedachte van de öfentliche Aufgabe der Presse zoals ontwikkeld in het ontwerp van Baecker. Paragraaf 1 van de wet bood de nazi's de mogelijkheid de pers naar hun hand te zetten: Mitwirkung an der Gestaltung des geistigen Inhalts der im Reichsgebiet herausgegebenen Zeitungen und politischen Zeitschriften in Wort, Nachricht und Bild ist eine in ihren beruflichen Pflichten und Rechten vom Staat geregelte öffentliche Aufgabe. De Schriftleiter, die zich moesten laten registreren, kregen als Mittel der Staatsfiuhrung, zoals de toelichting op de Schriftleitergesetz het noemde een beamtenähnliche Aufgabe. Wegens dringende redenen van publiek belang ( $\$ 35$ Schriftleitergesetz) kon de Reichsminister für Volksaufklärung und Propaganda te 
allen tijde en zonder nadere motivering journalisten van de Berufshiste verwijderen, waardoor het hun onmogelijk gemaakt werd hun beroep uit te oefenen. Uitgevers die de richting van hun kranten niet in nationaal-socialistische zin bijstelden werden onteigend of gedwongen hun krant te verkopen aan het Eher-concern in München, dat geheel in nazi-handen was.

De totale onderwerping van de pers aan de nazi-ideologie in het algemeen en Reichsminister Goebbels in het bijzonder blijkt onder andere uit het door Frei en Schmitz geschatte aantal van 80.000 tot 100.000 Anweisungen waarnaar de Duitse pers zich in de periode tot het einde van het Duizendjarig Rijk moest richten. (7)

(1) Uit de toelichting bij het wetsontwerp blijkt dat de opstellers ervan ook het staatsbelang in het oog hielden: (....) Sowohl der Schutz, den der Staat der Presse gegenuiber überflussigen und willkürlichen Beschränkungen gewährt, wie ungekehrt der Schutz, den Staat und Staatsbürger gegenüber einem Mißbrauch der Preßfreiheit bediurfen, hat sich in verschiedensten Beziehungen als unzulänglich erwiesen, so daß eine Neuregelung sowohl im Interesse der Presse wie des Staates und der Allgemeinheit erforderlich geworden ist. Karl Bringmann Die Presse und ihr Recht, pag. 134.

(2) Karl Bringmann Die Presse und ihr Recht, pag. 135, alwaar ook de samenstelling ervan.

(3) \$ 10: Rechtsgeschäfte jeder Art, die mit Riicksicht auf wirtschaftliche Vorteile insbesondere im Hinblick oder im Zusammenhang mit dem Abschluß von Anzeigenverträgen die Gestaltung des Textteils einer Zeitung oder politischen Zeitschrift binden sollen, sind wegen Verstoßßes gegen die guten Sitten nichtig.

(4) Haentzschel (seiner Linie nach Sozialdemokrat - Bringmann) emigreerde naar Brazilië, waar hij nog voor de oorlog bij een arbeidsconflict werd doodgeschoten.

(5) Karl Bringmann, id., pag. 137.

(6) Hans Schmidt-Osten in: Joumalistengesetze und Pressegesetze (1969) pag. 35.

(7) Norbert Frei/Johannes Schmitz Journalismus im Dritten Reich, pag. 32 e.v. Typisch voorbeeld van zo'n Anweisung is die van 17 januari 1940: Der Minister kritisiert auf das schärfste einen Artikè im Lokalteil der Börsenzeitung iaber die Kälte.

\subsection{Samenvatting}

De tijd van de Weimar-republiek, onmiddellijk na de eerste wereldoorlog, is in Duitsland een vruchtbare periode geweest voor de mediarechtelijke discussie over de verhouding tussen de uitgever en de redactie van een krant. De Nederlandse commissie-Van Blom nam kennis van tenminste één concreet Duits voorstel om die verhouding formeel te regelen. In tegenstelling tot Nederland, waar een dagbladfusie aanleiding was om die verhouding nader te bestuderen, waren het in Duitsland twee gelijktijdige ontwikkelingen in de dagbladwereld die de journalisten ongerust maakten: de opkomst van de "Generalanzeigerpresse", waarvan de uitgever eerder een economisch dan een ideëel doel nastreeft, en het toenemend belang van de advertenties voor het voortbestaan van de krant. De uitgever, die voordien vooral een "helper" van de journalist was geweest - als hij al niet zelf allereerst publicist was - nam voortaan de belangrijkste beslissingen, werd "Herr des Journals". De journalistiek zag in de steeds verder opdringende commercie een hinderpaal bij het vervullen van de "offentliche Aufgabe", de publieke taak, 
van de pers. Als afweermechanisme werd de "innere Pressefreiheit" gepropageerd, een regeling valu de verhoudingen binnen de dagbladonderneming, die zou garanderen dat het redactionele deel van de krant gevrijwaard zou blijven van inmenging van buitenaf, in het bijzonder van de zijde van de commercie.

De journalistiek gaf de voorkeur aan een regeling van de "innere Pressefreiheit" door middel van wetgeving; de uitgevers daarentegen zagen liever een regeling via een collectieve arbeidsovereenkomst, omdat zij die desgewenst aan het einde van haar looptijd konden opzeggen. Bovendien zou bij arbeidsovereenkomst de medezeggenschapsregeling begrensd worden door het arbeidsrecht in het algemeen en de sinds 1920 van kracht zijnde "Betriebsrätegesetz", die de inspraak van werknemers in "Tendenzbetriebe" beperkte, in het bijzonder.

De eerste poging om de verhouding uitgever - redactie in een overeenkomst vast te leggen was het nog steeds zeer modern aandoende ontwerp voor een "Reichstarifvertrag" (RTV) uit 1920. Dit ontwerp, dat duidelijk geïnspireerd is door letter en geest van art. 118 van de Weimarer Verfassung en ook door de Nederlandse Commissie-Van Blom bestudeerd is, ging zeer ver in het verzekeren van redactionele autonomie binnen de door de uitgever vastgestelde rich-ting van de krant. In de historische ontwikkeling van het begrip "innere Pressefreiheit" is de RTV tot de dag van vandaag een mijlpaal.

Een belangrijk element in de RTV was de introductie van prohibitief hoge "afkoopsommen" voor redacteuren bij vervreemding van de krant en/of zodanige wijziging van de redactionele uitgangspunten, dat van een redacteur niet gevergd kan worden dat hij langer in dienst blijft. De Commissie-Van Blom heeft dit sanctiemiddel overgenomen.

Het RTV-ontwerp was volstrekt onaanvaardbaar voor de uitgevers ("ein Versuch der geistigen Expropriirung"). Dat gold in nog sterkere mate voor de vele pogingen om de bijzondere positie van de journalist in wetgeving vast te leggen. In 1926 sloten de dagbladuitgevers en de Reichsverband der deutschen Presse" (RDP) de eerste collectieve arbeidsovereenkomst, voorafgegaan door een verklaring over de verhouding tussen uitgever en redactie, waaruit vrijwel alle exclusieve zeggenschap van de redactie over de inhoud van de krant weggeclausuleerd was. De werkgevers van hun kant kwamen de journalisten tegemoet met een "Tarifvertrag", die onder meer een pensioenvoorziening en een arbeidsongeschiktheidsverzekering bracht. Evenals de Nederlandse ruilden de Duitse journalisten "redaktionelle Pressefreiheit" in tegen betere arbeidsvoorwaarden. Daarbij heeft ook een rol gespeeld dat de materiële nood onder Duitse journalisten zeer groot was en de georganiseerde journalistiek - evenmin als in Nederland - niet toegerust was om een arbeidsconflict met succes uit te vechten.

Latere pogingen om de "innere Pressefreiheit" in een nieuwe "Pressegesetz" neer te leggen zouden tenslotte ontaarden in de nationaalsocialistische "Schriftleitergesetz" van 4 oktober 1933, waarin de "Grundsatz- und Richtlinienkompetenz" van de uitgever werd vervangen door de "Grundpflicht der Presse zum Dienst an der Nation", waartoe de "Schriftleiter" werden opgeroepen. 


\section{Van CAO tot modelstatuut voor hoofdredactie en redactie}

\subsection{Het ontwerp Wet op de journalistieke verantwoordelijkheid}

De periode onmiddellijk na de Tweede Wereldoorlog wordt, wat de externe en interne regeling van de Nederlandse dagbladpers betreft, vooral gekenmerkt door pogingen om via wettelijke regelingen "de moraliteit van het perswezen" (minister van Onderwijs, Kunsten en Wetenschappen Gielen) te verbeteren. De weinig heldhaftige rol van een groot aantal journalisten en leidinggevende functionarissen van persondernemingen tijdens de oorlog had niet alleen aanleiding gegeven tot een perszuivering, maar ook tot reflectie over de oorzaken van fout of weifelmoedig gedrag van zeer velen bij de "legalle" pers. Daarbij werd de ondernemingsgewijze produktie van de pers wegens haar winstoogmerk vaak als hoofdschuldige aangewezen.

De Persraad, opgericht op basis van het Tijdelijk Persbesluit 1945 om het naoor logse perswezen te ordenen, adviseerde artikel $7 \mathrm{Gw}$ zo te wijzigen, dat ruimte geschapen werd voor een perswet die "het recht om dagbladen, nieuwsbladen of tijdschriften uit te geven " zou kunnen beperken en die de uitoefening van de journalistiek aan "eisen van vakbekwaamheid en waardigheid" zou kunnen binden. (1) De nadruk in de ontwerp-wetgeving (die vrijwel geheel tot ontwerpen beperkt is gebleven) lag op de mogelijkheid bepaalde uitgaven te verbieden en journalisten en uitgevers aan een tuchtrecht te binden. Een van deze ontwerpen was dat voor een Wet op de journalistieke verantwoordelijkheid, (TK 1948-49, nr. 1179) ingediend op 25 maart 1949 op basis van een interim-rapport van de StaatscommissiePompe. Deze was in 1947 ingesteld door de ministers Gielen en Van Maarseveen (Justitie) om de wenselijkheid van een nadere regeling voor het perswezen te onderzoeken. (2)

Een zeer omstreden onderdeel van het ontwerp was de verplichte registratie van journalisten. Inschrijving in het register van journalisten zou een voorwaarde moeten worden om journalistieke arbeid als hoofdberoep te verrichten. Er was bovendien de instelling van persgerechten (in twee instanties) in voorzien, die een journalist maximaal vijf jaar uit het beroep zouden kunnen ontzetten. Andere sancties waren een waarschuwing, berisping, geldboete of schorsing, die een journalist te wachten stonden aan wiens opzet of grove schuld feitelijk onjuiste, dan wel oneerlijke of onverantwoordelijke voorlichting te wijten is, of die zich opzettelijk of door grove schuld gedraagt in strijd met de zorgvuldigheid, die een journalist in het maatschappelijk verkeer betaamt, of met de eer van zijn 
stand. In dit wetsontwerp, dat pas in 1960 definitief werd ingetrokken, kwam, zij het indirect, ook de verhouding tussen commerciële en redactionele leiding aan de orde. De uitgever van een dagblad werd verplicht een hoofdredacteur aan te stellen, die (artikel 4 van het ontwerp) herkenbaar verantwoordelijk moest zijn voor de redactionele inhoud.

Vooral van joumalistieke zijde is scherp tegen het ontwerp geprotesteerd. De Federatie van Nederllandse Joumalisten (FNJ), die in 1946 was opgericht als overkoepeling van de drie (protestants-christelijke, katholieke en neutrale) journalistenorganisaties, maakte er bezwaar tegen dat het ontwerp ook uitgevers tuchtrechtelijk verantwoordelijk stelde voor de redactionele inhoud van de krant en geheel zweeg over de verhouding hoofdredactie - directie en die tussen hoofdredactie en redactie. De FNJ nam het standpunt in dat uitsluitend de redactie verantwoordelijk is voor de redactionele inhoud en zag in de beoogde regeling een aanwijzing in de richting van directiebevoegdheid op redactioneel gebied. (3) De tijdschrift- en dagbladuitgevers van hun kant zagen in art. 4 van het ontwerp een aanwijzing dat uitsluitend de hoofdredacteur de redactionele verantwoordelijkheid kreeg toebedeeld. De hoofdredacteur, aldus de tijdschriftuitgevers, heeft in de praktijk weliswaar een grote mate van zelfstandigheid, maar in laatste instantie beslist, evenals in elk bedrijf, de directie. (4)

In het rapport "De Vrijheid van drukpers - Het recht op antwoord", een ontwerp van wet op het recht van antwoord van de Dr. Wiardi Beckman Stichting uit 1956 werd het wetsontwerp op de journalistieke verantwoordelijkheid op onderdelen bekritiseerd, maar over het tuchtrecht voor journalisten én uitgevers wordt gezegd: Er valt niet in te zien, waarom dit tuchtrecht zich niet tevens zal uitstrekken tot de uitgevers van persorganen. Niet alleen is de advertentie een essentieel deel van de krant, waarover de journalist geen zeggenschap heeft, ook de invloed van de uitgevers op de redactionele inhoud van hun krant is dikwijls zeer aanzienlijk. Het zal een verantwoorde journalistiek slechts ten goede komen, wanneer ook de uitgevers onder het perstuchtrecht vallen. Aan de uitgevers van persorganen dienen niet minder hoge eisen te worden gesteld dan aan de journalisten. (5)

(1) Uitwoerig: J.H.I. van den Heuvel De vrijheid van de pers: De overheid en her commerciele karakter wan de pers 1944-1949. pag. 61-82.

(2) De opdracht aan de commissie-Pompe luidde:

Van advies te dienen omtrent de wenselijkheid om met inachtneming wan de grondwettelijk gewaarborgde vrijheid van drukpers nadere wettelijke regelen te stellen met betrekking tot het perswezen, waarbif (............................) in het bijzonder ware ma te gaan.

1. of en in hoeverre het aanbeveling verdient bij de wet regelen te stellen met betrekking tot het uitgeven van dag- en nieuwsbladen en andere periodieken en het exploiteren van persbureaus, $(\ldots . . . . . . . . . . . . . . . .$.$) )$

2. of en in hoeverre er aanleiding bestaat de bestaande strafrechtelijke bescherming tegen misdragingen, door middel wan de drukpers begaam, wit te breiden;

3. of het wenselijk moet worden geach de strafrechtelijke bescherming, bedoeld onder 2. aan te wullen met een tuchtrechtelijke, in dier woege, dat aan een in te stellen of te erkennen organisatie 
van joumalisten de bevoegdheid wordt toegekend tor het in eigen kring opleggen van tuchtruadre. geten.

(3) Een minderheid binnen de FNJ, onder wie NJK-voonzitter M. Rooij, adviseerde de Tweede Kamer tot aanneming van het wetsontwerp Deze minderheid hoopte mede op basis van het journalistieke tuchtrecht de wettelijke erkenning van het journalistieke verschoningsrecht te bereiken. $M$. Rooij Het dagbladbedriff in Nederland. pag. 435. Over het verschoningsrecht zie ook W. F. Korthals Altes Naar een journalistiek priwilege (diss.) 1989 en Erik Jurgens Een journalisiek verschoningsrecht!. Mediaforum 1991 - 2, pag. 13 en bijlage 13 - 20; id. Mediaforum 1991. $11 / 12$ Nogmaals: journalistiek "verschomingsrecht", pag. $119-122$.

(4) Brief d.d. 27 mei 1949 van de NOTU aan de Tweede Kamer. De dagbladuitgevers wezen het ontwerp principieel af, omdat zij teveel tuchtprocedures vreesden. Schuijt Werkers van het woord, pag. 113-121 en 156-158; vgl. ook De Meij Uitingsvrijheid pag. 22-23; uitvoerig in De Meij De vrijheid en de verantwoordelijkheid van de pers, pag. 97 e.v.

(5) Wiardi Beckman Stichting De vrijheid wan drukpers, pag. 9. De commissie bestond uit prof. mr. dr. G. van den Bergh, voorzitter, dr. Th. van Veen, secretaris en dr. E. Brongersma.

\subsection{De CAO van 1948}

De ontwikkeling in de richting van een formele vaststelling van de verhouding uitgever-redactie sloeg na de oorlog de weg in die het rapport van de commissieVan Blom reeds in 1924 gewezen had: de afbakening van de bevoegdheden van directie en (hoofd)redactie via een collectieve arbeidsovereenkomst. Op 26 november 1947 gingen de leden van de NDP, die voortaan in haar statuten ook de bevoegdheid tot het afsluiten van CAO's had opgenomen, akkoord met de allereerste collectieve arbeidsovereenkomst voor dagbladjournalisten.

Contractpartners van de NDP waren de heropgerichte Nederlandse Journalisten Kring (NJK), waarvan mr. M. Rooij, hoofdredacteur van de Nationale (later weer Nieuwe) Rotterdams(ch)e Courant, voorzitter was, en de Katholieke Nederlandse Journalisten Kring (KNJK). (1)

Het CAO-ontwerp bevatte, naar het voorbeeld van het ontwerp van de commissie-Van Blom en de grafische CAO, een "closed shop-beding": journalisten werden verplicht lid te zijn van een der journalistenorganisaties. Deze bepaling moest worden geschrapt, omdat het College van Rijksbemiddelaars een dergelijk contract weigerde goed te keuren. De CAO trad op 1 september 1948 in werking.

De inleiding van de CAO van 1948 herinnert nadrukkelijk aan het ideële karakter van het dagblad. De overeenkomst moest niet alleen materiële verlangens bevredigen, maar voorop moest staan dat de CAO in haar opzet en gevolgen mede dienstbaar zou worden gemaakt aan de bevordering van de ideèle eisen, namelijk verheffing van het journalistieke beroep en van de vakbekwaamheid van zijn beoefenaren, waaruit een verbetering van het Nederlandse dagbladwezen en derhalve van de vrije voorlichting van het Nederlandse volk moet voortvloeien.

De contractpartijen, aldus de inleiding, waarvan de tekst sindsdien in elke CAO (gedeeltelijk) is overgenomen, zijn ervan overtuigd, dat met de daarin vervatte regeling in vrije samenwerking een grondslag is gelegd voor de verdere ontwikkeling van het Nederlandse perswezen.

De CAO bevat daarom, behalve de gebruikelijke voorziening in de materiële verlangens van de journalisten, ook een eerste aanzet tot taakafbakening tussen direc- 
tie en redactie. Dat gebeurt via de functie-accentuering van het hoofdredacteurschap, maar binnen een harmonie-model, in de navolgende $\mathrm{CAO}$-bepalingen:

Art. 8. 1 Als hoofdredacteur worden aangemerkt journalisten, die krachtens hun aanstelling verantwoording dragen voor het redactionele gedeelte der dagbladen. In de concept-tekst heeft gestaan "...die krachtens hun aanstelling de verantwoording dragen", wat de exclusieve verantwoordelijkheid van de hoofdredacteur zou inhouden, maar die tekst is niet in de definitieve CAO opgenomen.

Art. 14 lid 1. De directeur en de hoofdredacteur zullen met betrekking tot redactionele aangelegentheden voortdurend met elkander overleg plegen.

Art. 14 lid 2. Het behoort tot de taak van de hoofdredacteur (algemeen redactiechef) de journalisten aanwijzingen en voorschriften amtrent de te verrichten journalistieke arbeid te geven. (2) Over dit laatste artikel is fel gestreden tussen de delegaties van journalisten en de NDP. De journalisten wensten duidelijk vast te leggen, dat de hoofdredacteur bij uitsluiting van ieder ander - dus ook van de directeur - verantwoordelijk zou zijn voor de redactionele inhoud van de krant. De NDP-delegatie wees die exclusieve bevoegdheid af op grond van de civielrechtelijke medeverantwoordelijkheid van de directeur als uitgever voor de redactionele inhoud van de krant. Als toelichting bij het omstreden artikel werden partijen het tenslotte eens over de constatering dat de gekozen formulering (het is de normale taak van de hoofdredacteur om de redactie te leiden) de verhouding tussen directie en hoofdredactie schetst, zoals die bij veel bladen in de praktijk al bestaat.

In de toelichting bij de jongste CAO-tekst is het voorbehoud gebleven. Dat de hoofdredacteur verantwoordelijkheid draagt voor de inhoud van het redactionele gedeelte van het dagblad (eerste zin art. 8 lid 1) derogeert, aldus de toelichting bij dit artikel, niet aan de overlegplicht tussen directeur en hoofdredacteur (art. 13 lid 1), noch aan de aansprakelijkheid, die rechtens op de uitgever rust voor de inhoud van zijn uitgaven.

Het belangrijkste middel voor een hoofdredactie om eigen beleid te voeren is het aantrekken, en eventueel (laten) ontslaan, van redactionele medewerkers. De CAO van 1948 gaf de hoofdredactie enige inspraak: benoeming en ontslag van journalisten zouden geschieden door de directie na overleg met de hoofdredactie. De klasse-indeling van de journalisten geschiedt door de directie op voordracht van de hoofdredacteur.

Zelfs vergeleken met de concept-CAO van de commissie-Van Blom uit 1924 vergelijk bijwoorbeeld de artikelen $9,11,12$ en 13 uit dat concept - was de (hoofd)redactionele zeggenschap ten opzichte van de directie zeer beperkt. Schuijt (3) constateert dan ook terecht: De oogst voor de hoofdredacteuren - en voor hen die van de CAO een strikte scheiding tussen redactie en commerciële afdelingen verwachtten - was dus mager. De CAO verschafte de directies ruime mogelijkheden zich met de inhoud van de krant te bemoeien en het hing slechts af van hetzij de persoonlijkheid wan de hoofdredacteur, hetzij een individuele regeling. of een hoofdredacteur zijn directeur voor redactionele aangelegenheden 
buiten de deur kon houden. Schuijt noemt als-lichtende voorbeelden in dit verband de hoofdredacteuren van de NRC en van het Haarlems Dagblad. (4)

Een belangrijke plaats is in de $\mathrm{CAO}$ sinds 1948 ingeruimd voor de redactiecommissie. Ook de commissie-Van Blom had dit instituut al voorgesteld. In haar ontwerp-CAO had de redactiecommissie echter tevens een medezeggenschapsfunctie in het redactionele beleid. In de CAO van 1948 is haar taak beperkt tot overleg met directie en hoofdredactie over de naleving van de bepalingen ervan; leden van de hoofdredactie mogen dan ook geen lid zijn van de redactiecommissie. In de loop der jaren zouden haar bevoegdheden om naleving van de CAO ook daadwerkelijk te kunnen controleren worden uitgebreid. Als sluitstuk op de controle van de naleving ervan werd in de eerste dagblad-CAO de Raad van Uitvoering ingesteld, een vier personen tellend college, van wie twee door de NDP en twee door de georganiseerde journalistiek (thans de NVJ) worden aangewezen. De beslissingen van de Raad zijn bindend en sluiten in beginsel een beroep op de rechter uit. De samenstelling van de Raad laat toe dat de stemmen staken; in dat geval staat het partijen vrij hun geschil aan de rechter voor te leggen. De ontwerp-CAO van de commissie-Van Blom kende - in navolging van Duitse en Oostenrijkse voorbeelden - een soortgelijk orgaan, het permanent scheidsgericht (art. 19) van twee keer drie leden, maar met een neutrale voorzitter als zevende lid.

Van journalistieke zijde is vanaf het begin geijverd voor een zodanige salariëring dat deze de verheffing van het journalistieke beroep en van de vakbekwaamheid van zijn beoefenaren ook in materieel opzicht zou weerspiegelen. Daarbij zochten werkgevers en journalisten naar vergelijkbare groepen werknemers en hun beloning. In 1948 werd door beide partijen de noodzaak erkend om de scheppende en met grotere verantwoordelijkheid belaste journalisten gelijk te stellen met de hoogste groepen administratieve ambtenaren of onderwijzend personeel. Journalisten op lager niveau zouden voor een redelijk levensperspectief het salaris moeten krijgen van een onderwijzer; mét hoofdakte voor de A- en B-bladen, zonder hoofdakte voor de $\mathrm{C}$ - en $\mathrm{D}$-bladen. (5) $\mathrm{Bij}$ de onderhandelingen over een nieuwe CAO in 1953 bracht de journalistendelegatie dit punt opnieuw ter sprake. In de loop van dat jaar waren de salarissen van de vergelijkbare groepen ambtenaren en onderwijzers belangrijk gestegen, een van de redenen waarom de NDP er weinig voor voelde aan de afspraak van 1948 herinnerd te worden.

Voor Rooij raakt deze kwestie een fundamentele grondslag van het journalieke beroep. (6) De algemene salariëring zal volgens hem van zodanig niveau moeten zijn dat bekwame, talentvolle jonge mensen zich tot het vak aangetrokken voelen; zijn de verschillen met andere gelijkwaardige carrières in materieel opzicht te groot, dan zal de journalistiek in het algemeen het met de "tweede of derde sortering" moeten stellen. Rooij waarschuwde de uitgevers dat blijvende onderbetaling van journalisten tot kwaliteitsverlies zou leiden en de kranten in de concurrentiestrijd met andere publiciteitsorganen (Rooij noemde - in 1956 al! vooral de commerciële televisie als concurrent) zwakker zullen komen te staan 
dan bij een hoge geestelijke kwaliteit het geval zou zijn. Als effectief middel tegen de tv-journalistiek beveelt Rooij "interpretative writing" aan, een journalistiek genre dat een gedegen background en ervaring vereist.

De zaak van de journalistieke functievergelijking had voor Rooij nog een andere betekenis: die van een rechtserkenning van het journalistieke beroep. Als intellectuelen staan de journalisten met hun verenigingen, die wel vakorganisaties maar met het oog op hun tevens bestaande ideele taak mi. nooit strijdorganisaties kunnen en mogen worden, bij voorbaat zwak. Hun bedrijfsgemeenschap met de dagbladdirecties moet daarom op beginselen van het recht en niet op de macht gebaseerd zijn; daartoe bestaat te meer grond, omdat het wezen van de journalistieke arbeid dat is van een vrij beroep en omdat van deze arbeid, alsmede van de sfeer waarin deze behoort te worden verricht, de specifieke kwaliteit van het door de onderneming vervaardigde produkt vrijwel ten volle afhankelijk is. (7)

(1) Over de voorgeschiedenis van de CAO van 1948 zie M. Rooij Het dagbladbedrijf in Nederland, pag. 378 e.v.; over de bereidheid van de NDP om nu wel akkoord te gaan met een CAO zie Schuijt Werkers van het woord, pag. 231.

(2) De CAO van 1948 stond toe - in art. 14 lid 3 - dat bij kranten geen hoofdredacteur, maar een "algemeen redactiechef" aan het hoofd stond. Pas sinds de gewijzigde CAO van 1966 is dat niet meer geoorloofd.

(3) Schuijt Werkers wan het woord, pag. 261.

(4) Verg. daarvoor de bijna eensluidende statutaire bepalingen van de NV Damiate (Haarlems Dagblad) en NRC in: M. Rooij Het dagbladbedrifi in Nederland, pag. 50 en 51.

(5) Toelichting CAO van 1948.

(6) M. Rooij Het dagbladbedriff in Nederland, pag. 384 e.v.

(7) Rooij, idem, pag. 385 .

\subsection{Verhouding (hoofd)redactie - directie in latere CAO's}

In latere CAO's is de (hoofd)redactionele zeggenschap op een aantal punten versterkt. De journalist wordt thans aangesteld door de directie, maar in overleg met en op voordracht van de hoofdredacteur (art. 32 lid 1). De invloed van de directie op de personele samenstelling van de redactie is hiermee tot de budgettaire beperkt. De directie kan die invloed uitoefenen door middel van de indeling van de journalisten in salarisafdelingen (van beneden naar boven oplopend van III tot en met I-extra op grond van individuele taak en verantwoordelijkheid). Deze indeling geschiedt nog steeds door de directie op voordracht van de hoofdredacteur (art. 5 lid 3). De directie is bij de indeling van de journalisten over de verschillende afdelingen echter weer gebonden aan een kwantitatieve minimumregeling (art. 10). Deze komt er op neer dat de redactie van een krant in principe ongeveer evenveel journalisten van elke afdeling telt. Doel van de getalsverhouding is, blijkens de toelichting, te bevorderen, dat de samenstelling der redacties aan sociaal en journalistiek verantwoorde minimum-eisen zal voldoen. Het recht van de directie om een journalist te ontslaan na overleg (en dus niet: in overleg) met de hoofdredacteur is gebleven (art. 36.1). 
In dit kader moet uiteraard nu reeds genoemd worden art. $18 \mathrm{~A}$ van de $\mathrm{CAO}$ van 1972, waarin de contractpartners na langdurige onderhandelingen de wenselijkheid neerlegden dat de positie wan hoofdredactie en redactie per dagbladuitgawe duidelijk wordt vastgelegd in een statuut. Dit statuut dient tot stand te komen in overleg tussen directie, hoofdredactie en redactie en vervolgens door de directie te worden vastgesteld. De verplichting tot invoering van een statuut geldt sinds 1 januari 1977.

\subsection{CAO en persconcentratie}

Vanaf het begin van de jaren zestig kregen hoofdredacties en redacties met een wrgent probleem te maken: de concentratie in de dagbladwereld, waarvan de omvang de aanleiding tot instelling van de commissie-Van Blom in het begin van de jaren twintig verre zou overtreffen. Ging het toen om de samenvoeging van twee keer twee kranten, tussen 1960 en 1970 zou het aantal zelfstandige dagbladondernemingen van 54 tot 34 dalen. Ook in de jaren vijftig was het aantal dagbladondernemingen al met zes gedaald. Het aantal zelfstandige dagbladen (kranten met een eigen hoofdredactie) liep terug van 65 in 1950 tot 61 in 1960 en 54 in 1970. Vooral in de regionale pers vielen zware klappen. (1) De CAO voor Dagbladjournalisten is sinds 1966 aangevuld met bepalingen die de ideële en materiële positie van journalisten verbeteren in geval van wat thans "structuurwijziging" heet. Daarbij gaat het niet alleen om verkoop of opheffing van kranten, maar ook om samenwerkingsverbanden met andere ondernemingen en interne reorganisaties die ingrijpende gevolgen voor de journalisten zouden hebben.

Uit de toelichting in de CAO (art. 40) blijkt dat de contractpartners het ideèle aspect wel degelijk hebben onderkend: Gezien het feit dat een dagbladonderneming niet alleen een commerciële onderneming is, maar tevens ideële belangen vertegenwoordigt, ligt het voor de hand ervan uit te gaan dat bij structuurwijzigingen ( ......) naast de zuiver commerciële overwegingen ook ideële overwegingen een belangrijke rol spelen. Dit maakt het tevens gewenst dat, indien beslissingen van deze aard ten aanzien van dagbladen worden genomen, niet alleen met de materiële positie, maar ook met de ideële belangen van de journalisten, die door het geestelijk karakter van hun arbeid veelal sterk aan hun blad gebonden zijn, wordt rekening gehouden. Zodra de plannen voor een dergelijke structuurwijziging zover gevorderd zijn dat ze openbaar gemaakt kunnen worden moet de dagbladonderneming de besturen wan NDP en NVJ informeren en een van de, door NVJ en NDP aangezochte, "vertrouwensmannen" inschakelen, die "adviserend inspraak" krijgt om de belangen van de journalisten te behartigen. (Het instituut "vertrouwensman" verdween in 1978).

In 1968 werd de CAO opnieuw aangescherpt. Op het materiële vlak kwam er, naast loonsuppletie en een afvloeiingsregeling, ook een smartegelduitkering voor journalisten die wegens de structuurwijziging ontslagen werden. Op het immateriële vlak kwamen er in 1968 twee verbeteringen. Allereerst werd erkend dat een journalist ook om principiële redenen, verband houdende met zijn levensbe- 
schouwelijke of politieke beginselen ontslag zou kunnen nemen, welk ontslag gelijkgesteld zou worden met dat van het "gewone" gedwongen ontslag wegens structuurwijziging, inclusief het recht op smartegeld. Verder zal tegelijk met de mededeling aan de besturen van de NDP en de NVJ dat de structuurwijziging een feit is, de redactiecommissie - zo nodig vertrouwelijk - worden ingelicht en geraadpleegd over de uitwerking en de uitvoering van de desbetreffende overeenkomst, voor zover deze onmiddellijk of op den duur van invloed kan zijn op de positie van de redactie. Invloed op de beslissing zelf had en heeft de redactiecommissie dus niet.

De medezeggenschapsrol van de redactiecommissie bij structuurwijzigingen, die, zoals al aangegeven, toch al beperkt was, zou feitelijk nog verder in betekenis af-

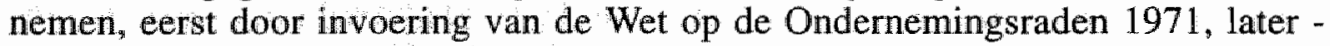
na de inwerkingtreding van het redactiestatuut - door introductie van de redactieraad.

De hoofdredactie heeft in de CAO-bepalingen over structuurwijziging geen bijzondere taak gekregen. Deze is er natuurlijk wel, maar vloeit impliciet voort uit de bepalingen over de werkverdeling en gezagsverhouding op de krant, in het bijzonder uit de bepaling, dat de directeur en de hoofdredacteur met betrekking tot redactionele aangelegenheden voortdurend met elkander overleg plegen. De CAO vanaf 1966 gaat er blijkens de toelichting bij - thans - art. 40 van uit dat indien beslissingen van deze aard worden voorbereid, in het algemeen de hoofdredactie ter zake zal worden ingelicht.

(1) Over de persconcentratie vanaf 1950 zie ook J.J. van Cuilenburg/J. Kleinnijenhuis/A. de Ridder Concentratie en persklimaat, VU Uitgeverij, Amsterdam, 1988.

\subsection{De opvattingen van Rooij}

Een belangrijk keerpunt in de naoorlogse ontwikkeling van de interne verhoudingen in de richting van het huidige redactiestatuut is ongetwijfeld de al eerder gememoreerde Rotterdamse dissertatie Het dagbladbedrijf in Nederland: een studie naar de sociaal economische besturing van de dagbladbedrijven in Nederland uit 1956 van M. Rooij geweest. Drie factoren hebben daarbij een rol gespeeld:

1. Rooij beschrijft de zijns inziens ideale verhouding tussen directie en hoofdredactie niet vanuit een theoretisch model, maar vanuit de praktijk, als hoofdredacteur van een in hoog aanzien staand dagblad. Bovendien beschrijft hij een hoofdredactionele taak die voor veel collega-hoofdredacteuren in hun eigen werkomstandigheden een soms heel ver verwijderd, maar nastrevenswaardig ideaal geweest moet zijn. Rooij plaatste de hoofdredacteur binnen de organisatie van de dagbladonderneming op gelijke hoogte met de directie (coördinatie) en niet in een van subordinatie. Hij koos voor deze erkenning van de zelfstandigheid van de hoofdredacteur omwille van de eisen van journalistieke objectiviteit en zuiverheid. Hij vervolgt dan: 
De opvattingen welke te dezen aanzien in de Nederlandse dagbladwereld aan den dag zijn getreden, bliken geen communis opinio te vormen. Het zal zeker geen tegenspraak ontmoeten, wanneer ik stel dat in de kringen der journalisten het door mij vertolkte standpunt algemeen wordt ingenomen. Even zeker is het dat in de kring der dagbladdirecties dit standpunt door verscheidenen hunner principieel wordt verworpen, hoezeer deze zelfde directies in de praktijk een dikwijls zeer vergaande "latitude" aan hun hoofdredacties laten. (1)

2. Rooij genoot ook zeer groot aanzien onder "gewone" journalisten. Dat respect had hij verworven door zijn pioniersarbeid binnen de georganiseerde journalistiek, onder andere ten behoeve van de eerste CAO voor dagbladjournalisten, en hij bracht dat respect over op een beroepsgroep, waarvan het aanzien (en het opleidingsniveau) niet bijster hoog lag. (2)

3. Rooijs dissertatie verdedigt niet alleen een sterke hoofdredactionele positie tegenover de directie, maar ook het standpunt dat kranten een stevige economische basis behoren te hebben. Krantebedrijven behoren rendabel te zijn en het is volgens hem mede de taak van de hoofdredactie daar rekening mee te houden. Dit standpunt gaf hem tevens groot gezag in de uitgeverswereld. Rooij beschrijft de eerste taak van de hoofdredacteur dan ook als: het bepalen en bewaken van zijn deel van het bedrijfsdoel: het dagelijks samenstellen van een zo goed mogelijke krant, naar haar vaste journalistieke karakter en naar de eisen van de journalistieke techniek en ethiek. (3) De gedachte dat directie en hoofdredactie - in nevenschikkend verband - samen moeten werken om een bedrijfsdoel te bereiken klinkt in het hele proefschrift door. (4)

De statutaire regeling van de positie van de hoofdredactie bij zijn eigen NRC, die Rooij in zijn dissertatie van 1956 als navolgenswaard beschrijft, is ook nu nog voorbeeldig. Zij luidt (NB: de cursiveringen zijn van Rooij):

1. De leiding van de redactie berust bij de hoofdredacteur die over de inhoud van het blad beslist.

2. Directie en hoofdredactie plegen overleg over de uitoefening harer functies; bij geschil van gevoelen heeft elk de bevoegdheid het geschil aan commissarissen ter bespreking voor te leggen. De raad van commissarissen kan zowel directie als hoofdredactie van advies dienen.

3. Aanstelling resp. ontslag van leden van de redactie alsmede vaststelling van hun salarissen geschiedt door de directie in overleg met de hoofdredactie. De leden van de redactie staan onder de hoofdredacteur.

4. Bespreking van de richting of van de inhoud van de door de vennootschap uitgegeven bladen vindt in de algemene vergadering van aandeelhouders niet plaats. (5)

Dat ook de eigenaren van de krant zich niet met de richting van de krant mogen bemoeien vloeide logisch voort uit het ook voor Rooij verrassende feit dat de 
NRC - evenals trouwens het Algemeen Handelsblad - die (liberale) richting niet in de ondernemingsstatuten had opgenomen. Uit het onderzoek van Rooij naar de identiteit van de toenmalige (midden jaren vijftig) kranten bleek dat slechts enkele ervan - in hoofdzaak katholieke kranten - hun politieke en/of godsdienstige richting ergens gepubliceerd hadden. Zelfs de statuten van Het Vrije Volk vermeldden niets over de politieke koers van de krant, al stond die impliciet wel vast door de statutaire bevoegdheid van de Partij van de Arbeid om de hoofdredacteur te benoemen en te ontslaan en zijn redactionele beleid te beoordelen. (6)

(1) M. Rooij Het dagbladbedriff in Nederland, pag. 227 (228) - 248; zie ook 101 e.v.

(2) Nog in 1968 had ruim 77 procent van de journalisten geen hoger opleidingsniveau dan (al dan niet woltooid) middelbaar onderwijs. Bron: Kempers en Wieten, geciteerd bij Schuijt Werkers van het woord, pag. 149. Uit een recente (1992) representatieve steekproef blijkt ruim 60 procent wan de journalisten thans een opleiding op $\mathrm{HBO}$ of een universitair niveau gevolgd te hebben. Bron: Onderzoek Actuele en toekomstige journalistieke arbeidsmarkt van de HBO-raad, pag. 18.

(3) M. Rooij Het dagbladbedriff in Nederland, pag. 231.

(4) Ook in zijn latere werk handhaaft Rooij zijn voorkeur voor en ongeschokt vertrouwen in de ondememingsgewijze exploitatie van dagbladen tegenover non profit-alternatieven. Deze laatste moeten ook een sluitende exploitatie en dus het maken van winst nastreven. M. Rooij Kranten * Dagbladpers en mactschappij, pag. 216; zie ook een interview met Rooij in De Journalist van 1 februari 1984, pag. 60.

(5) M. Rooij Het dagbladbedriff in Nederland, pag. $50 / 51$.

(6) M. Rooij, id. pag. 45 e.v. en bijlage I, pag. 533 - 546 . In deze bijlage staan van 65 dagbladondernemingen het doel, de rechtsvorm, het soort aandelen en de overdraagbaarheid daarvan beschreven. Slechts een dozijn ondernemingen blijken in hun statuten een indicatie van de redactionele identiteit wan hum krant(en) opgenomen te hebben. Dat zijn de "Stichting Het Parool"; N.V. Dagblad De Telegraaf en N.V. De Courant - Het Nieuws van den Dag; N.V. Drukkerij De Tijd; N.V. de Volkskrant; Stichting Oost-Brabant; Stichting Zeeuwsch Dagblad - Goes; N.V. Dagblad Het Binnenhof; N.V. Nieuwe Haagsche Courant; Stichting Je Maintaindrai - Friesland; N.V. Mij. tot Expl, van het Limburgs Dagblad; N.V. Noorderpers - Hoorn; Prow. Persvereniging Friesland.

\section{6 "Paper" van de Sectie Hoofdredacteuren}

De opvattingen over de verhouding van de hoofdredactie met de directie en de redactie, zoals Rooij die in zijn dissertatie had verdedigd en die hij in oktober 1957 op het congres van de Federatie van Nederlandse Journalisten had toegelicht, waren voor het bestuur van de Sectie Hoofdredacteuren van de Federatie aanleiding om een "paper", gedateerd 19 maart 1958, op te stellen: "De positie van de hoofdredacteur in de CAO-Dagbladjournalisten". Het sectiebestuur had daarvoor een drietal "vraagpunten" geformuleerd en van concept-antwoorden voorzien.

Bij vraagpunt $1 \mathrm{kwam}$ de eis naar voren om de medebeslissingsbevoegdheid van de hoofdredactie tegenover de directie over de samenstelling van de staf (benoeming, opslag, indeling) meer tot haar recht te doen komen. Daarom zouden de artikelen in de $\mathrm{CAO}$ die bepaalden dat

- de indeling van de journalisten geschiedt door de directie op voordracht van de hoofdredacteur (art. 6) en 
- aanstelling van de journalist (art. 24) of ontslag (art. 27) geschiedt door de directie na overleg met de hoofdredacteur

gewijzigd moeten worden in:

- De indeling van de journalisten en de vaststelling van hun salarissen (................) geschiedt door de directie op voorstel van en in overeenstemming met de hoofdredacteur.

- De journalist wordt aangesteld op voorstel van de hoofdredacteur.

- Een journalist wordt door de directie niet ontslagen dan in overeenstemming met de hoofdredacteur.

Het wijzigingsvoorstel zou de hoofdredacteur laten beslissen met welke journalisten hij zijn redactionele beleid zou uitvoeren en zou de invloed van de directie daarop vrijwel geheel elimineren. Het is niet toevallig dat de Sectie deze bevoegdheden voor haar leden opeiste; Rooij had immers diezelfde (reeds verkregen) bevoegdheid van de hoofdredacteur bij zijn NRC als navolgenswaard beschreven.

De beide andere vraagpunten raakten de kern van de verhouding hoofdredactie ten opzichte van directie en die tussen hoofdredactie en redactie. Vraagpunt 2 luidde: Kan de gedachte van de zelfstandige verantwoordelijkheid van de hoofdredacteur voor de redactionele inhoud van zijn blad in de nieuwe $C A O$ worden verankerd?

Ook hier is de voorbeeldwerking van de statutaire bepaling bij NRC ("De leiding van de redactie berust bij de hoofdredacteur die over de inhoud van het blad beslist.") zichtbaar. Het Sectiebestuur was van mening dat de vigerende CAO-bepalingen de positie van de hoofdredacteur op zichzelf op onvoldoende wijze tot uitdrukking brachten. Dat waren de bepalingen

14.1 De directeur en de hoofdredacteur (algemeen redactiechef) zullen met betrekking tot de redactionele aangelegenheden voortdurend met elkaar overleg plegen.

14.2 Het behoort tot de taak van de hoofdredacteur (algemeen redactiechef) de journalisten aanwijzingen en voorschriften omtrent de te verrichten journalistieke arbeid te geven.

Het bestuur voorzag echter onoverkomelijke problemen als het zou proberen via de CAO de bevoegdheden van de directies te beperken. Zoiets werd kansloos geacht. Bovendien zou een zelfstandige verantwoordelijkheid voor de redactionele inhoud onvermijdelijk nopen tot een conflictenregeling tussen directie en hoofdredacteur, die een beroep mogelijk moet maken op het hoogste beslissingsorgaan (raad van commissarissen of bestuur van de stichting). Hiermede zou men geheel in de sfeer van de statutaire regeling van bevoegdheden komen te verkeren. Het Sectiebestuur onderschrijft daarom het destijds door de journalistendelegatie ingenomen standpunt dat de algemene regeling van de betrekkingen tussen directie en hoofdredactie boven de in een CAO op te nemen arbeidsrechtelijke bepalingen uitrijst. De hier reeds aangeduide vraag of de interne verhouding hoofdredactie - directie binnen het dagbladbedrijf arbeidsrechtelijk (bij voorbeeld via de 
CAO) geregeld moet worden of onderdeel van de ondernemingsstatuten dienen te zijn zal later nog een grote rol spelen. (1)

Met vraagstuk 3 begaf het Sectiebestuur zich op het glibberige pad van de verhoudingen op de redactionele werkvloer. Is het mogelijk, zo luidde de vraag, de opvatting dat de hoofdredacteur als "primus inter pares" een zo vrij mogelijke werkgemeenschap voor zijn redacteuren moet scheppen, in de nieuwe CAO te belichamen?

Het bestuur zag hier twee onoverkomelijke problemen. Ten eerste leent dit vraagstuk zich moeilijk voor een scherp omschreven juridische regeling. Het tweede bezwaar herinnert er aan dat anno 1958 nog grote verschillen in redactionele verhoudingen bestonden tussen een paar toonaangevende landelijke bladen en de grote meerderheid van kleinere en regionale kranten. Het Sectiebestuur zegt het, enigszins versluierend, maar voor de goede verstaander in die tijd wel duidelijk, aldus: De in het vraagpunt bedoelde samenwerking in de redactie vereist een goed begrip van de grenzen welke door alle partijen in hun onderlinge betrekkingen uit eigen aandrift in acht moeten worden genomen. Het is de vraag of bij bladen die in dit opzicht nog geen traditie hebben, dit begrip reeds in voldoende mate aanwezig is. Meer dan formele regelingen is een in vrijheid gevormde praktijk ten deze van doorslaggevende betekenis. Ook dit vraagstuk werd daarom voor nadere bestudering binnen de Federatie van de $\mathrm{CAO}$-agenda gehaald.

(1) Zie 4.8.3.

\subsection{Naar een Statuut voor de Hoofdredactie}

Op 11 maart 1963 zette de Sectie Hoofdredacteuren van de Federatie van Nederlandse Journalisten deze discussie formeel voort via een op die dag gevormde commissie "ter bestudering van de positie van de hoofdredacteur in de Nederlandse dagbladonderneming". Voorzitter van de commissie werd (uiteraard) prof. mr. dr. M. Rooij. (1) Uit de installatierede van Sectievoorzitter mr. J.W. Niessink en het antwoord van commissievoorzitter Rooij (2) blijkt dat de hoofdredacteuren in het bijzonder over de navolgende drie punten duidelijkheid wensten:

- Welke positie neemt de hoofdredacteur in ten opzichte van de directie?

- Wat is de plaats van de hoofdredacteur binnen de redactionele organisatie?

- Hoe kan de krant als ideeel produkt beter beschermd worden?

Op basis van de aanbevelingen van de commissie-Rooij maakte Louis Frequin (hoofdredacteur van De Gelderlander) een eerste ontwerp van wat later het Statuut voor de Hoofdredactie zou worden. Het ontwerp, dat na amendering op 8 september 1964 door de Sectie Hoofdredacteuren was vastgesteld, werd als concept ingebracht in de gemengde studiecommissie van de Federatie van Nederlandse Journalisten en de NDP, die in 1966 was ingesteld om een statuut 
voor de hoofdredacteur te ontwerpen. Deze commissie bleek slechts moeizaam tot overeenstemming te kunnen komen. In 1969 nam de Sectie Hoofdredacteuren het initiatief om de onderhandelingen te reactiveren. Drs. M. Snijders, hoofdredacteur van het Utrechts Nieuwsblad, die als voorzitter van een naar hem genoemde commissie (3) het voortouw zou nemen om het hoofdredactiestatuut tot stand te brengen, noemt de democratiseringsgolf in de westerse wereld, die eind jaren zestig ook ons land beroerde (mei 1969: Maagdenhuisbezetting) als een van de ontwikkelingen die een nieuwe positiebepaling van de hoofdredacteur urgent maakten. De roep om medezeggenschap klonk ook op de dagbladredacties, waar journalisten een deel van de bevoegdheden van de hoofdredacties opeisten. Om hun bevoegdheden te kunnen delen moesten de hoofdredacties, aldus Snijders, echter eerst duidelijkheid verkrijgen over hun eigen bevoegdheden. Zij eisten daarom dat de hoofdredactie:

- voortaan niet langer ondergeschikt zou zijn aan de directie, maar - zoals reeds door Rooij bepleit - op gellijk niveau, nevengeschikt aan de directie, zou komen; - de vergaderingen van het hoogste orgaan van de onderneming (Raad van Commissarissen, Curatorium) zou mogen bijwonen;

- onmiddellijk zou worden gekend in eventuele plannen tot opheffing, verkoop of fusie van de krant;

- de beschikking zou krijgen over een jaarlijks redactioneel budget;

- het recht van voordracht van redactieleden zou krijgen en bij uitsluiting van ieder ander (inclusief de directeur) het gezag over de redactie zou uitoefenen.

De uitgevers, met deze eisen geconfronteerd, toonden zich weinig genegen om de hoofdredacties tegemoet te komen. Zij repten niet eens over het uitsluitende gezag over de redactie en de verantwoordelijkheid voor de redactionele inhoud. Integendeel, zij eisten onder meer dat de hoofdredacteur de directie vooraf in kennis stelde van zijn voornemen tot optreden buiten de krant en de aanwezigheid van de directie, ten minste een keer per jaar, in de vergadering van de hoofdredacteur met zijn staf. De inspraak die zij aanboden beperkte zich tot een informatieplicht over de jaarstukken, de funanciële positie, de advertentie-omzet, de oplage en voorgenomen wijzigingen in de kring van eigenaren en binnen de Raad van Commissarissen. Medezeggenschap kregen de hoofdredacties slechts over de grafische vormgeving van hun krant.

De volgens Snijders (4) meest opmerkelijke bepaling die de uitgevers in het statuut wensten op te nemen was de verplichting dat de hoofdredactie hoofdartikelen die een standpuntbepaling in belangrijke controversiële aangelegenheden bevatten vooraf ter kennis zou brengen van de directie.

Nadat de Sectie Hoofdredacteuren een nieuw ontwerp voor een statuut had goedgekeurd, werden in oktober 1970 de onderhandelingen met een delegatie van de Nederlandse Dagbladpers, die in 1966 waren onderbroken, hervat. De hoofdredacteuren hadden zich inmiddels verzekerd van de steun van het bestuur van de Nederlandse Vereniging van Journalisten (NVJ), waarin sinds 1968 de Federatie van Nederlandse Journalisten is opgegaan. Binnen dit bestuur was overigens wel 
bezorgdheid over de "Alleingang" van de hoofdredacteuren met hun eigen statuut. Het bestuur vulde daarom het concept van de Sectie aan met de bepaling, dat de betrekkingen tussen de hoofdredactie en de (gewone) redactieleden in een nieuw statuut (voor zowel de hoofdredactie als de redactie) zouden worden geregeld. Niemand vermoedde toen nog hoeveel problemen uit dat zinnetje zouden voortkomen, aldus Snijders, daarbij doelend op de grote commotie die het eindresultaat van de onderhandelingen met de NDP later in de NVJ zou veroorzaken.

In zijn verslag van deze onderhandelingen wijst Snijders (5) ook op druk van regeringszijde om de verhouding tussen directie en redactie in een statuut vast te leggen. Aanleiding daartoe was de reeds genoemde onrustbarende concentratie in de dagbladpers, die vanaf het begin van de jaren zestig had gewoed. Al in 1968 had de Persraad (6) daarover advies uitgebracht en in een passage had hij ook de onderhandelingen over een hoofdredactiestatuut gereleveerd. Na geconstateerd te hebben dat de geheel eigen plaats van de hoofdredacteur onmiskenbaar in verband staat met het probleem van de dagbladconcentratie, zegt de raad:Wanneer zulk een statuut regel zou zijn en wanneer daarin bepalingen zouden zijn opgenomen over inspraak van de hoofdredacteur bij transacties, waarbij het karakter van de krant in het geding is, alsmede sterke garanties voor het geval dat hij zich daarmede niet kan verenigen, dan zou dit zulke transacties op zijn minst bemoeilijken en zeker in voor de vrije journalistiek gunstige zin kunnen beïnvloeden.

De reële dreiging van een door de minister opgelegd statuut dat een instrumentarium zou kunnen bevatten om de persconcentratie te bemoeilijken, heeft bij de onderhandelingen met de NDP volgens Snijders, wel gewerkt: Want hoe weinig aardigheid de heren erin hadden met ons tot overeenstemming te komen, dat was altijd nog beter dan dat Den Haag ons allen iets zou voorschrijven.

De beide onderhandelingsdelegaties kwamen op 6 mei 1971 tot overeenstemming over een hoofdredactiestatuut, waaruit later een voor de Sectie Hoofdredacteuren onaanvaardbaar artikel werd geschrapt. In de oorspronkelijke versie heeft gestaan: Een hoofdredacteur geeft aan de directie kennis van een wijziging in zijn politieke of levensbeschouwelijke opvattingen voorzover daarvan in de krant zou blijken, alsmede van voorgenomen optreden, zowel in als buiten zijn hoedanigheid van hoofdredacteur, in geschrifte, in redevoeringen of omroepuitzendingen (.... ). Dit "betuttelingsartikel", zoals het werd genoemd, verdween, nadat de NVJ-delegatie had ingestemd met het notuleren van de uitleg van haar voorzitter Snijders dat een honorabel hoofdredacteur zelf ontslag zal nemen als zijn opvattingen zodanig zijn gewijzigd dat ze niet meer in overeenstemming zijn met de beginselen die hij eerder aanvaardde. (7)

Het heeft vervolgens nog tot 4 maart 1972 geduurd voordat de Verenigingsraad van de NVJ, die hoofdzakelijk uit niet-hoofdredacteuren bestond, instemde met het hoofdredactiestatuut. De raad had het resultaat twee maanden eerder verworpen, waarna het bestuur van de NVJ was afgetreden. Naast inhoudelijke bedenkingen tegen de inhoud van het statuut had de meerderheid in de Verenigingsraad ook principiële bezwaren, die er op neerkwamen dat zij vond dat de hoofdredac- 
teuren zich via dit statuut een bevoorrechte positie hadden verworven, terwijl zij juist één met de redacties behoorden te zijn. Er moest een commissie van goede diensten aan te pas komen om het bestuur weer te verzoenen met de Verenigingsraad. Deze laatste aanvaardde tenslotte het hoofdredactiestatuut onder de voorwaarden dat het slechts één jaar - gedurende looptijd van de CAO $1971 / 72$ - van kracht zou zijn en dat in dezelfde CAO de bepaling zou worden opgenomen die dagbladondernemingen verplichtte per dagbladuitgave een statuut op te stellen dat zowel de positie van de hoofdredactie als van de redactie zou regelen. Bij het opstellen van $\mathrm{zo}$ 'n statuut zouden de dagbladondernemingen gebruik kunnen maken van een "modelstatuut voor hoofdredactie en redactie", dat NVJ en NDP samen zouden ontwikkelen. In dit modelstatuut zou het thans overeengekomen hoofdredactiestatuut geïntegreerd worden.

(1) De overige leden waren H.W. Eldermans (Rotterdams Nieuwsblad), E. Evenhuis (Leeuwarder Courant), H. Greven (Dagblad van het Oosten), H.C.J.A. baron van Lamsweende (De Tijd), prof. mr. L.G.A. Schlichting en S.H.A.M. Zoetmulder (Eindhovens Dagblad). Schlichting, voormalig hoofdredacteur van De Tijd, doceerde het vak dagbladwetenschap bij het Katholiek Instituut voor de Journalistiek, gevestigd bij de Universiteit van Nijmegen.

(2) De Journalist van 16 maart 1963, geciteerd door M. Snijders Het redactiestatuat - geschiedenis en bedoelingen in Is de klant of de krant koning (red. J.P.M. van Beek), pag. 12/13

(3) Andere leden van deze commissie waren drs. L. Metzemaekers, hoofdredacteur van het Financieele Dagblad, en drs. J. Naninck van het Brabants Dagblad.

(4) M. Snijders, idem, pag. 16.

(5) M. Snijders, idem, pag. $17-20$.

(6) Advies Concentratie in de dagbladpers van 29 januari 1968, pag. 7, behorend bij de brief d.d.

19 april 1968 van de minister van Cultuur, Recreatie en Maatschappelijk Werk over Concentratietendenzen in de dagbladpers, zitting 1967-68,9571. Vgl. ook het rapport van de Interdepartementale Commissie Concentratietendenzen in de pers, TK 1969/70, $9571 \mathrm{nr} 2$.

(7) M. Snijders, idem, pag. 20. Schuijt Werkers van het woord, pag. 266.

\subsection{Naar een modelstatuut voor hoofdredactie en redactie}

\subsubsection{Rapport van de Studiecommissie Dagbladconcentraties van de NVJ}

Nog voordat de sectie Hoofdredacteuren gereedgekomen was met haar eindversie voor een statuut was er in een ander verband binnen de NVJ ook al nagedacht over de verhouding (hoofd)redactie - directie. Aanleiding daartoe was eveneens de onrust over de persconcentratie en de als ontoereikend gevoelde medezeggenschap daarin van de journalistieke medewerkers. De Verenigingsraad van de NVJ stelde - vooral op aandrang van de afdeling Brabant, waar de fusiegolf het eerst en het zwaarst had toegeslagen - een Studiecommissie Dagbladconcentraties in onder voorzitterschap van de toenmalige voorzitter van de Amsterdamse Pers, Han Lammers.

De opdracht van de commissie was niet alleen het probleem van de dagbladconcentraties te bespreken, maar ook het vraagstuk van de "interne democratie". 
Volgens Kees Bastianen (De Journalist van 1 december 1970) was de achtergrond daarvan dat in de (Brabantse) praktijk de hoofdredacteur meestal de lange arm van de directie was gebleken, die aanzienlijk minder weerstand aan de fusiedrang van de eigenaars had geboden dan zijin redacteuren wensten.

De commissie trok zich twee dagen ( 9 en 10 mei 1970) terug in het Larense hotel Hamdorff voor het opstellen van een rapport dat uit twee hoofdstukken bestond. (1) Hoofdstuk 1 werkte het plan uit om het beheer van de technische produktieapparatuur te scheiden van het beheer van de krant als journalistiek produkt. Het rapport noemt dat: een scheiding van de figuren van drukker en uitgever. In een bij wet geherstructureerd dagbladbedrijf zouden in het hele land drukfabrieken moeten verrijzen, waar "redactionele eenheden" hun kranten technisch kunnen laten vervaardigen. Het idee, dat geïnspireerd was op de omroepstructuur met haar scheiding tussen omroep en technisch facilitair bedrijf, heeft in ons land weinig aanhang gevonden. (2)

Het tweede hoofdstuk over de medezeggenschap van redactionele medewerkers van een krant is voor dit onderzoek interessanter, omdat het een aantal concrete voorstellen doet die volgens de opstellers in een toekomstig redactiestatuut terug te vinden zouden moeten zijn. De belangrijkste zijn (mijn cursiveringen w.t.):

- De uitgever en de redactie leggen in onderling overleg de ideële grondslag van de krant schriftelijk vast.

- De persoonlijke vrijheid van de journalisten wordt gewaarborgd binnen het kadler van de ideële grondslag van de krant. Zij kunnen niet gedwongen worden tegen hun overtuiging te schrijven.

- De hoofdredactie heeft de leiding van de krant. Zij wordt bijgestaan door de redactieraad. De hoofdredactie moet periodiek verantwoording afleggen aan de redactieraad; de redactieraad kiest uit zijn midden een voorzitter.

- De plenaire redactievergadering is binnen de redactionele sfeer het beslissende orgaan.

- De uitgever pleegt overleg met de hoofdredactie en de redactieraad over alle voorgenomen wijzigingen die de redactie aangaan, zoals: wijziging van de vastgestelde ideële grondslag; wijziging van de ondernemingsvorm; wijziging van de bezits- en aandelenverhoudingen; aangaan of wijzigen van samenwerkingsverbanden en verschijningsvorm van de krant; wijziging van de positie van de redactie; wijziging van of in de redactionele leiding.

- De hoofdredactie wordt door de uitgever aangesteld. De redactieraad stelt voor de benoeming van een hoofdredacteur een bindende voordracht op, welke de instemming moet hebben van tenminste tweederde deel van het aantal leden van de plenaine redactievergadering.

- Een hoofdredacteur wordt door de uitgever slechts ontslagen als tenminste tweederde deel van het aantal leden van de plenaire redactievergadering zich daarvoor heeft uitgesproken.

- De hoofdredactie beslist over de personele organisatie ter redactie. Belangrijke wijzigingen in de personele bezetting (adjunct-hoofdredacteur; rubriekschefs, po- 
litieke en parlementaire redacteuren, buitenlandse correspondenten) behoeven de instemming van tweederde deel van de redactieraad.

- Wat de financiële consequenties van het personeelsbeleild betreft handelt de hoofdredactie in overleg met de uitgever.

- De hoofdredactie en de redactie moeten door de uitgever geïnformeerd worden over de financiële positie van het bedrijf. De omvang van het operationele budget voor de redactie wordt vastgesteld door de uitgever in overleg met de hoofdredactie en de redactieraad.

De Studiecommissie Dagbladconcentraties had het als haar taak gezien aan de medezeggenschap van redactionele medewerkers van een krant een "institutionele vorm" te geven. Zij bedoelde daarmee dat de redactionele organen (plenaire redactievergadering en redactieraad, in die hiërarchische volgorde) een sterke positie zouden moeten innemen, ook tegenover de hoofdredactie. Deze laatste mocht niet meer als aparte macht binnen de krant optreden, maar moest zich als onderdeel van de redactie beschouwen. De tot nu toe ambivalente figuur van de hoofdredacteur (Bastianen) mocht niet langer het verlengstuk van de directie of van de eigenaars zijn, maar diende als primus inter pares ingedeeld bij de redactie.

Dat laatste was de strekking van een motie die tijdens een buitengewoon congres over het rapport van de commissie-Lammers op 6 juni 1970 werd aangenomen. Zoals Schuijt (3) terecht constateert zou het hier gemanifesteerde wantrouwen jegens de hoofdredacteuren (in dat opzicht ziet ook Schuijt overeenkomsten met de bevindingen van de commissie-Van Blom uit 1924) bij de latere interne discussies in de NVJ over de te volgen strategie bij de onderhandelingen met de werkgevers een belangrijke rol spelen. Het congres nam een resolutie aan om een redactiestatuut in de geest van het Larense rapport in de CAO op te nemen. Voor de hoofdredacteuren binnen de NVJ was het volstrekt onacceptabel dat de plenaire redactievergadering het beslissende orgaan in redactionele aangelegenheden zou worden. Dat bleek reeds op 12 oktober 1970, kort na het Amsterdamse congres, toen de Commissie Interne Democratie van de NVJ (paritair samengesteld met vier hoofdredacteuren) vastliep op een meningsverschil over de vraag of het rapport van de commissie-Lammers als bindend beschouwd moest worden, dan wel als discussiestuk voor de hele journalistiek. Volgens een van de hoofdredacteuren (Hoefnagels van de Haagsche Courant) was het Amsterdamse demonstratieve congres niet representatief geweest. Het was hem bekend dat een deel van de leden dit niet had bijgewoond, omdat zij de conclusies van het rapport-Lammers onzinnig vonden.

De (meerderheid in de) Commissie Interne Democratie legde in haar door $\mathrm{E}$. Evenhuis, hoofdredacteur van de Leeuwarder Courant, geschreven verslag als hoofdlijnen voor een nieuw geintegreerd statuut vast:

- de hoofdredacteur heeft de redactionele leiding van de krant en wordt daarin bijgestaan door een gekozen redactieraad; 
- de hoofdredacteur is zowel voorzitter van de redactieraad als van de redactievergadering;

- de redactievergadering onderhoudt via de redactieraad contact met de uitgever over de redactionele beginselverklaring; zij aanvaardt daarbij als uitgangspunt de beginselverklaring zoals die bestaat bij de inwerkingtreding van het redactiestatuut;"

- de uitgever hoort de redactieraad vóór de aanstelling of het ontslag van een hoofdredacteur; de redactieraad kan de mening van de redactievergadering vragen en die aan de uitgever laten weten, wanneer een tweederde meerderheid van de redactievergadering die mening onderschrijft;

- de hoofdredacteur beslist over de personele organisatie der redactie; over belangrijke wijzigingen in de personele bezetting raadpleegt hij de redactieraad;

- in een redactiestatuut wordt, mits de redactievergadering daarmee instemt, vastgelegd dat de redactie eventueel naast andere onderdelen van het bedrijf streeft naar een vertegenwoordiging in het hoogste orgaan van de onderneming; zij kan voorts streven naar de verwerving van aandelen in het eigen bedrijf;

- de redactievergadering beslist met meerderheid van stemmen in alle zaken waarin het statuut niet voorziet.

De conclusies van de Commisie Interne Democratie weken op drie punten principieel af van de uitgangspunten van het rapport van de Commissie-Lammers:

1. De redactieraad en niet de redactievergadering is het belangrijkste orgaan van medezeggenschap van de redactie;

2. de redactie heeft geen beslissende stem meer bij benoeming en ontslag van een hoofdredacteur;

3. de redactie heeft geen (mede-)beslissende stem bij de formulering van de beginselen van de krant.

Het NVJ-bestuur stelde de minderheid in de commissie, die niet wilde tornen aan de uiteindelijke beslissingsbevoegheid van de voltallige redactievergadering, in het gelijk. Het "Larense standpunt" ten aanzien van het primaat van de redactievergadering was volgens de NVJ-voorzitter zelfs nog "slapjes geformuleerd".

(1) De volledige tekst is te vinden in De Journalist van 30 mei 1970, pag. 22 e.v.

(2) De International Federation of Journalists (IFJ) heeft in $1989 \mathrm{op}$ zijn conferentie in Sydney over "transnational multi-media ownership" een verklaring aangenomen waarin bij regeringen wordt aangedrongen op the creation of alternative publishing and distributing networks als een middel tegen persconcentratie door internationaal vervlochten commerciële en naar monopolisering strevende ondernemingen. Ten atanzien van radio en televisie roept dezelfde "Sydney declaration" op (to) maintain medica systems outside the framework of commercial funding, for instance public broadcasting.

(3) Schuijt Werkers van het woord, pag. 243 


\subsubsection{Discussie binnen de NVJ}

Na de aanvaarding van het statuut voor de hoofdredactie in het voorjaar van 1972 zou het nog tot 1976 duren voordat NDP en NVJ overeenstemming bereikten over een modelstatuut voor hoofdredactie én redactie, dat de individuele dagbladen als richtsnoer zou moeten dienen bij het opstellen van hun redactiestatuten. In dit modelstatuut zou het bestaande statuut van de hoofdredactie geỉntegreerd moeten worden, hetgeen voor de hoofdredacteuren betekende dat niet getornd mocht worden aan de rechten die in hun statuut waren vastgelegd. Hier stuitten zij echter op ongekend heftig verzet van de "gewone journalisten".

De Verenigingsraad, het hoogste orgaan van de NVJ, bracht op 28 oktober 1972 in een enerverende en roerige vergadering in Utrecht meer dan dertig amendementen aan in het eerste concept. Het statuut, aldus de teneur van de vergadering, is bedoeld om de onafhankelijkheid van de gehele redactie te waarborgen en niet die van de hoofdredacteuren alleen. Voor de Verenigingsraad was de hoofdredacteur geen "apart soort journalist", maar "de eerste onder zijn gelijken". De belangrijkste, van het concept afwijkende, punten die de Verenigingsraad in het modelstatuut wenste, waren:

- de hoofdredacteur wordt niet benoemd noch ontslagen dan na goedkeuring door tweederden van de plenaire redactievergadering;

- de hoofdredacteur voert het personeelsbeleid in overeenstemming met de redactieraad;

- de plenaire redactievergadering is het belangrijkste orgaan voor de medezeggenschap van de redactie;

- een hoofdredacteur kan nooit automatisch voorzitter zijn van de redactieraad; per krant kan worden bepaald of de hoofdredacteur krachtens zijn functie deel uitmaakt van deze raad;

- de vergaderingen van de redactieraad zijn in principe openbaar. (1)

De Utrechtse vergadering was uitermate pijnlijk voor de toenmalige NVJvoorzitter J. van Raalte, zelf hoofdredacteur (van de Handels- en Transportcourant) en dus ook lid van de sectie Hoofdredacteuren. Het geamendeerde concept-statuut noemde hij heilloos, een onderhandelingsstuk waarmee wij ons alleen maar belachelijk maken.

Tijdens de vergadering van de sectie hoofdredacteuren in Bunnik op 6 november 1972, waar sectievoorzitter drs. M.L.Snijders verslag uitbracht van de vergadering van de Verenigingsraad, zei Van Raalte dat de Verenigingsraad volkomen op hol was geslagen. Hij had een hoofdredacteurenhaat geproefd. (2) Sectievoorzitter Snijders lichtte op de sectievergadering in Bunnik toe waarom hij in de Verenigingsraad het "onaanvaardbaar" had uitgesproken over het zwaar geamendeerde concept-modelstatuut. Zijn zwaarste kritiek gold de amendementen die de invloed van de redactieraad op het redactionele beleid en het personeelsbe- 
leid versterkten ten koste van die van de hoofdredacteur, die volgens hem gedegradeerd zou worden tot een soort boodschappenjongen tussen directie en redacthe. De redactie delegeert aan de hoofdredacteur in plaats dat de hoofdredacteur zijn bevoegdheden deelt met de redactie. Die functionaris zal bovendien bedacht moeten zijn op het verkrijgen of behouden van zijn populariteit, omdat anders zijn redactieraad hem kan voordragen voor ontslag, terwijl dat orgaan hem tevens kan omringen met naaste medewerkers die niet gekozen behoeven te zijn op grond van hun bekwaamheid, maar ondat ze zo goed vallen bij hun collega's die immers over hun carrière beslissen. (......................) Dit alles overziende, aldus Snijders, moeten we tot de conclusie komen dat we een illusie hebben nagejaagd. De illusie dat het mogelijk zou zijn de belangen van hoofdredacties en redacties binnen de NVJ op harmonische wijze te regelen.

De sectie oordeelde met 27 stemmen vóór en één onthouding (3) dat het op deze wijze geamendeerde modelstatuut onaanvaardbaar was voor de sectie en dat de besluiten van de Verenigingsraad in strijd waren met art. 18 A-3 van de CAO 1972. Dit bepaalde dat het statuut voor de hoofdredactie uitgangspunt voor nader overleg tussen NVJ en NDP over het redactiestatuut zou zijn. Een Brugcommissie uit het dagelijks bestuur van de NVJ wist de hoofdredacteuren en de Verenigingsraad weer op één spoor te krijgen en tot de erkenning door de Verenigingsraad dat

- de medewerking van de hoofdredacteuren bij het totstandkomen van redactiestatuten, zowel in de onderhandelingen met de NDP als bij de praktische uitvoering binnen de dagbladen, essentieel was;

- de wijze waarop de Verenigingsraad het personeelsbeleid in het modelstatuut geregeld wilde zien zowel praktisch als principieel onjuist was geweest.

(1) Verslag vergadering wan de Verenigingsraad in De Journalist van 15 november 1972 .

(2) Notulen van de vergadering van de sectie Hoofdredacteuren van 6-11-1972.

(3) Van drs. H. van Run (De Tijd) die pas kort deel uitmaakte van de sectie en de materie onvoldoende zei te kennen om er en uitgesproken standpunt over te hebben.

\subsubsection{Akkoord over het Modelstatuut}

Op 31 maart 1973 stemde de Verenigingsraad van de NVJ met de grootst mogelijke meerderheid in met een nieuw concept-modelstatuut. (1) Met dit stuk ging een NVJ-delegatie, onder leiding van hoofdredacteur drs. M. Snijders, onderhandelen met de NDP. (2) Dat Snijders als voorzitter optrad moest enerzijds tegenover de werkgevers de hervonden eenheid in het journalistieke kamp demonstreren en de hoofdredacteuren geruststellen dat er ook voor hun belangen werd gewaakt. Twaalf vergaderingen en bijna een jaar later, op 30 mei 1974, bereikten de onderhandelingsdelegaties van NVJ en NDP overeenstemming over een modelstatuut. Op 12 oktober 1974 ging de Verenigingsraad van de NVJ met het onderhandelingsresultaat akkoord. Het zou echter nog tot 21 april 1976 duren voor- 
dat ook de ledenvergadering van de NDP het statuut accepteerde. De zes slotgesprekken tussen 11 februari 1975 en 21 april 1976 werden gevoerd door de besturen van NVJ en NDP en niet meer tussen de (inmiddels ontbonden) onderhandelingsorganisaties van beide partijen. (3)

Vergelijking van het concept-modelstatuut dat de NVJ-Verenigingsraad op 31 maart 1973 goedkeurde met de definitieve versie uit 1976 (4) laat zien dat de NVJ in de onderhandelingen met de NDP aanzienlijke concessies, waaronder enkele van principiële aard, heeft gedaan. Zeventien jaar later zal NVJ-delegatievoorzitter Snijders over het prijsgeven van het bijzondere karakter van het redactiestatuut tijdens de onderhandelingen schrijven:

Wat de rechtskracht van het overeen te komen statuut, wordt geleidelijk duidelijk dat die nier moet worden gezocht in wijziging van ondernemingsstatuten, maar in vastlegging in de cao. (5) Deze zin typeert de principiële keuze voor een redactiestatuut binnen de grenzen - en de bijbehorende beperkingen - van het arbeidsrecht. De door Snijders genoemde "wijziging van ondernemingsstatuten" verwijst direct naar een van de kernartikelen van het NVJ-concept, dat de rechtskracht van het redactiestatuut op een wel zeer drastische, maar tegelijk effectieve, wijze geregeld wilde zien. Op grond van art. 16.2 NVJ-concept zou de onderneming verplicht worden haar statuten aan te passen voorzover deze in strijd zijn met het onderhavige statuut. Uitvoering van deze bepaling zou het redactiestatuut over het arbeidsrecht heentillen en de rechtskracht ervan effectief verzekeren. Het drastische zit hem in de generieke verplichting aan alle bij de NDP aangesloten kranten. Deze verplichting is uiteraard niet afdwingbaar.

De meest ingrijpende concessie is geweest dat de NVJ definitief afstand heeft genomen yan elk streven om via het statuut de redactie en hoofdredactie exclusief, buiten de Ondernemingsraad om, wezenlijke inspraak te geven bij voor de onafhankelijkheid van de redactie essentielle beslissingen van de uitgever, te weten de benoeming en het ontslag van de hoofdredactie en vaststelling en wijziging van de identiteit van de krant. Zoals hiervoor gememoreerd was een van de belangrijkste conclusies in het "Larense rapport" (van de Studiecommissie Dagbladconcentraties) dat de ideële grondslag van de krant vastgelegd zou moeten worden in onderling overleg tussen uitgever en redactie. Een instemmingsrecht voor de redactie dus. Het NVJ-conceptstatuut honoreerde deze wensen door de plenaire redactievergadering, die het belangrijkste orgaan wordt genoemd voor medezeggenschap van de redactie (art. 3.1.4), bij alle cruciale beslissingen dit instemmingsrecht te geven.

(1) De tekst van dit concept is als bijlage opgenomen.

(2) De overige leden van de NVJ-delegatie waren Volkskrant-hoofdredacteur J.M.M. van der Pluijm, NVJ-bestuurslid Max de Bok, Jan Rogier, Joop Bartman en Johan van Workum.

(3) Over de moeizame onderhandelingen tussen NVJ en NDP zie Snijders Het redactiestatuut - geschiedenis en bedoelingen, pag. 23-25 en Schuijt Werkers van het woord, pag. 245-246.

(4) De volledige tekst van het "Modelstatuut voor hoofdredactie en redactie" is eveneens als bijlage opgenomen.

(5) Snijders, idem, pag. 24. 


\subsection{Redactiestatuut en Ondernemingsraad}

\subsubsection{Artikel 5.4.1 van het Modelstatuut}

De georganiseerde journalistiek kreeg tijdens de onderhandelingen met de NDP over een statuut ook met een andere tegenkracht af te rekenen, namelijk met de grafische bonden, in het bijzonder die van de Federatie Nederlandse Vakbeweging (FNV). Daarbij speelde een belangrijke rol dat binnen de NVJ in de periode 1970 - 1973, dus gelijktijdig met onderhandelingen over een modelstatuut, een levendige interne discussie gevoerd werd over aansluiting van de toen nog categorale journalistenbond bij de FNV, welke aansluiting in 1976 geëffectueerd werd. Deze beslissing was binnen de NVJ niet onomstreden.

De grafische bonden wensten contact met de NVJ over het modelstatuut, omdat het hun niet was ontgaan dat de journalistieke medewerkers bij de dagbladen exclusieve medezeggenschap in redactionele aangelegenheden opeisten, met nadrukkelijke uitsluiting van de ondernemingsraden. $\mathrm{Zij}$ hadden dat kunnen ontnemen aan het hoofdredactiestatuut en het NVJ-concept voor een modelstatuut. Deze beide documenten, die bij de FNV bekend moeten zijn geweest, lieten aan duidelijkheid niets te wensen over. Artikel 5.2 Hoofdredactiestatuut en 10.1 van het NVJ-concept zijn gelijkluidend: Een ondernemingsraad van een dagbladuitgeverij kan geen geldige besluiten nemen met betrekking tot het redactionele beleid van het dagblad, tenzij die naar letter en geest als onverbindende adviezen zijn bedoeld.

Het hoofdredactiestatuut houdt er nog rekening mee dat de ondernemingsraad met de hoofdredactie over redactionele aangelegenheden will praten. In combinatie met het eraan voorafgaande artikel kan zo'n gesprek, wat de hoofdredactie betreft, slechts een vrijblijvend karakter dragen. Het betreffende artikel (art. 5.3), dat overigens niet in het latere NVJ-concept is opgenomen, luidt: Als de directie, de hoofdredactie of de ondernemingsraad behoefte gevoelt aan gedachtenwisseling in de ondernemingsraad over de redactionele functie zal de hoofdredactie de vergadering van de ondernemingsraad daartoe bijwonen.

Het artikel over de afzijdigheid van de ondernemingsraad in redactionele aangelegenheden was geen vondst van de hoofdredacteuren of van de NVJ-verenigingsraad. Het was vrijwel letterlijk overgenomen uit het Modelreglement voor een Ondernemingsraad van de Bedrijfscommissie voor het Uitgeverijbedrijf van Dagbladen, Nieuwsbladen en Tijdschriften. Dit modelreglement dateert uit 1971, het jaar waarin de ingrijpend herziene Wet op de ondernemingsraden in werking trad. In 1958 had in de modelreglementen van de bedrijfscommissies van zowel het Grafische Bedrijf als van het Uitgeverijbedrijf onder de toenmalige tekst van artikel 2 van de Wet op de ondernemingsraden (over de taak van de O.R.) nog als toelichting gestaan: Bij de vervulling van zijn taak dient de Ondernemingsraad onder meer de beginselen die aan de uitgaven der onderneming ten grondslag 
liggen en het beleid ten dezen, dat de ondememer c.q. de redactie der betrokken uitgaven regardeert, te eerbiedigen.

In het modelstatuut is de verhouding tot de ondernemingsraad geformuleerd in een op het eerste gezicht raadselachtig artikel

5.4.1: Indien een onderwerp behoort tot de bevoegdheden van de ondernemingsraad, belet zulks niet de uitoefening van de bevoegdheden van de redactieraad zoals in dit statuut omschreven.

De toelichting bij het modelstatuut schept in zoverre duidelijkheid dat het primaat van de ondernemingsraad, zoals geëist door de grafische bonden, daarin bevestigd werd. De medezeggenschap van bijvoorbeeld een redactieraad is beperkt tot die zaken die de redactionele functie betreffen. Uit de toelichting bij het modelstatuut blijkt dat "de redactionele functie" zeer restrictief moet worden uitgelegd. Over belangrijke zaken dient de ondernemingsraad de directie van advies; de redactieraad op zijn beurt mag de ondernemingsraad adviseren.

De toelichting over de verhouding tot de ondernemingsraad luidt:

Bij de onderhandelingen over het model is van $N V J$-zijde steeds gesteld dat het redactiestatuut nodig is vanwege de specifieke functie van het dagblad als communicatiemiddel. De NVJ beriep zich niet direct op de algemene democratiseringstendens in onze maatschappij. De algemene democratisering van het bedrijfsleven komt tot uiting in het streven van de Nederlandse vakbeweging waaronder de NVJ - naar uitbreiding van de bevoegdheden van de ondernemingsraden.

Juist gezien het specifieke karakter van het dagblad krijgen de redactionele medewerkers door een redactiestatuut medezeggenschap in die zaken, die de redactionele functie betreffen. In zoverre kan deze medezeggenschap gezien worden als een verbijzondering van de medezeggenschap van de totaliteit van de werknemers.

Een redactiestatuut bij een dagbladonderneming maakt daarom geen inbreuk op de bevoegdheden die de ondernemingsraad door de wet zijn toegekend. De ondernemingsraad vertegenwoordigt het volledige personeel. Een der taken van de redactieraad kan zijn de ondernemingsraad in te lichten over de specifieke aspecten van de redactie, de ideële doelstelling van het dagblad, als bijdrage tot een zo evenwichtig mogelijke advisering van de directie door de ondernemingsraad. Wanneer de directie op grond van het redactiestatuut zich verplicht heeft voor eenzelfde aangelegenheid advies te vragen aan de redactieraad of de redactie, betekent dit slechts dat hij naast het advies van de ondernemingsraad ook een advies krijgt wan de redactie of redactieraad.

Tenslotte geeft de toelichting het grafische en administratieve personeel (en indirect ook de directies) een waardevolle tip om de ondernemingsraad te gebruiken als middel om het verzet van de redacties te breken bij bijvoorbeeld een fusie of verkoop van een krant: En wanneer in het redactiestatuut wordt bepaald dat de directie (bijwoorbeeld bij een structuurwijziging) slechts om naar haar oordeel 
zwaarwichtige reden van het advies van de redactieraad mag afwijken, kan dat betekenen dat een advies van de ondernemingsraad, de vertegenwoordiger van het voltallige personeel, als een zwaarwichtige reden wordt aangemerkt om van het redactiestandpunt af te wijken. Aldus zal het overleg met de redactieraad c.q. redactie zich afspelen binnen het kader van het door de onderneming gevoende beleid dat mede tot stand komt door het overleg tussen directie en ondernemingsraad. Daardoor blijven de bevoegdheden van de ondernemingsraad onverlet, maar wordt tegelijkertijd van de ondernemingsraad gevraagd de specifieke functie van de redactie in acht te nemen.

\subsubsection{Poging tot herformulering relatie OR-redactieraad}

Al in 1977 kondigde het NVJ-bestuur aan met de andere "mediabonden" te zoeken naar een (her)formulering van de relatie tussen redactieraad en ondernemingsraad. In 1978 nam het bestuur, met slechts de stem van (hoofdredacteur) A. Laan tegen, een notitie aan van een "kleine commissie" die zich gebogen had over de vraag: Moet medezeggenschap van niet-redactionele werknemers over belangrijke redactionele zaken ten principale worden erkend? De commissie, bestaande uit Aad van Cortenberghe, Wim Klinkenberg, Joop Bartman en Gerard Schuijt, kwam - met de stem van Bartman tegen - tot de conclusie dat op de hoofdvraag met "ja" geantwoord moet worden. Het bestuur stelde vervolgens aan de FNV-mediabonden voor om de relatie als volgt te omschrijven:

a. erkenning van het feit dat ook de sociale positie van niet-redactionele werknemers bij persondernemingen c.q. zendgemachtigden nadelig kan worden beïnvloed door besluiten die de redactieraad - op grond van het vigerende statuut - kan nemen;

b. erkenning van het feit, dat in zwaarwegende kwesties aan de niet-redactionele werknemers - op grond van de noodzakelijke solidariteit tussen alle geledingen in het bedrijf - een beïnloedingsmogelijkheid dient te worden geboden, alvorens de redactieraad een definitief standpunt bepaalt;

c. de vorm waarin dit recht van medezeggenschap in voorkomende gevallen wordt uitgeoefend, zal worden bepaald door de plaats van de redactieraad, die in de toelichting op het model-redactiestatuut als "een verbijzondering van het werk van de Ondernemingsraad" is aangeduid;

d. de betrokken bonden beschouwen de redactieraad derhalve als een subcommissie van de Ondernemingsraad, waaraan de in het redactiestatuut toegekende bevogdheden zijn gedelegeerd, als exclusief recht van de redactie ten aanzien van de bewaking wan de identiteit en de verantwoordelijkheid voor de inhoud van het medium;

e. in gevallen waarin raadpleging van de niet-redactionele werknemers plaats dient te vinden, geschiedt dit in het kader van de gekozen leden van de Ondernemingsraad. (1) 
Deze notitie werd ingebracht in het "mediaberaad" waartoe de NVJ in 1979 het initiatief had genomen, een periodiek overleg van alle FNV-bonden die bij de media betrokken zijn. Naast de NVJ zijn dat Druk en Papier, de Federatie Dienstenbonden FNV en de Kunstenbond FNV; de FNV zelf was via een waarnemer vertegenwoordigd. Het "mediaberaad" voelde weinig voor het $\mathrm{NVJ}$-verzoek. In de eerste publicatie van het mediaberaad, de nota Media en Werknemer, een aanzet tot discussie uit 1981, komt de kwestie dan ook in het geheel niet ter sprake. In 1984 dringt het toenmalige NVJ-bestuur niet langer aan op een regeling met de andere bonden en legt ze zich neer bij het fait accompli van het modelstatuut. De "Nota Medezeggenschap" die het bestuur in dat jaar over de aangelegenheid uitbracht beperkt zich tot de aanbeveling om de contacten tussen de redactieraad, de redactiecommisie en de journalistieke leden in de ondernemingsraad te versterken. Combinatie van functies (een lid van de redactieraad is tevens lid van de ondernemingsraad) kan daartoe een middel zijn, aldus de nota. De Verenigingsraad van de NVJ had in zijn vergadering van 12 mei 1984 minder dan een halve minuut nodig om akkoord te gaan met de idee dat de medezeggenschap in de bedrijven nog het best geregeld is d.m.v. handhaving van de status quo van de respectieve medezeggenschapsorganen. (2)

(1) Jaarverslag NVJ 1978, pag. 38

(2) De Journalist van 5 juni 1984.

\subsubsection{De opvatting van Schuijt}

Schuijt (1) vindt de zelfopgelegde terughoudendheid van de ondernemingsraad in redactionele aangelegenheden, zoals opgenomen in vroegere modelreglementen van uitgeverijen, om twee redenen een wat eigenaardige bepaling. De ondernemingsraad kan niet de bevoegdheid worden ontnomen zaken aan de orde te stellen, waartoe hij krachtens de wet het recht heeft. Bovendien had de ondernemingsraad ten tijde van de onderhandelingen over het statuut terzake geen andere bevoegdheid dan het geven van naar letter en geest onverbindende adviezen. (Pas sinds de gewijzigde wet van 1979 zijn de bevoegdheden van de O.R. verruimd). Volgens Schuijt dient men de bepaling dan ook niet te beoondelen op zijn juridische mérites, maar op de intentie die er uit sprak, t.w. dat de specifieke functie van een dagblad of tijdschrift eist, dat haar redactie onafhankelijk is en niet door het technische en/of administratieve wordt beïvloed. De grafische en andere werknemers in de bedrijfstak hebben zich op dit punt dan ook zeer terughoudend opgesteld.

Nog afgezien daarvan dat ook aan deze praktijk van terughoudendheid een juridische betekenis (en ratio) niet kan worden ontzegd, redeneert Schuijt vanuit geheel andere opvattingen over de verhouding tussen redactionele en niet-redactionele werknemers in het dagbladbedrijf dan de "geestelijke vaders" van de redactiestatuten. De toenmalige secretaris van de NVJ heeft er ook in die functie nooit een geheim van gemaakt dat hij de journalisten primair als gewone werknemers be- 
schouwt, die zich ter onrechte onderscheiden van het technisch en administratief personeel van hun bladen of omroepen en die zich in het verleden overwegend elitair hebben opgesteld. (2) In zijn dissertatie werkt hij dat als volgt uit:

1. Het redactiestatuut geeft de redactieraad het recht mee te praten over louter redactionele aangelegenheden, maar zodra het redactionele beleid raakvlakken heeft met de onderneming als geheel dient de ondernemingsraad zijn wettelijke en dus betere rechten op te eisen. "Het redactionele beleid" is volgens Schuijt dan ook een aangelegenheid waarover de O.R. krachtens artikel 23 van de Wet op de Ondernemingsraden bevoegd is aan de ondernemer voorstellen te doen. De suggestie van het NVJ-bestuur uit 1979 om de redactieraad aan te wijzen als subcommissie van de ondernemingsraad en deze laatste de bevoegdheden uit het redactiestatuut te laten delegeren aan de redactieraad vindt Schuijt dan ook geen goede gedachte.

2. Bij de vraag over welke redactionele aangelegenheden de ondernemingsraad zijn bevoegdheden moet opeisen sluit Schuijt weer aan bij het redactiestatuut. Daar waar het modelstatuut overleg noemt tussen directie en hoofdredactie over beslissingen die ook de bedrijfsvoering en andere commerciële aspecten raken kan, behalve "directie" ook "ondernemingsraad" genoemd worden. Schuijt noemt hier in het bijzonder onderwerpen, zoals beslissingen ten aanzien het redactionele beleid die belangrijke invloed kunnen hebben op de bedrijfsvoering (art. 5.1.4 en 5.1.6), het redactionele personeelsbeleid (art. 6.1) en het redactionele budget (art. $8.1)$.

3. Journalisten mogen niet van andere werknemers eisen dat die hun eigen positie in de waagschaal stellen of laten stellen ten gunste van het journalistieke produkt. De handhaving van de identiteit en de onafhankelijkheid van een krant of tijdschrift zijn niet de verantwoordelijkheid van de werknemers, en journalisten mogen hen die verantwoordelijkheid ook niet opdringen. Als het redactionele beleid naar de mening van de ondernemingsraad het economisch voortbestaan van de onderneming op het spel zet dienen de werknemers in volle vrijheid en zonder terughoudendheid hun medezeggenschapsrechten te kunnen uitoefenen.

4. Gaat het om het dagelijkse redactionele beleid - waarover ook de directie al weinig te zeggen heeft - dan moet de ondernemingsraad zich terughoudend opstellen en als hij er toch over wil meepraten, doet de directie er goed aan de hoofdredacteur mee te brengen. Acties van werknemers die neerkomen op het uitoefenen van censuur op redactionele artikelen zijn uit den boze.

(1) Schuijt Werkers van het woord, pag. 341 e.v.

(2) Vgl. zijn bijdrage De Januskop van de NVJ houdt ons overeind aan het jubileumnummer "100 jaar georganiseerde journalistiek" van De Journalist van 2 februari 1984 , pag. $113-116$. 


\subsubsection{De opvatting van Rooij}

De typische vakbondsfilosofie van Schuijt is een geheel andere dan die van de "geestelijke vaders" van de eerste statuutontwerpen. Zij hadden zich over de bijzondere positie van de (hoofd)redactie binnen de onderneming immers vooral laten leiden door Rooij, die in zijn dissertatie (1) gedocumenteerd had aangetoond dat de redactionele onafhankelijkheid ook op de grafici bevochten is en dat de feitelijke verhouding ondernemingsraad-(hoofd)redactie zelfs neerkomt op een feitelijke erkenning in ons land van de dagbladonderneming als "Tendenzbetrieb" in de Duitse betekenis van dat woord. (2)

De strijd tussen de grafici en de redacties werd vanaf begin jaren vijftig uitgevochten tijdens de uitbouw van het sociale-verzekeringsstelsel en van de publiekrechtelijke bedrijfsorganisatie, waarbinnen sommigen (onder wie Rooij) een aparte regeling voor het dagbladwezen nastreefden. Voor de journalisten was het belangrijk te weten onder welke bedrijfsvereniging (bij voorbeeld voor de uitvoering van de Werkloosheidswet) of welke bedrijfscommissie (krachtens de Wet op de ondernemingsraden) de redacties van kranten, tijdschriften en nieuwsbladen zouden ressorteren. De journalisten- en uitgeversorganisaties verzetten zich met kracht tegen aansluiting bij de grafische bedrijfsvereniging. Zij waren het niet eens met de stelling van de bonden dat het wezen van het persbedrijf de grafisch-technische vervaardiging van het persprodukt zou zijn.

Het verzet van de uitgevers en de journalisten tegen dit drijven van de grafici (Rooij) had succes; de uitgeverijsector van de dagbladen kreeg een eigen bedrijfsvereniging. De S.E.R. moest er aan te pas komen om te beslissen of geïntegreerde persondernemingen (bedrijven waar de eigen uitgeverijprodukten ook technisch vervaardigd werden) bij de toepassing van de Wet op de Ondernemingsraden onder één bedrijfscommissie (voor de grafische bedrijfstak) zouden ressorteren of onder twee. Rooij: De uitgevers- en journalistenorganisaties betoogden wederom dat de eigen aard van het uitgeversbedrijf een samengaan met de grafische bedrijfstak verbood. De S.E.R. is, m.i. terecht, gevoelig gebleken voor dit argument en heeft twee bedrijfscommissies, een voor de uitge. verij van dagbladen, nieuwsbladen en tijdschriften en éen voor de grafische bedrijfstak ingesteld. (3)

Voor Rooij was het van fundamenteel belang dat de journalistiek zich niet zou laten bevoogden, niet door de directie, maar zeker niet door de kwantitieve meerderheid van niet-journalistieke werknemers in de dagbladonderneming. Rooij achtte het - naar het karakter van deze onderneming en haar produkt, de krant - ontoelaatbaar dat de ondernemingsraad zich zou inlaten met de algemene leidende beginselen van het ondernemingsbeleid, omdat dit mede door geestelijke factoren wordt bepaald. Bespreking van het redactionele beleid in de ondernemingsraad zou uitdrukkelijk uitgesloten moeten zijn, zoals bij sommige kranten (NRC en Haarlems Dagblad) in de ondernemingsstatuten staat dat ook de aandeelhouders daar niets over te vertellen hebben. (4) Twee jaar later werd Rooij op 
zijn wenken bediend: de modelreglementen voor de ondernemingsraden van zowel het uitgeversbedrijf als het grafisch bedrijf kregen de door hem gewenste en hiervoor (4.9.1.) geciteerde toelichting.

Rooij was er, zoals reeds opgemerkt, van overtuigd dat het dagbladbedrijf als "Tendenzbetrieb" in de Dutse betekenis moest worden aangemerkt, dat wil zeggen als een bedrijf waarop een zuiver economisch-sociale organisatiewetgeving geen toepassing behoort te vinden. De factoren die hem tot deze conclusie brachten zijn als een kernachtige samenvatting van zijn ideeën over de verhoudingen binnen de dagbladonderneming te beschouwen, ideeën die volgens hem in de journalistieke wereld algemeen worden aanvaard:

- De uitgeverij en de redactionele samenstelling van de krant is het kenmerk van de dagbladonderneming, niet het grafische bedrijf.

- De aard van het persprodukt moet de juridische structuur van de onderneming en de verhouding van de organen onderling, in het bijzonder die van directie en hoofdredactie, bepalen.

- Aan de exploitatie van een krant moeten niet alleen bijzondere economische eisen worden gesteld maar ook staatsrechtelijke (artikel 7 Grondwet) en ethische.

- De aard van de journalistiek - in wezen een vrij beroep dat echter in dienstbetrekking moet worden uitgeoefend - brengt mee dat de regeling van de rechtspositie van haar beoefenaren recht moet laten wedervaren aan zowel de materiële als de ideële eisen van hun positie.

Tot een door Rooij gewenste afzonderlijke wettelijke regeling van de P.B.O. voor het dagbladbedrijf is het nooit gekomen en evenmin tot de aanwijzing ervan tot Tendenzbetrieb. Rooij vond vooral teleurstellend dat de uitgevers absoluut geen oog hebben gehad voor de bijzondere positie van het dagbladbedrijf. Hij veegde de vloer aan met een brochure die het bestuur van de NDP in 1950 voor de leden uitgegeven had over de publiekrechtelijke bedrijfsorganisatie en het dagbladbedrijf. (5) Uit de brochure blijkt volgens Rooij dat de NDP nauwelijks heeft nagedacht over een "Tendenzbetrieb", noch over de consequenties daarvan voor de bevoegdheden van een ondernemingsraad bij een dagbladonderneming. De brochure beperkt zich volgens Rooij te zeer tot de sociaal-economische aspecten van het dagbladbedrijf en wanneer er al iets over de bijzondere aard van de bedrijfstak wordt geschreven ergert hij zich aan de volgende merkwaardige vermaning uit de brochure, waarin het NDP-bestuur naar artikel 7 van de Grondwet verwijst: "De NDP bedenke, dat zij als organisatie van uitgevers, die de uiteindelijke verantwoondelijkheid dragen voor hetgeen in de Nederlandse dagbladpers wordt gepubliceerd, de instantie par excellence is om de grondwettelijke rechten, neergelegd in dat artikel, te vendedigen." Deze vermaning houdt volgens Rooij een miskenning in van de structuur van het dagbladbedrijf, waarin met name de journalisten een specifieke plaats innemen. Hun verantwoordelijkheid voor de verdediging van persvrijheid is volgens Rooij niet geringer dan die van de uitgevers. (6) 
In een publicatie ten tijde van de totstandkoming van het modelstatuut (1973) spreekt Rooij zich concreter uit over de mogelijkheid van medebeslissingsrecht voor de redacties van een blad. (7) Hij is dan al zeven keer opgetreden als vertrouwensman om namens NDP en NVJ gezamenlijk bij structuurwijzigingen een directie te adviseren met het oog op de sociale en ideële belangen van de journalisten. Rooij juicht het (hoofd)redactiestatuut, waarover nog onderhandeld werd, toe, inclusief de niet-inmengingsbepalingen ten aanzien van de ondernemingsraad. Hij toont zich, op dezelfde gronden als de Persraad, geen voorstander van een wettelijke regeling van een dergelijk statuut.

(1) M. Rooij Het dagbladbedrijf in Nederlond; pag. 434 e.v.

(2) Onder "Tendenzbetrieb" verstaat men in Duitsland een onderneming die een ideeel produkt vervaardigt dat bijzondere grondrechtelijke bescherming geniet, zoals een dagblad. Bij een dergelijk bedrijf zijn de rechten van de ondernemingsraad beperkt. In hoofdstuk 6 wordt nader ingegaan op de relatie Tendenzscloutz - redactiestatuut in Duitsland.

(3) De tweedeling bestaat ook thans nog: er is de Bedrijfscommissie voor het Grafisch Bedrijf en die voor het Uitgeverijbedrijif.

(4) M. Rooij Het Dagbladbedrijf in Nederland, pag. 223.

(5) NDP en PBO - Beschonwingen inzake de publiekrechtelijke organisatie van het bedrijfsleven in Nederland en hare betekenis voor de dagbladondememingen (1950).

(6)(M. Rooij Het dagbladbedriff in Nederland, pag. 442.

(7) M. Rooij Kranten - Dagbladpers en maatschappij, pag. 216 e.v.

\subsection{De verhouding hoofdredactie - redactie}

\subsection{1 "Verlengstuk van die feodale directies"}

Ten tijde van de totstandkoming van de modelstatuten was pijnlijk duidelijk de verstoorde verhouding tussen hoofdredacteuren en "gewone journalisten" aan het licht getreden. Dat was niet toevallig, maar hield ook weer niet direct verband met dit statuut. De botsing was eerder een culminatie van in de loop der jaren gegroeide frustraties - onder meer door de recente fusiegolf - en van de geest van de tijd, die ook de redacties niet onberoerd had gelaten. Journalisten die over de studentenopstand van eind jaren zestig hadden bericht werd duidelijk dat ook zij binnen structuren werkten die zich nauwelijks onderscheidden van die waartegen de studenten te hoop waren gelopen. Hoofdredacteuren van dagbladen waren tratditioneel functionarissen die, letterlijk en figuurlijk gescheiden van het journalistieke voetvolk, de krant leidden en daarbij eerder geassocieerd werden met de directie dan met de redactie.

Dr. G. Pikkemaat, de toenmalige hoofdredacteur van de Gooi- en Eemlander, situeerde de hoofdredacteur midden in een machtsstrijd tussen de directie en de redactie. (1) Het democratiseringsproces betekende voor de directies een aantasting van hun machtspositie, terwijl het voor de redacteuren om het veroveren van een machtspositie ging.

Voor de hoofdredacteuren lag de zaak wat gecompliceerder. Door de directie belast met de journalistieke leiding van een dagblad, zaten zij op een stoel, die in 
het blikveld der redacteuren met macht bekleed was, maar in het oog der directie toch wat belangrijke centimeters lager was dan de hare. ( ..............) Zelf zagen zij zich als figuren, die enerzijds samen met hun redacteuren de directionele macht te groot vonden, maar anderzijds samen met hun directeuren de "machtshonger" van de redacties verafschuwden. In de duidelijkheid, die door de polarisatie met haar simplificaties en ongenuanceerdheden gebaard werd, voelden de hoofdredacteuren zich door de directie wel eens op één hoop gegooid met die arrogante redacteuren, maar werden door de redacteuren vaak gerekend tot een verlengstuk van die feodale directies.

H.J.A. Hofland, die in 1968 de laatst benoemde hoofdredacteur van het Algemeen Handelsblad werd - zelf omschreef hij zich in die functie, die hij in 1972 moest neerleggen, als commandant van de Grebbeberg - ervoer de baan als een van de zwaarste beroepen in de sector hersenarbeid (.........) Alles wat het dagblad aan conflicten veroorzaakt - persoonlijke, politieke, economische, prestigieuze, kortom alle conflicten die inherent zijn aan het brengen van nieuws, dus veel te veel om op te noemen - komen voor zijn rekening. Daarbij komt dat zijn functie ook te vergelijken is met het directeurschap van een gezelschap prima donna's, want een journalist doet wel zijn best maar is ook ijdel en lichtgeraakt. Verder wordt hij door zijn directie, bestuur, raad van commissarissen, aandeelhouders o .............. ) aangesproken op alles wat er in en met de krant mis kan gaan, en ook dat is grenzeloos. (2)

Hoofdredacteur Pikkemaat (3) signaleert, naast de tijdgeest en de algemene roep om democratisering, nog twee ontwikkelingen die eind jaren zestig, begin jaren zeventig een rol speelden en een redactielokaal in een slagveld, waarop betweterij en eigenwijsheid elkaar fel bestreden herschiepen:"

- De redacties waren de afgelopen jaren flink gegroeid, soms verdubbeld. Die grotere redacties misten de hechtheid, de intimiteit en de overzichtelijkheid van vroeger, met alle communicatiestoomissen vandien.

- Ten tweede waren de jonge journalisten die de redacties kwamen bevolken in sterke mate politiek bewust, maatschappelijk geëngageerd of polarisatieheil verwachtend. Vanuit deze habitus zagen zij de journalistieke taak dikwijls meer in het verkondigen van hun geloof in eigen politiek-sociaal gelijk dan in het verstrekken van een zo objectief mogelijke, feitelijke informatie, hetgeen veelal het dogma der oudere garde bleek te zijn. De hoofdredacteur, die geacht werd leiding te geven op dit slagveld, bleek daar niet voor toegerust. Pikkemaat: Ingehuurd als super-journalist, moest hij hier optreden als psycholoog, maatschappelijk werker, personeelsfunctionaris en organisator. ( ..............) Het uitoefenen van het schrijversvak, waartoe hij roeping bezat, waartoe hij was opgeleid en wat hij met plezier beoefende, werd hem langzaam maar zeker onmogelijk gemaakl door een voortdurend beroep op hem in een kwaliteit, waarvoor hij niet was opgeleid en waartoe reping hem onbekend was. 
Het onderscheid, om niet te zeggen "standverschil", tussen hoofdredacteuren en "gewone journalisten" was voor de oorlog nog aanzienlijk groter. Zoals hiervoor (4) reeds gereleveerd heeft het 36 jaar geduurd voordat een niet-hoofdredacteur voorzitter kon worden van de toenmalige journalistenwereniging. Over de situatio in de jaren twintig is het rapport van de commissie-Van Blom onthullend duidelijk. Ter toelichting bij haar voorstel om een redactievertegenwoordiger te laten kiezen, die met adviserende stem in de raad van commissarissen of een ander toezichthoudend of besturend orgaan zitting neemt, zegt de commissie dat die gekozen vertegenwoordiger eigenlijk altijd de hoofdredacteur zou moeten zijn. Zij voegt daar echter aan toe: De commissie wenscht geen bepaling aan te bevelen, krachtens welke de hoofdredacteur als zoodanig steeds zou worden aangewezen als redactie-vertegenwoordiger, ondat de redactie dien titularis niet altijd beschouwt als haar natuurlijken vertegenwoordiger. Hij behoorde het, naar het inzicht der commissie, wel te wezen, maar de praktijk wijst nu eenmaal uit, dat hij het niet altijd is. In hetzelfde rapport (pag. 80) bepleiten Van Blom c.s. om dezelfde reden de aanwezigheid van een redactiecommissie bij dagbladen temeer, wijl de commisie, zoals uit haar rapport is gebleken, zich op het standpunt heeft gesteld, dat de hoofdredacteur niet steeds is de natuurlijke vertegenwoordiger der journalisten.

(1) G. Pikkemaat Aangaande het redactiestatut, Massacommunicatie 6/1978, pag. 187-196.

(2) H.J.A. Hofland Uit de memoires van een joumalist, NRC Handelsblad van 24 juni 1989.

(3) $G_{m}$ Pikkemaat, idem, pag. 188 e.v.

(4) Zie 2.3: NJK: van vriendenkring tot belangenbelhartiger.

\subsubsection{Het Genootschap van Hoofdredacteuren}

Na de oorlog zou het verschil tussen hoofdredacteuren en "gewone journalisten" geformaliseerd worden in de vorming van een aparte sectie Hoofdredacteuren binnen de Federatie van Nederlandse Journalisten (FNJ) en de oprichting van het Genootschap van Hoofdredacteuren. De aanleiding tot de oprichting op 15 december 1959 van het Genootschap was een zuiver pragmatische. In de loop van 1959 wensten de hoofdredacteuren van de Nederlandse kranten met de uitgevers, verenigd in de Nederlandse Dagbladpers (NDP), en het Algemeen Nederlands Persbureau (ANP) te praten over de mogelijkheid van medezeggenschap in zaken van overwegend redactioneel beleid betreffende het ANP. (1) De kwestie was ter sprake gekomen tijdens een informeel samenzijn na een vergadering van de sectie Hoofdredacteuren en uit de levendige discussie was gebleken dat de aanwezige leden allen van gevoelen waren dat bij de bestaande verhoudingen de groep der hoofdredacteuren als totaliteit te zeer was ondergegaan in het grote geheel van de Federatie. Dat bleek een nadeel wanneer de hoofdredacteuren samen iets zouden willen ondernemen of bespreken waartoe ze als sectie binnen de Federatie geen formele bevoegdheid hadden. De inspraak die de hoofdredacteuren nastreefden binnen het ANP was daar zo'n voorbeeld van. Als sectie van de Federatie was zij 
geen gesprekspartner voor ANP en NDP, maar een ander verband waarin alle hoofdredacteuren zitten bestond er niet. Dit voelden de hoofdredacteuren - in dit geval, maar ook in andere heel goed denkbare gevallen - als een gemis.

De aanwezige hoofdredacteuren besloten om naast de sectie Hoofdredacteuren een "vereniging" van hoofdredacteuren op te richten, die telkens wanneer de sectie de grenzen van haar handelingsbevoegdheid had bereikt, naar binnen en naar buiten zou optreden om die vakbelangen - en uiteraard niet anders dan vakbelangen - te behartigen die duidelijk in het vlak van het collectieve hoofdredactionele beleid liggen. In de statuten beleden zij hun verbondenheid met de vakorganisatie, waarvan ook hun ondergeschikten lid waren. Volgens deze statuten stelde het genootschap zich ten doel de zelfstandige behartiging van gemeenschappelijke belangen, voortwloeiend uit de hoofdredactionele verantwoordelijkheid van zijn leden. voor zover het geen zaken betreft die al door de journalistenfederatie worden behartigd. Het bestuur van vijf leden zou worden aangevuld met de voorzitter en de secretaris van de Sectie Hoofdredacteuren. (2) Slechts één hoofdredacteur, J. Piebenga van de Leeuwarder Courant, wenste om principiële redenen geen lid van het Genootschap te worden. Piebenga voorzag de groei van zoiets als klassestrijd of antithese tussen "hogeren" en "lageren" in de journalistiek.

Hoewel het Genootschap formeel geen partij is geweest bij de totstandkoming van de beide statuten - dat was een zaak van de Sectie Hoofdredacteuren- was het de harde confrontatie tussen de Sectie en de Verenigingsraad van de NVJ over het redactiestatuut (zie 4.8 .2 ) die uiteindelijk zelfs tot een breuk heeft geleid tussen het Genootschap en de georganiseerde journalistiek. Het heeft nog tot 1975 geduurd, voordat het onvermijdelijke gebeurde: in dat jaar verbrak het Genootschap de statutaire band met de NVJ, een beslissing die praktisch al niet veel betekenis meer had, omdat nog slechts een minderheid van de hoofdredacteuren lid was van de NVJ. Artikel 2 van de nieuwe statuten ging nu luiden: Het Genootschap heeft ten doel - daarbij uitgaande van het beginsel der persvrijheid $(\ldots . . . . . .$.$) de zelfstandige behartiging van gemeenschappelijke belangen,$ voortwloeiend uit de hoofdredactionele verantwoondelijkheid van zijn leden, zoals vastgelegd in de collectieve arbeidsovereenkomst voor dagbladjournalisten en het daarop gebaseerde statuut voor hoofdredacties en redacties.

In de nieuwe statuten ontbreekt uiteraard bij artikel 7 het bestuurslidmaatschap qualitate qua van de voorzitter en secretaris van de sectie Hoofdredacteuren. De statutenwijziging haalde precies de vereiste tweederde meerderheid ( 24 tegen 12 stemmen), mede dank zij zes schriftelijk uitgebrachte stemmen. Sectiesecretaris Nico Bergkamp (De Limburger) heeft de stemprocedure nog (vergeefs) aangevochten met het argument, dat er meer tegenstemmers geweest zouden zijn als bekend was dat ook schriftelijk gestemd mocht worden. De statutenwijziging zou al in 1973 hebben plaatsgevonden, maar in dat jaar besloot de ledenvergadering van het Genootschap om redenen van tactische aard - de strijd met de NDP om het redactiestatuut was nog in volle gang - de stap nog even uit te stellen. 
Het NVJ-bestuur heeft nog geprobeerd de leden van het Genootschap tot andere gedachten te brengen, onder andere met het argument dat de strijd on het redactiestatuut nog niet gewonnen was; de onderhandelingen op ondernemingsniveau moesten nog beginnen. Bovendien beloofde de NVJ dat de secties binnen de vereniging - dus ook die van de hoofdredacteuren - betere mogelijkheden zouden krijgen om aan de besluitvorming van de organisatie deel te nemen. Het NVJ-bestuur zou de sectie beschouwen als enige groepering van hoofdredacteuren, waarmee overleg gepleegd diende te worden over hun specifieke belangen. (3) Twee hoofdredacteuren, Jan van der Pluijm (de Volkskrant) en Nico Bergkamp schreven hun collega's dat ze het volledig eens waren met de brief van het NVJ-bestuur en dat wijziging van de statuten ook een verbreking zou betekenen van de moeizaam opgebouwde solidariteit tussen hoofdredacties en redacties. Het besluit zou, aldus Van der Pluijm en Bergkamp, de hoofdredacteuren in een heilloos isolement drijven, hen meer de geur van de werkgever dan van journalist geven en hevig polariserend werken. Wij menen dat we al dat kwaad niet over onszelf moeten afroepen. Als hoofdredacteuren hun belangen willen verdedigen, dan behoren ze dat volgens ons te doen binnen het kader van de georganiseende journalistiek, derhalve binnen de NVJ en haar sectie hoofdredacteuren. Ook al zijn ze het niet op alle punten met de NVJ eens.

In augustus 1979 zaten Sectie en Genootschap van Hoofdredacteuren weer samen aan tafel met het NVJ-bestuur om tripartite over verbetering van hun relatie te praten. Vooral het NVJ-bestuur bleef kritisch over versterking van de invloed van het Genootschap en drong aan op snelle terugkeer "in het vaderhuis" van meer hoofdredacteuren, die eerder de NVJ de rug hadden toegekeerd. Een aantal van hen hadden dat al gedaan; de sectie telde in dat jaar 23 hoofdredacteuren van dagbladen, volgens sectie-voorzitter Han Mulder een "fraaie score want er zijn nog maar 42 onder een eigen hoofdredactionele verantwoordelijkheid verschijnende kranten of clusters van kranten". (4) Vanaf 1981 zijn de contacten tussen de "Beroepsgroep hoofdredacteuren", zoals de sectie binnen de NVJ sindsdien heet en het Genootschap verder verbeterd.

(1) Brief 5 november 1959 van $H$. Eldermans, hoofdredacteur van het Rotterdams Nieuwsblad, secretaris van de Sectie en voorzitter van de commissie die de oprichting van het latere Genootschap heeft voorbereid aan het bestuur van de FNJ. De andere leden waren S.J. (Simon) Koster (Haarlems Dagblad), H. Greven (Dagblad van het Oosten) die als secretaris optrad en J. Naninck (Brabants Dagblad.

(2) Het eerste bestuur had de volgende samenstelling: Simon Koster (voorzitter), H. Eldermans, secr., H. Greven, G.A. Knepfle, J. Naninck, A. Stempels en J.C. de Wit. Eldermans en Stempels (voorzitter van de Federatie) waren q.q. secretaris c.q. lid.

(3) Brief NVJ-bestuur aan het Genootschap van 21 mei 1975.

(4) Jaarverslag NVJ 1979, pag. 14; De Journalist van 13 september 1979, pag. 32-33. 


\subsection{Samenvatting}

De regeling van de verhouding tussen hoofdredactie, redactie en dagbladuitgever heeft zich na de oorlog aanvankelijk geheel geconcentreerd op versterking van de positie van de hoofdredacteur. Een aanzet daartoe is te vinden in de eerste CAO voor dagbladjournalisten uit 1948 , die de hoofdredacteur nadrukkelijk de leiding over de redactie gaf en hem verantwoordelijk maakte - zij het formeel niet bij uitsluiting wan de directie - voor het redactionele deel van de krant. Voor sommige hoofdredacteuren was het thans bereikte reeds een gepasseerd station. Een van hen was M. Rooij, die in zijn dissertatie (1956) de hoofdredacteur naast en niet onder de directeur plaatste en daarbij op een voorbeeldige regeling van de verhouding tussen redactie en commerciële afdelingen bij zijn eigen krant (NRC) kon wijzen.

Rooijs dissertatie heeft ertoe geleid dat de Sectie Hoofdredacteuren binnen de georganiseerde journalistiek opnieuw ging nadenken over versterking van de positie van haar leden, aanvankelijk via wijziging van de $\mathrm{CAO}$, maar later door middel van een Statuut voor de Hoofdredactie. De keuze voor een bijzondere, niet arbeidsrechtelijke regeling was weloverwogen. De georganiseerde journalistiek had in de jaren vijftig al uitgesproken dat de algemene regeling van de betrekkingen tussen directie en hoofdredactie boven de in een CAO op te nemen arbeidsrechtelijke bepalingen uitrijst.

Het Statuut voor de Hoofdredactie, dat in 1972 tot stand kwam, bracht de hoofdredacteuren in open conflict met de "gewone" journalisten binnen hun vakorganisatie. Deze laatsten wilden slechts voor één jaar met het hoofdredactiestatuut instemmen, en op voorwaarde dat gelijktijdig gewerkt zou worden aan een statuut dat de verhouding van alle betrokken partijen zou regelen.

Dit "Modelstatuut voor hoofdredactie en redactie" is in 1976 na moeizame onderhandelingen tot stand gekomen. De eindversie wijkt op essentiële punten nadelig af van de grondgedachten van het hoofdredactiestatuut, maar ook van het laatste concept van de verenigingsraad van de NVJ, het hoogste orgaan van de georganiseerde journalistiek. Een van deze punten betreft de verhouding tussen redactieraad en ondernemingsraad. Het hoofdredactiestatuut en het NVJ-concept bepalen expliciet dat de bevoegdheden van de ondernemingsraad zich niet tot redactionele aangelegenheden uitstrekken, impliciet dat dit ook die redactionele beslissingen betreft die anderen (grafici, administratief personeel) in het dagbladbedrijf aangaan.

In de eindversie is dit standpunt verlaten en is de principiële keuze gemaakt voor de arbeidsrechtelijke inpassing van het redactiestatuut, onder meer blijkend uit de medezeggenschap die de ondernemingsraad, ook in redactionele zaken, in het modelstatuut heeft gekregen. De positie van de OR is zelfs dominanter naarmate de beslissingen waarin het OR-adviesrecht wordt uitgeoefend bedreigender zijn voor de redactionele zelfstandigheid. De toelichting bij het modelstatuut laat daar geen enkel misverstand over bestaan. 
Het toenmalige bestuur van de NVJ heeft deze formulering niet alleen gedoogd, maar er ook op aangestuurd. Daarbij heeft waarschijnlijk ook een rol gespeeld dat ten tijde van de totstandkoming van het modelstatuut het bestuur van de (categorale) NVJ in overleg was met de FNV over aansluiting bij dezelfde vakorganisatie, waarvan ook de grafische en administratieve collega's van de dagbladjournalisten leden waren.

In de periode 1978-1984 heeft het NVJ-bestuur nog geprobeerd de andere FNVbonden die bij de media betrokken zijn te winnen voor een herformulering van de relatie tussen redactieraad en ondernemingsraad, maar daar voelden deze bonden niets voor; de NVJ heeft daarna niet meer aangedrongen.

In de eindversie van het modelstatuut is een standpunt ingenomen in een principieel discussiepunt:

- is journalistiek een beroep als zoveel andere; is de journalist een gewone werknemer, zij het met bijzonder gereedschap, een "werker van het woord" ? (Schuijt) of

- is journalistiek niet los te koppelen van het grondrechtelijk kader waarbinnen het beroep wordt uitgeoefend? Is de journalist dus een bijzondere werknemer, omdat hij een bijzonder produkt vervaardigt? (Rooij).

De eerste opvatting heeft geprevaleerd in het modelstatuut. De tweede opvatting erkent enerzijds dat de journalist met andere werknemers gemeen heeft dat goede arbeidsvoorwaarden bevochten en verdedigd moeten worden; daarvoor is een goede CAO, bevochten en beschermd door een vakbond, onontbeerlijk. Er is echter meer. De aard van het persproduct, aldus Rooij, moet in de functionering van de organen van de onderneming en in de regeling van hun onderlinge verhouding - met name die tussen directie en hoofdredactie - tot uitdrukking komen. Een regeling van deze interne verhouding overstijgt het arbeidsrechtelijke kader, zoals de Sectie Hoofdredacteuren van de Federatie van Nederlandse Journalisten al in 1958 had geconstateerd.

Het journalistieke beroep ("in wezen een vrij beroep" - Rooij) wordt omwille van het persprodukt uitgeoefend binnen een grondrechtelijke "setting", die bijzondere eisen stelt aan de interne regeling van bevoegdheden. Een van die eisen is dat de redactie - en in het bijzonder de hoofdredactie - binnen de dagbladorganisatie een grote mate van autonomie verwerft.

De nadruk die aanvankelijk heeft gelegen op versterking van de positie van de hoofdredacteur, heeft averechts gewerkt. Daarbij heeft eveneens een rol gespeeld dat ten tijde van de totstandkoming van het modelstatuut de verhouding binnen de FNJ (later NVJ) tussen de Sectie hoofdredacteuren en de "gewone" journalisten buitengewoon slecht was. Deze laatsten vonden dat de hoofdredacteuren bij de persconcentratiegolf te vaak de kant van de directie gekozen hadden. De hoofdredacteuren van hun kant vonden dat hun ondergeschikten onvoldoende oog hadden voor de werkelijke machtsverhoudingen op de krant. 


\section{Hoofdstuk 5}

\section{Het Modelstatuut voor hoofdredactie en redactie}

\subsection{Hoofdlijnen van het Modelstatuut}

Het Modelstatuut voor hoofdredactie en redactie is, in tegenstelling tot wat de benaming ervan suggereert, een driepartijencontract tussen de uitgever (meestal vertegenwoordigd door de directie), de hoofdredactie en de redactie. Dit in tegenstelling tot het Statuut voor de hoofdredactie $(\mathrm{SvdH})$, dat uitgaat van twee partijen, de uitgever (directie) en de hoofdredactie, zij het dat artikel 3.7 van het hoofdredactiestatuut ( $D e$ betrekkingen tussen directie, hoofdredactie en redactie worden per onderneming geregeld in een redactiestatuut) het latere Modelstatuut reeds als driepartijenovereenkomst aankondigde. Artikel 3.7 $\mathrm{SvdH}$ is daarmee overigens niet als derdenbeding te beschouwen, omdat "de redactie" via de NVJ partij is geweest bij het hoofdredactiestatuit.

Hoewel de nadruk van het Modelstatuut ligt op de verhouding van de hoofdredactie en de redactie enerzijds met de directie anderzijds, is ook de relatie redactie hoofdredactie en redactie - directie geregeld. Tevens kan de individuele journalist aan het statuut rechten ontlenen jegens de hoofdredactie. In het modelstatuut zijn de navolgende hoofdlijnen te onderscheiden:

A. Het dagblad wijkt af van andere industriële produkten, doordat het als massacommunicatiemiddel gestalte geeft aan het grondrecht van de vrijheid van meningsuiting. De organen die bij de vervaardiging van een krant betrokken zijn (directie, hoofdredactie en redactie) werken dan ook in een heel bijzondere structuur samen, die afwijkt van een organisatie die andere industriële produkten vervaardigt.

B. Het dagblad heeft met andere industriële produkten gemeen dat het uitgeven ervan de kosten minstens blijvend moet dekken.

C. De uitgever bepaalt de beginselen van de krant en de uitgangspunten van het redactionele beleid. De statuten van de uitgeverij bepalen wie de hoofdredactie benoemt en ontslaat. De directie, als vertegenwoordigster van de uitgever, bepaalt het aantal journalisten en de individuele arbeidswoorwaarden van het redactionele personeel. De journalistieke werknemers worden aangesteld in overleg met en op voordracht van de hootdredactie.

D. De hoofdredactie heeft de leiding van de redactie en is bij uitsluiting van ieder ander verantwoordelijk voor de redactionele inhoud van het dagblad.

E. Ingeval van een onoverbrugbaar verschil van mening over het redactionele beleid tussen een hoofdredacteur en de instantie die hem benoemt, welk verschil van mening tot het ontslag van de hoofdredacteur leidt, stelt een 
Bijzondere Ontslagkamer voor Hoofdredacteuren de voorwaarden van het ontslag vast, tenzij partijen zelf binnen vijf weken tot overeenstemming zijn gekomen over deze voorwaarden.

F. Er is een gekozen redactieraad die het orgaan is voor de medezeggenschap van de redactie in alle zaken betreffende de redactionele taak en functie. De redactieraad is verantwoording verschuldigd aan de redactievergadering.

G. De directie neemt een aantal voor het redactionele beleid belangrijke beslissingen niet dan nadat diepgaand overleg heeft plaatsgehad met de redactieraad.

H. Een journalist kan niet gedwongen worden een opdracht uit te voeren waar hij ernstige gewetensbezwaren tegen heeft.

I. De medezeggenschap van de redactionele medewerkers moet gezien worden als een verbijzondering van de medezeggenschap van de totaliteit van de werknemers, welke laatste primair gestalte krijgt in de ondernemingsraad.

\subsection{De inspraakmodaliteiten}

Het modelstatuut kent een grote variëteit aan inspraak-modaliteiten. Een glijdende schaal, berekend naar de mate van feitelijke inspraak door de hoofdredactie en/of de redactieraad ten opzichte van de directie en omgekeerd, ziet er als volgt uit:

1. De hoogste graad van inspraak is het instemmingsrecht: de andere partij kan slechts handelen met toestemming van de tegenpartij. Het modelstatuut bezigt daarvoor de woorden "in overleg" of zegt dat er "overeenstemming" moet zijn. Er zijn vijf artikelen waarin deze formuleringen voorkomen:

a. art. 4.2.5.: Per krant bepalen directie, hoofdredactie en redactieraad in onderling overleg of en in hoeverre redactionele medewerkers, al dan niet met stemrecht, tot de redactievergadering worden toegelaten.

b. art 5.1.5.: De journalistieke werknemers worden door de directie aangesteld in overleg met en op voordracht van de hoofdredactie. Een dubbele bevestiging van het hoofdredactionele primaat waar het gaat om het redactionele beleid. Een directie die dit beleid wil beïnvloeden komt voor twee gesloten deuren te staan: het instemmingsrecht van de hoofdredactie en haar uitsluitende recht van voordracht.

c. art. 5.1.6.: Beslissingen ten aanzien van de journalistieke produktie die belangrijke invloed kunnen hebben op de bedrijfsvoering van de uitgeverij, kan de hoofdredactie slechts nemen in overleg met de directie.

d. art. 6.1.: Hoofdredactie en redactieraad moeten overeenstemming bereiken over de hoofdlijnen van het redactionele personeelsbeleid.

e. art.11.1.: Wijziging van dit statuut (...................) geschiedt in overleg tussen directie, hoofdredactie en redactieraad. Deze laatste heeft de instemming van de redactievergadering nodig, alvorens hij een beslissing kan nemen.

2. Een zeer grote mate van inspraak - maar geen instemmingsrecht - vinden 
we in het kernartikel 3.7.: de directie neemt over een aantal limitatief opgesomde gevallen pas een beslissing nadat diepgaand overleg heeft plaatsgehad met de redactieraad. Wanneer dat overleg niet tot overeenstemming leidt kan de directie slechts om zwaanwichige redenen van het advies van de redactieraad afwijken.

3. Art. 5.1.7 noemt een limitatief opgesomd aantal punten waarover de directie en de hoofdredactie goed overleg voeren alvorens de directie een beslissing neemt.

4. Een subtiel onderscheid: hoofdredactie of directie beslissen pas na overleg met elkaar. Kenmerkend voor de gezagsverhoudingen is dat slechts één artikel (5.1.9) de hoofdredactie beslissingsbevoegdheid geeft na overleg met de directie en de redactieraad en in vijf andere gevallen de directie in staat gesteld is om te beslissen na overleg met alleen de hoofdredactie (artt. 5.1.4, 5.1.5 eerste zin, derde zin en vierde zin, en 8.1).

5. De laagste vormen van inspraak voor hoofdredactie en redactieraad zijn gereserveerd voor de meest ingrijpende besluiten van de uitgever. $\mathrm{Bij}$ structuurwijzigingen (onder andere reorganisatie, fusie of verkoop) wordt de hoofdredactie van de aanvang af betrokken bij eventuele plannen (art. 9.1). Zodra duidelijk is dat de plannen tot structuurwijziging tot uitvoering zullen komen, is de redactieraad in de gelegenheid zich een oordeel hierover te vormen. (art. 9.2). Art. 9.3.: Over een voorgenomen ingrijpende wijziging in de kring van eigenaren en van de raad van commissarissen wordt de hoofdredactie door de directie vertrouwelijk ingelicht. Zo spoedig mogelijk na de hoofdredactie wordt ook de redactieraad vertrouwelijk ingelicht.

\subsection{Artikelsgewijze behandeling}

Het thans volgende deel omvat de artikelsgewijze behandeling van het Modelstatuut voor hoofdredactie en redactie. Dit gebeurt voor elk artikel aan de hand van het volgende schema:

A. Allereerst wordt de tekst van het modelstatuut vergeleken met het Statuut voor de Hoofdredactie (SvdH) uit 1972;

B. daarna volgt vergelijking met het NVJ-concept "model voor een redactiestatuut" dat op 31 maart 1973 met de grootst mogelijke meerderheid (44 tegen 1) door de Verenigingsraad van de NVJ werd aanvaard.

C. Bij de vergelijking worden eveneens betrokken de "Toelichting model-redactiestatuut" van de NVJ en de "Nadere toelichting", gedateerd 8 juni 1976, van de begeleidingscommissie van de NVJ. (1) Deze toelichting was bestemd voor de leden van de krantenredacties die met de hoofdredacties en directies 
over de statuten voor hun kranten gingen onderhandelen. Krantenredacties hebben slechts incidenteel gebruik gemaakt van deze begeleidingscommissie.(2)

(1) Leden van de commissie waren M.M. de Bok (voorzitter), J.H. Bartman, J.M.M. van der Pluym, J.P. Rogier, J. van Workum en mr. G.A.I. Schuijt.

(2) Jaarverslag NVJ 1977, pag. 42.

\subsubsection{Considerans}

De considerans van het statuut is meer dan een obligate inleiding tot een aantal artikelen die er wél toe doen. $\mathrm{Zij}$ komt vrijwel lletterlijk uit het Hoofdredactiestatuut. Journalisten (én uitgevers) drukten erin uit wat hun gezamenlijk produkt zo uniek maakt. Naar goed journalistiek gebruik is de eerste zin Het dagblad onderscheidt zich van andere produkten een voltreffer. Het is de kernzin van het hele statuut en hij drukt niet alleen uit dat een geestelijk produkt als een dagblad niet met gewone handelswaar vergeleken kan worden, maar geeft ook kernachtig de essentie weer van een imposante hoeveelheid jurisprudentie over het bijzondere van het "artikel $7 \mathrm{Gw}$-produkt" krant. Hierbij is vooral te denken aan de ten tijde van de opstelling van het hoofdredactiestatuut voorhanden rechtspraak betreffende de verspreidingsvrijheid, welk "connex recht" niet is los te zien van de beschermwaardigheid van zijn materialisatie in de vorm van een pamflet, pocketboek of krant.

Opmerkelijk is dat de considerans, in de bewoordingen doordat het (dagblad) gestalte geeft aan het in Nederland geldende grondrecht van vrijheid van meningsuiting, informatieverwerving, -vermeninguldiging en -verstrekking, zoals vastgelegd in onder meer artikel 7 van de Grondwet en artikel 10 van het Verdrag van Rome er geen twijfel over laat bestaan dat het gehele communicatieproces, inclusief het recht van iedere burger om zich te informeren, binnen het grondrecht valt. Toen het stuk werd opgesteld was het kennelijk nog noodzakelijk deze "meerwaarde van het Europees mensenrechtenverdrag" (Boon) nadrukkelijk te attribueren.

De niet-limitatieve formulering onder meer artikel 7 van de Grondwet en artikel 10 van het Verdrag van Rome verwijst thans in het bijzonder naar artikel 19 van het BuPo-verdrag (1) dat op 11 maart 1979 - en dus na de totstandkoming van beide voorbeeldstatuten - voor het Koninkrijk in werking is getreden en thans ook als Nederlands recht moet worden beschouwd.

De considerans laat in haar tweedeling duidelijk zien dat zowel (hoofd)redacteuren als uitgevers er hun inbreng in hebben gehad. Schuijt (2) zegt dat het met name de uitgevers zijn geweest die behoefte hadden aan een considerans. Zij hadden uiteraard ook oog voor de ideële functie van de krant en hun eigen aandeel daarin. Zij dekten zich, door te wijzen op het bijzondere van het produkt dagblad, in tegen kritiek van de andere werknemers in het bedrijf op de vergaande medezeggenschap van de redacties. Bovendien zouden ze de considerans hebben aangegrepen om de journalisten duidelijk te maken dat hunkrant niet alleen een ideëel, maar ook een commercieel produkt is. Volgens Snijders (3) echter was 
een van de kernpunten van de hoofdredactionele wensen de constatering, reeds in het eerste ontwerp, dat een krant juist vanwege haar publieke functie een bijzonder produkt is. Voor de hoofdredacteuren was de considerans dan ook belangrijk als legitimatie van de bijzondere positie van de hoofdredacteur binnen de dagbladonderneming. Deze functionaris is niet vergelijkbaar met een hoofd van de administratie, met wie hij, volgens Snijders, tijdens de onderhandelingen wel eens werd gelijkgesteld.

Als bijzonder kernmerk van het dagblad wordt eveneens de publieke functie van massa-communicatiemiddel genoemd. In een eerder concept heeft zelfs gestaan dat de krant door middel van zijn publieke functie in een geestelijke en morele behoefte voorziet. De betekenis van "publieke functie" is hier overigens een geheel andere dan wat in het rapport van de commissie-Van Blom de "publieke taak" van de pers wordt genoemd. Verzette de commissie zich in de jaren twintig tegen de invloed van de adverteerders en zag zij de "courant" vooral als een door de overheid welwillend geholpen leider van de publieke opinie, het naoorlogse statuut beriep zich nadrukkelijk op het in de Grondwet gegarandeerde, primair tegen de overheid gerichte, grondrecht van de vrijheid van meningsuiting en de aan het Verdrag van Rome ontleende vrijheid van informatieverwerving en -verspreiding.

Snijders parafraseert de considerans aldus dat de dagbladonderneming zich van andere ondernemingen onderscheidt. Hij trekt vervolgens een parallel met een toneelgezelschap of een orkest waar men ook die functiescheiding kent van zakelijk en artistiek leider, maar ook ( .............) met een bedrijfsjurist bij een onderneming of een architect bij een bouwbedrijf.

Deze parallel doet onvoldoende recht aan het bijzondere karakter van het dagblad. Met de bedrijfsjurist of de architect bij een bouwbedrijf heeft de hoofdredacteur gemeen dat hij, in de typering van Rooij (4), een soort vrij beroep in dienstverband uitoefent. Het grote verschil met de bedrijfsjurist en de architect is echter dat de hoofdredacteur een organisatie (de redactie) vertegenwoordigt, waarvan de leden als groep en individueel een grondrecht gestalte geven.

De uitgevers hebben in de considerans nadrukkelijk het tweede (commerciële) kenmerk van het dagblad laten opnemen. Een krant is niet alleen communicatiemiddel voor nieuwsberichten en commentaar, maar ook voor betaalde reclameboodschappen, afkomstig van particulieren, het bedrijfsleven en de overheid. De krant kan de inkomsten verbonden aan het uitgeven van dat produkt niet missen; ze moeten de kosten blijvend dekken. In dat opzicht onderscheidt een dagblad zich niet van andere industriële produkten. In een eerder ontwerp stond slechts dat de inkomsten de kosten moesten dekken. De toevoeging verbonden aan het uitgeven van dat produkt doelt op andere inkomsten dan die uit advertenties en abonnementsgeld, in het bijzonder op inkomsten van de overheid of het Bedrijfsfonds voor de Pers. Volgens Schuijt (5) is de toevoeging erin gekomen op verzoek van de NVJ, die wilde voorkomen dat uitsluitend ge-keken zou worden naar de rentabiliteit van een krant. De formulering moet bijvoorbeeld ook verhinderen dat een uitgever een slecht renderende krant liever verkoopt of laat 
doodbloeden door opzettelijk geen beroep te doen op enig steunfonds. In het model waarmee de NVJ in 1973 aan de onderhandelingstafel kwam ontbreekt het kosten- en inkomstenartikel in zijn geheel.

Afgezien van ondergeschikte textuele veranderingen wijkt de considerans uit het modelstatuut op drie punten af van de versie in het hoofdredactiestatuut.

A. Het SvdH postuleert het bijzondere van het produkt dagblad, maar doet dat op een gecompliceerde en verwarrende wijze. De formulering is verwarrend door het gebruik in zowel de eerste zin als na de gedachtenstreepjes van hetzelfde oorzakelijk voegwoord "doordat", dat in de eerste zin correct is om het postulerende van de bewering "het dagblad onderscheidt zich......." te illustreren. Het modelstatuut handhaaft de tweedeling (1.1: bijzonder produkt -1.2 : vergelijkbaar produkt), maar adstrueert het postulerende karakter van de bijzonderheid van het produkt dagblad met vier "doordats". De tekst heeft daardoor als journalistiek credo aan kracht en helderheid gewonnen.

B. Een opmerkelijk verschil tusen het modelstatuut en het hoofdredactiestatuut is de vermelding in de considerans van de democratische functie van de krant. Het SvdH noemt deze functie in een tussenzin van het artikel over de verhouding tussen directie en hoofdredactie, dat op de considerans volgt. Het NVJ-model uit 1973 heeft de relatie dagblad-democratie (- doordat het, als massacommunicatie middel, een belangrijke functie verricht die mede het functioneren van de democratie mogelijk maakt) naar de considerans overgebracht. Het compromis in de eindtekst is duidelijk: de democratische functie gaat naar de considerans en de nadere omschrijving van de publieke functie van het "massacommunicatiemiddel" blijft gehandhaafd.

C. De redigerende hand van de uitgevers in het SvdH is zichtbaar in de formulering doordat zijn informatie elke dag opnieuw een inhoud en vorm krijgt naar de veronderstelde behoefte van het publiek op het tijdstip van de verstrekking. Een later terecht als gevaarlijk onderkende formulering. Uitgevers en hoofdredacteuren hebben geen verschil van mening gehad over de bedoeling ervan: een krant die niet biedt wat de lezers ervan verwachten is ten dode opgeschreven. De hier gekozen formulering gaat echter te ver. Het is een typisch verkopersargument dat inhoud en vorm van de krant aangepast dienen te zijn aan de smaak van het publiek. De nieuwe tekst heeft thans overigens weinig betekenis meer. Het tweede omstreden deel is niet alleen ingrijpend gewijzigd, maar ook verplaatst naar lid 1.2, waar het thuishoort. In de nieuwe tekst is het element dat onomwonden suggereert dat de redactie moet tegemoetkomen aan de smaak van het (grote) publiek weggelaten en vervangen door de impliciete overwegingen: 
- de lezers hebben behoefte aan informatie en

- het dagblad als massa-communicatiemiddel moet dus voldoen aan de behoeften van die lezers;

- het voldoen aan deze journalistieke opdracht levert lezers (abonnees) op die naast andere inkomsten - uiteraard vooral uit advertenties - de continuïteit van het dagbladbedrijf moeten garanderen.

Schuijt (6) ziet reeds in het vierde gedachtenstreepje van art. 1.1 van het modelstatuut (derde - van art. 1.a. van het $\mathrm{SvdH}$ ) de redigerende hand van de uitgevers. $\mathrm{Zij}$ zouden via de verwijzing naar de krant als advertentiemedium de journalisten willen waarschuwen het commerciële aspect niet uit het oog te verliezen. Dat de uitgevers deze boodschap in de considerans wensten, is niet alleen verklaarbaar, maar ook legitiem. Hetgeen Schuijt in doordat het (dagblad)........tevens medium is voor het tegen betaling overbrengen van mededelingen (advertenties) van particulieren, bedrijfsleven en overheden aan zijn publiek leest, lijkt mij weliswaar juist, maar toch met de kanttekening, dat dit een typisch voorbeeld is van interpretatie achteraf, i.c. van na de Grondwetswijziging van 1983 (toevoeging van artikel 7 , lid 4). Op het moment dat de SvdH-tekst geconcipieerd en vastgesteld werd (tussen 1966 en 1971) was de vraag of handelsreclame de bescherming geniet van art. $7 \mathrm{Gw}$ en art. 10 Verdrag van Rome weliswaar omstreden, maar de toenmalige doctrine neigde er toch toe, zij het op uiteenlopende gronden, commerciële reclame daarvan niet zonder meer uit te zonderen. (7)

(1) International Verdrag inzake burgerrechten en politieke rechten, aangenomen door de Algemene Vergadering van de Verenigde Naties op 19 december 1966 , resollutie 2200 A (XXI) (Trb. 1978,177 .

(2) Schuijt Werkers van het woord, pag. 248.

(3) Max Snijders Het redactiestatuut-geschiedenis en bedoelingen, pag. 13/14.

(4) M. Rooij Het dagbladbedriff in Nederland, pag. $234 / 35$.

(5) Schuijt Werkers van het woord, pag. 248.

(6) Schuijt, idem, pag. 248.

(7) Zie bij voorbeeld de conclusie van Adv-Gen. Kist bij HR 18 jan. 1972, N. 1972, 193.; Van der Pot-Donner Handboek van het Nederlandse Staatsrecht, tiende druk (1977), pag. 486-487.

Over (handels)reclame en art. 7 Gw zie ook HR 14 januari 1969, NJ 1969, 191, Manege Rehoboth, met nt. Prins); HR 18 januari 1972, "Café-Restaurant De Huifkar", NJ 1972, 193 met noot Prins; AA XXII, 104, met noot Jeukens); D.H.M. Meuwissen De Europese Conventie en het Nederlandse recht, diss. G.U. 1968, pag. 451.

Over art. 7 lid 4 Gw zie J.M. de Meij: Uitingsvrijheid, pag. 210 e.v., idem: Reclane en vrijheid wan weningsuiting, NJB 1977, pag. 925-931. Over art. 10 Verdrag van Rome en reclame zie de uitspraak van het Europese Hof voor de Rechten van de Mens van 20 november 1989 (zaak Markt intern Verlag in: Mediaforum 90/1-bijlage pag. 5); M. van Delft-Baas en M. van Driel in: Hoofdstukken Mediarecht (red. prof. mr. F. W. Grosheide) 1991, pag. 79 - 105, i.h.b. pag. 85; J.J.C. Kabel: Reclameverbod, NJB 1979, pag. 676-683, en idem: Uitingswrijheid en absolute beperkingen op handelsreclame, Deventer, 1981 (diss.) 


\subsubsection{Beginselverklaring}

Artikel 2.1 is uitsluitend gericht tot de uitgever. Het impliceert dat deze de beginselverklaring op schrift heeft gesteld, zodat de journalisten vooraf te weten kunnen komen aan wat voor krant zij zich binden. Art. 2.2 is er de pendant van: alle journalisten zijn aan deze uitgangspunten, etc. gebonden, mits deze hun vooraf op schrift zijn verstrekt.

Redactionele beginselen zijn geen dogma's; ze kunnen dus gewijzigd worden. Omdat wijziging van de redactionele uitgangspunten van grote invloed kan zijn op het werk van journalisten, voorziet het statuut in een aantal drempels (zie daarvoor artikel 3.7), voordat zo"n verandering geëffectueerd kan worden .

Een beginselverklaring geeft de ideologische koers van de krant slechts in globale lijnen aan en daarom kan er behoefte bestaan aan een nadere invulling of verduidelijking. Het modelstatuut noemt dat "richtlijnen". Het gevaar is niet denkbeeldig dat de uitgever (directie) via deze "richtlijnen" de redactie een koers opstuurt waar deze liever niet heenwil. Tijdens de onderhandelingen heeft de NVJ-delegatie dit gevaar onderkend en nadrukkelijk met de NDP vastgesteld dat een richtlijn geen incidenteel ad hoc-karakter mag hebben. Daarom is in art. 5.2.1 bepaald dat ook de wijziging van richtlijnen aan dezelfde zware procedure onderworpen is als de wijziging van de beginselverklaring.

Het modelstatuut ging er - wanneer we afgaan op de formulering van art. 2. 1 van uit dat de kranten midden jaren zeventig allemaal over zo'n beginselverklaring beschikken. Het Statuut woor de Hoofdredactie is in dit opzicht realistischer. Dit veronderstelt dat de dagbladuitgeverijen statuten hebben, die naar wettelijk voorschrift het doel van de "dagbladuitgeverij-onderneming" omschrijven, en dat in een aantal van deze statuten ook de beginselen van de krant(en) zijn opgenomen. Het houdt echter ook rekening met de mogelijkheid dat zo'n beginselverklaring geheel ontbreekt. Is dat laatste het geval, dan wenst de hoofdredactie bij het opstellen en wijzigen ervan betrokken te worden (artt. 3.2 en 3.3 hoofdredactiestatuut).

Het NVJ-concept uit 1973 kent als artikel II de volgende bepaling over de beginselverklaring: Bij elk dagblad dienen de beginselen en/of het redactioneel karakter te zijn vastgelegd op zodanige wijze dat de rechtskracht verzekerd is.

Een wat raadselachtige bepaling, omdat elders in het concept (art. 4.3) wordt geëist dat de beginselverklaring in de ondernemingsstatuten of een andere publiekelijk toegankelijke akte is vastgelegd. Ook in het modelstatuut zit de openbaarheid van de redactionele beginselverklaring in het artikel over de benoeming van een hoofdredacteur (art. 4.1.3) weggestopt. Logischer zou zijn geweest al in 2.1 te vermelden dat de beginselverklaring voor iedereen ter inzage moet liggen.

Volgens Schuijt (1) laat het hoofdredactiestatuut zelfs in het midden wie de beginselverklaring opstelt of wijzigt. Uit art. $3.5 \mathrm{SvdH}$ - en in het bijzonder de slotzin daarvan - blijkt echter dat de controle op de handhaving van de doelstellingen en/of beginselen berust bij een orgaan dat in elk geval hiërachisch boven zowel de 
directie als de hoofdredactie staat, met andere woorden bij het orgaan dat de hoofdredacteur benoemt of zijn benoeming fiatteert. Een logische conclusie is dat ditzelfde orgaan ook de beginselverklaring heeft vastgesteld. Wanneer nog geen beginselverklaring aanwezig is claimt het NVJ-concept de goedkeuring door de plenaire redactievergadering. Ook de bevoegdheid om de beginselen te wijzigen is in dit concept nadrukkelijk voorbehouden aan de redactie: Voorgestelde ontwerpen voor of wijzigingen in de beginselverklaring kunnen slechts worden ingevoerd met goedkeuring van de plenaire redactievergadering (art. 8.1 van het NVJ-concept).

Uit de data van de beginselverklaringen van de kranten is af te leiden dat de meeste hun redactionele uitgangspunten pas hebben vastgesteld (of opnieuw vastgesteld), nadat het Statuut voor de Hoofdredactie en later het modelstatuut zo'n verklaring hadden geëist. In veel gevallen hebben niet alleen de hoofdredacties, maar ook de redactionele werkgroepen die betrokken waren bij het opstellen van het eigen statuut, een belangrijke rol gespeeld bij het ontwerpen van de beginselverklaringen. In definitieve vorm zijn ze vervolgens goedgekeurd door de directie of een daartoe bevoegd hoger orgaan.

Ook de NVJ-begeleidingscommissie ging er in 1976 , bij het begin van de onderhandelingen per krant over een redactiestatuut, van uit dat de dagbladen nog geen beginselverklaring zouden kennen. Zij zag het opstellen ervan primair als een taak van de redactie en adviseerde dan ook actief mee te werken aan het formuleren van zo'n verklaring. Artikel 2, aldus de toelichting, heeft het karakter van een instructie aan de redacties, die voor de eigen krant een redactiestatuut gaan opstellen. In het eerste lid wordt het licht op groen gezet voor een interne redactionele discussie over het karakter van de krant, een discussie die dient te resulteren in een concept-beginselverklaring, waarover directie, hoofdredactie en redactie het eens moeten worden.

Dat de redactie in het eerste lid een uitnodiging zou mogen zien om de discussie over de eigen beginselverklaring te openen getuigt minder van juridische zuiverheid, maar des te meer van inzicht in de werkelijke verhoudingen bij de meeste kranten. Het zelf opstellen van een beginselverklaring is een nuttige excercitie voor de redacties, lijkt de toelichtende begeleidingscommissie te zeggen: De NVJ hecht grote waarde aan de invoering van deze verplichting per onderneming, omdat daarmee wordt bereikt dat journalisten en redacties zich bewust bezig gaan houden met de ideële implicaties van hun beroep en dat zij in vele gevallen algemene termen als "neutraal", "onafhankelijk" e.d. dienen te vertalen of uit te werken in een plaatsbepaling en een karakteromschrijving. Slechts op grond van de totstandgekomen beginselverklaring kunnen journalisten aanspraak maken op de bijzondere rechten en de grote mate van medezeggenschap, zoals deze in de rest van het redactiestatuut zijn vastgelegd.

In de Nederlandse praktijk wordt de verplichting om de beginselverklaring van de krant op schrift te stellen eerder geassocieerd met een verworvenheid voor de journalist dan met een onvervreemdbaar recht van de uitgever. Over de verplichting in het statuut om de identiteit van een blad duidelijk te omschrijven zegt 
Schuijt (2): Journalist, hoofdredacteur en uitgever weten waaraan zij toe zijn. Dat ook de uitgever in dit rijtje genoemd wordt, tekent de typisch Nederlandse praktijk: de beginselverklaring is een redactioneel stuk, waarmee de uitgever heeft ingestemd.

Exemplarisch voor de Nederlandse verhoudingen is de wijze waarop de identiteit van NRC Handelsblad werd vastgesteld. H.J.A. Hofland, de laatst benoemde hoofdredacteur van het Algemeen Handelsblad, beschreef deze als volgt: Nadat het besluit tot een fusie van NRC en Algemeen Handelsblad was genomen, waren de twee redacties en hoofdredacties het in ieder geval in zoverre eens dat ze een nieuwe, onafhankelijk van politieke partijen of expliciete levensovertuigingen staande krant wilden, liberaal in de ruime zin van het woord, ondogmatisch. Zo is het ook in het eerste hoofdartikel van NRC Handelsblad geformuleend. De directie wilde in eerste instantie iets anders: een soort Daily Telegraph, een dagblad voor de burgerij, zorgvuldig het midden van de weg houdend en zonder intellectuele poespas. De directie heeft het bij het denkbeeld gelaten en de vrijheid van de redactie niet aangetast. (3)

Hoewel het hoofdredactiestatuut en het latere modelstatuut woor hoofdredactie én redactie alleen maar voorschrijven dát de krant een op schrift gestelde beginselverklaring heeft, is het gebruikelijk deze verklaring in het statuut op te nemen. Schuijt (4) schrijft dat een goed redactiestatuut begint met de eigen journalistieke doelstelling en de journalistieke werkwijze te omschrijven, ook wel de identiteit van het medium genoemd. De Mediawet stelt de eis dat persorganen die voor steunverlening door het Bedrijfsfonds voor de Pers in aanmerking willen komen worden geredigeerd door een zelfstandige redactie op basis van een redactiestatuut (art. 129 lid 2 sub c). Het Bedrijfsfonds voor de Pers omschrijft het redactiestatuut als een tussen uitgever en (hoofd)redactie gesloten overeenkomst, waarin de identiteit van het betreffende persorgaan vastgelegd en de medezeggenschap van de (hoofd) redactie geregeld is. Ook De Meij (5) identificeert de beginselverklaring met het redactiestatuut, evenals Hemels, volgens wie de omschrijving van de identiteit een belangrijk element van het redactiestatuut is. (6) Dat is weliswaar feitelijk juist - de meeste kranten hebben in hun statuten ook de identiteitsverklaring opgenomen - maar een verplichting daartoe kunnen partijen niet aan het modelstatuut ontleend hebben. Dat schrijft slechts voor dát er zo'n identiteitsverklaring bestaat, niet dat ze deel uitmaakt van het statuut. Dit regelt daarentegen wel hoe de bestaande beginselverklaring gewijzigd kan worden.

De associatie van redactiestatuut en beginselverklaring herinnert er opnieuw subtiel aan dat Nederlandse redactiestatuten niet, zoals de Duitse literatuur, de nadruk leggen op de "Grundsatzkompetenz" van de uitgever, maar op de pas in de jaren zeventig begonnen gewoonte om de richting van de krant separaat op schrift te stellen.

Overigens geeft de beschreven beginselverklaring slechts een gedeeltelijk inzicht in de identiteit van een krant. Veel uitgeschreven beginselverklaringen, vooral van regionale kranten, laten letterlijk dezelfde formuleringen zien of zijn derma- 
te vaag dat ze onderling uitwisselbaar lijken. Toch hebben alle dagbladen een onmiskenbare identiteit. Over wat moet worden verstaan onder "identiteit" zijn de meningen echter verdeeld. De hoofdredacteur van het Financieele Dagblad L. Metzemaekers zag ten tijde van het opstellen van het modelstatuut de identiteit van een krant vooral als een relatie tussen dat dagblad en zijn lezerskring. Om het in economische termen uit te drukken: de krant moet zich richten op een duidelijk definieerbare markt. Sommigen zullen die marktgerichtheid wellicht afwijzen met verwijzing naar het geestelijk karakter van het produkt. Dat lijkt hypocriet en bovendien onjuist. Voor Metzemaekers maken daarom ook de advertentiekolommen deel uit van de identiteit van de krant. Hij noemt de pretentie van de redactie om uitsluitend zelf de identiteit te kunnen bepalen een grenzeloze zelfoverschatting en een belediging van de lezers. (7) Anderen zien juist een tegenstellling tussen identiteit en commercialiteit. Over de christelijke identiteit van zijn krant sprekend zegt de hoofdredacteur van Trouw, Jan Greven: De journalist werkt met hart en ziel aan die uniciteit (van de relatie tussen de krant en haar lezers). En wat mij betreft is de vraag van een journalist met een christelijke levensovertuiging niet anders dan de vraag van anderen met een christelijke overtuiging op een verantwoordelijke positie: hoe maak ik iets van mijn geloofsovertuiging in het dagelijks werk? Verhandelbaar is verruilbaar, het tegendeel van uniciteit. Dit is geen pleidooi tegen fusies op zich, maar wel een indicatie dat het bij kranten om heel wat meer gaat dan om verhandelbare publieksgroepen, winstmarges, schaalvergroting en dergelijke.

Onder "redactionele identiteit" moet men bij voobeeld ook verstaan:

- de redactionele formulle: landelijk of regionaal of een "mix" daarvan, de zogenaamde "dubbelformule"; mikt de krant op een zo breed mogelijk lezerspubliek of op een hoger opgeleid en/of welgesteld segment; is er meer of minder podium voor andere opinies; een rustige of aandacht trekkende lay out;

- en vooral de moeilijker te definiëren "redactionele cultuur". Daaronder valt niet alleen de typische "huisstijl", maar ook de redactionele organisatie en de sfeer die een krant uitstraalt. De hoofdredactie en een soms vrij kleine, maar gezichtbepalende groep eindredacteuren, columnisten, commentatoren, een paar verslaggevers en rubriekschefs kunnen al een redactionele cultuur kweken die in de hele krant doorwerkt. "Redactionele cultuur" is geen statisch, in een beginselverklaring te beschrijven, gegeven, maar een zich autonoom en permanent voltrekkend proces. Kenmerk van dit proces is dat de uitgever (directie) er bij de meeste kranten vrijwel geen invloed op heeft.

Pas in een overigens geheel overbodig artikel 4.1 .3 wordt aanvullend bepaald dat de redactionele uitgangspunten en de daarmee verband houdende richtlijnen voor de hoofdredactie ook voor derden toegankelijk moeten zijn. Die instructie hoort bij artikel 2 thuis. Wanneer de uitgangspunten en richtlijnen niet in de ondernemingsstatuten staan moet de directie er voor zorgen dat derden er toch kennis van 
kunnen nemen. Publieke toegang tot een document waaruit de richting van de krant blijkt zou eigenlijk vanzelfsprekend moeten zijn, zeker voor de eigen lezers. Verwijzen naar de statuten van de dagbladonderneming bij de Kamer van Koophandel schiet echter tekort; van de modale lezer kan niet gevergd worden dat hij de identiteit van zijn krant op deze plaats gaat achterhalen. Het zou eigenlijk vanzelfsprekend moeten zijn de redactionele uitgangspunten periodiek in de eigen krant te publiceren, bij voorbeeld op de eerste verschijningsdag van elk kwartaal, zoals de Duitse Entwurf für ein Presserechtsrahmengesetz uit 1976 $(\$ 10$, lid 2$)$ voorstelde. In elk geval zou een nieuwe krant in het eerste nummer een dergelijke verklaring over de redactionele richting moeten publiceren. Dit is onder meer gebeurd bij het verschijnen (op 1 april 1991) van het Rotterdams Dagblad. Ook bij wijziging van de redactionele uitgangspunten hebben de lezers er recht op daarover in hun eigen krant geïnformeerd te worden.

Welke houding tegenover de beginselen mogen de kranten eisen van hun journalisten? Het modelstatuut is hierin vrij neutraal: de hoofdredactie en redactie beschouwen de uitgangspunten, etc. als een gegeven. Dat impliceert naar mijn mening geen nadrukkelijke instemming met deze beginselen, wel minimaal het eerbiedigen ervan. De meeste dagbladstatuten beperken zich tot het als een gegeven beschouwen of hebben de bepaling weggelaten. De NVJ-toelichting tenslotte: Tegenover zoveel waarborgen dat de journalist weet waar hij met zijn krant aan toe is, is het logisch dat de journalist van zijn kant de vastgelegde identiteit van zijn krant erkent en eerbiedigt.

Art. 2.2 van het modelstatuut heeft ook een historische achtergrond. De uitgevers wensten het artikel in het hoofdredactiestatuut om te verhinderen dat reeds voorliggende beginselverklaringen opnieuw ter discussie zouden worden gesteld bij het per krant opstellen van een redactiestatuut. (9)

(1) Schuijt Werkers ..., pag. 264.

(2) Idem, pag. 305)

(3) H.J.A. Hofland Uit de memoires wan een journalist, NRC Handelsblad van 24 juni 1989.

(4) Schuijt Werkers, pag. 82

(5)J.M. de Meij Overheid en uitingswrijheid, Wetenschappelijke Raad voor het Regeringsbeleid, 1982, pag. 116; id. Vitingsvrijheid, pag. 77.

(6) Joan Hemels De krant in bedrijf. pag. 108.

(7) Drs. L. Metzemaekers Wat is dat, die "identiteit"? De Journalist van 15 september 1972; eveneens geciteerd in Joan Hemels De krant in bedriff, pag. 277/278.

(8) Brochure De media als handelswaar ... en hun identiteit van het Centrum voor Christen-journalisten, een verslag van een bijeenkomst op 22 april 1989 over dit thema.

(9) Snijders Het redactiestatuut, pag. 19. 


\subsubsection{De organen}

De moeizame onderhandelingen om het hoofdredactiestatuut om te zetten in een regeling voor de hele redactie hebben vooral in dit artikel hun sporen achtergelaten. Het SvdH kent slechts twee "organen", de directie en de hoofdredactie, resp. "de algemene leiding van de uitgeverij" en "de dagelijkse leiding van de redactie". Beide zijn van elkaar te onderscheiden, maar niet te scheiden (art. 2.2 van het $\mathrm{SvdH}$ ). Het SvdH bepaalt in art. 2.3 dat de directie overeenkomstig de wet de leiding van de dagbladuitgeverij als onderneming heeft en verantwoordelijk is ( .......) woor de continuiteit, de economische gang van zaken en het geheel van de produktie van het dagblad. Art. $2.3 \mathrm{SvdH}$ keert in het modelstatuut niet terug en dat is jammer, omdat het, in combinatie met art. $2.4 \mathrm{SvdH}$ (De hoofdredactie heeft de leiding van de redactie van het dagblad en is verantwoordelijk voor de redactionele inhoud ervan) impliciet onderschrijft dat de taak van de directie op het economische en niet op het redactionele vlak ligt.

Artikel 3 begint met een paragraaf die, na de considerans, opnieuw uiteenzet waarom het produkt "dagblad" in een bijzondere bedrijfsstructuur vervaardigd wordt. Volgens Schuijt (1) is dit artikel bedoeld om zich tegenover de niet-redactionele medewerkers van het krantebedrijf te verantwoorden. De NVJ wil erin uitgedrukt zien dat de redactionele medezeggenschap niet opgeëist wordt vanuit een streven naar democratisering van de maatschappij, maar op grond van de specifieke functie van het dagblad als communicatiemiddel. De algemene democratisering van het bedrijfsleven komt tot uiting in het streven van de Nederlandse vakbeweging - waaronder de NVJ - naar uitbreiding van de bevoegdheden van de ondernemingsraden. Juist gezien het specifieke karakter van het dagblad krijgen de redactionele medewerkers door een redactiestatuut medezeggenschap in die zaken, die de redactionele functie betreffen, aldus de NVJtoelichting.

Art. 3. 1 van het modelstatuut is een variant op art. 2.1 van het $\mathrm{SvdH}$, waarin staat dat de bijzondere aard van het dagblad bijzondere eisen stelt aan de structuur van de dagelijkse leiding, dat wil zeggen aan de verhouding tussen hoofdredactie en directie. Volgens de toelichting van de NVJ-begeleidingscommissie wordt hier de onafhankelijkheid van de redactie, als natuurlijk uitvloeisel van de eigenaardigheid van het dagblad gegarandeerd.

Toegevoegd is de verwijzing naar de beginselverklaring; weggelaten (want in de considerans opgenomen) de verwijzing in het hoofdredactiestatuut naar wat in Duitsland de "politische Aufgabe", het belang van een onafhankelijke krant voor het functioneren van de democratie, genoemd zou worden.

Het modelstatuut onderscheidt vier organen die bij het produceren van de redactionele inhoud van het dagblad zijn betrokken: hoofdredactie, directie, redactieraad en redactievergadering. Het NVJ-concept kent dezelfde vier organen, maar voegt er nog een aan toe: de redactie als informatieverwervend en -verstrekkend orgaan (art.III, 1.1 concept). Waarschijnlijk berust dit op een vergissing en moet het woord "orgaan" uit III 1.1 functioneel begrepen worden, namelijk als onder- 
deel van het dagbladbedrijf. Dat blijkt mede uit art. III 1.4 van hetzelfde concept, waar de plenaire redactievergadering opgevoerd wordt als orgaan van de redactie; daarmee kan niet "orgaan van een orgaan" bedoeld zijn.

In de artt. III 1.4 en 1.5 (concept) is een hiërarchie aangebracht tussen de redactievergadering en de redactieraad; de eerste is het belangrijkste orgaan voor medezeggenschap van de redactie. De redactieraad is dat dus niet, maar treedt op namens de plenaire redactievergadering.

Het modelstatuut is de NVJ op dit onderdeel niet tegemoetgekomen. De NDP was er tegen, omdat de formulering zou kunnen leiden tot een soort "directe democratie". Maar ook de hoofdredacteuren hadden er nooit een geheim van gemaakt dat ze hun beleid liever niet wensten te verantwoorden aan een in veler ogen ondeskundig en/of polariserend collectief. In het modelstatuut is de redactieraad, met in de regel een hoofdredacteur als voorzitter, het belangrijkste overlegorgaan van de redactie met de hoofdredactie en de directie geworden.

In de "Nadere toelichting" van de NVJ-begeleidingscommissie wordt deze concessie gebagatelliseerd met de opmerking dat aan de intentie van de NVJ niet getornd is. Immers, de redactieraad is weliswaar het orgaan van de medezeggenschap geworden, maar deze laatste berust, aldus de begeleidingscommissie, wel degelijk bij de redactie, want de redactieraad is de plenaire redactie verantwoording verschuldigd en is bij belangrijke beslissingen verplicht de redactieleden te raadplegen. De beperkende formulering dat de redactieraad orgaan van medezeggenschap is in alle zaken betreffende de redactionele taak en functie moet strijdigheid met de bevoegdheden van de ondernemingsraad (medezeggenschap in de onderneming als geheel) uitsluiten.

In het modelstatuut heeft de NVJ naast de "degradatie" van de plenaire redactievergadering een opeenvolgende reeks principiële concessies gedaan aan de uitgevers. Het NVJ-concept van 1973 kent de directie slechts een (verplicht) ondersteunende rol toe bij de vervaardiging van de krant. Zij moet zorgen voor optimale voorwaarden om de informatieve functie van het dagblad tot haar recht te doen komen, onverlet de verantwoordelijkheid van de hoofdredactie (art. III 1.3). Pas in het slotlid (III 1.6), het "harmoniemodel-artikel", worden nauwe sa " menwerking, voortdurende, wederzijdse informatie en blijvend goed overleg tussen directie, hoofdredactie en redactie voorgeschreven. Het NVJ-concept beperkt de zeggenschap van de directie in een aantal met name genoemde belangrijke beslissingen (benoeming en ontslag van een hoofdredacteur, wijziging van identiteit en verschijningsvorm van de krant) tot het recht om voorstellen daartoe te doen; de beslissing ligt in al deze gevallen feitelijk bij de plenaire redactievergadering. Omdat ook wijziging van het statuut aan het fiat van de redactiemeerderheid was onderworpen, wisten de uitgevers dat aanvaarding van het NVJ-concept hun invloed blijvend zou beperken tot de uitsluitend economische. In NDPogen kwam dit er zelfs op neer dat de ondernemingen hun eigen statuten zouden moeten aanpassen. Partijen zijn uit de impasse die dreigde te ontstaan gekomen door het NVJ-concept als volgt aan te vullen en te wijzigen: 
1. De rechtskracht van het redactiestatuut zou niet, zoals voorzien in artikel 3.7 van het Statuut voor de hoofdredactie, ondergebracht worden in de ondernemingsstatuten, maar in de CAO. Er zou een CAO-artikel komen dat NDP-leden verplicht tot invoering van en gebondenheid aan een redactiestatuut per dagbladuitgave.

2. Het laatste en beslissende woord bij een aantal limitatief opgesomde belangrijke besluiten blijft voorbehouden aan de directie c.q. een andere beslissende instantie. Dat zijn:

a. benoeming en ontslag van een hoofdredacteur;

b. ontwerpen voor de uitgangspunten van het redactionele beleid of wijzigingen daarin;

c. wijziging van karakter en verschijningsvorm van de krant, wijziging van de positie van de redactie en de hoofdredactie of aangaan resp. wijziging van redactionele samenwerkingsverbanden.

Ook wanneer de redactieraad zich tegen deze beslissingen verzet, behoudt de directie het recht ze te nemen, doch voordat zij deze tot uitvoering brengt moet de directie "diepgaand overleg" gepleegd hebben met de redactieraad. Dit "diepgaand overleg" legt zowel de directie als de redactieraad een schriftelijke motiveringsplicht op; de directie moet schriftelijk en gemotiveerd "de naar haar oordeel zwaarwichtige redenen" mededelen om af te wijken van een advies van de redactieraad. Geschillen over de toepassing van de procedure-voorschriften kunnen door de meest gerede partij worden voorgelegd aan de president van de rechtbank.

Over dit art. 3.7 is lang en moeizaam onderhandeld. De NVJ moest toegeven dat de principiêle keuze voor het harmoniemodel (verplichting van alle partijen tot nauwe samenwerking en blijvend goed overleg) nooit kon betekenen, dat de journalisten bij belangrijke kwesties het laatste woord zouden hebben, terwijl de NDP-delegatie het met de journalisten eens was dat de bepaling "dan beslist de directie" ook wat te gemakkelijk zou zijn; de directie mocht beslissen, maar alvorens dat te doen zou ze wel een hoge drempel moeten nemen. De onderhandelingen hebben tot een compromis geleid. Aan dit compromis heeft een door de NDP-delegatie ingebracht advies van ondernemingsrechtdeskundige prof. mr. P. Zonderland ten grondslag gelegen. De tekst van het huidige art. 3.7 laat, aldus de toelichting, het directionele beslissingsrecht onverlet, maar laat recht wedervaren aan de redactionele inspraak.

Hoewel het artikel de redactie(raad) nauwelijks mogelijkheden biedt om de directie iets in de weg te leggen, eiste de NDP-achterban, na afronding van de onderhandelingen tussen de beide delegaties, nog een correctie, die zij ook kreeg. De uitgevers wensten de mogelijkheid van de redacties om naar de rechter te stappen in geval van verschil van mening met de redactieraad verderte verkleinen. Hernieuwd ingewonnen juridisch advies leidde tot een nieuwe concessie: 
3. De kort-gedingrechter, spraken partijen af, zal een beroep op zwaarwichtige redenen uitsluitend marginaal toetsen: $d . w . z$ dat hij niet zal treden in de beleidsbeoordeling, maar zich slechts zal afuragen of het beroep op zwaanwichtige redenen in redelijkheid gedaan kan worden. (Toelichting op het modelstatuut). De beperking tot marginale toetsing zit opgesloten in de later toegevoegde bewoordingen naar haar oordeel in de formulering over de motiveringsplicht van de directie, indien zij om zwaarwichtige redenen wil afwijken van het advies van de redactieraad.

De NVJ-begeleidingscommissie noemt het aldus gekortwiekte art. 3.7 van het modelstatuut niettemin de hoeksteen van het statumt. Dank zij deze tekst krïgt een redactie een juridisch been om op te staan, wanneer zij in een belangrijke kwestie niet met de directie tot overeenstemming kan komen. Zij zag twee drempels alvorens een directie een belangrijke beslissing kon nemen: het voorgeschreven overleg met de redactieraad en de verantwoordingsplicht, dat wil zeggen de plicht van de directie/c.q. om de zwaarwichtige redenen die zij zegt te hebben onder woorden te brengen. Ook Schuijt noemt art. 3.7 een paragraaf waarin de medezeggenschap van de redactie gestalte heeft gekregen.

In de vijftien jaar dat de kranten met redactiestatuten werken waarin deze formulering is opgenomen, is het niettemin nog nooit tot een rechterlijke toetsing gekomen, ook niet in die gevallen waarin over een van de bedoelde belangrijke beslissingen conflicten zijn uitgebroken. Dat is op zijn minst een indicatie dat de redacties in art. 3.7 nauwelijks een mogelijkheid zien om met kans op succes een rechterlijk oordeel te vragen over een, naar de mening van de journalisten, ongewenste beslissing van een directie.

Art. 3.2 van het modelstatuut (De hoofdredactie heeft de leiding van de redactie van het dagblad en is verantwoordelijk voor de redactionele inhoud ervan) is letterlijk overgenomen uit het hoofdredactiestatuut (art. 2.4, eerste volzin). Niet overgenomen - althans op deze plaats - is de tweede volzin uit het SvdH: Zowel terwille van onafhankelijke informatie als ter wille van een zelfde begeleiding van die informatie in opiniërende zin, een en ander overeenkomstig de doelstellingen en/of beginselen van de individuele dagbladuitgaven is de leiding van de redactionele produktie toevertrouwd aan een hoofdredactie, die als zodanig binnen het grotere geheel van de dagbladuitgeverij een eigen zelfstandige verantwoordelijkheid heeft voor de redactionele inhoud van het dagblad. Volgens Schuijt was de tweede volzin in het SvdH bedoeld om de voor de hoofdredacteuren belangrijkste bepaling in de eerste volzin nog eens nadrukkelijk te motiveren aan de directies en de "gewone journalisten". Tegenover de directies wensten de hoofdredacteuren hun eigen verantwoordelijkheid voor de redactionele inhoud van de krant duidelijker te formuleren dan in de "magere CAO-bepalingen" (Schuijt) was vastgelegd. De "gewone" journalisten zagen in in het SvdH in het algemeen en deze bepaling in het bijzonder aanwijzingen dat de hoofdredacteuren zich meer en meer als leiders en als "bijzondere journalisten" gingen profileren. 
Snijders is aanzienlijk positiever over de tweede zin. Hij acht de geciteerde zelfstandige verantwoordelijkheid van de hoofdredacteur eveneens essentieel voor een goede vervulling van die eerdergenoemde publieke functie. Dat is in de eerste plaats nodig om te voorkomen dat de redactionele inhoud kan worden beinvloed door wensen van adverteerders Maar ook, om ervoor te zorgen dat maatschappelijke groeperingen die de eigenaars na staan, geen mogelijkheid hebben op grond van diens machtspositie hun standpunten verwoord te krijgen. (2)

De "eigen zelfstandige verantwoordelijkheid" keert in het modelstatuut (art. 5.1.1) terug bij de beschrijving van de bevoegdheden van de hoofdredactie, maar zonder de vermelding dat in het bijzonder de hoofdredacteur toeziet op de onafhankelijkheid van nieuws- en commentaarrubrieken.

$\mathrm{Bij}$ de introductie van de organen wordt de directie eveneens genoemd, doch slechts als een orgaan dat de opdracht heeft te zorgen voor optimale voorwaarden om de informatieve functie van het dagblad tot haar recht te doen komen. onverlet de verantwoordelijkheid van de hoofdredactie. Het $\mathrm{SvdH}$ formuleert de directionele taak ten opzichte van de redactie scherper: $\mathrm{De}(\mathrm{...})$ verantwoordelijkheid van de hoofdredactie wordt mede bereikt doordat de directie de hoofdredactie vrijwaart voor belemmeringen bij de uitoefening van haar taak( ......) (art. $2.5 \mathrm{SvdH}$ ).

Impliciet zijn taak en bevoegdheid van het orgaan "directie" duidelijker af te lezen uit het "harmoniemodel-artikel" 3.6. Directie en hoofdredactie worden daarin nog nevenschikkend geplaatst als organen belast met de dagelijkse leiding van het dagblad. De opsomming van de "specifieke facetten van het dagblad" waarmee directie, hoofdredactie en redactie rekening moeten houden, helt echter zichtbaar over ten gunste van de directie: Daarbij zullen zij-met behoud van hun specifieke verantwoordelijkheden - zowel de redactionele, als de financiële, commerciële, sociale, technische en administratieve factoren ter harte dienen te nemen.

Sinds de jaren zeventig is de Nederlandse dagbladpers in toenemende mate geconfronteerd met het fenomeen concernvorming: voorheen zelfstandige krantenbedrijven zijn onderdelen van grotere concerns geworden. Dat heeft consequenties gehad voor de directies van deze kranten, die in dit proces in feite degradeerden. De directeur van de voorheen zelfstandige krant is een van de directeuren van een werkmaatschappij geworden, met een ondergeschikte en meestal uitvoerende taak; de belangrijke beslissingen worden genomen door de concernleiding. Deze ontwikkeling is ook in de journalistiek onderkend, zoals in 5.3.5.1 zal blijken.

(1) Schuijtwerkers..., pag. 248.

(2) Snijders Het redactiestatumt, pag. 14. 


\subsubsection{Benoeming/verkiezing en werkwijze organen}

De benaming van dit artikel is niet juist en zou moeten luiden: "Benoeming/verkiezing en werkwijze van de redactionele organen". Van het in het vorige artikel genoemde "orgaan" directie horen de benoemingsprocedure en de beschrijving van de werkwijze hier uiteraard niet thuis.

\subsubsection{Benoeming van de hoofdredactie}

Dit artikel is vrijwel letterlijk overgenomen uit het modelstatuut voor de hoofdredactie. De enige toevoeging is de opneming van de rechten van de redactieraad. Ook het hoofdredactiestatuut liet de vraag wie de hoofdredacteur benoemt open. Partijen waren het niet eens kunnen worden over een voor elke onderneming geldende regeling. De NVJ-onderhandelaars wisten echter een belangrijk punt te scoren. Zij realiseerden zich dat, wanneer bij een dagbladonderneming de directie het recht zou hebben de hoofdredacteur te benoemen en te ontslaan, de "eigen zelfstandige verantwoordelijkheid" van de hoofdredacteur illusoir zou worden. Dit wensten $\mathrm{zij}$ tot elke prijs te voorkomen. Ingewonnen juridisch advies leidde tot een compromis: het SvdH (art. 3.1) bepaalt weliswaar niet wie precies de hoofdredactie benoemt, schorst, ontslaat en haar arbeidsvoorwaarden vaststelt (dat dienen de statuten van de onderneming te bepalen), maar wanneer de directie de benoemende, schorsende, etc. instantie is, dan alleen na goedkeuring van een hoger orgaan (eigenaar(s)/aandeelhouders, raad van commissarissen of een vergelijkbaar college).

Artikel 3.5 SvdH bepaalt dat de hoofdredactie voor het handhaven van de doelstellingen en/of beginselen niet alleen aan de directie, maar mede aan het hogere orgaan verantwoording verschuldigd is. Dat dit hogere orgaan de eindbeslissing neemt blijkt uit de slotzin van art. 3.5: Degene(n) aan wie de hoofdredacteur verantwoordelijk is voor het handhaven van de doelstellingen en/of beginselen alsmede van de daarop gebaseerde richtlijnen zal/zullen bij het vormen van een oordeel hierover, zowel de hoofdredacteur als de directie horen. Dit artikel is in het definitieve statuut in artikel 5.1.2, over de bevoegdheden van de hoofdredactie, opgenomen met de toevoeging dat naast directie en hoofdredactie ook de redactieraad gehoord moet worden.

De benoeming van een hoofdredacteur is een van de in art. 3.7 limitatief opgesomde belangrijke beslissingen waarvoor de in dat artikel bedoelde "zware procedure" gevolgd moet worden: de redactieraad moet om advies gevraagd worden en wanneer deze het niet eens is met de keuze van de benoemende instantie kan deze laatste haar kandidaat slechts handhaven wanneer zij schriftelijk en gemotiveerd uiteen kan zetten welke zwaarwichtige redenen haar bewogen hebben het "nee" van de redactieraad te negeren. Bovendien krijgt de redactieraad het recht van voordracht. Volgens Schuijt werd bij de opstelling van het SvdH reeds ge- 
dacht aan de mogelijkheid om een redactioneel orgaan dit recht te verlenen. Het concept waarmee de $\mathrm{NVJ}$ de onderhandelingen inging kent een inspraakprocedure in twee fasen:

- alvorens een besluit te nemen vraagt de benoemende instantie advies aan de redactieraad, die mede het recht tot voordracht heeft (art. 4.2, eerste zin concept); - de feitelijke bevoegdheid tot het doen van een bindende voordracht aan de benoemende instantie ligt vervolgens bij een tweederde meerderheid van de plenaire redactïevergadering, waarvan tenminste tweederde deel aan de stemming deelneemt. Het bindende karakter blijkt uit art. 4.2 laatste zin (een hoofdredacteur wordt niet benoemd dan na goedkeuring door de plenaire redactievergadering) juncto art. 5.4 concept.

Deze regeling is niet in het definitieve modelstatuut terechtgekomen. De instemming met de benoeming door een meerderheid van de redactieleden is vervangen door de "zware procedure" van art. 3.7 en daarmee is de kans dat een redactie opgezadeld wordt met een ongewenste hoofdredacteur weliswaar kleiner geworden, maar niet uitgesloten. De kans is vooral klein, omdat het ook een welbegrepen ondernemingsbelang is om geen ongewenste hoofdredacteur op een redactie te parachuteren. Zoiets zal onvermijdelijk een negatieve uitwerking op het redactionele produkt hebben. Tijdens de onderhandelingen werd zelfs van uitgeverszijde nog herinnerd aan de slechte ervaringen die, onder andere bij de Haagse Post, waren opgedaan met een onwelkome hoofdredacteur.

Art. 4.1.3 van het modelstatuut (eveneens overgenomen uit het hoofdredactiestatuut - art. 3.2 en het NVJ-concept - 4.3) is deels overbodig, deels onlogisch en deels op de verkeerde plaats opgenomen. In art. 2.1 is reeds bepaald dat de uitgangspunten van het redactionele beleid en de daaruit afgeleide richtlijnen schriftelijk moeten zijn vastgelegd. In art. 4.1 .3 wordt alleen toegevoegd dat deze beginselen en richtlijnen opgenomen moeten zijn in de statuten (van de onderneming), een aanstellingsakte of een nadere akte. Het was logischer geweest wanneer art. 2.1 duidelijkheid zou verschaffen waar de beginselverklaring te vinden is en dat ze publiekelijk toegankelijk dient te zijn. Dat ook de hoofdredactie aan deze beginselverklaring gebonden is vloeit reeds nadrukkelijk voort uit art. 2.2.

\subsubsection{Redactievergadering}

Zoals hiervoor reeds vermeld is dit orgaan in de slotronden van de onderhandelingen tussen NDP en NVJ gedegradeerd. In het NVJ-concept is de redactievergadering nog het belangrijkste orgaan voor de medezeggenschap van de redactie. Het artikel over de werkwijze van de redactievergadering staat in dit concept dan ook vóor dat van de redactieraad. In het modelstatuut is de redactieraad aanzienlijk belangrijker. Het zou dan ook logischer geweest zijn wanneer de volgorde van de artikelen over verkiezing en werkwijze van de organen in het modelstatuut dienovereenkomstig aangepast zou zijn. Bij de introductie van beide organen in de artt. 3.4 en 3.5 modelstatuut is deze volgorde namelijk wel aangehouden. Andere opvallende verschillen tussen NVJ-concept en modelstatuut: 
A. Wie zijn stemgerechtigd? Een van de punten waarover partijen langdurig hebben onderhandeld.

- Concept (art. 1.4): Alle journalisten bij de onderneming die vallen onder de CAO-Dagbladjournalisten; per krant kan de plenaire redactievergadering bepalen of en zo ja welke medewerkers eveneens tot de plenaire redactievergadering behoren.

- Modelstatuut (4.2.5): Alle journalisten, vallende onder de CAO voor dagbladjournalisten voor zover zij hun proeftijd hebben voltooid. Of en zo ja welke redactionele medewerkers, al dan niet met stemrecht, tot de redactievergadering worden toegelaten bepalen directie, hoofdredactie en redactieraad in onderling overleg.

Het NVJ-concept suggereert ten onrechte dat een plenaire redactievergadering uit alle journalisten bij de onderneming kon bestaan. Het modelstatuut maakt aan dat misverstand - dezelfde onderneming heeft na dertig jaar dagbladenfusies in de regel meer dan één redactioneel zellstandig dagblad - een einde.

In het modelstatuut is het begrip "medewerkers" terecht nader gepreciseerd als "redactionele medewerkers". Men kan hierbij denken aan functionarissen als leden van het redactiesecretariaat; stenografen en daarmee gelijk te stellen redactie-assistenten, die telefonisch doorgegeven berichten van correspondenten uitwerken en daarbij enige redigerende bevoegdheden hebben; medewerkers van graphics-afdelingen die niet onder de journalisten-CAO vallen; documentalisten; lay-out-assistenten, die op aanwijzing van de opmaakredactie de redactionele pagina's vormgeven en bij voorbeeld nieuwsberichten mogen inkorten.

B. Duidelijker dan in het NVJ-concept is het de redactieraad die de agenda vaststelt voor de redactievergadering.

C. Het NVJ-concept daarentegen geeft de redactievergadering veel grotere bevoegdheden, onder andere instemmingsrecht bij een aantal belangrijke beslissingen:

- de benoeming en het ontslag van een hoofdredacteur en

- wijziging van de beginselen van de krant, van karakter en verschijningsvorm en van de positie van redactie en hoofdredactie, verandering van samenwerkingsverbanden met andere bladen en wijziging van het redactiestatuut.

D. Het NVJ-concept maakt weliswaar de redactieraad ondergeschikt aan de redactievergadering en deze laatste kan de redactieraad ter verantwoording roepen, er zijn echter geen consequenties aan verbonden. Die omissie is hersteld. Art. 4.2.1, laatste zin, modelstatuut bepaalt dat de redactieraad moet aftreden indien de redactievergadering in een speciaal daartoe bijeengeroepen vergadering als haar oordeel uitspreekt dat de redactie door de zittende redactieraad niet meer naar behoren wordt vertegenwoordigd. De bepaling dat de redactievergadering uit haar midden haar eigen voorzitter kiest (art. 4.2.3), in combinatie met de eerste zin van art. 4.2.1 (de redactieraad legt de redactievergadering verantwoording af 
over zijn beleid) sluit uit dat een lid van de redactieraad - hoewel stemgerechtigd lid van de redactievergadering - er voorzitter van kan zijn. De toevoeging "uit haar midden" verbiedt het een niet-redactielid, bij voorbeeld een NVJ-vertegenwoordiger, te vragen een redactievergadering te leiden.

E. De vereisten voor de gekwalificeerde meerderheid bij belangrijke besluiten zijn in het modelstatuut $z$ waarder dan in het NVJ-concept: drievierden van het aantal stemmen tegen tweederde deel in het concept. In beide is het quorum gelijk: tweederden van de stemgerechtigde leden. In tegenstelling tot het NVJ-concept biedt het modelstatuut een oplossing wanneer het quorum niet gehaald wordt en beslissingen genomen moeten worden waarvoor geen gekwalificeerde meerderheid nodig is. In dat geval wordt de redactieraad over de geagendeerde onderwerpen geacht te spreken namens de redactie.

\subsubsection{Redactieraad}

De verschillen tussen het NVJ-concept en de uiteindelijke tekst van het modelstatuut over de redactieraad zijn op het eerste gezicht niet bijzonder groot. Toch is er volgens Snijders en Schuijt langdurig over onderhandeld. Bij de werkgevers bestond grote huiver voor openbaarheid van vergaderingen van de redactieraad. Tot het laatste moment heeft de NDP-achterban zich ertegen verzet. Het NVJconcept bepaalt (art. 6.3) dat de vergaderingen van de redactieraad in principe openbaar zijn. Dat zou kunnen inhouden dat ook derden de vergaderingen mogen bijwonen. Dat werd in de eindtekst gepreciseerd tot: voor de eigen redactie in principe openbaar. Blijkens de toelichting bij het modelstatuut maakt deze formulering een afwijkende regeling mogelijk, overeen te komen tussen directie, hoofdredactie en redactie.

Evenals het NVJ-concept heft het modelstatuut de openbaarheid op, wanneer de redactieraad voor beslotenheid kiest. Het modelstatuut voegt daar echter aan toe dat de leden van de raad tot geheimhouding verplicht zijn, wanneer dat vooraf met de hoofdredactie en/of de directie is overeengekomen. De redactieraad of individuele leden ervan kunnen niet tot zo'n overeenkomst verplicht worden, maar daar staat als sanctie tegenover dat, wanneer de redactieraad niet vooraf belooft het besprokene geheim te houden, directie en/of hoofdredactie overleg in deze aangelegenheid - zelfs in de gevallen dat dit volgens het statuut verplicht is - met de redactieraad achterwege kunnen laten.

Als concessie aan de NDP is art. 4.3.6 opgenomen. Het geeft de directie, de hoofdredactie en ook de redactieraad de mogelijkheid een lid van de redactieraad voor ontslag voor te dragen aan de redactievergadering. Hierbij is concreet gedacht aan individuele leden van de redactieraad die zich niet aan de bij meerderheid overeengekomen geheimhoudingsplicht wensen te houden. Het modelstatuut bepaalt dat, wanneer de redactievergadering een lid ontslaat, dit lid in beroep kan gaan bij de Raad van Uitvoering als bedoeld in art. 51 e.v. van de CAO voor dagbladjournalisten. Wanneer de directie het ontslag vraagt en de 
redactievergadering dit ontslag niet verleent kan ook de directie naar de Raad van Uitvoering stappen. Zodra een krant een redactiestatuut heeft opgesteld kan dit statuut een beroepsinstantie aanwijzen; dat kan de Raad van Uitvoering zijn, maar alleen wanneer directie, redactie(s) en hoofdredactie(s) per dagbladonderneming (mogelijk voor meer dan één krant) daarvoor gekozen hebben. (1)

Tot de openbaarheid behoort ook het verslag. Het modelstatuut verplicht tot een verslag van elke vergadering met de kanttekening dat, wanneer met de directie en/of hoofdredlactie geheimhouding overeengekomen is, het besprokene niet gepubliceerd hoeft te worden. De tekst van het NVJ-concept suggereert abusievelijk dat ook wanneer de redactieraad een besloten vergadering heeft gehouden, daarvan een verslag gemaakt moet worden.

Een voor het wantrouwen ten aanzien van hoofdredacteuren typerend twistpunt (Schuijt) is geweest of een hoofdredacteur die qualitate qua deel uitmaakt van de redactieraad, er ook voorzitter van moet zijn. Compromis werd dat de hoofdredacteur voorzitter is behoudens zijn vrijwillige afstand van dit recht of een afwijkend onderling akkoord te dezen. Volgens de Begeleidingscommissie van de NVJ is in de interne discussie gezegd dat hoofdredacteuren die benoemd zijn volgens de daarvoor geldende procedure van het redactiestatuut (art. 4.1.2 jo. 3.7), geacht mogen worden het vertrouwen van de redactie te genieten en dus vanzelfsprekend ook geaccepteerd zullen worden als voorzitter van de redactieraad; "geparachuteerde" hoofdredacteuren zouden dus niet als voorzitter geaccepteerd hoeven worden.

Bij een afwijkend onderling akkoord kan men denken aan het kiezen van een vice-voorzitter, die bij afwezigheid van de hoofdredacteur of wanneer de gekozen leden dat gewenst achten, het voorzitterschap, eventueel tijdelijk, overneemt. Wanneer de hoofdredactie uit twee of meer leden bestaat kan (het hoeft niet) de benoemende instantie in de aanstellingsakte of een nadere akte bepalen welke van de hoofdredacteuren zitting neemt in de redactieraad (art. 5.1.3).

De redactieraad wordt gekozen door en uit de redactievergadering. Volgens art. 4.3.5 kunnen alle stemhebbende leden van de redactievergadering - en dus ook de leden van de hoofdredactie c.q. de hoofdredacteur die al qualitate qua in de redactieraad vertegenwoordigd is - in de redactieraad gekozen worden. Om aan deze onduidelijke sitatuatie een eind te maken kan een kiesreglement de leden van de hoofdredactie uitsluiten van het passieve kiesrecht.

(1) Toelichting model-redactiestatuut. Zie ook art. 5॥ lid 3 van de CAO. 


\subsubsection{Bevoegdheden van de organen}

Zoals ook reeds bij art. 4 opgemerkt zou de artikelaanduiding moeten luiden "Bevoegdheden van de redactionele organen". In dit artikel zijn de bevoegdheden van de hoofdredactie, redactieraad en redactievergadering samengebracht. Vergeleken met het statuut voor de hoofdredactie bestaat de toevoeging vooral uit de beperking van de macht van de hoofdredactie, die belangrijke beslissingen niet meer kan nemen zonder advies dan wel instemming van de redactieraad.

\subsubsection{Hoofdredactie}

Bij de integratie van het statuut voor de hoofdredactie in het modelstatuut voor hoofdredactie én redactie was overeengekomen dat niet getornd zou worden aan de verworven rechten van de hoofdredacteuren (art. 3.7 van het hoofdredactiestatuut). Wat hun verhouding tot de directie betreft is dat over het algemeen ook niet gebeurd. De beschrijving van de bevoegdheden van de hoofdredactie in artikel 5.1 van het modelstatuut is dan ook soms vrijwel woordelijk uit de artikelen 2, 3 en 4 van het hoofdredactiestatuut overgenomen in het NVJ-concept en vervolgens in de definitieve tekst van het modelstatuut.

- Art. 5.1.1: De eigen zelfstandige verantwoordelijkheid van de hoofdredacteur voor de redactionele inhoud van het dagblad, een van de fundamenten uit het hoofdredactiestatuut, wordt erkend. Toegevoegd is de beperking: met inachtne ming van de bevoegdheden van de redactieraad en de redactievergadering. De verwijzing naar de rol van de hoofdredacteur als waarborg voor onafhankelijke informatie en de begeleiding daarvan in opiniërende zin is niet uit het hoofdredactiestatuut (art. 2.4) overgenomen.

- Art. 5.1.2: Het "contragewicht" voor de macht van de hoofdredactie. De zelfstandige verantwoordelijkheid vindt hatr grens in de door de uitgever vastgestelde uitgangspunten van redactioneel beleid. Toegevoegd is dat bij een oordeelvorming over de wijze waarop de hoofdredacteur binmen de redactionele uitgangspunten functioneert de oordelende ( $\mathrm{d} . \mathrm{w} . \mathrm{z}$, de benoemende) instantie ook de redactieraad hoort. Dit laatste stant niet in het NVJ-concept, dat hier ook voor de plenaire redactievergadering geen rol ziet weggelegd. Herhaald is dat wanneer de directie de hoofdredactie heeft benoemd, deze laatste uiteindelijk verantwoording verschuldigd is aan de instantie die de benoeming heeft goedgekeurd. Zoals eerder (bij art. 4.1.1) beschreven moet deze bepaling verhinderen dat de hoofdredactie in deze belangrijke beleidsbeoordeling ondergeschikt gemaakt wordt aan de directie.

- Art. 5.1.3: Bij een hoofdredactie die uit meer dan één lid lid bestaat moet bij een benoeming de onderlinge verhouding worden geregeld. Het hoofdredactiestatuut (art. 3.6) beschouwt dit als een aangelegenheid die slechts de leden van de 
hoofdredactie regardeert, het NVJ-concept en het modelstatuut voorzien in een mededelingsplicht aan de redactie. Het modelstatuut wijst aanvullend op de mogelijkheid afspraken te maken over het voorzitterschap van de redactieraad.

De artikelen 5.1.4 tot en met 5.1.11 zijn grotendeels overgenomen uit het hoofdredactiestatuut, zij het met soms opmerkelijke afzwakkingen. Ze betreffen werkafspraken tussen de hoofdredactie en de directie en zijn parallel geformuleerd, doch met een duidelijk overwicht voor de directie. Vergelijk bij voorbeeld

- art. 5.1.4: over beslissingen die invloed van belang kunnen hebben op het redactioneel beleid pleegt de directie vooraf overleg met de hoofdredactie en

- art. 5.1.6: de hoofdredactie kan journalistieke beslissingen die belangrijke invloed kunnen hebben op de bedrijfsvoering slechts nemen in overleg met de directie.

Art. 5.1.4 is een afzwakking van het NVJ-concept. Daarin staat dat de directie vooraf overleg met de hoofdredactie moet voeren wanneer zij weet of kan vermoeden dat haar beslissingen ten aanzien van de algemene bedrijfsvoering rechtstreeks of zijdelings invloed kunnen hebben op het redactionele beleid. De NDP verzette zich daartegen: elke directionele beslissing heeft invloed op het redactionele beleid. De toevoeging "invloed van belang" beperkt de verplichting tot raadpleging. Volgens de NVJ is in deze formulering tevens impliciet opgenomen dat de beoordeling of sprake is van "invloed van belang" niet uitsluitend aan de directie wordt overgelaten.

Reeds bij de opstelling van het hoofdredactiestatuut moest men zich het hoofd breken over de vraag wie als "directie" moet worden beschouwd als de krant deel uitmaakt van een concern. Het SvdH kiest voor de formulering: Bij de dagbladuitgeverijen die deel uitmaken van concernconstructies is, tenzij anders geregeld, de directie van de dagbladwerkmaatschappij als "directie" te beschouwen. Deze tekst is vrijwel letterlijk overgenomen in het modelstatuut, met de aanvulling: Als "raad van commissarisen" van de werkmaatschappij is, tenzij anders geregeld, te beschouwen het orgaan waaraan de directie van de werkmaatschappij directe verantwoording verschuldigd is. (Art. 5.1.6).

Pas ruim tien jaar later zouden in het bijzonder de hoofdredacteuren zich realiseren dat zij zich in veel gevallen met een in feite subalterne gesprekspartner hebben laten opzadelen. Belangrijke werkafspraken moet de hoofdredactie maken met de directie, die thans vaak slechts een ondergeschikte functionaris binnen de dagbladonderneming blijkt te zijn. Als voorzitter van het Genootschap van Hoofdredacteuren wees drs. H.A. Lockefeer (De Volkskrant) er tijdens de jaarvergadering van zijn vereniging op 30 mei 1991 op, dat de praktijk op dit punt de redactiestatuten uit de jaren zeventig heeft achterhaald: Toen het statuut werd gemaakt, werd de hoofdredacteur in een min of meer evenwaardige positie gebracht aan de directeur. Zulks om de journalistieke zelfstandigheid en verantwoordelijkheid te waarborgen, en zeker te stellen dat de directie bij haar beleidsvoering op het hoogste niveau rekening zou houden met redactionele desiderata. 
Inmiddels is de directeur van de zelfstandige krant nagenoeg verdwenen. Vrijwel alle kranten maken onderdeel wit van een dagbladconcern, waarin de belangrijke beslissingen worden genomen door de concernleiding. De directeur van de plaatselijke werkmaatschappij vervult daarin een ondergeschikte en meestal uitvoerende laak. Houden we letterlijk vast aan het huidige statuut, dan is de hoofdredacteur niet nevengeschikt aan de concerntop, maar aan de plaatselijke directeur van de werkmaatschappij. Dit is naar letter en geest van het statuut een devaluatie te noemen. De concernvorming dient dan ook gevolgen te hebben voor het redactiestatuut c.q. de bedoelingen van het statuut dienen doorvertaald te worden naar de positie van de hoofdredacteuren in dagbladconcerns.

Over een negental limitatief opgesomde beslissingen van de directie is goed overleg met de hoofdredactie voorgeschreven (art. 5.1.7, letterlijk overgenomen van art. 4.5 hoofdredactiestatuut). De meeste liggen geheel in de redactionele sfeer en een beslissing na goed overleg behoort derhalve ook aan hogere eisen van zorgvuldigheid te voldoen dan een na overleg. Enkele van die beslissingen zijn: de bepaling van de omvang van de krant en de verhouding redactionele- en advertentiepagina's; het veranderen van de "kop" van de krant; ingrijpende typografische wijzigingen; wijziging van de "sluittijden" van de redactionele pagina's; wijziging van de editie-indeling en van het tijdstip waarop de krant bezorgd wordt. Het NVJ-concept schrijft in het artikel onder h. (verkoop aan derden van foto's en berichten aan derden) overleg voor met het desbetreffende lid van de redactie, een regeling die overbodig is sinds de opneming van art. 16 in de CAO, waarmee een collectief afwijkend beding volgens art. 7 Auteurswet geintroduceerd werd.

De formulering in art. 5.1.9 (De hoofdredactie neemt in het bijzonder over de volgende punten geen beslissing dan na overleg te hebben gepleegd met de directie en de redactieraad) duidt op een niet-limitatieve opsomming. Het gaat in dit artikel o.a. om de invoering van nieuwe dan well opheffing van bestaande redactionele rubrieken en ingrijpende wijzigingen in de opmaak van de krant. Dit laatste ligt in de praktijk dicht bij de ingrijpende typografische wijzigingen van de krant uit art. 5.1.7 sub c. Is wijziging van de broodletter of verandering van het aantal kolommen op de nieuwspagina's een kwestie van lay-out - en dus redactioneel van aard - of van typografie en dus technisch van karakter? Een richtsnoer in geval van een competentiestrijd zou kunnen zijn: is het initiatief tot dergelijke wijzigingen in het verleden uitgegaan van de redactie of van de technische leiding? Is het eerste het geval dan gaat het om wijziging van de lay-out.

Het SvdH kent in art. 4.7 sub a. een hoogst ongelukkige formulering. De hoofdredactie moet wooraf overleg voeren met de directie over invoering van nieuwe alsmede opheffing van bestaande rubrieken behorende tot de algemene informatie over het actuele gebeuren en/of zijnde van bijzondere betekenis voor de verkoopbaarheid van het dagblad.

Om wat voor rubrieken gaat het hier? De gekozen formulering duidt niet alleen 
op vaste redactionele rubrieken, maar ook op populaire strips en geliefde dan wel omstreden columns. Schuijt noemt in dit verband columns als "Kronkel" (Het Parool) en "Stoker (De Volkskrant). In het NVJ-concept (art. 7.9) is deze formulering terecht in het geheel niet overgenomen, omdat zij in deze vorm de directie inspraak geeft in een puur redactionele aangelegenheid. Van NDP-zijde wenste men de garantie dat de hoofdredactie niet zonder overleg belangrijke rubrieken (genoemd werden onder meer: marktberichten, beurskoersen, scheepvaartberichten, kerkdiensten en de agenda) zou schrappen. In het modelstatuut is voor een compromis gekozen: het noemt als onderwerp voor overleg met de directie "opheffing van bestaande servicerubrieken". Hoofdkenmerk van service-rubrieken is de geringe journalistieke betrokkenheid bij de samenstelling ervan, die bij veel kranten dan ook aan het redactiesecretariaat wordt overgelaten. Tenslotte zij er nog op gewezen dat het modelstatuut de hoofdredactie ook verplicht tot overleg met de redactieraad over de in 5.1.9 genoemde onderwerpen.

Essentieel voor de hoofdredactie is de exclusieve bevoegdheid de journalisten te selecteren om het beleid gestalte te geven. In tegenstelling tot de toenmalige $\mathrm{CAO}$, die bepaalde dat de directie de journalisten anstelde na overleg met de hoofdredactie, werd in het hoofdredactiestatuut (art. 4.3) opgenomen dat journalisten uitsluitend worden aangesteld in overleg met en op voordracht van de hoofdredactie. De NVJ-delegatie heeft vastgehouden aan de verworvenheid van het hoofdredactiestatuut. Zij bleef zich verzetten tegen het NDP-argument dat het artikel discriminerend zou werken door bevoorrechting van de redactie boven andere groepen van het personeel. De NVJ achtte de bepaling naar de geest in overeenstemming met de zelfstandige verantwoordelijkheid van de hoofdredacteur. (1)

Bij de directionele bevoegdheid journalisten te ontslaan onderscheidt het hoofdredactiestatuut twee gevallen: ontslag op journalistieke gronden en op andere dan journalistieke gronden. In het eerste geval geschiedt ontslag in overleg met de hoofdredactie, in het tweede na overleg. Het NVJ-concept maakt geen onderscheid tussen de ontslaggronden: Ontslag kan alleen geschieden in overeenstemming met de hoofdredactie (art. 7.5. Op dit punt volgt het modelstatuut de CAObepaling (de directie ontslaat na overleg met de hoofdredactie, thans art. 36 lid 1).

De artikelen 5.1.8 en 5.1.10 komen ook reeds voor in het hoofdredactiestatuut. In het NVJ-concept zit de verplichting om de boeken open te leggen zelfs twee keer; de directie moet de redactieraad ook geregeld op de hoogte stellen van de financiële positie van het bedrijf (art. 13.2 over het redactiebudget).

Het NVJ-concept geeft de hoofdredactie toegang tot vergaderingen van commissarissen en andere colleges van toezicht voor zover het behandelde betrekking heeft op journalistieke aangelegenheden. De eindtekst is behalve taalkundig exacter ook restrictiever: uit de agenda moet duidelijk zijn dat een onderwerp rechtstreeks invloed heeft; niet gevolgd is de nog restrictiever formulering van het hoofdredactiestatuut, die de hoofdredactie alleen toeliet wanneer het behandelde 
invloed van belang zou hebben op de redactionele functie.

Artikel 5:1.1.1 is overgenomen uit het NVJ-concept. De redactieraad kan de hoofdredactie dwingen zich bij het overleg met de (concern)directie) en/of de raad van commissarissen te laten vergezellen door een of meer leden van de raad. Niet geregeld is of de (concern)directie en de raad van commissarissen de "chaperonnerende" lleden van de raad ook te woord moeten staan. In het NVJ-overleg met de NDP heeft deze laatste de bepaling dan ook zo begrepen dat met de genoemde specifieke gevallen "incidentele gevallen" bedoeld zijn: de redactieraad zou er geen gewoonte van moeten maken de hoofdredactie te vergezellen.

(1) In de vigerende $\mathrm{CAO}$ is de formulering uit het modelstatuut overgenomen (art. 32 lid 1).

\subsubsection{Redactievergadering}

Het modelstatuut handhaaft bij de beschrijving van de bevoegdheden de volgorde redactievergadering (5.2) - redactieraad (5.3) in navolging van het $\mathrm{NVJ}$-concept. In dat laatste is deze volgorde logisch, want hiërarchisch.

De belangrijkste strekking van de artikelen 5.2.1 en 5.2.2 onder het hoofdstuk "bevoegdheden van de organen" is aan te geven dat de redactievergadering vrijwel geen bevoegdheden heeft. De bevoegdheden die ze wel heeft zijn reeds in artikel 4.2.1 opgesomd. Vergelijking met de parallelle artikelen in het NVJ-concept (8.1 en 8.2) maakt duidelijk dat in de laatste fase van de onderhandelingen over de eindtekst van het modelstatuut de redactievergadering dramatisch is gedevalueerd. Het NVJ-concept geeft de redactievergadering, die al eerder (art. 1.4) als het belangrijkste orgaan voor medezeggenschap van de redactie is geintroduceerd, instemmingsrecht bij voorstellen tot wijziging in de redactionele beginselen en/of het redactionele karakter. Art. 8.2 gaat nog verder: de redactievergadering heeft niet alleen instemmingsrecht bij belangrijke besluiten van directie en/of hoofdredactie, waaronder met name genoemd worden: wijziging van karakter en verschijningsvorm van de krant, wijziging van de positie van redactie en hoofdredactie of wijziging van samenwerkingsverbanden, maar beslist ook zelf of besluiten van de directie en/of hoofdredactie tot de categorie besluiten ....... van fundamenteel belang (........) woor de taak en functie van de redactie gerekend moeten worden.

In het modelstatuut is daar formeel vrijwel niets van overgebleven. Art. 5.2.1 noemt de redactievergadering nog slechts als orgaann dat door redactieraad en hoofdredactie geraadpleegd wordt; art. 5.2.2 noemt haar niet eens. Slechts indirect - via art. 4.2.1 - speelt de plenaire redactievergadering een rol. De bepaling verwijst onder meer naar het slotartikel (11.1), dat de redactieraad verplicht de instemming van de redactievergadering te verwerven, namelijk bij wijziging van het statuut. Daarnaast blijft de redactievergadering uiteraard het orgaan waaraan de redactieraad verantwoording verschuldigd is voor zijn beleid en dat de raad tot aftreden kan dwingen. 


\subsubsection{De redactieraad}

Het NVJ-concept, dat de redactieraad (RR) slechts uitvoerende bevoegdheden toekent, telt vier artikelen, twee meer dan het modelstatuut, dat de RR juist een prominente positie verleent. Weggelaten is de inderdaad geheel overbodige bepaling 9.1 van het concept, dat ook de RR de beginselen en/of het redactionele karakter als een gegeven moet beschouwen. In het modelstatuut is onderkend, dat wat geldt voor de hoofdredactie en alle redactieleden individueel (art. 2.2) ook voor een orgaan als de RR heeft te gelden. Eveneens weggelaten is art. 9.4 concept: $D e$ $R R$ ontwerpt een huishoudelijk reglement dat ter goedkeuring wordt voorgelegd aan de plenaire redactievergadering. Toch is zo'n reglement onmisbaar, onder meer om de verkiezingsprocedure te regelen.

De beschrijving van de bevoegdheden van de redactieraad is een nadere uitwerking van wat art. 3.4 noemt de medezeggenschap van de redactie in alle zaken betreffende de redactionele taak en functie. Die beschrijving is zo ruim dat er nauwelijks een onderwerp denkbaar is dat niet op de agenda van de RR thuishoort. Het modelstatuut noemt het algemene, politieke, maatschappelijke en levensbeschouwelijke beleid als discussiestof en dat is al heel ruim. Als de raad de redactionele koers van de krant met de hoofdredactie bespreekt impliceert dit, dat er ook ruimte moet zijn voor aanpassing van die koers, mits binnen de vastgelegde uitgangspunten van redactioneel beleid. De tekst van art. 5.3.1 geeft bovendien een niet-limitatieve opsomming aan van de onderwerpen die in de RR ter sprake kunnen komen; in dit opzicht wijkt de modeltekst af van het conceptstatuut. Volgens Schuijt geeft deze niet-limitatieve opsomming de redactieraad de mogelijkheid ook bij voorbeeld de managerskwaliteit van de hoofdredacteur en zijn optreden als teamleider ter discussie te stellen. (1)

Uit de formulering dat de redactieraad het orgaan van wederzijdse informatie en onderling beraad tussen hoofdredactie en redactie is moet worden geconcludeerd dat de RR de hoofdredacteur niet kan dwingen zijn beleid te laten bepalen door de (meerderheid in de) redactieraad. Wat echter wanneer de hoofdredacteur bij voortduring overhoop ligt met de redactieraad of over een zeer belangrijke beleidskwestie van mening verschilt? Een dergelijk structureel conflict tussen $R R$ en hoofdredacteur kan zo hoog oplopen, dat een onwerkbare situatie ontstaat en de redactieraad niets anders rest dan - na raadpleging van de redactievergadering, art. 4.2.1 - de hoofdredacteur voor ontslag voor te dragen bij de instantie die hem heeft benoemd; art. 10.6 maakt dit mogelijk. (2)

In de praktijk is de RR niet het enige forum voor overleg van de hoofdredactie met redactieleden over de inhoud van cle krant. De periodiek vergaderende redactieraad zal over het algemeen slechts hoofdlijnen van beleid bespreken. Het beleid op korte termijn vergt frequent overleg via korte overleglijnen. Het Statuut voor de Hoofdredactie is daar in zijn aankondiging van het latere model- 
statuut (art. 3.7) heel expliciet over: naast de toekomstige inspraak van de hele redactie blijft de reeds bestaande inspraak via het dagelijks overleg van de hoofdredactie met de redactionele kaderfunctionarissen, zoals afdelings- of rubriekschefs, of met individuele journalisten gehandhaafd.

Art. 5.3.1 legt de nadruk op het beraad van de redactieraad met de hoofdredactie. De orgaanbeschrijving wijst de redactieraad aan als vertegenwoordiger van de redactie bij het overleg met de directie. Slechts via de verwijzingen naar artikel 9 (over structuurwijzigingen) en 10.6 (ontslag van een hoofdredacteur) komt het overleg met de directie in beeld.

(1) G.A.L. Schuijt Redactiestatuut: instrument voor journalistieke onafhankelijkheid in Is de klant of de krant koning?, pag. 33/34.

(2) Voor een aangescherpte regeling op dit punt zie de redactiestatuten van de Brabant Pers-bladen in 7.4 .3 .2 .

\subsubsection{Verhouding van de redactieraad tot de ondernemingsraad en de redactiecommissie}

Zoals reeds in het vorige hoofdstuk uitvoerig behandeld, is het cryptische artikel over de verhouding redactieraad - ondernemingsraad de meest ingrijpende wijziging van zowel het hoofdredactiestatuut als het NVJ-concept. Beide laatste documenten ontzeggen de ondernemingsraad een beslissende stem in redactionele aangelegenheden; het modelstatuut daarentegen herstelt de OR als het feitelijk belangrijkste - zo niet enige - medezeggenschapsorgaan van de onderneming, waarbinnen de redactie slechts haar invloed kan proberen uit te oefenen. Dat blijkt minder uit de tekst van art. 5.4.1 dan uit de officiële toelichting bij het modelstatuut. Artikel 5.4.1 en de toelichting verklaren waarom de redactieraad slechts een adviserende stem heeft in besluiten van de directie of hoofdredactie zoals beschreven in art. 5.2.2. Het NVJ-concept geeft het in dit stuk belangrijkste redactionele orgaan, de plenaire redactievergadering, nog instemmingsrecht.

De NVJ-begeleidingscommissie heeft de suggestie gedaan het statuutartikel op te nemen in het reglement van de ondernemingsraad, als instructie voor de OR. Het woord "instructie" is hier misplaatst. Ook het reglement van een OR - dat overigens alleen de ondernemingsraad en niet de ondernemer bindt - mag geen afbreuk doen aan de wettelijke rechten van de OR. (1) Een "instructie"' aan de OR kan dan ook niet anders bedoeld zijn dan als "vriendelijk verzoek", in dit geval om ook rekening te houden met de redactie, die in de OR vrijwel altijd een minderheid zal vormen.

Weinig problematisch is de bepaling dat de redactieraad niet in de bevoegdheden van cle redactiecommissie treedt. (2) De redactiecommisie ziet toe op naleving van de CAO en de gekozen leden moeten lid van zijn van de NVJ. Een hoofdredacteur, ook al is hij NVJ-lid, mag geen deel uitmaken van de commissie; hij mag zelfs niet aan de verkiezing ervan deelnemen. Commissie en raad hebben soms tegengestelde belangen te verdedigen. Volgens Schuijt zijn beide weliswaar medezeggenschapsorganen, maar is het - hoewel niet formeel vastgelegd - een goede 
praktijk dat in de RR geen leden van de redactiecommissie zitten en omgekeerd. (3)

(1) Art. 8 lid 1 Wet op de ondernemingsraden; over het OR-reglement zie ook Inzicht in de ondernemingsraad, pag. 51 .

(2) Het modelstatuut spreekt van bevoegdheden krachtens art. $42 \mathrm{CAO}$; in de vigerende $\mathrm{CAO}$ is dat art. 49.

(3) Over de verhouding tussen redactiecommissie en redactieraad zie Schuijt Werkers van het woord, pag. $331-334$ en $336-338$.

\subsubsection{Personeelsbeleid}

Het artikel over het personeelsbeleid is opnieuw geformuleerd tijdens de discussie over de relatie tussen redactieraad en ondernemingsraad. In het hoofdredactiestatuut is het personeelsbeleid een zaak tussen de hoofdredactie, die de taakvervulling van de redactie regelt (art. 3.4) en de directie, die de journalisten aanstelt en hun arbeidsvoorwaarden vaststelt. Eventueel kan de directie bevoegdheden delegeren naar de hoofdredactie en het haar beschikbaar gestelde budget. Het spreekt vanzelf dat vooral van NVJ-zijde het personeelsbeleid een hoge prioriteit zou krijgen in een statuut voor hoofdredactie én redactie. In een voorontwerp van het NVJ-concept heeft gestaan dat de hoofdredactie het personeelsbeleid voert in overleg met de redactieraad. Na bezwaren wan de Sectie hoofdredacteuren kwam de volgende formulering in het NVJ-concept: Art. 11. De hoofdredactie en de $R R$ dienen tot overeenstemming te komen over de uitgangspunten van het personeelsbeleid. Op grond daarvan voert de hoofdredactie het personeelsbeleid uit. De hoofdredactie doet geen voordracht voor de benoeming van een adjuncthoofdredacteur en een chef-redacteur dan na de RR te hebben gehoord.

Van NDP-zijde werd hierbij opgemerkt dat deze tekst in strijd is met de Wet op de ondernemingsraden, die de OR een adviesrecht in het algemene personeelsbeleid toekent (het toenmalige art. 26 lid 1, dat de ondernemer verplichtte om advies te vragen alvorens een besluit te nemen ter zake van wijziging of vaststelling van een der hoofdlijnen van het aanstellings-, ontslag of promotiebeleid). Daarom gaat thans aan de eerste zin van art. 11 NVJ-concept de bijzin vooraf dat het redactionele personeelsbeleid moet passen binnen het kader van het in de onderneming op grond van het overleg tussen directie en ondernemingsraad te voe. ren personeelsbeleid. (1)

De NDP was bang dat de RR de bevoegdheden van de hoofdredacteur bij zijn personeelsbeleid zou uithollen. De NVJ bracht daar tegen in dat het instemmingsrecht van de RR zich beperkt tot de hoofdlijnen van dat beleid. In dat verband is als voorbeeld genoemd het uitgangspunt dat bij opengevallen functies eerst mensen uit de eigen redactie in aanmerking komen. Om misverstanden te vermijden is in de definitieve tekst de "chef-redacteur" uit het NVJ-concept vervangen door een algemeen redactiechef als bedoeld in artikel 6 van de CAO. (2) De bedoeling was te vermijden dat de hoofdredacteur de voorgenomen benoe- 
ming van een chef van een afdeling in de $R R$ zou moeten bespreken. (Een verstandige hoofdredacteur zal het overigens toch doen.)

(1) Sinds 1979 is vaststelling, wijziging of intrekking van een regeling op het gebied van het aanstellings"- ontslag-of bevorderingsbeleid onderworpen aan instemming van de OR (WOR art. 27 lid 1$)$.

(2) In de thans geldende CAO kont de functievermelding niet meer voor.

\subsubsection{Persoonlijke verantwoordelijkheid}

Dit artikel, dat de journalist ervoor beschermt dat hij iets zou moeten schrijven of een opdracht zou moeten uitvoeren waar hij gewetensbezwaren tegen heeft is een "Fremdkốrper". Het is namelijk het enige artikel in het redactiestatuut dat zich tot de individuele journalist (in dienstverband) richt, waarmee de systematiek - toch al niet het sterkste punt in het modelstatuut - geweld wordt aangedaan. De regeling die het artikel bevat is weliswaar wenselijk, maar zij hoort hier niet thuis. Met Schuijt ben ik van mening dat het hierin geregelde in aangescherpte vorm ingepast moet worden in de CAO. Schuijt doet daar concrete voorstellen voor. (1)

De twee artikelen in het modelstatuut over het recht van een journalist om bepaalde opdrachten te weigeren en om in beroep te gaan tegen de wijze waarop de hoofdredactie met artikelen omspringt zijn vrijwel woordelijk overgenomen uit het NVJ-concept. Van NDP-zijde werd weliswaar opgemerkt dat er praktische bezwaren aan de regeling kleefden (querulanten zouden er misbruik van kunnen maken), maar de NVJ-onderhandelaars verzekerden dat dit in de praktijk wel mee zou vallen.

Overbrengen naar de $\mathrm{CAO}$ is om nog een andere reden te verdedigen. Beide artikelen hebben gemeen dat ze reeds als een nadere uitwerking te beschouwen zijn van bestaande CAO-bepalingen. Artikel 7.1 is een pendant van (thans) artikel 39.2 van de CAO. Dit bepaalt dat de journalist die een opdracht ontvangt, welker uitvoering in strijd zou zijn met zijn ernstige overtuiging daarin een dringende reden mag zien om onmiddellijk ontslag te nemen. De statuutbepaling is daarmee niet zonder zin. Zoals Schuijt (2) over de CAO-bepaling terecht opmerkt is een journalist in een dergelijk geval weinig gebaat met het recht om op staande voet ontslag te mogen nemen; hij wil juist in dienst blijven, maar zonder het risico te lopen dat hij door een opdracht in gewetensnood komt. De procedure van art. 7.1 van het statuut voorziet daarin.

In de praktijk zal de betekenis van het artikel waarschijnlijk gering zijn. Wanneer het om oprechte gewetensbezwaren gaat is het slecht journalistiek beleid een onwillig en daarom kennelijk ongeschikt redactielid een opdracht te verstrekken. Bovendien is dit soort gewetensproblemen vaak voorspelbaar en daarmee vermijdbaar. De sportjournalist die principiële opvattingen over de zondagsrust huldigt zal beseffen dat een baan bij de meeste dagbladen gewetensproblemen zal opleveren en zal zo'n functie dan ook niet ambiëren. Het zullen de twijfelgevallen zijn (is de strijdigheid met een ernstige overtuiging oprecht of een verkapte 
uitvlucht?) waarover de hoofdredactie en, in geval van beroep tegen haar beslissing, de redactieraad een uitspraak moeten doen. Op te merken is nog dat de redacteur die een beroep doet op deze bepaling de redactieraad onmiddellijk om een uitspraak kan vragen en niet hoeft te wachten tot hij de ongewenste opdracht alsnog heeft uitgevoerd of met de gevolgen van een weigering geconfronteerd is. Artikel 7.2 heeft meer praktische betekenis. Het biedt de journalist enige steun bij de navolgende situaties:

- De hoofdredactie brengt zodanige wijzigingen aan in een verslag of een artikel, dat de auteur, wiens naam bij het stuk staat (of pleegt te staan) het niet meer voor zijn rekening wil nemen. (3) De wijzigingen moeten verder gaan dan de gebruikelijke bewerkingen door een eindredactie, zoals het herstellen van taal- en stijlfouten, invoegen van tussenkoppen, bescheiden inkortingen, en dergelijke. De journalist kan nu verlangen dat het stuk niet onder zijn naam verschijnt. Wanneer het niettemin met vermelding van de naam van de auteur gepubliceerd wordt kan deze zich achteraf tot de redactieraad wenden met het verzoek om een uitspraak.

Als het gaat om artikelen die door meer dan één redacteur geschreven zijn - in de moderne journalistiek een veel voorkomende werkwijze - kan zich een complicatie voordoen: hoe moet de redactieraad handelen als slechts é́n auteur bezwaren heeft tegen de wijzigingen en diens naam toch wordt vermeld? Een redelijke uitleg van de bepaling geeft ook deze klager een beroepsmogelijkheid.

- De hoofdredactie weigert een artikel of verslag te plaatsen wegens de inhoud of strekking ervan. Dit laatste staat wel niet expliciet in de tekst, maar het dient er wel in gelezen te worden. Er kunnen immers plausibele redenen (ruimtegebrek bij voorbeeld) zijn waarom een artikel (nog) niet geplaatst wordt. Wanneer de redacteur echter meent dat de inhoud van zijn artikel de reden is van niet-plaatsing kan hij zich, eveneens achteraf, tot de RR wenden om een uitspraak.

De slotzin van art. 7.2 (Wanneer de hoofdredactie meent een conclusie van de redactieraad niet te kunnen aanvaarden, maakt zij haar standpunt gemotiveerd. kenbaar aan de andere leden van de raad.) was duidelijker geweest wanneer hij als apart artikel 7.3 was opgenomen. Hij geldt namelijk ook voor art. 7.1. (4) Het uiteindelijke beslissingsrecht van de hoofdredactie is geheel in lijn met de in 5.3.1 genoemde functie van de redactieraad als orgaan van wederzijdse informatie en onderling beraad. De motiveringsplicht moet een garantie zijn voor een zorgvuldig gebruik van de hoofdredactionele bevoegdheid. De formulering "de andere leden van de raad" in combinatie met het woord "hoofdredactie" in deze slotzin is formeel onjuist. Niet "de hoofdredactie" is lid van de raad, maar "de hoofdredacteur" of "een hoofdredacteur". Weglating van "de andere leden van" lost het probleem op.

Uit het gebruik van het woord "redacteuren" blijkt dat alleen journalisten die in dienst zijn van de krant gebruik kunnen maken van art. 7.2. Een medewerker die niet in dienst is en wiens artikel of verslag zodanig gewijzigd wordt dat de auteur 
het niet meer voor zijn rekening wenst te nemen staat echter niet zwakker, maar juist sterker. Deze paradox is te verklaren uit het feit dat de free lancer het persoonlijkheidsrecht van artikel 25 Auteurswet (Aw) kan uitoefenen, dat hij ook na overdracht van het exploitatierecht behoudt. Deze discrepantie houdt verband met de regeling van artikel $7 \mathrm{Aw}$, waarin de werkgever in beginsel als auteursrechthebbende voor in zijn dienst vervaardigde werken wordt aangemerkt.

De regeling van art. 7.2 is als een bescheiden mitigatie te beschouwen van artikel 7 Aw en herinnert in dit opzicht aan art. $16 \mathrm{CAO}$ voor Dagbladjournalisten. De verzachting van art. 7 Aw gaat in de $\mathrm{CAO}$ verder, omdat hierin de werkgever rechtstreeks partij is wan de journalist en niet de hoofdredactie. De CAO geeft de journalist-werknemer enige zeggenschap over publicatie van zijn werk in andere bladen of publicatie in andere vorm, bijvoorbeeld als boek. De journalist kan onder bepaalde voorwaarden zijn voor de krant geschreven artikelen doorverkopen. Wanneer de werkgever journalistiek werk van zijn werknemers wil doorverkopen heeft de journalist recht op een redelijke vergoeding; de journalist kan publicatie in een ander orgaan weigeren, wanneer hij principiële bezwaren tegen dat orgaan heeft.

Art. 7 Aw geeft ruimte (tenzij tussen partijen anders is overeengekomen) voor regelingen die van het hoofdbeginsel afwijken. $\mathrm{CAO}$ en redactiestatuut gaan in de richting van institutionalisering van bepaalde afwijkende bedingen. Daarmee komt de vraag aan de orde of er reden is art. 7 Aw te herijken en mogelijk meer in overeenstemming te brengen met regelingen in ons omringende landen. (5) Het begrip "persoonlijke verantwoordelijkheid" en het journalistieke belang ervan zijn ontwikkeld in de Duitse literatuur. Reeds de "Reichstarifentwurf" uit 1920 bevat in $\$ 15$ een regeling van wat vijftig jaar later algemeen "Gewissensschutz für Redakteure" genoemd zou worden. Een van de eerste (1969) Duitse redactiestatuten, dat van het weekblad Der Stern, kent een artikel 2 dat door zijn expliciete en zeer ruime formulering grote bekendheid kreeg. Het luidt: Kein Redakteur des STERN kann veranlaßt werden, etwas gegen seine Überzeugung zu tun, zu schreiben oder zu verantworten. Aus seiner Weigerung darf ihm kein Nachteil entstehen.

(1) Schuijt Werkers van het woord, pag. 203 e.v. 281 e.v.

(2) Schuijt Werkers, pag. 286.

(3) "Hoofdredactie" belekent blijkens de woorden "of doet aanbrengen" tevens elk lid van de redactie dat bevoegd is beslissingen te nemen, welke beslissingen achteraf gedekt worden door de hoofdredactie. In de praktijk zal meestal de chef van een eindredactieteam bedoeld zijn.

(4) Zo ook Schuijt Werkers, pag. 286.

(5) Het "werkgeversauteursreclit" staat al jaren ter discussie. Een interessant en veelzijdig overzicht van de hedendaagse opvattingen is te vinden in Het Werkgeversauteursrecht - Kan de werkgever het maken? - red. G.J.H.M. Mom en P.J. Keuchenius (1992). Over art. 7 Aw en de CAO voor Dagbladjournalistien zie ook Schuijt Werkers van het woord pag. 288 - 291; pag. 299-300 en Theo van Tienen De dagbladjoumalist en artikel 7 Auteurswet in: Ars Aequi XXV, 1976/2, pag. 72 e. v. 


\subsubsection{Redactiebudget}

De artikelen 3.2 en 3.3 van het modelstatuut (de hoofdredactie is verantwoordelijk voor de redactionele inhoud van de krant; de directie moet de optimale voorwaarden scheppen om een zo goed mogelijke krant te maken) kennen een logisch vervolg in de beide artikelen over het redactiebudget. De eindversie van art. 8.1 van het modelstatuut is voor het overgrote deel letterlijk overgenomen uit het hoofdredactiestatuut (art. 4.1). De hoofdlijnen zijn:

- De directie stelt, na overleg met de hoofdredactie, het redactionele budget vast.

- Dat gebeurt periodiek, bijvoorbeeld per jaar, waarbij als kortste periodiek het kwartaal wordt genoemd; de ratio daarvan is dat een kortere periode de directie grotere mogelijkheden zou bieden het redactionele beleid financieel te sturen.

- De hoofdredactie bepaalt de besteding van dit budget binnen de richtlijnen die zij daarvoor heeft gekregen.

- De hoofdredactie is tegenover de directie verantwoordelijk voor de kostenbewaking.

Dit laatste is een compromis. In het SvdH staat nog dat de hoofdredactie aan de directie verantwoording schuldig is over de doelmatigheid van de besteding. De NDP-delegatie wenste deze zin in het modelstatuut te handhaven. Het NVJ-concept laat de zin helemaal weg, maar tijdens de onderhandelingen ging de NVJ-delegatie overstag. Zij sprak wel de angst uit dat een gesprek over de doelmatigheid van bepaalde uitgaven er onvermijdelijk toe zou leiden dat de directie het redactionele beleid zou beïnvloeden. Als compromis is de verantwoordelijkheid voor de kostenbewaking uit de bus gekomen, met de aantekening dat de hoofdredactie niet verplicht is tot een gedetailleerde verantwoording van de bestede bedragen.

De redactieraad krijgt in het NVJ-concept het recht met de hoofdredactie te overleggen over de hoogte en de verdeling over de verschillende posten van het redactiebudget. Ook hier is de eindtekst afgezwakt: de redactieraad overlegt over de hoogte en de hoofdlijnen van de verdeling over de verschillende posten van het redactiebudget. Geheel verdwenen is de slotzin van art. 13.2 uit het NVJ-concept dat de directie de redactieraad geregeld op de hoogte moet stellen van de financiële positie van het bedrijf. In het modelstatuut (art. 5.1.8) is het de hoofdredactie die regelmatig vertrouwelijk mag kennisnemen van bescheiden die relevant zijn voor een inzicht in de exploitatie van het dagblad.

\subsubsection{Structuurwijzigingen}

De bepalingen in het modelstatuut over de inspraak van de redactie bij structuurwijzigingen zijn vrijwel woordelijk overgenomen uit het hoofdredactiestatuut. De enige toevoeging betreft de rol van de redactieraad, die bescheiden genoemd moet worden. Ook hier is het eindresultaat ver verwijderd gebleven van wat de NVJ zich aanvankelijk ten doel had gesteld. Het NVJ-concept stelt nog de volgende procedure voor bij een structuurwijziging, dat wil zeggen bij reorganisatie, 
fusie, verkoop of liquidatie van de dagbladuitgeverij of de dagbladuitgave, opneming in concernverband en/of verbindingen van andere aard:

1ste fase: Reeds wanneer de directie c.q. uitgever plannen heeft voor een structuurwijziging licht zij zo spoedig mogelijk de hoofdredactie en de RR in;

2de fase: Vóór het begin van onderhandelingen die tot een beslissing kunnen leiden hoort de directie c.q. uitgever de redactieraad. De RR kan zich laten bijstaan door een onafhankelijke deskundige, die vertrouwelijk inzage krijgt in alle bescheiden, die bepalend zijn geweest voor het vornemen om tot onderhandelingenover te gaan.

Deze procedure bevestigt de positie van de redactieraad als de belangrijkste overlegpartner, naast de hoofdredactie, van de directie c.q. uitgever bij een eventuele structuurwijziging. De ondernemingsraad wordt niet genoemd. Dit stuitte op grote bezwaren van de NDP en de grafische bonden, die niet wensten dat de redactieraad eerder ingelicht zou worden en eerder zijn mening kon geven dan de OR. Geheel in lijn met de eerder genomen principiële beslissing om de ondernemingsraad aan te wijzen als het belangrijkste medezeggenschapsorgaan, ook in redactionele aangelegenheden die ook andere werknemers aangaan, werd de inspraakprocedure van de redactionele organen ingrijpend gewijzigd. In de nieuwe regeling krijgt de hoofdredactie haar prominente positie als eerste overlegpartner van de directie c.q. uitgever terug. De procedure is thans als volgt:

1ste fase: De hoofdredactie wordt van de aanvang af betrokken bij plannen tot structuurwijziging. Deze formulering is, zoals de begeleidingscommissie terecht opmerkt, beter dan zo spoedig mogelijk uit het NVJ-concept, maar van de aanvang af staat ook al in het hoofdredactiestatuut. Onder structuurwijziging wordt ook verstaan samenwerking met andere dagbladuitgeverijen met behoud van zelfstandigheid. Deze aanvulling is eveneens uit het SvdH overgenomen.

2de fase: Zodra de plannen tot reorganisatie, fusie, etc. rond zijn stelt de directie gelijktijdig de redactieraad en de ondernemingsraad daarvan in kennis. Wat het tijdstip van informatie betreft is gekozen voor het moment waarop de ondernemer verplicht is de ondernemingsraad te lichten: de ondernemingsraad moet om advies gevraagd worden op een zodanig tijdstip dat het van wezenlij-ke invloed kan zijn op het te nemen besluit. (art. 25 lid 2 WOR). Volgens Schuijt is het gebruikelijk gelijktijdig met de OR ook de redactiecommissie (zie art. 40 lid 2 van de $\mathrm{CAO}$ ) in te lichten.

Het modelstatuut geeft de RR eveneens de mogelijkheid zich door een deskundige te laten bijstaan, maar dan wel zo mogelijk in samenwerking met de ondernemingsraad. Artikel 9.1 zegt niet nadrukkelijk door welk orgaan de hoofdredactie van de aanvang af betrokken moet worden bij een structuurwijziging. Art. 5.1.10 zegt dat de hoofdredactie wordt uitgenodigd tot het bijwonen van vergaderingen 
van commissarissen of van een ander college van toezicht voor zover het te behandelen rechtstreeks invloed heeft op de redactionele functie van dagbladuitgave(n). Een redelijke interpretatie van beide artikelen leidt tot de conclusie dat de hoofdredactie de eerste besprekingen van een eventuele reorganisatie, fusie, verkoop, etc. binnen de raad van commissarissen of een vergelijkbaar college bijwoont en dat zij daarin ook haar oordeel over de plannen mag geven.

Eveneens overgenomen uit het hoofdredactiestatuut is art. 9.3: de directie licht de hoofdredactie vooraf vertrouwelijk in over een voorgenomen ingrijpende wijziging in de samenstelling van de kring der eigenaren en van de raad van commisarissen of een daarmee te vergelijken college. Uit het feit dat de directie de hoofdredactie inlicht kan geconcludeerd worden dat een dergelijke "voorgenomen ingrijpende wijziging" geen "rechtstreekse invloed van belang" zal hebben op het redactionele beleid; anders zou de hoofdredactie zo'n mededeling wel in een vergadering van de raad van commissarissen of een ander college van toezicht vernomen hebben.

Het NVJ-concept verplicht de directie zo spoedig mogelijk de redactieraad in te lichten; de hoofdredactie wordt niet genoemd. In het modelstatuut wordt de redactieraad zo spoedig mogelijk na de hoofdredactie vertrouwelijk ingelicht. Inlichten over een "voorgenomen" wijziging impliceert dat op het moment van mededelen de beslissing nog niet genomen is.

Overbodig en daarom weggelaten is art. 14.3 uit het NVJ-concept, dat bepaalt dat de bevoegdheden van de redactieraad niet derogeren aan de regeling in de CAO voor dagbladen bij structurwijziging. De CAO-bepalingen zijn naar hun aard specifiek bedoeld voor de individuele journalist en zijn alleen van toepassing wanneer de structuurwijziging de werksituatie van de journalisten ingrijpend verandert. Wanneer de structuurwijziging een fusie betreft is de regeling in de CAO over het inschakelen van het bestuur van de NVJ een uitvloeisel van het SER- besluit Fusiegedragsregels 1975.

\subsubsection{Regeling meningsverschillen/ontslag}

Dit hoofdstuk is vrijwel woordelijk overgenomen uit zowel het hoofdredactiestatuut als het NVJ-concept. De enige wijziging van belang vergeleken met hetSvdH is de inschakeling van de redactieraad, waartoe de directie op grond van artikel 10.6 verplicht is voordat een hoofdredacteur voor ontslag wordt voorgedragen. Het betreft een besluit waarvoor de "zware procedure" van artikel 3.7 voorgeschreven is. Bovendien bepaalt artikel 10.6 dat de redactieraad mede het recht tot voordracht voor ontslag heeft. Het NVJ-concept gaat aanzienlijk verder in redactionele medezeggenschap: de redactievergadering krijgt daarin instemmingsrecht bij een eventueel ontslag van een hoofdredacteur. Art. 15.6 bepaalt namelijk: een hoofdredacteur wordt niet ontslagen dan na goedkeuring door tweederde wan de plenaire redactievergadering. (1) Er is slechts één kleine tekstuele wijziging: waar het hoofdredactiestatuut in art. 6.5 spreekt van de tucht en orde binnen het be- 
drijf noemen NVJ-concept (art. 15.5) en modelstatuut (art. 10.5) dat de algemene regels binnen het bedrijf. De bijzondere regeling van artikel 10 is - hoewel zij over het ontslag wan een hoofdredacteur gaat - juist ter bescherming van zijn positie geschreven. Het artikel maakt een onderscheid tussen

A. Een onoverbrugbaar verschil van mening over het redactionele beleid voor zover dat de doelstellingen en/of beginselen van de krant betreft. In dit geval is het hoogste orgaan van de krant de "tegenpartij" van de hoofdredacteur.

B. Een onoverbrugbaar verschil van mening over een onderwerp dat niet te maken heeft met de doelstellingen en/of beginselen van de krant; het statuut geeft als voorbeelden het financiële beheer, de algemene regels binnen het bedriff of de doelmatigheid van de redactionele leiding. Dit is een geschil van de hoofdredactie met de directie (art. 10.5).

Het statuut maakt geen verschil in de afwikkeling van een dergelijk arbeidsconflict, hetgeen voor de hoofdredactie bepaald een versterking van de positie betekent. Wanneer zo'n conflict eindigt in het ontslag van de hoofdredacteur worden de voorwaarden van het ontslag bij bindend advies geregeld door een "Bijzondere Ontslagkamer voor Hoofdredacteuren" van drie leden (een benoemd door het bestuur van de NDP, een door het bestuur van de NVJ en een derde, benoemd door de twee eerder vermelde leden). De Ontslagkamer is overigens niet bevoegd een oordeel te geven over de aard van het conflict (art. 10.3 laatste zin). De ontslagprocedure bij deze Kamer vervalt slechts wanneer beide partijen het binnen vijf weken zelf eens zijn geworden over de voorwaarden van het ontslag. Tussen de aanzegging en het definitieve ontslag (de Kamer krijgt maximaal zes maanden voor het opstellen van het bindend advies) is de betrokken hoofdredacteur op non-actief gesteld met behoud van zijn volledig salaris (art. 10.2, laatste zin).(2)

Er is wel een verschil in de wijze waarop het ontslag tot stand komt. Bij een "ideologisch" conflict over het redactionele beleid zal de instantie die de hoofdredactie benoemd heeft tot een eindoordeel komen, waar de hoofdredacteur zich naar kan voegen of niet. In dit laatste geval biedt hij zijn ontslag aan. Bij de vorming van het eindoordeel hoort de beslissende instantie ook de directie. Het statuut suggereert daarmee dat het de directie is die een conflict over de beginselen constateert. Dat hoeft uiteraard niet het geval te zijn; het is ook mogelijk dat de directie juist partij kiest voor de hoofdredacteur.

Wanneer de directie en de hoofdredactie een onoverbrugbaar verschil van mening hebben dat geen verband houdt met de beginselen van de krant kan de directie de hoofdredacteur zelf ontslaan, zij het met goedkeuring van de raad van commissarissen of een andere toezichthoudende instantie. De hoofdredacteur heeft in dat geval formeel niet meer het recht het geschil aan de beslissende instantie voor te leggen, noch het recht vooraf ter zake gehoord te worden. In de praktijk zal de hoofdredacteur dat recht uiteraard niet onthouden worden. 
(1) De opmerking van Schuijt (Werkers van het woord. pag. 250) dat ook in het modelstatuut voor een ontslag van de hoofdredacteur de instemming nodig is van de Redactieraad moet op een vergissing berusten.

(2) Het modelstatuut houdt eveneens rekening met ontslag op staande woet (zie art. 10.6, laatste zin), maar onduidelijk is of de afwikkeling daarvan ook in handen gesteld kan worden van de Bijzondere Ontslagkamer. Een redelijke uitleg van art. 10.5 maakt hier geen uitzondering.

\subsubsection{Slotbepaling}

De belangrijkste en in zijn gevolgen meest verstrekkende afwijking van het $\mathrm{NVJ}$ concept is de weglating van art. 16.3 van dit laatste document: De dagbladonderneming verplicht zich haar statuten aan te passen voorzover deze in strijd zijn met het onderhavige statuut. Zoals in het vorige hoofdstuk reeds betoogd is een dergelijke generieke verplichting uiteraard onmogelijk, mede wegens strijdigheid met het grondrecht van art. $7 \mathrm{Gw}$.

Wijziging van een statuut is slechts mogelijk in overleg tussen directie, hoofdredactie en redactieraad. Deze laatste heeft op zijn beurt de instemming van de redactievergadering nodig alvorens met een wijziging akkoord te gaan. Alle partijen hebben dus instemmingsrecht. Dat hebben zij ook bij het opstellen van het statuut voor hun krant, zoals blijkt uit de toelichting bij artikel 14 van de CAO. Het NVJ-concept (art. 16.4) legt het instemmingsrecht eenzijdig bij de plenaire redactievergadering.

Zowel het hoofdredactiestatuut als het NVJ-concept hebben opgenomen dat reeds bestaande, voor de hoofdredactie c.q voor de redactie, gunstiger regelingen niet aangetast zouden mogen worden bij het opstellen van een redactiestatuut. Het modelstatuut hoefde die bepalingen niet over te nemen, omdat de CAO in artikel 14.3 daarin reeds voorziet.

\subsection{Samenvatting}

Vergelijking van het "Modlelstatuut voor hoofdredactie en redactie" (en de officiële toelichting erbij) met de twee belangrijkste documenten die als bouwstenen van het Modelstatuut beschouwd moeten worden - het hoofdredactiestatuut en het NVJ-concept voor een modelstatuut - laat zien dat het eindresultaat niet aan hooggespannen verwachtingen heeft voldaan.

Zoals in het vorige hoofdstuk reeds uiteengezet heeft de NVJ-delegatie concessies van principiële aard gedaan aan de uitgevers en de FNV-bonden van het nietjournalistieke personeel van de dagbladen. Het NVJ-concept, waarmee de delegatie de onderhandelingen was ingegaan, had een spilfunctie toebedacht aan het instemmingsrecht van de plenaire redactievergadering; deze laatste zou het belangrijkste orgaan worden voor de medezeggenschap van de redactie. Daar is in het modelstatuut niets van overgebleven.

De volledige degradatie van de plenaire redactievergadering heeft het statuut niet 
onberoerd gelaten, zoals de artikelen uit het NVJ-concept die tijdens de laatste onderhandelingsronden zijn gesneuveld laten zien:

- 4.2 Een hoofdredacteur wordt niet benoemd dan na goedkeuring door de plenaire redactievergadering.

- 8.1 Door de directie of de redactieraad voorgestelde ontwerpen voor of wijzigingen in de beginselen en/of het redactionele kader van de krant kunnen slechts worden ingevoerd met goedkeuring van de plenaire redactievergadering.

- 8.2 Besluiten wan de directie en/of hoofdredactie die naar het oordeel van de redactieraad van fundamenteel belang zijn voor de taak en functie van de redactie kunnen slechts worden genomen na goedkeuring van de plenaire redactievergadering. Dit geldt met name voor wijziging van karakter en verschijningsvorm van de krant, wijziging van de positie van redactie en hoofdredactie of wijziging van samenwerkingsverbanden.

- 15.6 Een hoofdredacteur wordt niet ontslagen dan na goedkeuring door tweederde van de plenaire redactievergadering.

De inspraakmogelijkheid bij deze belangrijke beslissingen zijn in het modelstatuut gereduceerd tot de procedureregels van art. 3.7 waaraan de uitgever zich te houden heeft; de beslissingen zelf zijn feitelijk onttrokken aan toetsing door de rechter, zoals uit de officiële toelichting bij het modelstatuut blijkt. Het modelstatuut bevat een paragraaf, gewijd aan de persoonlijke verantwoordelijkheid van de individuele journalist, die niet in een statuut thuishoort. Voorgesteld wordt de regeling van het modelstatuut, die waardevolle elementen bevat, op te nemen in de CAO, waar zij op haar plaats is. 


\section{Hoofdstuk 6}

\section{De naoorlogse Duitse ontwikkeling}

\subsection{Inleiding}

(Opmerking vooraf: Dit hoofdstuk over de naoorlogse ontwikkelingen in Duitsland is beperkt tot het voormalige West-Duitsland. Het medialandschap in de deelstaten van de voormalige DDR is sinds de "Wende" zo sterk veranderd en nog zo in beweging dat onduidelijk is of de verhouding tussen de uitgevers en de journalisten van de nieuwe dagbladen zich in "Westduitse" richting zal ontwikkelen of wellicht een geheel eigen weg zal volgen. (1)

$\mathrm{Na}$ de capitulatie van nazi-Duitsland troffen de geallieerde overwinnaars in de westelijke zone de restanten aan van een Duitse pers die vrijwel geheel $(82,5$ procent van de totale oplage) in handen was van het Eher-concern, dat op zijn beurt voor 100 procent eigendom was geweest van de NSDAP. De Franse, Britse en Amerikaanse autoriteiten hechtten er groot belang aan in de door hen bezette zones slechts die dagbladen toe te laten die van nazi-smetten vrij zouden zijn. Er $\mathrm{kwam}$ een strikt vergunningensstelsel waarbij alleen door de geallieerde witgekozen "Lizenzträger" toestemming kregen een krant of tijdschrift uit te geven. Naast de doelstelling van "heropvoeding" van het Duitse volk in democratische zin hadden de geallieerden in hun persbeleid ook andere politieke doelstellingen, onder meer de acceptatie van de federale staatsvorm. Aan het "Lizenzierungs"systeem kwam een einde in de zomer van 1949, kort na de inwerkingtreding, op 24 mei van dat jaar, van de nieuwe grondwet (Grundgesetz - GG), waarvan artikel 5 de tot nu toe gegolden beperkingen nadrukkelijk uitsloot.

(1) Voor een vergelijking van de pers in de voorheen gescheiden delen van Duitsland zie A.B. van Rijn Defunctie wan de wribheid van meningsuiting in beide Duitse staten, diss. (1985)

\section{2 "Innere Pressefreiheit" in grondrechtelijk perspectief}

In de Duitse literatuur over het afbakenen van bevoegdheden op redactioneel gebied tussen uitgever en (hoofd)redactie ("innere Pressefreiheit") zijn sinds 1949 over en weer tussen voor- en tegenstanders uiteraard vooral de nieuwe grondwettelijke bepalingen - niet alleen art. 5, maar ook de artt. $18,19,75$ en 79 GG - over de uitingsvrijheid als argumenten voor en tegen een bepaald standpunt in het strijdperk gebracht. Alle direct betrokkenen binnen de media zelf, de uitgevers en de journalisten met hun eigen belangenorganisaties, hebben - in tegenstelling tot ons land - de mediapolitiek in het algemeen en de "innere Pressefreiheit" in het bijzonder vooral beargumenteerd vanuit de grondrechten. Hoffmann-Riem heeft dit kernachtig tot uitdrukking gebracht in de constatering, die in elk geval voor Duitsland opgaat: Medienpolitik ist Grundrechtspolitik. (1) 
Artikel 5 GG luidt: (1) Jeder hat das Recht, seine Meinung in Wort, Schrift und Bild frei zu äußern und zu verbreiten und sich aus allgemein zugänglichen Quellen ungehindert zu unterrichten. Die Pressefreiheit und die Freiheit der Berichterstattung durch Rundfunk und Film werden gewährleistet. Eine Zensur findet nicht statt.

(2) Diese Rechte finden ihre Schranken in den Vorschriften der allgemeinen Gesetze, den gesetzlichen Bestimmungen zum Schutze der Jugend und in dem Recht der persönlichen Ehre.

(3) Kunst und Wissenschaft, Forschung und Lehre sind frei. (2) Die Freiheit der Lehre entbindet nicht von der Trene zur Verfassung.

Daarnaast zijn op het in artikel 5 geformuleerde grondrecht de navolgende grondwettelijke bepalingen van toepassing:

Art. 18 Wer die Freiheit der Meinungsäußerung, insbesondere die Pressefreiheit (Art. 5 Abs. 1), die Lehrfreiheit (Art. 5 Abs. 3) (........) zum Kampfe gegen die freiheitliche demokratische Grundordnung mißbraucht, verwirkt diese Grundrechte. Die Verwirkung und ihr Ausmaß werden durch das Bundesverfassungsgericht ausgesprochen.

Art. 19 (1) Soweit nach diesem Grundgesetz ein Grundrecht durch Gesetz oder auf Grund eines Gesetzes eingeschränkt werden kann, muß das Gesetz allgemein und nicht für den Einzelfall gelten. Außerdem muß das Gesetz das Grundrecht unter Angabe des Artikels nennen.

(2) In keinem Falle darf ein Grundrecht in seinem Wesensgehalt angetastet werden. (.....)

Art. 79 lid 3 GG garandeert de persvrijheid ook in geval van een grondwetswijziging. Art. 75 lid 2 GG geeft de "Bund" (de federale overheid) slechts de bevoegdheid de "allgemeine Rechtsverhältnisse der Presse und des Films" in de vorm van raamwetgeving te regelen. Art. 75 lid $2 \mathrm{GG}$ geldt als een beperking van de bevoegdheden van de federale wetgever; een raamwet moet iets substantieels voor de deelstaten te regelen overlaten. Deze beperking van bevoegdheid ten gunste van de Länder (deelstaten) werd gewenst door de westelijke geallieerde bezettingsmogendheden; doel ervan was eveneens het versterken van de federale staatsinrichting. Omdat de "Bund" er tot nu toe niet in geslaagd is zo'n raamwet aanvaard te krijgen hebben alle Länder in de periode 1949 (Beieren) tot 1966 (Noordrijnland-Westfalen) hun eigen Landespressegesetze (LPG) opgesteld. In de periode tot de verschillende deelstaten hun eigen perswetgeving tot stand hadden gebracht bleef de Bismarckse Reichspreßgesetz uit 1874 in de meeste deelstaten deels geheel, deels als aanvullend recht, van kracht. (3) Pas na de inwerkingtreding van de laatste deelstatperswet (Pressegesetz für das Land NordrheinWestfalen van 24 mei 1966) is de Reichspreßgesetz buiten toepassing gesteld.

Drie thema's hebben de Duitse juridische discussie rond de "innere Pressefreiheit" beheerst:

A. Is de persvrijheid van art. 5 GG institutioneel of "individualrechtlich" van aard?

126 
B. Heeft de pers een "öffentliche Aufgabe" te vervullen, zo ja welke, en wat voor consequenties heeft dat voor de interne structuur van de dagbladonderneming?

C. Is de verhouding (hoofd)redactie - uitgever uitsluitend arbeidsrechtelijk van aard of, omdat ze de uitoefening van een grondrecht betreft, van een bijzonder karakter? Concreet in de Duitse situatie: hoe is "innere Pressefreiheit" te combimeren met $\$ 118$ van de "Betriebsverfassungsgesetz" ?

Alle drie moeten ze hieronder - noodzakelijkerwijs beknopt - aan de orde komen, omdat de combinatie ervan verklaart, waarom aan het einde van dit hoofdstuk geconstateerd zal worden dat de Duitse "Statutenbewegung", vergeleken met die in ons land, zo'n pover resultaat heeft opgeleverd. Bij de dagbladen in Duitsland zijn sinds de beginjaren zeventig slechts een twaalftal redactiestatuten tot stand gekomen, waarvan er inmiddels weer enkele beëindigd zijn, hetzij door opzegging door de uitgever of doordat de krant opgehouden heeft te bestaan.

(1) Wolfgang Hoffmann-Riem Massenmedien. 6. Abschnitt in Benda-Maihofer-Vogel Handbuch des Verfassungsrechts der Bundesrepublik Deutschland (1983), pag. 390.

(2) In de Duitse literatuur wordt de claim van jounalisten op "innere Pressefreiheit" ook vergeleken met de "Wissenschaftsfreiheit" wan bij voorbeeld het wetenschappelijk personeel wan een universiteit. In het bekende Hochschul-Urteil (BVerfGE 35, 79/80) heeft het constitutionele hof dit individuele recht erkend soweit das unter Berïcksichtigung der anderen legitimen Aufgaben der Wissenschaftseinrichtungen und der Grundrechte der verschiedenen Beteiligten möglich ist. Een uniwersitaire bestuursstructuur waarin groepen medewerkers zeggenschap hebben, is aldus het arrest, weliswat grundsäzlich mit Art. 5 Abs. 3 GG vereinbar maar wel onder het voorbehoud dat bei unmittelbar die Lehre betreffenden Fragen (...) und bei unmittelbar die Forschung und die Hochschullehrerberufung betreffenden Fragen de hoogleraren als groep een maßgebenden Einfluß resp. ausschlaggebenden Einfluß in den Entscheidungsgremien toekomt. Kritisch over de huidige betekenis van het arrest Peter Glolz/Klaus Faber Richtlinien und Grenzen des Grundgesetzes für das Bildungswesen in: Benda-Maihofer-Vogel Handbuch des Verfassungsrechts der Bundesrepublik Deutschland, 2. Abschnitl, pag. 1024-1025).

(3) B VerfGE 7, 29 .

\subsubsection{Persvrijheid: institutioneel of "Jedermann-Recht"?}

Art. $5 \mathrm{GG}$ lid 1 brengt in de eerste twee volzinnen een duidelijk tekstonderscheid aan tussen

- Satz 1: het recht van ieder individu om zijn mening in woord, beeld en geschrift, dus ook via de pers, vrij te uiten en te verspreiden en

- Satz 2: de persvrijheid, dat wil zeggen de vrijheid van meningsuiting van en door de periodieke pers, radio, televisie en film.

In de literatuur wordt de relatie tussen volzin $\mathbb{l}$ en volzin 2 onder meer historisch verklaard. Aanvankelijk was de vrijheid van meningsuiting vooral bedoeld om het individu een stem te geven tegen een feodale of anderszins onderdrukkende staat. Ook de geschreven en gedrukte uitingen waren het werk van individuele burgers. Met de opkomst van de pers als onderneming - in Duitsland vanaf het midden van de vorige eeuw - krijgt zij formele erkenning, zo niet als instituut 
dan toch als fenomeen, zij her als een fenomeen dat regeling behoeft, bij voorbeeld in een Reichspreßgesetz.

In de Duitse medialiteratuur is nog steeds een levendige discussie gaande over de vraag of de persvrijheid van de tweede volzin eveneens een Doppelcharakter heeft:

- enerzijds de bescherming van het subjectieve grondrecht wan het individu, telkens wanneer dat individu zich via de drukpers uit;

- daarnaast de grondrechtelijke bescherming van het instituut pers.

De "Institutsgarantie" steunt op de tekst van art. 5 lid 1 volzin 1 en 2 . Zo redeneert bij voorbeeld Franz Schneider (a contrario): de grondwetgever zou de pers niet in Satz 2 genoemd hebben als hij daarin het individu aangesproken zou hebben. (1) Algemeen wordt de "institutionele opvatting" vooral verdedigd met verwijzing naar het belang van de pers voor het demokratische besluitvormingsproces. De aanhangers van de leer dat de pers als instituut bijzondere bescherming toekomt (2) kunnen erop wijzen dat de "Bundesverfassungsgericht" in een groot aantal beslissingen deze opvatting kennelijk deelt. De persvrijheid, aldus een van de eerste standaardarresten van het constitutionele hof in Karlsruhe over artikel 5 $\mathrm{GG}$, ist mehr als nur ein Unterfall der Meinungsfreiheit, da darüber hinaus die institutionelle Eigenständigkeit der Presse von der Beschaffung der Information bis zur Verbreitung der Nachricht und der Meinung gewährleistet ist. Diese institutionelle Sicherung der Presse als eines der Träger und Verbreiter der öffentliche Meinung im Interesse einer freien Demokratie schließt das subjektiv-öffentliche Recht der in Pressewesen tätigen Personen ein, ihre Meinung in der ihnen geeignet erscheinenden Form ebenso frei und ungehindert zu äußern wie jeder andere Bürger. (3) In het nog oudere Lüth-arrest (15 januari 1958) had het hof reeds vastgesteld dat de persvrijheid schlechthin konstituierend (ist) für eine freiheitlich-demokratische Staatsordnung want dit grondrecht ermöglicht erst die ständige geistige Auseinandersetzung, den Kampf der Meinungen, der ihr Lebenselement ist". (4) Volgens Löffler (5) heeft het hof in Karlsruhe daarmee de ausschließlich individualrechtlichen Sicht (.........) eine Absage erteilt. Daar is lang niet iedereen het mee eens. De "individualrechtliche" opvatting - in de Duitse literatuur ook wel aangeduid als de "liberale" interpretatie van de persvrijheid - wordt verwoord door Czajka, die er op wijst dat het begrip "persvrijheid" in de loop van zijn ontwikkeling durchaus zur Bezeichnung eines reinen Individualrechts, eben des jedermann zustehenden Rechts, seine Meinung durch die Presse zu äußern (6) geëvolueerd is en dat de (grond)wetgever aan deze betekenis gedacht heeft. In dezelfde zin laat zich (de Zwitser) Rehbinder uit: Meinungsbildung (.....) und Meinungsäußerung gehören als aktive Beteiligung am demokratischen Leben zu denjenigen Aufgaben, zu denen in der Demokratie jeder einzelne Staatsbürger aufgerufen ist. Rehbinder (7) en Klein (8) komen op historische gronden eveneens tot de conclusie dat die Entstehungsgeschichte des Art. 5 GG eine Institutsgarantie nicht begrïnden (kann). Een verklaard tegenstander van de institutionele leer als Forsthoff (9) waarschuwt krachtig tegen de 
gevaren die aan een "Institutsgarantie" kleven: Die offentliche Meinung. für sich genommen, ist ihrem Wesen nach liberal und nicht demokratisch. (......) Jeder Eingriff des Staats in den Prozess der Bildung der offentlichen Meinung, sei es durch Unterdrückung, sei es durch Privilegierung der an diesem Prozess beteiligten Faktoren, macht der öfentlichen Meinung ein Ende.

Het is niet toevallig dat vooral mediajuristen die nauwe banden onderhouden met de dagbladuitgevers in volzin 2 het recht van het individu benadrukken. Dit individu, dat het grondrecht via de drukpers uitoefent, de "Träger des Grundrechts" bij uitstek, is bij hen uiteraard de uitgever; de journalist in dienst van deze uitgever heeft slechts een van de uitgever afgeleid recht. Deze opvatting is volgens Doehring de heersende leer in Duitsland.(10)

Een genuanceerd tussenstandpunt neemt de Hamburgse mediajurist Wolfgang Hoffmann-Riem in. Een belangrijk thema in zijn geschriften over de vrijheid van de massamedia is de eis van de "kommunikative Chancengleichheit". (11) Hij verstaat daaronder dat het grondrecht nooit aan een (kleine) groep die over de massamedia kan beschikken "kommunikative Privilegien" (Pressefreiheit ist privilegienfeindlich!) mag verlenen, zonder dat daar de garantie tegenover staat dat rekening wordt gehouden met het algemeen belang, met de "Offenheit des Meinungsbildungsprozesses" of wat Hoffmann-Riem elders die demokratie- und sozialstaatliche Funktion der Presse noemt. Om die reden moet het "objectivrechtliche" (institutionele) gehalte van Art. 5 GG Abs. 1 Satz 2 hoog blijven. (12) In Satz 2 zijn, in de opvatting van Hoffmann-Riem, echter ook individuele, subjectieve rechten verankerd. In tegenstelling tot Werner Weber e.a. heeft hij hierbij niet uitsluitend het oog op de uitgever, maar op allen die in het proces van de uitoefening van het grondrecht betrokken zijn en wel in de mate dat zij daaraan bijdragen: Während Träger des Grundrechts aus Art. 5 Abs. 1 Satz 1 GG jedermann ist und jedermann dieses Grundrecht auch real nutzen kann, gibt es faktische und gegebenenfalls rechtliche Zugangsbarrieren bei Art. 5 Abs I Satz 2 $G G$. ( ..............). Ist der Zugang eröffnet, so genießt den subjektiv-rechtlichen Grundrechtsschutz jeder, der an der publizistischen Nutzung des Massenmediums teilhat. (13)

(1) F. Schneider Presse- und Meinungsfreihet, pag. 88 .

(2) Onder anderen, hoewel individueel weer met soms grote verschillen in opvatting: Adolf Arndt, P. Dagtoglou, W. Geiger, Rolf Groß, A. Hamann, Martin Löffler, Walter Mallmann, H. Ridder, Franz Sichneider.

Over de historische achtergronden van de institutionele benadering zie de dissertatie van Aernout $\mathrm{J}$. Nieuwenhuis Perswribleid en persbeleid (1991), pag. 70 c.v.

In ons land is de Duitse discussie wooral bekend geworden door P.J. Boukema's dissertatie Enkele aspecten wan de wrijheid wan meningsuiting in de Duitse Bondsrepubliek en in Nederland uit 1966. Vgl. ook J.M. de Meij Uitingsvrijheid, pag. 227 e.v; id. Overheid en Vitingsvrijheid, pag. 99; vgl. ook Schuijt, Werkers wan het woord, pag. $49 \mathrm{e.}$.

(3) Nordrhein-Westfalen-Entscheidung van 6 oktober 1959 , BVerfGE 10, 121.

(4) BVerfGE 7, 198. Het tweezijdige karakter van art. 5 Abs. I Satz 2 wordt in recente jurispru- 
dentie (BVerfGE 80, 124 (133) met verwijzing naar het Spiegel-arrest (BVerfGE 20,162 (175) bevestigd. Vgl. ook B VerfGE 62, 230 (247) me herhaling van de formulering (...) fiur eine freiheitliche demokratische Ordnung sichlechthin konstituierend (...)

(5) Loffler/Ricker Handbuch des Presserechts, 3. Kap. Rz. 2.(6) D. Czajka Pressefreiheit und offentliche Aufgabe der Presse (1968) pag. 103.

(7) M. Rehbinder Die offentliche Aufgabe und rechliche Verantwortung der Presse (1962), pag. 125 e.v.

(8) Horst Peter Klein Die offentliche Aufgabe der Presse, pag. 84 e.v.

(9) Ernst Forstholf Tagespresse und Grundgesetz in Pressefreiheit pag. 341-342.

(10) Karl Doehring Staarspecht der Bundesrepublik Deutschland, 2. Auf1. 1980, 309 e.v. Behalve de hierbovengenoemden ook Werner Weber Innere Pressefreiheit als Verfassungsproblem, pag. 71; Edgar Kull Mäzen oder Publizist? Zur Rolle und Rechtsstellung des Herausgebers in Die offentliche Verwaltung (DÓV) 1972 , pag. 453 e.v.

Kunt Nuspriger Pressefreiheit und Pressevielfalt, diss. Bern (1980), pag. 248, noemt aok Peter Lerche, Peter Hanau en Rupert Scholtz als auteurs wier werk ondersteund wordt door de Bundesverband Deutscher Zeitungsverleger (BVDZ). Hij citeert van Hans Paul Prïmm de waaarschuwing Es ist einfach notwendig, sich dieser Verzahnung von Pressewirtschaft und presse. rechtlicher Literatur zu vergewissern, da es sonst nicht möglich ist, die prinzipielle Ausrichtung der presserechilichen Literatur fur die Verlegerseite vichtig zu verstehen.

(1 1) Wolfgang Hoffmann-Riem 6. Abschritt (Massermedien) in Benda, Maihofer, Vogel Handbuch des Verfassungsrecht, pag. 409 e.v.

(12) W. Hoffmam-Riem/H. Plander Rechtsfragen der Pressereform, pag. 64 en 67.

(13) Hoffmann-Riem 6. Abschnit Massenmedien in: Benda, Maihofer, Vogel Handbuch des Verfassungsrechts; pag. 410 .

\subsection{2 "Die öffentliche Aufgabe der Presse"}

Het institutionele karakter van de persvrijheid is niet los te zien is van de bijzondere functie die de pers in het democratische staatsbestel vervult. Tegenover de gepriviligieerde positie van de pers - vergeleken met andere beroepsgroepen die toch ook een belangrijke rol spelen in staat en maatschapij - staat in de Duitse mediarechtelijke traditie van rechtspraak en literatuur dan ook een "öffentliche Aufgabe" van de pers. Het naoorlogse constitutionele hof gebruikte de term voor het eerst in het "Fernsehurteil" van 28 februari 1961 (1). Volgens Löffler (2) is in het Spiegel-Urteil van 5 augustus 1966 (3) zelfs een Verfassungsauftrag der Presse te lezen.

De formulering die het hof daarin gebruikt is ook terug te vinden in de perswetten van de deelstaten, die op één na (Hessen) de öffentliche Aufgabe vermelden. Paragraaf 3 van de perswet van Nordrhein-Westfalen, die als allerlaatste tot stand gekomen is, over de öffentliche Aufgabe der Presse luidt: \$ 3 Die Presse erfült eine offentiche Aufgabe insbesondere dadurch, daß sie Nachrichten beschafft und verbreitet, Stellung nimmt, Kritik übt oder auf andere Weise an der Meinungsbillung mitwirkt. Klein omschrijft de "öffentliche Aufgabe" als eine an die (insbesondere bei den Zeitungen beschäftigten) Pressetätigen und den von ihnen produzierten Presseinhalt gerichtete Erwartung ihrer Umwelt, die die Qualitat der produzierten Informationen und deren Wirkung in der und auf die Demokratie betrifft.

De gedachte dat de pers een belangrijke rol vervult in het democratische proces stamt in Duitsland al uit het midden van de vorige eeuw. Het opkomend liberalis- 
me associeerde de "öffentliche Meinung" en de daarbij behorende vrije pers met de idee van de volkssouvereiniteit. Ook na de opkomst van de moderne en commerciële massapers bleef de journalist in aanzien als "Anwalt des öfffentlichen Interesses". Alle ontwerpen voor perswetgeving uit de Weimartijd noemden de "öffentliche Aufgabe" van de pers. In geperverteerde vorm deed het begrip tenslotte zijn intrede in de nationaalsocialistische "Schriftleitergesetz", die de journalist tot orgaan van de staat degradeerde.

Over de vraag of de pers een "öffentliche Aufgabe" heeft en wat deze dan concreet inhoudt, zijn de meningen veelal langs dezelfde lijnen verdeeld als bij de vraag of de persvrijheid institutioneel dan wel uitsluitend individueelrechtelijk van karakter is. Maar ook binnen de school die de "öffentliche Aufgabe" aanneemt zijn er opvallende verschillen. Het verst gaan Helmut Ridder en Franz Schneider. Ridder (5) acht het afweerrecht van de pers tegenover de staat ("status negativus") onvoldoende. Hij wil dat recht op het niveau van de "status politicus" brengen, zoals die aan de politieke partijen wordt toegekend. Ridder en Schneider bezien de "öffentliche Aufgabe" vooral als "staatsbezogen", met vergaande consequenties: de taak van de pers wordt in deze theorie ook in zoverre met die van de politieke partijen gelijkgesteld dat zij aan dezelfde inrichtingseisen van art. 21 GG moet voldoen. (6) De interne organisatie van de pers moet volgens hen daar-

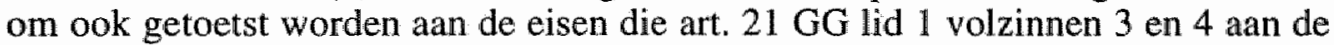
politieke partijen stellen. Dat deze leer gevaarlijk in de buurt van de nationaal-socialistische opvattingen over de taak van de pers (Schriftleitergesetz \$1) komt zij het mit anderen Absichten - signaleert Donsbach. (7) Het constitutionele hof heeft overigens geweigerd de inhoud van een publicatie als maatstaf te nemen voor de beschermwaardigheid ervan, zoals uit diverse uitspraken blijkt. (8)

Moderne schrijvers als Reinhold Oertel en Horst Peter Klein relativeren het begrip "offentliche Aufgabe". Volgens Oertel (9) is het begrip, onder meer omdat het niet afdwingbaar is, lediglich als soziologische Aussage zu werten. Klein (10) komt eveneens tot de conclusie dat de persvrijheid, evenals de vrijheid van meningsuiting, waarvan zij een verbijzondering is, "aufgabenfrei" is.

Voor Hoffmann-Riem is "die öffentliche Aufgabe der Medien" meer dan een irrelevant sociologisch begrip. Er is ook bij hem weliswaar geen sprake van een afdwingbare verplichting aan de media om hun afnemers van bepaalde informatie te voorzien, maar hij beschouwt haar veeleer als een instructie aan de wetgever om de media in staat te stellen om hun "offentliche Aufgabe" te vervullen. Richtsnoer voor wetgeving moeten zijn de bevrediging van de algemene behoefte aan informatie en, waar nodig - Hoffmann-Riem denkt hier onder andere aan de omroep het legitimeren van zekere privileges. (11)

(1) BVerfGE 12, pag. 243.

(2) Martin Löffler Presserecht Band I, \& 3 Rdz 38 e.v.

(3) BVerfGE 20, pag. 162 e.v.

(4) Horst Peter Klein Die öffentliche Aufgabe der Presse, pag. 17.

(5) Helmut Ridder Meinungsfreiheit in Neumann, Nipperdey. Scheuner (Herausg.) Die Grundrechte, Bd 2, pag. 243 e.v. 
(6) Lid I van dit artkel luid: Die Parreien wirken bei der polinschen Wilensbildwng des Volkes mit Ihre Grindung ist frei. Thre innere Ordnung muss demokratischen Grundsätzen entsprechen. Sie muissen uber die Herkunft ihrer Mittel offentlich Rechenschaft geben. De invulling van de opdracht tot politieke wilsvorming van het wolk is te vinden in de "Parteiengesetz", die in 1967 tot stand kwam. Ower Art. 21 GGi en de Parteiengeselz zle A.K. Koekkoek Partileiders en kabinetsfomatie, (diss.) 1978, pag. 81/82.

(7) Wolfgang Donsbach Le gitmationsprobleme des Joumalismus; pag. 21.

(8) B VerfGE 21,27 "Sudkurier-Untel": ook het advertentiedeel valt onder art $5 \mathrm{GG}$; BVerfGE 34. 269, "Soraya-Unteil: art. $5 \mathrm{GG}$ beperkt zich niet tot de "senteuze" pers. Idem: BVerfGE 66, 116 (134): Der Begrift" "Presse" ist weit und forwal auszulegen. (....) Die Pressefreiheit ist mithin nicht auf die "seriose" Presse beschromkt.

(9) Reinhold Oentel Das Verhätnis Verleger - Redakteur im Hinblick auf die Sicherung der "Thmeren Pressefreiheit" pag. $15 \mathrm{c}$.v.

(10) Horst Peter Klein Die óffentliche Aufgabe der Presse, pag. $96-113$.

(11) Wolfgang Hoffmann-Rien Massenmedien, in Benda-Maihofer-Vogel Handbuch des Verforssungsrechts, pag. 402/03.

\section{3 "Pressefreiheit" en "Verlegerfreiheit"}

\subsubsection{De opvattingen van Mallmann}

Reeds in 1959 had Walter Mallmann in een later vaak geciteerde rede erop gewezen dat het politieke en staatsrechtelijke debat over de verhouding tussen pers en staat (de "äußere Pressefreiheit") feitelijk grotendeels achterhaald is. Er is, aldus Mallmann, al lange tijd een probleemgebied ontstaan dat men gewoonlijk met het nog niet exact gedefinieerde begrip "innere Pressefreit" omschrijft. Hier geht es um die innere Struktur der Presse, die Verteidigung ihrer inneren Unabhängigkeit, der Sauberkeit ihrer Berichterstattung, Meinungsbildung und Meinungsäußerung gegen ubermächtige kommerzielle Einflüsse, gegen finanzielle Korrumpierung, dagegen daß die Presse, statt ein Organ der öfentlichen Meinung zu sein, als Instrument wirtschaftlicher, zumal anonymer Kräfte mißjbraucht wird. (1) $\mathrm{Na}$ een historisch overzicht en de thans geldende grondwettelijke bepalingen ten einde denkend komt Mallmann tot twee conclusies:

A. Das primäre Schutzgut, die "materielle Pressefreiheit" ist (.....) die Meinungsfreiheit der Presse, das Grundrecht der freien publizistischen Meinungsäußerung. Erster Träger dieses Grundrechtes ist der, dessen Aufgabe es

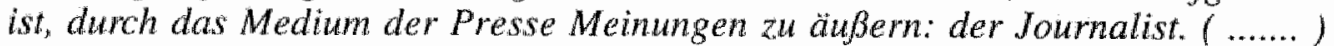
In de Duitse terminologie staat tegenover de "materiële persvrijheid" de als connex beschouwde "formele persvrijheid". Daarbij gaat het vooral om bijzondere regelingen, die reeds in de "Reichspreßgesetz" (1874) voorkwamen - thans in $\$ 2$ ("Zulassungsfreiheit") van de "Landespressegesetze" - en die de uitgever de ongestoorde commerciële exploitatie van zijn blad, de "Pressegewerbefreiheit", garanderen. Het betreft hier, in de formulering van Mallmann, Konnexinstitute die als eine Art Schutzring um die "materielle Pressefreiheit", der sie dienen, herumgelegt sind.

B. Het kan niet de bedoeling van de grondwetgever geweest zijn dat de uitgever von dem erfahrungsgemäß in der Regel die sachfremden, kommerziellen 
Einflüsse auf die publizistische Funktion ausgehen (........) Träger der Funktion und Herr der Presse sein soll. Er ist - neben den anderen Pressegewerbetreibenden - Träger der Pressegewerbefreiheit und hat Einfluß auf die publizistische Funktion nur, soweit diese seine Freiheit reicht. Uberschreitet er die dadurch gesteckte Grenze, so verletzt er die "materielle Pressefreiheit" der Joumalisten, die somit nicht nur - im Sinne der äßßeren Pressefreiheit" - "staatsgerichtet", sondern auch-als innere Pressefreiheit - "verlegergerichtet" ist.

Het zal geen verwondering wekken dat Mallmanns ideeën over de dragers van het grondrecht van de persvrijheid op grote tegenstand van de uitgevers stuitten. In deze gechargeerde vorm hebben ze dan ook niet standgehouden. Ze staan dan ook ver af van de heersende leer.

(1) Walter Mallmann in Es geht nicht nur um Springer, pag. 12/13.

\subsubsection{De opvattingen van Hoffmann-Riem}

Hoffmann-Riem, wiens opvattingen evenmin algemeen gedeeld worden, kiest voor de oplossing van het probleem van het gelijktijdig uitoefenen van grondrechten door met elkaar samenwerkende personen, zoals binnen een personderneming, het door Hesse (1) verdedigde gebod van de Herstellung praktischer Konkordanz. Wanneer de grondrechten van twee dragers ervan met elkaar botsen is het niet altijd vanzelfsprekend dat het recht van de een moet wijken voor dat van de ander, maar moet veeleer gezocht worden naar een zodanige afweging van door het recht beschermde belangen daß jedes von ihnen Wirklichkeit gewinnt. In de verhouding uitgever - journalist(en) betekent dit niet dat de journalist in dienstverband recht kan doen gelden op onbeperkte vrijheid, maar evenmin kan de uitgever de journalisten tegenwerpen dat ze, als ze persvrijheid wensen zonder volledige onderwerping aan de directieven van een uitgever, zelf maar pamfletten moeten verspreiden. Beiden, uitgever en journalist, moeten zoeken naar een oplossing die an den konkreten Bedingungen arbeitsteiliger Grundrechtsausübung orientient ist und versucht, der Grundrechtsbetätigung der verschiedenen Beteiligten zu "optimaler Wirksamkeit" (Hesse) zu bringen. "Praktische Konkordanz" betekent voor de uitgever geen "meestbegunstigdenclausule" en geen "Status quo-Vorbehalt", zeker niet wanneer deze laatste ten koste gaat van de sociaal zwakkere dragers van het grondrecht. Daarbij wijst Hoffmann-Riem zowel op het "Sozialstaatsprinzip", dat ook moet doorwerken in de interpretatie van grondrechten, als op de bijzondere functie die de pers in het democratische besluitwormingsproces bekleedt.

Een heftig bestreden kernthema in het werk van Hoffmann-Riem is dat de grondrechtsuitoefening door de eigenaren en bestuurders van een media-onderneming primair voortvloeit uit de "Pressegewerbefreiheit" van de artt. art. 12 GG (Berufsfreiheit) en art. $14 \mathrm{GG}$ (Eigentumsfreiheit). (2)

Hoe verhoudt art. $5 \mathrm{GG}$ zich tot de artt. 14 en $12 \mathrm{GG}$ ? Kan de persvrijheid de "Eigentumsfreiheit" en de "Pressegewerbefreiheit" van de uitgever beïnvloeden? 
Hoffmann-Riem heeft zich uitvoerig met dit collisievraagstuk beziggehouden bij zijn verdediging van het, elders (zie 6.7) te bespreken, ontwerp voor een nieuwe raamwet voor de pers (Entwurf eines Gesetzes über die allgemeinen Rechtsverhältnisse der Presse) uit 1974, een initiatief van het toenmalige kabinet Brandt-Scheel. (3) Hoffmann-Riem komt daarbij tot oplossingen die, hoewel de Duitse grondrechtenkatalogus terminologisch verschilt van de Nederlandse, onze aandacht verdienen. (4)

Hoffmann-Riem verdedigt het uitgangspunt van het raamwetontwerp, dat het niet in strijd met de grondwet is binnen de personderneming een "Aufgabenabgrenzung zwischen Verleger und Redakteuren" wettelijk voor te schrijven. "Verlegernahe" mediajuristen zoals Forsthoff, Lerche en Weber hebben dit bestreden met als belangrijkste argument dat het eigendomsrecht van de uitgever een onaantastbaar bestanddeel is van art. 5 GG. Genuanceerder dan Mallmann, volgens wie "Verlegerfreiheit" uitsluitend "Pressegewerbefreiheit" is (5) rekent Hoffmann-Riem ook de uitgever tot de dragers van het grondrecht van art. 5 GG. Zijn eigendomsrecht geeft de uitgever binnen de ruimte die door art. $5 \mathrm{GG}$ beschermd wordt echter geen geprivilegieerde positie ten opzichte van andere dragers van de persvrijheid. Soweit zum Schutz der Pressefreiheit erforderlich ist, ist auch die Eigentimerstellung durch Art. $5 \mathrm{GG}$ geschützt. Nicht aber richtet sich die Pressefreiheit nach Maßgabe der Eigentumsfreiheit. ( .........) Eigentum verschafft sicherlich grundsätzlich Vorteile. Er bedingt aber keine rechtliche Privilegierung bei der Absicherung der Pressefreiheit, insbesondere nicht im Verhältnis zu anderen, die arbeitsteilig zusammen mit dem Eigentümer das Grundrecht der Pressefreiheit ausüben. (6)

De "verlegerzentrierte" Duitse literatuur legt sterk de nadruk op de zegeningen van de commerciële exploitatie van de media. Daarbij geldt in het bijzonder de passage Presseunternehmen ( .........) arbeiten nach privatwirtschaftlichen Grundsatzen und in privatrechtlichen Organisationsformen. Sie stehen untereinander in geistiger und wirtschaftlicher Konkurrenz uit de "SpiegelEntscheidung" (7) als legitimatie. Volgens Hoffmann-Riem is dit echter een empirische en geen normatieve uitspraak van het hof in Karlsruke en is een commerciële persstructuur verfassungsgemäß, wenn auch nicht verfassungsgeboten. (8)

(1) Konrad Hesse Grundzuge des Vevassungsrechts der Bundesrepublik Deutschlands.

(2) Jurisprudentie en literatuur leggen baj art. 12 GG de nadruk op zijn betekenis voor de zelfstandige beroepsuitoefening ("Gewerbefreiheit"). Volgens Hoffmann-Riem ten onrechte: art. $12 \mathrm{GG}$ regeit ook de arbeid in dienstverband. Op de "Eigentumsfreiheit" kunnen in Duitsland ook journalisten in dienstverband een beroep doen, omdat zij - in tegenstelling tot de Nederlandse regeling van art. 7 Auteurswet - in beginsel auteursrechthebbenden zijn, waarmee een vermogenrechtelijke component onder de bescherming van art. 14 GG valt. Zie Wolfgang Hoffmann-Riem Imnere Pressefreiheit als politische Aufgabe. Uber die Bedingungen und Möglichkeiten arbeirsteiliger Aufgabenwahmehmung in der Presse, pag. 88-97 en pag. 112 , voetnoot 23.

(3) Een maand voor de publicatie van het ontwerp zouden beiden vervangen worden door resp. Helmut Schmidt - na het aftreden van Willy Brandt - en Hans-Dietrich Genscher; Walter Scheel was inmiddels tot bondspresident gekozen. 
(4) Wolfgang Hoffmann-Riem 6. Abschwitt (Massemmedien) in Benda-Mahofer-Vogel Handbul des Verfassungsrechis, pag. 411 e.v.; idem Innere Pressefreiheit als politische Aufgabe, pag. 87e.v:; idem/Harro Plander Rechtsfragen der Pressereform, pag, $68 \mathrm{e} \%$

(5) Walter Mallmann ook o.a. in zijn Diskussionsbeitrag 49. DJT, N 20.

(6) Wolfgang Hoffmann-Riem Innere Pressefreiheit als politische Aufgabe, pag. 92-93.

(7) BVerfGE 20, 175

(8) Wolfgang Hoffmann-Riem Inmere Pressefretheit als politische Aufgabe, pag. 4 e.v., Hoffmann-Riem - Plander Rechtsfragen der Pressereform, pag. $69 / 70$.

\subsection{Medezeggenschap en $\S 118$ Betriebsverfassungsgesetz (BetrVG)}

Net als voor elke andere onderneming geldt ook voor het Duitse persbedrijf dat de bevoegdheid van de eigenaar niet onbeperkt is. De in artikel 20 GG neergelegde "Sozialstaatsprinzip" heeft geleid tot wetgeving die aan een grondrecht als de "Eigentumsgarantie" (Art. 14 GG) van de eigenaar van een onderneming beperkingen oplegt. De "Mitbestimmungsgesetz" in het algemeen en de "Betriebsverfassungsgesetz" in het bijzonder regelen de verhouding werkgever werknemer zodanig, dat de werknemers bij besluitvorming die ook hen raakt betrokken worden.

Voor sommige bedrijven echter - de zogenaamde "Tendenzbetriebe" - gelden deze wetten slechts gedeeltelijk. Onder een "Tendenzbetrieb" wordt in het algemeen verstaan een onderneming die (ook) een ideëel doel nastreeft. Aan werknemers mogen in deze ondernemingen al die inspraakrechten onthouden worden die het ideële doel kunnen beinvloeden. Sinds de wijziging in 1972 van de Betriebsverfassungsgeset $z$ wordt in $\$ 118$ de personderneming (voor het eerst) met name genoemd als een van de "Tendenzbetriebe". \$ 118 BetrVG luidt (gedeeltelijk):

(1) Auf Unternehmen und Betriebe, die unmittelbar und überwiegend

1. politischen, koalitionspolitischen, konfessionellen, karitativen, erzieherischen, wissenschaftlichen oder künstlerischen Bestimmungen oder

2. Zwecken der Berichterstattung oder Meinungsäußerung, auf die Art. 5 Abs. 1 Satz 2 des Grundgesetzes Anwendung findet, dienen, finden dieVorschriften dieses Gesetzes keine Anwendung, soweit die Eigenart des Unternehmens oder des Betriebes dem entgegensteht. Die $\$ \$ 106$ bis 110 sind nicht, die $\$ \$ 111$ bis 113 nur insoweit anzuwenden, als sie den Ausgleich oder die Milderung wirtschaftlicher Nachteile für die Arbeitnehmer infolge von Betriebsänderungen regeln.

(2)

De $\S \S 106$ - 110 regelen de verplichte instelling en bevoegdheden van een "Wirtschaftsausschuß" in bedrijven met meer dan honderd medewerkers. Deze commissie moet door de werkgever geïnformeerd worden over alle economische aangelegenheden die voor het personeel van belang zijn. Van bijzonder belang voor de verhouding uitgever - redactie is $\$ 105$ BetrVG, die voor alle bedrijven, dus ook "Tendenzbetriebe", geldt en die de ondernemingsraad elke inspraak ontzegt bij benoeming of ontslag van "leitende Angestellte"; tot deze groep behoren in elk geval de leden van de hoofdredactie. Een benoeming of ontslag hoeft de 
ondernemingsraad alleen maar meegedeeld te worden.

Het begrip "Tendenzbetrieb" heeft in Duitsland een traditie die teruggaat tot de eerste regeling van arbeidsinspraak in het bedrijfsleven, de "Betriebsrätegesetz" (BRG) van 4 februari 1920. Hoewel zij niet nadrukkelijk genoemd is, wordt uit de parlementaire behandeling vrij algemeen aangenomen dat $\$ 67 \mathrm{BRG}$, die voor bedrijven met "politischen (... ) künstlerischen und ähnlichen Bestrebungen" medezeggenschap van het personeel uitsloot, ook in 1920 al de pers tot de uitgezonderde bedrijuen rekende. (1) In 1952 nam de Bondsdag de Betriebsverfassungsgesetz aan met opnieuw een artikel $\left(\begin{array}{l}\S 1\end{array}\right)$ dat "Tendenzbetriebe" wrijstelde van werknemersinspraak, wanneer daardoor de ideêle of ideologische doelstellingen van het bedrijf gevaar zouden lopen. Opmerkelijk was overigens dat de uitzonderingsregeling voor "Tendenzbetriebe" noch in de adviezen van de werkgevers noch in die van de vakbonden voorkwam. (2)

Volgens Löffler/Ricker (3) is de ratio van de invoeging van persondernemingen en de nadrukkelijke verwijzing naar de grondrechtsnorm een consequente toepassing van de jurisprudentie (4) die op de bijzondere betekenis van de pers voor het demokratische staatsbestel heeft gewezen. Om aan die betekenis recht te kunnen doen is voorwaarde dat de pers volkomen onafhankelijk is om haar "öffentliche Aufgabe" te kunnen uitvoeren, niet alleen vrij van beïnvloeding door de staat en zijn organen, maar ook onafhankelijk van economische machtsgroepen. Tot die machtsgroepen bij een krant rekent Löffler in het bijzonder de niet-redactionele medewerkers, zoals drukkers en zetters, die in de ondernemingsraad (Betriebsrat) in de regel de meerderheid zullen vormen en die bij gebruikmaking van hun inspraakrechten uit de Betriebsverfassungsgesetz ongewenste invloed zouden kunnen uitoefenen op de redactionele inhoud van de krant. Doch ook de journalistieke medewerkers zijn object van de beperkingen op grond van de BetrVG, in het bijzonder wanneer redactionele inspraak invloed zou krijgen op de uitoefening van het grondrecht door de uitgever. Deze invloed wordt in Duitsland vrij gemakkelijkaangenomen, omdat de "Grundsatzkompetenz" van de uitgever, die ermee in het gedrang zou kunnen komen, nu eenmaal onomstreden is. Sindsdien is formeel een vrijwel onneembare hindernis opgeworpen voor al die dagbladredacties die effectieve inspraak wensen bij de belangrijkste beslissingen die directies en eigenaren voor en over de krant kunnen nemen. In $\$ 118$ BetrVG culmineren alle hiervoor aangehaalde grondrechtelijke aspecten die in de Duitse discussie rond de "innere Pressefreiheit" een rol spelen. De "Grundsatzkompetenz" van een drager van het grondrecht van art. 5 GG, de uitgever van een krant, waarin de "öffentliche Aufgabe der Presse" vervuld wordt, zou illusoir zijn zonder effectieve bescherming van de uitgever tegen krachten binnen de personderneming zelf.

Omdat het hier om een wet gaat, is een nieuwe wet nodig om $\$ 118$ BetrVG te "overrulen". Zo'n nieuwe wet - zoals de hierna te bespreken "Presserechtsrahmengesetz" uit 1974 - is nooit voorbij het ontwerpstadium geraakt. En zelfs dit wetsontwerp houdt $\$ 118$ BetrVG grotendeels intact. 
De discussie over de ruimte tot redactionele inspraak die $\$ 118$ BetrVG toch nog biedt betreft voornamelijk de "Relativklausel", de vraag dus of een ondernemingsbeslissing "tendensgevoelig" is en dus buiten het instemmings- of adviesrecht van de ondernemingsraad valt. Het zal niet verwonderen dat in literatuur (5) en jurisprudentie, in het bijzonder van de BAG (Bundesarbeitsgericht), vooral inspraak van de ondernemingsraad bij het personeelsbeleid een belangrijke rol speelt. Het gaat dan om toepassing, of juist niet, of slechts gedeeltelijk van bij voorbeeld. $\$ 102$ BetrVG. Daarvan luidt Abs. 1: Der Betriebsrat ist vor jeder Kündigung zu hören. Der Arbeitgeber hat ihm die Gründe für die Kündigung mitzuteilen. Eine ohne Anhörung des Betriebsrats ausgesprochene Kündigung ist unwirksam. De BAG neigt ertoe de ondernemingsraad bij ontslagkwesties een "Anhörungsrecht" niet te weigeren, ook als het om duidelijke identiteitrakende beslissingen gaat. (6)

Bij de uitleg van $\S 118$ BetrVG (voordien $\$ 81$ ) wordt meestal verwezen naar een passage uit een "Gutachten" van de indertijd (1969) in Salzburg arbeidsrecht docerende hoogleraar Theo Mayer-Maly, waarin deze elke poging om via de omweg van een redactiestatuut een dwingende wettelijke bepaling te omzeilen bij voorbaat kernachtig afwijst. De betreffende passage luidt:

1. Redaktionsräte sind keine Betriebsräte und können diese weder ersetzen noch verdrängen. 2. Die vom Gesetzgeber dem Betriebsrat zugewiesenen Aufgaben können nicht auf Grund eines Redaktionsstatuts von einem Redaktionsrat ubernommen werden. 3. Die gesetzgeberische Abgrenzung der Mitbestimmungsmöglichkeiten in Betrieben, die unter $\$ 81$ BetrVG fallen, kann nicht durch irgendwelche Vereinbarungen verschoben werden. (7) Wolfram Klein en Edwin Kau menen dat $\$ 118$ BetrVG nooit bedoeld kan zijn om elke vorm van redactionele inspraak bij voorbaat uit te sluiten.(8) De paragraaf kan bij voor beeld nooit een overeenkomst tussen uitgever en redactie op vrijwillige basis in de weg staan. Consequentie van een zeer extensieve uitleg van $\$ 118$ BetrVG door Mayer-Maly, volgens welke de "Tendenzschutz" geen ruimte meer biedt waarbinnen inspraak mogelijk is en waarbinnen die inspraak ook niet overgedragen kan worden aan een ander orgaan, zou er volgens Klein en Kau op neerkomen dat de uitgever die daarvan wil afwijken, hetzelfde grondrecht ontnomen wordt, dat $\$$ 118 BetrVG nu juist beoogt te beschermen. In dezelfde zin, maar op andere gronden, Karl Doehring: Selbstverständlich sind allgemein vertragliche, tarifvertragliche oder kollektivvertragliche Vereinbarungen unter Verlegern, Journalisten und Redakteuren zur inneren Ordnung des Verlagwesens zulässig. (9)

De georganiseerde journalistiek in Duitsland heeft - hoewel zij zich formeel tegen $\$ 118$ BetrVG heeft uitgesproken, o.a. opnieuw in het vernieuwde beginselprogramma van de Deutscher Journalistenverband (DJV) (I0) - vaak een wat ambivalente houding aangehouden tegenover de ook haar beperkende regeling. Uit onderzoeken blijkt dat in Duitsland de meerderheid van de journalisten zich niet als "gewone werknemers" beschouwt. Dat is ook het standpunt van de veruit grootste 
Duitse vakbond van journalisten, de DJV. (11) Voor de meeste journalisten is het dan ook niet altijd vanzelfsprekend dat cle ondernemingsraad het aangewezen orgaan is om de specifieke belangen van de redactie te behartigen. De kleinste journalistenbond, de dju (Deutsche Journalisten-Union), heeft daarentegen wel steeds met overtuiging gepleit voor afschaffing van $\$ 118$ BetrVG, teneinde de redactionele inspraak via de ondernemingsraad te vergroten; de dju is dan ook gelieerd aan de grafische vakbond IG Druck und Papier.

De Duitse journalisten richtten hun aandacht in de jaren zestig en zeventig (niet toevallig de tijd van de persconcentratiegolven en "das große Zeitungsstirben") op voor hen zeer concrete zaken als:

- effectieve bescherming van hun banen bij persconcentratie;

- reéle inspraak bij de benoeming van hoofdredacteuren en rubriekschefs;

- een gekozen redactieraad die beslissingen van de hoofdredactie en de uitgever zou kunnen beïnvloeden;

- de garantie dat zij niet gedwongen kunnen worden een opdracht uit te voeren die hen in gewetensnood zou brengen ("Gesinnungsschutz").

De smalle marges van de wettelijke regeling van de medezeggenschap in "Tendenzbetriebe" noopten journalisten hun inspraakwensen te verwezenlijken via andere wegen. Vanuit drie richtingen, die in de navolgende paragrafen beschreven worden, is geprobeerd de verhouding tussen uitgever en redactie te regelen:

1. via redactiestatuten op basis van een CAO (Tarifvertrag);

2. door middel van statuten tussen redactie en uitgever;

3. gelijktijdig is de vooroorlogse traditie weer opgenomen om te proberen "innere Pressefreiheit" in een nieuwe perswet onder te brengen.

(1) Vgl. Edwin Kau, a.w., pag. 42; anders: Werner Breede Pressefreiheit und Redaktionsfreiheit, pag. 349 e.v.

(2) Edwin Kau, a.w., pag. 43, met literatuurverwijzingen.

(3) Martin Löffler/Reinhart Ricker Handbuch des Presserechts, pag. 222 e.v.

(4) In het bijzonder het Spiegel-arrest, BVerfGE 20, pag. 162 e.v.

(5) In het bijzonder Hoffmann-Riem/Plander Rechtsfragen der Pressereform, pag. 143 e.v.; Werner Breede Pressefreiheit und Redaktionsfreiheit, pag. 342 - 392, Wolfram Klein Der Tendenzschutz von Presseunternehmen und die Reform ihrer Binnenstruktur durch Redaktionsstatute, diss. Göttingen, 1976, pag. 10-59, Edwin Kau, Die Mitbestimmung in Presseuntemehmen, pag. $20-45$.

(6) Aldus Löffler/Ricker, a.w. pag. 234, Rz. 39. Over de vraag of \& 118 BetrVG ook van toepassing is op publicaties die slechts in beperkte mate "Zwecken der Berichterstattung oder Meinungsäußerung dienen", zoals advertentiebladen (ja) en papierfabrieken en loondrukkerijen (neen) zie Löfler/Ricker, a.w. pag. $226-228$.

(7) Theo Mayer-Maly Das Redaktionsstatut als Mitbestimmungsinstrument, in AfP (Archiv für Presserecht) Nr. 80, 1969.

(8) Wolfram Klein Der Tendenzschutz von Presseunternehmen und die Reform ihrer Binnenstruktur durch Redaktionsstatute, pag. 103 e.v.; Edwin Kau Die Mitbestimmung in Presseunternehmen, pag. 108 e.v.

(9) Karl Doehring Staatsrecht der Bundesrepublik Deutschland, pag. 310

(9) Gepubliceerd in "Der Journalist" Heft 7/1981 en Heft 3/1982.

(10) Vgl. enquêteresultaten bij Kau, a.w., tabel 9, pag. 185. 


\subsubsection{Redactiestatuut via. Tarifvertrag}

Nadat begin jaren zestig pogingen van de drie journalistenorganisaties om de uitgevers te interesseren voor een regeling van de interne verhouding in een collectieve arbeidsovereenkomst op niets waren uitgelopen - de uitgevers vonden zo"n regeling in 1964 "weder notwendig noch zweckmäßig" - kwam het eind 1969 tot nieuwe onderhandelingen met de Bundesverband Deutscher Zeitungsverleger (BDZV). In juni 1970 werden de onderhandelingsdelegaties van de vier partijen het eens over een ontwerp-Tarifvertrag, waarin de hoofdlijnen van de bevoegdheden als volgt waren neergelegd:

- De uitgever stelt de redactionele beginselen vast en nadere richtlijnen voor toepassing van deze beginselen bij principiële kwesties die de dagelijkse actualiteit overstijgen ("Grundsatz- und Richtlinienkompetenz").

- De redactie heeft binnen de redactionele beginselen en de nadere richtlijnen de vrije hand ("Detailkompetenz"). Niettemin heeft de uitgever tegenover de hoofdredacteur en de betreffende afdelingschefs de mogelijkheid zijn standpunt te bepalen, wanneer de beoogde publicatie van een artikel wellicht ernstige gevolgen voor de krant, de uitgeverij of de uitgever zou kunnen hebben.

- Er is een redactieraad (facultatief), die evenals de hoofdredacteur gehoord wordt en geïnformeerd bij wijziging van de redactionele lijn van de krant, wijziging van karakter en verschijningsvorm, bijstelling van het redactionele budget, bij veranderingen in de ondernemingsvorm, de eigendomsverhouding en bij voorgenomen samenwerking met andere uitgeverijen, wanneer ook de redactie daarbij betrokken is.

- Uitgever en hoofdredacteur moeten het met de redactieraad eens worden over een regeling, waarin de bevoegdheden en de taken binnen de redactie worden beschreven ("Redaktionsordnung").

De drie journalistenbonden wezen het ontwerp af. Een van hun bezwaren was dat het op enkele punten een verslechtering was vergeleken met de reeds afgesloten redactiestatuten bij Stern, Die Zeit en het dagblad Mannheimer Morgen. De bonden dienden op 14 juli 1971 een nieuwe "Entwurf eines Vertrages über die Abgrenzung der Kompetenzen von Verlag und Redaktion" in, dat de bevoegdheid van de uitgever in redactionele zaken feitelijk beperkt tot het vaststellen van de redactionele beginselen. Wijziging van deze beginselen zou slechts mogelijk zijn met instemming van de redactievergadering. Een hoofdredacteur kan niet benoemd of ontslagen worden tegen de wens van de meerderheid van de redactievergadering. De uitgevers verwierpen het journalistenontwerp, omdat het op wezenlijke punten afweek van het eerder bereikte compromisvoorstel.

De belangrijkste reden om voor een redactiestatuut op basis van een "Tarifvertrag" te kiezen is gelegen in de bindende rechtskracht ervan gedurende de periode waarvoor het wordt aangegaan. Een "Tarifvertrag" wordt namelijk afgesloten door een, soms meer, erkende vakbond(en) ten behoeve van de bij deze uitgever werkende journalisten; de vakbond(en) kan/kunnen naleving gerechtelijk 
afdwingen. Kau wijst er op dat de collectieve arbeidsovereenkomst - hetzij algemeen verbindend verklaard voor alle media-bedrijven of voor één bepaalde onderneming afgesloten - eigenlijk een ondeugdelijk middel is om medezeggenschapsregelingen te treffen. Zo"n regeling is grondrechtelijk alleen aanvaardbaar wanneer de medezeggenschap van de redactie feitelijk beperkt blijft tot een adviesrecht. Wanneer de uitgever geheel vrijwillig de redactie reële inspraak bij belangrijke beslissingen toestaat, kan hij dat slechts doen via uitbreiding van de bevoegdheden van de ondernemingsraad. Invoering via $\mathrm{CAO}$ van een redactiestatuut met een eigen redactioneel orgaan, zoals een redactieraad, stuit af op de "Tarifvertragsgesetz", waarvan $\$ 1$ bepaalt dat CAO's uitsluitend "arbeitsrechtliche" zaken mogen regelen en dus geen "presserechtliche"; $\$ 3$ verbiedt de instelling van een ander personeelsorgaan, tenzij dit bedoeld is om de samenwerking tussen ondernemingsraad en de werknemers te bevorderen. Redactiestatuten hebben echter ten doel redactionele inspraak tegenover de uitgever te bereiken.(1)

Kenmerk van de statuten op basis van een "Haustarifvertrag" van een of meer vakbonden bij ến dagbladonderneming was dat in alle gevallen de uitgever sympathiek stond tegenover medezeggenschap van de redactie en van alle overige personeelsleden, ondanks $\$ 118$ BetrVG.

Het eerste redactiestatuut bij een dagblad op basis van een "Tarifvertrag" kwam tot stand in april 1973 tussen de uitgever van de Westfälische Rundschau en de IG Druck und Papier. (2) In feite ging het om twee overeenkomsten. De ene gold alle personeelsleden en daarin werd de "Tendenzschutz" ten gunste van de ondernemingsraad in feite opgeheven, de andere regelde de verhouding tussen redactie en uitgever. Het statuut was geen lang leven beschoren. Het werd opgezegd per 1 januari 1975, toen de Westfälische Rundschau opging in de Westdeutsche Allgemeine Zeitung (WAZ) van Zeitungsverlag Westfalen.

Soortgelijke dubbele overeenkomsten kwamen tot stand tussen enerzijds de uitgeverijen (eigendom van de SPD) van de Hamburger Morgenpost en van de Vorwărts met anderzijds de IG Druck und Papier en de Deutscher Journalistenverband. Beide kranten zijn inmiddels opgeheven. Momenteel is in Duitsland geen enkel statuut meer van kracht dat op een "Tarifvertrag" is gebaseerd. (3)

(1) Edwin Kau Die Mitbestimmung in Presseuntemefwnen, pag. $119 \mathrm{e} . \mathrm{v}$.

(2) Het initiatiof tot dit statuut was volgens Christina Holtz-Bacha (Mitspracherechte für Jommalisten, pag. 24) uilgegaan van de joumalisten van de krant.

(3) Christina Holtz-Bacha Tendenz Iwstlos - Flaute in der Statutenbewegung in: Der Journalist 9/1989, pag. 10, waar ook de kortstondige (1972 - 1973) "Tarifvertrag" bij het publiekstijdschrift Konkret vermeld wordt. Sinds 1973 - andere uitgever - is ook bij dit blad geen statuut meer van kracht. 


\subsubsection{Statuten tussen redacties en dagbladuitgevers}

De meeste Duitse statuten staan op de, wat rechtskracht betreft, wankele basis van de individuele arbeidsovereenkomst of van de "Betriebsvereinbarung", zoals bij de Nene Westfälische (opgezegd door de uitgever in 1987) en de Süddeutsche Zeitung. Aan het redactiestatuut als onderdeel van de arbeidsovereenkomst van de individuele journalist zitten, zoals Kau en Klein (1) hebben laten zien, nogal wat arbeidsrechtelijke haken en ogen:

- Om rechtskracht te bezitten is het noodzakelijk met iedere reeds in dienst zijnde journalist individueel een nieuwe overeenkomst te sluiten waarin deze het statuut accepteert. In theorie kan zo'n journalist dus ook weigeren. Nieuw personeel kan wel gedwongen worden, namelijk door acceptatie van het statuut bij indiensttreding. De uitgever kan het statuut echter uithollen door het niet meer in nieuwe arbeidscontracten op te nemen, zodat na een bepaalde periode de redactieraad niet meer het gehele personeel vertegenwoordigt.

- Omdat het gaat om individuele overeenkomsten is naleving ervan door de werkgever nauwelijks afdwingbaar. Deze kan het vrij risicoloos van de ene dag op de andere opzeggen.

Bij een statuut op basis van een "Betriebsvereinbarung", zoals bij de Süddeutsche Zeitung, is ook de ondernemingsraad betrokken, niet als partij bij het statuut, maar uitsluitend als mede-ondertekenaar. De constructie staat volgens Kau (2) op gespannen voet met de Betriebsverfassungsgezetz.

Ondanks de wankele basis waarop deze statuten berusten hebben ze de beste overlevingskansen getoond. De oudste (Rhein-Zeitung, Stern, Mannheimer Morgen en Saarbrücker Zeitung, alle vier uit 1969) bestaan, zij het in bijgestelde versies, nog steeds.

Het redactiestatuut wan het publiekstijdschrift Stern heeft een zeer belangrijke voorbeeldfunctie vervuld. Daarbij speelde een rol dat het werd afgesloten met een specifiek doel van veel redactiestatuten, namelijk om een ongewenste medeeigenaar redactionele invloed te ontzeggen. Aanleiding was het voornemen van Richard Gruner om zijn aandeel (39,5 procent) over te doen aan de BauerVerlag. De redactie, inclusief de zeer invloedrijke hoofdredacteur Henri Nannen, was tegen deze verkoop gekant, omdat zij bang was dat daardoor de redactionele lijn in gevaar zou komen. De redactie stond daarin niet alleen. Ook Gruners partners Gerd Bucerius (28,25 procent) en John Jahr (32,25 procent) verzetten zich tegen het binnenhalen van de Bauer-Verlag. De redactie dreigde zelfs met een staking, een dreiging die ook uitgever Bucerius gerechtvaardigd achtte. (3) In uitgever Bucerius had de redactie van Stern een overtuigd medestander. In een artikel over "Die Freiheit des Journalisten" (4) sprak hij zich uit tegen machtsconcentratie in de pers: Demokratie bedeutet die Auswechselbarkeit der Träger von Machtspositionen. Da (private) Verleger nicht "auswechselbar" sind, dürfen sie keine Macht haben. Die großen Verlagskonzentrationen haben solche Macht. ......... ) Oligopole sind immer bedenklich; in der Presse sind sie unertäglich. Later heeft Bucerius als eigenaar/uitgever van Die Zeit zijn fiat gegeven aan een statuut dat de zelfstandigheid van de redactie en haar onafhankelijkheid van de 
uitgever omstandig, maar formeel voorbeeldig regelt. (5) Het Stern-statuut van 19 mei 1969 is geheel door leden van de redactie opgesteld en daarna door de uitgevers geaccepteerd. (6) Het bevat een aantal elementen die bij de opstelling van andere statuten als voorbeeld gediend hebben.

Een geval apart is de Frankfurter Allgemeine Zeitung (FAZ). De krant "hatte zu keiner Zeit ein Redaktionsstatut" laat de hoofdredactie desgevraagd weten in reactie op de opvatting van Holtz-Bacha, dat de regeling die de onafhankelijkheid van de redactie garandeert met een redactiestatuut vergelijkbaar is. (7) De beslissingsbevoegdheid binnen de $\mathrm{GmbH}$, die de krant uitgeeft, is verdeeld tussen

- de in 1959 opgerichte FAZIT-Stiftung, geleid door een curatorium,

- de Societäts-Druckerei GmbH en

- de "Herausgeber" en directieleden. Deze laatsten hebben samen een klein aantal, aan de functie gebonden, aandelen, doch zonder hun stemmen kan de vergadering van aandeelhouders geen rechtsgeldige besluiten nemen. De "Herausgeber" hebben bovendien een feitelijk vetorecht bij de overdracht van aandelen, zowel bij de FAZIT-stichting als bij FAZ GmbH, wanneer die overdracht de onafhankelijkheid van de krant in gevaar zou kunnen brengen.

De "Herausgeber", die de belangrijkste redactionele beslissingen nemen, hebben op hun beurt in 1972 met de redactie een "Vereinbarung" afgesloten, die nog steeds geldt en waarin de verkiezing van een "Redakteursrat" is voorzien. Deze "Redakteursrat" moet gehoord worden bij benoeming en ontslag van een "Herausgeber" en een rubriekschef, en bij het ontslag van redacteuren.

De hierna apart besproken zes redactiestatuten van dagbladen zijn de enige die nog steeds van kracht zijn. Wanneer men de regeling van de Frankfurter Allgemeine Zeitung ook als redactiestatuut beschouwt, zijn er bij de Duitse dagbladen in totaal nooit meer dan twaalf geweest.

Holtz-Bacha noemt in 1986 drie redenen waarom de statutenbewegung na het aanvankelijke elan van de jaren zeventig verflauwd is:

- berusting in het geringe effect van het bereikte resultaat, want ook daar waar statuten tot stand zijn gekomen bleek slechts beperkte medezeggenschap mogelijk; - teleurstelling over het niet tot stand komen van de begin jaren zeventig aangekondigde wettelijke regeling van de redactionele inspraak;

- gebrek aan solidariteit onder journalisten; ze lossen problemen liever zelf op

- hun lage organisatiegraad.

Bovendien vermoedt zij dat andere onderwerpen bij de journalisten een hogere prioriteit hebben gekregen: de invoering van nieuwe technologieën op de krantenredacties en bezorgdheid om het behoud van banen en inkomen. (8)

(1) Wolfram Klein Der Tendenzschutz won Presseunternehmen..., pag. 121.

(2) Edwin Kau Die Mitbestimmung......., pag. 117.

(3) De aandelen var Gruner werden overgenomen door Bucerius en Jahr. De resterende 25 procent behield Gruner voorlopig zelf. Hij verkocht ze later aan de Bertelsmann-Verlag, die tenslotte meerderheidsaandeelhouder werd.

(4) Der Volkswirt, Beiheft Wirtschafts-und Finanz-Zeitung van 4 juli 1969, pag. 35-37.

142 
(5) De nieuwste versie van het Zeit-statuut, gedateerd 31 maat 1983 , is opgenomen in Christina Holtz-Bacha Mitspracherechte .... pag. 194 e.v. Voor een recent profiel van Die Zeil: J.M. Bik Het Duise schaduwkabinet in NRC Handelsblad wan 28 maart 1992.

(6) De tekst van zowel het Stern-statut van 1969 als de nieuwe versie van 1 februari 1974 is opgenomen in Christina Holtz-Bacha Mitspracherechte ..., pag. 204-209; Edwin Kau Mibestimmung ..., pag. 252-253 geeft alleen de versie van 1974.

(7) Christina Holtz-Bach Mitspracherechte ..., pag. 32.

(8) Christina Holtz-Bacha Goodwill des Verlegers in: Der Journalist 10/1986, pag. 40.

\subsection{Zes Duitse dagbladstatuten}

\subsubsection{Rhein-Zeitung}

De Rhein-Zeitung (RZ) in Koblenz was de eerste Duitse krant waar een redactiestatuut tot stand kwam. Dat was op 1 april 1969, anderhalve maand eerder dan het hiervoor reeds genoemde Stern-statuut. (1) Sinds 1 januari 1976 is een "Zweite Fassung" van het RZ-statuut van kracht. Ook deze nieuwe versie is, vergeleken met de meeste andere nog geldende statuten, een mager stuk op het punt van redactionele medezeggenschap. Heeft hier wellicht de "wet van de remmende voorsprong" toegeslagen? In 1989 vond ook de "Sprecher" van de "Redaktionsvertretung" tal van onderdelen van het statuut völlig uberholt. Derzeit iiberarbeiten wir das Statut, Reformen sind angesagt. (2) De versie uit 1976 is echter nog ongewijzigd van kracht.

Het redactiestatuut begint traditioneel met een uiteenzetting van de "grundsätzliche Haltung", die door de uitgever is vastgesteld. Daaruit blijkt een primaire gerichtheid in Wahrnehmung ihrer öffentlichen Aufgabe voor alle lagen van de bevolking in het verspreidingsgebied. Darüber hinaus dient sie ihren Lesern mit journalistischen Beiträgen zur Unterhaltung, zur praktischen Lebenshilfe und zu allgemeinmenschlich interessierenden Themen. De krant hoedt het christelijkhumanistische cultuurerfgoed, is echter onafhankelijk van staat en partijen, van politieke, godsdienstige of economische instellingen of van beïnvloeding van welke soort dan ook.

Het redactiestatuut zwijgt geheel over de procedure tot wijziging van de "grundsätzliche Haltung", waaruit geconcludeerd moet worden dat de redactie hierbij geen rol speelt. Onderdeel B. van het statuut is geheel gewijd aan de richtlijnen, waaraan hoofdredactie en redactie zich te houden hebben. Deze richtlijnen zijn overeengekomen tussen directie en hoofdredacteur, die het recht hebben ze per twee jaar op te zeggen. Hoofdlijnen daarvan zijn:

- Samenwerking tussen uitgever en redactie vloeit voort uit de publieke functie (öffentliche Funktion) die de pers heeft in het democratische staatsbestel. De redacteur is verplicht das Gesamtinteresse der Zeitung zu beachten. Dies setzt eine vertrauensvolle Zusammenarbeit von Verlag und Redaktion voraus.

- Binnen de door de uitgever vastgestelde "grundsätzliche Haltung" heeft een redacteur geistige Bewegungsfreiheit bei der Gestaltung des Textteils im einzelnen. 
- Een redacteur kan niet gedwongen worden iets te doen wat tegen zijn overtuiging ingaat.

- Bij twijfel of een publicatie mogelijk in strijd is met de lijn van de krant of wanneer een publicatie voraussehbar einen nicht zumutbaren Schaden für die Zeitung zur Folge haben kann moet de hoofdredacteur zich vooraf met de uitgever verstaan. De hoofdredacteur is tegenover de uitgever verantwoordelijk voor het naleven van de tichtlijnen.

- De hoofdredactie stelt een "Redaktionsordnung" op, waarin de bevoegdheden van de hoofdredactie, de afdelingschefs, de redacteuren en de "Redaktionskonferenz" zijn vastgelegd. De hoofdredacteur moet instemmen met het aannemen en overplaatsen van redactieleden en is mede-ondertekenaar van aanstellingscontracten. Hij moet - evenals de ondernemingsraad - gehoord worden, wanneer het noodzakelijk is redacteuren te ontslaan.

- Het overleg van de redactie met de uitgever vindt plaats in de "Redaktionsbeirat". Dit is bij de Rhein-Zeitung een slechts gedeeltelijk gekozen orgaan, namelijk een commissie waarin de directie, de hoofdredacteur, zijn plaatsvervangers en vijf leden van de "Redaktionsvertretung" zitting hebben.

(1) Bijna een jaar vóór het Rhein-Zeitung-statuut, in mei 1968 , had een andere regionale krant, de Neue Ruhr Zeitung, zijn "Leitsåtze und Redaktionsordnung" gepubliceerd, maar deze regeling beperkt zich tot de redactionele uitgangspunten van de krant en de bepaling over de "Gesinnungsschutz" van redacteuren. Redactionele inspraak ontbreekt nagenoeg geheel. Het stuk mist daarmee teveel kenmerken om als redactiestatuut beschouwd te worden. Vgl. Ansgar Skriver Schreiben und schreiben lassen, pag. 65 e.v. en Holtz-Bacha, Mitspracherechte für Joumalisten, pag. 28.

(2) Bernd Paetz in Der Joumalist van september 1989

\subsubsection{Saarbrücker Zeitung}

De eerste versie van het redactiestatuut van de Saarbrücker Zeitung, gedateerd 20 oktober 1969, heeft een bijzondere voorgeschiedenis. Het statuut maakte deel uit van een transactie die de goedkeuring behoefde (en kreeg) van het deelstaatparlement van Saarland. Opmerkelijk is eveneens dat in de beginselverklaring staat dat de Saarbrücker Zeitung (sich) bekennt zur engen deutsch-französischen Zusammenarbeit. Beide, de parlementaire goedkeuring en de vermelding van de relaties met het buurland Frankrijk, hebben met elkaar te maken.

Tot oktober 1956, toen de Franse bezetting van het Saarland eindigde, was de Saarbriicker Zeitung feitelijk in Franse handen. (Dat was ook aan de krant te merken. "Französische Zeitung in deutscher Sprache", werd zij spottend genoemd). Tegelijk met het Duits-Franse verdrag over de teruggave van het Saarland werd een protokol over de Saarbrücker Zeitung ondertekend, waarbij de regering van Saarland voor 110 miljoen francs de Franse financiers van de krant uitkocht. De regering bracht de aandelen vervolgens onder bij een trust, beheerd door een consortium van drie grote banken.

In de loop van de jaren zestig nam de kritiek toe van concurrerende kranten, die beweerden dat de Saarbrücker Zeitung in feite een regeringsblad was en werd be- 
voordeeld. In 1968 besloot de regering van Saarland de aandelen opnieuw te privatiseren. Het deelstaatparlement stemde daarmee in, mits in de koop een redactiestatuut zou worden betrokken, dat de onafhankelijkheid van de krant zou waarborgen. De redactie maakte vervolgens een ontwerpstatuut, dat voorgelegd werd aan de toenmalige "Aufsichtsrat", waarin de regering, de politieke partijen en het bankconsortium dat de aandelen beheerde waren opgenomen. De "Aufsichtsrat" bracht zoveel kritiek op het conceptstatuut naar voren dat de redactie in de eindversie nauwelijks bevoegdheden overhield. De redactievergadering overwoog aanvankelijk het aangeboden statuut dan ook maar geheel af wijzen. Met het argument dat een statuut met geringe inspraakmogelijkheden te verkiezen is boven helemaal niets is de redactie op haar afwijzende standpunt teruggekomen. Sinds de herprivatisering, die tenslotte in februari 1970 haar beslag $\mathrm{kreeg}$, is het aandelenbezit van de Saarbruicker Zeitung als volgt verdeeld:

49 procent is in handen van de Georg von Holtzbrinckgruppe (o.a. uitgever van de krant Christ und Welt);

26 procent is eigendom van de "Gemeinnützige Förderungsgesellschaft Saarbrücker Zeitung m.b.H". Deze is zelf weer eigendom van "Stiftungen" van drie politieke partijen CDU $(10,4 \%)$, SPD (ook $10,4 \%)$ en FDP $(5,2 \%)$;

10 procent is bij het bankconsortium gebleven dat tot 1970 de aandelen voor de regering van Saarland beheerde;

15 procent van de aandelen berusten bij een personeelsfonds van de krant, de "Beteiligungsgesellschaft Saarbriicker Zeitung"". Via dit personeelsfonds heeft de ondernemingsraad stemrecht (3 van de 21) in de "Aufsichtsrat", het hoogste orgaan van de onderneming.

De verdeling van de aandelen over onder meer de politieke partijen, die in Saarland in wisselende coalities aan de macht kwamen, en het eigen personeel leek een garantie dat het redactiestatuut goed zou functioneren. Het tegendeel was het geval; het statuut bleek nauwelijks te werken. Dat werd duidelijk in 1974, toen een nieuwe hoofdredacteur benoemd moest worden, en de redactie uit andere kranten moest vernemen dat de grootste vennoot (von Holtzbrinck) al een opvolger had uitgezocht. Die benoeming is weliswaar niet doorgegaan, maar voor de redactieraad was het voorval aanleiding om het statuut te amenderen. Volgens Kau (1) liet de redactie zich daarbij vooral inspireren door de eerder afgesloten statuten bij de Mannheimer Morgen en de Kölner Stadtanzeiger. De wijzigingsvoorstellen zouden er toe moeten leiden dat:

1. een hoofdredacteur niet benoemd of ontslagen zou worden wanneer 70 procent van de leden van de redactie daar tegen zijn;

2. een rubriekschef niet benoemd of ontslagen wordt wanneer 4 van de vijf leden van de redactieraad het daar niet mee eens zijn;

3. de redactieraad een instemmingsrecht zou verkrijgen bij benoeming, ontslag of overplaatsing van en redacteur;

4. ingrijpende veranderingen, zoals redactionele samenwerking met andere uitgeverijen, wijzigingen van type en verschijningsvorm van de krant en aantasting 
van het redactionele budget aan het instemmingsrecht van de redactieraad onderworpen zuilen zijn;

5. wijziging van de redactionele uitgangspunten slechts met instemming van de meerderheid van de redactieleden mogelijk zou zijn.

De redactie had er alle vertrouwen in dat de eigen ondernemingsraad en de politieke partijen via hun stemgerechtigde leden in de "Aufsichtsrat" haar wensen zou honoreren, maar zij werd daarin zeer teleurgesteld. De politieke partijen hadden vooraf de redactie aangemoedigd wijzigingen voor te stellen, maar "wegens tijdgebrek" "kwamen de concrete voorstellen niet meer aan de orde op de "Aufsichtsratssitzung" van hun "Förderungsgesellschaft". Rondweg afwijzend was - nota bene - de "Beteiligungsgesellschaft" van het eigen personeel (2) en minder verrassend - de von Holltzbrinck-Gruppe; samen goed voor dertien van de 21 stemmen. Deze ervaring was voor de redactieraad eind 1975 aanleiding om af te treden. Met dit statuut was volgens de redactieraad geen reële inspraak mogelijk bij beslissingen die de redactie direct aangingen. Er werd geen nieuwe redactieraad gekozen, maar het statuut werd ook niet opgezegd.

Sinds 7 juni 1983 is bij de Saarbrücker Zeitung een nieuwe versie van het statuut van kracht, dat vergeleken met het oude uit 1969 slechts op ondergeschikte punten gewijzigd is. (3) Van de hiervoor genoemde voorgestelde wijzigingen is er in het geldende statuut geen enkele opgenomen.

Over de verhouding tot ce politieke partijen, waarvan de drie grootste (CDU, SPD en FDP) zoals reeds opgemerkt mede-eigenaar van de krant zijn, zegt de beginselverklaring dat de Saarbrücker Zeitung "überparteilich" is en "unabhängig". Sie steht den demokratischen Parteien und den von ihnen gebildeten Regierungen des Bundes und der Länder - ohne jede Bindung - in Freiheit und Eigenständigkeit gegenüber. In de statuten van de "gemeinnützliche Fördergesellschaft Saarbrücker Zeitung", waarin de drie partijen met 26 procent van de aandelen in de krant vertegenwoordigd zijn, staat dat de krant in konfessioneller und politischer Neutralität de belangen van het Saarland moet behartigen. De redactie zou vinden dat de eigen formuleringen "Überparteilichkeit" en "Unabhängigkeit" verder gaan dan "Neutralität". (4)

De beginselverklaring eindigt met de gebruikelijke formulering dat de krant ook winst moet maken. Over de vraag wie bevoegd is/zijn de "Grundsätze" vast te stellen of te wijzigen laat het redactiestatuut zich niet uit, hetgeen slechts kan betekenen dat de (hoofd)redactie daar niets over te vertellen heeft. De geringe invloed van de redactie blijkt eveneens uit het ontbreken van enige inspraak bij de benoeming van een hoofdredacteur. Wie de hoofdredacteur benoemt of ontslaat staat niet eens in de het statuut beschreven; slechts uit de vermelding dat hij voor de naleving van de beginselverklaring verantwoording verschuldigd is aan de (vier) vennoten is af te leiden dat zij benoemen en ontslaan. Dat daar geen redactionele inspraak an te pas komt is volgens de vennoten vanzelfsprekend, omdat de hoofdredacteur anders afhankelijk zou zijn van de redactieleden.

In de redactieraad is de hiërarchische top oververtegenwoordigd: drie van de vijf 
leden moeten "leitende Redakteure" zijn. Daaronder verstaat het statuut rubriekschefs, chefs van bijkantoren en redacteuren in de hogere * niet onder een $\mathrm{CAO}$ vallende - salarisklassen. De "gewone" redactieleden hebben in het statuut (in de paragraaf "Rechte, Pflichten und Verantwortung der Redaktion") vrijwel uitsluitend plichten. Gerhard Franz, "Sprecher" van de redactieraad, geeft in zijn evaluatie van het statuut van zijn krant toe dat het allemaal weinig voorstelt: Dadurch, daß der Redaktion Mitwirkungsmöglichkeiten eingeräumt werden, die gleichzeitig im Statut ihre Einschränkung erfahren, hat der Beirat trotz grundsätzlicher Zustimmung Akzeptanz-Probleme. Da fällt schon einmal der Satz: "Das ist doch alles Quatsch, Ihr könnt ja doch nichts machen."

(1) Edwin Kau Die Mitbestimmung... pag. 79.

(2) Over de achtergronden darvan zie Kau Die Mitbestimmung.. pag. 82.

(3) De oude versie is gepubliceerd in Kau Die Mitbestimmung.. pag. 270 e.v. De nieuwe is te vinden in Holtz-Bacha Mitspracherechre für Joumalisten, pag. 157 e.v.

(4) Edwin Kau Die Mitbestimmung..., pag. 273, die een bericht uit de Frankfurter Allgemeine van 5 september 1970 citeert dat de deelneming van de politieke partijen in de dagbladondentneming "nicht unproblematisch" is.

\subsubsection{Süddeutsche Zeitung}

De Süddeutsche Zeitung (SZ), opgericht in 1945 door het Amerikaanse militaire bestuur en gevestigd in München, is de in oplage grootste van de vier bovenregionale "kwaliteitskranten" van (West-)Duitsland. (De andere zijn de Frankfurter Allgemeine Zeitung, Die Welt en de Frankfurter Rundschau). De politieke lijn is "links-liberaal", wat als opmerkelijk geldt in de als conservatief bekend staande deelstaat Beieren. Die paradox wordt verklaard uit de lange liberaal-humanistische traditie van de Beierse hoofdstad. Bovendien zouden de Beieren betrekkelijk tolerant staan tegenover kritiek, zolang die door Beieren zelf op hen wordt geleverd. Deze relatieve lankmoedigheid geeft de $S Z$ de nodige speelruimte, zij verklaart ook waarom een-derde van de lezers van de Süddeutische Zeitung CSUkiezers zijn. (1)

Het redactiestatuut van de $S Z$ is afgesloten op 4 augustus 1971 voor een periode van vijf jaar met verlenging van telkens opnieuw vijf jaar, tenzij het éen jaar voor afloop van deze termijn opgezegd wordt door de redactieraad, met instemming van de redactievergadering, of door de uitgever (art. 11). Hetzelfde artikel 11 omschrijft de juridische status van het statuut: Dieses Statut ist eine Betriebsvereinbarung, deren Inhalt und Geltungsdauer durch Änderungen in den Besitzverhaltnissen des Süddeutschen Verlags nicht berührt werden. Om die reden is het statuut behalve door de uitgever (Süddeutscher Verlag $\mathrm{GmbH}$ ) en de hoofdredactie (Chefredaktion) ook ondertekend namens de redactieraad (Redaktionsausschuß) en de voorzitter van de ondernemingsraad (Betriebsrat). (2) Dat de redactieraad mede-ondertekenaar is van hetzelfde statuut, dat deze redactieraad in het leven roept, houdt verband met de moeizame totstandkoming van het statuut bij de SZ; de redactieraad was er namelijk eerder dan het statuut. Het eerste concept ervan 
was afkomstig van de redactie zelf. Aanleiding was het voomemen van de directie om personele wijzigingen in de hoofdredactie aan te brengen waar de redactie niet gelukkig mee was.

Het eerste artikel bevat zoals gebruikelijk in Duitse statuten de "Grundsatz" van de krant. Het luidt: Die Süddeutsche Zeitung ist eine politische Tageszeitung, unabhängig von Parteien, Interessengruppen und Wirtschaftverbänden. Sie bemuht sich um unverfalschte und möglichst vollständige Information über alle Ereignisse won offentichem Interesse. Sie verteidigt und erstrebt freiheitliche, demokratische Gesellschaftsformen nach liberalen und sozialen Grundsätzen. Die Suldeutsche Zeitung (......) achtet die Glaubens-, Gewissens- und Meinungsfreiheit des einzelnen und lehnt alle Bestrebungen radikaler Gruppen $a b$, welche die rechtsstaatliche Ordnung gefahrden.

Een van de, voor de redactie onbevredigend geëindigde, conflicten betreft de regeling van de "Richtlinienkompetenz" op basis van de in de identiteitsverklaring neergelegde "Grundsatz". De redactie wenste deze bevoegdheid aan zich te houden door middel van de formulering: Die politische Linie der Zeitung bestimmt die Redaktion unter Vorsitz des Chefredakteurs im Rahmen der vorgenannten Grundsatze. Die Meinungsbildung geschieht durch die Aussprache in der Redaktionskonferenz. De uitgever wenste echter in zijn ontwerp aan directie en aandeelhouders een beslissende stem te geven bij het vastleggen van "Richtlinien für alle grundsätzlichen Fragen der Gestaltung der Zeitung", zij het dat de richtlijnen "im Benehmen" met hoofdredactie en redactieraad tot stand zouden komen. Alle partijen werden het tenslotte eens over de tekst van een compromis, dat inhield:

- de directie stelt de "Richtlinien für die grundsätzliche Gestaltung der Zeitung" op, "nach Zustimmung" door de aandeelhouders en "im Einvernehmen" met hoofdredactie en redactieraad;

- ook de redactie kan het initiatief nemen tot opstelling van de richtlijnen.

Zoals Welzel (3) terecht opmerkt, is de waarde van dit redactionele recht van initiatief zeer betrekkelijk, zolang de uitgever zich een beslissende stem inzake de "Richtinienkompetenz" voorbehoudt. Ook deze compromistekst heeft het uiteindelijke redactiestatuut echter niet gehaald. De erin uitgedrukte gedachte läßt sich nur erahnen (Kau) in de tekst van artikel 2: Den redaktionellen Teil der Siuddeutschen Zeitung gestaltet die Redaktion im Rahmen des Artikels 1 dieses Sratuts wie bisher frei und unbeeinflußt unter der Verantwortung der Chefredaktion. Die Redaktion nimmt bei ihrer Arbeit auf das Gesantinteresse der Suddeutschen Zeitung Ritcksicht; in Fragen von besonderer Bedeutung stimmen sich Redaktion und Verlagsleitung wie bisher miteinander ab und handeln einvernetwhlich.

In het geheel niet geregeld is de bevoegdheid tot wijziging van de "Grundsatz", noch de gevolgen daarvan woor de joumalisten die wegens ingrijpende wijziging van de redactionele utitgangspunten met langer bij de Süddeutsche Zeitung zouden willen werken. Bovendien onbreken:

- een regeling van de "Gewissensschutz" voor redacteuren;

- een regeling voor de vaststeling en verdeling van het redactionele budget. 
De redactieleden hebben well inspraak bij de benoeming van de leden van de hoofdredactie, van rubriekschefs en van andere "leitenden Redakteure", zoals commentaarschrijvers en andere journalisten die hooggekwalificeerde en/of verantwoordelijke arbeid verrichten. Volgens artikel 4 worden de leden van de hoofdredactie benoemd door de vergadering van aandeelhouders. De andere leden van de hoofdredactie, de rubriekschefs, de "leitende Redakteure" en de redactieraad kunnen met een meerderheid van tweederden een veto uitspreken over de benoeming (hetzelfde geldt voor het ontslag) van een lid van de hoofdredactie. (4) Voor benoeming en ontsłag van afdelingschefs en "leitende Redakteure" heeft de hoofdredactie de instemming nodig van de meerderheid van de andere rubriekschefs, de andere "leitende Redakteure" en de redactieraad samen. Overige personele wijzigingen neemt de hoofdredactie in overleg met de directie en de betreffende rubriekschef, na hierover eerst de redactieraad geïnformeerd te hebben.

In haar eerste concept van het statuut wenste de redactie dat haar 0,25 procent (niet vervreembaar) van het aandelenkapitaal in eigendom zou worden toegezegd. Een lid van de redactieraad zou op grond daarvan de vergadering van aandeelhouders kunnen bijwonen um auch in unternehmerische Entscheidungen redaktionellen Sachverstand einbringen zu können. Dit voorstel, dat volgens Kau waarschijnlijk uniek is geweest bij onderhandelingen over Duitse redactiestatuten en dat bei einer Verwirklichung weitreichende Konsequenzen hätte haben können heeft de eindversie dan ook niet gehaald.

De redactieraad bestaat uit vijf leden, die voor twee jaar gekozen worden. De leden hebben volgens artikel 10 dezelfde ontslagbescherming als de leden van de ondernemingsraad hebben op grond van de "Betriebsverfassungsgesetz".

(1) Erik Boogerman Een gezaghebbende krant met twee gezichten, NRC Handelsblad van 7 januari 1991.

(2) De ondernemingsraad heeft, vrijwel gelijktijdig met het redactiestatuut, een soortgelijk contract met de uitgever afgesloten ("Beiriebsvereinbarung über die Errichtung eines Unternehmensausschusses"). Deze Ausschuß bestaat uit zes leden, die benoemd worden door directie en ondernemingsraad samen, en heeft uitsluitend een adviserende functie. Hij krijgt valn de directie inzage in alle bescheiden die betrekking hebben op "wirtschaftliche Angelegenheiten" van de uitgeverij, waaronder ook vallen produktie en oplage, het investeringsprogramma, bezuinigingsmaatregelen en sonstige Vorgänge, welche die Interessen der Arbeimehmer des Unternehmens wesentlich berühren. De tekst van de overeenkomst is te vinden bij Kau Die Mitbestimmung in Presseunternehmen, pag. 333 e.v. Over de achtergrond van deze overeenkonst zie Kau Die Mitbestimmung.... pag. 85 e.v.

(3) Susanne Welzel Redaktionsstatuten. Zum Problem der inneren Pressefreiheit in der Bundesrepublik Deutschland, "Magisterarbeit" uit 1972, pag. 103.

(4) Anders: Christina Holtz-Bacha Mitspracherechte für Journalisten, pag. 30, die in de betreffende bepaling abusievelijk een vetorecht voor tweederden van alle redactieleden leest.

\subsubsection{Abendzeitung (München)}

Het redactiestatuut van de Abendzeitung is om twee redenen interessant: het betreft het enige Duitse boulevardblad met een statuut en de vigerende versie, vanaf 1 april 1991, is al de vierde. De eerste dateert van 19 augustus 1972. Zij vertoont 
grote overeenkomsten met het enkele maanden eerder (22 mei 1971) totstandgekomen statuut van de Kölner Stadt-Anzeiger. Dit hield verband met de omstandigheid dat de eigenaresse van de Keulse krant, Verlagsgruppe M. DuMont Schauberg en de "Herausgeber" van de Stadt-Anzeiger, Jürgen Neven DuMont, in 1971 samen $331 / 3$ procent van de aandelen van Verlag Die Abendzeitung GmbH \& Co. $\mathrm{KG}$ hadden verworven.

Inmiddels heeft de Keulse uitgeverij haar belang in de Abendzeitung weer verkocht, hetgeen in 1991 tot een gedeeltelijk herschreven redactiestatuut heeft geleid. Het is per 31 maart 1994 opzegbaar. (1) In hun evaluatie uit 1975 van de Duitse statuten vermelden Branahl en Hoffmann-Riem (2) noch de Stadt-Anzeiger noch de Abendzeitung, omdat bij beide kranten de redactionele inspraak niet aan minimale eisen zou voldoen. Bovendien vinden zij een vergelijking van een boulevardkrant met andere, meer serieuze dagbladen onmogelijk. Kau vindt beide argumenten onterecht. Overigens is de definitieve tekst van het statuut ver verwijderd gebleven van wat de journalisten van de Abendzeitung nastreefden. (3) Omdat de nieuwe versie van het statuut van de Abendzeitung nog nergens gepubliceerd is, zijn hieronder vooral die bepalingen opgenomen die afwijken van de bij Kau (1980) en Holtz-Bacha (1986) gepubliceerde tekst. Präambel: Das nachfolgende Redaktionsstatut macht der Herausgeber der Abendzeitung fuir die Dauer seiner Laufzeit zum Inhalt der Anstellungsverträge aller in der Abendzeitung tätigen Redakteure, einschließlich der Chefredaktion. Es hat die Festschreibung der kritisch-liberalen Tendenz der Abendzeitung zum Ziel. Die journalistische und unternehmerische Freiheit wird dadurch nicht eingeschrankt. Es enthalt auch keine Regelungen des Redaktionsalltags.

$\$ 1$ Die Abendzeitung ist eine kritisch-liberale Straßenverkaufszeitung und AboZeitung besonderen Charakters. Sie bemiiht sich um unverfalschte und möglichst vollständige Information über wesentliche Vorgänge auf politischen, kulturellen und anderen Gebieten von allgemeinem offentlichen Interesse, und kommentiert und erläutert sie. Sie mißt dem kommunalen und regionalen Geschehen besonderes Gewicht bei und berücksichtigt die Eigenarten der Stadt München. Sie setzt sich zum Ziel, den Typ einer engagierten, unterhaltsamen und bürgernahen Boulevardzeitung und Abo-Zeitung fortzuentwickeln, wie er von ihrem Grïnder Werner Friedmann geschaffen und werwirklicht worden ist.

$\$ 2$ ( .....) Herausgeber und Verlag ihrerseits verpflichten sich, bei ihrer Arbeit die grundsätzliche Haltung der Abendzeitung zu beachten und Richtlinien nur im Rahmen der in $\$ 1$ formulierten Maßgaben zu erteilen. Maßnahmen, die aus rechtlichen oder wirtschaftlichen Gründen getroffen werden müssen, bleiben hiervon unberïht, jene Grïnde werden den Redakteuren erläutert.

Deze laatste bepaling is tekenend voor de verhouding redactie - uitgever in het hele statuut: in belangrijke beslissingen wordt de redactie noch de redactieraad, die uit vijf leden bestaat, enige reële inspraak geboden. Over het statuut uit 1972 schreef een lid van de redactieraad in 1989: Lieber kein Statut als dieses. Es gibt auch in der Redaktion der "Abendzeitung" durchaus Hardliner, die - nicht ohne 
Grund und innere Logik - diesen Standpunkt vertreten. Denn hinsichthch der Mitsprache räumt das AZ-Statut von 1972 dem Redaktionsbeirat kaum Rechte ein. Von echter Mit-Bestimmung ganz zu schweigen. Dat dezelfde journalist toch tot een positieve beoordeling komt (Lieber dieses Statut als keines) schrijft hij mede toe aan de normative Kraft des Faktischen. Was heißen will, daß dank des Statuts über die rein formale Ebene des Umgangs zwischen Redaktion und Verlag hinaus sich besondere nichtinstitutionalisierte Beziehungen entwickelt haben. (4)

In één opzicht is het statuut sterk verbeterd. De oude tekst zweeg geheel over de verantwoordelijkheid van de (hoofd)redactie voor het redactionele deel van de krant. In $\$ 3$ is die verantwoordelijkheid thans vastgelegd, zij het dat ook de "Herausgeber" een rol kan spelen, wanneer hij dat wenst. De betreffende tekst luidt: $\$ 3$ Den redaktionellen Teil der Abendzeitung gestaltet die Redaktion frei und unbeeinflußt unter der Verantwortung der Chefredaktion. Der Meinungsbildung dienen die regelmäßigen Redaktionskonferenzen unter Leitung der Chefredaktion, an denen auch der Herausgeber teilnehmen kann.

In veel andere opzichten is het nieuwe stuk nauwelijks een verbetering vergeleken bij het oude. De verhouding uitgever - redactie blijkt treffend uit de regelingen die betrekking hebben op redactionele invloed bij wijziging van de uitgangspunten en het personeelsbeleid, inclusief benoeming en ontslag van een lid van de hoofdredactie.Treten Meinungsverschiedenheiten uber die Auslegung der grundsätzlichen Haltung zwischen Herausgeber und Redaktion oder zwischen Redakteuren untereinander auf, so sind diese vom Herausgeber zusammen mit der Chefredaktion und den betroffenen Redakteuren oder in einer Ressortleiterkonferenz zu klären. (....)

De redactieraad adviseert bij voorgenomen benoeming, ontslag of overplaatsing van een hoofdredacteur of rubriekschefs. Een sollicitant wordt de mening van de redactieraad meegedeeld.(5)Mindestens einmal jährlich wird der Beirat über die wirtschaftliche Lage und Entwicklung des Unternehmens informiert. Die Information kann auch durch einen Beauftragten erfolgen. Alles wat de redactieraad verneemt van "Herausgeber", hoofdredactie en directie is in beginsel geheim, zelfs tegenover de ondernemingsraad.

(1) De Kölner Stadt-Anzeiger heeft sinds 1988 helemaal geen statuut meer. Over de achtergronden daarvan zie Connie Strauch Götterdämmerung in Der Journalist van september 1988, pag. 22 e.w. en Christina Holtz - Bacha Tendenz lustlos - Flaute in der Statutenbewegung. Der Journalist van september 1989 , pag. 10 e.v.

(2) Udo Branahl/Wolfgang Hofmann-Riem Redaktionsstatute in der Bewährung, pag. 141 e.v.

(3) Edwin Kau Die Mitbestimmung... pag. 91.

(4) Fritz Janda in Der Journalist van september 1989.

(5) Als voorbeeld van de werking van de normative Kraft des Faktischen noemt AZ-journalist Janda het geval van de nicuwe hoofdredacteur die reeds benoemd was, maar de functie weigerde na een unaniem negatief oordeel van de redactievergadering. Der Journalist van september 1989. 


\subsubsection{Mannheimer Morgen}

Het redactiestatuut van de Mannheimer Morgen, een regionale krant in en rond Mannheim en Ludwigshafen, dateert in zijn eerste versie van 22 oktober 1969 en is daarmee een van de oudste van Duitsland. Het initiatief ertoe kwam van de twee eigenaar-uitgevers, die tevens als "Herausgeber" en hoofdredacteuren optraden. De krant was toen nog een puur uitgeversprodukt; de technische vervaardiging was als drukorder uitbesteed aan het bedrijf dat later met de uitgeverij zou fuseren tot Mannheimer Morgen Großdruckerei und Verlag GmbH (MMGD).De redactie had na enkele wijzigingen, die de redactionele inspraak nog verbeterden, slechts én voormiddag nodig om met het uitgeversconcept akkoord te gaan. Volgens Kau werd het aanbod van de uitgevers allgemein als großzügiges Geschenk angesehen.

Sinds 1 september 1975 is een gewijzigde versie van kracht. De wijzigingen hielden verband met de invoeging van de krant in de nieuwe onderneming, waarin ook andere activiteiten dan de uitgeverij uitgeoefend worden. Bedoeling van de aangepaste tekst was de bijzondere positie van de redactie te benadrukken en haar gemakkelijk toegang tot de bedrijfsleiding te geven zoals voorheen, toen de uitgevers zelf cleel uitmaakten van de redactie. In het statuut is dit als volgt omschreven:

Die Redaktion hat ihrer weittragenden Verantwortung entsprechend einen maßgebenden Platz im Zeitungsverlag der MMGD. Sie ist mit der Unternehmensleitung durch die Herausgeber und die für den Zeitungsbereich verantwortlichen Gesellschafter aktiv verbunden. Unternehmensleitung und Herausgeber einerseits sowie der Radaktionsrat andererseits verpflichten sich zu ständigem Gedankenaustausch über geplante und bevorstehende Veränderungen, soweit sie sachlich oder technisch die Redaktion berïhren.

Het statuut zoals dat ook thans nog van kracht is maakt op het punt van de redactionele inspraak bij personele beslissingen een voorbeeldige indruk: Der Chefredakteur wird, soweit er nicht Gesellschafter ist, auf Vorschlag der Herausgeber im Einvernehmen mit dem Redaktionsrat durch die Unternehmensleitung berufen und entlassen. Die Herausgeber verzichten auf ihren Vorschlag, wenn der Redaktionsrat mit vier Fünfteln Mehrheit widerspricht. Der Widerspruch muß sachlich begründet sein. Die Herausgeber werden dann einen neuen Vorschlag unterbreiten. Die Bestellung oder Abberufung eines Ressortleiters erfolgt auf Vorschlag des Chefredakteurs und im Einvernehmen mit dem Redaktionsrat durch die Unternehmensleitung. Innerhalb der Ressorts haben die Ressortleiter das Vorschlagsrecht für ihre Mitarbeiter: Bestellung und Abberufung erfolgen im Einvernehmen mit dem Redaktionsrat.

Dat die inspraak ook in de praktijk goed functioneert, daarvan getuigt een evaluatie uit 1989: Die Erfahrungen mit dem Statut: Insgesamt sehr gut. Ernsthafte Konflikte, theoretisch ja durchaus vorstellbar, hat es in der Praxis nie gegeben. Ein wesentlicher Grund: das Statut hat vorbeugenden Charakter, läßt viele 
Konflikte erst gar nicht entstehen, da alle Beteiligten - Unternehmensleitung, Herausgeber, Chefredakteure - ihr Verhalten von vornherein auf einen breiten Konsens hin auslegen müssen. (1)

De redactionele uitgangspunten van de Mannheimer Morgen zijn, zoals gebruikelijk bij regionale kranten, in vrij algemene bewoordingen gesteld. Over een specifieke politieke signatuur is dan ook weinig terug te vinden. Volgens Kau hebben de uitgevers met hun concept-statuut in 1969 mede ten doel gehad aber die Zeit ihrer persönlichen Tätigkeit ( .......) eine gewisse liberale Grundhaltung der Zeitung in Redaktion und Verlag zu sichern. De procedure bij wesentliche Anderungen van de identiteitsverklaring is voorbeeldig; zij geeft de meerderheid van de stemgerechtigde leden van de redactie een instemmingsrecht.

Voorbeeldig geregeld is eveneens de exclusieve verantwoordelijkheid van hoofdredactie en redactie voor de inhoud van de krant en van de "Gewissensschutz": Die Redaktion wird von einem Chefredakteur geleitet. Dieser uiberwacht im Einvernehmen mit dem Sprecher des Redaktionsrates die Linie der Zeitung. In diesem Rahmen bleibt die journalistische Arbeit der Verantwortung der Ressortleiter für ihre Arbeitsgebiete überlassen.

Meinungsverschiedenheiten zu Tagesfragen - falls sie nicht mit dem Ressortleiter abgeklärt werden können - müssen mit dem Chefredakteur bereinigt werden. Auf Wunsch eines der Beteiligten ist der Sprecher des Redaktionsrates hinzuzuziehen. In Fällen eines Gewissenkonflikts ist der betroffene Mitarbeiter, falls der Ressortleiter keine Entscheiding treffen mag, durch den Chefredakteur von der ihn belastenden Aufgabe freizustellen.

De redactieraad bestaat uit vijf leden, van wie er twee rubriekschefs moeten zijn, gekozen door redactieleden die tenminste een jaar in dienst zijn. (2) Gekozen kunnen worden redacteuren die tenminste twee jaar bij de krant werken. De hoofdredacteur heeft geen zitting in de redactieraad, hij heeft ook geen actief stemrecht. De werkwijze van de redactieraad is vrij informeel. Hij komt bijeen wanneer een lid of de "Sprecher" dit noodzakelijk acht. Wanneer de leden vinden dat het, gezien het onderwerp, doelmatig lijkt dat de hoofdredacteur en de "Herausgeber" bij de besprekingen aanwezig zijn, worden zij uitgenodigd.

(1) Gert Goebel, lid van de redactieraad van de Mannheimer Morgen, in Der Journalist van september 1989 .

(2) Uit het onderzoek van Branahl/Hoffmann-Riem Redaktionswatute in der Bewährung. pag. 184, gepubliceerd in 1975, blijkt dat "Ressortleiter" ook daar waar zij niet statutair verplicht in de redactieraad vertegenwoordigd zijn uberdurchschnitlich stark verireten zijn.

\subsubsection{Südwest Presse UIm}

Het redactiestatuut van de Südwest Presse-Ulm/Neue Württembergische Zeitung, gevestigd in Göppingen, van 1 januari 1977 is wat zijn ontstaansgeschiedenis betreft vergelijkbaar met dat van de Mannheimer Morgen. Ook hier nam een uitgever, die tevens "Herausgeber" en directeur was, het besluit zijn krant te beschermen tegen een ongewenste koerswijziging na zijn overlijden. Samen met de re- 
dactie stelde hij een statuut op dat feitelijk de redactieraad en de rubriekschefs instemmingsrecht geeft bij de benoeming van een hoofdredacteur. Wijziging van de redactionele uitgangspunten is zonder toestemming van de redactie lastig. In geval van fusie of verkoop kunnen journalisten gebruik maken van een afvloeiingsregeling die als prohibitief royaal beschouwd kan worden.

De beginselverklaring en de bepaling van de verschijningsvorm zijn voorbehouden aan de "Verleger/Herausgeber". De identiteit is in zeer algemene bewoordingen vastgelegd: Die im Verlag der Neuen Pressegesellschaft $m b H$ \& $C o K G$ erscheinenden Tageszeitungen sind unabhängig, überparteilich und überkonfessionell. Sie stehen ein für die im Grundgesetz niedergelegte freiheitlich demokratische Grundordnung der Bundesrepublik. Radikale Entwicklungen, die diese Grundordnuing gefahrden, lehnen sie $a b$.

$\mathrm{Bij}$ meningsverschillen tussen uitgever en redactie waarbij de identiteit betrokken is, wordt onderscheiden of ze auf den Einzelfall betrekking hebben dan wel of het om Fragen von grundsätzlicher Bedeutung gaat die nach Ansicht des Verlegers/Herausgebers der Klärung bedürfen. In het eerste geval beslist de hoofdredacteur samen met de betreffende rubriekschef(s) en - zo mogelijk - met de auteur. Alleen wanneer zij er samen niet uitkomen moet de "Verleger/Herausgeber" erbij gehaald worden und notfalls entscheiden.

Bij een meer principiële kwestie proberen de uitgever, de hoofdredactie en de rubrieksredacties war de kwestie speelt eerst $z u$ einer einvernehmlichen Regelung zu kommen. Lukt dat niet dan beslist de uitgever en deelt hij zijn beslissing, die niet mag afwijken van de beginselverklaring, aan de redactie mee.

De uitgever heeft eveneens een beslissende stem over een publicatie die unzumutbare Folgen für den Verleger/Herausgeber, den Verlag oder die Zeitung haben könnte.

Artikel IV beschrijft de procedurele horden die de uitgever moet nemen wanneer hij de beginselverklaring of de verschijningsvorm van de krant wil veranderen. Het beslissingsrecht blijft uiteindelijk bij de uitgever; het is ook hier de hoogte van de afkoopsommen (minimaal zes en maximaal 15 maandsalarissen, bij fusie zelfs tot 24 maanden) die beschermend moet werken.

Artikel VII over "Personelle Angelegenheiten" bepaalt dat een nieuwe hoofdredacteur niet benoemd wordt wanneer van de overige leden van de hoofdredactie, van de rubriekschefs en de redactieraad samen zich een meerderheid van drievierden tegen de benoeming uitspreekt. De inspraak van de redactie wordt gemotiveerd met een inleidende bijzin, waarin staat dat de hoofdredacteur het bijzondere vertrouwen van zowel de uitgeverij als van de redactie behoeft.

De redactieraad is het overlegorgaan van de redactie met de uitgever en niet met de hoofdredactie. De redactieraad mag keinen Einflu $\beta$ auf die redaktionelle Arbeit nehmen. Het overleg met de uitgever beperkt zich tot "Meinungsaustausch". Dabei informiert der Verleger/Herausgeber auch über beabsichtigte Änderungen in finanzieller, organisatorischer und technischer Hinsicht, die sich erheblich auf die Redaktion auswirken können. Auch über die gesamtwirtschaftliche Situation des Verlags wird berichtet.. De hoofdredactie 
wordt uitgenodigd in de vergaderingen van de leiding van de uitgeverij, doch slechts voor zover er kwesties aan de orde komen die de redactie betreffen. Contact tussen hoofdredactie en redactieraad is incidenteel.

Per saldo is de mate van echte inspraak van de redactie niet indrukwekkend, zoals ook de "Redaktionsratssprecher" toegeeft. Het redactiestatuut met zijn royale afkoopsommen waar journalisten recht op hebben bij fusie of verkoop van de krant (dieser vergoldete Abgang) ... schließt weder die Lücken, die ein Presserechtsrahmengesetz schließen könnte, noch ersetzt es Redakteure, die die besondere Rolle von Presse und Journalismus in Konfliksituationen auch im Innenbetrieb hochhalten. (1)

(2) Der Joumallist van september 1989.

\subsection{Het ontwerp uit 1974 voor een nieuwe perswet}

\subsubsection{De voorgeschiedenis}

De resultaten van de "Statutenbewegung" in de Duitse dagbladpers zijn tegengevallen. Ook daar waar redactiestatuten tot stand zijn gekomen bieden ze de redacties weinig reële inspraakmogelijkheden. Bij de vroege statuten (1969 - 1972) speelde mee, dat de redacties genoegen hebben genomen met een zwak statuut in de hoop, dat een federale perswet de beperkingen die thans reële inspraak in de weg staan - in het bijzonder de verstikkende werking van de Betriebsverfassungsgesetz - zou opheffen.

In juli 1974 heeft het ministerie van binnenlandse zaken van het toenmalige kabinet Schmidt - Genscher, een coalitie van SPD en FDP, een ontwerp voor een nieuwe perswet gepubliceerd, waarin het tweede hoofdstuk is gereserveerd voor een regeling van de verhouding redactie - uitgever. Het ontwerp is in de loop van dit hoofdstuk reeds verscheidene keren genoemd, meestal in combinatie met zijn meest prominente verdediger, Wolfgang Hoffmann-Riem.

Het was overigens lang niet de eerste aanzet sinds de oorlog om een nieuwe perswet voor heel (West-)Duitsland op te stellen; reeds in de jaren voor 1949 zijn daartoe in de verschillende bezettingszones pogingen ondernomen. $\mathrm{Na} 1949$ hebben zowel uitgevers- als journalistenorganisaties, groepen mediajuristen ("Aktionsgruppe Heidelberg" van 1949; Arbeitskreis Pressefreiheit I (1970) en II (1972) van Armbruster e.a. in Tübingen) en het ministerie van binnenlandse zaken ontwerpen gepubliceerd, die echter geen van alle het eerste wetgevingsstadium bereikt hebben. (1)

Er worden verscheidene oorzaken genoemd waarom het tot begin jaren zeventig geduurd heeft voordat een nieuw ontwerp wel politieke en publieke aandacht kreeg. Tijdens de politieke en economische opbouw van de Bondsrepubliek was men aanvankelijk huiverig om via wetgeving te raken aan het pasverworven grondrecht van de uitings- en persvrijheid en om een belangrijke industriële bedrijfstak voor de voeten te lopen. Begin jaren zestig liepen ook de (slecht georga- 
niseerde) Duitse journalisten steeds minder warm voor een ideëel aspect als "innere Pressefreiheit" en waren zij meer geinteresseerd in een goede CAO. Bovendien moesten zij zich in toenemende mate verdedigen tegen verdachtmakingen als zouden zij voor zichzelf een geprivilegieerde positie opeisen tegenover andere werknemers.

De ingrijpende persconcentratie van de jaren zestig en zeventig maakte de journalistiek er harchandig op attent dat de angst voor een te grote invloed van uitgevers op de redactionele inhoud van hun kranten verre van irreèel was. Tussen 1954 en 1976 zakte het aantal zelfstandige dagbladondernemingen van 225 naar 121, zestien minder dan bij het opheffen in 1949 van de geallieerde licensieregeling. Weliswaar bleef het aantal arbeidsplaatsen op peil, de keuzemogelijkheid binnen de branche werd echter drastisch beperkt. De eerste redactiestatuten bij een paar kranten en tijdschriften ontstonden, aanvankelijk buiten de georganiseerde journalistiek om, als reactie op het schrikbeeld van een steeds kleinere groep, internationaal opererende uitgevers die een steeds groter deel van de markt gingen beheersen en oligopolistische, hier en daar al monopolistische kenmerken vertoonden. Een nieuw begrip deed zijn intrede: "diagonale concentratie" (de media-onderneming als onderdeel van een concern dat ook andere produkten op de markt brengt).

De persconcentratie bracht de politiek op het hoogste niveau in actie. In de regeringsverklaring van 28 oktober 1969 kondigde kanselier Willy Brandt de komst van een raamwet voor de pers aan. Drie jaar later was de wet er nog niet, maar: Zur Pressefreiheit und Medienfreiheit gehört die Freiheit in der Presse und in den Medien. Die Arbeit am Entwurf des Presserechtsrahmengesetzes ist darum vordringlich stond in de regeringsverklaring aan het begin van de tweede ambtstermi.jn van kanselier Brandt.

De eerste versie van de "Entwurf eines Gesetzes über die allgemeinen Rechtsverhältnisse der Presse (Presserechtsrahmengesetz - PRRG)", gedateerd 25 juli 1974, kreeg van alle kanten een vemietigende kritiek. Een op enkele onderdelen aangepaste versie, gedateerd 25 september 1974, is niet eens meer officieel openbaar gemaakt. (2)

Vooral de journalistiek reageerde teleurgesteld. Het belangrijkste journalistieke bezwaar was dat het wetsontwerp op het punt van de regeling van de interne verhouding bij persorganen veel te mager was en in veel opzichten zelfs achterbleef bij reeds afgesloten redactiestatuten.

De journalistieke kritiek is niet geheel terecht. Een belangrijk winstpunt voor de journalisten is het fundamentele uitgangspunt in het ontwerp, dat de verhouding uitgever - redacteur niet arbeidsrechtelijk van aard is, maar ihrer Natur nach, zoals in de memorie van toelichting herhaaldelijk wordt opgemerkt, presserechtlicher Art. Het ontwerp handhaaft weliswaar $\$ 118$ BetrVerfG, maar het maakt inspraak van een "Redakteurvertretung" mogelijk, zolang deze wordt uitgeoefend zur Erfillung der Aufgaben der Presse und zur Wahrung der Pressefreiheit der 
für die Zeitung tätigen Redakteure ( $\$ 19$ lid 1$)$. Het ontwerp laat de overige bevoegdheden van de ondernemingsraad en van individuele personeelsleden op grond van de Betriebsverfassungsgesetz intact ( $\$ 19$ lid 3).

Daarnaast biedt de raamwet de redacties die er een beroep op doen de rechtskracht en de algemene verbindendheid die de bestaande redactiestatuten, evenals de redactiestatuten op basis van een bedrijfs-CAO missen. Het ontwerp voor de raamwet biedt bovendien de mogelijkheid verdergaande overeenkomsten te treffen, namelijk door middel van een redactiestatuut ( $\$ 22$ van de ontwerp-PRRG). Dit redactiestatuut kan weliswaar opgezegd worden, maar dan blijft de wet als minimumregeling ter beschikking.

Tegen de fundamentele mediarechtelijke kritiek van onder anderen Werner Weber, Kull, Rehbinder en Lerche dat het wetsontwerp de interne structuur van de personderneming beïnvloedt en daarom in strijd is met art. 5 GG hebben Hoffmann-Riem en Plander het ontwerp verdedigd. (Wolfgang HoffmannRiem/Harro Plander Rechtsfragen der Pressereform, Baden-Baden 1977). Deze nadere uitwerking en actualisering van het deskundigenrapport dat zij in opdracht van het ministerie van binnenlandse zaken over het PRRG-ontwerp schreven, geeft blijk van soms onorthodoxe opvattingen over de kern van het grondrecht van artikel $5 \mathrm{GG}$, die in Duitsland nog geen ingang gevonden hebben. Deze opvattingen zijn hiervoor reeds, onder andere in $\$ 6.3 .2$, aan de orde geweest.

(1) Een overzicht tot 1954 van alle wetsontwerpen met integrale teksten is te vinden in Joumalistengesetze und Pressegesetze - die Entwärfe von 1924 bis 1954. Eine Dokumentation vorgelegt vom Deutschen Journalisten Verband (1969). Voor de periode van na 1954 zie o.a. Holtz-Bacha Mitspracherechte ...., pag. 14 e.w., Edwin Kau Die Mitbestimmung.., pag. 54 e.v.", Ansgar Skriver Schreiben und schreiben lassen, pag. 35 e.v. Löffler-Ricker, Handbuch des Presserechts, pag. 238 e.v.

(2) Deze laatste versie is als bijlage opgenomen.

\subsubsection{De "Begründung" van het PRRG-ontwerp}

Van het PRRG-ontwerp van 25 juli 1974 is voor dit onderzoek de "memorie van toelichting" ("Begründung") interessanter dan de regeling zelf. Kernpunten daaruit zijn:

- De persvrijheid is niet alleen een grondrecht voor iedere burger, maar ook het instituut "pers" wordt grondrechtelijk beschermd. Darin ist die Zusammenarbeit der in der Institution "Presse" Tätigen eingeschlossen. Verlegern und Redakteuren steht die Pressefreiheit gemeinsam zu. In hun onderlinge verhoudingen kan sprake zijn beperkingen op grond van arbeidscontract en CAO, maar die beperkingen müssen ein Mindestmaßß an "Innerer Pressefreiheit" ermöglichen.

- De samenwerking uitgever - redacteuren, zoals in deze wet geregeld, erhält darüber hinaus in der Informationsfreiheit des Bürgers eine wichtige Zielorientierung. Daarbij is vooral gedacht aan de pluriformiteit van de pers als belang voor iedere staatsburger dessen Meinungsbildung durch umfassende Information erleichert werden soll. 
- De verhouding uitgever - redacteur is ihrer Natur nach ( ....) als Konkretisierung der Wertentscheidung des Artikels 5 Abs. 1 GG presserechtlicher, nicht arbeitsrechtlicher oder betriebsverfassungsrechtlicher Art. Ausgangspunkt der Regelung des Verhälmisses Verleger-Redakteur is nämlich das Verhältmis von Pressefreiheit zu Meinungsfreiheit und Informationsfreiheit. Deze principiéle keuze voor een "presserechtliche" regeling maakt redactionele inspraak mogelijk, zij het clat deze beperkt is tot die kwesties die de uitingsvrijheid - in de ruimste zin van het woord - raken; voor het overige blijft \& 118 Betriebsverfassingsgesetz van kracht.

- Een wettelijke regeling mag geen afbreuk doen aan de beschikkingsbevoegdheid die de uitgever aan zijn eigendomsrecht ontleent. De "Grundsatzkompetenz" van de uitgever dient mede om het "publicistische engagement" van de uitgever te behouden als voorwaarde voor het optimaal functioneren van de commercieel gestructureerde pers.

- De "Gesinnungsschutz" van journalisten wordt gegarandeerd; zij mogen niet gedwongen kunnen worden tegen hun overtuiging te schrijven, bij voorbeeld bij een blad, waarvan de uitgever de redactionele uitgangspunten zodanig wijzigt dat van een journalist in redelijkheid niet gevergd kan worden ervoor te blijven werken.

In de "Begründung" wordt toegegeven dat het verzoenen van zoveel verschillende en soms tegengestelde belangen gesetzgeberische Lösungen aufgibt, die, um allen rechtlichen Erfordernissen gerecht zu werden, teilweise nicht unkompliziert erscheinen müssen. Diese Schwierigkeit muß um der Bewahrung der Rechtsordnung willen in Kauf genommen werden.

\subsubsection{Hoofdlijnen van het ontwerp-PRRG van 25 juli 1974}

Het ontwerp bestaat uit 34 paragrafen in drie delen, waarvan de laatste twee onder meer betrekking hebben op de instelling van aparte perskamers bij de "Landgerichte", nader te regelen door de "Länder", de strafrechtelijke aansprakelijkheid en misbruik van databanken.

Van het eerste deel is het tweede hoofdstuk geheel gewijd aan de afbakening van bevoegdheden tussen uitgever en redactie. De "intensiteit" van medezeggenschap kent vier gradaties:

1. "Selbsbestimmung": slechts één partij is beslissingsbevoegd. In het ontwerp geldt dit voor

- de "Grundsatzkompetenz" van de uitgever: zijn recht om de redactionele beginselen vast te stellen te wijzigen;

- de "Richtlinienkompetenz" van de hoofdredacteur. Daarbij gaat het om kwesties die in ihrer Tragweite erheblich über die Tagesaktualität hinausgehen. Het ontwerp heeft hier een principiẻle knoop ten gunste van de redactie doorgehakt: de "Richtlinienkompetenz" gaat naar de hoofdredacteur en niet naar de uitgever. Deze laatste mag zich alleen verzetten, wanneer een richtlijn in strijd zou zijn met 
de redactionele beginselen. Een niet te onderschatten winstpunt is bovendien dat de functie van hoofdredacteur voor het eerst een wettelijke erkenning zou krijgen.

- de "Detailkompetenz" van de redacteur, binnen de redactionele uitgangspunten van de uitgever en de richtlijnen van de hoofdredacteur, bij het inhoudelijk vormgeven van zijn artikelen. Einzelweisungen des Verlegers sind insoweit unzulässig.

2. Van een geringere intensiteit is "Mitbestimmung" ("Einvernehmen"): partijen moeten het in beginsel met elkaar eens zien te worden, maar een partij mag een kenmelijk onredelijk veto van een/de andere partij negeren. In het ontwerp is deze procedure o.a. voorzien bij aanneming en overplaatsing van redacteuren $(\$ 16)$.

3. Een "Widerspruchsrecht", zoals bij voorbeeld aan de "Redakteurvertretung" toegekend bij het ontslag van de hoofdredacteur, kan het ontslag opschorten tot de rechter over de rechtmatigheid van het ontslag beslist heeft.

4. "Anhörungsrecht": uitgever en hoofdredacteur moeten alvorens een beslissing te nemen de "Redakteurvertretung", soms ook de afdelingschefs (o.a. \$ 12 lid 2) of een individuele redacteur $(\$ 13$, lid 2$)$, raadplegen.

De beperkte inspraak van de redactie bij de voor haar belangrijkste beslissingen (wijziging van redactionelle beginselen, afwijzing van een hoofdredactionele richtlijn en benoeming van een hoofdredacteur tegen de wens van de redactievertegenwoordiging) wordt in het ontwerp "gecompenseerd" met afkoopsommen voor individuele journalisten die wegens deze beslissingen niet langer bij dit blad willen werken en ontslag nemen. Hiermee sluit het ontwerp aan bij een vooroorlogse traditie in zowel Duitsland als Nederland om het een uitgever financieel moeilijk te maken bepaalde beslissingen te nemen. De afkoopsommen zijn in de latere versie van het ontwerp teruggebracht van zes maanden tot drie maanden salaris.

Een in maart 1981 door de DJV gepubliceerde ontwerp voor een persraamwet (1) gaat op de volgende punten aanzienlijk verder dan het regeringsontwerp:

- $\$ 118$ Betriebsverfassungsgesetz wordt zo gewijzigd dat persondernemingen niet meer onder de "Tendenzschutz" vallen.

- De uitgever legt de redactionele beginselen vast. Wijziging van deze beginselen behoeft de toestemming van de gekozen vertegenwoordiging van de redactieleden. Wijst deze de wijziging af dan kan de uitgever de kwestie voorleggen aan de "paritaire commissie" (drie leden aangewezen door de redactionele vertegenwoordiging, drie leden aangewezen door de uitgever en een door de uitgever en de redactievertegenwoordiging samen aangewezen neutrale voorzitter). De uitspraak van de paritaire commissie is bindend. De redacteur die na wijziging van de redactionele beginselen ontslag neemt heeft tenminste twaalf maanden recht op doorbetaling van salaris.

- Voor benoeming en ontslag van een hoofdredacteur heeft de uitgever de goedkeuring nodig van de gekozen redactionele vertegenwoordiging, die de plenaire 
redactievergadering moet raadplegen. Gaat deze niet akkoord wordt de zaak voorgelegd aan de "paritaire commissie", die een bindende uitspraak doet.

- Andere personele beslissingen zoals benoeming en ontslag van rubriekschefs behoeven de goedkeuring van de gekozen redactionele vertegenwoordiging.

- Uitgever en redactievertegenwoordiging kunnen overeenkomsten over de verhouding tussen uitgever, hoofdredacteur en redactionele organen afsluiten die verder gaan dan de wettelijke bepalingen.

(1) De tekst van het DJV-ontwerp is opgenomen in Wemer Breede Pressefreiheit und Redaktionsfreiheil, pag. 525-527.

\subsection{Samenvatting}

De naoorlogse inspanningen om in (West-)Duitsland de interne gezagsverhouding tussen uitgever en redactie in wetgeving of overeenkomst te regelen hebben slechts bescheiden resultaten opgeleverd. Invoering van redactiestatuten via CAO, zoals in ons land, is slechts bij enkele ondernemingen (tijdelijk) gelukt, van de per dagbladonderneming afgesloten redactiestatuten zijn er nog slechts een zestal van kracht en ook de laatste poging de "innere Pressefreiheit" via een federale pers-raamwet te regelen is na stormen van kritiek gestaakt.

Een belangrijke oorzaak voor het Duitse "falen" is - paradoxalerwijs - de zeer intense belangstelling van de wetenschap voor het onderwerp geweest. In het naoorlogse Duitsland hebben juristen vooral de grondrechtelijke implicaties van een interne gezagsregeling doorzien. "De pers" wordt in de grondwet als instituut genoemd en beschermd, in het bijzonder wegens haar publieke taak in het democratische besluitvormingsproces. Haar bescherming is in de Duitse doctrine gefixeerd op eigenaar als uitgever. De eigenaar van een persorgaan is niet alleen gevrijwaard tegen bedreigingen van de kant van de staat, maar ook tegen pressie van binnenuit: als "Tendenzbetrieb" hoeft de dagbladonderneming geen inspraak van het personeel te dulden, wanneer deze de redactionele beginselen zou raken. In $\$ 118$ van de Betriebsverfassungsgesetz komen alle grondrechten samen die de uitgever beschermend omringen: zijn grondrecht van art. 5 GG om de "Grundsatzkompetenz" uit te oefenen bij een krant die een "öffentliche Aufgabe" vervult zou immers illusoir zijn zonder effectieve bescherming tegen medezeggenschap van ondergeschikten.

De bijna onaantastbare positie van de uitgever als drager van elkaar versterkende grondrechten (eigendom, beroepsvrijheid en persvrijheid) is tot de dag van vandaag uitgangspunt gebleven bij elke poging om de interne verhouding binnen de dagbladonderneming te regelen.

Het is de verontrustende persconcentratie van de jaren zestig geweest die de aanzet heeft gegeven om het vooroorlogse begrip "innere Pressefreiheit" een nieuwe inhoud te geven: een zodanige afbakening van bevoegdheden tussen uitgever, hoofdredacteur en redactie dat de redactionele onafhankelijkheid gewaarborgd zou zijn. De redacties streefden daarbij naar effectieve inspraak bij enkele van de belangrijkste beslissingen van de uitgever: vaststelling en wijziging van de redac- 
tionele uitgangspunten; benoeming en ontslag van de hoofdredacteur. Voor de vitgevers betekende dit echter een uitholling van hun onbetwiste "Grundsatzkompetenz" en strijdigheid met de Betriebsverfassungsgesetz.

In afwachting van een nieuwe perswet die de "innere Pressefreiheit" algemeen verbindend zou regelen, hebben eind jaren zestig enkele uitgevers en redacties zelf initiatieven ontwikkeld om hun interne verhouding vast te leggen in redactiestatuten. Daarbij heeft vooral het statuut van het weekblad Stern, mede geinitieerd door een welwillende mede-uitgever (Gerd Bucerius), een voortrekkersrol vervuld. In de loop der jaren zijn slechts bij een twaalftal dagbladen statuten tot stand gekomen, waarvan er inmiddels weer enkele door de uitgever opgezegd zijin. Analyse van deze redactiestatuten laat zien dat slechts één ervan (dat van de Mannheimer Morgen) de (hoofd)redactie een redelijke mate van medebeslissingsrecht in belangrijke aangelegenheden biedt, waarbij overigens bedacht dient te worden dat ook dit statuut slechts interne werking heeft en gemakkelijk opzegbaar is.

Pogingen om de rechtskracht te verzekeren door middel van een statuut als onderdeel van een "Haustarifvertrag" bij kranten van een sympathiserende uitgever (gelieerd aan de SPD) hebben slechts tijdelijk succes opgeleverd; de kranten zijn inmiddels ter ziele.

Het langverwachte ontwerp (1974) voor een nieuwe federale perswet met daarin opgenomen een regeling van de bevoegdheden van uitgever en redactie is in een storm van kritiek tenondergegaan. De journalistieke kritiek dat het ontwerp te weinig reële inspraak biedt is niet geheel terecht. Een wettelijke regeling zou het probleem van de ontbrekende rechtskracht bij de huidige redactiestatuten ondervangen: Bovendien is het principiële uitgangspunt van het wetsontwerp, dat een regeling van bevoegdheden van uitgever en redactie "naar haar aard" onder het persrecht en niet onder het arbeidsrecht ressorteert, van niet te onderschatten betekenis.

De kritiek dat elke wettelijke regeling die de beslissingsbevoegdheid van de uitgever aantast in strijd is met het grondrecht van art. 5 GG gaat er, zoals HolfmannRiem overtuigend heeft aangetoond, ten onrechte van uit dat de uitgever de primaire drager van het grondrecht is. Hij is dat niet, evenmin als "de journalist" trouwens.

Elke poging de "innere Pressefreiheit" te regelen is tot nu toe afgestuit op de formidabele hindernis van $\S 11.8$ Betriebsverfassungsgesetz (BetrVG). Kau heeft dan ook gelijk, wanneer hij tot de conclusie komt daß eine für die betroffenen Journalisten befriedigende Lösung nur erfolgen kann, wenn kombiniert vorgegangen wird, das heißt $\$ 118$ BetrVG dahingehend modifiziert wird, daß Presseunternehmen ihm nicht mehr unterfallen und anderseits die Regelung der Mitbestimmungsbefugnisse in einem speziellen Pressegesetz fesrgeschrieben wird. (1) Het ontwerp voor een nieuwe perswet van de Deutscher Journalistenverband uit 1981 komt aan een groot aantal wensen tegemoet.

(1) Edwin Kau Die Mitbestimmung....... , pag. 133.) 


\section{Hoofdstuk 7}

\section{Nederlandse redactiestatuten}

\subsection{Inleiding}

De redactiestatuten bij de Nederlandse dagbladen zijn ingevoerd op basis van een CAO-bepaling (thans art. 14) die de dagbladondernemingen verplicht per dagbladuitgave een statuut vast te stellen dat zowel de positie van de hoofdredactie als die van de redactie regelt (...... ). De CAO noemt in de toelichting bij dit artikel de datum van 1 januari 1977, waarop de verplichting ingaat. Dat betekent niet dat per die datum alle dagbladen hun statuut gereed moesten hebben, wel dat op de drie betrokken partijen (directie, hoofdredactie en redactie) de inspanningsverplichting rustte de datum van invoering te halen. Bij de meeste dagbladen is dat ook gelukt. Niet bij allemaal, zoals uit het jaarverslag van de NVJ over 1977 (pag. 42) en een enquête uit 1978 van het Genootschap van Hoofdredacteuren blijkt. (1) Enkele bladen hebben de datum van invoering ver overschreden. Bovendien zijn er kranten die in het geheel geen redactiestatuut kennen, zoals het Reformatorisch Dagblad en Het Financieele Dagblad. Dat is evenwel niet in strijd met de CAO. Artikel 14 geldt namelijk als een artikel dat niet de arbeidsvoorwaarden betreft en dus niet bij CAO dwingend kan worden opgelegd. (2)

(1) Zie 4.10.2.

(2) Toelichting bij art. 1 (Draagwijdte der overeenkomst) van de CAO.

\section{2 "Model" of minimumregeling}

De teksten van de meeste dagbladstatuten vertonen grote overeenkomst, doordat zij bijna allemaal het modelstatuut als (letterlijk) voorbeeld hebben genomen. De begeleidingscommissie van de NVJ had haar leden daartoe geadviseerd. Zij was tevens van opinie dat het overeengekomen model als minimumregeling beschouwd moest worden. De NVJ-commissie verschilde daarin van mening met de NDP, die de nadruk legde op het "model"karakter van de overeengekomen tekst. De CAO verplicht tot vaststelling van een statuut "na overleg" (de toelichting spreekt van "in overleg" en deze formulering is ook in alle redactiestatuten terug te vinden) tussen directie, hoofdredactie en redactie. "Bij dit overleg zal gebruik gemaakt kunnen worden van het tussen NDP en NVJ overeengekomen model voor een dergelijk statuut." (art.14.3 CAO).

Deze laatste formulering is volstrekt helder: partijen kúnnen (ze moeten niet) gebruik maken van het model. Ze kunnen dus, in onderling overleg, tot afwijkende regelingen besluiten. Dat hoofdredactie en redactie tot een voor hen in gunsti- 
ge zin afwijkende regelingen kunnen komen staat nadrukkelijk in de CAO (art. 14 lid 3). Kunnen directie, hoofdredactie en redactie ook een statuut afsluiten dat een van de partijen minder biedt dan het model? In de toelichting worden het hoofdredactiestatuut en het modelstatuut "referentiekader" genoemd voor de positie van hoofdredactie resp. redactie. Wat in dit verband ook de betekenis van "referentiekader" is, in elk geval kan de term niet betekend hebben, dat een in negatieve zin van het model afwijkend statuut in strijd met de $\mathrm{CAO}$ zou zijn. Als dat wel bedoeld was, zou dat ongetwijfeld uit CAO-bepaling en toelichting hebben moeten blijken. Het feit dat de CAO voor Publiekstijdschriften in artikel 13 expliciet bepaalt dat, indien geen statuut is overeengekomen, automatisch het modelstatuut voor publiekstijdschriften geldt, is in tegenstelling tot wat Schuijt meent, eerder een aanwijzing voor de a contrario-interpretatie dan een aanwijzing van het model als ondergrens.

Dat partijen per dagblad speelruimte hadden bij het opstellen van hun eigen statuut valt bovendien uit de toelichting af te leiden, waar deze het "referentiekader" adstrueert met de opmerking dat partijen aldus hoopten te bereiken dat de statuten in de verschillende ondernemingen rekening zouden houden met en aangepast zijn aan "de specifieke behoeften en structuur van de dagbladondernemingen en de positie van de daarin werkzame journalisten." Slechts selectieve interpretatie leidt hieruit af dat van het modelstatuut alleen in "positieve" zin mag worden afgeweken. De "specifieke structuur" van een dagbladonderneming zou wel eens een andere richting in kunnen wijzen. Het redactiestatuut van het Nederlands Dagblad (7.4.12) is daar een voorbeeld van.

"Minimumregeling" impliceert bovendien dat per 1 januari 1977, de verplichte datum van invoering van een statuut, bij elk dagblad waar partijen op die dag nog geen overeenstemming over een eigen statuut hadden bereikt, automatisch het modelstatuut zou gelden. Partijen kunnen dit nooit bedoeld hebben. Door opzettelijk traineren zou één partij de andere een overeenkomst kunnen opdringen, waar zij principieel bezwaar tegen heeft/hebben.

Schuijt meent dat het modelstatuut als minimumregeling gaat werken, wanneer partijen er niet in slagen tot overeenstemming te komen. De goede trouw eist van partijen dat zij de totstandkoming van een overeenkomst niet blokkeren. Uit het feit dat het modelstatuut op enkele plaatsen zelf alternatieve regelingen aanbiedt leidt Schuijt af dat de mogelijkheden tot afwijking van het modelstatuut daartoe beperkt zijn en dat op grond daarvan niet van een model gesproken kan worden. (1) Dit argument kan niet overtuigen; daarvoor zijn de alternatieve regelingen van te ondergeschikt belang. Ze sluiten bovendien het "model"-karakter niet uit. Een andere reden waarom het modelstatuut "de facto en de jure" als ondergrens heeft te gelden is volgens Schuijt gelegen in het hoofdredactiestatuut, dat het karakter van minimumregeling zou hebben voor al die hoofdredacteuren, die er bij hun krant nog niet in geslaagd waren via individuele arbeidsvoorwaarden of de statuten van de onderneming hun onafhankelijke positie vast te leggen. Wat hiervan zij, het gaat naar mijn mening wat ver éen, toegegeven zeer belangrijk, on- 
derdeel van de verhouding uitgever - hoofdredactie de gehele inhoud van een driepartijenstatuut te laten bestrijken.

(1) Schuijt Werkers vart het woord, pag. $252 / 53$.

\section{3 "Redactiestatuten" bij andere media}

\subsubsection{Schrijvende Pers (niet-dagbladen); de zaak "Voorwaarts"}

In de voorafgaande paragraaf is er al aan herinnerd dat niet alleen de dagbladen een redactiestatuut kennen. Korte tijd na de kranten kregen ook de publiekstijdschriften en de opimiebladen hun eigen "modelstatuten", die in veel opzichten op die van het dagblad lijken. Invoering ervan geschiedde eveneens via een CAO, overeengekomen door NVJ en NOTU (Nederlandse Organisatie van Tijdschriftuitgevers). Inmiddels werken ook vaktijdschriften, nieuwsbladen, vakbondsbladen en huis-aan-huisbladen met eigen redactiestatuten. Ze zijn buiten dit onderzoek gehouden, mede omdat per type publicatie en per blad de verhouding uitgever - redactie nogal verschillend is. Over het algemeen hebben ze met elkaar gemeen, dat ze kleinere, soms zeer kleine, redacties kennen en een sterkere ideële dan wel commerciële band (soms beide) met hun uitgever hebben dan dagbláden. Dat kan eerder dan bij dagbladen tot conflicten leiden.

Een typisch voorbeeld van zo'n conflict deed zich voor bij het maandblad "Voorwaarts" dat zich als opinieblad afficheert. De zaak verdient daarom hier ruime aandacht, omdat voor het eerst een regeling in het redactiestatuut tot wijziging van de beginselen of van het redactionele karakter en de invloed van de (hoofd)redactie daarop (indirect) ter toetsing aan de rechter is voorgelegd.(1) Het bijzondere van "Voorwaarts" is dat het een orgaan is van een politieke partij (PvdA) met een hoofdredacteur die binnen de breed geformuleerde beginselen van het blad verantwoordelijk is voor de inhoud. De beginselverklaring geeft de redactie alle ruimte om over alles te schrijven wat direct of indirect met de sociaaldemocratie te maken heeft. "Voorwaarts" richt zich tot een publiek van ook niet-partijleden en noemt zich daarom opinieblad. In hoeverre de hoofdredacteur bij uitsluiting van anderen de verantwoordelijkheid kan opeisen is echter twijfelachtig, omdat volgens het redactiestatuut:

- bestuur en Tweede-Kamerfractie van de PvdA ruimte kunnen claimen in het blad;

- er een redactie-adviesraad is, bestaande uit prominente partijleden;

- in de drie maanden voor een verkiezing de redactie voeling moet houden met de campagneleiding over artikelen die de partij mogelijk zouden schaden. In die periode ontvangt de partijvoorzitter alle kopij vooraf ter inzage.

Schuijt (2) acht in het bijzonder het toezicht op de redactie tijdens de verkiezingscampagne een smet op dit statuut. Een blad dat zich als opinieblad afficheert, aldus Schuijt, mag zich ook in de verkiezingsstrijd niet verlagen tot een propagandamiddel. Daarvoor kan de partij brochures en pamfletten vervaardigen. De 
partij (uitgever), vond Schuijt, hinkte hier op twee gedachten en diende zijns inziens een duidelijke keus te maken.

Inderdaad heeft de partij zo'n keus gemaakt. Toen in 1987 de oplage van het blad hard achteruitholde en de financiële positie zeer slecht werd liet het partijbestuur een onderzoek uitvoeren naar de overlevingskansen van "Voorwaarts". Naar aanleiding van dit onderzoek deed het bestuur het voorstel een meerjarig beleidsplan op te stellen, waarin onder meer een versterkte binding tussen "Voorwaarts" en het partijbestuur opgenomen zou moeten zijn. Volgens de hoofdredacteur kwam het plan er echter op neer dat "Voorwaarts" minder als onafhankelijk opinieblad en meer als spreekbuis voor het partijstandpunt zou gaan fungeren. Volgens het redactiestatuut moet over een dergelijke redactionele koerswijziging diepgaand overleg met de hoofdredacteur gevoerd worden. Omdat de hoofdredacteur vond dat dit niet of in onvoldoende mate gebeurd was en het duidelijk werd dat aan de redactionele onafhankelijkheid getornd zou worden, zodat het hem niet langer mogelijk was naar behoren te functioneren, eiste hij in 1989 ontbinding van de arbeidsovereenkomst wegens wijziging in omstandigheden als bedoeld in artikel $1639 \mathrm{w}$ BW met schadevergoeding (drie jaarsalarissen).

De kantonrechter liet van zijn twijfel blijken of het partijbestuur wel diepgaand genoeg met de hoofdredacteur had overlegd, erkende dat deze nauwelijks invloed op de besluitvorming had kunnen uitoefenen, maar kwam tot de conclusie dat er nog geen definitieve beslissing gevallen was. Derhalve kan verweerster nog geen concrete inhoud geven aan het bij haar bestaande voornemen om de opzet van "Voorwaarts" ook in redactionele zin te wijzigen. Eerst als dit gebeurd is kan blijken of en in welke zin verweerster een gewijzigde opzet in bedoelde zin voorstaat en zo ja, of zij in haar streven tot het realiseren daarvan al dan niet handelt in overeenstemming met het dienaangaande in het Redactiestatuut bepaalde. Volgt toewijzing van de ontbinding van de arbeidsovereenkomst wegens het verstoord raken van de mogelijkheid tot samenwerking, echter zonder toekenning van een vergoeding, omdat niet is gebleken dat het verstoord raken van de mogelijkheid tot samenwerking in overwegende mate aan het partijbestuur is te wijten. Schuijt komt in zijn annotatie tot de conclusie dat de zaak voor de hoofdredacteur zo vervelend afgelopen is, omdat de kantonrechter niet aan de kernvraag is toegekomen; de zware adviesprocedure die het redactiestatuut voorschrijft in geval van wijziging van de redactionele formule was immers formeel nog niet bereikt. Hoewel Schuijt vanuit de plicht van de werkgever om zorgvuldig om te gaan met zijn personeel uit de feiten een andere uitkomst mogelijk oordeelt, acht hij de beschikking in het licht van het redactiestatuut van "Voorwaarts" te billijken. Het redactiestatuut als juridische bescherming van de journalist blijft volgens hem dan ook recht overeind.

Men kan echter ook stellen, dat een politieke partij als uitgever van een bladals "Voorwaarts" de (hoofd)redactie nooit de illusie had mogen geven dat zij een echt onafhankelijk opinieblad binnen een zo ruime beginselverklaring mocht maken. Hier is typisch sprake van een uitgever die zich ten aanzien van de identiteit niet afstandelijk kan en zal opstellen, een "Herausgeber - Verleger" in de typering van 
Rebe; zoals die in het volgende hoofdstuk ter sprake komt. Een dergelijke uitgever bemoeit zich zeer nadrukkelijk met de redactionele inhoud van krant of blad. Een (hoofd)redactie die ermee akkoord gaat in de verkiezingstijd haar kopij door de uitgever te laten controleren heeft dat in feite ook geaccepteerd.

(1) Kg Amsterdam, 16 november 1989; gepubl. in Mediaforum 1990-2, Bijlage pag: 21; met noot Schuijt.

(2) Schuijt Werkers wan het woord, pag. 371.

\subsubsection{De programmastatuten van de omroepen}

De omroepen, commerciële zowel als publieke, houden zich eveneens bezig met grondwettelijk beschermd openbaren en verspreiden van meningen en informatie, waarvoor bij de grondwetswijziging van 1983 een afzonderlijke regeling (art. 7 lid $2 \mathrm{Gw}$ ) is opgenomen. (1) Omroepen zijn dus ook journalistieke organisaties met interne gezagswerhoudingen die vergelijkbaar zijn met die van de schrijvende media. Net als in elke journalistieke organisatie zijn bij een omroep conflicten mogelijk met als inzet de vraag wie verantwoordelijk is voor een publicatie of uitzending. Reeds in 1969 was een geschil over de journalistieke onafhankelijkheid bij een omroep voor de NVJ aanleiding geweest om te proberen via de CAO regels aanvaard te krijgen voor dit soort conflicten. (2) Pas in $1982 \mathrm{kwam}$ in de $\mathrm{CAO}$ een aanbeveling - geen verplichting - aan alle zendgemachtigden om "programmastatuten" af te sluiten.

Waarom programmastatuten en geen redactiestatuten? Het bijzondere van omroeporganisaties is dat onder dezelfde leiding zowel journalistieke produkties in de traditionele zin van het woord, alsmede met publiekstijdschriften te vergelijken omroepbladen, tot stand komen, maar ook programma's die slechts met de grootste welwillendheid onder de noemer "journalistiek" te vangen zijn, zoals drama, film, concerten, amusementsprogramma's, etc. Eveneens bijzonder is dat de omroepen die onder de Mediawet vallen verplicht zijn de rechtsvorm "vereniging" te voeren, met de daarbij behorende gezagsstructuur. Dat heeft consequenties voor de gezagsverhoudingen. Reeds artikel 10 van de Omroepwet (thans art. 48 Mediawet) stelt elke instelling die zendtijd heeft verkregen verantwoordelijk voor hetgeen in haar zendtijd wordt uitgezonden. Verantwoordelijkheid voor uitzendingen leggen bij een met een hoofdredacteur vergelijkbare functionaris en niet bij het bestuur zou, zo was de opvatting van de omroepen, in strijd zijn met de wet. (3) Bovendien moeten zendgemachtigden, in tegenstelling tot dagbladen en tijdschriften, zich bij de inhoudelijke invulling van hun programma's houden aan bijzondere wettelijke voorschriften; zij moeten een volledig programma brengen met zelfs een procentueel voorgeschreven minimaal aandeel culturele, informatieve, educatieve en verstrooiende elementen.

Tenslotte is er met de inwerkingtreding van de Mediawet (1 januari 1988) nog een verschil met dagbladen en andere periodieken: de omroepverenigingen ex art. 14 Mediawet hebben een wettelijke plicht tot invoering van een eigen "programmastatuut". (Afgezien van de bladen als bedoeld in art. 129 Mediawet, die 
een redactiestatuut moeten overleggen alvorens in aanmerking te kunnen komen voor steun uit het Bedrijfsfonds voor de Pers). Artikel 64 lid 1 sub dis in de wet gekomen na aanneming in 1986 van het amendement Van der Sanden-Beinema en luidt: Omroepverenigingen die zendtijd hebben verkregen voor landelijke omroep: ( ......... ) brengen op de grondslag van hun verenigingsstatuten een programmastatuut tot stand, waarin de rechten en plichten van hun werknemers belast met de samenstelling van de omroepprogramma's, worden geregeld.

Op 1 oktober 1992, later verlengd tot 1 november 1992, moesten alle landelijke omroepen hun programmastatuut gereed hebben op straffe van een hoge geldboete. Zij zijn daar, zij het op het nippertje, ook in geslaagd. De NOS, hoewel daartoe niet verplicht, besloot vrijwillig een programmastatuut te laten opstellen. (4) De omroepen hebben er nauwelijks een geheim van gemaakt dat ze zonder veel enthousiasme aan het opstellen van hun statuut begonnen zijn. De meeste zien de noodzaak er niet van in en zeggen over hun statuut dat het slechts de al lang bestaande praktijk beschrijft. De wettelijke bepaling biedt bovendien weinig houvast voor wat er inhoudelijk in het statuut moet staan; de wet schrijft immers alleen voor dát er een programmastatuut moest zijn. Daar waar in het grote voorbeeld, de dagbladstatuten, bijvoorbeeld sprake is van waarborging van zoiets wijds als de redactionele vrijheid, is die vrijheid bij de omroepen bij voorbaat look in de wet) beperkt tot de ruimte die de verenigingsstatuten bieden. En die wáren altijd al richtsnoer voor het programmatisch handelen. Büna geen omroep beschouwt de nu door het Commissariaat afgedwongen huisarbeid daarom als echt inhoudelijk nieuw en van belang. (5) Alleen het programmastatuut van de VPRO, een omroep die relatief veel journalistieke medewerkers kent, vertoont overeenkomsten met de redactiestatuten van de dagbladen. Het VPRO-statuut kent bijvoorbeeld een programmaraad, die net als een redactieraad bij kranten gekozen wordt door de redactievergadering. (Bij het opstellen van het VPRO-programmastatuut heeft het Volkskrant-redactiestatuut model gestaan). Schuijt had er al eerder op gewezen dat bij deze omroep de regeling van de verhouding bestuur - programmamakers "nagenoeg alle elementen van een redactiestatuut" bevat.

Schuijt komt mede op grond van de parlementaire behandeling tot de conclusie dat een redelijke uitleg van de wettelijke bepaling tot inhoudelijke eisen aan het programmastatuut zou nopen. Het zou inhoudelijk vergelijkbaar moeten zijn met het redactiestatuut. Waar art. 64 lid 1 d spreekt over "rechten en plichten" van de programmamakers doelt de wet volgens hem op rechten en plichten met be trekking tot de journalistieke onafhankelijkheid, de benoeming van de programma-directeuren of hoofdredacteuren, medezeggenschap in het beleid van de hoofdredacteuren en medezeggenschap bij belangrijke besluiten, die invloed op het redactionele beleid kunnen hebben. (6) De praktijk heeft Schuijt daarin niet gevolgd, zoals ook NVJ-secretaris Robert Zaal bij de evaluatie van de ingeleverde programmastatuten constateert. (7) Vrijwel alle statuten (de VPRO is een uitzondering) leggen de journalistieke eindverantwoordelijkheid, die in de dagbladstatuten altijd bij de hoofdredacteur berust, in handen van functionarissen die als "di- 
recteur" worden aangeduid en die op hun beurt weer verantwoording verschuldigd zijn aan een algemeen directeur of aan het bestuur.

Zijn omroepen bij hun interne regeling van bewoegdheden inderdaad vergelijkbaar met dagbladen, zoals Schuijt - en met hem Zaal - aannemen? Daar past een genuanceerd antwoord op. Omroepen onderscheiden zich van de meeste dagbladen door de grote betekenis van de ideële identiteit voor hun bestaansrecht. Op enkele uitzonderingen na zijn de zendgemachtigden nog nauw gelieerd aan een maatschappelijke, politieke en/of godsdienstige zuil en nog steeds herinneren de identiteitsverklaringen van KRO, NCRV, VARA en in mindere mate AVRO daaraan. De jongere omroepverenigingen (Veronica, TROS) hebben weliswaar geen expliciete binding met een geestelijke, politieke of maatschappelijke stroming, maar claimen wel degelijk een eigen identiteit. (8) De verplichte verenigingsvorm met de (formeel) daarbij behorende inspraak van de leden versterken het belang van de gekozen identiteit alleen maar. In dat opzicht zijn zij te vergelijken. met een bijzonder soort dagbladen, namelijk de nog overgebleven typische "richtingbladen", zoals het Nederlands Dagblad, het Reformatorisch Dagblad en het Friesch Dagblad, welk laatste blad ook door een vereniging wordt uitgegeven; het bijzondere blijkt ook uit hun redactiestatuten (of de afwezigheid ervan). Bij de Nederlandse dagbladen is het in de regel eerder de redactie dan de uitgever die de identiteit van de krant representeert; bij de meeste omroepen is het door de leden gekozen bestuur de belichaming van de identiteit. Het is dit verschil dat het bijzondere karakter van de omroepprogrammastatuten verklaart. De V.P.R.O./VPRO is als uitzondering illlustratief. Daar is in de loop van de jaren zeventig en tachtig de verhouding ledenvergadering - bestuur - programmamakers juist heel sterk geẻvolueerd in de richting van de verhouding uitgever (directie) hoofdredactie - redactie bij een dagblad. Dat het programmastatuut van de VPRO geinspireerd is op het redactiestatuut van een dagblad, i.c. de Volkskrant, is dan ook niet toevallig. (9)

(1) Over de ratio daarvan vgl. o.a. J.M. de Meij Vitingsvrijheid, pag. 154 e.w.

(2) Naar aanleiding van de geruchtmakende affaire rond de journalist Frits wan der Poel, die door het KRO-bestuur ontslagen werd, nadat hij het plan had ingediend om een uitzending te wijden aan Phil Bloom, die eerder bloot was opgetreden in een VPRO-programma.

(3) Vgl. ook de opvatting van de toenmalige minister van CRM Engels, instemmend geciteerd door Schuijt Werkers van het woord, pag. 373 .

(4) Een auntal lokale en regionale omroepen, o.a. Omroep Brabant, Radio Rijnmond, Radio STAD Amsterdam, kenden, hoewel eveneens onverplicht, al eerder statuten.

(5) Spreek'buis van september 1992 Redactiestatuat: men doet braaf mee, mada...

(6) Schuijt Werkers van het woord. pag. 376 met voorstel tot wetswijziging in die geest op pag 400.

(7) Robert Zaal Commissariaat moet statuten inhoudelijk toetsen in De Journalist van 12 februari 1993 , pag. 35.

(8) Veronica heeft in de verenigingsstatuten onder de "beginselen en uitgangspunten van het programmabeleid" o.a. opgenomen dat zij in haar beleid uitgat van liberale opvattingen en zich in haar programma's richt tot alle groepen van de bevolking, waarbij in het bijzonder aan plaats en verantwoordelijkheid van de jongeren in de samenleving aandacht zal worden besteed. Veronica streeft er naar datgene in de ether te brengen waarin andere omroeporganisaties (nog) niet voorzien. Haar programma's moeten een positieve benadering van het maatschappelijk gebeuren 
stimuleren:

(9) Voor deze paragraaf is onder meer gebruik gemakt van gegevens uit de atstudeerscriptie $f$ et programmastatuut - noodzak of fomalitet? van Danielle Kool, Academie voor Jourmalistiek on Voorlichting - Tilburg, 1992.

\subsection{Korte beschrijving van alle Nederlandse dagbladstatuten}

In deze paragraaf wordt een korte karakteristiek gegeven van de redactiestatuten bij de Nederlandse dagbladen die ten behoeve van dit onderzoek ter beschikking werden gesteld. Bij de beschrijving is vooral gekeken naar datgene wat de diverse statuten onderscheidt van het modelstatuut voor hoofdredactie en redactie. Ook de identiteitsbeschrijving krijgt, wanneer zij deel uitmaakt van het redactiestatuut, hetgeen niet altijd het geval is, daarom aandacht. In de samenvatting en aan het eind van dit hoofdstuk zijn de naar mijn mening in positieve zin opvallende elementen uit deze redactiestatuten verzameld. Deze aanvankelijk als bijlage bedoelde paragraaf werd afgesloten op 31 oktober 1992. Sindsdien is tenminste éen krant met een eigen redactiestatuut (Het Binnenhof/Leidse Courant) verdwenen. Dit statuut komt in onderstaand overzicht dan ook niet meer voor. Ook de redactiestatuten van de gespecialiseerde dagbladen (Agrarisch Dagblad, Cobouw en de Nederlandse Staatscourant) zijn niet opgenomen. Zij zijn door hun speciale karakter en doelgroep moeilijk vergelijkbaar met het naar zijn aard "generalistische" dagblad. In deze categorie hoort ook Het Financieele Dagblad, dat geen redactiestatuut kent. Bij deze krant is de medezeggenschap van de redactie verreweg het beste, namelijk in de ondernemingsstatuten, gegarandeerd.

\subsubsection{Holdingmaatschappij De Telegraaf}

\subsubsection{De Courant Nieuws van de Dag}

Het redactiestatuut van De Telegraaf en van De Courant Nieuws van de Dag herinnert slechts globaal aan het modelstatuut en het is in zijn eigenzinnigheid dan ook een van de beste. Slechts weinig bladen hebben de verhouding uitgever en (hoofd)redactie, redactie - hoofdredactie (vice versa) en redactieraad - ondernemingsraad zo helder en werkbaar beschreven. Het Telegraaf-statuut geeft een naar journalistieke onafhankelijkheid strevende hoofdredactie en redactie meer kansen dan het gemiddelde redactiestatuut. De belangrijkste in positieve zin opvallende bepalingen uit het Telegraafstatuut:

1. Het benoemen van een hoofdredacteur, waarnemend-, plaatsvervangend- of adjuncthoofdredacteur tegen de wens van de redactieraad (waarin geen hoofdredacteur zit) is dermate lastig, dat het waarschijnlijk nooit zal gebeuren. (De ontslagprocedure daarentegen is eenvoudiger). De procedure bij de benoeming is als volgt:

- De directie draagt een kandidaat $(\mathrm{m} / \mathrm{v})$ voor; zij kijkt daarbij bij voorkeur naar kandidaten uit de redacties van De Telegraaf/De Courant Nieuws van de Dag. 
- De redactieraad heeft een gesprek met de kandidaat. Als de raad geen bezwaren heeft volgt voordracht tot benoeming.

- Heeft de redactieraad "redelijke bezwaren ( .... ) tegen de betrokkene met het oog op zijn of haar geschiktheid en/of bekwaamheid" dan brengt hij de bezwaren gemotiveerd ter kennis van de raad van commissarissen (het benoemende orgaan) en de afgewezen kandidaat.

- Als de directie de bezwaren van de redactieraad deelt of de kandidaat zich terugtrekt, komt de directie met een nieuwe kandidaat en herhaalt de procedure zich.

- Als de directie de bezwaren niet deelt, wordt de betrokkene kandidaat van de directie. In deze fase mag de redactieraad zelf ook met een kandidaat komen. De directie moet vervolgens uitvoerig aan de redactieraad motiveren, waarom zij haar kandidaat handhaaft.

- Blijft de redactieraad bij zijn bezwaren tegen de kandidaat van de directie, dan deelt hij die bezwaren mee aan de raad van commissarissen.

- Pas als dit niet tot wijziging van het standpunt leidt volgt benoeming door de raad van commissarissen van de kandidaat van de directie.

2. De "machtenscheiding" tussen hoofdredactie en directie is strikt omschreven: de hoofdredactie heeft de leiding van de redactie, de directie van de dagbladuitgeverij als onderneming. Het Telegraafstatuut vult die algemene regel aan met een paar bijzondere bepalingen:

- Hoofdredactie en redactie streven naar een vertrouwensbasis bij de begeleiding van de redactionele inhoud, al of niet in de vorm van een hoofdartikel.

- De hoofdredactie ziet er op toe dat ook de individuele leden van de redactie binnen de uitgangspunten van de krant in vrijheid hun tak kunnen uitoefenen.

- Als (een lid van) de hoofdredactie naar het oordeel van de redactieraad in strijd handelt met het redactiestatuut, kan de raad een klacht indienen bij de directie en als dat niet helpt zich tot de raad van commissarissen wenden. De hoofdredactie kan overigens hetzelfde doen, wanneer zij vindt dat de redactieraad of een lid ervan in strijd handelt met het statuut.

3. De directie zoekt voor beslissingen die van belang kunnen zijn voor het redactionele beleid vooraf overeenstemming met de hoofdredactie en de redactieraad. Tot die beslissingen behoren onder meer: belangrijke wijzigingen in het gezicht en de presentatie van de krant; ingrijpende wijzigingen in de organisatie van de redactie; blijvende ingrijpende wijzigingen van het tijdstip van het sluiten van de tekstpagina's; ontslagkwesties bij de redacties van de dagbladen.

4. Heel opmerkelijk is artikel IX over "ernstige geschillen van mening over de uitvoering en het van toepassing zijn van het redactiestatuut". Een partij die zich benadeeld voelt moet eerst proberen het conflict intern op te lossen. Als dat niet lukt "kan de zich benadeeld voelende partij zich wenden tot de burgerlijke rechter". De regeling is vooral daarom zo opmerkelijk, omdat de rechter het conflict ten volle mag beoordelen en niet op voorhand tot marginale toetsing beperkt is.

5. De identiteitsverklaring maakt deel uit van de ondernemingsstatuten van de beide bv"s die de bladen uitgeven. Zowel uitgever als (hoofd)redactie zijn er aan 
gebonden. De tekst van de verklaring is zo summier (de kranten geven "onpartijdig nieuws, zonder gebonden te zijn aan enige staatkundige partij, kerkelijke richting of belangengemeenschap, uitsluitend in dienst van 's lands belang") dat zij een redactie in beginsel ruime bewegingsvrijheid biedt.

\subsubsection{Limburgs Dagblad}

Hoofdredactie, redactie en directie van het Limburgs Dagblad, sinds 1972 eigendom van het Telegraaf-concern, hebben pas in november 1991 overeenstemming bereikt over een nieuw redactiestatuut, dat een statuut vervangt dat als onwerkbaar en beneden de minimumeisen van het NVJ-NDP-model werd beoordeeld. (1) Het nieuwe redactiestatuut is voor een belangrijk deel letterlijk overgenomen van het modelstatuut, maar bevat ook artikelen, waarvoor enkele minder geslaagde passages uit het Telegraafstatuut model hebben gestaan, zoals dat over het ontslag van de hoofdredacteur.

De beginselverklaring, die in het statuut is geïntegreerd, benadrukt de gerichtheid op het verspreidingsgebied. In de beginselverklaring is tevens de letterlijke tekst van artikel 3.1 uit het modelstatuut opgenomen, hetgeen alleszins te verdedigen is. Dat de hoofdredacteur de krant volgens conservatieve katholieke beginselen zou moeten redigeren (De Journalist) blijkt niet uit de relevante passages uit de beginselverklaring:

2.1 De uitgave Limburgs Dagblad is een regionaal dagblad, niet politiek gebonden, met een open oog en oor voor de belangen van en de ontwikkelingen in de regio. Feiten en ontwikkelingen in kerkelijke en levensbeschouwelijke gemeenschappen vinden - waar dat nodig en wenselijk is - hun weerslag in de uitgave Limburgs Dagblad. (.....)

2.3 Daarnaast dient er naar gestreefd te worden de functie als algemene krant zodanig te vervullen dat door een verantwoorde selectie uit het volledige algemene nieuws, beschouwingen daarover en commentaar daarop de lezers optimaal worden geinformeerd, waarbij de lezers toetsingsmaatstaven aangereikt krijgen voor de betekenis van, hun mening over, en de maatschappelijke relevantie van dat algemene nieuws. ( ................)

Ten onrechte is in de beginselverklaring ook opgenomen dat het statuut deel uitmaakt van de arbeidsvoorwaarden van iedere journalist ("van het betrokken dagblad") en dat de tekst van het redactiestatuut gewijzigd kan worden. In een beginselverklaring zijn dat irrelevante gegevens.

In de regeling voor de benoeming van een hoofdredacteur zit een ongelukkig element. De directie benoemt deze functionaris onder goedkeuring van de Raad van Commissarissen. Deze laatste is echter ook bevoegd een voordracht te doen aan de directie. Wanneer de raad van die bevoegdheid gebruik zou maken is de keuzemogelijkheid van de directie wel heel beperkt. Om van de inspraak van de redactieraad nog maar te zwijgen. De constructie is verdedigbaar wanneer de identiteit van het Limburgs Dagblad "verknocht" zou zijn aan de belangen die de 
Raad van Commissarissen in het bijzonder moet behartigen, maar daarvan blijkt niets.

De rol van de directie en de Raad van Commissarissen is ook opmerkelijk te noemen in art. 7.1 over de persoonlijke verantwoordelijkheid van een redactielid: Wanneer een lid van de redactie ernstige gewetensbezwaren heeft tegen een aan hem verstrekte opdracht en hij zich niet kan neerleggen bij een door de hoofdredactie genomen beslissing kan hij zich behalve tot de directie en de Raad van Commissarissen ook wenden iot de redactiecommissie en/of redactieraad voor een uitspraak en met een verzoek om te bemiddelen. (.......)

Onnodig ingewikkeld - en daarmee verhullend - is de verwijzing naar art. 51.3 $\mathrm{CAO}$ om aan te geven dat de redactieraad zich tot de kortgedingrechter kan wenden bij een meningsverschil over procedureregels bij een aantal belangrijke beslissingen van de directie.

(1) De Journalist van 8 september 1986.

\subsubsection{Nederlandse Dagbladunie}

\subsubsection{Algemeen Dagblad}

Bij het Algemeen Dagblad is sinds 1. maart 1991 een nieuwe versie van het redactiestatuut van kracht. Het is een aanpassing van het statuut dat als datum november 1984 draagt, dat op zijn beurt weer een eerdere versie verving.

Ook het nieuwste statuut is tamelijk traditioneel in de zin dat het in grote lijnen het modelstatuut volgt. De korte en zakelijke beginselverklaring maakt er deel van uit: Het Algemeen Dagblad heeft geen binding met enige politieke partij; enig kerkgenootschap of andere maatschappelijke groepering. Het Algemeen Dagblad wordt in vrijzinnige geest geredigeerd vanuit de beginselen die ten grondslag liggen aan de parlementaire democratie en vanuit de beginselen van een sociaal-economische orde op basis van de ondememingsgewijze produktie via de particuliere ondernemingsvorm, waarbij het instemt met uit de eisen van de tijd voortvloeiende beperkingen van de ondernemingsgewijze produktie. In de daaropvolgende "uitgangspunten" is de redactionele formule vastgelegd: Het Algemeen Dagblad is een populair, betrouwbaar, landelijk ochtendblad. Het legt zich toe op het verschaffen van nieuws, commentaar, beschouwingen en onderhoudende bijdragen in woord en beeld aan een breed lezerspubliek. In de uitgangspunten is ook opgenomen de (hoofd)redactionele zelfstandigheid en de gebruikelijke redelijk-rendementseis.

Het AD-stuk wijkt op een aantal punten af van het model en van andere dagbladstatuten:

- Tot de organen van de dagbladonderneming wordt ook de redactie zelf gerekend. Ook het NVJ-concept uit 1973 doet dat. Het is echter een orgaan zonder bevoegdheden.

- Nieuw is dat het geautomatiseerd redactioneel systeem, zijn beheer, de vertrou- 
welijkheid van de gegevens en het privédomein binnen het systeem van de inclividuele redacteur in het statuut geregeld zijn.

- In het vorige statuut was de hoofdredacteur nog q.q voorzitter van de redactieraad. In het nieuwe mag geen lid van de hoofdredactie meer zitting hebben in de redactieraad. De hoofdredacteur woont wel elke vergadering bij en mag er ook het woord voeren; dat laatste blijkt impliciet uit de bepaling dat de redactieraad ook "het orgaan van wederzijdse informatie en onderling beraad tussen redactie en hoofdredacteur" is. Ten overvloede is vermeld dat hij geen stemrecht heeft.

- De hoofdredacteur moet met de redactieraad "uitvoerig" overleggen wanneer hij intern of extern een columnist aanzoekt. Is de raad het met de keuze niet eens, dan moet de hoofdredacteur schriftelijk motiveren waarom hij het advies negeert. - Uit het oude statuut is overgenomen dat ontslag van leden van de redactie slechts kan geschieden "in overleg met de hoofdredacteur". Dit is een positieve afwijking van de $\mathrm{CAO}$.

\subsubsection{Rijn en Gouwe}

Rijn en Gouwe ("Ochtendblad voor Midden-Holland") is een kopblad van het Algemeen Dagblad, maar met een eigen hoofdredactie en een eigen statuut. Het blad neemt in beginsel de landelijke pagina's over van het Algemeen Dagblad, maar heeft de vrijheid om bijvoorbeeld een AD-columnist buiten de eigen pagina's te houden. (1) De beginselverklaring is die van het $\mathrm{AD}$, maar met de toevoeging in de redactionele uitgangspunten dat het een regionaal ochtendblad, dat oog heeft voor de gelijkgerichte belangen, die zich in Midden-Holland manifesteren (is). Het geeft het redactionele beleid zodanig gestalte, dat het overeenkomt met de culturele, godsdienstige en maatschappelijke opvattingen van een zo breed mogelijke laag van de bevolking in het verschijningsgebied.

Hoewel Rijn en Gouwe inhoudelijk nauw gelieerd is aan het Algemeen Dagblad komt de naam van deze krant niet in het statuut voor. De directie ressorteert onder de directie van "N.R.C." B.V., die tevens als raad van commissarissen van Dagblad van Rijn en Gouwe B.V. optreedt. De benoeming door de directie van de hoofdredacteur van Rijn en Gouwe is onderworpen aan de goedkeuring van de directie van "N.R.C." B.V.

(1) De Journalist wan 17 juli 1989

\subsubsection{De Dordtenaar}

De Dordtenaar is, evenals Rijn en Gouwe, een kopblad van het Algemeen Dagblad, eveneens met een eigen hoofdredactie. De band met het Algemeen Dagblad, het regionale karakter en het verspreidingsgebied worden in de redactionele uitgangspunten genoemd: De Dordtenaar is een dochterblad van het Algemeen Dagblad en als zodanig voornamelijk aangewezen op de binnen-en buitenlandse berichtgeving van dit blad, alsmede op de commentaren die uit de 
berichtgeving kumen voortspruiten. Niet opgenomen is dat het redactionele beleid overeenkomt met de "culturele, godsdienstige en maatschappelijke opvattingen" van de bevolking van het verspreidingsgebied (de Dordtse-, Zwijndrechtse-, Hoelkse- en Alblasserwaard).

Voor het overige is het redactiestatuut van de Dordtenaar gelijk aan dat van Rijn en Gouwe - op enkele details na, in dat van de Dordtenaar bij voorbeeld geldt de gewetensbescherming ook voor een fotojournalist die bij de krant in dienst is.

\subsubsection{NRC Handelsblad}

Het redactiestatuut van NRC Handelsblad, gedateerd 8 januari 1985, kent een gecompliceerde, maar vrijwel waterdichte regeling om te verhinderen dat een hoofdredacteur benoemd wordt tegen de wens van tweederden van de redactievergadering.

De hoofdredacteur wordt benoemd door de directie van de NDU BV, na voorafgaande goedkeuring van de raad van commissarissen van de NDU. Wanneer de directie over wil gaan tot benoeming van een kandidaat, tegen wie tweederden van het totale aantal redactieleden "onoverkomelijke bezwaren" hebben, "een en ander op gronden ontleend aan het redactionele kennen en kunnen en de leiderschapskwaliteiten van de te benoemen hoofdredacteur", zulks in het bijzonder in relatie tot de redactionele beginselen en uitgangspunten van de krant, "zal de raad van commissarissen zijn goedkeuring aan de benoeming onthouden". Wanneer de raad van commissarissen meent dat de besluitvorming van de redactievergadering "niet in redelijkheid heeft plaatsgevonden" moet de redactieraad een nieuwe redactievergadering uitschrijven, die zich nogmaals over de voorgenomen benoeming moet uitspreken. Tussen deze en de vorige redactievergadering moet tenminste een periode van tien dagen liggen. Hoewel het niet expliciet in het statuut staat, moet de raad van commissarissen gebonden worden geacht aan de bevestiging van de afwijzing.

Evenals bij het Algemeen Dagblad zijn de "beginselen plus uitgangspunten" van NRC Handelsblad summier en zakelijk. Zij luiden (gedeeltelijk): NRC Handelsblad is een landelijk dagblad, dat geen binding heeft met enige politieke of religieuze groepering of met belangengroepen, een objectieve nieuwsvoorziening nastreeft en een kritische functie vervult binnen het Nederlands parlementair staatkundig bestel. NRC Handelsblad wordt geredigeerd vanuit een liberale geesteshouding met eerbied voor het individu en de beginselen van verdraagzaamheid, redelijkheid en openheid voor de geest van de tijd. NRC Handelsblad streeft een brede en diepgaande berichtgeving na, die analyserend wordt begeleid. Binnen de eindverantwoordelijkheid en de bevoegdheid van de hoofdredacteur wordt bij de journalistieke vormgeving aan de gestelde beginselen de eigen verantwoondelijkheid van de redacteuren voor het door hen geleverde werk als beginsel genomen.

Werd bij het Algemeen Dagblad nog een "redelijk rendement van het geïnvesteerde vermogen van Dagbladunie" geëist, NRC Handelsblad moet ter bevordering 
van de continuiteit "een bijdrage" leveren aan het rendement van het geinvesteerde vermogen.

De hoofdredacteur is geen lid van de redactieraad (hij hoort niet tot de redactie; een adjunct-hoofdredacteur wel), maar wanneer de redactieraad met de hoofdre dacteur vergadert is deze laatste voorzitter van het overleg. Het NRC Handelsblad-statuut heeft de mogelijke gewetensbezwaren die een redactielid kan aanvoeren eng geformuleerd. Die moeten zo ernstig zijn dat "redelijkerwijs van hem niet kan worden gevraagd de dienstbetrekking te laten voortduren". Evenals in het $A D$-statuut kan - in afwijking van de $C A O$ - de directie een personeelslid slechts ontslaan "in overleg" met de hoofdredacteur.

\subsubsection{Brabants Nieuwsblad}

Het Brabants Nieuwsblad, dagblad yoor West-Brabant, behoort sinds 1979 tot de Nederlandse Dagbladunie. Het redactiestatuut is vrijwel letterlijk overgenomen van het "modelstatuut". Er zijn een paar wijzigingen aangebracht:

- de plenaire redactievergadering heet in dit statuut weer "het belangrijkste orgaan voor de medezeggenschap van de redactie". De formulering stamt uit het NVJ-concept van 1973, maar is niet overgenomen in het modelstatuut. De vergaande consequenties van het NVJ-concept zijn echter niet gevolgd.

- De redactieraad heeft zijn zwaarwegend adviesrecht niet alleen bij de benoeming van een hoofdredacteur, maar ook van een adjunct-hoofdredacteur en een algemeen redactiechef, aan wie een gedeelte van de taak van de hoofdredactie gedelegeerd wordt.

- Wanneer de hoofdredacteur, die lid en voorzitter is van de redactieraad, met de raad overlegt over het beleid van de hoofdredactie, zijn de conclusies van de raad niet bindend, maar evenmin vrijblijvend. Indien de hoofdredactie in haar werantwoordelijkheid meent een conclusie van de redactieraad niet te kumnen aanvaarden, maakt zij op zo kort mogelijke termijn haar standpunt gemotiveerd kenbaar aan de andere leden van de raad.

- De drectie bepaalt het ammal joumalisten en hun individuele arbeidsvoorwaarden "met instemming van de hoofdredactie".

Het Brabants Nieuwsblad heeft zun beginselverklanng ook opgenomen in de stawhen van de onderneming. Het is de oorspronkelike tekst van vốr de overneming door de NDU. Zij luidt: De Vennootschap heeft ten doel het uitgeven wan dagbladen, watin her redactionele beleid zodanig gestalte krigt dat dit beteid overeenkomt met de culturele, godsdienstige en ideele opvatingen van een zo breed mogelike laag wan de bevolking in het verspreidingsgebied. De redactie verstat deze doelstelling als volgt: (...) BN is een onafhankelijk dagblad aat uitgat wan algemene waarden wan christendom en humanisme. BN zal niet opreden als orgaan wan enige polineke, naatschappelijke, religieuze of andere groepering. 


\subsubsection{VNU Dagbladengroep}

\subsubsection{1 $w / h$ AUDET: (De Gelderlander; De Limburger; De Stem; Dagblad voor Noord-Limburg)}

Sedert de overneming in 1988 van de dagbladen van de ALDET-groep door de Verenigde Nederlandse Uitgeversbedrijven (VNU) vormen zij samen met de bladen van de Brabant Pers de VNU Dagbladengroep B.V. De statuten van de AUDET- en Brabant Persbladen dateren van vóór 1988. De statuten "voor hoofdredacteur en redactie" van de vier voormalige AUDET-kranten zijn op kleine onderdelen na geheel identiek. De beginselverklaring benadrukt de gerichtheid op de lezers en de belangen van het verspreidingsgebied. Het redactionele beleid (...... ) zal uitgaan van de beginselen van het christendom en de daarmee corresponderende waarden van het humanisme (De Gelderlander: van de waarden van het christendom en humanisme) en gericht zijn op het bevorderen van menselijke en verdraagzame verhoudingen in de samenleving, zoals die herkend worden

- in de eerbied voor de mens en voor het menselijk leven

- in de erkenning van de gelijkwaardigheid van allen en deswege in de bevordering van democratische verhoudingen in de samenleving- in het streven naar de geestelijke, maatschappelijke en culturele ontplooiing van de mens

- in de plicht recht te doen aan de opvattingen van minderheden

- in het getuigen van gerechtigheid en naastenliefde (De Gelderlander: ... van gerechtigheid, naastenliefde en medemenselijkheid)

- in de bevordering van de vrede in alle sectoren van de menselijke samenleving

- in het opkomen voor zwakken en onderdrukten.

Anders dan bij de meeste statuten zijn bij de ex-AUDET-bladen ook de redactionele richtlijnen in het redactiestatuut verwerkt. Het beginsel van "hoor en wederhoor", adequate beantwoording van reacties van lezers en het streven naar "een onpartijdige" (De Gelderlander: "zo objectief mogelijke") en accurate weergave van zorgvuldig gecontroleerde feiten" zijn erin opgenomen. Alleen in het statuut van het Dagblad voor Noord-Limburg is opgenomen dat de redactieraad toeziet "op de interpretatie en naleving" van de redactionele richtlijnen. Dat berust waarschijnlijk op een vergissing, omdat die bevoegdheid ligt bij het orgaan waaraan de hoofdredacteur verantwoording is verschuldigd en dat hem benoemd heeft.

De hoofdredacteur wordt benoemd door de algemene vergadering van aandeelhouders; voor alle vier kranten is dat thans de directie van VNU Dagbladengroep B.V. (1) Voordracht tot benoeming hebben de directie en de raad van commissarissen samen. Alvorens hun aanbeveling op te maken plegen zij diepgaand overleg met de redactieraad, die ook het recht van voordracht heeft. Wanneer de redactieraad van dat recht gebruik maakt is zij verplicht de redactievergadering te raadplegen, die bij gekwalificeerde meerderheid (driekwart van tenminste het quorum van tweederden van alle stemgerechtigden) een uitspraak doet over de voordracht van de redactieraad, dat wil zeggen een uitspraak over de keuze van 
de redactieraad, niet over eventuele andere kandidaten. In het reglement voor de redactieraad en de redactievergadering van de Gelderlander is de procedure nader omschreven. De raadpleging van de redactievergadering wordt daarin omschreven als "een zakelijke toetsing van de kwalificaties van de beoogde kandidaat aan criteria, zoals die zijn neergelegd in het profiel van een hoofdredacteur". Dit profiel is opgemaakt door de redactieraad en ter goedkeuring voorgelegd aan de redactievergadering.

Wanneer de voordracht van de redactieraad een andere is dan die van directie en raad van commissarissen volgt de procedure zoals in het modelstatuut in 3.7 beschreven.

De vergaderingen van de redactieraad, waarvan de hoofdredacteur zowel hid als voorzitter is, zijn besloten, tenzij de raad zelf beslist dat de vergadering toegankelijk moet zijn voor alle redactieleden. De ex-AUDET-bladen hebben het modelstatuut aangevuld met de aantekening dat de conclusies van het overleg binnen de redactieraad voor de hoofdredacteur niet bindend zijn, maar ook niet vrijblijvend. Voor het overige volgen de redactiestatuten in grote lijnen het modelstatuut.

(1) Bij de bladen van Brabant-Pers is rekening gehouden met de mogelijkheid dat de directie van Brabant Pers ook vertegenwoordigd is in de directie van de VNU-Dagbladengroep. In dat geval wordt de hoofdredacteur benoemd door de Raad van Bestuur van VNU.

\subsubsection{Brabant Pers (Eindhovens Dagblad, Brabants Dagblad, Het Nieuwsblad)}

Deze drie kranten hebben sinds 1985 een identiek statuut, dat in grote lijnen ontleend is aan het modelstatuut van NVJ en NDP. In tegensteling tot de ex-AUDETbladen hebben de Brabant-Persbladen hun nawwe relatie tot elkaar in de statuten opgenomen. Brabant Pers B.V. wordt namelijk omschreven als "uitgever van de zelfstandige doch onderling samenwerkende dagbladen", terwijl elk statuut als gemeenschappelijk orgaan het "College van Hoofdredacteuren" kent. Dit is het "overleg- en beleidsorgaan voor de tenuitvoerlegging van de samenwerking tussen de BP-dagbladen". De hoofdredacteuren van de drie kranten zijn er stemgerechtigd lid van. Voor zover het de redactionele samenwerking betreft is het college in zijn geheel en zijn de leden persoonlijk verantwoordelijk voor de overeengekomen gemeenschappelijkheid; de afzonderlijke hoofdredacteuren zijn daarnaast verantwoordelijk voor het aandeel van hun redactie daarin. Samenwerking is er ook tussen de drie redactieraden die met elkaar kunnen vergaderen en zich, samen of afzonderlijk, tot het College van Hoofdredacteuren kunnen wenden. Als een van de kranten wijzigingen aanbrengt in een artikel van een journalist van een andere BP-krant of een artikel om zijn inhoud of strekking weigert te plaatsen, is beroep op de eigen redactieraad van die journalist mogelijk.

De beginselverklaring van de drie kranten is uiteraard ook identiek. Zij is als preambule onder de benaming "redactionele beleidslijn" in het statuut opgenomen. $\mathrm{Z}_{\mathrm{ij}}$ moet samen met de richtlijnen waaraan elke hoofdredacteur voor de 
eigen krant gebonden is publiekelijk toegankelijk zijn. De redactionele beleidslijn beschrijft enerzijds de samenwerking tussen de bladen en anderzijds hun redactionele zelfstandigheid, die berust op hun gebondenheid aan hun specifieke regio's die elk voor zich in meer of mindere mate een sterk homogeen karakter hebben. (.........) Met de redactionele zelfstandigheid van de dagbladen van Brabarit Pers wordt tevens beoogd, voor een niet nodeloos prijs te geven deel bij te dragen aan de pluriformiteit, in nieuwsvoorziening en vooral in meningsuiting en meningsvorming, van de gehele Nederlandse dagbladpers. De beleidslijn omvat ook een beschrijving van de "dubbelformule": regionale krant en algemene krant, onder de erkenning dat niet elke redactie de dubbelformule identiek zal interpreteren en toepassen. De BP-bladen hebben in hun monopoloilde positie en gegeven het feit, dat van 70 tot 85 procent van hun lezers op geen ander dagblad is geabonneerd, de vanzelfsprekende verplichting ook hun algemene berichtgeving (.....) optimaal te verzorgen.

De beleidslijn eindigt met de ideële uitgangspunten, die zoals gebruikelijk bij regionale bladen, verwijzen naar de waarden en normen van de westerse democratie, het christendom en het humanisme.

De hoofdredacteur wordt benoemd door de directie van Brabant Pers B.V. onder goedkeuring van de directie van de VNU-Dagbladengroep. Ingeval de directie van Brabant Pers B.V. ook vertegenwoordigd is in de directie van VNU Dagbladengroep B.V. moet de Raad van Bestuur van de VNU de benoeming goedkeuren. De samenwerking tussen de drie bladen speelt ook een rol bij de benoeming. Het College van Hoofdredacteuren heeft een recht van voordracht, evenals de redactieraad van de betreffende krant en de directie van de VNUdagbladengroep. Wanneer deze laatste - die tenslotte de feitelijk benoemende instantie is - van dat recht gebruik zou maken, lijkt het recht van voordracht van alle andlere partijen illusoir. Hetzelfde geldt voor het aanbevelingsrecht van de redactieraad wanneer het College van Hoofdredacteuren een voordracht (tot coöptatie) zou doen. In de verdere afwikkeling volgen de BP-statuten het model.

De BP-bladen hebben er explicieter dan de meeste andere statuten rekening mee gehouden dat er (ernstige) meningsverschillen tussen de hoofdredacteur en de redactieraad kunnen optreden. Artikel 4.3 .3 over de redactieraad luidt: De redactieraad kan binnen zijn competentie besluiten nemen. Hij gaat over tot stemming indien een lid dat wenst. Indien de hoofdredacteur kenbaar maakt zich niet met een door stemming tot stand gekomen besluit te kunnen verenigen, kan de redactieraad het geschilpunt aan de redactievergadering voorleggen.

Dit artikel wordt gevolgd door de navolgende toelichting: De hoofdredacteur is aangesteld om leiding te geven bij het vervaardigen van het journalistieke produkt. Hij kan deze functie alleen dan zinvol en doelmatig uitoefenen wanneer er tussen hem en de redactie in het algemeen een consensus bestaat over de beleids handelingen die zijn taak als hoofdredacteur meebrengt. Het spreekt daarbij vanzelf dat beide partijen deze consensus nastreven.

De huidige structuur van de dagbladonderneming laat toe dat verschillen van 
mening tussen redactie en hoofdredacteur worden blootgelegd. Artikel 4.3 .3 biedt daartoe de mogelijkheid. De hoofdredacteur kan immers bestuiten van de redactievergadering naast zich neerleggen.

Een incidenteel verschil van mening tussen hoofdredacteur en redactie hoeft niet in te houden dat zich tussen leider en team een structureel conflict voordoet. Wanneer echter aan de hand van procedures conform art. 4.3 .3 een fundanemteel meningsverschil zich herhaaldelijk voordoet, kan wël van een structureel conflict worden gesproken. Een dengelijk conflict maakt de noodzakelijke redactionele samenwerking onmogelijk, omdat dan van de gewenste consensus geen sprake meer is.

\subsubsection{Wegener-Tijl-Oostelijke Dagbladen Combinatie}

\subsubsection{Utrechts Nieuwsblad}

Het Utrechts Nieuwsblad (UN), met zijn kopbladen Tielse Courant en Dagblad Rivierenland, heeft de identiteit tot uitdrukking gebracht in de "Richtlijnen van het Utrechts Nieuwsblad", waarvan de laatste versie uit januari 1979 dateert. Deze richtlijnen zijn, geheel volgens de bedoeling van het Modelstatuut, opgenomen in een apart document, dat voor elke gënteresseerde op aanvraag verkrijgbaar is.

Vergeleken met de identiteitsverklaring van de meeste kranten is die van het Utrechts Nieuwsblad lang en detaillistisch. Des te opmerkelijkijker is dan ook dat de verklaring slechts terloops en in een ongelukkige context het regionale karakter van de krant noemt. De verklaring daarvoor kan slechts zijn dat de naam van de krant het regionale karakter al voldoende uitdrukt en dat de gerichtheid op haar regio daarom niet opnieuw geëxpliciteerd hoeft te worden.

Aan de richtlijnen gaat een preambule vooraf, met de gebruikelijke "onafhankelijkheidsverklaring" en een passage alls: De pluriformiteit van de krant wil de redactie bevorderen door het plaatsen van bijdragen van opiniërende aard van eigen redactieleden, van speciaal daartoe aangetrokken columnisten en van ande. ren, wier opinie de meningsvorming over alle ontwikkelingen in de maatschappij, in het bijzonder die in het verspreidingsgebied, ten goede komt.

In de richtlijnen vallen punten op als: Ondersteuning en verdediging van een democratische rechtsorde met parlementaire regeringsvorm, algemeen kiesrecht, ( ..... ) Erkenning van de waarde van de historische eenheid van Nederland en Oranje, binnen het verband van de constitutionele monarchie. ( ..........) Erkenning van de Nederlandse samenleving als een levende werkelijkheid, in staat uitheemse elementen in zich op te nemen, gelijk zij door de eeuwen deed. ( ....... Bescherming van het particulier bezit als een der grondslagen van de persoonlijke vrijheid. Aanvaarding van de ondernemingsgewijze productie en vrije vakverenigingen als basis van de sociaal-economische orde, bevordering van een zo breed mogelijke toepassing van de democratie in het bedriffsleven. ( .........) Ondersteuning van een defensiebeleid, actief gericht op vrede en op bescherming 
en beveiliging van Nederland, de democratische vrijheden en de maatschappelijke verworvenheden van ons land.

Het redactiestatuut, gedateerd 11 oktober 1976, is vrijwel letterlijk overgenomen van het "modelstatuut". Dat is geen wonder, ondat de toenmalige hoofdredacteur van het UN, drs. M. Snijders, een belangrijke rol heeft gespeeld bij de totstandkoming van de definitieve tekst van het model. Hij was voorzitter van de NVJ-delegatie:

Het UN-statuut bevat ook enkele tekstwijzigingen die als een duidelijke verbetering op te vatten zijn. Zo is art. 5.2.2 van het model overgebracht naar de paragraaf over de bevoegdheden van de redactieraad, waar het ook thuishoort. Na de bepaling dat de directie verplicht is zowel de redactieraad als de ondernemingsraad in te lichten over vergevorderde plannen tot reorganisatie, fusie, verkoop of liquidatie van de krant volgt: Dit geschiedt op een zodanig tijdstip, dat bovengenoemde organen niet voor een voldongen feit worden gesteld.

Art. 5.1.8 van het UN-statuut (idem in het model) zegt dat de directie de hoofdredactie regelmatig al dan niet vertrouwelijk laat kennisnemen van bescheiden die belangrijk zijn voor een inzicht in de exploitatie. Het modelstatuut bepaalt dat dit altijd vertrouwelijk moet gebeuren. In art. 5.1.10 (idem modelstatuut) wordt de hoofdredactie uitgenodigd tot het bijwonen van de vergadering van commissarissen en directie. Wanneer de UN-hoofdredactie zo'n uitnodiging krijgt moet zij daarvan de redactieraad op de hoogte brengen.

\subsubsection{Wegener-Dagbladen}

De bladen die op 1 januari 1980 tot Wegener's Couranten Concern behoorden hebben een eigen statuut. Dat waren indertijd de Nieuwe Apeldoornse Courant (thans Apeldoornse Courant) en haar toenmalige kopbladen Noord Veluws Dagblad, De Vallei, Tielse Courant "of in deze combinatie nog uit te geven of te wijzigen titels." Inmiddels heeft hier een wijziging plaatsgevonden. De Vallei is, samen met de Edese Courant opgegaan in het Het Gelders Dagblad en de Tielse Courant is kopblad van het Utrechts Nieuwsblad geworden.

Het redactiestatuut volgt vrijwel woordelijk het modelstatuut. Het wijkt af op de volgende punten:

- Wijziging van het redactiestatuut door de directie is mogelijk via de "zware procedure" van het modelstatuut; het Wegener-statuut bepaalt echter ook dat het slechts gewijzigd kan worden "in overleg" met de hoofdredacteur en de redactieraad.

- De hoofdredacteur heeft voorafgaande goedkeuring van de directie nodig wanneer hij geregelde commentariërende joumalistieke arbeid aan anderen dan de hoofdredacteur wil overlaten. De bepaling wekt de sterke indruk dat de directeur zich met een zeer journalistieke beslissing mag bemoeien.

- De hoofdredacteur is lid en voorzitter van de redactieraad, waarvan de vergaderingen niet openbaar zijn. Tenminste een zetel in de raad is gereserveerd voor de kopbladen. 
- Een journalist die een functie aanvaardt die strijdig kan zijn met het vervullen van zijn functie op de krant moet dit aan de hoofdredactie melden. Wanneer deze en ook de redactieraad van mening zijn dat beide functies niet combineren zijn, kan de journalist gevraagd worden zijn nevenfunctie neer te leggen. Weigert hij, dan kan dat consequenties hebben voor zijn functie op de krant.

Het Wegener-statuut legt in zijn beginselverklaring grote nadruk op de gerichtheid op het verspreidingsgebied. En hoewel de dagbladen uitgaan "van het democratisch beginsel dat de lezers zich zelf wel een oordeel zullen vormen", willen zij "niet neutraal zijn in de zin van karakterloos. Zij begeleiden hun informatie in woord en beeld met daarvan duidelijk gescheiden comentaren, die het gebeuren toetsen", waarna een tiental criteria volgen.

De meeste bewoners in het verspreidingsgebied zijn voor hun regionale nieuws uitsluitend aangewezen op de kranten van Wegener. Daarom zullen deze dagbladen in het bijzonder zorgvuldig zijn bij de behandeling van controversielle onderwerpen, informatie die de privacy van inwoners wan verspreidingsgebieden raakt en de berichtgeving over extreme gebeurtenissen (........... . . De beginselverklaring laat zich ook uit over de uiterlijke vorm van de Wegenerbladen: In de typografische vormgeving en expressie van de dagbladen wordt voortdurend gestreefd naar evenwichtige verhoudingen en een gematigd koppenbeeld. De toon van de dagbladen zal blijk geven van respect voor de menselijke waardigheid en van een normaal, beschaafd taalgebruik.

NB: Overigens komen hele passages uit de beginselverklaring in het redactiestatuut van de Wegenerbladen vrijwel woordelijk overeen met die in het statuut van de Sijthoff-pers (Haagsche Courant).

\subsubsection{Drents-Groningse Pers}

Het redactiestatuut van de bladen van de Drents-Groningse Pers B.V., dochteronderneming van Wegener Tijl Couranten Concern N.V., dateert van 1989. Het is een vooral zeer leesbare bewerking van het modelstatuut, waarvan het de inhoud vrijwel geheel heeft overgenomen. Leesbaarheid en luciditeit kenmerken ook de uitwerking van de beginselverklaring uit de ondernemingsstatuten, waarin onder meer verwezen wordt naar de "traditionele vrijzinnige houding, die de bedoelde dagbladen sinds hun oprichting hebben gekenmerkt". Ook hier ligt de nadruk op hun gerichtheid op het verspreidingsgebied: De kranten houden bij de witoefening van hun functie als regionaal communicatiemiddel voor alle inwoners van Noord-Nederland (specifiek Drenthe en Groningen) rekening met het feit dat hun lezerskring zeer gedifferentieerd is van samenstelling, zowel qua politieke en/of religieuze en/of levensbeschouwelijke gezindheid, als qua leeftijd, opleiding, beroep en welstand.

Evenwichtige typografische vormgeving, een zo groot mogelijke leesbaarheid van stukken, begrijpelijke en beschaafde koppen en "een zorgvuldige vormgeving, met als doel een levendig paginabeeld", hebben ook een plaats gekregen in de beginselverklaring. 


\subsubsection{Zwolse Courant}

Het redactiestatuut van de Zwolse Courant met de kopbladen Nieuw Kamper Dagblad en Het Nieuwe Land dateert van maart 1983 en is het resultaat van een overeenkomst tussen directie van de Kon. Drukkerij en Uitgeverij van de Erven J.J. Tijl B.V., de hoofdredactie en de redactiecommissie. Een protocol over de totstandkoming van dit statuut voor zowel dag-als nieuwsbladen maakt er deel van uit. De drie contractpartijen wensen daarin vast te leggen "dat het statuut niet is ontstaan in een gepolariseerde opstelling". Een opvallende opmerking in dit protocol is de toelichting bij het artikel dat de redactieraad ook het recht van voordracht van ontslag van de hoofdredacteur geeft. Dit artikel is opgenomen met inachtneming van de hierbij neergelegde verklaring dat van dit recht uitsluitend gebruik zal worden gemaakt indien sprake is van "een uiterste consequentie waarbij alles spaak loopt".

In het protocol is over de verhouding redactieraad - ondernemingsraad opgenomen, dat een vertegenwoordiger van de OR "in bepaalde gevallen als toehoorder tot de redactieraad (kan) worden toegelaten".

Het statuut wijkt slechts op één punt opvallend af van het modelstatuut. Bij de beschrijving van de organen is die van de redactieraad aangevuld met: Journalisten, die niet voor Tijls dagbladen in dienst zijn en voor wie dit statuut ook niet van toepassing is, worden zoveel mogelijk bij de redactie betrokken. Tenminste tweemaal per jaar zullen zij hun belangen met de hoofdredacteur kunnen bespreken, waarbij ook een afgevaardigde van de redactieraad aanwezig zal zijn.

De verklaring over de doelstellingen van Tijls dag- en nieuwsbladen is kort en traditioneel:

- onafhankelijk van levensbeschouwelijke, politieke en maatschappelijke groeperingen;

- geworteld in de regio en in hoofdzaak gericht op het eigen verspreidingsgebied. De doelstellingen zijn nader vitgewerkt in vrij gedetailleerde richtlijnen voor de journalisten.

\subsubsection{Dagblad Tubantia en}

7.4.4.6 Arnhemse Courant

De redactiestatuten van beide kranten, die deel uitmaken van Uitgeversmaatschappij Van der Loeff B.V., zijn vrijwel identiek en op enkele onderdelen na overgenomen van het modelstatuut. De "nauwe samenwerking" van de twee kranten binnen dezelfde onderneming en binnen de Gemeenschappelijke Persdienst (GPD) is in beide statuten aandachtspunt voor hoofdredacties, redacties en directies van de kranten. Een afwijking van het modelstatuut is de beslotenheid van de vergaderingen van de redactieraad. Als onderwerp van goed overleg tussen directie en hoofdredactie is toegevoegd: "prijsvragen voor de abonnees buiten de bestaande". Een kennelijke vergissing is de bepaling dat journalisten 
"door de directie conform de geldende CAO woor Dagbladjournalisten aangesteld resp. ontslagen (worden) na overleg met de hoofdredactie". Volgens de CAO worden journalisten uitsluitend "in overleg met en op voordracht van" de hoofdredacteur aangesteld. De hoofdredacteur is lid en voorzitter van de redactieraad. Bij zijn afwezigheid wijst de directie in overleg met de hoofdredactie een plaatsvervanger aan, gehoord de gekozen leden van de redactieraad.

De uitgangspunten van het redactionele beleid zijn niet in de statuten van de onderneming opgenomen. Daarin staat slechts dat vaststelling en wijziging ervan de instemming behoeven van de algemene vergadering van aandeelhouders, gehoord de raad van commissarissen.

In de beginselverklaring staat het regionale en lokale karakter van de kranten voorop; daarnaast moeten de kranten het landelijke en internationale nieuws brengen. Wat de toelichting resp. het commentaar betreft zullen de dagbladen, rekening houdende met de (....) verschillende schakeringen van de bevolking van de verspreidingsgebieden en zo mogelijk met vermijding van het kwetsen van bevolkingsgroepen, op doelmatige wijze dienen bij te dragen aan het algemene culturele en sociale peil der bevolking, aan de welvaart en het welzijn in die gebieden alsmede aan het behoud van de historisch gegroeide Nederlandse constitutionele monarchie en aan de veiligheid van staat en burgerij.

\subsubsection{Deventer Dagblad Combinatie}

Het Statuut voor hoofdredactie en redactie van de dagbladen uitgegeven door Kluwer's Courantenbedrijf B.V., van kracht sinds 15 december 1977 , heeft eveneens het modelstatuut gevolgd. Met één opmerkelijke variant: bij de opsomming van de redactionele organen wordt de redactievergadering aangeduid als "het hoogste orgaan voor medezeggenschap van de redactie in alle zaken betreffende de redactionele taak en functie; zij delegeert een deel van haar uitvoerende taak aan de redactieraad." Die formulering stamt uit het NVJ-concept uit 1973, maar is gesneuveld bij de onderhandelingen over het uiteindelijke modelstatuut.

De hoofdredacteur is lid en voorzitter van de redactieraad. Het statuut vermeldt niet hoeveel gekozen leden er moeten zijn; slechts dat het een even aantal is. (Zess volgens het huishoudelijk reglement). In de regeling wanneer een redactievergadering dient te worden gehouden staat een bepaling die niet in het redactiestatuut thuishoort: Tevens kan de redactiecommissie de redactievergadering bijeenroepen om haar te raadplegen over onderwerpen waarvan de behandeling krachtens de CAO tot haar bevoegdheden behoort.

De redactionele doelstelling van de Kluwerbladen staat in een afzonderlijke akte, die voor het publiek toegankelijk is. Zij geldt niet alleen voor de hoofdredactie en de redactie, maar ook voor de directie als een gegeven. De inhoud is kort en vaag geformuleerd: ( ......) op basis van democratische beginselen zo objectief en veelzijdig mogelijk nieuws en achtergrondinformatie te verschaffen, zodat de lezers zich zelfstandig een oordeel kunnen vormen. (........) De dagbladen brengen naast de verstrekking van nationale en internationale informatie vooral tot 
uitdrukking hun geworteld zijn in de regio waarin zij verschijnen. Aan nieuws uit en de ontwikkelingen in het eigen verspreidingsgebied wordt in het bijzonder aandacht besteed.

\subsubsection{Twentsche Courant}

In het redactiestatuut van de Twentsche Courant/Overijssels Dagblad, dat vrijwel geheel is overgenomen van het modelstatuut, valt de beginselverklaring op. Hoewel de krant het woord "katholiek" niet letterlijk gebruikt, is het duidelijk dat de Twentsche Courant een regionale krant is met een overwegend katholieke lezerskring. De beginselverklaring luidt (gedeeltelijk): De Twentsche Courant en het Overijssels Dagblad zijn onafhankelijke, regionale dagbladen. ( .......) Met voorrang voor het plaatselijke en regionale nieuws behoort daarbij zo veel nationaal en internationaal nieuws, dat een redelijk alternatief wordt geboden voor landelijke dagbladen. De door Drukkerij Twentsche Courant B.V. witgegeven dagbladen worden geredigeerd vanuit een levensbeschouwelijke visie. De redactie eerbiedigt het feit, dat deze visie haar uitgangspunt vindt in de boodschap van $v$ rede en heil zoals die wordt aangereikt in de Schriften van het Oude en Nieuwe Testament en zoals die onder meer beleden wordt in het Credo van de ene, ongedeelde Kerk. Aan die boodschap, die opgesloten ligt in de Westeuropese, joodschristelijke traditie, waarin ook het humanisme en het sociale rechtvaardigheidsdenken hun oorsprong vinden, ontleent zij ethische normmodellen voor haar praktische beleid.

De redactieraad bestaat uit de hoofdredacteur, die tevens voorzitter is, en zes gekozen leden. Uit het modelstatuut is overgenomen dat de raad moet opstappen wanneer de redactievergadering vindt dat de raad de redactie niet meer naar behoren vertegenwoordigt. In 1988 is de redactieraad van de Twentsche Courant afgetreden, omdat hij het niet eens was met de redactievergadering. Deze was wel akkoord gegaan met de benoeming van een interne kandidaat als hoofdredacteur, terwijl de redactieraad ook een externe sollicitatieprocedure wenste.

\subsubsection{Perscombinatie}

De dagbladen van de Perscombinatie (De Volkskrant, Het Parool en Trouw) hebben redactiestatuten, waarin de bijzondere structuur van de onderneming een grote rol speelt. De redactionele onafhankelijkheid van de bladen is geïnstitutionaliseerd in drie stichtingen die als buffers tussen de redacties en de hoofddirectie van de uitgeverij zitten. De Stichting Het Parool beheert 90 procent van de certificaten van aandelen van de Perscombinatie, De Stichting De Volkskrant negen procent en de Stichting ter Bevordering van de Christelijke Pers in Nederland een procent. Doel van de stichtingen is, naast beheer en eigendom van de certificaten (zonder stemrecht) van de aandelen, bovenal het bewaken van de identiteit van de onderscheiden bladen. Het stemrecht van de aandelen berust bij de Stichting Administratiekantoor Perscombinatie; in het bestuur van deze stichting 
zijn de voorzitters van dagbladstichtingen ook weer vertegenwoordigd.

De constructie biedt een uitstekende bescherming van de redactionele onafhankelijkheid van de drie kranten, welke bescherming nog versterkt wordt door achtergrond van de Perscombinatie als ideële, niet aan de beurs genoteerde onderneming, waarvoor winst een andere functie heeft. Zij biedt bescherming, geen garantie. In de Perscombinatiestatuten ontbreekt bijvoorbeeld de "zware procedure" van art. 3.7 van het modelstatuut. Bij de totstandkoming van het eerste statuut van de Volkskrant was dat dan ook reden voor de toenmalige secretaris van de NVJ, Gerard Schuijt, om te blijven streven naar "strakkere voorwaarden als de directie van het standpunt van de redactie wil afwijken". (1)

(1) Geciteerd in De Volkskrant van 4 oktober 1975.

\subsubsection{De Volkskrant}

Het huidige redactiestatuut van De Volkskrant dateert van 27 juni 1991 en vervangt het statuut van 2 oktober 1975, indertijd een van de eerste van het land. Onveranderd is de zeer korte identiteitsverklaring: De Volkskrant is een landelijk ochtendblad, dat zich tot taak stelt de lezers eerlijk en zo veelzijdig mogelijk te informeren. Zij is voortgekomen uit de katholieke arbeidersbeweging. Mede daarom wil zij vooruitstrevend zijn en vooral opkomen voor verdrukten en ontrechten. $\mathrm{Zij}$ is zelfstandig in haar meningsvorming. In het bijzonder beoogt zij ontwikkelingen te bevorderen, die een belofte inhouden voor een menswaardiger samenleving. (1)

Hoofdredactie en redactie zijn gebonden aan de identiteitsverklaring; de hoofddirectie (van de Perscombinatie) en de directie (van de Volkskrant B.V.) "respecteren bij hun beleid de identiteit". Voor wijziging van de identiteitsverklaring is overeenstemming vereist tussen hoofddirectie en Stichting, die daarvoor de hoofdredacteur en/of de redactieraad raadpleegt. Zijn die tegen, dan kan de Stichting niet instemmen dan om "zwaarwichtige redenen".

De hoofdredacteur is voor handhaving van de identiteit verantwoording verschuldigd aan de Stichting. Hij wordt dan ook benoemd en ontslagen na voorafgaande goedkeuring van de Stichting. Wanneer de hoofdredacteur vindt dat een besluit van de Volkskrantdirectie de identiteit dreigt aan te tasten, kan de hoofdredacteur in beroep gaan bij de hoofddirectie, die de voorzitter van de Stichting raadpleegt. De Stichting heeft echter niet de hoogste zeggenschap bij een conflict over de vermeende aantasting van haar eigen identiteit; die ligt uiteindelijk bij de raad van commissarissen van de Perscombinatie.

De redactieraad (zeven leden; geen lid van de hoofdredactie) heeft geen recht tot voordracht voor benoeming of ontslag van een hoofdredacteur of waarnemend hoofdredacteur. Hij kan een negatief advies uitbrengen, dat de Stichting wegens zwaarwichtige redenen kan negeren. Alvorens dit advies uit te brengen moet de redactieraad overleg voeren met de redactievergadering.

De redactieraad heeft een belangrijke stem in de samenstelling van het bestuur 
van de Stichting: vijf van de tien leden worden benoemd op bindende voordracht van de redactieraad; de andere vijf komen uit de vakbeweging.

Voor een aantal beslissingen van de directie, waarover het modelstatuut slechts overleg vooraf met de hoofdredacteur eist, is in het Volkskrant-statuut de instemming vooraf van de hoofdredacteur vereist. De hoofdredacteur heeft ook grote bevoegdheden op het gebied van het personeelsbeleid. Hij doet de voordracht voor de benoeming van een adjunct en is door de directie gedelegeerd tot aanstelling en ontslag van redactieleden.

(1) De Volkskrant is het enige Nederlandse dagblad dat het woord "katholiek" in de beginselverklaring heeft gehandhaafd. In de katholieke Twentsche Courant komt en in het inmiddels als zelfstandig dagblad opgeheven Binnenhof kwam het woord niet voor.

\subsubsection{Het Parool}

Het redactiestatuut van Het Parool is verreweg het omvangrijkste van alle bij Nederlandse dagbladen afgesloten overeenkomsten. Het volgt in grote lijnen het modelstatuut, met afwijkingen waar de hierboven beschreven bijzondere en gecompliceerde Perscombinatiestructuur dat vereist. Bij Het Parool is die structuur nog extra ingewikkeld, omdat er naast het bestuur van de Stichting Het Parool ook een curatorium van de stichting bestaat; beide tellen zeven leden. Drie leden van dit curatorium, dat in het bijzonder waakt over de identiteit van de krant, dat wil zeggen de doelstellingen van de stichting Het Parool, worden benoemd op voordracht van de redactieraad.

De doelstellingen zijn (verkort weergegeven): - De openbare mening in Nederland en voor zover wenselijk en mogelijk ook daarbuiten te beinvloeden in de geest van de denkbeelden, welke zijn voorgestaan in het tijdens de Duitse bezetting in Nederland verschenen illegale blad "Het Parool", dat streefde naar een radicale vernieuwing der democratie, zowel in staatkundige als in sociale en economische zin. Dit sluit enerzijds in een krachtige bestrijding van alle totalitaire verschijnselen in het maatschappelijke en politieke leven, nationaal zowel als internationaal. (............) Het sluit voorts in het stimuleren van een voortdurende bereidheid tot verandering en vernieuwing der democratie, overal waar de noodzaak daartoe zich woordoet.

- De nagelaten betrekkingen te steunen van hen, die op grond van hun medewerking aan het illegale blad "Het Parool" tengevolge van de Duitse bezetting van het leven zijn beroofd ( ...........).

Bij de procedure tot wijziging van de identiteitsverklaring en bij conflicten tussen de hoofdredacteur en de (hoofd)directie over mogelijke aantasting van de identiteit geldt m.m. dezelfde regeling als bij De Volkskrant. De hoofdre-dacteur is gebonden aan de identiteitsverklaring, directie en hoofddirectie zijngehouden ze te respecteren. Bij een conflict heeft de raad van commissarissen het laatste woord na overleg en advies van de Stichting Het Parool.

De hoofdredacteur, waarnemend hoofdredacteur en adjunct-hoofdredacteur(en) worden benoemd, geschorst en ontslagen door het bestuur van de Stichting, na 
raadpleging van het curatorium. Het bestuur pleegt vooraf "goed overleg" met de plenaire redactievergadering volgens cen nadere procedure, die hoofddirectie en bestuur vaststellen in overleg met de hoofdredacteur en de redactieraad. Opmerkelijk is de bepaling dat de redactieraad (zes personen, geen lid van de hoofdredactie, geen part-timers met minder dan een halve baan) in zijn geheel aftreedt en nieuwe verkiezingen uitschrijft, wanneer een nieuwe hoofdredacteur in dienst treedt.

Uit het modelstatuut is overgenomen de regeling van de persoonlijke verantwoordelijkheid, maar met een vreemde variant. Wanneer een redactielid ernstige gewetensbezwaren heeft tegen een opdracht of wanneer de hoofdredacteur wijzigingen aanbrengt in zijn artikel is beroep op de redactieraad mogelijk. Wanneer de hoofdredacteur de uitspraak van de redactieraad negeert, kan deze laatste zilch wenden tot de directeur van Het Parool B.V., die - alls een soort super-hoofdredacteur - een bindende uitspraak doet. De regeling staat ook in het Trouw-statuut (zie: 7.4.5.2.) Van de andere kranten in ons land kennen alleen het Limburgs Dagblad en het Nederlands Dagblad een procedure die daarop lijkt.

Overgenomen is de standaardclausule dat de redactieraad en de redactievergadering niet in de bevoegdheden van de ondernemingsraden van Het Parool en de Perscombinatie mogen treden. De clausule is aangevuld met de bepaling dat het omgekeerde ook geldt: wanneer de ondernemingsraden zich bezighouden met zaken die ook in het redactiestatuut geregeld zijn, verhindert dit niet dat de redactieraad en de redactievergadering hun bevoegdheden uitoefenen.

\subsubsection{Trouw}

Het redactiestatuut van Trouw zoals vastgesteld in april 1982 loopt ook voor een groot gedeelte parallel met het modelstatuut en met dat van Het Parool voor wat betreft de bijzondere Perscombinatieconstructie. Ook hier waakt een stichting (de Stichting ter Bevordering van de Christelijke Pers in Nederland) over de identiteit van Trouw. Zij moet instemmen met benoeming, ontslag en schorsing van een hoofdredacteur, waarnemend hoofdredacteur of adjunct-hoofdredacteur. Ook wijziging van de identiteitsverklaring is slechts mogelijk na goedkeuring van het bestuur van de Stichting. Directie van Trouw/Kwartet B.V. en hoofdclirectie van de Perscombinatie B.V. moeten de identiteit van Trouw respecteren. Wanneer de hoofdredacteur meent dat een beslissing van de (hoofd)directie de identiteit aantast komt het bestuur van de Stichting in het geweer, maar evenals bij De Volkskrant en Het Parool ligt de eindbeslissing bij de raad van commissarissen van de Perscombinatie. Het bestuur van de Stichting telt twee leden die benoemd worden op voordracht van de redactievergadering van Trouw.

De identiteitsverklaring is tweeledig: enerzijds de doelstelling van de Stichting, anderzijds de praktische uitwerking ervan als redactionele doelstelling. De verklaring en de wijze waarop Trouw ook feitelijk geredigeerd wordt rechtvaardigen het Trouw tot de zgn. "richtingbladen", dat wil zeggen bladen met een ideële 
boodschap, te rekenen. Het (omvangrijke) bestuur wan de Stichting onderhoudt een nauwer contact met de (hoofd)redactie van Trouw dan bij De Volkskrant en het Parool en hun stichtingen het geval is. (1)

De tekst van de identiteitsverklaring luidt: Trouw is een landelijk ochtendblad van protestants-christelijke signatuur, dat zich wil richten tot al degenen die verwantschap voelen met hetgeen in de identiteit van Trouw besloten ligt. De identiteit van Trouw, die wordt bepaald door de doelstelling van de Stichting ter Bevordering van de Christelijke Pers in Nederland, wordt als volgt omschreven: "Het dienen van God en Zijn wereld in gehoorzaamheid aan het evangelie van Jezus Christus. Getracht wordt dit doel met name te bereiken door zoveel mogelijk ernst te maken met de actuele betekenis van het evangelie en bijzondere redactionele aandacht te schenken aan andere organisaties met overeenkomstige doelstelling."

Met inachtneming van het bovenstaande wordt het redactionele uitgangspunt van Trouw bepaald door het streven de samenleving, nationaal en internationaal, journalistiek te benaderen vanuit de overtwiging dat deze fundamentele kritiek behoeft, in zoverre ze de verwerkelijking belemmert van de oproep van de bijbel tot gerechtigheid, vrede, vrijheid en naastenliefde. Deze overtuiging leidt tevens tot serieuze en kritische aandacht voor velerlei uitingen van vernieuwingsdrang, bijvoorbeeld op politiek, sociaal en kerkelijk terrein.

Zonder dat Trouw gebonden is aan enigerlei organisatie van politieke of andere aard, zal de geschakeerdheid van haar lezerskring, vooral in kerkelijk, politiek. en sociaal opzicht, medebepalend zijn voor de selectie van het nieuws en de keuze van de artikelen.

Uiteraard oefent het ideële uitgangspunt van Trouw ook invloed op deze selectie uit, niet in die zin dat bepaalde gebeurtenissen of ontwikkelingen worden genegeerd, maar wel in dier voege, dat sommige nieuwsfeiten meer aandacht krijgen dan andere.

De redactieraad van vijf leden (geen lid van de hoofdredactie, geen parttimer met minder dan een halve baan) kan slechts vergaderen in aanwezigheid van de hoofdredacteur. Taak van de redactieraad is onder meer het voeren van overleg met het bestuur van de Stichting, waartoe het bestuur het initiatief neemt. Dit overleg, waaraan als regel ook de hoofdredacteur en de directie deelnemen, kan alleen gaan over redactionele aangelegenheden die de identiteit raken. De redactieraad is beroepsinstantie voor redactieleden met gewetens-bezwaren tegen een bepaalde opdracht of tegen wijziging van hun artikelen. Evenals bij Het Parool kan de redactie zich tot de directie wenden als de hoofdredacteur bij zijn afwijkend standpunt blijft. De directie neemt dan een bindende beslissing. Zowel Trouw als het Parool hebben de bepaling opgenomen dat behandeling van een aangelegenheid in de ondernemingsraad niet belet dat de redactievergadering en de redactieraad zich ook met deze kwestie kunnen bezighouden.

(1) NRC Handelsblad van 23 november 1988. 


\subsubsection{Hollandse Dagbladen Combinatie}

\subsubsection{Haarlems Dagblad}

In de beginselverklaring ("Signatuur") van het Haarlems Dagblad, die uit 1975 dateert, wordt onder de tussenkop "Onafhankelijkheid" naar het redactiestatuut verwezen. De tekst van deze passage luidt: De redactie dient in alle opzichten onafhankelijk te zijn in de uitoefening van haar journalistieke taak. De onafhankelijkheid stoelt op de bepalingen, daaromtrent neergelegd in het redactiestatuut, en op de volgende voor onze kranten geldende overwegingen: I. Alleen bij onafhankelijkheid is het mogelijk tot de redactionele kolommen alles toe te laten wat informatief en opinievormend is, ongeacht de maatschappelijke richting of levensbeschouwelijke stroming waaruit het afkomstig is. 2. Een goede en betrouwbare informatie en een verantwoorde bijdrage tot de opinievorming, die het uitgangspunt van ons redactionele beleid vormen, kunnen slechts op die manier worden verwezenlijkt.

De "signatuur"-beschrijving, met vrij gedetailleerde redactionele richtlijnen, typeert de krant met haar kopbladen als "regionaal-plaatselijk", die tussen de regionale bladen in ons land een speciale plaats inneemt door haar verschijningsgebied: de Randstad eist een specifieke aanpak van de nieuwswerving en achtergrondinformatie, doondat het grootste deel van het nationale nieuws uit dit deel des lands komt.

Bijzonder aan het statuut van het Haarlems Dagblad is ook dat de procedure bij de benoeming van een nieuwe hoofdredacteur in een apart document is uitgeschreven, dat deel uitmaakt van het redactiestatuut. De tekst van het statuut is verder vrijwel geheel overgenomen van het NVJ-NDP-model. Kleine varianten zijn o.a.

- de samenstelling van de redactieraad: een lid van de hoofdredactie, die tevens voorzitter is, en tenminste zeven leden, gekozen door de redactievergadering, maar zo dat elke redactie-afdeling een afgevaardigde en een vervanger kiest.

- De hoofdredacteur wordt uitgenodigd tot het bijwonen van alle vergaderingen van de raad van commissarissen.

\subsubsection{Verenigde Noordhollandse Dagbladen (VND)}

Het redactiestatuut van de Verenigde Noordhollandse Dagbladen - de Alkmaarsche Courant en haar kopbladen (Dagblad voor West-Friesland, Enkhuizer Courant, Helderse Courant, Schager Courant, Dagblad Kennemerland, Dagblad Zaanstreek, Nieuwe Noordhollandse Courant) - heeft de verhouding tussen redactieraad en ondernemingsraad op een bijzondere manier geïnstitutionaliseerd. De redactieraad fungeert, aldus art. 4.3.9 van het VND-statuut, als gesprekspartner van de redactievertegenwoordigers in de ondernemingsraad en overlegt met hen over de te volgen gedragslijn als er in de OR voor de redactie belangrijke zaken aan de orde komen. De redactieleden in de OR mogen de 
vergadering van de redactieraad bijwonen wanneer deze dit overleg wenst; in de regel zijn de vergaderingen van de redactieraad niet openbaar. In de raad zitten de hoofdredacteur en vijf gekozen leden. Deze laatsten moeten tenminste twee jaar in dienst zijn bij de uitgever en een volledige baan hebben. Bij de benoeming van een hoofdredacteur stellen directie en redactieraad de sollicitatieprocedure vast.

De beginselverklaring van de bladen is traditioneel: regionaal, niet gebonden, bijzondere aandacht voor de eigen kenmerken van de verschillende regio's in het verschijningsgebied, dubbel-formule (voldoende nationaal en internationaal nieuws). De krant wil kennis van en inzicht in de maatschappelijke verhoudingen bevorderen, daarbij beoordelend in hoeverre die hun bijdrage tot een rechtvaardiger samenleving en een gezond leefmilieu leveren. Op deze wijze wil de krant bijdragen aan het bereiken van een maatschappij, waarin iedereen gelijko kansen krijgt om zich te ontwikkelen en te ontplooien.

\subsubsection{Noordelijke Dagbladen Combinatie}

\subsubsection{Nieuwsblad van het Noorden}

Het Nieuwsblad van het Noorden introduceert in zijn statuut de "redactiegemeenschap" als orgaan met een eigen opdracht en zelfs financiële inkomsten. Alle leden van de redactie vormen samen deze gemeenschap met als taken: $a$. een zo goed mogelijk journalistiek produkt te maken; $b$. de beginselen en doelstellingen, de identiteit, het karakter en de traditie van het Nieuwsblad van het Noorden te bewaken; c. te bevorderen dat de zelfstandigheid en de continuitteit van het Nieuwsblad van het Noorden gehandhaafd blijven.

Als inkomsten van de redactiegemeenschap worden genoemd de vergoedingen van de GPD voor journalistieke werkzaamheden, giften en legaten. Nadere regelingen over de redactiegemeenschap in het statuut ontbreken.

De beginselen en doelstellingen van de krant verwijzen naar art. $7 \mathrm{Gw}$ (in de versie van vóór de grondwetswijziging van 1983) en artikel 19 van de Universele Verklaring van de Rechten van de Mens; een verwijzing naar art. 10 Verdrag van Rome, zoals het modelstatuut doet, ontbreekt. Over het regionale karakter zegt de beginselverklaring onder meer: Het Nieuwsblad van het Noorden beseft en aanvaardt dat het in de Noordelijke samenleving een eigen specifieke plaats inneemt en zal zich bij het redactionele beleid daarnaar richten. Naar aard en traditie acht het Nieuwsblad van het Noorden zich een deel van de Noordelijke identiteit.

De redactieraad heeft geen recht van voordracht van een nieuwe hoofdredacteur, wel tot zijn ontslag. De redactieraad kan zijn mening geven over de kandidaten van de directie. Dat moet gebeuren op zodanige termijn dat het advies van de raad nog invloed kan hebben. Wanneer de redactieraad, gesteund door tweederden van de plenaire redactievergadering, de hoofdredacteur voor ontslag wil voordragen wordt hij vooraf daarvan op de hoogte gebracht.

De redactieraad bestaat uit de hoofdredacteur, tevens voorzitter, zeven gekozen 
leden en de adjunct-hoofdredacteuren als leden met adviserende stem. De conclusies uit het overleg zijn "voor de hoofdredacteur niet vrijblijvend, hoewel zij zijn eindverantwoordelijkheid en beslissingsbevoegdheid ten aanzien van de redactionele inhoud van de krant ( ......... ) niet aantasten". In het statuut, dat dateert van 1 januari 1978 en in de plaats kwam van een zes jaar ouder contract, ontbreekt het artikel over de verhouding ondernemingsraad - redactieraad.

\subsubsection{Leeuwarder Courant}

De beginselverklaring van de Leeuwarder Courant is van meer dan gewone betekenis voor het redactiestatuut. Als enige krant van Nederland is in de statuten van de onderneming, de Friese Pers Courantengroep B.V., vastgelegd dat de eigenaren van de krant (twee stichtingen van onderscheiden politieke afkomst) de instructie voor de redactie niet kunnen wijzigen zonder overleg met en instemming van driekwart van de leden van de redactievergadering. In deze instructie, die eveneens in de ondernemingsstatuten staat, is onder meer de journalistieke onafhankelijkheid vastgelegd, het democratisch en vooruitstrevend karakter van de krant, haar podiumfunctie en haar verbondenheid met Friesland en het Noorden. Over de Friese taal zegt de instructie: de krant erkent de situatie van tweetaligheid in Friesland en bevordert een vrije en harmonieuze ontplooiing van het Friestalig naast het Nederlandstalig element met gebruikmaking van de Friese naast de Nederlandse taal en ruime aandacht voor ontwikkelingen, manifestaties en activiteiten op het gebied van de Friese naast de Nederlandse taal en cultuur.

Bij de fusie in 1988 van de uitgevers van de Leeuwarder Courant en van het Nieuwsblad van het Noorden tot Noordelijke Dagbladen Combinatie hoefde de redactie van de Leeuwarder Courant dan ook niet bezorgd te zijn voor de redactionele onafhankelijkheid. De verhouding van de bladen werd vergeleken met die van de Perscombinatie. (1) Benoeming en ontslag van een hoofdredacteur zijn voorbehouden aan de besturen van twee stichtingen-aandeelhouders. De benoemingsprocedure geeft de redactie daar een psychologisch zwaarwegende stem in en maakt de kans op benoeming van een hoofdredacteur tegen de zin van de redactie - theoretisch althans - wel heel klein: De redactieraad stelt de redactievergadering in staat zich uit te spreken over de benoeming en ontslag van een hoofdredacteur. Hij zal het resultaat daarvan medededelen aan de betrokkene en aan de directie en aandeelhouders ( ..............) De redactievergadering heeft mede het recht tot voordracht van benoeming van een hoofdredacteur. Dat het in de praktijk minder harmonisch toegaat blijkt uit een aantal recente hoofdredactiewisselingen bij deze krant. (2)

Evenals Het Nieuwsblad van het Noorden kent de Leeuwarder Courant een redactie-gemeenschap ("Leovardia"'), waarvan alle journalisten bij de krant lid zijn. De redactie-gemeenschap wijst leden aan voor de ondernemingsraad en streeft, blijkens de (ludieke) statuten, naar een eigen vertegenwoordiging in de raad van commissarissen en de verwerving van aandelen. In tegenstelling tot het Groningse 
blad komt de redactie-gemeenschap niet voor in het statuut, dat sinds augustus 1977 van kracht is.

(1) De Journalist van 1 februari 1988

(2) De Journalist van 18 jan., 25 febr., 25 april en 30 mei 1988.

\subsubsection{Haagsche Courant/Dagblad Het Binnenhof}

De beginselverklaring van de Sijthoff Pers, waartoe de Haagsche Courant behoort, is hiervoor al in grote lijnen bij het redactiestatuut van de bladen van Wegener"s Couranten Concern N.V. besproken. In het Sijthofstatuut is zij aanzienlijk korter. Enkele typerende passages zijn: De dagbladen (.......) gaan uit van het democratisch beginsel, dat de lezers zich zelf wel een oordeel zullen vormen. Zij streven daarom naar een optimum aan objectiviteit in berichtgeving en achtergrondinformatie. (......... ) De dagbladen willen echter niet neutraal zijn. in de zin van karakterloos. Zij begeleiden hun informatie met daarvan gescheiden commentaren, die het gebeuren toetsen aan beginselen van verdraagzaamheid en humaniteit (in het bijzonder ten gunste van hen die menselijkheid het hardst nodig hebben), vrijheidszin, gelijke kansen voor iedereen ( ............) De dagbladen kunnen slechts onafhankelijk blijven, als zij zichzelf kunnen bedruipen. Als norm daarvoor is aangenomen, dat zij in hun verspreidingsgebied een dekkingspercentage van meer dan viffig verwerven of behouden. Zij streven een voldoende populair karakter na om aan deze norm te kunnen beantwoorden.

Het Sijthoff-statuut volgt in grote lijnen het modelstatuut; het heeft wel de systematiek ervan gewijzigd, zodat het geheel een overzichtelijke indruk maakt. Waarschijnlijk onjuist is de opmerking in het inleidend artikel dat het redactiestatuut door de directie is vastgesteld na overleg met de hoofdredacteur en de redactie; de CAO schreef voor dat dit "in overleg" zou gebeuren. Ook het wijzigingsvoorstel moet in die geest aangepast worden. De redactieraad, waarvan de hoofdredacteur lid en voorzitter is, moet zo samengesteld zijn dat zowel journalisten uit de centrale redactie als uit de regionale en plaatselijke redacties in een zekere evenredigheid vertegenwoordigd zijn.

\subsubsection{Rotterdams Dagblad}

Het Rotterdams Dagblad is in april 1991 voor het eerst uitgekomen als opvolger van het Rotterdams Nieuwsblad en Het Vrije Volk. Precies een jaar later werd het redactiestatuut van de nieuwe krant vastgesteld. In de beginselverklaring van het Rotterdams Dagblad ligt de nadruk op het regionale en onafhankelijke karakter, met verwijzingen naar de drie grote politieke stromingen (liberalisme, sociaaldemocratie en christen-democratie) binnen het verschijningsgebied. Nadrukkelijker dan in de "Signatuur" van het Haarlems Dagblad is de betekenis van het redactiestatuut in de beginselverklaring geïntegreerd:

6. De (hoofd)redactie dient haar informatieverwervende en -verstrekkende taak, 
binnen hetgeen in deze beginselverklaring is vastgelegd, te kunnen uitwoeren zonder rechtstreekse beinvloeding door wie dan ook noch wan buitenaf noch van binnenuit, anders dan op de wijze als in het redactiestatuut yan het Rotterdams Dagblad wordt geregeld.

7. Krachtens het redactiestatuut is uitsluitend de hoofdredactie verantwoordelijk voor de redactionele inhoud van de krant.

8. Deze beginselverklaring wordt op de eerste verschijningsdag van elk jaar in het Rotterdams Dagblad gepubliceerd.

De laatste bepaling heeft mede tot doel uitwoering te geven aan de verplichting om de beginselverklaring publiek toegankelijk te maken. Bovendien kunnen derden kennis nemen van de uitsluitende verantwoordelijkheid van de hoofdredactie voor de redactionele inhoud van de krant.

In de beginselverklaring is opgenomen dat de krant, die vooral leesbaar (moet) zijn voor een groot en veelzijdig samengesteld lezerspubliek zich ook uiterlijk van andere onderscheidt: Tevens zal de krant toegankelijk worden gemaakt door gebruik van grafieken en andere moderne vormgevingstechnieken, waar mogelijk en zinvol ondersteund door het gebruik van kleur.

Het redactiestatuut is afgeleid van het modelstatuut, de bestaande statuten van Sijthoff en Het Vrije Volk, met enkele elementen ontleend aan het Volkskrantstatuut. In de redactieraad zitten de hoofdredacteuren, die samen éen stem hebben, en minimaal vijf en maximaal zeven gekozen leden. Samen kiezen zij uit hun midden een voorzitter. Als onderwerp van bespreking is onder meer "vaste rubrieken en vaste columnisten" opgenomen.

\subsubsection{Provinciale Zeeuwse Courant (PZC)}

Het unieke van het statuut van de Provinciale Zeeuwse Courant is de verhouding van de hoofdredacteur tegenover de directie. In alle andere statuten is er, in navolging van het modelstatuut, nadrukkelijk voor gezorgd dat de hoofdredacteur zich bij een conflict met de directie kan wenden tot een orgaan dat boven de directie staat. Dit orgaan, dat ook de benoeming en het ontslag van de hoofdredacteur moet goedkeuren, is in de regel een raad van commissarissen, een curatori$\mathrm{um}$, soms de algemene vergadering van aandeelhouders. Bij de $\mathrm{PZC}$ ontbreekt dit orgaan, althans het wordt niet genoemd in het redactiestatuut.

$\mathrm{Bij}$ een onoverbrugbaar verschil van mening tussen de hoofdredacteur en de directie over de uitvoering van het redactionele beleid conform de beginselverklaring en de journalistieke gedragsregels, is het echter niet alleen de directie die beslist. Het statuut voorziet in dit geval in arbitrage door een commissie van drie leden: een lid aangewezen door de directie, een door de hoofdredacteur en een derde lid, door beide vorige leden benoemd, die als voorzitter optreedt. Als deze commissie de hoofdredacteur in het ongelijk stelt, richt hij zich naar de conclusie van de commissie of neemt hij ontslag.

De beginselverklaring en de daaruit voortvloeiende journalistieke gedragsregels zijn beknopt en sober: de PZC is een niet partijgebonden regionaal dagblad met 
bijzondere aandacht voor Zeeland. De presentatie van het nieuws moet onbevooroordeeld en zakelijk zijn en in het bijzonder de eigen nieuwsgaring en verslaggeving moet rekening houden met het bestaan van verschillende levensbeschouwelijke, politieke en culturele opvattingen en stromingen binnen de samenleving van het verschijningsgebied, zodat de totale voorlichting representatief voor deze samenleving kan worden geacht.

\subsubsection{De Gooil- en Eemlander}

De identiteitsverklaring, gedateerd april 1986, van het dagblad De Gooi- en Eemlander beperkt zich tot een beschrijving van het verspreidingsgebied, het voornemen het lezerspubliek een zo gevarieerd mogelijke krant te bieden en de verklaring dat het dagblad geen politieke of levensbeschouwelijke signatuur heeft. De beginselen van walaruit de commentaren geschreven worden doen sterk denken aan de redactionele richtlijnen van het Utrechts Dagblad. Er zitten zelfs dezelfde onnauwkeurigheden in. De beginselverklaring, die voor eenieder ter inzage op het hoofdkantoor van de krant (ligt), noemt ook de vrijheid van partijvorming naast die van vereniging en vergadering, waarbij eveneens over het hoofd is gezien dat de in 1983 gewijzigde Grondwet de vrijheid van vereniging (art. 8) en de vrijheid van vergadering en betoging (art. 9) onderscheidt. Het redactiestatuut van de Gooi- en Eemlander volgt de tekst van het modelstatuut vrijwel woordelijk. De belangrijkste afwijking is de bepaling dat de redactieraad, die bestaat uit een hoofdredacteur en tenminste vijf gekozen leden, zijn eigen voorzitter, vicevoorzitter en secretaris kiest. De hoofdredacteur is dus well lid, maar niet automatisch voorzitter.

De hoofdredacteur wordt benoemd, geschorst en ontslagen door de directie na verkregen goedkeuring van de vergadering van aandeelhouders, die ook het recht van voordracht tot benoeming heeft, naast de directie en de redactieraad. Ook hier kan men zich afvragen welke betekenis nog kan worden toegekend aan het recht van voordracht van de redactieraad, zodra de feitelijk benoemende instantie dit recht ook uitoefent.

Aan de punten van overleg tussen directie en hoofdredactie alvorens de directie een beslissing neemt is er een toegevoegd: prijsvragen voor abonnees.

Van artikel 5.1.9 van het modelstatuut (drie punten waarover de hoofdredactie overlegt met de directie en de redactieraad, alvorens een beslissing te nemen) is de laatste regel gewijzigd. Er staat nu dat overleg vereist is over invoering van nie uwe alsmede opheffing van bestaande rubrieken. Dat was ook de tekst van het hoofdredactiestatuut, die de NDP graag gehandhaafd zag, maar waar de NVI bezwaren tegen aanvoerde. De directie zou daarmee zeggenschap krijgen over een zuiver redactionele aangelegenheid. Onderhandelingen tussen NVJ en NDP over het modelstatuut leverden als compromistekst op dat het zou moeten gaan om servicerubrieken (kerkdiensten, scheepvaartberichten, theater- en filmagenda e.d.), naar hun aard minder gevoelige kopij. 


\subsubsection{Nederlands Dagblad}

Het redactiestatuut wan het Nederlands Dagblad/Gereformeerd Gezinsblad, gedateerd mei 1983, is strikt genomen geen statuut voor hoofdredactie én redactie. Het is gesloten tussen de directie en de hoofdredacteur en goedgekeurd door de Raad van Commissarissen. De redactie heeft geen enkele formele bevoegdheid. $\mathrm{Zij}$ komt weliswaar als regel twee keer per maand bijeen in een redactievergadering om te worden geinformeend en met de hoofdredacteur van gedachten te wisselen over de wijze waarop de doelstelling van het dagblad in de redactionele activiteiten kan worden verwezenlikt, en over andere zaken waarover de hoofdredacteur met de directie in overleg treedt en hij het advies van de redactievergadering gewenst acht. Deze vergadering draagt het karakter van werkoverleg en heeft geen besluitnemende bevoegdheid.

Als de redactievergadering erop staat zal een redactieraad worden gekozen om de hoofdredacteur te adviseren. Welke zaken de redactieraad met de hoofdredacteur kan bespreken komt dan in een reglement, dat de hoofdredacteur in overleg met de redactie vaststelt.

De redactievergadering wordt "op vertrouwelijke basis" betrokken bij de benoeming van een hoofdredacteur, plaatsvervangend of adjunct-hoofdredacteur: Daartoe wordt zij in de gelegenheid gesteld een profielschets van de desbetreffende functionaris bij directie en hoofdredacteur in te dienen en tevens met de kandidaten naar wie de voorkeur van de vergadering van houders van aandelen A der B.V. of van de directie uitgaat, een onderhoud te hebben, van welk onderhoud de bevindingen aan directie en hoofdredacteur worden kenbaar gemaakt alvorens tot benoeming wordt overgegaan.

Het Nederlands Dagblad is een typisch richtingblad, waarvan de op het gereformeerde volksdeel in Groningen, Overijssel en Zuid-Holland toegesneden doelstelling allereerst uit de statuten van de BV Nederlands Dagblad/Gereformeerd Gezinsblad blijkt. Die zijn het belangrijkste; het redactiestatuut, dat om die reden ook geen beginselverklaring bevat, is slechts afgeleid van en ondergeschikt aan de doelstelling. De aandeelhouders van deze B.V. zijn uitgevers met een boodschap. De hoofdredactie en redactie van het Nederlands Dagblad staan in een geheel andere verhouding tot hun uitgever dan bij de meeste kranten gebruikelijk is. De "Grundsatzkompetenz" van deze uitgever wordt niet alleen gepretendeerd, maar ook waargemaakt.

Het "redactiestatuut", dat alleen de taak en verantwoordelijkheid van de hoofdredacteur beschrijft, volgt daarin overigens in grote lijnen het model hoofdredactiestatuut dat in 1972 tussen NVJ en NDP is afgesloten. 


\subsubsection{Friesch Dagblad}

Dit in oplage kleinste Nederlandse dagblad onderscheidt zich van alle andere doordat zijn eigenaresse en uitgeefster een vereniging is: de Provinciale Persvereniging voor Friesland. De uitgangspunten en beginselen van het redactionele beleid zijn vastgelegd in artikel 2 van de Statuten en het huishoudelijk reglement van de vereniging. Art. 2 luidt: De vereniging staat op de grondslag van de Bijbel als Gods. Woord. Zij stelt zich ten doel de bevordering van de Christelijke pers in Friesland en gaat daarbij uit van de overtuiging, dat tot bescherming, activering en versterking van de reformatorische krachten in het leven van het volk. Christelijke politieke partijvorning noodzakelijk is. Krachtens deze statuten is de hoofdredactie voor het handhaven van de uitgangspunten van het redactionele beleid, de beginselen en doelstellingen verantwoordelijk tegenover de "Commissie van Redactie" en tegenover het bestuur van de Persvereniging. Deze "Commissie van Redactie" wordt door het bestuur benoemd via dezelfde procedure als de benoeming van een hoofdredacteur. Voor beide benoemingen moet de redactieraad geraadpleegd worden in de "zware procedure" van art. 3.7 van het modelstatuut en voor beide heeft de redactieraad een recht van voordracht.

Het verenigingskarakter leeft bij de krant. Op de ledenvergaderingen blijkt telkens weer, hoe de leden het Friesch Dagblad beschouwen als hun krant. Zij vragen aandacht voor hun kritiek en richten zich dan voornamelijk tot de redactie. Over balans- en verliesrekening spreken alleen de weinigen, die daarvan verstand hebben. Maar over de inhoud van de krant kan ieder zijn mening zeggen. (1) Het redactiestatuut van het Friesch Dagblad onderscheidt zich voor het overige nauwelijks van het modelstatuut. Ook wanneer de vereniging het bestuur zou machtigen de beginselverklaring van de krant te wijzigen moet de reclactieraad om advies volgens de "zware procedure" gevraagd worden.

(1) Jubileumboek Friesch Dagblad 1979, pag. 43.

\subsection{Samenvatting}

De redactiestatuten bij Nederlandse dagbladen zijn ingevoerd op basis van een in de CAO opgenomen bepaling en naar het voorbeeld van een door werkgevers (NDP) en werknemers (NVJ) overeengekomen "modelstatuut", hetgeen verklaart waarom in zo korte tijd vrijwel alle dagbladen een eigen statuut hadden. De partijen die het "modelstatuut" tot stand hadden gebracht waren het niet eens over de status van dit stuk: is het uitsluitend als voorbeeld en model te beschouwen (NDP) of is het modelstatuut een minimumregeling (NVJ-begeleidingscommissie en haar toenmalige lid en NVJ-secretaris mr. G.A.I. Schuijt). Op verschillende gronden neig ik tot de "uitsluitend model-status" van het stuk. Door het korte tijdsbestek tussen de invoeringsdatum die de CAO voorschreef ( 1 januari 1977) en de feitelijke invoering bij de meeste bladen heeft dit verschil van mening kennelijk geen rol gespeeld. 
Behalve bij de dagbladen zijn in de loop van de jaren ook bij andere media redactiestatuten ingevoerd. Bij de opiniebladen en de publieksbladen gebeurde dat eveneens op basis van een CAO en met een "modelstatuut". als voorbeeld. Deze periodieken onderscheiden zich van dagbladen, doordat de uitgever dichter bij de identiteit (opiniebladen) en de redactionele formule (publieksbladen) staat. Dit kan tot het soort problemen leiden als zich heeft voorgedaan bij het maandblad "Voorwaarts".

lets soortgelijks vinden we bij de omroepen ex art. 14 Mediawet, die niet alleen een specifieke identiteit, vergelijkbaar met die van de "richtingbladen" onder de kranten, vertegenwoordigen, maar deze identiteit nog versterken door de verenigingsstructuur. De (wettelijk voorgeschreven) programmastatuten van de omroepen zijn om die reden niet vergelijkbaar met de redactiestatuten van de (meeste) dagbladen.

De Nederlandse dagbladen hebben bij hun eigen statuten in meerderheid het modelstatuut gevolgd. Inhoudelijk hebben de meeste dan ook weinig meer te bieden dan het in hoofdstuk 5 beschreven modelstatuut. Er zijn echter ook redactiestatuten die in positieve zin afwijken en iets hebben toegevoegd aan het model:

1. De bladen van de Perscombinatie hebben alle een eigen, geïnstitutionaliseerde "buffer" tussen de redactie en de hoofddirectie van de uitgever Perscombinatie N.V. Drie stichtingen waken binnen de uitgeverij over de identiteit van de onderscheiden bladen en benoemen de hoofdredacteuren. De redacties zijn bij de stichtingen betrokken door het recht van bindende voordracht voor bestuursleden.

2. Bij de "Leeuwarder Courant" is de instructie voor de redactie vastgelegd in artikel 17.2 van de statuten van de Friese Pers Courantengroep bv die door de aandeelhouders niet zullen worden gewijzigd zonder overleg met en instemming van driekwart van de leden van de redactievergadering. (Artikel 2.1 van de "Beginselverklaring" van het redactiestatuut).

De instructie begint met de (normatieve) vaststelling dat de krant wordt samengesteld door een journalistiek onafhankelijke redactie.

De regelling is voorbeeldig omdat wijziging van de beginselverklaring in de ondernemingsstatuten is voorbehouden aan een gekwalificeerde meerderheid van de redactie. Bij de fusie van de uitgevers van de Leeuwarder Courant en van Het Nieuwsblad van het Noorden in 1988 was er dan ook geen angst dat de Leeuwarder Courant de zelfstandigheid zou verliezen.

3. De redactieraad van NRC Handelsblad, gesteund door een tweederde meerderheid van alle leden van de redactie, kan de voorgenomen benoeming van een hoofdredacteur blokkeren.

4. Ook de Telegraaf heeft het de directie zeer lastig gemaakt een hoofdredacteur te laten benoemen, die niet het vertrouwen van de redactieraad heeft. In het sta- 
tuut is eveneens bepaald dat bij het zoeken naar een hoofdredacteur, waarnemend, plaatsvervangend of adjunct-hoofdredacteur bij voorkeur wordt gekeken naar kandidaten uit de redacties van De Telegraaf/De Courant Nieuws van de Dag. Bij een groot aantal voor de redactie belangrijke beslissingen is de directie verplicht vooraf tot overeenstemming te komen met de hoofdredactie en de redactieraad. Bij geschillen over naleving van het redactiestatuut is een beroep op de burgerlijke rechter mogelijk, die zich niet tot marginale toetsing hoeft te beperken.

5. Het Rotterdans Dagblad verwijst in zijn beginselverklaring naar het redactiestatuut en de daarin geregelde uitsluitende verantwoordelijkheid van de hoofdredactie voor de redactionele inhoud van de krant. De beginselverklaring wordt op de eerste verschijningsdag van elk jaar gepubliceerd. Het Haarlems Dagblad noemt het redactiestatuut in zijn beginselverklaring ("Signatuur") als basis voor zijn journalistieke onafhankelijkheid.

6. De dagbladen van de Brabant Pers hebben in hun redactiestatuten de mogelijkheid van een ernstig conflict tussen hoofdredacteur en redactie aangestipt. In een toelichting bij de bevoegdheden van de redactieraad wordt benadrukt dat de hoofdredacteur en de redacticraad consensus nastreven. De hoofdredacteur kan besluiten van de redactieraad naast zich neerleggen. Wanneer een fundamenteel meningsverschil zich echter herhaaldelijk voordoet kan van een structureel conflict gesproken worden. Een dergelijk conflict maakt de noodzakelijke redactionele samenwerking onmogelijk, omdat dan van de gewenste consensus geen sprake meer is.

Dezelfde gedachte, maar veel voorzichtiger geformuleerd, is te vinden in de redactiestatuten van de voormalige Audet-bladen: De conclusies van het beraad binnen de redactieraad zijn voor de hoofdredacteur niet vrijblijvend, maar tasten zijn zelfstandige eindverantwoordelijkheid en beslissingsbevoegdheid t.a. v. de inhoud, de samenstelling en de presentatie van de krant, alsmede zijn leiding van de redactie niet aan. Ook het Brabants Nieuwsblad en het Nieuwsblad van het Noorden tekenen aan dat het overleg van de hoofdredactie in de redactieraad "niet vrijblijvend" is. 


\section{Het rechtskarakter van het redactiestatuut}

\subsection{Grondrechtelijke aspecten van de verhouding uitgever * hoofdredactie - redactie}

\subsubsection{Inleiding}

Zoals in het vierde hoofdstuk (4.8.3 en 4.9.1) beschreven heeft de NVJ tijdens de slotfase van de onderhandelingen over de definitieve tekst van het "modelstatuut voor hoofdredactie en redactie" op een cruciaal onderdeel - de verhouding tussen de ondernemingsraad en de redactieraad - een concessie van principiële aard gedaan. Het daaruit resulterende modelartikel over deze verhouding bracht, zo luidde een conclusie van dat hoofdstuk, het redactiestatuut binnen het arbeidsrechtelijk kader en daardoor raakte het zicht op een mogelijk grondrechtelijke betekenis ervan versluierd.

Het eerder afgesloten "hoofdredactiestatuut" en het concept waarmee de NVJdelegatie naar de onderhandelingen met de uitgevers werd gestuurd bevatten beide de bepaling dat de ondernemingsraad met betrekking tot redactionele zaken geen besluiten kan nemen en hooguit, naar letter en geest onverbindende, adviezen mag geven. In beide laatste regelingen vloeit dat direct voort uit de bijzondere positie die de (hoofd)redactie in het geheel van de dagbladonderneming inneemt, een positie die in deze beide documenten als bijzonder wordt beschouwd, ondat zij op haar beurt voortvloeit uit het grondrechtelijke kader waarbinnen het produkt dagblad wordt vervaardigd.

Dit laatste betekent niet dat uit het grondrecht de bijzondere positie van de (hoofd)redactie binnen een dagbladorganisatie rechtstreeks is af te lezen. De considerans van de "modelstatuten" gaat bij de verwijzing naar het grondrechtelijke kader uit van het "produkt dagblad" dat zich onderscheidt van andere industriële produkten, doordat het gestalte geeft aan het grondrecht en er, als "art. $7 \mathrm{Gw}$-produkt", een materialisatie van is. Daaruit vloeit weer voort dat de bijzondere aard van het dagblad bijzondere eisen stelt aan de interne regeling van de verhoudingen tussen de organen die bij het produceren van de redactionele inhoud zijn betrokken.

Op welke wijze past het redactiestatuut als regeling van de verhouding uitgever hoofdredactie - redactie binnen het grondrechtelijke kader, waar de considerans van het modelstatuut naar verwijst? Om deze vraag, als probleemstelling in deze dissertatie opgeworpen, te beantwoorden zijn drie verschillende invalshoeken mogelijk. Zij zullen in de hierna volgende paragrafen worden voorgesteld. 


\subsubsection{Het grondrecht als afweerfunctie én zorgplicht}

Het grondrecht van artikel $7 \mathrm{Gw}$, zoals dat thans wordt geinterpreteerd - dus met de "meerwaarde" van de in art. 10 EVRM en art. 19 IVBPR besloten vrijheid om inlichtingen en denkbeelden door te geven en te ontvangen - is meer dan uitsluitend een afweerrecht tegen de overheid. Vooral sinds de tweede wereldoorlog is het besef gegroeid dat van de overheid niet alleen verwacht wordt dat zij zich onthoudt van controle vooraf op datgene wat geschreven, uitgezonden of anderszins geopenbaard wordt, maar dat zij er ook voor behoort te zorgen dat de feitelijke uitoefening van het grondrecht niet illusoir wordt. Dat vraagt van de overheid een actief beleid om haar burgers bij de uitoefening van dit recht te stimuleren en zo nodig zelfs te helpen. Schuijt meent, met verwijzing naar o.a. de Medianota 1975, dat het grondrecht van de communicatievrijheid daarom tevens een sociaal grondrecht genoemd kan worden. (1) Deze ontwikkeling kan niet los gezien worden van de erkenning, ook in ons land, dat het grondrecht weliswaar voor eenieder geldt, maar tevens een institutioneel karakter heeft, al is ook bij de grondwetswijzing van 1983 een verwijzing naar de pers als institutioneel drager van grondrechten, zoals in het Duitse artikel $5 \mathrm{GG}$, niet in de tekst van het nieuwe artikel 7 opgenomen, ondanks suggesties in die richting, onder meer van Tammes (in 1949 al), Boukema en De Meij.

Achterliggende idee bij beide ontwikkelingen is dat vooral sinds de oorlog ook in ons land het belang is ingezien van een ruim en geschakeerd media-aanbod ten behoeve van de democratische discussie en de cultuurvorming. Voor de oorlog werd zelfs in journalistenkringen, zoals in hoofdstuk 2 bleek, de publieke taak van de pers nog nauwelijks geassocieerd met het politieke debat. Pers en overheid werkten hartelijk samen en het dagblad diende beschouwd te worden als "een middel voor de geestelijke, intellectueele en sociale scholing van het publiek", zoals de in paragraaf 2.4 .2 geciteerde resolutie uit 1923 van de toenmalige journalistenbond het uitdrukte. Thans staat het belang van een pluriforme pers voor de informatievoorziening en opinievorming voorop. Een vrije en veelzijdige pers is essentieel voor het functioneren van de democratie en kan uitdrukking geven aan "de veelkleurigheid van ons cultuurpatroon", zoals de Medianota 1983 het formuleerde.

De overheid is in de praktijk haar zorgplicht nagekomen, ook ten behoeve van het dagblad. Zo verleent zij via het in 1974 opgerichte Bedrijfsfonds voor de pers, thans op basis van art. 122 e.v. van de Mediawet, zelfs financiële steun aan noodlijdende bladen. Zij is bovenal niet blind gebleven voor de verontrustend voortschrijdende persconcentratie, met haar schadelijke gevolgen voor de pluriformiteit binnen de mediawereld.

Is in de aldus begrepen grondrechtelijke zorgplicht ook plaats voor het redactiestatuut? Noopt de zorgplicht tot behoud van een pluriforme pers ook tot bij voorbeeld - een wettelijke regeling van een dergelijk statuut?

Feit is dat in de discussie over maatregelen tegen de concentratietendens binnen de dagbladpers door middel van een persfusiecontroleregeling, vanaf het begin 
het redactiestatuut een rol gespeeld, zelfs toen het begrip "statuut" nog nauwelijks bekend was. (2) Reeds in 1968 pleitte de Persraad, in zijn eerste voorstel over een regeling van persfusies, voor een statuut waarin de inspraak van de hoofdredacteur bij beslissingen die het karakter van de krant zouden beínvloeden geregeld zou zijn. Een dergelijk statuut zou transacties waarbij het karakter van de krant in het geding is "op zijn minst bemoeilijken". De rechter (een speciaal in te stellen Kamer voor Persconcentraties van het Hof in Amsterdam) zou voorgenomen persfusies geheel of gedeeltelijk moeten kunnen verbieden, wanneer daardoor de publieke voorlichting in ernstige mate zou worden geschaad. Voor een wettelijke regeling van het statuut voelde de Persraad niet, vooral omdat NDP en NVJ in 1968 nog in onderhandeling waren over een hoofdredactiestatuut en de raad dit overleg niet wilde beïnvloeden. In een advies uit 1971 herhaalle de Persraad zijn standpunt dat een wettelijke regeling van het redactiestatuut niet opportuun was en bovendien een persfusieregeling niet overbodig zou maken. In 1975 - NVJ en NDP waren het nog steeds niet eens geworden over een "modelstatuut" - nam de Tweede Kamer de motie-Roethof (PvdA) aan, waarin de regering werd gevraagd de mogelijkheden te onderzoeken om minimumregels voor een redactiestatuut in een wettelijke regeling vast te leggen. (3)

De grondrechtelijke aspecten, verbonden aan een persfusieregeling en/of een wettelijk geregeld redactiestatuut, zijn uitvoerig aan de orde gekomen toen de regering uitvoering gaf aan een op 11 februari 1988 aangenomen motie van het PvdA-Tweede-Kamerlid Niessen. Deze motie sprak de vrees uit voor verdere aantasting van de pluriformiteit in het perswezen en vroeg om een studie naar de inhoud van een persfusiecontroleregeling. De studie heeft een omvangrijk dossier opgeleverd, waarbij voor het onderdeel "persfusiecontrole" zij verwezen naar de reeds opgevoerde publikaties van De Meij en Van Vollenhoven. Deze discussie is medio 1993 (voorlopig) afgesloten met het voornemen van de betrokken bewindslieden om in te stemmen met een voorstel tot zelfregulering, opgesteld door de NDP. (4)

Vier jaar eerder had minister Brinkman, op grond van de studie waar de motieNiessen om gevraagd had, nog geconcludeerd dat invoering van een persconcentratieregeling vooralsnog niet noodzakelijk was. De pluriformiteit, aldus de minister in zijn brief van 25 januari 1989 aan de Kamer, wordt naar het oordeel van het kabinet niet zozeer aangetast door de aanbiedersconcentratie (concentratie op uitgeversniveau) op zich, maar veeleer door redactionele concentratie (concentratie op bladniveau). (............) Een eventuele regeling ter handhaving en bevordering van de pluriformiteit van de pers dient zich volgens het kabinet te richten op een versterking van de positie van de redactie ten opzichte van de directie, en niet op het tegengaan van aanbiedersconcentratie als zodanig.

Het kabinet, dat grondrechtelijke en praktische bezwaren tegen een persfusiecontrole aanvoerde, zag voor het behoud van de pluriformiteit van de pers meer in het wettelijk verplicht stellen van een schriftelijk statuut. Het ging 
daarbij aanzienlijk verder dan de Mediawet, die slechts een redactiestatuut verplicht stelt voor bladen om in aanmerking te komen voor financiële steun van het Bedrijfsfonds, maar geen inhoudelijke eisen stelt aan dit statuut. Het ging ook verder dan de $\mathrm{CAO}$ voor Dagbladjournalisten, die in artikel 14.1 zegt dat elke dagbladonderneming met vijftien of meer journalisten gehouden is een statuut vast te stellen dat zowel de positie van de hoofdredactie als die van de redactie regelt. (5) Een wettelijk geregeld redactiestatuut zou in het voorstel van het kabinet inhoudelijk wel aan bepaalde minimumeisen moeten voldoen. De minister schrijft namelijk: Het kabinet is van mening dat de regeling krachtens de c.a.o. voor dagbladjournalisten niet in alle gevallen voldoende waarborgen voor de redactionele onafhankelijkheid inhoudt. Het kabinet overweegt daarom een schriftelijk statuut wettelijk verplicht te stellen, in welk statuut in ieder geval dienen te zijn vastgelegd de redactionele identiteit van het dagblad alsmede een regeling betreffende de samensteling van de redactieraad en de wijze van verkiezing van zijn leden. Wijziging van het statuut zou slechts mogelijk moeten zijn met instemming van de redactieraad.

"Het overwegen waard" is volgens het kabinet aan de redactieraad een adviesrecht toe te kennen met betrekking tot de benoeming en het ontslag van die redacteuren, die het karakter van het dagblad in overwegende mate bepalen. Daarbij denkt het kabinet ook aan een regeling die inhoudt dat de directie met betrekkking tot een voorgenomen besluit tot opheffing van een dagblad, vermindering of opheffing van de redactionele zelfstandigheid van een dagblad of vermindering van de verschijningsfrequentie van een dagblad, reeds in een zo vroeg mogelijk stadium overleg moet voeren met de redactieraad. Komen directie en redactieraad niet tot overeenstemming, dan zou in dit voorstel de redactieraad de bevoegdheid moeten krijgen tegen het besluit beroep in te stellen bij de rechter, waarbij de rechter het belang van de redactionele onafhankelijkheid dient af te wegen tegen de (economische) belangen van de uitgever en de (sociale) belangen van de werknemers.

De minister is zich ervan bewust dat een wettelijke regeling problemen op zou leveren en het voorstel zou "met name op zijn juridische merites nader uitgewerkt moeten worden". In zijn brief aan de Kamer noemt hij in dit verband de verhouding van bevoegdheden tussen de redactieraad en de (centrale) ondernemingsraad. Eventuele grondrechtelijke bezwaren, die het kabinet wel tegen persfusiecontrole had aangevoerd, ziet het niet tegen een wettelijke regeling van het redactiestatuut.

Tijdens het mondeling overleg op 23 maart 1989 met de vaste Commissie voor Welzijn en Cultuur (6) kritiseerden de kamerleden Niessen (PvdA), die in dit verband o.a. Schuijt citeerde, en Van der Sanden (CDA) de minister op dit punt, omdat deze geen woord had gewijd aan de grondrechtelijke implicaties van bij voorbeeld een rechterlijke toetsing van een redactionele samenvoeging zonder daarbij een inhoudelijke toetsing van de identiteit der kranten te betrekken.

Op 14 februari 1990 bracht een nog door minister Brinkman aangezochte 
commissie van drie deskundigen advies uit aan de ambtsopvolger op WVC minister d'Ancona over de grondrechtelijke aspecten van een eventuele persfusieregeling. (7) Hun conclusie ten aanzien van een wettelijke regeling van de verhouding uitgever - (hoofd)redactie vloeit logisch voort uit het criterium dat zij aanleggen voor de grondwettigheid van persfusieregelingen: alleen een absoluut verbod van elke fusie die een marktaandeel boven een bepaald percentage oplevert (bij voorbeeld 25 procent of meer) is grondrechtelijk toelaatbaar; elke toetsing van een persfusie die op enigerlei wijze verband houdt met de inhoud van een blad is de overheid op grond van artikel 7 van de grondwet ontzegd. De adviseurs laten daar, of wetgeving met betrekking tot het verplichtend voorschrijven van een redactiestatuut zich verdraagt met artikel 7 grondwet maar zij zijn van oordeel, dat zulke wetgeving, indien al geoorloofd, in elk geval dient te gelden voor eenieder en niet alleen voor de kranten die inzet zijn, of zijn geweest, van een persfusie. Wanneer een wettelijke regeling de redactieraad een instemmingsrecht zou toekennen met betrekking tot een wijziging van de (schriftelijk vastgelegde) redactionele identiteit, zou, aldus de commissie, ook de uitgever met een wijziging moeten instemmen. (8) De commissie lijkt de minister voorzichtig te willen waarschuwen voor generieke regelingen van zo grondrechtgevoelige aard. De Meij concludeert terecht dat de deskundigencommissie wijselijk niet ingaat op de vraag wat de rechter hier bij meningsverschil zou kunnen doen. Het ( ............ ) commissiestandpunt dat slechts een verbod op grond van vaste kwantitatieve gegevens toelaat, lijkt mij weinig ruimte te bieden voor rechterlijke beslissingen over opheffing en voortbestaan van bepaalde bladen binnen dit kader. (9) Het advies van de commissie Van der Hoeven c.s. is voor minister d'Ancona mede aanleiding geweest de wettelijke regeling van een redactiestatuut niet verder te overwegen. $\mathrm{Zij}$ liet daarbij meewegen dat alle dagbladen reeds krachtens cao een redactiestatuut kennen. (10) Dit laatste is, zoals uit het vorige hoofdstuk blijkt, feitelijk overigens niet juist.

Een generieke wettelijke regeling van de verhouding uitgever - hoofdredactie redactie zou, zoals De Meij heeft opgemerkt, bij een conflict over een voor de identiteit van een blad belangrijke beslissing, waarbij een van de partijen eèn beroep zou doen op de rechter, kunnen nopen tot een belangenafweging waarbij ook de inhoud van een periodiek betrokken zou kunnen worden. Een dergelijke toetsing staat op gespannen voet met het grondrecht. Schuijt (11) concludeert eveneens tot afwijzing van een wettelijke regeling van het redactiestatuut bij dagbladen en bij omroepen op commerciële basis, zij het op andere gronden. Wanneer een wettelijke regeling van het redactiestatuut op grondrechtelijke bezwaren stuit, moet een generiek bedoelde regeling van lagere status, zoals invoering via een $\mathrm{CAO}$, a priori afgewezen worden, wanneer deze inhoudelijke eisen aan het statuut zou stellen.

(1) Schuijt Werkers van het woord, pag. $36 \mathrm{e} . \mathrm{v}$.

(2) Voor een overzicht van de voorstellen over persfusiecontrole zie L. van Vollenhoven Omroep 
en pers in F.W. Grosheide (red.) Hoofdstukken Mediarecht pag. 32 - 42; G.A.I. Schuijt Werkers van het woord pag. 121 e.v. J.M. de Meij Uitingsvrijheid pag. 240 e.v.; id. Persfusies en perswrifheid in Ned. Juristenblad van 11 februari 1989, pag. $177-182$; id. Toch een persfusieregeling? in Informatierecht/AMI oktober 1990, pag. $175-179$.

(3) Handelingen der Tweede Kamer 1975/76, 2588.

(4) Ken van de "Code woor Dagbladconcentraties:" een verbod op dagbladconcentraties die leiden tot een marktaandeel van een derde of meer wan de totale oplage van de dagbladmarkt in Nederland, tenzij een verklaring van geen bezwaar is verleend door een in te stellen Commissie voor Dagbladeoncentraties. De Commilssie kan de verklaring van geen bezwaar slechts verlenen indien de aangemelde concentratie niet tot gevolg heeft dat een daadwerkelijke mededinging op de Nederlandse dagbladenmarkt structureel en op significante wijze wordt belemmerd. (Artikel 3 uit de ontwerpcode, bijlage van de brief aan de Tweede Kamer d.d: 9 juni 1993 van de minister van Welzijn, Volksgezondheid en Cultuur en de staatssecretaris van Economische Zaken. TK 1992 $1993,20984, \mathrm{nr} .10$.

(5) Over de vraag of de inhoud van de dagbladstatuten zou mogen afwijken van het "modelstatuut", dat in de CAO als "referentiekader" wordt genoemd zie paragraaf 7.2.

(6) TK 1988-89, 20984, nr. 4 pag. 6 e.v.

(7) J. van der Hoeven, P.J. Boukema en M.C.B. Burkens; TK 1989/90, stuk separaat bij 20984, ni. 6.

(8) Advies Van der Hoeven, Boukema en Burkens, pag. 7 en 9.

(9) I.M. de Meij Toch eem persfusiecontrole? in: Informatierecht/AMI, pag 179.

(10) TK 1989-90, 20984, nr. 6, pag. 6.

(11) Schuijt Werkers van het woord pag. 400.

\subsubsection{Tussenconclusie}

Concluderend kunnen we stellen dat uit het grondrecht van de uitingsvrijheid ook een zorgplicht van de overheid voortvloeit. $\mathrm{Zij}$ is gehouden een mediabeleid te voeren dat de communicatie tussen burgers onderling bevordert, waardoor een bijdrage geleverd wordt aan de democratische discussie. Zij mag in dat kader maatregelen treffen die een pluriform media-aanbod bevorderen. Daarbij is zij door hetzelfde grondrecht van de burgers in zoverre beperkt dat haar regelgeving ten aanzien van de media, bij voorbeeld door middel van een persfusiecontrole, niet mag leiden tot enigerlei toetsing op basis van de inhoud van de media. Het wettelijk invoeren van een redactiestatuut met een zekere voorgeschreven inhoud - in plaats van een wettelijke persfusiecontroleregeling kan leiden tot zo'n grondrechtelijk verboden toetsing en is daarom in strijd met artikel $7 \mathrm{Gw}$. Invoering van een redactiestatuut via CAO kan daarmee a priori nooit een algemeen bindend karakter verwerven. Daarmee wordt tevens een (ontkennend) antwoord gegeven op de eerste probleemstelling.

\subsubsection{Het redactiestatuut als voorbeeld van de horizontale werking (derdenwerking) van het grondrecht}

Sinds de jaren zestig, naar aanleiding van de herziening van de Grondwet, is een nieuw element in de discussie over grondrechten gekomen, namelijk de vraag of grondrechten uitsluitend gelden in de verhouding overheid - burger, dan wel of ze wellicht van ruimere strekking zijn en eveneens toepasbaar in de verhouding 
tussen burgers onderling; de vraag derhalve of ze ook "horizontale werking" of (naar het Duits) "derdenwerking" hebben.

De oorsprong van het leerstuk moet in Duitsland gezocht worden. In paragraaf 3.3 is reeds gewezen op de artikelen 118 (vrijheid van meningsuiting) en 159 (recht van vergadering) van de Weimarer Verfassung, waarvan wordt aangenomen dat ze door hun formulering rechtstreeks toegepast konden worden in verhoudingen tussen burgers onderling. Uit de Duitse doctrine komt ook het onderscheid tussen:

A. Directe horizontale werking ("unmittelbare Drittwirkung"): het grondrecht kan rechtstreeks worden toegepast op andere verhoudingen dan die tussen overheid en burger. In Duitsland wordt zij aangenomen voor de "Koalitionsfreiheit" (recht van vereniging) van Art. 9 Abs. $3 \mathrm{GG}$. In ons land noemen sommige auteurs artikel $17 \mathrm{Gw}$ ("Niemand kan tegen zijn wil worden afgehouden van de rechter die de wet hem toekent.") een grondrecht met horizontale werking. (1)

B. Indirecte horizontale werking ("mittelbare Drittwirkung"): grondrechten zijn niet rechtstreeks van toepassing op de verhouding tussen burgers onderling, maar zij kunnen op uiteenlopende wijzen ook in meer of minder vergaande mate in horizontale verhoudingen doorwerken. De Memorie van Toelichting bij het grondrechtenhoofdstuk onderscheidt omzichtig verschillende modaliteiten van horizontale werking volgens een glijdende schaal (2):

- Als "minst vergaand" wordt genoemd de opdracht aan de wetgever of de overheid om een nader geformuleerd belang of beginsel ook in particuliere verhoudingen te verwezenlifken; dat is het geval met de instructienormen die men bijeen aantal sociale grondrechten aantreft. Boukema signaleerde deze vorm van indirecte derdenwerking eerder in de Duitse doctrine, waar zij echter niet beperkt is tot instructienormen bij sociale grondrechten. Aan de Duitse grondrechten kan in deze opvatting een opdracht aan de overheid worden ontleend om die maatregelen te treffen die nodig zijn om de in de grondrechten vervatte menselijke vrijheid te beschermen tegen aantasting door anderen dan de overheid. (3)

- De grondrechten hebben betekenis voor de interpretatie door de rechter van privaatrechtelijke normen, in het bijzonder de algemene begrippen als goede trouw, maatschappelijke zorgvuldigheid, onzedelijke oorzaak, etc. Ook hier zijn weer gradaties in. In de jurisprudentie zijn inmiddels voldoende voorbeelden te vinden van toepassing van grondrechtelijke normen in relaties tussen burgers, die men als horizontale werking kan typeren, maar waar anderen slechts spreken van "inkleuring van open juridische begrippen" (Kortmann). (4) Akkermans constateert bij contractuele en daarmee vergelijkbare rechtsrelaties dat de rechter in de praktijk volstaat met een belangenafweging in het kader van de invulling van globale normen als gewichtige, dringende redenen, waarbij de vrijheid van meningsuiting als een der elementen al dan niet expliciet meegewogen wordt. In het algemeen valt deze belangenafweging in het nadeel uit van degene die zich in 
zijn verweer tegen naar aanleiding van zijn uitingen opgelegde sancties (ontslag e.d.) op het grondrecht beroept. (5)

- Als intensiefste vorm van "derdenwerking" kan een grondrecht beogen zich dwingend aan de rechter op te leggen en slechts die afwijkingen toe te staan, welke tot een grondwettelijke beperkingsclawsule herleidbaar zijn. Volgens Van Wissen (6) is alleen in deze vorm uiberhaupt sprake van horizontale werking; in de overige gevallen van de glijdende schaal gaat het volgens hem om doorwerking op de een of andere manier van een ongeschreven fundamenteel recht. Hij noemt deze vorm dan ook "directe horizontale werking", waarvan hij in het kortgedingvonnis naar aanleiding van de weigering van het Congresgebouw om zaalruimte te verhuren aan de Stichting "Nederlands ZuidAfrikaanse Werkgemeenschap" een voorbeeld van toepassing ziet. (7)

Het leerstuk van de horizontale werking van grondrechten is nog steeds omstreden. (8) Koekkoek vraagt zich bij voorbeeld af of grondrechten zich er wel toe lenen rechtstreeks te worden toegepast in zuiver privaatrechtelijke verhoudingen. Dreigt niet een verwatering van de grondrechten als zij in verticale verhoudingen onverkort gelden, maar in horizontale betrekkingen in rechtskracht kunnen variëren van interpretatiefactor tot onverkort recht? Het komt mij juister voor in privaatrechtelijke betrekkingen te volstaan met het aanleggen van maatstaven van burgerlijk privaatrecht. (9)

Kritisch - om niet te zeggen laatdunkend - is het handboek van Van der PotDonner-Prakke, dat het regeringsstandpunt over horizontale werking afdoet als "onbestemd proza" van een "constitutionele slaapwandelaar". (10) Kortmann noemt de "zogenaamde horizontale werking" van grondrechten een van de themata van het constitutionele recht, waarover grote begripsverwarring heerst. ( .......... ) Daarbij komt bovendien dat aanvaarding van horizontale werking een wan de grondslagen van het privaatrecht, de contractsvrijheid, in sterke mate aantast. ( .....) Behalve in extreme gevallen van maatschappelijke machtsmonopolies valt echter niet in te zien, waarom de burger op dezelfde wijze tegen zijn medeburgers beschermd moet worden als tegen de overheid. De burger is nu eenmaal (en gelukkig) niet onderworpen aan het gezag van zijn medeburgers op de wijze waarop hij dit aan de overheid is. (11)

De formulering "extreme gevallen van maatschappelijke machtsmonopolies" die Kortmann bezigt, suggereert dat in ons land (nog) geen sprake is van problemen waar correctie via een vorm van horizontale werking van grondrechten zinvol kan zijn. Is dat geen vrij naief standpunt? Heringa-Zwart merken terecht op dat uit de gedachte dat grondrechten de burger een vrije sfeer beogen te garanderen voortvloeil dat het merkwaardig zou aandoen indien deze sfeer niet gewaarborgd kan worden tegenover machtige private organisaties. Dat geldt des te sterker indien private organisaties een publieke taak vervullen. Genoemd worden in dit verband de woningbouwcorporaties. Vooral wanneer machtige particuliere organisaties een monopolie innemen geldt dat de in het privaatrecht zo bewierookte contractsvrijheid op velerlei terrein een illusie is geworden. Reden 
te meer om zulke organisaties aan strenge normen te onderwerpen. ook op het terrein van de grondrechteneerbiediging. (12)

Vanuit deze opvatting, die meer recht doet aan feitelijke verhoudingen, kan men zich ook afvragen wie in ons land de uitingsvrijheid van de burger nog serieus bedreigt: de overheid of "machtige private organisaties"? Geldt ook hier niet de constatering voor Duitsland dat die Auseinandersetzung der Presse gegen den Staat im wesentlichen zum Abschluß gekommen (ist)? (........ ) Grundsätzlich droht unserer Presse heute von seiten des Staates keine Gefahr. ( ..........) Dominierend ist heute vielmehr die Auseinandersetzung zwischen Verleger und Redakteur, bei der insbesondere die Redakteure, bei aller Gemeinsamkeit mit den Verlegern, nach Profilierung und Kodifikation ihrer eigenen Rolle streben. Als Urheber von Zeitungsartikeln und als Gestalter der einzelnen Zeitungsausgabe beanspruchen sie größeren Einfluß in allen Entscheidungsprozessen, die die Formung "ihrer Zeitung" berühren. (13)

Het grondrecht van de uitingsvrijheid verbiedt de overheid de informatiestroom vooraf te controleren. Dit censuurverbod is niet slechts van historische en theoretische betekenis. Daarnaast hebben echter recente ontwikkelingen in de mediawereld, in het bijzonder de persconcentratie binnen de dagbladpers, journalisten ervan bewust gemaakt dat niet alleen de overheid, maar ook een naar oligarchie tenderende kleine groep dagbladeigenaren in staat is de informatiestroom naar hun hand te zetten. Een redactiestatuut kan hier corrigerend optreden. In dit licht is het te verdedigen wanneer journalisten het redactiestatuut, deze Kodifikation ihrer eigenen Rolle, beschouwen als voorbeeld van horizontale werking van het grondrecht van de uitingsvrijheid in de contractuele verhouding uitgever - (hoofd)redactie.

De opvatting is echter nog moeilijk te rubriceren onder een van de wijzen waarop horizontale werking tot stand kan komen. Tegen een opdracht aan de wetgever om, als uitvloeisel van een instructienorm, het redactiestatuut wettelijk te regelen bestaan, zoals in de vorige paragraaf uiteengezet, grondrechtelijke bezwaren. Een statuut als doorwerking van grondrechtelijke normen in privaatrechtelijke verhoudingen zal de rechter - Akkermans signaleerde het in vergelijkbare gevallen al - nog niet zo snel accepteren.

Hetgeen zich rond het redactiestatuut voltrokken heeft is wellicht te beschouwen als een illustratie van een door Meuwissen - maar wel in een minderheidsstandpunt - al in 1969 voorspelde "autonome rechtsontwikkeling", in dit geval resulterend in een de facto-derdenwerking van art. 7 Gw: Het is weinig zinvol te zeggen dat derdenwerking niet wordt beoogd noch wenselijk wordt geacht. Een dergelijke witspraak pretendeert greep te hebben op de toekomstige rechtsontwikkeling, doch zulks is slechts schijn, ondat deze rechtsontwikkeling zich toch betrekkelijk autonoom (en dus los van enige toelichting) voltrekt. (14) De conclusie moet luiden dat het redactiestatuut wel raakvlakken heeft met het leerstuk van de horizontale werking van grondrechten, maar dat het leerstuk zelf 
nog te weinig uitgekristalliseerd is en te controversieel om op deze basis het statuut en het grondrecht van de uitingsvrijheid met elkaar in verband te brengen.

(1) PJ. Boukema Preadvies naar aanleiding van het rapport wan de Staatscie. Cals-Donner. Geschriften wan de VAR, 1972, pag. 42 ex. A.G. Maris en I.M. Polak (preadviezen NJV 1969); kritisch over het "ius de non evocando" als grondrecht Van der Pot-Donner Handboek van het Nederlandse stadisrecht, 10 de druk (1977) pag. 457 en 12 de druk (1989) pag. 339.

(2) MvT billage TK 13872 , nr. 3 , blz 15 en 16.

(3) P.J. Boukema Enkele aspecten van de vrijheid van meningsuiting in de Duitse Bondsrepubliek en in Nederland, pag. A4.

(4) De meest geciteerde voorbeelden zijn Hof Amsterdam 30 oktober 1980, NJ 1981,422 (Boycot Outspan Actie); Hof Amsterdam 27 mei 1982, NJCM-Bulletin 1982, pag. 246 ex. (Advertentie Medisch Comite Palestina); HR 5 jun 1987, NJ 1988, 702 (Goeree-CIDI.)

(5) Akkermans-Koekkoek (red.) De Grondwet pag. 169 e.v. met jurisprudentieopgave.

(6) G.J.M. van Wissen Grondrechten, pag. 41-42.

(7) Pres. Rb. Den Haag van 9 juni 1987; KG 1987, nr. 268; AB 1987, 580. Van der Pot Donner- Prakke, Handboek van het Nederlandse staatsrecht, 12 de druk, pag. 251 - vindt overigens dat door het grote overheidsbelang in en bemoeiing met de NV Nederlands Congresgebouw - zes van de acht commissarissen worden benoemd door de gemeente Den Haag en de Staat - geen sprake is van "horizontale werking".

(8) Vgl. de opvattingen van enerzijds J. Boesjes De horizontale werking van grondrechten, NJB 1973, pag. 905 e.v. en anderzijds $\mathrm{F}$. de Graaf en M. de Haas Horizontale werking van grondrechten, een heilloos leerstuk, NJB 1984, pag. 1353 e.v.

(9) A.K. Koekkoek, Willem Konijnenbelt, F.C.L.M. Crijns (red.) in Grondrechten ("Jeukensbundel"), pag. 20.

(10) Van der Pot-Donner-Prakke Handboek van het Nederlandse staatsrecht, 12 de druk, pag. 250 .

(11) C.A.J.M. Kortmann Constitutioneel recht, pag. 345.

(1.2) A.W. Heringa-T. Zwart De Nederlandse grondwet, pag. 23.

(13) Armbruster u.A. Pressefreiheit. Entwurf eines Gesetzes zum Schutze freier Meinungsbildung und Dokuwentation des Arbeitskreises Pressefreiheit, pag. 45.

(14) D.H.M.Meuwissen: Staatscommissie Cals-Donner, tweede rapport, 1969, Minderheidsnota II, pag. 102 e.v. Vgl. ook Meuwissen Grondrechten pag. $70-71$ en 228 e.v.

\subsubsection{Wie is "drager van het grondrecht"}

\subsubsection{Inleiding}

In de beide vorige paragrafen zijn twee mogelijke invalshoeken om de verhouding uitgever - hoofdredactie - redactie in de sleutel van het grondrecht te plaatsen onderzocht en niet bruikbaar of (nog) te controversieel bevonden. Er is een derde invalshoek, waarvoor een aanknopingspunt gevonden kan worden in de kern van het grondrecht: de uitingsvrijheid in het algemeen en dus ook de uitingsvrijheid via de pers is primair een subjectief recht van iedere burger om een bepaalde mening of mededeling te mogen formuleren en verspreiden zonder enige preventieve beperking. Archetype van degene die ten onzent het grondrecht van art. $7 \mathrm{Gw}$ (art. 10 EVRM) uitoefent is dan ook de pamflettist: de burger die zijn mening of mededeling op schrift stelt, eventueel vermenigvuldigt, en vervolgens verspreidt. Ook de dagbladpers valt binnen deze omschrijving: de 
persvrijheid is in haar kern niets anders dan de vrijheid van de individuele burger om met alle hem ter beschikking staande middelen, waaronder ook die wan kapitaal en techniek, zijn mening en/of feitelijke mededelingen aan een groter publiek te openbaren en te verspreiden dan de pamflettist kan bereiken.

Tot het begin wan deze eeuw beantwoordde in ons land de dagbladuitgever (de "courantier") herkenbaar aan dat beeld: In de gehele 19de eeuw was de uirgever van bladen en van schoolboeken nog in hoge mate een drukker met een boodschap. De dagbladen waren geprofileerd, de familiebladen stichtelijk en de vakbladen een middel tot verheffing van de Nederlandse ambachtsstand. (1) De huidige dagbladonderneming laat een geheel ander type uitgever zien: een rechtspersoon die, vaak naast anderssoortige periodieken, onder andlere ook een dagblad - en in de meeste gevallen zelfs meer dan één - uitgeeft. De band van de uitgever met de identiteit van zijn krant(en) is een losse. Zoals uit het overzicht van de redactiestatuten in het vorige hoofdstuk blijkt, hebben maar weinig uitgevers de identiteit van hun dagblad(en) in de ondernemingsstatuten vastgelegd. In tegenstelling tot de Duitse hebben de meeste Nederlandse dagbladondernemers zich namelijk nooit veel gelegen laten liggen aan hun "Grundsatzkompetenz" en de daaruit voortvloeiende rechten om zich, wanneer de "Grundsatz" in het geding is, met de inhoud van hun kranten te bemoeien. Slechts zelden schrijven uitgevers in hun eigen bladen. (2) Dat ook de Nederlandse uitgever de "Grundsatzkompetenz" in beginsel toekomt wordt evenwel niet betwist.

De uitgever met zijn kennis van en macht binnen de markt, waarin het commerciële produkt dagblad vervaardigd en verkocht moet worden, is binnen de moderne persstructuur niettemin even onmisbaar als onvervangbaar. De moderne uitgever, die in de praktijk vooral optreedt als managementteam, legt en onderhoudt de economische basis onder eén of meer dagbladen. Experimenten met andere ondernemingsstructuren, zoals redactionele (mede)eigendom van de krant (Le Monde) of scheiding van de commerciële en redactionele vervaardiging van de krant via voor iedereen beschikbare technische faciliteiten ("drukfabrieken"), hoewel in het recente verleden wel gepropageerd, (3) worden nog met grote terughoudendheid bekeken. Hoffmann-Riem - om een onverdachte bron te citeren - formuleert als "Faustregel": Anderungen der Binnenstruktur gefährden die Funktionsfähigkeit der Presse und gleichzeitig die Möglichkeit zur Ausübung der Pressefreiheit, wenn sie zum ersatzlosen Entzug der für die Presse erforderlichen ökonomischen Grundlage führen. De meerderheid van de uitgevers zal, zo verwacht Hoffmann-Riem, geen kapitaal meer in een dagblad steken, wanneer hun zeggenschap tot die van een maecenas beperkt zou worden. (4)

De Duitse formulering van het grondrecht van art. $5 \mathrm{GG}$ en de discussie over de bevoegdheden binnen de dagbladonderneming ("Grundsatz-, Richtlinien- en Detailkompetenz") voerden, zoals in hoofdstuk 6 bleek, onvermijdelijk tot een kernvraag in het Duitse mediarecht: wie van de verschillende binnen het verband van bij voorbeeld een dagbladonderneming samenwerkende uitoefenaars van 
grondrechten zijn "dragers" van het grondrecht van art. 5 GG?

In de door belangengroepen (vooral die van de uitgevers) sterk beinvloede discussie zijn globaal twee hoofdlijnen te onderscheiden. Van uitgeverszijde (Weber, Forsthoff, Lerche e.a.) wordt benadrukt dat de "Verleger" de primaire grondrechtdrager is; de uitingsvrijheid van de journalist via de pers is in deze opvatting een van de uitgever afgeleid grondrecht. In deze visie gelden vooral de, grondwettelijk (art. $14 \mathrm{GG}$ ) beschermde, "Eigentumsfreiheit", maar ook (art. 12 GG) de "Berufsfreiheit" als onaantastbare bestanddelen van de persvrijheid. De heersende leer omschrijft het grondrecht van de persvrijheid als de vrijheid om de richting ("Tendenz") van een blad vast te leggen, te behouden, te effectueren en te veranderen (5). "Tendenzträger" zijn allereerst de "Verleger" of de "Herausgeber". Journalisten und Redakteure sind zwar unmittelbar an der inhaltlichen Ausgestaltung des Presseerzeugnisses beteiligt, sind damit aber nicht Tendenzträger. (6)

Vanuit de journalistieke optiek is het standpunt verdedigd dat de feitelijke uitoefenaar van het grondrecht, de journalist, de primaire drager ervan is. Das primäre Schutzgut, die "materielle Pressefreiheit", ist $(\ldots .$.$) die$ Meinungsfreiheit der Presse, das Grundrecht der freien publizistischen Meinungsäußerung. Erster Träger dieses Grundrechtes ist der, dessen Aufgabe es ist, durch das Medium der Presse Meinungen zu äußern: der Journalist. De uitgever is Träger der Pressegewerbefreiheit, een tot de "formele persvrijheid" behorend connex recht, dat dienstbaar is aan de "materiële persurijheid" van de publicist. (7) Binnen deze grondrechtelijk gefixeerde richtingenstrijd heeft zich in Duitsland de principiële en daarom moeizame discussie over de verdeling van bevoegdheden over de redactionele inhoud van een krant bewogen.

(1) R.E.M. van den Brink Informatie over informatie. Handboek van de informatiemedia in Nederland 1938-1985, (diss. Leiden) pag. 51 .

(2) Uitgever Van den Brink, die een groot artikel voor "Elseviers Weekblad" van 1 februari 1964 schreef ("Open brief aan minister Andriessen" over prijsbeheersing in de foliomedia) veronderstelt dat dit de enige uitzondering na 1945 is geweest. R.E.M. van den Brink Informatie over infomatie, pag. 257.

(3) Rapport van de Studiecommissie Dagbladooncentraties van de NVJ uit 1970.

(4) Wolfgang Hoffmann-Rien Innere Pressefreiheit als politische Aufgabe, pag. 94.

(5) B VerfGE 52, 283 (Tendenzschutz).

(6) Von Mangold-Klein -Starck Das Bonner Grundgesetz - Band 1, Rz 60, pag. 525 e.v.

(7) Walter Mallmann in Es geht nicht nur um Springer, pag. $17 / 18$

\subsubsection{2 "Openbaren" en "hulphandelingen"}

De Nederlandse formulering van de grondrechten in het algemeen en die van de uitingsvrijheid in het bijzonder geeft minder aanleiding tot collisievraagstukken zoals in Duitsland. Dat betekent niet dat de Duitse discussie over de toedeling van het grondrecht van de uitingsvrijheid aan de verschiedenen arbeitsteilig zusammenwirkenden Grundrechtsträger in ons land niet gevoerd kan of hoeft te worden. Een aanknopingspunt voor de discussie over de verhouding uitgever - 
(hoofd)redactie in ons land is naar mijn mening te vinden in de uitvoerige jurisprudentie over een belangrijk facet van het uitingsrecht, namelijk over de vraag in hoeverre de verspreiding van gedrukte stukken beperkt mag worden.

In de bekende "verspreidingsjurisprudentie" heeft de Hoge Raad, vooral sinds de beide arresten van 28 november 1950 (1), een principiële cesuur aangebracht binnen het proces van het openbaren van "gedachten of gevoelens", welke cesuur ook de verhouding uitgever - (hoofd)redactie kenmerkt. In deze arresten maakt de Hoge Raad onderscheid tussen:

- enerzijds het grondrecht van een ieder om, zonder voorafgaand verlof der Overheid, gedachten of gevoelens door middel van de drukpers te uiten zo dat zij voor anderen kenbaar zijn. (.......)

- en de overweging anderzijds: dat later naast dit de geesteswereld betreffende recht tevens, als tot het met dat recht beoogde doel onmisbaar doch aan dat recht ondergeschikt, door den rechter is aangenomen het recht van eenieder om een gedrukt schrift en het daarin gedrukte, door het te verspreiden, openlijk ten toon te stellen of door enig ander middel, in het openbaar aan het publiek bekend te maken, welk het verkeer op den openbaren weg rakend en dus een ruimtelijke sfeer bestrijkend recht evenwel wegens dien anderen aard zijn eigen beperking medebracht $(. .$.

Het "de geesteswereld betreffende" openbaringsrecht, aldus leerde de Hoge Raad, mag slechts door middel van een wet in formele zin beperkt worden. Het verspreidingsrecht daarentegen mag door een lagere regelgever, zoals de gemeenteraad op basis van art. 168 (thans 150) Gemeentewet, preventief aan voorschriften onderworpen worden, mits

- die "in het belang der openbare orde, bepaaldelijk ter beveiliging van het openbare verkeer" zijn; de HR haalde dit laatste bijna woordelijk uit HR 7 november 1892, W. 6259 (Haags ventverbod) en

- de beperkingen niet van dien aard zijn dat ze in feite neerkomen op een totaal verbod (APV-Nuth, HR 17 maart 1953, NJ 1953, 389). (2)

Vooral maatschappelijke minderheden maken - noodgedwongen - vaak gebruik van muurkranten en aanplakbiljetten. Wie zich tot een groot publiek wil richten en geen gebruik kan maken van dure verspreidingsmiddelen, zoals het laten bezorgen van krant of tijdschrift - om nog maar te zwijgen van verspreiding via radio en televisie - is op (onder meer) "plakken" aangewezen. Dat is naar zijn aard "een ruimtelijke sfeer bestrijkend" verspreidingsmiddel en dus vatbaar voor preventieve beperkingen van lagere regelgevers dan de formele wetgever. Bovendien kan het inbreuk maken op andermans onroerend goed. De uitgebreide jurisprudentie over het verspreidingsrecht, die op het Tilburgse arrest gevolgd is, had dan ook vaak betrekking op gemeentelijke plakverboden. Op grond van de diverse uitspraken over gemeentelijke beperkingen van onder meer het "plakken" noemt De Meij de verspreidingsvrijheid binnen art. $7 \mathrm{Gw}$, in navolging van Van der Hoeven, een "connex recht, dus een recht van de tweede orde". Niettemin - 
daar bestaat geen verschil van mening meer over - is ook dit connexe recht beschermi door art. 7 Gw: (3)

Wat heeft deze jurisprudentie met de verhouding uitgever - (hoofd)redactie te maken? Binnen de dagbladonderneming is het verspreiden en het technisch vervaardigen (zetten en drukken) van de krant een activiteit van het nietredactionele deel van de onderneming. Naast het verspreiden mag ook thet drukken zo'n connex recht genoemd worden; Boon concludeert dat HR 23 mei 1961, NJ 427 (Vestigingsbesluit Grafische Bedrijven I 1952) daarvoor ruimte laat. (4)

De Meij pleit ervoor het begrip "openbaren" eng te interpreteren en alle hulphandelingen die geen verband houden met de inhoud van een publikatie aan andere criteria te toetsen dan in de grondwetstekst zelf zijn opgenomen. De Meij maakt daarom onderscheid tussen:

- handelingen die direct met de inhoud verband houden, zoals het hele redactionele proces, de formulering van de redactionele identiteit door de eigenaar en diens beslissing om een blad uit te geven, en

- de vele "hulphandelingen" zoals het drukken en allerlei commerciële activiteiten in het kader van de bedrijfsuitoefening, die van meer indirecte betekenis voor de inhoud zijn. Deze "hulphandelingen" vallen onder het lager (connex) recht. (5)

$\mathrm{Nu}$ kan men tegenwerpen dat bij de jurisprudentie over het onderscheid tussen openbaren en hulphandelingen zoals het verspreiden, niet de bedoeling heeft voorgezeten de verhouding uitgever - (hoofd)redactie binnen, bij voorbeeld, de dagbladonderneming te beschrijven, laat staan te normeren. Dat is juist. Het is echter eveneens juist:

- dat bij het vervaardigen van een krant onderscheid te maken valt tussen het "de geesteswereld betreffende" openbaren (schrijven, redigeren) enerzijds en de onmisbare technische en economische activiteiten, zoals het zelten, drukken, advertenties werven, en verspreiden anderzijds. (De vraag of ook "uitgeven" tot het "openbaren" gerekend moet worden komt in de volgende paragraaf aan de orde).

- dat in het algemeen de redactie - en zij alleen - zich bezighoudt met het schrijven en redigeren en de activiteiten van de uitgever (directie) zich daar in de regel nadrukkelijk niet op richten.

Deze strikte tweedeling van activiteiten is geformalliseerd in de positie van de hoofdredacteur, in de CAO - vanaf 1948 - (hoewel de regeling daar niet thuishoort) en sinds de jaren zeventig in de redactiestatuten. Daarin kreeg de hoofdredacteur een bijzondere plaats, namelijk die van exclusief verantwoordelijke voor de redactionele inhoud van de krant.

(1) APV Tilburg, NJ 1951, 137 en Sittard, NJ 1951, 138, met nt. W. P.J. Pompe; A.A. 1 (1951), pag. 13, met nt. J.P. Hooykas.

(2) In de Algemene Plaatselijke Verondening van Tilburg, zoals deze in 1989 opnieuw door de raad 
is yastgesteld, staat overigens geen artikel meer dat het verspreiden van gedrukte stukken in Tilburg kan beperken. Volgens de toelichting van b. en w. aan de raad is hiervoor niet gekozen, "omdat de noodzaak daartoe niet is gebleken".

(3) APV Dordrecht, HR 2 oktober 1979, NJ 1980, 105, A.A. 30 (1981) 7, pag. 368-377; A.W. Heringa - R. de Winter Plakwerordening Dordrecht-een reactie, A.A. 30 (1981) 11, pag. 718 721 ; F.H. van der Burg Naschiff op: Plakwerordening Dordrecht-een reactie; A.A. 30 (1981) 11. pag. 721 - 722; A.W. Heringa - R. de Winter De kleefkrach van de wriheid van meningsuiting, NJB 57 (1982) 12, pag. 352 - 354; APV Gouda, HR 21 januari 1986, N1 1986. 572. Een overzicht van de verspreidingsjurisprudentie is te vinden in J.M. de Meij Uitingsvrijheid, pag. 100-116. Zeer kritisch over de vermeende duidelijkheid die de Hoge Raad in zijn Tilburgse en Sittardse arresten aan de dag gelegd zou hebben is Reiner de Winter De heersende leer - 100 jaar verspreidingsjurisprudentie 1892 - 1992, (diss. Maastricht - 1993) pag. 106 e.v. Vgl. ook Martijn Polak Het recht van plakken, A.A. 32 (1983) 1, pag. 35 - 42 en hoofdstuk III van F.H. Kistenkas Vrije straatcommunicatie (diss.) Arnhem/Deventer 1989.

(4) P.J. Boon Zonder voorafgaand verlof, pag. 18.

(5) J.M. de Meij Toch een persfusieregeling? Informatierecht/AMI oktober 1990, nr. 8, pag. 177 e.v. ; id. Persfusies en perswrijheid, NJB 11 februari 1989, afl. 6. pag. 181. In De nieuwe media en artikel 7 wan de grondwet. Auteursrecht/AMI november 1985, pag. 100 onderscheidt De Meij het "publiceren" van "het brengen van de boodschap bij het publiek".

Bij de omroep ervaart de kijker/luisteraar dezelfde "tweedeling" onder meer via het fenomeen etherreclame ter (mede)financiering van het programma. Jurgens signaleert de vooral economisch. georiënteerde opvatting van de Europese Commissie over de veihouding omroepprogramma en reclame via de omroep in haar Groenboek "Televisie zonder grenzen" uit 1984: In de visie van het Groenboek is niet zazeer het programma de economisch relevante dienst die wordt verricht, maar de reclame! Daar staat tegenover de gangbare opvatting van cultuur-politieke aard, die ook steun ondervindt van kijkers en luisteraars, dat het juist om de programma's gaat en dat die reclame hooguit een lastige bijkomstigheid is, nodig voor de financiering. E.C.M. Jurgens en N. van Lingen Omroeprecht en auteursrech, pag. 9.

\subsubsection{Tussenconclusie}

Een probleemstelling uit het eerste hoofdstuk luidde: Op welke wijze is het redactiestatuut als regeling van de verhouding uitgever - hoofdredactie - redactie in te passen in een grondrechtelijk kader?

Om die vraag te beantwoorden is eerst onderzocht of de uit het grondrecht afgeleide zorgplicht van de overheid om een pluriforme pers te bevorderen en in stand te houden tot een (wettelijk geregeld) statuut zou nopen, met als conclusie dat zulks juist op grondrechtelijke bezwaren stuit. Erkenning van een zekere derdenwerking van het grondrecht van de uitingsvrijheid blijkt wel aanknopingspunten op te leveren - niet de staat, doch een steeds kleinere groep uitgevers zou een bedreiging kunnen vormen voor de vrije informatiestroom maar dit valt af omdat het leerstuk nog te weinig uitgekristalliseerd en daarom omstreden blijft. Als derde invalshoek is tenslotte de kern van het grondrecht gekozen: de uitingsvrijheid en dus ook de persvrijheid is primair een subjectief recht van elk individu om zich zonder preventieve beperking te uiten. De uitgebreide verspreidingsjurisprudentie - in het bijzonder het Tilburgse-APVarrest - levert aanknopingspunten voor een regeling op grondrechtelijke basis van de verhouding uitgever - (hoofd)redactie. Het arrest maakt onderscheid tussen publicistische activiteiten die grondrechtelijk ook onderscheiden worden 
bescherma: het "de geesteswereld betreffende" openbaren en het verrichten van diverse connexe hulphandelingen. Bij een dagblad (maar het gaat natuurlijk ook op voor andere geschreven media) zall in de regel de (hoofd)redactie zich met het eerste bezighouden, de uitgever met het tweede. Dit onderscheid in grondrechtelijke bescherming is een basis voor afbakening van bevoegdheden tussen uitgever en (hoofd)redactie zoals deze in een redactiestatuut kunnen worden overeengekomen.

\subsubsection{Uitgever en identiteit}

De Meij betrekt in zijn formulering van wat onder het "de geesteswereld betreffende" openbaren moet worden verstaan ook de inbreng van de eigenaar (uitgever) die de identiteit van de krant heeft vastgelegd en de beslissing heeft genomen deze krant uit te geven. Geldt die inbreng in gelijke mate voor alle dagbladuitgevers?

Rebe (1) onderscheidt bij de Duitse dagbladuitgeverijen met een eigen redactie (2) globaal twee uitgeverstypen, waartussen zich nog "verschiedene Übergangsformen" bevinden:

1. Der sogenannte "Herausgeber-Verleger" bestimmt (tatsächlich) die Grundrichtiung seiner Zeitung und ubt auch sonst weitgehenden Einfluß auf die Auswahl und Gestaltung des Inhalts aus. Een dergelijke uitgever houdt zich onmiskenbaar bezig met het "de geesteswereld betreffende" openbaren, zoals onderscheiden in HR APV-Tilburg. Een Duits onderzoek uit 1969 (3) onder redacteuren, rubriekschefs en hoofdredacteuren van dagbladen wees uit dat 85 procent van de uitgevers zich op enige wijze met de inhoud van de krant bemoeiden. Een op de zes ondervraagden meende dat hun uitgever zich meer gedroeg als journalist dan als uitgever of dat hij zijn invloed gebruikte om commerciële doeleinden te ondersteunen.

2. Ihm steht der "Unternehmer-Verleger" gegenüber, für den das Presseunternehmen nur eine Form der Kapitalanlage oder der erwerbswirtschaftlichen Betätigung ist und der die Bestimmung der publizistischen Grundrichtung und uberhaupt die Auswahl des Inhalts und seine Gestaltung einem Herausgeber oder dem Chefredakteur überläßt. Hier hebben we te maken met een uitgever die zich vooral met de voor het openbaren weliswaar onmisbare, maar grondrechtelijk lager geplaatste hulphandelingen bezighoudt. Waarbij nogmaals benadrukt moet worden dat ook deze hulphandelingen de grondrechtelijke bescherming van art. $7 \mathrm{Gw}$ genieten.

Tot welk type horen de Nederlandse dagbladuitgevers? Geheel binnen een van de extreme typeringen van Rebe valt er waarschijnlijk geen. Of ze dichter bij de typering "Herausgeber-Verleger" zitten danwel bij de "Unternehmer-Verleger" is een vraag van feitelijke aard, een vraag die daarom alleen maar per dagblad en per dagbladonderneming beantwoord kan worden. Uitgever, hoofdredactie en redactie dienen het daarom allereerst eens te worden over een beschrijving van 
de feitelijke, in de loop der jaren gegroeide, verhouding van elk der partijen tot de identiteit van de krant en alleen partijen zelf kunnen dat.

Een buitenstaander kan slechts globale indicaties geven. Er zijn uitgevers die, naar de formulering van De Meij, zelf de identiteit van hun krant hebben bepald en de beslissing hebben genomen de krant met déze politieke en/of godsdienstige uitgangspunten en binnen déze redactionele formule uit te geven. $\mathrm{Zij}$ zien er nauwlettend op toe, dat de (hoofd)redactie deze identiteit trouw blijft uitdragen. Het Friesch Dagblad en het Nederlands Dagblad, bladen waarvan de identiteitsverklaringen daarom ook deel uitmaken van de ondernemingsstatuten, zijn daar duidelijke voorbeelden van. Dat geldt in nog sterkere mate voor het Reformatorisch Dagblad, dat om die reden zelfs geen redactiestatuut kent. Ook Trouw, waar de Stichting ter Bevordering van de Christelijke Pers in Nederland de identiteit van Trouw bewaakt en daarom nauw contact met de redactie onderhoudt, hoort waarschijnlijk in dit rijtje van typische "richtingbladen". Bij de meeste andere kranten, vooral de regionale, is de band van de uitgever met de identiteit losser. Bij regionale bladen is echter wel degelijk sprake van identiteit: de redactionele gerichtheid op het verschijningsgebied. Binnen de regionale dagbladpers heeft zich de afgelopen jaren een tweede concentratiegolf voorgedaan, die thans - eind 1993 - nog niet uitgewoed is. Daarbij kan de identiteit wel eens in het geding komen.

De identiteit van een regionaal dagblad na een fusie, maar dan bezien vanuit het perspectief van de lezer-abonnee, speelde een belangrijke rol in een zaak die zich in de Zaanstreek heeft voorgedaan. (4) Kiburg was sedert 1985 abonnee van de in de Zaanstreek verschijnende avondkrant De Typhoon. Sedert 15 februari 1992 , na de fusie van de uitgever van De Typhoon met de Verenigde Noord-Hollandse Dagbladen $B V$, uitgeefster van het concurrerened dagblad De Zaanlander, werd bij de abonnees van De Typhoon voortaan het Dagbllad Zaanstreek, een ochtendblad, bezorgd. Kiburg liet de nieuwe krant doorbezorgen, maar betaalde niets, waarop de uitgever ter invordering van f 182,31 abonnementsgeld Kiburg voor de kantonrechter daagde. Het standpunt van gedaagde komt kort en bondig geformuleerd hierop neer, dat hij zich niet tot betaling verplicht acht $(\ldots . .$. omdat hij zich nooit op dat blad heeft geabonneerd en op bezorging daarvan geen prijs stelt. De nieuwe krant is voor hem niet te vereenzelvigen met de Typhoon.

De kantonrechter was het met dit principiële standpunt van Kiburg eens: Voorop moet worden gesteld dat een dagblad voor de vaste lezers in de regel een produkt is, dat zich niet zonder meer laat vervangen door een ander. De redenen waarom men zich op een bepaalde krant abonneert kunnen van zeer uiteenlopende aard zijn. Feit van algemene bekendheid is dat een dagblad veelal een bepaalde (althans een zo door de lezerskring gevoelde) identiteit heeft, hetgeen betekent dat men niet zomaar van de lezer mag verwachten dat hij genoegen neemt met een andere krant. Zo zal een abonnee op de Volkskrant meestal niet erg blij zijn 
als de bezorger op een dag besluit voortaan De Telegraaf in de bus te stoppen, hetgeen natuurlijk ook opgaat voor die abonnees die om moverende redenen hebben gekozen voor een regionaal verschijnend dagblad. Gelet hierop mocht eiseres, als rechtsopwolgster van de Typhoon, er dan ook net op vertrouwen, dat de abonnees op de Typhoon stilzwijgend akoord zouden gaan met een abonnement op Dagblad Zaanstreek (... ).

Een uitgeversfusie hoeft niet per definitie te leiden tot het verdwijnen van een krant. Heeft zo' $n$ fusie dan geen consequenties voor de verhouding van uitgever tot de identiteit? Wanneer bij de acquisitie van een krant de identiteitsverklaring overgenomen werd - de vaste formulering bij krantenfusies om dit uit te drukken luidde steevast dat "de redactionele identiteit en het karakter van de krant geëerbiedigd zullen worden" - heeft de nieuwe eigenaar echter niet de identiteit van deze krant bepaald; eerder het omgekeerde is het geval: de identiteitsverklaring van de overgenomen krant verplicht thans (ook) de nieuwe uitgever zich eraan te houden.

Identiteit - het is hiervoor al eerder betoogd - omvat meer dan op papier te zetten ijkpunten voor het redactioneel beleid; die zijn, zoals in het vorige hoofdstuk gebleken is, bij veel dagbladen trouwens vaag en soms zelfs onderling uitwisselbaar. Kranten - ook sommige regionale - onderscheiden zich vooral door de in de loop der jaren gegroeide "redactionele cultuur". Het aandeel van de uitgever in dit aspect van de "identiteit" is in de regel beperkt tot welwillende afzijdigheid.

Tenslotte is er, in de formulering van De Meij, de beslissing om de krant uit te geven als element van "openbaren". Die beslissing kan, zoals bij de "HerausgeberVerleger" een ideële achtergrond hebben, maar kan ook vooral, zo niet uitsluitend, economisch gemotiveerd zijn. Daar is niets op tegen - integendeel, een degelijke economische basis is onmisbaar voor een krant - maar het onderscheid is mede bepalend voor de vraag of en in hoeverre de uitgever zich met "openbaren" bezighoudt danwel overwegend of zelfs uitsluitend met weliswaar onmisbare, maar grondrechtelijk wat lager ingeschaalde "hulphandelingen". Of een krant uit economische dan wel ideologische overwegingen - mogelijk zelfs beide - uitgegeven wordt is opnieuw een vraag van feitelijke aard, die niet generiek, maar per dagbladonderneming door de partijen uitgever, hoofdredactie en redactie beantwoord moet worden.

(1) Bernd Rebe Die Träger der Pressefreiheit nach dem Grundgesetz, pag. 69.

(2) In tegenstelling tot uitgeverijen van zogenaamde "Maternzeitungen", bladen waarvan de inhoud geheel door anderen wordt aangeleverd; deze uitgevers zorgen slechts voor het drukken en verkopen van het blad en gelden daarom volgens Rebe niet als "Träger der Pressefreiheit".

(3) Tabelle A 44 uit: Rudiger Schulz Entscheidungsstrukturen der Redaktionsarbeit, geciteerd in: Wolfgang Hoffmann-Riem Innere Pressefreiheit als politische Aufgabe, pag. 184-185.

(4) Ktg. Zaandam van 4 maart 1993 (Verenigde Noord-Hollandse Dagbladen B.V. tegen R.G. Kiburg), Mediaforum 1993-6, pag. B69. 


\subsubsection{5 "Träger der Pressefreiheit"}

Keren we thans terug tot de vraag wie zich dragers van het grondrecht van art. 7 Gw mogen noemen: uitsluitend de uitgever of uitsluitend de individuele journalist, om twee extreme standpunten te noemen die beide in de Duitse doctrine verdedigd zijn? Met Hoffmann-Riem ben ik van menung dat bij de uitoefening van het grondrecht van de uitingsvrijheid via de pers iedereen die aan een publikatie via een medium meewerkt, van hoofdredacteur tot zetter en boekhouder, grondrechtelijke bescherming geniet und zwar nach Maßgabe ihrer Rolle im publizistischen Prozeß. Grundrechtsschutz steht auch dem Medienunternehmer zu, also dem Verleger. (...... ) Mit dem Grundrechisschutz ist jedoch nicht zwingend ein durch Art. 5 Abs. I Satz 2 GG abgesicherter Bestandsschutz verknuipft. ( ..........) Auch die Rolle des Verlegers (als Inhaber des Verlagsunternehmens) genießt nach Art. 5 Abs. 1 Satz 2 GG Bestandsschutz nur insoweit, als die Stellung eines Verlegers im Rahmen der jeweiligen Ausgestaltung des Pressewesens prinzipiell vorgesehen ist bzw. im Interesse der Funktionsfähigkeit des öfentlichen Kommunikationsprozesses vorgesehen werden muß. (1)

Deze formulering wie "Träger der Pressefreiheit" binnen een mediaonderneming zijn past geheel binnen ons art. $7 \mathrm{Gw}$, dat immers in beginsel iedereen omsluit. In de Nederlandse doctrine wordt er weliswaar rekening mee gehouden, dat het vooral journalisten zijn die dagelijks met het grondrecht omgaan, maar er is consensus over dat de uitingsvrijheid via de pers niet beperkt is tot deze beroepsgroep. (2)

Hoffmann-Riems formulering brengt hanteerbare nuances in de "Grundrechtsschutz" aan: of en in hoeverre een contribuant aan een publikatie het grondrecht uitoefent is volgens hem afhankelijk van

- de mate waarin hij aan de publikatie meewerkt en

- de mate waarin zijn aandeel noodzakelijk en onmisbaar is geweest in het geheel van het "publiceerproces".

Die feitelijke gedraging, de intensiteit waarmee bij voorbeeld de uitgever betrokken is bij het "openbaren", is van feitelijke aard en zal opnieuw per krant en onderneming verschillen: van "in zeer hoge mate" (de uitgever is de identiteit) tot "in geringe mate" (de uitgever voert vrijwel uitsluitend "hulphandelingen" uit). Die intensiteit mag dan ook consequenties hebben.

Is de uitgever in hoge mate ideëel betrokken bij een blad, dan staat het hem, naar mijn mening, vrij in beginsel elke publicatie inhoudelijk te sturen en te controleren, niet alleen via de redactionele beginselen, maar ook via nadere richtlijnen en zelfs via de "Einzelweisung", de instructie door de uitgever aan de individuele journalist. Zo'n uitgever mag ook zelf schrijven en redigeren. Een overeenkomst met een hoofdredactie en een redactie waarin deze bevoegdhedenverdeling tussen partijen is overeengekomen mag "redactiestatuut" genoemd worden. De hier beschreven situatie is een extreme, maar elke 
generieke regeling, hetzij bij wet of collectieve arbeidsovereenkomst, die een dergelijk redactiestatuut uitsluit staat - zoals hiervoor reeds betoogd - op gespannen voet met het grondrecht van de uitingsvrijheid. Voor een goed begrip: dit is geen pleidooi voor in eigen blad publicerende uitgevers, slechts de constatering dat er zulke journalistiek geëngageerde uitgevers (mogen) zijn.

Is de activiteit van de uitgever bij een krant daarentegen uitsluitend of in hoofdzaak economisch van aard - en zijn partijen het er over eens dat dit bij hun krant het geval is (3) - dan past de uitgever terughoudendheid waar het (nieteconomisch gemotiveerde) beslissingen betreft die grote invloed op het redactionele werk hebben.

Deze terughoudendheid moet dan eveneens blijken uit het redactiestatuut. Tot die beslissingen behoren onder meer

- het recht de hoofdredacteur te benoemen of

op gronden die verband houden met de beginselen van de krant te ontslaan;

- wijziging van de redactionele uitgangspunten;

- wijziging van karakter of verschijningsvorm van de krant;

- wijziging van de positie van de redactie en hoofdredactie;

- aangaan respectievelijk wijzigen van samenwerkingsverbanden, die

van fundamenteel belang zijn voor de taak en functie van de redactie.

De positie van de individuele journalist-in-dienstverband in het geheel van het "grondrechtsdragerschap" is gecompliceerd. Is hij, zoals Mallmann veronderstelt, binnen het geheel van de bij een dagblad samenwerkende uitoefenaren van grondrechten bij uitstek drager van het grondrecht van de uitingsvrijheid? Dat is moeilijk vol te houden. Uiteraard oefent de individuele journalist het grondrecht van de uitingsvrijheid uit, maar steeds in verbondenheid met het medium, dat zijn aitingen publiceert. De journalist-in-dienstbetrekking is ondergeschikt aan de redactionele uitgangspunten (identiteit) van zijn blad en aan zijn hoofdredactie. Voor de meeste journalisten geldt bovendien dat zij hun werk verrichten binnen een team dat de individuele vrijheid van ieder van hen sterk kan beperken: journalisten krijgen opdrachten van een team, een eindredactie dicteert de lengte van hun stukken, herschrijft artikelen en kan ze zelfs weigeren.

Schuijt, die de vrijheid en onvrijheid van de journalist-in-dienstverband beschrijft aan de hand van $\mathrm{CAO}$-bepalingen en uitspraken van de Raad van Uitvoering over beperking van de vrijheid van individuele journalisten, komt - naar mijn mening terecht - tot de conclusie dat de vrijheid van het medium boven die van de individuele journalist moet prevaleren. Een massamedium functioneert nu eenmaal niet goed indien het slechts een verzameling is van individuele journalistieke prestaties en niet geredigeerd wordt vanuit een bepaalde beleidsvisie. Conflicten over dat beleid kunnen niet met individuele redacteuren worden opgelost, maar moeten langs de weg van medezeggenschapsregelingen worden beslecht. (4) In dat licht is het meer in overeenstemming met de praktijk van het "de geesteswereld betreffende" openbaren om het redactionele collectief onder leiding van - en gepersonifieerd in - de hoofdredactie aan te wijzen als 
primaire drager van het grondrecht. De uitingsvrijheid van de individuele journalist in dienstverband is een van dit collectief afgeleid grondrecht.

(1) Wolfgang Hoffmann-Riem in: Benda-Mahofer-Vogel Handbuch des Verfassungsrechts der Bundesrepublik Deutschland ${ }_{n}$ pag. 410.

(2) Dezelfde ruime opvatting van "journalistiek" is bij voorbeeld terug te vinden in de toelichting bij Jurgens" ontwerp voor een "Wet op het journalistiek privilege": Het privilege geldt personen die een bepaalde relatic hebben met het publiceren wan informatie in een voor het algemeen publiek toegankelijke vorm van openbare communicatie. (.........) Beperking tot de leden vam een beroepsgroep zou miskennen dat de vrijheid van witing en onwangst alle burgers geldt. Hoewel jowmalisten een bijzondere functie vervullen in de verschaffing wan informatie en de vorming van de openbare mening, mag dit - wit de aard van het grondrecht a niet leiden tot een monopoliepositie. Mediaforum 1991-2, pag. 13 e.w; id. $1991-11 / 12$, pag. 120.

(3) Het hier bepleite "gewetensonderzoek" van de betrokken partijen kan er natuarlijk toe leiden dat een uitgever die zich tot nu toe weinig intensief met het publiceerproces heeft bemoeid, daarin een aansporing ziet om meer uit zijn "Grundsatzkompetenz" voortvloeiende rechten te claimen. Op zich hoeft dat geen bedreiging voor de (hoofd)redactie te zijn, integendeel: met een redactioneel geëngageerde uitgever staat zo"n (hoofd)redactie juist sterk. Of het in de praktijk ook zal gebeuren is twijfelachtig. De meeste uitgevers hebben meer dan ến krant en hun gepretendeerde engagement met álle bladen zou weinig geloofwaardig overkomen. Het zou bovenal een breuk zijn met de gevestigde traditie in ons land dat uitgevers zich tot de economische exploitatie beperken.

(4) Schuijt Werkers van het woord, pag. 305.

\subsubsection{De "zware procedure" volgens Hoffmann-Riem}

Gerekend naar de betrokkenheid van de uitgever bij de redactionele identiteit is een glijdende schaal te tekenen, globaal lopend van

- de uitgever is tevens identiteit (Nederlands Dagblad, Friesch Dagblad en vergelijkbare richtingkranten), en geeft slechts één krant uit, via

- de uitgever heeft binnen een ruim interpreteerbare beginselverklaring de redactie in staat gesteld een krant te vervaardigen met een thans onmiskenbare identiteit tot

- de uitgever exploiteert meer dan één krant en heeft er geen andere dan een economische band mee.

Redactiestatuten zullen ten aanzien van de reeds genoemde belangrijkste identiteitbepalende beslissingen (vaststelling en vooral wijziging van de redactionele uitgangspunten en richtlijnen, benoeming en ontslag van de hoofdredactie, etc.) deze glijdende schaal moeten weerspiegelen. Het "modelstatuut" kent in art. 3.7 een als "zware procedure" beschreven regeling, die zeker voor aanscherping in aanmerking komt bij die dagbladen waar de uitgever slechts een economische band met de krant onderhoudt of waar de redactie van mening is dat zij meer dan de uitgever de redactionele identiteit van de krant vertegenwoordigt.

Een werkbaar model voor zo'n aanscherping biedt Hoffmann-Riem. (1) Hij onderscheidt twee, naar hun "Intensität" onderscheiden, vormen van redactionele inspraak bij een zevental uitgeversbeslissingen van economische, organisatorische of technische aard die ook de redactionele arbeid raken. 


\section{A. Information und Anhörung}

Dit recht van de redactie om vooraf en tijdig geinformeerd te worden en de eigen mening te geven sichert keine formelle Entscheidungsteilhabe, ermöglicht es aber, publizistisch motivierte Bedenken vorzubringen. Eine Garantie zur Beriucksichtigung dieser Bedenken besteht freilich nicht. (.....) Jedenfalls in Fallen, die zu einer weitgehenden Solidarisierung der Redaktion führen, kann die Artikulation des Widerstandes faktische Entscheidungsteilhabe bedeuten. Deze beperkte vorm van inspraak acht Hoffmann-Riem voldoende bij wijziging van de ondernemingsvorm, wijziging binnen de kring van eigenaren en eveneens bij al die beslissingen die economisch noodzakelijk zijn en waarvoor de redactie de verantwoordelijkheid niet kan nemen, zoals bij voorbeeld het staken van de publicatie van een dagblad of van een kopblad. Ook voor zuiver technische en organisatorische matregelen en het vaststellen van het redactiebudget hoeft de uitgever niet verder te gaan dan de inspraakvorm "Information und Anhörung".

\section{B. Het totstandbrengen van "Benehmen" (2) tussen uitgever en redactie}

Deze inspraakvorm gaat aanzienlijk verder en is vergelijkbaar met de formulering "in overleg" in Nederlandse modelstatuten en in de CAO. Wanneer de uitgever "nur im Benehmen mit der Redaktion" kan beslissen, kan hij dat welliswaar ook doen zonder tot overeenstemming met de redactie te zijn gekomen, maar volgens Hoffmann-Riem "nur in Ausnahmefällen". De redactie heeft dus geen instemmingsrecht, maar het komt er wel dicht bij. Wat onder "Ausnahmefälle" verstaan moet worden defininieert Hoffmann-Riem als volgt: Ohne Zustimmung der. Redaktion sollte er (der Verleger) in Fällen des Benehmens nur handeln können, wenn die Entscheidung im Interesse der Bestandserhaltung der Zeitung oder gar des Betriebs geboten ist.

Vergeleken met de in art. 3.7 van het "modelstatuut" opgenomen regeling van belangrijke beslissingen is er een opmerkelijk verschil. "Herstellung von Benehmen" gaat ervan uit dat beide partijen het eens moeten worden; slechts in uitzonderlijke gevallen kan de uitgever zijn zin doordrijven tegen de wens van de redactie. Bij art. 3.7 is precies het omgekeerde de hoofdregel: de uitgever kan in beginsel het eigen voornemen doordrukken en alleen in uitzonderlijke gevallen wanneer de uitgever procedurefouten maakt of wanneer de rechter, marginaal toetsend, de beslissing onaanvaardbaar acht - kan de redactie uitvoering van het besluit tegenhouden. De hier voorgestelde procedure ten aanzien van de belangrijkste identiteitbepalende beslissingen laat de uiteindelijke economische beslissingsbevoegdheid van de uitgever en ook de uitoefening van de rechten van de ondernemingsraad onverlet.

Hoffmann-Riem geeft de volgende voorbeelden van beslissingen die de "Benehmen-procedure" moeten doorlopen: 
- De bevoegdheid tot vaststelling wan de redactionele beginselen blijft voorbehouden aan de uitgever Hoffmann-Riem hecht aan duidelijk geformuleerde beginselen omwille van wat hij de voor de persvrijheid noodzakelijke "Gebot der Transparenz" noemt, niet alleen ten behoeve van de journalisten, maar ook van de lezers. Eenzijdige wijziging van de redactionele uitgangspunten door de uitgever wijst hij echter af. De redactie moet niet alleen geinformeerd en gehoord worden, maar ook effectieve inspraak bij de besluitvorming krijgen, omdat zij het is die de gewijzigde beginselen in thet dagelijke werk moet uitdragen. In diesem Sinne erscheint es gerechtfertigt, daß die Anderung der Grundhaltung "im Benehmen" mit der Redaktion erfolgt.

In het ontwerp voor een nieuwe perswet uit 1974 (EPRG) verschillen op dit punt de eerste en tweede versie aanzienlijk. In de eerste staat: $\$ 11$ (1) Der Verleger kann die Grundsätze für die publizistische Haltung der Zeitung ändern. Vor einer Änderung dieser Grundsätze sind der Chefredakieur und die Redakteurvertretung zu hören. In de tweede versie luidt de beginzin: Der Verleger kann im Benehmen mit dem Chefredakteur die Grundsäte ( ......) ändern. Hoffmann-Riem wijst deze tussenoplossing af. Hij vindt dat "Benehmen" tot stand gebracht moet worden met de gekozen vertegenwoordiging van de redactie, tenzij men mag aannemen dat de hoofdredacteur als spreekbuis van de redactie optreedt. Wegen der typischen Doppelrolle des Chefredakteurs ( .......) ist eine solche Annahme allerdings problematisch. (3) De bevoegdheid om richtlijnen vast te stellen die als madere uitwerking van de "Grundsätze" zijn bedoeld wil Hoffmann-Riem wél bij de hoofdredacteur lleggen; in dit opzicht sluit hij zich aan bij de EPRG-ontwerpen. De uitgever zou daarmee zijn "Richtlinienkompetenz" kwijtraken.

- Samenwerking met andere bedrijven ("Kooperation") die aanzienlijke invloed heeft op de redactionele autonomie zou ook slechts via het totstandbrengen van "Benehmen" toelaatbaar zijn. Hoffmann-Riem gebruikt daarbij het voorbeeld van een voorheen zelfstandige krant die alleen het regionale katern overhoudt en zich bij het redigeren daarvan moet oriënteren op door anderen aangeleverd materiaal. "Benehmen" ontneemt de uitgever in de regel de mogelijkheid om zonder instemming van de redactie te handelen. Slechts in bijzondere omstandigheden kan de uitgever het afwijkende standpunt van de redactie negeren. Dies wäre z.B. der Fall, wenn ökonomische Erwägungen eine Kooperation dringend nahelegen. Dafür wird es - mit Rücksicht auf die objektivrechtliche Komponente der Pressefreiheit - allerdings nicht ausreichen, wenn die Zeitung auch ohne Kooperation ökonomisch erfolgreich betrieben werden könnte, die Kooperation allerdings dazu führt, den Gewinn weiter zu erhöhen. (4)

- "Herstellung von Benehmen" wordt eveneens aanbevolen bij vaststelling en wijziging van het redactionele personeelsbeleid op kortere en langere termijn en besluiten tot overplaatsing, inkrimping of opheffing van redactionele onderdelen. 
In de lijst van beslissingen via deze zware procedure ontbreken bij HoffmannRiem de benoeming en het ontslag van de hoofdredacteur. Dit houdt verband met dwingende bepalingen in de Betriebsverfassungsgesetz over het verbod op inspraak bij de benoeming van leidinggevende employés bij "Tendenzbetriebe". (5) Nederlandse redactiestatuten kennen deze drempels uiteraard niet.

(1) Wolfgang Hoffmann-Riem Innere Pressefreiheit als politische Aufgabe - Über die Bedingungen und Möglichkeiten arbeirsteiliger Aufgabenwahrnehmung in der Presse, pag. 147 e.y.

(2) sich mit jmdm ins Benehmen setzen = sich mit jmdm über etwas aussprechen, mit jmdm übereinkommen - Wahrig Deutsches Wörterbuch.

(3) Wolfgang Hoffmann-Riem Innere Pressefreiheit als politische Aufgabe, pag. 173.

(4) Wolfgang Hoffmann-Riem, id. pag. 152.

(5) Vgl. als voorgesteld alternatief de \& 814 en 15 van het ontwerp van de federale persraamwet van 1974 in de bijlagen.

\subsubsection{Tussenconclusie}

Het Tilburgse-APV-arrest brengt een cesuur aan tussen het "de geesteswereld betreffende openbaringsrecht" en de grondrechtelijk lager beschermde hulphandelingen, zoals het technisch vervaardigen en verspreiden van (bij voorbeeld) een dagblad. Het is echter niet zonder meer zo, dat steeds en overal uitsluitend de hoofdredacties en redacties het superieure recht uitoefenen en de uitgevers uitsluitend de connexe hulphandelingen verrichten. Belangrijkste criterium daarbij is de vraag: wie vertegenwoordigt het meest de identiteit van een blad, de (hoofd)redactie of de uitgever? Partijen kunnen alleen na analyse van de feitelijke verhoudingen bij hun dagblad duidelijkheid verschaffen of de uitgever zich in meer of mindere mate als "Herausgeber-Verleger" dan wel als "Unternehmer-Verleger" gedraagt. Wanneer dit laatste het geval is dan moet dit in een redactiestatuut uit de regeling van bevoegdheden ter zake van identiteitgevoelige beslissingen blijken. Het dient in het bijzonder consequenties te hebben voor beslissingen die van grote invloed zijn op het redactionele beleid.

Het redactiestatuut is te beschouwen als een nadere uitwerking van de redactionele beginselen en uitgangspunten; de inhoud van het statuut zal alleen om die reden al van dagblad tot dagblad (moeten) verschillen. Van belang voor de inhoud van een statuut is vooral het antwoord op de vraag of en in hoeverre de uitgever een hechte band heeft met de redactionele identiteit van de krant, waarbij onder "identiteit" niet alleen de geschreven beginselverklaring verstaan dient te worden. Bij die kranten waar uitgever, hoofdredactie en redactie samen tot de conclusie komen dat primair de redactie de identiteit vertegenwoordigt dient dat tot uiting te komen in de afbakening van bevoegdheden. Hierbij kan aanscherping van het huidige statuut op punten waar de bescherming van de identiteit in het geding is aanbeveling verdienen. In dit verband is de door Hoffmann-Riem bepleite procedure "Herstellung von Benehmen" tussen uitgever 
en redactie in overweging te nemen. De verhouding uitgever - (hoofd)redactie terzake in vrijwel alle vigerende statuten is afgeleid van de "zware procedure" van art. 3.7 van het Modelstatuut voor hoofdredactie en redactie. Hoffmann-Riem biedt een werkbaar model voor omkering van de procedure van 3.7 Modelstatunt bij die kranten waar partijen het er over eens zijn dat de uitgever hoofdzakelijk, zo niet uitsluitend als "Unternehmer-Verleger" optreedt.

\subsection{Redactiestatuut en arbeidsrecht}

\subsubsection{Redactiestatuut en CAO}

Het Statuut voor de Hoofdredactie en het NVJ-concept-statuut van 31 maart 1973 , de documenten die de basis vormden voor de onderhandelingen over het uiteindelijke modelstatuut, hebben beide het karakter van overeenkomsten die uitsluitend de uitgever (directie), de hoofdredactie en de redactie betreffen en binden. Dat is in beide stukken een vanzelfsprekend uitvloeisel van hetgeen erin opgenomen is over de bijzondere aard van het "produkt" dagblad. Beide documenten kennen dan ook bepalingen die de niet-redactionele medewerkers van de dagbladonderneming nadrukkelijk uitsluiten van zeggenschap in redactionele aangelegenheden. De Ondernemingsraad van een dagbladuitgeverij, aldus art. 5.2 van het hoofdredactiestatuut en art. 1.0.1 van het NVJ-concept, "kan geen geldige besluiten nemen met betrekking tot het redactionele beleid van het dagblad, tenzij die naar letter en geest als onverbindende adviezen zijn bedoeld".

Met deze opvatting werd in feite uitgedrukt dat een redactiestatuut een bijzondere regeling is die niet binnen het kader van het arbeidsrecht valt. Dat blijkt ook uit de vorm en de inhoud ervan. Het bijzondere van het statuut is allereerst dat het een tripartite overeenkomst is tussen de werkgever en twee categorieen werknemers: hoofdredactie en redactie. De statuten geven bovendien niet de individuele journalist, maar steeds de redactie of hoofdredactie rechten en plichten tegenover elkaar en de werkgever.

Dezelfde Verenigingsraad van de NVJ die een concept-statuut goedkeurde waarin de Ondernemingsraad buiten de regeling tussen (hoofd)redactie en uitgever (directie) werd gehouden, zorgde er vervolgens voor dat het statuut toch binnen het arbeidsrechtelijk kader terechtkwam. In 1972 besloot de Verenigingsraad het hoofdredactiestatuut voor één jaar te accepteren, doch slechts op voorwaarde dat het modelstatuut dat de positie van zowel hoofdredactie als redactie moest regelen, via de $\mathrm{CAO}$ zou worden ingevoerd. Een per dagblad verplicht statuut zou vervolgens deel gaan uitmaken van de arbeidsovereenkomst van alle journalisten in vaste dienst van een bij de NDP aangesloten dagbladonderneming.

De NVJ-onderhandelingsdelegatie heeft tenslotte ingestemd met de invoering van het redactiestatuut via de $\mathrm{CAO}$ en niet via verplichte aanpassing van de ondernemingsstatuten. Collectieve verplichting tot wijziging van de statuten van een dagbladonderneming zou overigens op grote grondrechtelijke bezwaren zijn 
gestuit. Wanneer het al tot aanpassing van ondernemingsstatuten komt zal dit het resultaat zijn van besluiten per onderneming, zoals dat bij voorbeeld bij de Leeuwarder Courant is gebeurd.

In het definitieve modelstatuat is de ondergeschikte rol van de Ondernemingsraad omgezet in de onderschikking van de Redactieraad ten opzichte van de O.R. Het cryptische artikel 5.4.1 van het modelstatuut ("Indien een onderwerp behoort tot de bevoegdheden van de ondernemingsraad, belet zulks niet de uitoefening van de bevoegdheden van de redactieraad zoals in dit statuut omschreven.") betekent, zo wordt in de toelichting verduidelijkt, dat uiteindelijk de ondernemingsraad het enige orgaan van medezeggenschap in het dagbladbedrijf is. De raad kan wel worden "gevraagd de specifieke functie van de redactie in acht te nemen".

Onder deze voorwaarde, die het redactiestatuut reduceert tot een overeenkomst die alleen de interne redactionele verhoudingen regelt, was de NDP uiteindelijk bereid haar leden te verbinden ingaande 1 januari 1977 mee te werken aan de totstandkoming van een statuut. Het is wooral aan de invoering via de CAO te danken geweest, dat in ons land - in tegenstelling tot Duitsland - binnen enkele jaren vrijwel alle dagbladen hun statuten gereed hadden.

\subsubsection{Eigen opvatting}

De inpassing van de verhouding uitgever(directie) - (hoofd)redactie in overeenkomsten van arbeidsrechtelijk karakter miskent naar mijn mening de essentie van deze verhouding, namelijk dat zij grondrechtelijk van aard is en voortvloeit uit de identiteit, dat wil zeggen de geformuleerde en ongeschreven uitgangspunten van het redactionele beleid van het dagblad. Een statuut behoort de afspiegeling te zijn van het eigene van déze krant, van déze uitgever, van déze redactie en haar tradities en cultuur. De beschrijving van de verhouding uitgever - hoofdredactie - redactie zal daarom van krant tot krant verschillen.

De verhouding uitgever - hoofdredactie - redactie is van arbeidsrechtelijke aard waar zij de positie van de individuele journalist betreft. $\mathrm{Zij}$ wordt geregeld in de CAO. Regelingen die verder gaan dan de individuele rechtspositie van journalisten overstijgen de arbeidsrechtelijke verhouding. De afbakening van bevoegdheden tussen thet collectief van redactie en hoofdredactie enerzijds en de uitgever anderzijds, en die tussen redactie en hoofdredactie hoort thuis in een redactiestatuut, dat als een nadere uitwerking van de beginselverklaring beschouwd moet worden. Een en ander dient consequenties te hebben voor zowel de statuten per dagblad als de CAO.

Een uitzondering op de regel dat het statuut geen bepalingen bevat waar de individuele journalist een beroep op kan doen - en daarom als "Fremdkörper" te beschouwen - is art. 7 in het modelstatuut over de persoonlijke verantwoordelijkheid van de journalist, het "Gewissensschutz"-artikel. In Hoofdstuk 5 is reeds opgemerkt dat het hier een regeling betreft die als nadere uitwerking is te beschouwen van de artikelen 39.2 (opdracht in strijd met ernstige overtuiging) en 16 (auteursrecht) van de CAO voor Dagbladjournalisten en die 
daarom niet thuishoort in een redactiestatuut: Aldus ook Schuijt.

De bepaling over de verhouding van de redactieraad tot de ondernemingsraad, zoals deze in het modelstatuut geformuleerd is, is niet onjuist, maar, mede door de toelichting erop, verwarrend. In deze vorm geformuleerd is zij overbodig. Uiteraard kan een redactieraad geen inbreuk maken op de wettelijke bevoegdheden van de ondernemingsraad en uiteraard vertegenwoordigt de ondernemingsraad het volledige personeel. In plaats van, zoals in de toelichting gebeurt, de subalterne positie van de redactieraad tegenover de ondernemingsraad nog eens te benadrukken, is het zinvoller wanneer per dagbladonderneming beide raden afspraken maken over de wijze waarop zij met elkaar omgaan. De in 4.9 .2 beschreven "herformulering" van de verhouding ORredactieraad, die het NVJ-bestuur in 1978 tevergeefs heeft voorgesteld, kan hierbij als leidraad dienen.

De CAO op haar beurt bevat artikelen die geen betrekking hebben op de individuele arbeidsvoorwaarden van de journalist inloondienst. Daarbij valt allereerst te denken aan het artikel dat een statuut voor hoofdredactie en redactie verplicht stelt, maar ook art. 13 lid 1, dat de werkverdeling en gezagsverhouding tussen de directeur en de hoofdredacteur regelt hoort er niet in thuis. De regeling zal van krant tot krant kunnen verschillen en dat zal blijken uit het redactiestatuut.

\subsection{Verantwoordelijkheid en aansprakelijkheid voor de redactionele inhoud}

\subsubsection{Inleiding}

Tot nu toe heeft steeds de verhouding uitgever - redactie als een rode draad door het betoog gelopen. Binnen de redactie neemt de hoofdredactie een bijzondere plaats in. In de loop van de afgelopen eeuw heeft de hoofdredactionele verantwoordelijkheid een onmiskenbare evolutie doorgemaakt. Dit proces heeft daarbij globaal de volgende stadia doorlopen:

1.De uitgever, een "courantier" die zowel het commerciële als het journalistieke vak verstaat, voert ook de hoofdredactie.

2. Vanaf de jaren twintig manifesteert zich aantoonbaar de hoofdredacteur die nadrukkelijk de leiding heeft over het redactionele deel van de krant. Artikel 11 van de ontwerp-CAO van de Comissie-Van Blom uit 1924 geeft de feitelijke situatie bij de vooraanstaande kranten uit die tijd weer: De hoofdredacteur of zijn plaatsvervanger heeft de journalistieke leiding der courant. Hij is verantwoordelijk voor den redactioneelen inhoud (....).

De georganiseerde journalistiek van die dagen ziet de ratio van de gewenste "machtenscheiding" tussen directie (uitgever) en hoofdredactie in de noodzakelijke scheiding tussen de beide aspecten die een krant nu eenmaal zo bijzonder maken: enerzijds de materiële (commerciële) waarde, anderzijds de 
ideële en culturele betekenis van de krant.

3. De eerste formele erkenning, dat de hoofdredactie verantwoordelijk is voor de inhoud van de krant en dat zij de journalisten aanwijzingen geeft omtrent de te verrichten arbeid, laat tot 1948 - eerste CAO voor Dagbladjournalisten - op zich wachten. Partijen bij de CAO werden het er echter niet over eens om de hoofdredactie bij uitsluiting bevoegd te verklaren de journalisten aanwijzingen te geven. Evenmin kwam expliciet in de $\mathrm{CAO}$ te staan, dat alleen de hoofdredactie verantwoordelijkheid draagt voor het redactionele gedeelte van de krant.

4. Het streven van vooral de hoofdredacteuren om hun positie tegenover de directie te versterken heeft geresulteerd in het Statuut voor de hoofdredactie, waarover de sectie Hoofdredacteuren van de NVJ en de NDP in 1971 overeenstemming bereikten. Dit statuut formaliseerde, binnen de doelstellingen en beginselen van de krant, de "eigen zelfstandige verantwoordelijkheid" van de hoofdredactie voor de redactionele inhoud (art. 2.4 Hoofdredactiestatuut).

5. Het "Modelstatuut voor hoofdredactie en redactie" uit 1976 tenslotte verklaart de hoofdredactie, binnen de door de uitgever vastgelegde beginselen, bij uitsluiting van elke andere instantie verantwoordelijk voor de redactionele inhoud. Het primaat van de hoofdredactie over de inhoud van de krant is thans zelf de ratio geworden van de formele scheiding tussen redactie en uitgever. Alleen deze scheiding immers garandeert de redactionele onafhankelijkheid.

In de paragrafen 8.1.5.5 e.v. heb ik er voor gepleit bij die dagbladen waarvan de uitgever zich feitelijk beperkt tot de economische exploitatie ervan, de regeling van enkele belangrijke identiteitbepalende beslissingen in hun redactiestatuten ten gunste van de redactie en hoofdredactie aan te scherpen. In het bijzonder bij deze bladen verdient het tevens aanbeveling het redactiestatuut op een ander punt aan de nieuwe werkelijkheid aan te passen, namelijk die van de civielrechtelijke aansprakelijkheid van de hoofdredacteur en de uitgever.

\subsubsection{Verantwoordelijkheid en aansprakelijkheid}

De dagbladstatuten geven de uitgever, vooral via "nauwe samenwerking, voortdurende, wederzijdse informatie en blijvend goed overleg" weliswaar geen verantwoordelijkheid voor, maar wel invloed op het hoofdredactionele beleid. De uitgever ontleent dit recht mede aan zijn gepretendeerde uiteindelijke juridische aansprakelijkheid voor de inhoud van de krant. Sinds de eerste CAO voor Dagbladjournalisten (1948) wordt het artikel dat de hoofdredacteur aanwijst als verantwoordelijk voor het redactionele gedeelte nog steeds geclausuleerd met de toelichting dat de hoofdredactionele verantwoordelijkheid niet derogeert aan de aansprakelijkheid die rechtens op de uitgever rust voor de inhoud van zijn uitgaven. (1) De CAO biedt de uitgever (via de directie) daarom ook voldoende mogelijkheden om zich met de inhoud van de krant te bemoeien.

Daar heeft de introductie van redactiestatuten in wezen weinig verandering in 
gebracht. De directie kan een hoofdredactie die een redactioneel beleid voert dat haar niet aanstaat, corrigeren via het verplichte "blijwend goed overleg" en de "financiële en commerciële factoren" die de directie in het overleg zal betrekken. Uiteraard spelen hierbij ook andere factoren een rol: een sterke persoonlijkheid in de hoofdredactie en/of langjarige ervaring in de ook commercieel succesvolle leiding van een redactie kunnen een hoofdredactie een sterke positie bezorgen, vooral wanneer de directie die karakteristieken juist mist.

Het onderzoek van Van $\mathrm{Zijl}$ (2) signaleert een wankel evenwicht tussen hoofdredactie, redactie en uitgever (directie). De verhouding tussen uitgever en hoofdredacteur wordt treffend omschreven door de constatering van een hoofdredacteur dat beiden tot vriendschap veroordeeld zijn, omdat een conflictueuze relatie onwerkbaar is. De meeste hoofdredacteuren beschrijven hun relatie met de uitgever als goed tot zeer goed, eenderde als redelijk. Bijna de helft van de deelnemers aan de enquête vulden een antwoord in op de vraag op welke gronden de uitgever zich met het redactionele werk bemoeide. Van Zijl: We kunnen er dus gevoeglijk van uit gaan dat bemoeienis van directiezijde geen incidentele gevallen betreft. Afgaande op de resultaten van onze enquête gebeurt dit over het algemeen vanuit economische overwegingen en slechts in een enkel geval blijken ideologische opvattingen expliciet een rol te spelen. (3)

Hoe sterk staat een hoofdredactie tegenover een directie bij een conflict binnen het domein dat volgens het redactiestatuut nadrukkelijk tot de exclusieve bevoegdheid van de hoofdredactie behoort? Daarbij kan men aan diverse soorten conflicten denken. Meestal zullen ze uitsluitend van interne aard zijn en onttrekken ze zich aan elke waarneming, zelfs aan die van de eigen redactie. Er zijn echter ook conflicten denkbaar waar derden bij betrokken zijn en die dus in de openbaarheid kunnen komen. Enkele voorbeelden:

A. Redactionele publikaties zijn met enige regelmaat aanleiding tot processen, waarbij de krant vaak in het ongelijk gesteld wordt.

B. Een redactionele publikatie is door de rechter onrechtmatig geoordeeld en daaruit is een schadeclaim ontstaan.

C. De redactie laat zich met enige regelmaat kritisch wit over een grote adverteerder. Deze laatste wendt zich tot de directie en zinspeelt daarbij op het opzeggen van het advertentiecontract. (4)

D. (de pendant van C.) De hoofdredactie, daarin gesteund door de redactie, will om principiële redenen niet dat een advertentie, of een bepaalde soort advertenties, in de krant komt.

Voor een goed begrip: in de meeste van deze gevallen zal de directie de hoofdredactionele autonomie en haar wensen respecteren; het onderzoek van Van Zijl geeft geen reden daaraan te twijfelen. Is hier echter uitsluitend sprake van welwillendheid? Van welbegrepen ondernemingsbelang? Een combinatie van beide? Of kan een hoofdredactie de directionele non-interventie ook juridisch (laten) regelen? Is het mogelijk, binnen het huidige recht, de bijzondere aard van 
het dagblad, die bijzondere eisen stelt aan de structuur van de organen, tot uitdrukking te laten komen in een erkenning van de hoofdredactionele verantwoordelijkheid die aangepast is aan deze bijzondere aard en structuur?

\section{Dat leidt onvermijdelijk tot de kernvragen:}

- Wie is strafrechtelijk en civielrechtelijk verantwoordelijk en dus ook aansprakelijk woor strafbare en onrechtmatige perspublicaties? (5)

- Kan een hoofdredactie op geloofwaardige wijze de exclusieve verantwoordelijkheid opeisen, zonder tegelijk de aansprakelijkheid te accepteren?

(1) Toelichting bij art. 8. CAO voor Dagbladjournalisten; zie ook 4.2. De bepaling kan zoals eerder al betoogd, uit de $C A O$ verdwijnen; de regeling boort thuis in een redactiestatuat.

(2) Annejet van Zijl Hoofdredacteur in Nederland, doctoraalscriptie UvA 1987, pag. 34 - 42.

(3) Onderzoekingen in Duitsland, o.a. van Sehulz en Branahl/Hoffmann Riem uit de jaren zestig en zeventig leveren het beeld op van uitgevers, vooral van kleinere, economisch zwakkere kranten die zich tot "aàn steen" met de inhoud van de krant bemoeien. Vgl. Wolfgang Hoffmann-Riem Innere Pressefretheit als politische Aufgabe, pag. 183-185.

(4) Volgens H.J.M. Boukema in Recht voor joumalisten, pag. 83, dwingt het redactiestatuut voor publiekstijdschriften de hoofdredacteur een negatieve publikatie over een belangrijke adverteerder met de uitgever te bespreken. Een mogelijke pendant ervan in het modelstatuut voor dagbladen zou art. 5.1.6 kunnen zijn, dat echter minder expliciet is geformuleerd.

(5) Dit onderzoek beperkt zich tot de Nederlandse doctrine en jurisprudentie ten aanzien wan de strafrechtelijke en civielrechtelijke aansprakelijkheid. Vergelijking met Duitsland is lastig in verband met een aantal fundamentele verschillen in dit opzicht tussen beide landen. Factoren die vergelijking met het Duitse recht bemoeilijken zijn onder meer:

- een wettelijk geregeld verschoningsrecht voor joumalisten;

- een "Gegendarstellungstecht" om een onjuist of onvolledig geachte publicatie te pareren;

- de wettelijk voorgeschreven "verantwoordelijke redacteur" met geheel eigen bevoegdheden. Dat us niet noodzakelijkerwijs de hoofdredacteur.

\subsubsection{De strafrechtelijke aansprakelijkheid}

Perspublikaties kunnen aanleiding zijn tot strafrechtelijke vervolging en veroordeling. Het Wetboek van Strafrecht noemt een aantal strafbare feiten die vooral door middel van de drukpers (in de ruimste zin van het woord) gepleegd worden, zoals de gekwalificeerde beledigingsdelicten van de artt. 111 - 114 (belediging van de Koning en leden van het Koninklijk Huis), de artt. $137 \mathrm{c} \mathrm{t} / \mathrm{m}$ e (belediging of aanzetten tot discriminatie van bevolkingsgroepen) en de artt. 261 e.v. (bellediging). Hoewel het aantal ingezette vervolgingen en daadwerkelijke veroordelingen van dagbladen terzake van uitingsdelicten al jarenlang verwaarloosbaar laag is (1) is bespreking hier op haar plaats, omdat het strafrecht al meer dan honderd jaar een aansprakelijkheidsregeling kent die in meer dan één opzicht voorbeeldig is.

Als daders van een drukpersmisdrijf via een dagblad komen in de eerste plaats de schrijver en de verantwoordelijke hoofdredacteur die het artikel heeft toegelaten, voor vervolging in aanmerking. Bij een gesigneerd artikel is duidelijk wie de auteur is. Voor een niet-ondertekend artikel is de hoofdredacteur 
aansprakelijkheid, wanneer hij de naam van de auteur niet noemt. (2)

Het Wetboek van Strafrecht sluit in de artt. 53 en 54 de vervolgbaarheid uit van respectievelijk de uitgevers en de drukkers; zij het onder bepaalde voorwaarden, waarvan de belangrijkste zijn

- dat de uitgever op eerste aanmaning de auteur, de drukker zijn lastgever, moet aanwijzen, en

- dat de dader resp. lastgever in Nederland strafrechtelijk vervolgbaar moeten zijn.

Om te verhinderen dat uitgevers en drukkers deze vervolgingsuitsluitingsgronden zouden misbruiken, zijn in de begunstigingstitel van het WvStr. de artt. 418 en 419 opgenomen. Uitgever en drukker zijn strafbaar, wanneer zij een geschrift of afbeelding van strafbare aard uitgeven of drukken en zij niet aan een van de voorwaarden, verbonden aan 53 en $54 \mathrm{Sr}$ voldoen. Voor het dagblad zijn de artt. 418 en $419 \mathrm{Sr}$ alleen van belang in het nogal theoretische geval dat na een uitingsdelict de hoofdredacteur niet vervolgbaar is, bijvoorbeeld wegens afwezigheid, en deze ook geen vervanger heeft achtergelaten die de dader kan aanwijzen.

Reeds bij de parlementaire behandeling van het Wetboek van Strafrecht (1879/80) is de ratio van de artt. 53 en 54 ter sprake gekomen: de wetgever wenste niet dat uitgever en drukker - ter vrijwaring van zichzelf tegen strafrechtelijke vervolging - de censuur zouden gaan uitvoeren die de overheid zelf grondwettelijk ontzegd was. Het grondrecht om zonder voorafgaand verlof gedachten of gevoelens te openbaren zou weinig betekenen, wanneer geen uitgever of drukker bereid zou zijn aan dit openbaren mee te werken. De Amsterdamse, later Leidse, hoogleraar A.E.J. Modderman, die eerst als lid van "De Staatscommissie voor de Zamenstelling van een Wetboek van Strafregt" en later als minister van justitie het huidige Wetboek tot stand bracht, wenste niet een censuur van drukkers en uitgevers, nog oneindig hatelijker dan de staatscensuur en nog schandelijker dan deze, omdat zij door minder bevoegden zou worden uitgeoefend.

Schuijt wijst erop dat sinds 1976, toen de wetgever met art. 51 Sr de algemene strafbaarheid van rechtspersonen mogelijk heeft gemaakt, bij art. $53 \mathrm{Sr}$ (de vervolgingsuitsluiting van de uitgever) bijzondere aandacht gevestigd moet worden op de formulering in art. $53 \mathrm{Sr}$ dat de uitgever als zodanig niet vervolgd wordt. Art. $51 \mathrm{Sr}$ bepaalt dat strafbare feiten kunnen worden begaan door natuurlijke personen en rechtspersonen. Wanneer een uitgeverij-rechtspersoon een strafbaar feit pleegt kan strafvervolging worden ingesteld:

- tegen de uitgeverij zelf,

- dan wel tegen hen die daartoe opdracht hebben gegeven, alsmede tegen hen die feitelijke leiding hebben gegeven aan de verboden gedraging,

- dan wel tegen zowel de uitgeverij als de opdrachtgevers en de feitelijkleidinggevers samen. 
Op basis van de formulering van art. 53 Sr zijn thans twee soorten uitgevers te onderscheiden:

- zij die handelen "als zodanig" (het vitgeven - en in de meeste gevallen ook drukken - van andermans geschriften);

- zij die hun eigen geschriften uitgeven. Onder deze laatsten schaart Schuijt ook de dagbladuitgever die een redactionele formule heeft bedacht en een hoofdredacteur en redacteuren in dienst heeft genomen, die volgens deze formule een krant maken. Dagbladuitgevers die een redactiestatuut naar het voorbeeld van het Modelstatuut kennen, vallen volgens Schuijt ook in deze categorie. Men moet $\mathrm{er}$, volgens Schuijt, naar maatschappelijke verkeersopvattingen van uitgaan, dat hier niet sprake is van een situatie, dat een uitgever voor een ander uitgevershandelingen verricht, maar dat een uitgever zijn eigen blad op de markt brengt, een blad dat er in grote lijnen uitziet, zoals hij dat wil. (3)

Wanneer deze laatste uitgever tevens rechtspersoon is - en alle dagbladuitgevers in ons land zijn dat - kan hij geen beroep doen op art. $53 \mathrm{Sr}$, omdat dit slechts geldt voor alleen-maar-uitgevers, en is vervolging op grond van $51 \mathrm{Sr}$ mogelijk. Dan zou, naast de feitelijke dader en de hoofdredacteur als mededader, ook de uitgeverij zelf en de directeur van de uitgeverij aansprakelijk zijn, tenzij deze laatste aantoont - wat vrijwel altijd het geval zal zijn - dat niet hij, maar de hoofdredacteur opdracht heeft gegeven tot de strafbare gedraging, dan wel daaraan feitelijke leiding heeft gegeven.

Wanneer de uitgeverij zelf vervolgd zou worden ligt het volgens Schuijt voor de hand, dat de verantwoordelijke hoofdredacteur de uitgeverij in het strafproces vertegenwoordigt. De hoofdredacteur als vertegenwoordiger in een strafproces terzake van het meest voorkomende uitingsdelict - smaadschrift - is bovendien processueel een goede keus, omdat hij de rechtvaardigingsgronden van 261 lid 3 Sr mee mag brengen. Schuijt merkt daarbij op:

Men zou kunnen tegenwerpen dat deze door mij in beginsel mogelijk geachte vervolgbaarheid van de uitgeverij de gevreesde censuur vanwege de leiding van de onderneming weer oproept. Dat behoeft echter niet het geval te zijn. Bij interne afspraken kan. bijy door middel van een redactiestatuut, worden yastgelegd wie verantwoordelijk is voor de uitgave . (mijn onderlijning - w.t.) In dat geval behoeven de (zakelijk) directeuren niet te vrezen voor hun persoonlijke strafrechtelijke aansprakelijkheid. Wel zou een eventuele veroordeling van de uitgeverij tot een boete financiële consequenties voor de onderneming kunnen hebben. In dat opzicht is er echter geen verschil met een civielrechtelijke procedure, warin de uitgeverij tot een schadevergoeding kan worden veroondeeld.

Het geheel van de strafrechtelijke aansprakelijkheid bij dagbladen overziende, kunnen we constateren dat bij een uitingsdelict de hoofdredacteur, naast de feitelijke dader, vrijwel altijd aansprakelijk is of zich aansprakelijk zal voelen. Tot dezelfde conclusie kwam in 1956 ook de Wiardi Beckmann Stichting in haar rapport De vrijheid van drukpers - het recht op antwoord. Daarin wordt ervoor 
gepleit de feitelijke hoofdredacteur strafbaar te stellen voor de drukpersdelicten die in zijn blad zijn gepleegd. Het rapport motiveert dat als volgt: Von een dergelijke strafrechtelijke aansprakelijkheld zou niet slechts een preventieve werking uitgaan, zij zou ook het accent van de strafbaarheid daar leggen waar dat behoort: bij degene die voor de publikatie verantwoondelijk is. (4)

(1) Vgl. het vaak geciteerde advies om niet te procederen tegen beledigende publicaties van de toenmalige PG, mr. G.E. Langemeijer, in De bescherming van eer en gaede naam in ons land, NJB 1961, pag. 89 e.v.

(2) Literatuur en jurisprudentie verschillen van mening over de vraag of hier sprake is van medeplichtigheid van de hoofdredacteur of van mededaderschap, de ernstiger vorm van deelneming. Hazewinkel-Suringa /bew. Remmelink Inledding tot de studie van het Nederlandse strafrecht, pag. 454, noemt hem deelnemer. Rooij Het dagbladbedriff in Nederland, pag. 237 kiest voor het mededaderschap, naar mijn mening op de enig juiste, namelijk journalistieke, grond dat een hoofdredacteur altijd de aansprakelijkheid behoort op te eisen; het ontkennen van materiële verantwoordelijkheid zou, in de woorden van Rooij, een de verantwoordelijke joumalist onwaardig verweer zijn.

(3) G. A.I. Schuijt Werkers van het woord, pag. 167-168.

(4) De vrijheid van drukpers - Het recht op antwoord, Rapport van de dr. Wiardi Beckmann Stichting (1956), pag. 7. Over de problematiek van de strafrechtelijke atansprakelijkheid bij rechtspersonen in het algemeen: R.A. Torringa De rechtspersoon als dader; strafbaar leiding geven aan rechtspersonen. Deel 2 Monografieën Strafrecht, 1984. Daarin wordt de opvatting verdedigd (pag. 41) dat de persoonlijke verantwoordelijkheid voorop moet staan, zodat het straffen van de niet-natuurlijke dader in beginsel op de tweede plaats moet worden gesteld en de natuurlijke persoon eerder als dader dan als feitelijke leidinggever moet worden vervolgd.

\subsubsection{De civielrechtelijke aansprakelijkheid}

Het civiele recht kent geen pendant van de artt. 53 en 54 Sr. Uitgever en drukker kunnen de civielrechtelijke aansprakelijkheid niet ontlopen door de dader van een beledigende of anderszins onrechtmatige perspublikatie aan te wijzen. Dat zou erop kunnen wijzen dat het gevaar van censuur door uitgever en/of drukker, dat de strafwetgever ruim een eeuw geleden reëel aanwezig achtte, in het civiele recht niet aanwezig geacht hoeft te worden.

Eerder het tegendeel is het geval. Zoals hiervoor reeds aangegeven komt strafrechtelijke vervolging van een dagblad zelden meer voor. Wie tegen een krantepublikatie optreedt doet dat civielrechtelijk, bij voorkeur door middel van het kort geding, eventueel later gevolgd door een schadeprocedure. Dan is de vraag naar de aansprakelijkheid van bijzonder belang. Wordt uitsluitend de uitgever aansprakelijk en schadeplichtig gesteld, dan kan deze daarin een door de rechter gegeven aanwijzing (bevestigd) zien, dat hij toezicht dient te houden op wat er in zijn krant(en) gepubliceerd wordt.

Wat de civielrechtelijke aansprakelijkheid voor onrechtmatige perspublicaties betreft laat ook het NBW weinig twijfel wie aangesproken kunnen worden: de feitelijke dader, de hoofdredacteur en de uitgever als werkgever; ieder van hen is hoofdelijk aansprakelijk. De kwalitatieve aansprakelijkheid van de werkgever voor onrechtmatige daden van hun ondergeschikten - NBW 6.170 (6.3.2.2), 
voorheen BW 1403 lid 3 - is in de literatuur de voor de hand liggende keuze. Het begrip "ondergeschiktheid" wordt ruim genomen. Oldenhuis (1) zegt over het soort arbeidsverhoudingen waartoe ook het hoofdredacteurschap gerekend kan worden: Naast de gevallen waarin "zeggenschap" zowel formele als feitelijke zeggenschap omvat, bestaan er tal van functies, waarbij de zeggenschap niet verder gaat dan de aanstellings-en ontslagbevoegdheid en de werkzaamheden zelf geheel zelfstandig worden verricht. Reeds de formele zeggenschap acht ik voldoende aanknopingspunt voor toepassing van art. 6.3.2.2. (2)

Uit BW 1403 lid 3 bleek dat het hier om risico-aansprakelijkheid gaat. In het NBW is dat - uiteraard zou men geneigd te zeggen - eveneens het geval.(3)

Dit alles lijkt de vraag naar de civielrechtelijke aansprakelijkheid voorgoed te beslissen: de uitgever is in elk geval altijd aansprakelijk.Lijkt, want als het gaat om onrechtmatige perspublikaties is ook een andere invalshoek mogelijk. Zoals we dat hiervoor ook hebben gedaan voor de strafrechtelijke aansprakelijkheid, kunnen we op zoek gaan naar de ratio van de kwalitatieve aansprakelijkheid in het algemeen en die van uitgever-werkgever in het bijzonder.

In het strafrecht zagen we als ratio voor de vervolgingsuitingsgronden van de artt. 53 en $54 \mathrm{Sr}$ de vrees voor censuur door uitgevers en drukkers. Ter verdediging van civielrechtelijke kwalitatieve aansprakelijkheid zijn verscheidene theorieën in omloop, met daarin éen constante: de bescherming van de belangen van derden. In die geest dan ook Asser-Hartkamp III, met verwijzing naar HR 7 januari 1983, NJ 1984, 607 (uitgeleende arbeider): Opvallend is, dat bij de verdediging van elk dezer theorieën zo dikwijls de gedachte naar voren komt, dat de arbeider meestal niet in staat is de door hem veroorzaakte schade te vergoeden, terwijl het onrechtwaardig wordt geacht dat de benadeelde zelf de schade zou moeten dragen. De gedachte dringt zich dan ook op, dat de bepaling voor een groot deel is gegrond op de wens om de benadeelde een solvente debiteur te verschaffen ( ......). (4) Ook Schuijt constateert dat, als het de gelaedeerde om schadevergoeding in geld te doen is, hij eerder geneigd zal zijn de uitgever dan de eenvoudige journalist aan te spreken.

Bij onrechtmatige publikaties hebben de gelaedeerden meestal allereerst belang bij een rectificatie of een verbod van herhaling. Volgens Schuijt kan het dan van belang zijn wie er gedagvaard wordt; wil de gelaedeerde een verbod van herhaling dan moet dat primair tegen de auteur en de hoofdredacteur gericht zijn. Schuijts argumentatie voor dit laatste is nogal theoretisch: als de auteur of de hoofdredacteur niet gedaagd zouden zijn, zouden zij in een ander blad, resp. door een andere journalist de onrechtmatige publikatie kunnen (laten) voortzetten. Wat de rectificatie betreft valt bij Schuijt opnieuw de terechte constatering en de nogal gezochte onderbouwing op: Bij de eis een rechtzetting - in enigerlei vorm - te publiceren doet de gelaedeerde er goed aan niet alleen de auteur, maar ook de hoofdredacteur en de uitgever te dagvaarden. De hoofdredacteur zou immers een rechtzetting watroe alleen de auteur zou worden veroordeeld, kunnen weigeren. 
De uitgever zou kunnen weigenen de publikatie uit te geven d.w. te verspreiden. Weliswaar zou hun weigering mee te werken aan de bewerkstelliging van de rectificatie op zichzelf onrechmatig kumen zijn, maar het zou een omslachtige weg zijn als de gelaedeerde wederom bij kort geding die medewerking zou moeten afdwingen.

De hier gevreesde chicanes van een hoofdredacteur of uitgever zijn, zeker in de dagbladwereld, dermate onwaarschijnlijk, dat er een beter argument moet zijn. Dat is er ook, en daarvoor keer ik terug bij het redactiestatuut en de verhouding hoofdredactie - uitgever (directie).

Wanneer een perspublikatie onrechtmatig en/of beledigend is (in het NBW is de aparte regeling van BW 1408 e.v. vervallen) heeft de gelaedeerde recht op adequate genoegdoening. Het slachtoffer staan, naast de niet in kort geding toewijsbare en dus weinig voorkomende verklaring voor recht dat een bepaalde publikatie onrechtmatig is (5), als belangrijkste vorderingen ter beschikking:

1. De schadevergoeding. De meest voorkomende vorm van schadevergoeding bij onrechtmatige en/of beledigende publikaties is de rectificatie van de onjuiste of beledigende mededeling. Rectificatie geldt ook als "herstel in de vorige toestand". Aldus ook Boon (6) De rechtzetting wordt in de regel in kort geding toegewezen en in diverse varianten. (7)

2. Een verbod van herhaling van de onrechtmatige c.q. beledigende uiting.(8) Ook een verbod van een publikatie die nog moet plaatsvinden is mogelijk. Deze laatste vordering is overigens omstreden.(9)

Wanneer we voorlopig afzien van de schadevergoeding in geld (ik kom daar nader op terug) zien we dat de gelaedeerde voor de hierboven genoemde vorderingen zich bij een krant tot de hoofdredactie dient te richten. Uitsluitend deze kan een rectificatie op een redactionele pagina plaatsen en erop toezien, via haar exclusieve aanwijzingsbevoegdheid, dat de onrechtmatige uiting niet herhaald wordt. In de termen van Asser-Hartkamp is daarom de hoofdredacteur voor de benadeelde de meest solvente debiteur. (10)

Vrijwel altijd wordt echter primair de uitgever van een krant gedagvaard en al dan niet veroordeeld tot het publiceren van een rechtzetting op de redactionele pagina's. Wanneer tegelijk met de uitgever ook de hoofdredacteur en/of de auteur van het litigieuze artikel worden gedagvaard heeft dat vooral een processueel oogmerk. Twee typerende voorbeelden uit zeer vele van een kort geding tegen een dagblad:

- Rb 's-Gravenhage 26 januari 1983, KG 1983, 64. Eisers zijn twee bestuursleden van een Leidse woningbouwvereniging, die zich in hun eer en goede naam aangetast achten door een publikatie in het Leidsch Dagblad. Gedagvaard wordt uitsluitend de besloten vennootschap "Uitgeversmaatschappij Leidsch Dagblad", die, aldus het vonnis, als uitgeefster aansprakelijk (is) voor elke onrechtmatige publikatie in haar dagblad. Vervolgens wordt de uitgeefster veroordeeld over te 
gaan tot publikatie (......) van dit vonnis op de derde bladzijde van één der dagelijkse oplagen van het Leidsch Dagblad op kosten van gedaagde. Deze "derde bladzijde" is een redactionele pagina.

- Rb Amsterdam 25 september 1986, KG 1986, 441 (Kraker Jack). In de Telegraaf en het Nieuws van de Dag zijn onrechtmatig geoordeelde artikelen verschenen over de beweerde betrokkenheid van een zekere "Jack" bij gewelddadige acties. Gedaagd zijn uitsluitend de uitgeefsters van beide kranten, die veroordeeld worden tot een door de president opgestelde, van opmaakinstructies en pagina-aanduiding voorziene rectificatie, met als ondertekening: de Hoofdredactie.

Uitgevers kunnen uit deze jurisprudentie de conclusie trekken dat de hoofdredactie weliswaar een eigen zelfstandige verantwoordelijkheid voor de redactionele inhoud van de krant toekomt, maar dat die verantwoordelijkheid betrekkelijk is, omdat de civielrechtelijke aansprakelijkheid immers bij de uitgever blijft. Pogingen van hoofdredacties om de rechter(s) tot andere gedachten te brengen, waarvan in de volgende paragraaf een overzicht, lijken de voorstanders van de opvatting dat primair de uitgever zo niet verantwoordelijk dan toch aansprakelijk is, in het bijzonder Schuijt (11) en Van Vollenhoven (12) hoewel op andere en door Schuijt bestreden gronden, in het gelijk te stellen.

(1) F.T. Oldenhuis Onrechtmatige daad: aansprakelijkheid voor personen, pag. 37 e.V.

(2) Vgl. ook G.A.I. Schuijt Onrechtmatige publikaties naar Nieuw BW, Informatierecht/AMT jan. 1992, pag. 13-14.

(3) Asser-Hartkamp III Verbintenissenrecht - De verbintenis uit de wet, nr 146.

(4) Asser - Hartkamp III Verbintenissenrecht. Deel III De verbintenis uit de wet. pag. 149; ook reeds in Asser - Rutten De overeenkomst en de verbintenis wit de wet, pag. 496.

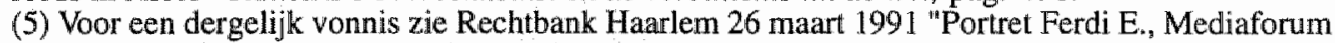
1991-6, pag. 53-54, met annotatie W. F. Korthals Altes, pag. 71.

(6) P.J. Boon Zonder voorafgaand verlof, pag. 80.

(7) O.m.: bevel tot publikatie in het redactionele deel van het eigen blad van een door de rechter geformuleerde rectificatie: Fgd. pres. Rb "s Hertogenbosch, 11 aug. 1978, niet gepubl. (Ned. Genootschap van Leraren - Brabant Pers); Pres. Rb. Amsterdam, 10 juni 1988, KG 1988, 258* bevel tot herplaatsing van eigen rectificatie: Pres. Rb. Amsterdam, 28 aug. 1986, KG 1986, 404 (BONK - Bonaventura); bevel tot publikatie van "Verklaring" (in plaats van "Rectificatie"): Pres. Rb Amsterdam 15 tebr. 1983, KG 1983,121 (VARA en Frits Bom - De Telegraaf); Pres. Rb. Amsterdam 7 december 1992 (Leon de Winter - Propria Cures), Mediaforum 1993-2, pag. B2426 ;

- bevel tot publikatie van rectificatie door middel van een advertentie: Pres. Rb Amsterdam 10 dec. 1981, KG 1982, 2 (Dekker - Vermaat); Pres. Rb Roermond, 21 dec. 1985, KG 1985, 29 (Van Zuijlen - "Helden Links"); Pres. Rb Amsterdam, 26 november 1992 (Cinemien - Meteor Film) Mediaforum 1993-1, pag. B15/16;

- bevel tot laten publiceren van ingezonden brief: Pres. Rb. 's Gravenhage 5 juni 1985, KG 1985,196 (Katwijks Modehuis);

- bevel tot publikatie van (een deel) van het veroordelende vonnis: Pres. Rb 's Gravenhage, 26 jan. 1983, KG 1983, 64 (bestuurders woningbouwver - Leidsch Dagblad).

(8) 0.m. Pres. Rb Zwolle 6 mei 1987, KG 1987, 236 (Echtpaar Goeree); id. 17 mei 1988, KG

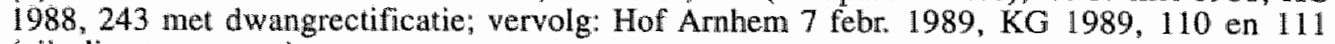
(gijzeling toegestaan). 
(9) P.J. Boon Zonder woorafgaand verlof, pag. 82 en 83 met literaturverwijzingen.

(10) Vgl. ook de Declaration of principles on the conduct of journalists, in ons land ook bekend als de "Code van Bordeaux", waarvan art. 5 luidt: The joumalist - mijn onderlijning w.t." shall do the utmost to rectify any published information which is found to be hamfully inaccurate.

(11) Schuijt Werkers van het woord, pag. 170 e.v.

(12) L. van Vollenhoven Overheid en media, inaug, rede, pag. 16 e:v.

\subsubsection{De hoofdredactie aansprakelijk?}

\subsubsection{De zaak Diekstra - Het Parool BV}

De uitsluitende verantwoordelijkheid en aansprakelijkheid van de hoofdredactie voor de redactionele inhoud van de krant werd erkend in het kort geding dat de Leidse hoogleraar in de klinische psychologie R. Diekstra had aangespannen tegen Het Parool BV, eerste gedaagde, als uitgeefster en Wouter Gortzak (tweede gedaagde) als hoofdredacteur. (1) Aanleiding tot het kort geding was een artikel van Paroolmedewerker Boudewijn Büch, waarin deze, aldus het vonnis, op de hem eigen wijze met sterke overdrijving de consequentie schildert, waartoe zijns inziens de onjuiste opvattingen van eiser voeren. Diekstra eiste rectificatie van dit artikel en een verbod van vergelijkbare uitlatingen over eiser. De advocaat van de krant, mr. W.C. van Manen, bracht als principieel bezwaar tegen aanwijzing van de uitgeefster als gedaagde partij naar voren dat ook bij Het Parool, net als bij alle respectabele kranten, een redactiestatuut van kracht is dat de uitgeefster nu juist geen zeggenschap geeft over de redactionele inhoud. Verantwoordelijk voor de redactionele inhoud is de hoofdredacteur, die het artikel vooraf gelezen heeft en goedgekeurd voor plaatsing. De hoofdredacteur, aldus het verweer tegen dagvaarding van Het Parool BV, erkent en aanvaardt zijn verantwoordelijkheid ten volle.

De President (mr. W.J. Borgerhoff Mulder) was het daarmee eens: Aangezien voldoende aannemelijk is geworden dat uitsluitend de hoofdredacteur ( ......... in deze verantwoordelijk is voor de redactionele inhoud van de krant en niet de uitgeefster (......) behoort de vordering ten aanzien van deze laatste reeds om die reden te worden afgewezen.

Dezelfde President "rectificeerde" ruim een half jaar later zichzelf in een kort geding (2), door de toenmalige ambassadeur van Suriname H.F. Herrenberg aangespannen tegen resp. Het Parool BV, hoofdredacteur Gortzak en de journalist Paul Grijpma als gedaagden. Hoewel gedaagde sub I aanvoert als uitgever niet aansprakelijk te zijn voor de litigieuze publicaties, zijn Wij van oordeel dat zulks mede gelet op de terzake door het Gerechtshof te Amsterdam in zijn overgelegd. arrest (...) d.d. 10 november 1982 gegeven uitspraak, wel degelijk het geval is. Het arrest waar Borgerhoff Mulder op doelde betrof een geval waar in eerste instantie de Haarlemse President mr. H.F. van den Haak in kort geding een uitspraak over had gedaan. (3)

Twee Nieuwe Revu-journalisten, de free lancer Storms en Voskuil, welke laatste in dienst was van De Geillustreerde Pers BV, de uitgeefster van het blad, hadden 
in de Nieuwe Revu en de Haagse Post kritische artikelen gewijd aan transacties van Van de Putte. Deze liet daarop conservatoir beslag leggen op salarisvorderingen en de bank- en girotegoeden van beide journalisten ter verzekering van verhaal van een gepretendeerde vordering van $\mathrm{f} 150.000$ tot vergoeding van schade wegens beweerd onrechtmatig handelen. In kort geding eisten Voskuil en Storms opheffing van alle beslagen wegens het vexatoire karakter ervan, terwijl zij tevens aanvoerden dat de uitgevers van de Nieuwe Revu en de Haagse Post hoofdelijk mede-aansprakelijk zijn en bovendien feitelijk solvabel. De President overwoog ten aanzien van de aansprakelijkheid:

In beginsel zijn, behalve de journalisten Storms en Voskuil als auteurs van de betrokken artikelen, ook De Gelllustreerde Pers BV en BV Haagse Post uit eigen hoofde als uitgevers van de bladen waarin de artikelen zijn opgenomen op de voet van artikel 1401 of 1408 (........) hoofdelijk voor het geheel jegens Van de Putte aansprakelijk. Immers hun zonder voorbehoud in deze ontwikkelde uitgeversactiviteiten hebben een onmisbare voorwaarde gevormd voor het openbaar maken en verspreiden van de bedoelde artikelen. Daarbij komt dat beide uitgevers (....) uitdrukkelijk en zonder reserve hun verantwoordelijkheid en aansprakelijkheid hebben aanvaard voor de financiële gevolgen van de door Van de Putte in deze aangespannen procedures. De vraag of daarnaast misschien ook aansprakelijkheid voor een van beide uitgevers op grond van BW 1403 lid 3 bestond kon daarmee onbesproken blijven.

In hoger beroep trachtte Van de Putte alsnog de noodzaak van de beslagen bij de journalisten persoonlijk aan te tonen. Vergeefs, omdat de bevestiging door de beide uitgevers dat zij de aansprakelijkheid voor de door Storms en Voskuil geschreven publikaties op zich nemen, volgens het Hof voldoende verhaalsmogelijkheid biedt. Dit leidt dus tot het oordeel dat de beslagen als onnodig moeten worden aangemerkt en dat overigens voorshands in het midden kan blijven of (.....) slechts de vermelde uitgevers en niet de betrokken journalisten zelf aansprakelijk kunnen worden gehouden (.....).

Drie kanttekeningen bij deze beide beslissingen:

1. Allereerst valt in het hierboven beschreven geval het a-typische karakter ervan op: een geding tussen twee partijen, waarin derden (de uitgevers) zich, zonder procespartij te zijn of zich als zodanig te voegen, als aansprakelijke schadeplichtigen aanmelden. Terecht natuurlijk - een goed werkgever laat zijn medewerkers in zo'n geval niet in de steek - maar als a-typisch geval te ongebruikelijk om als richtsnoer te dienen.

2. A-typisch is eveneens dat in de procedure de hoofdredacties van Nieuwe Revu en de Haagse Post geen enkele rol spelen. Dit wordt in de dagvaarding als volgt gemotiveerd: De Geillustreerde Pers BV is werkgever van Voskuil en als zodanog aansprakelijk voor de door hem gepleegde onrechtmatige daden in het kader van diens beroepsuitoefening (....) De uitgever heeft de dagelijkse leiding met betrekking tot de Nieuwe Revu in handen gesteld van een hoofdredactie, 
maar zowel volgens $C A O$ als volgens redactiestatuut heeft de witgever de laatste zeggenschap behouden over wat in Nieuwe Revu wordt gepubliceerd en heeft daardoor ook de laatste verantwoordelijkheid ten deze.

Het redactiestatuut waar de auteur van de dagvaarding (mr. H.J.M. Boukema) op doelt is dat voor publiekstijdschriften. De verhouding uitgever-hoofdredactie bij publiekstijdschriften, zoals beschreven door Boukema, wijkt echter naar letter en geest af van die bij dagbladen. Publiekstijdschriften zijn naar hun aard, meer dan dagbladen, typische uitgeversprodukten, dat wil zeggen publikaties waarop de uitgever door middel van zijn redactionele formule een sterk stempel drukt. (4) Grote uitgevers van publieksbladen, zoals VNU, tasten zelf de markt af, op zoek naar behoeften en stellen de redactionele formule op, die het best in die behoeften voorziet. Pas daarna worden een hoofdredactie en redactie aangezocht. Blijkt de markt niet of onvoldoende bereid een tijdschrift naar de uitgeversformule op te nemen wordt de uitgave gestaakt.

3. Vermelding verdient tenslotte de opmerking van het Hof dat het de opvatting van Boukema dat uitsluitend de uitgever aansprakelijk is niet deelt.

(1) Rb. Amsterdam, 6 januari 1983, KG 1983, 46.

(2) Rb Amsterdam 25 juli 1983/ HR 8 maart 1985, NJ 1986, 437. Op 8 september 1983 wees nr. Asscher in de zaak Brookman-De Volkskrant (KG 1983, 290) op verzoek van gedaagden een veroordeling toe tegen de hoofdredacteur en niet tegen de BV De Volkskrant.

(3) Rb Haarlem 2 februari 1982, rolnr. KG/1982 (niet gepubliceerd).

(4) Aldus ook een van de stellingen van H.J.M. Boukema in de congresbundel (pag. 65) Media en maatschappelijke verantwoordelijkheid (VU 1980):Vooral bij publieksbladen kunnen uitgevers" een effectieve preventieve censuur toepassen. Zij doen dat te pas en te onpas.

\subsubsection{Hof Leeuwarden (Rauwerda - Schuurmans); Rb. Rotterdam (Frank Hubert Croes e.a. - BV NDU); Pres. Rb. Arnhem (Lamers - De Gelderlander BV); Hof Arnhem (De Gelderlander BV - Lamers)}

Hof Leeuwarden 3 februari 1988, NJ 1989, 314 betrof een beledigend geachte publikatie, waarbij eiser de hoofdredacteur van Het Nieuwsblad van het Noorden als eerste had gedagvaard en als tweede en derde resp. de uitgeefster en de auteur van het artikel, die niet in dienst van de krant was. Het Hof achtte de vennootschap Nieuwsblad van het Noorden BV als uitgeefster ter zake van belediging aansprakelijk indien zij de gewraakte tekst voor publikatie heeft gekend, de beledigende strekking daarvan heeft begrepen en desondanks zonder billijke grond en aanleiding tot publikatie heeft besloten. In het geval van een rechtspersoon als de vennootschap is aan voormelde eisen voldaan, indien dat kennen, begrijpen en besluiten heeft bestaan bij, onderscheidenlijk is gedaan door een terzake bevoegd orgaan van de rechtspersoon dan wel bij een persoon wiens kennen, besluiten en begrijpen in het maatschappelijk verkeer als een kennen, begrijpen en besluiten van de rechtspersoon heeft te gelden. 
Hoofdredacteur A.A.M. Schuurmans (die korte tijd later directeurhoofdredacteur - en dus orgaan van de vennootschap - zou worden) is, aldus het Hof, op grond van zijn bevoegdheden krachtens het redactiestatuut als zo'n persoon aan te merken dat zijn gedragingen als gedragingen van de vennootschap moeten gelden. Daarnaast is hij ook nog persoonlijk als hoofdredacteur aansprakelijk, evenals de auteur van het artikel.

Het Hof erkent, op basis van het redactiestatuut van Het Nieuwsblad van het Noorden, de uitsluitende bevoegdheid en verantwoordelijkheid van de hoofdredacteur voor de inhoud van de krant, maar concludeert daaruit dat in het maatschappelijk verkeer zijn besluit tot publikatie als een besluit van de rechtspersoon heeft te gelden.

De vraag wiens gedraging in het maatschappelijk verkeer het is wanneer een krant met een redactiestatuut een onrechtmatige publicatie brengt kwam eveneens aan de orde, toen de uitgeefster van het Algemeen Dagblad, Nederlandse Dagbladunie (NDU) BV, als enige werd gedagvaard naar aanleiding van een artikel in die krant over corruptie van het bestuurscollege van Aruba. (1) NDU had gesteld dat eisers niet-ontvankelijk verklaard hadden moeten worden, omdat bij het $A D$ krachtens het redactiestatuut de hoofdredacteur de leiding van de redactie heeft en hij verantwoordelijk is voor en beslist over de inhoud van het Algemeen Dagblad. De rechtbank wees dit verweer af, op twee gronden:

- Wanneer een onrechtmatig artikel in het Algemeen Dagblad verschijnt geldt dit als een onrechtmatige gedraging van NDU, die als uitgeefster de krant op grote schaal openbaar maakt en verspreidt.

- Dat (de directie van) NDU er krachtens een intern geldende regeling van afziet te controleren wat in het Algemeen Dagblad gepubliceerd wordt en dat overlaat aan de hoofdredacteur doet daar niet aan af, (......).

Het principiële karakter van het geschil kwam niet in de uitspraak, omdat aan eisers de vordering werd ontzegd en de directie van NDU geen rectificatie op een redactionele pagina hoefde te plaatsen.

Het principiële karakter kwam wel naar voren in de zaak Lamers-De Gelderlander uit 1988. (2) In de krant was een kritisch artikel verschenen over de hondenkennel van Lamers, een publicatie die volgens vonnis van de President van de Arnhernse rechtbank onrechtmatig was. Lamers had uitgeefster De Gelderlander BV, de chef-redacteur van de streekeditie waarin het artikel was verschenen en de journalist die het geschreven had gedagvaard en eiste rectificatie. Volgens de krant kon een bevel tot rectificatie uitsluitend tegen de niet in het geding betrokken hoofdredacteur worden toegewezen. De President was echter van mening dat de uitgeefster op grond van haar aansprakelijkheid ex 1403 lid 3 BW gedwongen kon worden tot het plaatsen van een rectificatie. De motivering van de President is opmerkelijk: De omstandigheid, dat uitsluitend de hoofdredacteur de inhoud van de redactionele pagina's bepaalt, staat daaraan niet in de weg. In de eerste plaats valt niet te vrezen, dat de hoofdredacteur 
publicatie zal willen tegenhouden, doch bovendien is het duidelijk, dat een publicatie, waartoe een uitgever bij rechterlijk vonnis wordt gedwongen. uiteraand niet onder verantwoordelijkheid van de hoofdredacteur valt, zodat hij zich daartegen ook niet zal kunnen verzetten.

De krant publiceerde de door de President opgestelde rectificatie, doch met de opvallende vermelding Buiten verantwoordelijkheid van de hoofdredacteur boven de afgedrukte tekst, daarbij kennelijk refererend aan het vonnis. In het commentaar werd, met verwijzing naar het Redactiestatuut waarmee onze krant, zoals vrijwel alle andere Nederlandse kranten, al sinds jaar en dag werkt, kritiek geleverd op het negeren van de hoofdredacteur en daarmee het negeren van de traditionele scheiding tussen dagbladcommercie en redactionele inhoud. Het niet dagen van de hoofdredacteur is geen kleine vormfout. Het is principieel buiten de goede orde, aldus het commentaar.

In hoger beroep (3) voerde De Gelderlander als grieven aan dat de hoofdredacteur niet in het geding was betrokken en dat, ingevolge het redactiestatuut, de directie (de uitgever) niet kan bevelen een door de rechter bevolen rectificatie in de redactionele pagina's van de krant te publiceren. De wel gedaagde journalisten, aldus De Gelderlander, zijn volledig ondergeschikt aan de hoofdredacteur en verkeren daarom niet in een positie dat zij plaatsing van een rectificatie door uitgever en/of hoofdredacteur kunnen afdwingen.

Het Hof verwierp dit betoog. $\mathrm{Bij}$ een onrechtmatige perspublikatie, aldus het Hof, kan de partij jegens wie die onrechtmatige uitlatingen zijn gedaan de rectificatie daarvan in elk geval afdwingen door de uitgever en - indien bekend - de auteur in rechte te betrekken. Van de gelaedeerde kan niet worden geëist dat hij zich eerst moet verdiepen in de vraag hoe binnen het bedrijf van de dagbladuitgever de verantwoordelijkheden tussen directie en hoofdredacteur ondering zijn verdeeld. De uitgever kan zich aan zijn verantwoordelijkheid tot rectificatie niet onttrekken door een beroep te doen op een redactiestatuut, waarbij de uitgever zich verplicht heeft om de verantwoordelijkheid van de redactionele inhoud, samenstelling en presentatie van het dagblad volledig toe te vertrouwen aan de hoofdredacteur:

Het Hof voegt daaraan toe dat niet te verwachten zou zijn dat de hoofdredacteur zich tegen opname van een eventueel aan uitgever of auteur bevolen rectificatie zou verzetten. De rectificatie is inderdaad geplaatst, zoals bevolen. Van een weigering van de hoofdredacteur tot het meewerken aan plaatsing van een rectificatie is niet gebleken. Deze laatste overweging doet enigszins vreemd aan in het licht van de dwangsom van 10.000 gulden per nalatige dag die de President in haar vonnis, uitvoerbaar bij voorraad, had opgelegd en van de opvallende, niet voor tweëerlei uitleg vatbare, hoofdredactionele mededeling boven de rectificatie, waar het Hof kennelijk aan voorbijgegaan is. De wijze waarop de Gelderlander het vonnis nagekomen is kan slechts worden uitgelegd als een bevestiging dat de hoofdredacteur de rectificatie niet heeft geplaatst en er ook niet aan wenste mee te werken. 
Opmerkelijk in de Gelderlander-zaak is dat het Hof ten aanzien van de aansprakelijkheid van de hoofdredactie voor perspublicaties geheel de lijn volgt van de Nijmeegse dissertatie Persoon en pers van Aubel uit het jaar 1968, toen het begrip redactiestatuut nog slechts bij weinigen bekend was. Dat is dezelfde mr. C.P. Aubel die thans, als advocaat van De Gelderlander, het vonnis van de Arnhemse president in de eerste grief bestreden heeft met het bezwaar dat eiser Lamers de hoofdredacteur niet in het geding had betrokken. Aubel heeft in zijn proefschrift verdedigd dat alleen de uitgever en de auteur van het onrechtmatige artikel civielrechtelijk aansprakelijk zijn. De rol van de hoofdredacteur en diens verantwoordelijkheid worden volgens hem overdreven. Alleen wanneer bewezen kan worden dat hij (of zijn vervanger) het artikel vóór publikatie onder ogen heeft gehad of wanneer de identiteit van de auteur niet kan worden vastgesteld is de hoofdredacteur aansprakelijk te stellen. Maar dan nog is de uitgever de beste keus: de vordering van het slachtoffer tegen de uitgever biedt namelijk altijd kans op succes. De uitgever zal, aldus Aubel, gewoonlijk ook het meeste verhaal bieden, en degene zijn die in de praktijk uiteindelijk de lasten van een veroordeling draagt.(4)

Volgens annotator Schuijt (5) is sinds de Leeuwarder en Arnhemse arresten sprake van constante jurisprudentie dat in het maatschappelijk verkeer het optreden van de hoofdredacteur als optreden van de uitgeverij dient te worden aangemerkt. Dat was indertijd in haar kern ook de conclusie van Aubel: De beslissende vraag bij het probleem van de aansprakelijke personen is deze: als wiens publicatie geldt naar maatschappelijke verkeersopvattingen een bepaald artikel in een krant of ander persorgaan? Het antwoord daarop moet steeds luiden: Als publicatie van "de krant" - waarmee wordt gedoeld op de uitgever -, en als publicatie van degene die ervoor "tekent". De ondertekening wijst op de auctor intellectualis. Ontbreekt deze, dan geldt de hoofdredacteur als zodanig. (6)

(1) Rechtbank Rotterdan 29 april 1988, gepubl. in Informatierecht/AMI, okt. $1988 \mathrm{nr} 5$, met noot G.A.I. Schuijt.

(2) $\mathrm{KG} 1988, \mathrm{nr}^{4} 48$.

(3) Hof Arnhem 31 oktober 1989 , rolnr. $669 / 88 \mathrm{KG}$

(4) C.P. Aubel Persoon en pers: over onrechtmatige aantasting van persoonsbelangen door perspablicaties, pag. $173 \mathrm{e.v}$.

(5) G.A.l. Schuijt in Informatierecht/AMT april 1990, nr. 4, pag. 73.

(6) C.P. Aubel Persoon en pers, pag. 172.

\subsubsection{Maatschappelijke verkeersopvattingen en het redactiestatuut}

Welke betekenis dient 25 jaar na Aubels dissertatie aan begrippen als "in het maatschappelijk verkeer gelden" en "naar maatschappelijke verkeersopvattingen" toegekend te worden, wanneer het gaat om de verantwoordelijkheid en aansprakelijkheid voor dagbladpublikaties? Schuijt verwijst voor het criterium of het handelen van een natuurlijke persoon die geen orgaan van een rechtspersoon 
is, in het maatschappelijk verkeer moet worden opgevat als een handeling van de rechtspersoon naar het bekende arrest HR 6 april 1979, NJ 1980, 34 (Kleuterschool Babbel). Het geval betrof een wethouder van onderwijs, die onrechtmatig geoordeelde uitlatingen had gedaan over de aansprakelijkheid van een aannemer voor gebreken aan een door deze aannemer gebouwde openbare kleuterschool. Niet beslissend, aldus de Hoge Raad, is of de wethouder in de Gemeentewet als orgaan van de gemeente wordt genoemd; voldoende is dat de wethouder in functie heeft gehandeld. De gedragingen van een wethouder kunnen immers ook dan een onrechtmatige daad van de Gemeente opleveren, wanneer zij in het maatschappelijk verkeer als gedragingen van de gemeente hebben te gelden. Brunner merkt in zijn annotatie bij het arrest op dat de moeilijkheid van het nu aanvaarde criterium is, dat de rechter niet gemakkelijk zal kunnen achterhalen wat de verkeersopvatting inhoudt, zodat hij veelal op eigen oordeel is aangewezen.

"Maatschappelijke verkeersopvattingen" - het woord geeft het reeds aan - is geen statisch maar een dynamisch begrip: ze wijzigen zich. In de loop van de recente geschiedenis is de uitgever van een dagblad geëvolueerd van een geëngageerde journalist-zakenman tot een managegementsteam dat journalisten in staat stelt hun geestelijke arbeid te materialiseren en te verspreiden. Die evolutie is gepaard gegaan met een terugdringen van de invloed van de uitgever op de redactionele inhoud van het dagblad ten gunste van de redactionele onafhankelijkheid. Het is bij verreweg de meeste kranten de hoofdredacteur - als personificatie van de redactie - die in feite bij uitsluiting van ieder ander, inclusief de uitgever, het redactionele beleid ervan bepaalt. Het is dan ook een fictie dat de uitgever van een dagblad een onrechtmatige publikatie zou kunnen verhinderen. Slechts weinig lezers zullen er bij voorbeeld aan twijfelen dat een boze brief naar aanleiding van een publikatie aan de (hoofd)redactie gericht dient te worden en niet aan de directie.

De door Brunner bedoelde rechter zal er, afgaande op het eigen oordeel, dan ook geen probleem mee hebben de verantwoordelijkheid voor een onrechtmatige dagbladpublikatie allereerst te associëren met de hoofdredacteur van de krant in plaats van met de uitgever; deze laatste zal hij daarentegen wel allereerst associëren met financiële solvabiliteit. Wanneer de hoofdredacteur "naar maatschappelijke verkeersopvattingen" in een concreet geval als dat van De Gelderlander, een krant met een redactiestatuut, niet alleen verantwoordelijk is voor, maar zelfs als enige "solvabel" ten aanzien van de geëiste prestatie (een rectificatie), doet het wereldvreemd aan hem zelfs niet te dagvaarden.

Moet het ook voor de gelaedeerde duidelijk zijn dat hij zich tot de hoofdredactie moet wenden? Zowel het Rotterdamse vonnis als het Arnhemse arrest leggen de vinger op een gevoelige plek, wanneer ze over het redactiestatuut opmerken dat dit een "intern geldende regeling" is (Rb Rotterdam) of dat van de onrechtmatig 
bejegende niet geëist kan worden dat hij zich eerst verdiept in de verdeling van verantwoordelijkheden binnen de dagbladorganisatie (Hof Amhem). Deze bezwaren treffen doel. Hoofdredacties die het gewenst vinden hun uitsluitende redactionele verantwoordelijkheid naar buiten toe bekend te maken doen er dan ook goed aan maatregelen te treffen die dat doel bereiken. De eenvoudigste maatregel is de vermelding in het dagelijks colofon dat de redactie werkt op basis van een redactiestatuut, op grond waarvan uitsluitend de hoofdredacteur verantwoordelijk is voor de redactionele inhoud van de krant. Hiervoor hoeft het redactiestatuut niet aangepast te worden. Eveneens aan te bevelen is het - wanneer dit nog niet gebeurd is - de verantwoordelijkheidsregeling op te nemen in de beginselverklaring van de krant en deze periodiek, bij voorbeeld op de eerste verschijningsdag van elk kwartaal, integraal in de krant af te drukken. (1)

Afdoende externe werking van de regeling van de verantwoordelijkheid bereikt men echter pas door de beginselverklaring met verwijzing naar de verantwoordelijkheidsregeling op te nemen in de statuten van de dagbladonderneming, waarin zij ook thuis hoort.

(1) Vgl. het redactiestatuut van het Rotterdams Dagblad en $\$ 10$ Abs. 2 van de Entwurf für ein Presserechtsrahmengesetz:

\subsubsection{De hoofdredacteur vrijwillig aansprakelijk}

In het verlengde van de verantwoordelijkheid ligt de civielrechtelijke aansprakelijkheid voor onrechtmatige publicaties. Volgens Schuijt valt de exclusieve verantwoordelijkheid van de hoofdredacteur theoretisch en in de praktijk heel goed te combineren met de aansprakelijkheid van de uitgever. Een en ander hoeft naar zijn mening niet te leiden tot censuur door de uitgever. Deze laatste moet de hoofdredacteur de ruimte geven, mede op grond van zijn wettelijke verplichting zich als een goed werkgever te gedragen. Deze gehoudenheid sluit uit dat de uitgever zich met de dagelijkse redactionele gang van zaken bemoeit. De hoofdredacteur is een werknemer met leidinggevende bevoegdheden (.....) een werknemer die voor een belangrijk deel van zijn arbeid contractueel een grote mate van vrijheid heeft bedongen: in zijn dagelijkse redactionele beleid behoeft hij geen aanwijzingen van de zijde van de werkgever te dulden. (1)

Vinden uitgevers dat zelf ook? Zoals al eerder opgemerkt heeft de NDP sinds 1948 de CAO-bepaling over de positie van de hoofdredacteur geclausuleerd met de toelichting dat verantwoordelijkheid dragen voor de inhoud van het redactionele gedeelte niet derogeert aan de aansprakelijkheid, die rechtens op de uitgever rust voor de inhoud van zijn uitgaven. Dat de invoering van het redactiestatuut de impliciete betekenis van de $\mathrm{CAO}$-toelichting niet achterhaald heeft, valt af te leiden uit de opvattingen van (uitgever) Van Vollenhoven. In zijn inaugurele rede Overheid en media (pag. 19/20) zegt hij, met verwijzing naar het Rotterdamse Aruba-vonnis: Het gevolg van een en ander is dat de uitgever 
zal moeten opkomen voor de schade van onzorgvuldige publikaties in zijn persorganen. Indien de uitgever niet kritisch de vinger aan de pols kan houden op basis van stringente afspraken met of controle van de hoofdredactet, zon daardoor in het ergste geval zelfs de continuiteit van de onderneming in gevaar komen. Van Vollenhoven gaat heel ver in het identificeren van de uitgever met de redactionele inhoud van de krant. De abonnees kunnen van de uitgever eisen dat zij kranten of tijdschriften ongestoord blijven ontvangen en met een inhoud waarop zij blijkens de aanbieding van de uitgever meenden te mogen rekenen. Zou immers de inhoud (niet alleen de redactionele maar ook de advertentionele) (.......) niet voldoen aan die aanbieding, dan wordt wanprestatie gepleegd. (2)

Van den Brink leidt de aansprakelijkheid van de uitgeverij af uit het auteursrecht: Aangezien de (hoofd)redactie in dienst is van de uitgeverij die het auteursrecht bezit en voor eigen rekening exploiteert, is alleen de uitgeverij aansprakelijk voor de eventuele vermogensrechtelijke claims uit hoofde wan de publikatie van de inhoud. (3)

In de opvatting van Van Vollenhoven is de onafhankelijkheid van de hoofdredacteur heel betrekkelijk. Het redactiestatuut mag hem intern exclusief verantwoordelijk gemaakt hebben voor het redactionele deel van de krant, de uitgever - lees: de directie - blijft aansprakelijk en op grond daarvan gerechtigd de hoofdredacteur op de vingers te kijken om de eigen aansprakelijkheid te beperken. In de visie van Schuijt is de uitgever (niet te verwarren met "de directie") aansprakelijk, maar de hoofdredacteur hoeft daar niet bezorgd over te zijn; de praktijk geeft daar geen aanleiding toe. De jurisprudentie tenslotte maakt geen onderscheid tussen de kwalitatieve aansprakelijkheid van de uitgever en elke willekeurige andere werkgever en negeert de in het redactiestatuut neergelegde bevoegdhedenregeling, onder meer omdat de gelaedeerde er ook geen boodschap aan heeft.

Daarmee zou voor een groot gedeelte het fundament wegvallen onder het redactiestatuut als juridisch relevant document. Dat fundament is de redactionele onafhankelijkheid, gepersonifieerd in de positie van de hoofdredacteur. Hoofdredacteuren die met enige geloofwaardigheid hun exclusieve verantwoordelijkheid willen claimen voor alles wat er op de redactionele pagina's verschijnt, zouden er daarom, naar mijn mening, goed aan doen vrijwillig de gepretendeerde civielrechtelijke aansprakelijkheid van hun uitgever over te nemen. Tegelijkertijd moet er voor gewaakt worden de positie van de gelaedeerde niet te verzwakken. De hoofdredacteur dient daarom dezelfde solvabiliteit te kunnen bieden die van de uitgever verwacht wordt. Beide aanbevelingen hoeven geen onoverkomelijke moeilijkheden op te leveren.

Het overnemen van de civielrechtelijke aansprakelijkheid kan via een interne overeenkomst worden geëffectueerd, namelijk door opneming in het redactiestatuut van een vrijwaringsbepaling, waardoor de uitgever (via de directie) altijd het regresrecht van NBW 6.170 lid 3 kan uitoefenen op de hoofdredacteur. Uiteraard niet op de hoofdredacteur als persoon of als 
individuele werknemer, maar als het in het redactiestatuut genoemde orgaan ("de hoofdredactie"). NBW 6.170 lid 3 beperkt het recht van de werkgever om de schade uit onrechtmatige daad op een ondergeschikte te verhalen tot opzet of bewuste roekeloosheid, of, mede gelet op de aard van hun verhouding, uit de omstandigheden van het geval anders voortvloeit. Een onrechtmatige dagbladpublikatie zal vaak kenmerken van opzet, in de perceptie van derden in elk geval van "bewuste roekeloosheid", vertonen, en op grond daarvan al onder de termen van het wetsartikel vallen. Daarnaast is er de bijzondere verhouding tussen hoofdredactie en directie zoals vastgelegd in het redactiestatuut, die basis kan zijn voor een dergelijke overeenkomst. Deze bijzondere verhouding hangt weer samen met het bijzondere produkt: het dagblad dat zich onderscheidt van andere industriële produkten.

Ten overvloede dient hier herhaald dat deze voorstellen niet voor de hoofdredacties van alle dagbladen bestemd zijn. Van belang is de verhouding van partijen tot de identiteit van de krant, waarover zij het met elkaar eens moeten zijn.

De vrijwaringsbepaling dient de civielrechtelijke pendant te worden van een soortgelijke bepaling in het redactiestatuut, die Schuijt heeft bepleit (4) teneinde de strafrechtelijke aansprakelijkheid van de bestuurder van de onderneming voor de inhoud van de krant uit te sluiten. Schuijt wenst de strafrechtelijke vrijwaring om dezelfde reden als hier bepleit voor de civielrechtelijke aansprakelijkheid: het vermijden van interne censuur.

Blijft over de vraag: kan de hoofdredacteur dezelfde solvabiliteit bieden als de uitgever, waarop eventuele gelaedeerden recht hebben? Zoals hiervoor al betoogd (5), is voor enkele van de meest voorkomende vormen van schadevergoeding de rectificatie en het verbod van herhaling - de hoofdredacteur zelfs de enige en derhalve ook de meest solvente debiteur. Gaat het om schadevergoeding in geld, dan is een hoofdredacteur, die immers over een redactioneel budget beschikt, voor de in ons land gebruikelijke schadevergoedingen niet insolvent, wanneer bij de vaststelling van dat redactionele budget al rekening is gehouden met mogelijke claims. Eventueel kan de hoofdredacteur uit het redactionele budget een aansprakelijkheidsverzekering afsluiten om het risico af te dekken. Dergelijke verzekeringen zijn in het bedrijfsleven eerder regel dan uitzondering. (6)

Voor de gelaedeerde maakt het weinig verschil wie de schade vergoedt; hij hoeft zich bij de hier voorgestelde aansprakelijkheidsregeling ook niet in de interne aansprakelijkheidsverdeling te verdiepen. Hoewel niet alle toegekende en door dagbladen betaalde schadeclaims bekend zijn (er kunnen schikkingen getroffen zijn) geven de bedragen van de wel bekende schadevergoedingsbedragen geen reden tot beduchtheid, dat hiermee een verontrustend beslag wordt gelegd op het redactionele budget.

Wat de materiële schade betreft speelt de aard van het dagblad daar ook een rol bij: de (hoofd)redactie kan haar fout toegeven en een onrechtmatige publikatie 
binnen zeer korte tijd - mogelijk de volgende dag al - vrijwillig (laten) rectificeren, hetgeen de materiële schade aanzienlijk kan beperken. Immateriële schade zal in de regel voortvloeien uit belediging, waarbij de hoofdredacteur het voordeel heeft dat hij, net als bij een strafrechtelijke afdoening, naar het civielrechtelijke proces de rechtvaardigingsgronden mag meebrengen van 261 lid $3 \mathrm{Sr}$. Bij materiële schade is er vanuit een ander gezichtspunt een bijkomend argument om de hoofdredacteur (feitelijk echter het redactiebudget) aansprakelijk te maken. Wanneer de hoofdredacteur moet betalen kan dat namelijk een extra genoegdoening betekenen voor het slachtoffer van een beledigende publikatie. (7) Wanneer de uitgever de materièle-schadevergoeding voor zijn rekening neemt zal dit het genoegdoeningselement voor het slachtoffer sterk verminderen, tenzij het slachtoffer ervan uit mag gaan dat de uitgever dit de hoofdredacteur "betaald zal zetten", hetgeen in de bijzondere verhouding dagbladuitgever - hoofdredactie weer ongewenst is; en ook het slachtoffer zou dit niet mogen wensen.

(1) Schuijt Werkers van het woord, pag. 268

(2) Schuijt heeft - in Informatierecht/AMI, januari $1991 \mathrm{nr} .1 \mathrm{pag} .14$ - de opvatting van Van Vollenhoven bestreden met het argument dat war de jurisprudentie over "de uitgever" spreekt, daarmee de rechtspersoon "uitgeverij" of "onderneming" bedoeld is en niet "de directeur", aan wie de hoofdredacteur in het redactiestatuut niet langer ondergeschikt is. Dit lijkt mij een spel met woorden. Onderscheid maken tussen de uitgeverij en de directie van een werkmaatschappij die in de regel het dagblad uitgeeft, is formeel juist, maar doet gekunsteld aan. Nergens blijkt dat de door Schuijt bedoelde jurisprudentie onderscheid maakt tussen de rechtspersonen en de directies die de rechtspersoon als procespartij vertegenwoordigden.

(3) R.E.M. van den Brink Informatie over informatie, pag. 257. Over art. 7 van de Auteurswet zie in dit verband G.J.H.M. Mom en P.J. Keuchenius (red.) Het werkgeversauteursrecht - Kan de werkgever het maken? met het in dit werband opmerkelijke standpunt van Schuijt: Schrap artikel 7 Auteurswet!, pag. 21-28.

(4) Zie 8.3.3.

(5) Zie 8.3.4.

(6) Volgens Oldenhuis hadden in $1984 \mathrm{ca} .65$ procent van alle bedrijven (waronder mede begrepen de beroepen) hun aansprakelijkheid uit dezen hoofde verzekerd. F.T. Oldenhuis Onrechtmatige daad: aansprakelijkheid woor personen, pag. 61.

(7) Deze gedachte is ook terug te vinden in M.A.B. Chao - Duivis Vergelding als schadevergoeding - Enkele opmerkingen over de nakoming van de verbintenis ait delict, NIB 7 april 1990, afl. 14, pag. $513 \mathrm{e} . \mathrm{v}$.

\subsubsection{Conclusie bij 8.3}

Is de gepretendeerde exclusieve verantwoordelijkheid van de hoofdredacteur voor de redactionele inhoud van de krant voldoende geloofwaardig zonder de bereidheid ook de civielrechtelijke aansprakelijkheid te accepteren? Deze laatste probleemstelling uit het eerste hoofdstuk kreeg een positief antwoord, mits aan een aantal voorwaarden wordt voldaan. De belangrijkste is dat de vraag slechts relevant is voor die bladen waar alle betrokken partijen (uitgever, hoofdredacteur 
en redactie) het erover eens zijn dat de identiteit van de krant vooral belichaamd is in de (hoofd)redactie, ondat de uitgever zich vrijwel uitsluitend bezighoudt met de economische exploitatie van de krant. Vervolgens dienen derden ervan op de hoogte te zijn dat uitsluitend de hoofdredacteur de redactionele verantwoordelijkheid draagt. Dit kan in een extern werkende vorm vastgelegd worden. Een dergelijke exclusieve verantwoordelijkheid wordt intern - in de relatie to de uitgever - pas geloofwaardig, wanneer zij overgaat in een exclusieve civielrechtelijke aansprakelijkheid. Daar bestaat geen bezwaar tegen mits eventuele derden-gelaedeerden hier nooit het slachtoffer van worden. De hoofdredacteur kan aan die voorwaarde voldoen door in het redactiebudget de daarvoor noodzakelijke voorzieningen te treffen. 


\section{Bijlage 1}

\section{Statuut voor de hoofdredactie}

\section{Het dagblad en zijn functie}

a. Het dagblad onderscheidt zich van andere industriële produkten doordat het gestalte geet aan het in Nederland geldende grondrecht van vrijheid van meningsuiting, informatieverwerving, - wermenigvuldiging en -verstrekking, zoals vastgesteld in $0 . \mathrm{m}$. artikel 7 van de Grondwet en artikel 10 van het Verdrag van Rome:

- doordat het, door de algemene aard van zijn informatie in woord en beeld, aan vele duizenden ower het maatschappelijk gebeuren, de publieke functie vervult van massa-communicatiemiddel; - doordat zijn informatie elke dag opnieuw een inhoud en vorm krijgt naar de veronderstelde behoefte van het publiek op het tijdstip van de verstrekking;

- doordat het als massa-communicatiemiddel geheel onathankelijk van vorenbedoelde eigen infor" matie tevens medium is voor het tegen betaling overbrengen van mededelingen (advertenties) van particulieren, bedrij fsleven en overheden aan zijn publiek.

b. Het dagblad heeft met andere industriële produkten gemeen dat de produktie erwan afhankelijk is van een situatie, waarbij de inkomsten, verbonden aan het uitgeven van dat produkt, ten minste de daaraan verbonden kosten blijvend dekken.

\section{De algemene leiding van de uitgeverij en de redactionele leiding van het dagblad.}

2.1 De bijzondere aard van het dagblad stelt bijzondere eisen aan de structuur van de dagelijkse leiding teneinde te waaborgen dat, tot behoud van de democratie, vorenvermelde informatieve publieke functie kan worden vervuld zonder rechtstreekse beïnloeding door wie dan ook, noch van buitenaf, noch van binnenuit, anders dan op de wijze als in dit statuut geregeld.

2.2 De algemene dagelijkse leiding van de dagbladuitgeverij en de dagelijkse leiding van de redactie zijn van elkaar te onderscheiden, maar niet te scheiden. Slechts door nawwe samenwerking, voortdurende wederzijdse informatie en blijvend goed overleg, zijin zij in staat om de in 1. gestelde specifieke facetten van het dagblad optimaal tot hun recht te laten komen. Daarbij zullen beide - met behoud van hun specifieke verantwoordelijkheden - zowel de redactionele als de financiële, commerciële, sociale, technische en administratieve factoren ter harte dienen te nemen.

2.3 De directie heeft overeenkomstig de wet de leiding van cle dagbladuitgeverij als onderneming en is verantwoordelijk tegenover colleges van toezicht, eigenaar(s), personeel en derden voor de continuiteit, de economische gang van zaken en het geheel wan de produktie van het dagblad.

2.4 De hoofdredactie heeft de leiding van de redactie van het dagblad en is verantwoordelijk voor de redactionele inhoud ervan.

Zowel terwille yan onafhankelijke informatie als terwille van een zelfde begeleiding van die informatie in opinièrende zin, een en ander overeenkomstig de doelstellingen en/of beginselen van do individuele dagbladuitgaven is de leiding van de redactionele produktie toevertrouwd an een hoofdredactie, die als zodanig binnen het grotere geheel van de dagbladuitgeverij een eigen zelfstandige verantwoordelijkheid heeft voor cle redactionele inhoud van het dagblad.

$2.5 \mathrm{De}$ in 2.4 vermelde verantwoorclelijkheid van de hoofdredactie wordt mede bereikt doordat de directie de hoofdredactie vrijwaart voor belemmeringen bij de uitoefening van haar taak in overeenstemming met het in punt 2.1 geste]de. Voorts zal de directie, onverlet de verantwoordelijkheid van de hoofdredactie, in het kader van de algemene bedrijfsvoering de voorwaarden scheppen om de informatieve functie van het dagblad optimaal tot haar recht te doen komen. 


\section{Aanstelling, arbeidswoorwaarden, taak en verantwoordelijkheid van de hoofd- redactie.}

3.I De statuten van de dagbladuitgeverij-onderneming dienen te bepalen wie (of welk college)bevoegd is/zijn tot benoeming, schorsing, ontslag en vaststelling van de arbeidsvoorwaarden van een hoofdredacteur. Deze bevoegdheden kunnen, telkens met inachtneming van de voor de betreffende onderneming geldende wettelijke bepalingen o.m. berusten bij de eigenaar(s)/aandeelhouders, de raad van commissurissen, een ander college van toezicht, of bij de directie mits na verkregen goedkeuring van een der eerderbedoelden. De statuten dienen tevens te bepalen wie bevoegd is of zijn, tot het doen yan een woordracht voor de benoeming van een hoofdredacteur.

3.2 De vorenbedoelde statuten, een aanstellingsakte of een nadere akte zullen voorts $0 . \mathrm{m}$. vastleggen de doelstellingen en/of beginselen wan het dagblad en de daarmee verband houdende richtlijnen wilaraan de hoofdredacteur bij de uitoefening van zijn taak is gebonden.

De aldus vastgelegde doelstellingen en/of beginselen, voor zover niet reeds in de statuten opgenomen, dienen publiekelijk toegankelijk te zijn.

Wanneer de doelstellingen en/of beginselen van het dagblad en de daarmee verband houdende richtlijnen voor de eerste malal op bovenbedoelde wijze worden vastgesteld, dient de hofdredactie terzake te worden gehoord, tenzij de hoofdredactie nog niet is benoemd.

3,3 Uit de onder 3.2 bedoelde statuten, de aanstellingsakte en/of de nadere akte dient tevens te blijken door wie en op welke wijze de doelstellingen en/of beginselen resp. de richtlijnen woor de redactie worden vastgesteld resp. gewijzigd.

Wijzigingen van de doelstellingen en/of beginselen resp. de richtlijnen kan slechts geschieden nadat de hoofdredactie terzake is gehoord.

3.4 De hoofdredactie bepaalt de redactionele inhoud van het dagblad en regelt de takvervulling van de redactie, met inachtneming van de onder 3.2 bedoelde doelstellingen en/of beginselen alsmede richilijnen.

3.5 De hoofdredactie is voor het handhaven van de doelstellingen en/of beginselen alsmede daarop gebaseerde richtlijnen verantwoordelijk tegenover wie haar benoem(t)en en/of ontslaa(t)(n) als vermeld in 3.1.

Indien de directie de hoofdredactie benoemt en ontslaat is de hoofdredactie voor het handhaven van de doelstellingen en/of beginselen alsmede de daarop gebaseerde richtijnen mede verantwoordelijk tegenover de instantie(s) van wie de goedkeuring tot de benoeming en het ontslag overeenkomstig 3.1 moet worden verkregen.

Degene $(n)$, aan wie de hoofdredacteur verantwoordelijk is voor het handhaven van de doelstellingen en/of beginselen alsmede van de daarop gebaseerde richtlijnen zal/zullen bij het vormen van een oordeel hierover, zowel de hoofdredacteur als de directie horen.

3.6 Indien meer dan én hoofdredacteur is of wordt aangesteld zal de onderlinge gezagsverhouding en een eventuele takkverdelling bij aanstellings- of nadere akte worden geregeld.

3.7 De betrekkingen tussen directie, hoofdredactie en redactie worden per onderneming geregeld in een redactiestatuut. Een regeling in de individuele dagbladonderneming waarbij de inspraak ta.v. de redactionele inhoud van het dagblad aldus wordt geinstitutionaliseerd (d.w.z. naast de reeds bestaande inspraak val het dagelijks overleg van de hoofdredactie met de redactionele kaderfunctionarissen, zoals afdelings- en rubriekschefs, of met de individuele journalisten) zal slechts tot stand kunnen komen in overleg tussen directie, hoofdredactie en redactie, en aldus door de directie worden vastgesteld. Daarbij zal niets in strijd mogen zijn met het onderhavige statuut voor de hoofdredactie of met een regeling ats bedoeld in de slotbepaling onder 7 .

De doelstellingen en/of beginselen van de individuele dagbladuitgave(n) als bedoeld onder $3.2 \mathrm{zijn}$ bij de inspraak een gegeven.

\section{Overleg directie-hoofdredlactie}

4.1 De hoofdredactie heeft de beschikking over een bepaald budget, eventueel gespecificeerd naar hoofdstukken. Dit beschikbare bedrag voor de redactionele kosten wordt door de directie

periodiek (b.v. per kwartaal of per jaar) vastgesteld na overleg met de hoofdredactie die tot ditoverleg door regelmatige berichtgeving vanwege de directie omtrent het verloop van die kosten gedu- 
rende de voorafgaande periode in staat zal zijn gesteld. De hoofdredactie bepall de besteding van dit budget binnen de haar gegeven richtlijnen en overeenkomstig de doelstellingen en/of beginselen als bedoeld in 3.2 en is aan de directe omtrent de doelmatigheid wan die besteding varantwoording schuldig.

$4.2 \mathrm{In}$ alle gevallen waarin de directie weet of kan vermoeden dat has beslissingen tav de algemene bedrijfswoering rechtstreeks of zijdelings invloed van belang kunnen hebben op het redactionele beleid pleegt zij vooraf overleg met de hoofaredactie.

4.3 Na overleg met de hoofdredactie bepaalt de directie het aantal journalisten en de individuele arbeidsvoorwaarden van het redactionele personeel. De journalistieke werknemers worden door de directie aangesteld in overleg met en op voordracht van de hoofdredactie.

Ontslag op journalistieke gronden kan alleen geschieden in overleg met de hoofdredactie; ontslag op andere dan op journalistieke gronden geschiedt na overleg met de hoofdredactie. Wijziging in de salariëring resp. honorering van de journalistieke medewerkers, de toepassing van de CAO voor Dagbladjoumalisten en de regeling van de vergoedingen wordt door de directie na overleg met de hoofdredactie geregeld, voor zover die niet aan laatstgenoemde doon de directie zijn gedelegeerd binnen het raam van de onder 4.1 bedoelde beschikbare bedragen.

4.4 De hoofdredactie regelt met inachtneming van hetgeen omschreven is in de statuten van de dagbladuitgeverij, in haar aanstellingsakte en/of nadere akte en het bepaalde in 4 . I naar eigen in" zicht de redactionele produktie. Beslissingen die belangrijke inwloed kunnen heben op de bedrijfsvoering van die uitgeverij, kan zij slechts nemen in overleg met de directie.

Indien geen andere regeling is getroffen zal bij een meerhoofdige directie de hoofdredactie zich tot ieder van de directeuren kunnen wenden voor overleg. Bij afwezigheid van de directie voor langere duur zal aan de hoofdredactie kennis zijn gegeven welke persoon of personen de directionele taak waarnemen.

Bij de dagbladuitgeverijen die deel uitmaken van concernconstructies is, tenzij anders geregeld, de directie van de dagbladwerkmaatschappij als "directie" te beschouwen.

4.5 De volgende punten zijn onderwerp van goed overleg tussen directie en hoofdredactie alvorens de directie een beslissing neemt:

a. bepaling van de onvang van de krant, de verhouding daarin tussen redactionele en advertentieruimte en de verdeling wan beide over de pagina"s, in het bijzonder I.M.-ruimte op tekstpagina's van belang voor het "gezicht" van de krant;

b. veranderen van de "kop" van de krant;

c. ingrijpende typografische wijzigingen van de krant;

d. opnemen of weigeren van advertenties waarbij de redactionele inhoud van het dagblad is betrokken;

e. reclamecampagnes t.b.v. het dagblad, waarbij redactionele inhoud en/of medewerkers een rol spelen, die afwijkt wan de bij dat dagblad gebruikelijke campagnes;

f. wijziging van het tijdstip van "sluiten" van de tekstpaginavormen en van de verstrekking van het dagblad aan de lezers/abonnees;

g. wijziging van de indeling van het verspreidingsgebied in redactionele edities;

h. verkoop aan derden van artikelen, berichten en foto's, vervaardigd door de redactie;

i. wijziging van de werksituatie van de redactie, zoals huisvesting, inventaris, transmissite- en communicatiemiddelen.

4.6 De directie geeft aan de hoofdredactie regelmatig vertrouwelijke kennisname van bescheiden die relevant zijn voor een inzicht in de exploitatie van het dagblad.

4.7 De hoofdredactie neemt in het bijzonder over de volgende punten geen beslissing dan na overleg te hebben gepleegd met de directie:

a. inwoering van nieuwe alsmede opheffing van bestaande rubrieken behorende tot de algemene informatie over het actuele gebeuren en/of zijnde wan bijzondere betekenis voor de verkooplbaanheid van het dagblad;

b. opneming als redactionele informatie van mededelingen, die door ard en/of vorm voordien uitsluitend als advertenties in het dagblad werden gepubliceerd;

c. ingrijpende wijzigingen in de opmaak van de krant. 


\section{Colleges van toezicht, ondernemingsraad en directie/hoofdredactie}

5.1 De hoofdredactie wordt uitgenodigd tot het bijwonen van vergaderingen van de raad van commissarissen en andere colleges van toezicht voor zover het behandelde rechtstreeks invloed van belang heeft op de redlactionele functie van dagbladuitgave(n).

5.2 Een ondernemingstaad van een dagbladuitgeverij kan geen geldige besluiten nemen met betrekking tot het redactionele beleid van het dagblad, tenzij die naar letter en geest als onverbindende adviezen zijn bedoeld.

5.3 Als de directie, de hoofdredactie of de ondernemingsraad behoefte gevoelt aan gedachtenwisseling in de ondernemingsraad over de redactionele functie zal de hoofdredactie de vergadering van de ondernemingsraad daartoe bijwonen.

5.4 De hoofdredactie wordt van de aanvang af betrokken bij eventuele plannen tot reorganisatie, fusie, verkoop of liquidatie van de dagbladuitgeverij of de dagbladuitgave(n), tot opneming in een concernverband en/of verbindingen van andere aard, zoals samenwerking met andere dagbladuitgeverijen met behoud van zelfstandigheid.

De hoofdredactie wordt door de directie voorts vertrouwelijk ingelicht over een voorgenomen ingrijpende wijziging in de samenstelling van de kring der eigenaren en wan de raad van commissarissen en/of andere colleges van toezicht.

\section{Verschil van mening tussen hoofdredactie en uitgeverij en/of directie}

6.1 Wanneer tussen een hoofdredacteur en degene(n) tegenover wie hij krachtens 3.5 verantwoordelijk is voor de handhaving van de in 3.2 genoemde doelstellingen en/of beginselen alsmede de daarop gebaseerde richtlijnen, een onoverbrugbaar verschil van mening bestaat over het redactionele beleid voorzover dat de genoemde doelstellingen en/of beginselen alsmede de daarop gebaseerde richtlijnen betreft, heeft de hoofdredacteur evenals de directie het recht gehoord te worden.

De in de vorige alinea bedoelde instantie zal binnen veertien dagen nadat zij de hoofdredacteur en de directie heeft gehoord haar conclusie schriftelijk geven. Wanneer de hoofdredacteur in het ongelijk wordt gesteld zal hij zich binnen veertien dagen na ontvangst van bedoelde conclusie er naar richten of ontslag vragen.

6.2 Indien de hoofdredacteur op grond van gebeurtenissen als bedoeld in 6.1 ontslag vraagt, zullen op verzoek van de meest gerede partij de voorwaarden van het ontslag worden geregeld door een Bijzondere Ontslagkamer voor Hoofdredacteuren van de Dagbladuitgeverij als bedoeld onder 6.3 tenzij het daartoe bevoegde orgaan van de uitgeverij en de betrokken hoofdredacteur binnen vijf weken na het tijdstip van mededeling van de beoordeling resp. de interpretatie, definitieve overeenstemming zouden hebben bereikt over de voorwaarden van het ontslag.

In de periode tussen opzegging en het einde van het dienstverband is dle betrokken hoofdredacteur op non-actief gesteld met behoud van volledige bezoldiging.

6.3 De Bijzondere Ontslagkamer voor Hoofdredacteuren van de Dagbladuitgeverij, nader te noemen "de Kamer", zal een continu college zijn, dat bestaat uit drie leden en drie platsvervangende leden. De Kamer oordeelt met drie personen. Van deze zes personen zullen steeds één lid en diens plaatsvervanger zijn benoemd door het bestuur van de vereniging De Nederlandse Dagbladpers en én lid en diens plaatsvervanger door het bestuur van de Nederlandse Vereniging van Journalisten. Beide leden zullen na overleg met ieders plăatsvervanger het derde lid en diens plaatsvervanger benoemen; bij gebreke hiervan zal op verzoek van de meest gerede partij de president van de rechtbank te Amsterdam het derde lid en diens plaatsvervanger benoemen. De (plaatsvervangende) leden van de Kamer zullen van vorenbedoelde verenigingen onafhankelijke juristen-buitenstaanders dienen te zij.lu.

De Kamer zal naar eigen inzicht en methodiek zo spoedig mogelijk maar in ieder geval binnen zes maanden na opzegging door de hoofdredacteur de voorwaarden van de beëindiging van het dienstverband bij bindend advies vaststellen.

De in 6.1 bedoelde beoordeling resp. interpretatie op zichzelf is woor de Kamer een gegeven.

6.4 Bij gebreke van een schriftelijke verklaring van de betrokken hoofdredacteur dat deze zich zal. richten naar de beoordeling resp. de interpretatie als bedoeld in 6.2 binnen de daarvoor gestelde termijn, heeft het tot een ontslag van een hoofdredacteur bevoegde orgaan van de uitgeverij, met 
inachtneming van de wetelijke bepalingen terzake, het recht het dienstverband met de in gebreke blijvende betrokkene op te zeggen, in welk geval de Kamer de voorwaarden van het ontslag van die betrokkene vaststelt binnen zes maanden.

6.5 Wanneer tussen een hoofdredacteur en de directie een onoverbrugbaar verschil van mening ontstaat (b.v. over het financiele beheer, de tucht en orde binnen het bedriff of de doelmatigheid van de redactionele leiding) dat niet te maken heeft met de onder 3.2 genoemde doelstellingen entof beginselen, alsmede de daarop gebaseerde richtlijnen, zal, indien een dergelijk geschil leidt tot ontslag van de hoofdredacteur, eveneens de Kamer de voorwaarden regelen van het ontslag.

\section{Slotbepaling}

Het staat de dagbladondernemingen vrij in een voor de hoofdredactie gunstige zin een wan dit statuut afwijkende regeling overeen te komen. De bepalingen van dit statunt zijn als een basisregeling te beschouwen, die reeds bestaande gunstiger regelingen als vorenbedoeld niet kan aantasten.

\section{Bijlage 2}

\section{Model voor een redactiestatuut}

\section{zoals aanvaard door de Nederlandse Vereniging van Journalisten op 31 maart 1973}

(in dit proefschrift aangeduid als: NVJ-concept.

\section{Het dagblad en zijn functie}

Het dagblad onderscheidt zich van andere industriele produkten:

- doordat het gestalte geeft aan het in Nederland geldende grondrecht van vrijheid van meningsuiting, informatieverwerving, -vermenigvuldiging en -verstrekking, zoals vastgelegd in o.m. artikel 7 van de Grondwet en artikel 10 van het Verdrag van Rome;

- doordat het, als massacommunicatiemiddel, een belangrijke functie verricht die mede het functioneren van de democratie mogelijk makkt;

- doordat zijn informatie elke dag opnieuw een inhoud en vorm krijgt;

- doondat het, als massacommunicatiemiddel, geheel onafhankelijk var vorenbedoelde eigen informatie tevens medium is voor het tegen betaling overbrengen van mededelingen (advertenties) van particulieren, bedrijfsleven en overheden aan zijn publiek.

\section{Beginselverklaring}

Bij elk dagblad dienen de beginselen en/of het redactioneel karakter te zijn vastgelegd op zodanige wijze dat de rechtskracht werzekerd is.

\section{De organen}

1. 1. De redactie, als informatieverwervend en -verstrekkend orgatan, dient haar taak binnen het kader van hetgeen in de beginselverklaring is vastgelegd, te kunnen uitvoeren zonder rechtstreekse beinvloeding door wie dan ook, noch van buiten af, noch van binnen uit, anders dan op de wijze als in dit statuut wordt geregeld.

1.2 De hoofdredactie heeft de leiding van de redactie van het dagblad en is verantwoordelijk voor de redactionele inhoud ervan. 
1.3 De directie zorgt in het kader van de algemene bedrijfsvoering voor optimale voorwaarden om de informaticve functie van hel dagblad tot haar recht te doen komen, onverlet de verantwoordelijkhetd van de hoofdredactie.

1.4 Er is een plenaire redactievergadering, die het belangrijkste orgaan is voor medezeggenschap van de redactie en bestaat uit alle joumalisten bij de onderneming die vallen onder de CAODagbladjoumalisten.

Per krant kan de plenare redactievergadering bepalen of en zo ja welke medewerkers eveneens tot. de plenaire redactievergadering behoren.

$1.5 \mathrm{Er}$ is een Redactieraad die optreedt namens de plenaire redactievergadering. De RR is het orgaan van wederzijdse informatie en onderling beraad tussen redactie en hoofdredactie en vertegenwoordigt bovendien de redactie bij overleg met de directie.

1.6 Slechts door nauwe samenwerking, voortdurende, wederzijdse informatie en blijvend goed overleg zijn directie, hoofdredactie en redactie in staat de specifieke facetten van het dagblad optimaal tot hun recht te laten komen. Daarbij zullen zij - met behoud van hun specifieke verantwoordelijkheden - zowel de redactionele, als de financièle, commercièle, sociale, technische en administratieve factoren ter harte dienen te nemen.

\section{Benoeming/verkiezing en werkwijze organen}

\section{Hoofdredactie}

4.1 De statuten van de dagbladuitgeverij-onderneming dienen te bepalen wie (of welk college) bevoegd is/zijn tot benoeming, schorsing, ontslag en vaststelling van de arbeidsvoorwaarden van een hoofdredacteur. Deze bevoegheden kunnen, telkens met inachtneming van de voor de betreffende onderneming geldende wettelijke bepalingen, o.m. berusten bij de engenaar(s)/aandeelhouders, de raad van commissarissen, een ander college van toezicht, of bij de directie mits na verkregen goedkeuring van een der eerder bedoelden. De statuten dienen tevens te bepalen wie bevoegd is of zijn, tot het doen van een voordracht voor de benoeming van een hoofdredacteur.

4.2 $\mathrm{Bij}$ benoeming van een hoofdredacteur is de directie verplicht voorafgaand aan de besluitvorming in de daartoe aangewezen organen, advies in te winnen bij de RR, die mede het recht heeft tot voordracht. Een hoofdredacteur wordt niet benoemd dan na goedkeuring door de plenaire redactievergadering.

4.3 De vorenbedoelde statuten, een aanstellingsakte of een nadere akte zullen voorts $0 . \mathrm{m}$. vastleggen de beginselen en/of het redactioneel karakter van het dagblad en de daarmee verband houdende richtlijnen waaraan de hoofdredacteur bij de uitoefening van zijn taak is gebonden. De aldus vastgelegde beginselen en/of redactioneel karakter, voor zover niet reeds in de statuten opgenomen, dienen publiekellijk toegankelijk te zijn.

\section{Plenaire redactievergadering}

5. 1 Do plenaire redactievergadering komt ten minste énmal per jaar bijeen. In deze vergadering legt de RR verantwoording af van zijn beleid.

5.2 Op verzoek van de hoofdredactie, RR of op schriftelijk verzoek van ten minste eenvijfde van het totalal aantal leden dient een plenaire redsctievergadering te worden gehouden.

5.3 De plenaire redactievergadering kiest uit haar midden haar voorzitter.

5.4 De plenaire redactievergadering kan slechts geldige besluiten nemen wanneer tweederde van de leden aan de stemming deelneemt. Err wordt besloten met gewone meerderheid van stemrnen. In de gevallen genoemd in de artikelen $4.2,8.1,8.2,15.6$ en 16.4 wordt besloten met een meerderheid van ten minste tweederde van het aantal aanwezige leden.

\section{Redactieraad}

6.1 De RR bestaat uit een hoofdredacteur en ten minste 5 leden, gekozen door en uit de plenaire redactievergadering.

6.2 De hoofdredacteur is voorzitter van de RR behoudens zijn vrijwillige afstand van dit recht of 
een onderling afwijkend akkoord te dezen.

6.3 De vergaderingen wan de $\mathbb{R} R$ zijn in principe openbaar. Alleen wanneer de $R R$ zelf tot de concllusie komt dat een vergadering een besloten karakter moet dragen kan wan deze openbaarheid worden afgeweken. Van elke vergadering van de RR wordt een verslag gepubliceerd.

\section{Bevoegdheden organen}

\section{Hoofdredactie}

7.1 Met inachtneming van de bevoegdheden van de RR en de plenaire tedactievergadering heeft de hoofdredactie aan wie de leiding van de jourmallistieke productie is toevertrouwd, als zodanig binnen het geheel van de dagbladonderneming een eigen zelfstandige verantwoordelijkheid voor de redactionele inhoud van het dagblad. Zij regelt de taakverdeling van de redactie.

7.2 De hoofdredactie is voor het handhaven van de beginselen en/of het redactioneel karakter, vastgelegd krachtens artikel $\Pi$, veraniwoordelijk tegenover wie haar benoent(en) en/of ontslaat(n), als vermeld in 4.1 .

Indien de directie de hoofdredactie benoemt en ontslaat is de hoofdredactie voor het handhaven van de beginselen en/of het redactioneel karakter, alsmede de daarop gebaseerde richtlijnen mede verantwoordelijk tegenover de instantie(s) van wie de goedkeuring tot de benoeming en het ontslag overeenkomstig 4.1 moet worden verkregen.

Degene(n) aan wie de hoofdredactie verantwoording schuldig is voor het handhaven van de beginselen en/of het redactioneel karakter alsmede van de daarop gebaseerde richtlijnen zal/zullen bij het vormen van een oordeel hierover, zowel de hoofdredactie als de directie horen.

7.3 Indien meer dan eén hoofdredacteur is of wordt aangesteld zal de onderlinge verhouding en een eventuele taakverdeling bij aanstellings- of nadere akte worden geregeld en aan de redactie worden meegedeeld.

7.4 In alle gevallen waarin de directie weet of kan vermoeden dat haar beslissingen ten aanzien van de algemene bedrijfsvoering rechtstreeks of zijdelings invloed kunnen hebben op het redactionele beleid pleegt zij vooraf overleg met de hoofdredactie.

$7.5 \mathrm{Na}$ overleg met de hoofdredactie bepaalt de directie het aantal journalisten en de individuele arbeidsvoorwaarden van het redactionele personeel. De journalistieke werknemers worden door de directie aangesteld in overleg met en op voordracht van de hoofdredactie. Ontslag kan alleen geschieden in overeenstemming met de hoofdredactie. Wijzigingen in een salariêring resp. honorering van de journalistieke medewerkers, de toepassing van de $\mathrm{CAO}$ voor dagbladjournalisten en de regeling van de vergoeding worden door de directie na overleg met de hoofdredactie geregeld, voorzover die niet aan laatstgenoemde door de directie zijn gedelegeerd binnen het raam van de onder 13.1 bedoelde beschikbare bedragen.

7.6 Beslissingen ten aanzien van de journalistieke productie die belangrijke inwloed kunnen hebben op de bedrijfsvoering van de uitgeverij, kan de hoofdredactie slechts nemen in overleg met de directie.

Indien geen andere regeling is getroffen zal bij een meerhoofdige directie de hoofdredactie zich tot ieder van de directeuren kunnen wenden voor overleg. Bij afwezigheid van de directie voor langere duur zal aan de hoofdredactie kennis zijin gegeven welke persoon of personen de directionelle taak waarmemen.

Bij dagbladuitgeverijen die deel uitmaken van concernconstructies is, tenzij anders geregeld, de directie van de dagbladwerkmaatschappij als "directie" te beschouwen.

7.7 De volgende punten zijn onderwerp van goed overleg tussen directie en hoofdredactie alvorens de directie een beslissing neemt:

a. bepaling van de omvang van de krant, de verhouding tussen redactionele en advertentienuimte en de werdeling van beide over de pagina's, in het bijzonder I.M.-ruimte op tekstpagina's van belang voor het "gezicht" van de krant;

b. veranderen wan de "kop" van de krant;

c. ingrijpende typografische wijzigingen van de krant;

d. opnemen of weigeren van advertenties waarbij de redactionele inhoud van het dagblad is betrok ken; 
e. reclamecampagnes ten behoewe van het dagblad, watrbiy redactionele inhoud en/of medewerkers een rol spelen, die afwijken van de bij dat dagblad gebruikelijke campagnes;

f. wijziging van het tijdstlp vain "sluiten" van de tekstpaginavormen en van de verstrekking van het dagblad aan de lezers/abonnes;

g. wijziging van de indeling van het verspreidingsgebied in redactionele edities;

h. verkoop aan derden van artikelen, berichten en foto's vervaardigd door de redactie, tevens in overleg met het desbetreffende lind van de redactie;

i. wijziging van de werksituatie van de redactie, zoals huisvesting, inventaris, transmissie- en communicatiemiddeler.

7.8 De directie laat de hoofdredactie regelmatig vertrouwelijk kennisnemen van bescheiden die relevant zijin voor een inzicht in de exploitatic van het dagblad.

7.9 De hoofdredactie neent in het bijzonder over de wolgende punten geen beslissingen dam naoverleg te hebben gepleegd met de directie:

a. opneming als redactionele informatie van mededelingen, die door aard en/of vorm voordien uitsluitend als advertenties in het dagblad werden gepubliceerd;

b. ingrijpende wijzigingen in de opmaak van de krant.

7.10 De hoofdredactie wordt uitgenodigd tot het bijwonen van vergaderingen wan de raad van commissarissen en andere colleges van toezicht voorzover het behandelde betrekking heeft op journalistieke aangelegenheden.

7.11 De hoofdredactie kan zich op eigen initiatief of zal zich, wanneer ten minste tweederde van de gekozen leden van de RR hierom verzoekt, in het overleg met de directie (uitgever) en/of raad van commissarissen laten bijstaan door een of meer leden van de RR.

\section{Plenaire redactievergadering}

8.1 Door de directie of door de RR voorgestelde ontwerpen voor of wijzigingen in de beginselen en/of het redactionele karakter wan het blad worden door de RR en hoofdredactie voorgelegd aan de plenaire redactievergadering. Dergelijke ontwerpen en wijzigingen kunnen slechts worden ingevoerd met goedkeuring wan de plenaire redactievergadering.

8.2 Besluiten van de directie en/of hoofdredactie die naar het oordeel van de RR van fundamenteel belang zijn voor de taak en functie van de redactie kunnen slechts worden genomen na goedkeuring van de plenaire redactievergadlering. Dit geldt met name voor wijziging van karakter en verschijningsvorm van de krant, wijziging van de positie van redactie en hoofdredactie of wijziging van samenwerkingswerbanden.

\section{Redactieraad}

9.1 De RR beschouwt de beginselen on/of het redactionele karakter als een gegeven indien en voorzover deze an iedere in dienst wan het betrokken dagblad zijnde journalist schriftelijk zijn meegedeeld.

9.2 De RR, als orgaan van wederzijdse informatie en onderling beraad tussen hoofdredactie en redactie, bespreekt het algemene; politieke, matschappelijke en levensbeschouwelijke beleid in het kader van de beginselen en/of het redactionele karakter van het dagblad, de samenstelling, de inhoud en de presentatie van de krant, alsmede de in de artikelen 11,12,13.2, 14 en 15.6 genoemde onderwerpen.

9.3 De RR kan redkcteuren die geen lid zijn van de RR uitnodigen op grond van hun deskundigheid om deel te nemen an de beraadslagingen.

9.4 De RR ontwerpt een huishoudelijk reglement dat ter goedkeuring wordt voorgelegd aan de plenaire redactievergadering.

\section{Verhouding tot ondernemingsraad en redactiecommissie}

\section{Ondernemingsraad}

10.1 De ondememingsraad van een dagbladuitgeverij kan geen geldige besluiten nemen met be- 
trekking tot het redactionele belieid van het dagblad, tenzij die naar letter en geest als onverbindende adviezen zijn bedoeld.

\section{Redactiecommissie}

10.2 De RR treedt niet in de bevoegdheden die krachtens artikel 42 CAO behoren tot die van de redactiecommissie.

\section{Personeellsbeleid}

11. De hoofdredactie en de RR dienen tot overeenstemming te komen over de uitgangspunten van het personeelsbeleid. Op grond daarvan voert de hoofdredactie het personeelsbeleid uit. De hoofdredactie doet geen voordracht voor de benoeming van een adjunct-hoofdredacteur en een chefredacteur dan na de RR te hebben gehoord.

\section{Persoonlijke verantwoordelijkheid}

12.I Wanneer een lid van de redactie ernstige gewetensbezwaren heeft tegen een aan hem verstrekte opdracht en hij zich niet kan neerleggen bij een door de hoofdredactie ter zake genomen beslissing, kan hij zich wenden tot de RR voor een uitspraak.

12.2 Wanneer de hoofdredactie krachtens haar bevoegdheid onder art. 1.2 wijzigingen aanbrengt of doet aanbrengen in verslagen of artikelen van redacteuren, kan de betrokkene verlangen dat het stuk niet wordt ondertekend.

Als betrokkene het niet met de genomen beslissing eens is, kan hij zich achteraf wenden tot de RR met het verzoek om een uitspraak.

Wanneer de hoofdredactie krachtens eerder genoemde bevoegdheid besluit een verslag of artikel niet te plaatsen, kan de betrokkene zich eveneens wenden tot de RR met het verzoek om een uitspraak.

Wanneer de hoofdredactie meent een conclusie van de RR niet te kunnen aanvarden, maakt zij haar standpunt gemotiveerd kenbaar aan de andere leden van de raad.

\section{Redactiebudget}

13.1 De hoofdredactie heeft de beschikking over een bepaald budget, eventweel gespecificeerd naar hoofdstukken. Dit beschikbare bedrag voor de redactionele kosten wordt door de directie periodiek (bijw. per kwartaal of per jaar) vastgesteld na overleg met de hoofdredactie die tot dit overleg door regelmatige berichtgeving vanwege de directie omtrent het verloop van die kosten gedurende de voorafgaande periode in staat zal zijn gesteld.

De hoofdredactie bepaalt de besteding van dit budget binnen de haar gegeven richtlijnen en over" eenkomstig de beginselen van het dagblad.

13.2 De hoofdredactie pleegt met de RR overleg over de hoogte en de verdeling over de verschillende posten wan het redactiebudget, alsmede over ingrijpende wijziging in de besteding.

De boofdredactie verschaft de RR de hiertoe noodzakelijke informatie.

De RR moet door de directie geregeld op de hoogte worden gesteld van de financiele positie wan het bedrijf.

\section{Structuurwijzigingen}

14.1 De directie c.q. uitgever licht de hoofdredactie en de RR zo spoedig mogelijk in over eventuele planmen tot reorganisatie, fusie, verkoop of liquidatie van de dagbladuitgeverij of de dagbladuitgave, tot opneming in concernverband en/of verbindingen van andere aard.

De RR wordt voor het begin van onderhandelingen die tot een beslissing kunnen leiden door de directie c.q. uitgever gehoord over bovengenoemde aangelegenheden. Bovendien kan de RR zich laten bijstaan door een, in overeenstemming met de directie c.q. uitgewer uit te nodigen, onafhan- 
kelijke deskundige, die vertrouwelijk inzage krijgt in alle bescheiden, die bepalend zijn geweest voor het woornemen om tot onderhandelingen over te gaan.

14.2 De directie licht de $\mathrm{RR}$ zo spoedig mogelijk in over een voorgenomen ingrijpende wijziging in de samenstelling van de kring van eigenaren van de uitgeverij, alsmede van de raad van commissarissen en/ol: andiere colleges van loezicht.

14.3 De bevoegdheden van de RR met betrekking tot structuurwizigingen doen niet af aan de ter zake getroffen voouzieningen in de CAO voor dagbladjoumalisten.

\section{Regeling meningsverschillen/ontslag}

15.1 Wanneer tussen een hoofdredacteur en degene(n) tegenover wie hij krachtens 7.2 werantwoordelijk is voor de handhaving van de beginselen en/of het redactionele karakter alsmede de eventueel darop gebaseerde richtlijnen, een onoverbrugbaar verschil van mening bestaat over het redactionele beleid woorzover dat de genoemde beginselen en/of het karakter alsmede de eventueel daarop gebaseerde richthijnen betreft, heeft de hoofdredacteur evenals de directie het recht gehoord te worden.

De in de vorige alinea bedoelde instantie zal binnen veertien dagen nadat zij de hoofdredacteur en de directie heeft gehoord haar conclusie schriftelijk geven. Wanneer de hoofdredacteur in het ongelijk wordt gesteld zal hij zich binnen veertien dagen na ontvangst van bedoelde conclusie er naar richten of ontslag wragen.

15.2 Indien cen hoofdredacteur op grond van gebeurtenissen als bedoeld in 15.1 ontslag vraagt, zullen op verzoek van de meest gerede partij de voorwaarden van het ontslag worden geregeld door een Bijzondere Ontslagkamer voor Hooldredacteuren van de Dagbladuitgeverij als bedoeld in 15.3, tenzij het datartoe bevoegd orgaan van de uitgeverij en de betrokken hofdredacteur binnen vijf weken na het tijdstip van mededeling van de beoordeling resp. de interpretatie, definitieve overeenstemming zouden hebben bereikt over de voorwaarden van het ontslag. In de periode tussen opzegging en het einde van het dienstverband is de betrokken hoofdredacteur op non-actief gesteld net behoud wan volledige bezoldiging.

15.3 De Bijzondere Ontslagkamer voor Hoofdredacteuren van de Dagbladuitgeverij, nader te noemen de Kamer, zal een continu college zijn, dat bestat uit drie leden en drie plaatsvervangende leden. De Kamer oordeelt met drie personen. Van deze zes personen zullen steeds één lid en diens plaatsvervanger zijn benoemd door het bestuur van de vereniging De Nederlandse Dagbladpers en én lid en diens plaatsvervanger door het bestuur van de Nederlandse Vereniging van Journalisten. Beide leden zullen na overleg met jeders plaatsvervanger het derde lid en diens plaatsvervanger benoemen; bij gebreke hiervan zal op verzoek van de meest gerede partij de president van de rechtbank van Amsterdam het derde lid en diens plaatsvervanger benoemen. De (plaatsvervangende) lieden van de Kamer zullen van vorengenoemde verenigingen onafhankelijke juristen-buitenstaanders dienen te zijn.

De Kamer zal naar eigen inzicht en methodiek zo spoedig mogelijk, mar in ieder geval binnen zes matnden na opzegging door de hoofdredacteur, de voorwarden van de beëindiging van het dienstverband bij bindend advies vaststellen. De in 15.1 bedoelde beoordeling resp. interpretatie op zichzelf is woor de Kamer een gegeven.

15.4 Bij gebreke van een schriftelijke verklaring van de betrokken hoofdredacteur dat deze zich zal richten naar de beoordeling resp. de interpretatie als bedoeld in 15.2 binnen de daarvoor gestelde termijn, heeft het tot cen ontslag van een hoofdredacteur bevoegde orgaan van de uitgeverij, met inachtneming van de wettelijke bepalingen terzake, het recht het dienstwerband met de in gebreke blijwende betrokkene op te zeggen, in welk geval de Kamer de voorwarden van het ontslag van die betrokkene vaststelt binnen zes matanden.

15.5 Wanneer tussen een hoofdredacteur en de directie een onoverbrugbaar verschil van mening ontstatat (bijw. over het financièle beheer, de algemene regels binnen het bedrijf of de doelmatigheid van de redactionele leiding) dat niet te maken heeft met de beginselen en/of karakter van het blad alsmede de evetueel daarop gebaseerde beginselen, zal, indien een dergelijk geschil leidt tot ontslag van de hoofdredacteur, eveneens de Kamer de voorwaarden regelen van het ontslag.

15.6 Bij ontslag van een hoofdredacteur is de directie verplicht voorafgaand aan de besluitvorming in de daartoe aangewezen organen advies in te winnen bij de RR, die mede het recht tot voordracht 
voor ontslag heeft; een hoofdredacteur wordt niet ontslagen dan na goedkeuring door tweederde van de plenaire redactievergadering.

\section{Slotbepaling}

16.1 Het staat de dagbladonderneming vrij in een voor de redactie gunstige zin een van dit statuut afwijkender regeling overeen te komen. De bepalingen van dit statuut zijn als een basis-regeling te beschouwen, die reeds bestaande gunstiger regelingen als vorenbedoeld niet kan aantasten.

16.2 Het voor een dagblad geldende statuut makt deel uit van alle arbeidscontracten.

16.3 De dagbladonderneming verplicht zich haar statuten aan te passen voorzover deze in strijd zijn met het onderhavige redactiestatuut.

16.4 Voor wijziging van een voor een dagblad geldend statuut is de goedkeuring vereist van de plenaire redactievergadering.

\section{Bijlage 3}

\section{Modelstatuut voor hoofdredactie en redactie}

\section{Het dagblad en zijn functie}

1.1. Het dagblad onderscheidt zich van andere industriële produkten:

- doordat het gestalte geef aan het in Nederland geldende grondrecht van vrijheid van meningsuiting, informatieverwerving, -vermenigvuldiging en -verstrekking, zoals vastgelegd in onder meer artikel 7 van de Grondwet en artikel 10 van thet Verdrag van Rome;

- doordat het, door de algemene aard van zijn informatie in woord en beeld, atan vele duizenden over het maatschappelijk leven, de publieke functie vervult van massa-communicatiemiddel en aldus het functioneren van de democratie mogelijk maakt;

- doordat zijn informatie elke dag opnieuw een inhoud en vorm krijgt;

- doordat het, als massa-conmunicatiemiddel, geheel onafhankelijk van vorenbedoelde eigen informatie tevens medium is voor het tegen betaling overbrengen wan mededelingen (advertenties) van particulieren, bedrijfsleven en overheden aan zijn publiek.

1.2 Het dagblad heeft, doordat het als massa-communicatiemiddel voldoet aan de behoefte aan informatie van de lezers, met andere industriéle produkten gemeen dat het mede afhankelijk is van de behoefte van het lezerspubliek en voorts van een situatie waarbij de inkomsten, verbonden aan het uitgeven van dat produkt, minstens de daaraan verbonden kosten blijvend dekken.

\section{Beginselverklaring}

2.1. Bij elk dagblad dienen de uitgangspunten van het redactionele beleid en/of de beginselen en/of de redactionele doelstellingen duidelijk schriftelijk te zijn vastgelegd.

Van deze uitgangspunten respectievelijk beginselen respectievelijk doelstellingen kan een nadere uitwerking zijn vastgelegd in richtlijnen.

2.2. De hoofdredactie en redactie beschouwen de uitgangspunten en/of beginselen en/of doelstellingen als een gegeven, indien en voor zover deze aan iedere in dienst van het betrokken dagblad zijnde joumalist schriftelijk zijn meegedeeld.

\section{De organen}

3.1 De bijzondere aard wan het dagblad stelt bijzondere eisen aan de structuur van de organen die 
bij het produceren van de redactionele inhoud wan het dagblad zijn betrokken. De redactie dient haar informatieverwervende en -verstrekkende taak binnen het kader van hetgeen in de beginselverklaring is vastgelegd, te kunnen uitvoeren zonder rechtstreekse beinwloeding door wie dan ook, noch van buitenaf noch van binnenuit, anders dan op de wijze als in dit statuut wordt geregeld.

3.2 De hoofdredactie heeft de leiding van de redactie van het dagblad en is verantwoordelijk voor de redationele inhoud ervan.

3.3 De directie zorgt in het kader van de algemene bedrijfsvoering voor optimale voorwaarden om de informatieve functie van het dagblad tot haar recht te doen komen, onverlet de verantwoordelijkheid van de hoofdredactic.

3.4 Er is een redactieraad, die het orgaan is voor de medezeggenschap van de redactie in alle zaken betreffende de redactionele tiak en functie. De redactieraad is tevens het orgaan wan wederzijdse informatie en onderling beraad tussen redactie en hoofdredactie en vertegenwoordigt bovendien de redactie bij het overleg met de directie.

3.5 De leden van de redactie komen periodiek bijeen in een redactievergadering waaraan de redachieraad uiteindelijk verantwoording verschuldigd is.

3.6 Slechts doof natwe samenwerking, voortdurende, wederzijdse informatie en blijvend goed overleg zijn directie en hoofdredactie, als organen belast met de dagelijkse leiding van het dagblad, en redactie in staat de specifieke facetten van het dagblad optimaal tot hun recht te laten komen. Daarbij zullen zij - met behoud van hun specifieke verantwoordelijkheden - zowel de redactionele, als de financièle, commerciêle, sociale, technische en administratieve factoren ter harte dienen te nemen.

3.7 In de gevallen genoemd in de artikelen 4.1.2, 5.2.1, 5.2.2 en 10.6 neemt de directie c.q. andere beslissende instantie van de dagbladuitgeverij pas een beslissing nadat diepgaand overleg heeft plaatsgehad.

Wanneer de directie en de redactieraad niet tot overeenstemming komen, brengt de redactieraad, ongeacht of hij zich reeds eerder uitgesproken heeft, zo spoedig mogelijk schriftelijk en gemotiweerd advies uit.

Indien de directie c.q. andere beslissende instantie vervolgens van dit advies afwijkt brengt $\mathrm{zij}$ schriftelijk en gemotiveerd de naar haar oordeel zwaarwichtigge redenen die hiertoe hebben geleid ter kennis van de redactieraad.

De uitvoering van dit besluit heeft, tenzij zwaarwichtige redenen zich daartegen verzetten, niet eerder plaats dan 14 dagen na dagtekening van deze schriftelijke motivering, en in het geval een geschil als bedoeld in het volgende lid is amnangig gemaakt niet eerder dan nadat uitspraak is gedlaan door de president van de rechtbank.

Geschillen over de toepassing van de procedure-voorschriften van dit artikel worden binnen 14 dagen door de meest gerede partij aanhangig gemaakt bij de president van de rechtbank in het betrokken arrondissement.

\section{Benoeming/verkiezing en werkwijze organen}

\subsection{Hoofdredactie}

4.1.1 De statuten wan de dagbladuitgeverij-onderneming dienen te bepalen wie (of welk college) bevoegd is/zijn tot benoeming, schorsing, ontslag en vaststelling van de arbeidsvoorwaarden van een hoofdredacteur. Deze bevoegdheden kunnen telkens met inachtneming van de voor de betreffende onderneming geidende wettelijke bepalingen, onder meer berusten bij de eigenaar(s)/aandeelhouders, de raad van commissarissen, een ander college van toezicht "of bij de directie mits na verkregen goedkeuring van een der eerder bedoelden. De statuten dienen tevens te bepalen wie bevoegd is of zijn, tot het doen van een voordracht voor de benoeming van een thoofdredacteur.

4.1.2 Bij benoeming wan een hoofdredacteur is de directie verplicht voorafgaand aan de besluitvorming in de daartoe aangewezen organen, overeenkomstig het in artikel 3.7 bepaalde, advies in te winnen bij de redactieraad, die mede het recht heeft tor voordracht.

4.1.3 De vorenbedoelde statuten, een aanstellingsakte of een nadere akte zullen voorts onder meer vastleggen de uitgangspunten van het redactionele beleid en/of de beginselen en/of de redactionele 
doelstellingen van het dagblad en de daamee verband houdende richtlijnen waaraan de hoolde. dacteur bij de uitoefening van zijn taak is gebonden. De aldus vastgelegde uitgangspunten, beginselen of redactionele doelstellingen, voor zower niet reeds in de statuten opgenomen, dienen publiekelijk toegankelijk te zijn.

\subsection{Redactievergadering}

4.2.1 De redactieraad legt ten minste éenmal per jaar verantwoording af over het door hem gevoerde beleid. De redactieraad dient de redactievergadering te raadplegen over de in de artikelen $4.1 .2,5.2 .1,5.2 .2,9.3,10.6 \mathrm{en} 11.1$ genoemde onderwerpen, behoudens in de gevallen warin en voor zolang krachtens artikel 4.3.4 geheimhouding is overeengekomen. Overigens staat het de redactieraad vrij naar eigen inzicht te bepalen over welke onderwerpen hij verder de redactievergadering wil raadplegen.

Indien de redactievergadering in een speciaal daartoe bijeengeroepen vergadering als oordeel uitspreekt, dat de redactie door de zittende redactieraad niet meer naat behoren wordt vertegenwoordigd, treedt de redactieraad af.

4.2.2 Op verzoek van de hoofdredactie, redactieraad of op schriftelijk verzoek van ten minste eenvijfde van het totaal aantal leden dient een redactievergadering te worden gehouden.

4.2.3 De redactievergadering kiest uit haar midden haar voorzitter.

4.2.4 Voor het nemen van rechtsgeldige besluiten door een redactievergadering is do aanwezigheid vereist van ten minste tweederde van de in artikel 4.2 .5 bedoelde journalisten. Indien de redactievergadering een uitspraak wil doen over de in artikel 4.2 .1 , tweede zin, bedoelde onderwerpen is daarvoor een meerderheid van drievierde der uitgebrachte stemmen vereist. Overige uitspraken kunnen worden gedaan bij gewone meerderheid van stemmen. Indien het quorum niet wordt bereikt, wordt de redactieraad over de geagendeerde onderwerpen geacht te spreken namens de redactie.

4.2.5 Stemgerechtigde leden van de redactievergadering zijn alle journalisten, wallende onder de cao voor dagbladjournallisten voor zover zij hun proeftijd hebben voltooid. Per krant bepalen directie, hoofdredactie en redactieraad in onderling overleg of en in hoeverre redactionele medewerkers, al dan niet met stemrecht, tot de redactievergadering worden toegelaten.

\subsection{Redactieraad}

4.3. 1. De redactieraad bestaat uit een hoofdredacteur en ten minste vijf leden, gekozen door en uit de redactievergadering.

4.3.2 De hoofdredacteur is voorzitter van de redactieraad behoudens zijn vrijwillige afstand van dit recht of een afwijkend onderling akkoord te dezen.

4.3.3 Onverminderd het in artikel 4.3 .4 bepaalde zijn de wergaderingen van de redactieraad voor de eigen redactie in principe openbaar. Alleen wanneer de redactierad zelf tot de conclusie komt dat een vergadering een besloten karakter moet dragen, kan van deze openbaarheid worden afgeweken. Van elke vergadering van de redactieraad wordt cen verslag gepubliceerd, eveneens onver" minderd thet in artikel 4.3 .4 bepalalde.

4.3.4 De leden van de redactieraad zijn tot geheimhouding verplicht wan alle aangelegenheden ten aanzien waarvan met de hoofdredactie en/of de directie vooraf geheimhouding is overeengekomen. Indien over deze geheimhouding geen overeenstemming wordt bereikt, kan dit in de weg staan aan het voldoen aan de plicht tot informeren c.q. advies vragen aan de redactieraad.

4.3.5 Tot lid van de redactieraad kunnen worden gekozen stemhebbende leden van de redactievergadering.

4.3.6 De directie, de hoofdredactie en de redactieraad kunmen een lid van de redactieraad bij de redactievergadering met opgave van redenen voor ontslag als lid van de redactieraad voordragen. De betrokkene dient in de gelegenheid te worden gesteld over de voordracht te worden gehoord.

Vanaf het moment dat een dergelijke procedure is ingezet, is de betrokkene in de uitoefening van zijn functie als lid van de redactieraad geschorst. Van de uitspraak van de redactievergadering kan beroep worden aangetekend bij de Raad van Uitvoering. 


\section{Bewoegdheden organen}

\subsection{Hoofdredactie}

5.1. Met inachtneming van de bevoegdheden van de redactieraad en de redactievergadering heeft de hoofdredactie, aan wie de leiding van de journalistieke produktie is toevertrouwd, als zodanig binnen het geheel van de dagbladondernerning een eigen zelfstandige verantwoordelijkheid voor de redactionele inhoud van het dagblad. Zij regelt de taakverdeling van de redactie.

5.1.2 De hoofdredactie is voor het handhaven van de uitgangspunten van het redactionele beleid en/of de beginselen en/of de redactionele doelstellingen, vastgelegd krachtens artikel 2, verantwoordelijk tegenover wie haar benoemt/benoemen of ontslaat/ontslaan, als vermeld in artikel 4.1.1.

Indien de directie de hoofdredactie benoemt en ontslaat, is de hoofdredactie voor het handhaven van de uitgangspunten van het redactionele beleid en/of de beginselen en/of de redactionele doelstellingen, alsmede de daarop gebaseerde richtlijnen mede werantwoordelijk tegenover de instantie(s) van wie de goedkeuring tot de benoeming en het ontslag overeenkomstig artikel 4.1.1 moet worden verkregen.

Degene $(\mathrm{n})$ aan wie de hoofdredactie verantwoording schuldig is woor het handhaven van de uitgangspunten van het redactionele beleid en/of de beginselen en/of de redactionele doelstellingen alsmede van de daarop gebaseerde richtlijnen zal/zullen bij het vormen van een oordeel hierover zowel de hoofdredactie als de directie en de redactieraad horen.

5.1.3 Indien meer dan één hoofdredacteur is of wordt aangesteld, zal de onderlinge verhouding, een eventuele taakverdeling, waaronder desgewenst een regeling omtrent het voorzitterschap van de redactierad, bij de aanstellings- of nadere akte worden geregeld en aan de redactie worden meegedeeld.

5.1.4 In alle gevallen waarin de directie weet of kan vermoeden dat haar beslisingen ten aanzien van de algemene bedrijfsvoering rechtstreeks of zijdelings invloed van belang kunnen hebben op het redactionele beleid pleegt zij vooraf overleg met de hoofdredactie.

5.1.5 Na overleg met de hoofdredactie bepaalt de directie het aantal journalisten en de individuele arbeidsvoorwaarden van het redactionele personeel. De journalistieke werknemers worden door de directie aangesteld in overleg met en op voordracht van de hoofdredactie. Ontslag kan alleen geschieden na overleg met de hoofdredactie.

Wijzigingen in een salariëring respectievelijk honorering van de journalistieke medewerkers, de toepassing van de $\mathrm{CAO}$ voor dagbladjournalisten en de regeling van de vergoeding worden door de directie na overleg met de hoofdredactie geregeld, voor zover die niet aan laatstgenoemde door de directie zijn gedelegeerd binnen het raam van de onder 8.1 bedoelde beschikbare bedragen.

5.1.6 Beslissingen ten aanzien van de journalistieke produktie, die belangrijke invloed kunnen hebben op de bedrijfsvoering van de uitgeverij, kan de hoofdredactie slechts nemen in overleg met de directie. Indien geen andere regeling is getroffen, zal bij een meerhoofdige directie de hoofdredactie zich tot ieder van de directeuren kunnen wenden voor overleg. Bij afwezigheid van de directie voor langere duur zal an de hoofdredactie kennis zijn gegeven welke persoon of personen de directionele taak waarnemen.

Bij dagbladuitgeverijen die deel uitmaken van concernconstructies is, tenzij anders geregeld, de directie van de dagbladwerkmaatschappij als "directie" te beschouwen.

Als "raad van commissarissen" van de werkmaatschappij is, tenzij anders geregeld, te beschouwen het orgaan waaraan de directie van de werkmaatschappij directe verantwoording verschuldigd is.

5.1.7 De volgende punten zijn onderwerp van goed overleg tussen directie en hoofdredactie alvorens de directie een beslissing neemt:

a. bepaling van de omvang van de krant, de verhouding tussen redactionele en advertentieruimte en de verdeling van beide over de pagina's, in het bijzonder I.M.-ruimte op de tekstpagina's, van belang voor het "gezicht" van de krant;

b. veranderen wan de "kop" van de krant;

c. ingrijpende typografische wijzigingen van de krant;

d. opnemen of weigeren van advertenties warbij de redactionele inhoud van het dagblad is betrokken; 
e. reclamecampagnes ten behoeve van het dagblad, waarbij redactionele inhoud en/of medewerkers een rol spelen, die afwijken van de bij dat dagblad gebruikelijke campagnes;

f. wijziging van het tijdstip van "sluiten" van de tekstpaginavormen en van de verstrekking van het dagblad aan de lezers/abonnees;

g. wijziging van de indeling van het verspreidingsgebied in redactionele edities;

h. verkoop aan derden wan artikelen, berichten en foto's, vervaardigd door de redactie;

i. wijziging van de werksituatie van de redactie, zoals huisvesting, inventaris, transmissie- en communicatiemiddelen.

5.1.8 De directie laat de hoofdredactie regelmatig vertrouwelijk kennisnemen wan bescheiden die relevant zijn voor een inzicht in de exploitatie van het dagblad.

5.1.9 De hoofdredactie neemt in het bijzonder over de volgende punten geen beslissingen dan na: overleg te hebben gepleegd met de directie en de redactieraad:

a. opneming als redactionele informatie van mededelingen, die door aard en/of vorm voordien uitsluitend als advertenties in het dagblad werden gepubliceerd;

b. ingrijpende wijzigingen in de opmaak van de krant;

c. invoering van nieuwe alsmede opheffing van bestaande service-rubrieken.

5.1.10 De hoofdredactie wordt uitgenodigd tot het bijwonen van vergaderingen van commissaris sen en andere colleges van toezicht voor zover het te behandelen rechtstreeks invloed heeft op de redactionele functie van de dagbladuitgave $(n)$.

5.1.11 De hoofdredactie kan zich op eigen initiatief of zal zich, wanneer ten minste tweederde van de gekozen leden van de redactieraad in specifieke gevallen hierom verzoekt, in het overleg met de directie (uitgever) en/of de raad van commissarissen laten bijstaan door een of meer leden van de redactieraad.

\subsection{Redactievergadering}

5.2.1 Door de uitgeverij, directie of door de redactieraad voorgestelde ontwerpen voor of wijzigingen in de uitgangspunten van het redactionele beleid en/of de beginselen en/of de redactionele doelstellingen van het blad, alsmede voor de eventuele richtlijnen, worden door de redactieraad en de hoofdredactie voorgelegd aan de redactievergadering. Dergelijke ontwerpen en wijzigingen kunnen slechts worden ingevoerd na het vragen van advies aan de redactieraad overeenkomstig het in artikell 3.7 bepaalde.

5.2.2 Over besluiten van de directie of hoofdredactie betreffende wijzigingen van karakter en werschijningsvorm van de krant, wijziging van de positie van de redactie en hoofdredactie of aangaan respectievelijk wijziging van samenwerkingsverbanden, die van fundamenteel belang zijn voor de taak en functie van de redactie, wordt de redactieraad advies gevraagd overeenkomstig het artikel 3.7 bepaalde.

\subsection{Redactieraad}

5.3.1 De redactieraad is het orgatan van wederzijdse informatie en onderling beraad tussen hoofdredactie en redactie en bespreekt in die functie onder meer het algemene, politieke, maatschappelijke en levensbeschouwelijke beleid in het kader van de untgangspunten van het tedactionele beleid en/of de beginselen en/of de redactionele doelstellingen van het dagblad, de samenstelling, de in. houd en de presentatie van de krant, alsmede de in de artikelen 6.1, 7, 8.2, 9 en 10.6 genoemde onderwerpen.

5.3.2 De redactieraad kan redacteuren die geen lid zijn van de redactieraad uitmodigen op grond van hun deskundigheid om deel te nemen aan de beraadslagingen.

\subsection{Verhouding tot ondernemingsraad en redactiecommissic}

\section{Ondernemingsraad}

5.4.1 Indien een onderwerp behoort tot de bevoegdheden wan de ondernemingsraad, belet zulks niet de uitoefering van de bevoegdheden van de redactieraad zoals in dit statuut omschreven. 


\section{Redacthecommissie}

5.4.2 De redactierad treedt niet in de bevoegdheden die krachtens artikel 42 CAO behoren tot die wan de redactiecommissie.

\section{Personeelsbeleid}

6.1 Binnen het kader van het in de ondememing op grond van het overleg tussen directie en ondernemingstaad te voeren personeelsbeleid dienen de hoofdredactie en redactieraad tot overeenstem ming te komen ower de hoofdlijnen van het redactionele personeelsbeleid. Op grond daarvan voert de hoofdredactie het personeelsbeleid vit: De hoofdredactie doet geen voordracht voor de benoeming van een adjunct-hoofdredacteur of een algemeen redactiechef als bedoeld in artikel 6 van de CAO dan na de redactierad te hebben gehoord.

\section{Persoonlijke verantwoordelijkheid}

7.1 Wanner een lid van de redactie ernstige gewetensbezwaren heefit tegen een aan hem verstrekte opdracht en hij zich niet kan neerleggen bij een door de hoofdredactie ter zake genomen beslissing, kan hij zich wenden tot de redactieraad voor een uitspraak.

7.2 Wanneer de hoofdredactie krachtens haar bevoegdheid onder artikel 3.2 wijzigingen aanbrengt of doet aanbrengen in verslagen of artikelen van redacteuren, kan de betrokkene verlangen dat het stuk niet wordt ondertekend.

Als betrokkene het niet met de genomen bestissing eens is, kan hij zich achteraf wenden tot de redactieraad met het verzoek om een uitspraak. Wanneer de hoofdredactie krachtens eerder genoemde bevoegdheid besluit een verslag of artikel niet te plaatsen, kan de betrokkene zich eveneens achteraf wenden tot de redactieraad met het werzoek om een uitspraak.

Wanneer de hoofdredactie meent een conclusie van de redactieraad niet te kunnen aanvaarden, maakt zij haar standpunt gemotiveerd kenbaar aan de andere leden van de raad.

\section{Redactiebudget}

8.1 De hoofdredactie heeft de beschikking over een bepaald budget, eventueel gespecificeerd naar hoofdstukken. Dit beschikbare bedrag voor de redactionele kosten word door de directie periodiek (bij voorbeeld per kwartaal of per jaar) vastgesteld na overleg met de hoofdredactie die tot dit overleg cloor regelmatige berichtgeving vanwege de directie omtrent het verloop van die kosten gedurende de voorafgaande periode in staat zal zijn gesteld. De hoofdredactie bepaalt de besteding van dit budget binnen de haar gegeven richtlijnen en overeenkomstig de uitgangspunten, beginselen en dioelstellingen van het dagblad en is tegenover de directie verantwoordelijk voor de kostenbewaking.

8.2 De hoofdredacte pleegt met de redactieraad overleg over de hoogte en de hoofdlijnen van de verdeling over de verschillende posten van het redactiebudget, alsmede over ingrijpende wijziging in de besteding. De hoofdredactie verschaft de redactieraad hiertoe de noodzakelijke informatie.

\section{Structuurwijxigingen}

9. 1 De hoofdredactie wordt van de aanvang af betrokken bij eventuele plannen tot reorganisatie, fusie, verkoop of liquidatie van de dagbladuitgeverij of de dagbladuitgave( $n$ ), tot opneming in een. concernverband en/of verbindingen van andere aard, zoals samenwerking met andere dagbladuitgeverijen met behoud van zelfstandigheid.

9.2 Zodra de verwachting gewettigd is, dat de in artikel 9.1 bedoelde plannen tot witvoering zullen komen, stelt de directie te zelfder tijd als zij de ondememingsraad verplicht is in te lichten de redactieraad in de gelegenheid zich een oordeel hierover te vormen. De redactieraad kan zich, zo mogelijk in samenwerking met de ondernemingsraad, laten bijstaan door een, in overeenstemming met de directie c.q. uitgever vit te nodigen onathankelijke deskundige, die vertrouwelijk inzage krijgt in alle bescheiden die voor de te nemen beslissing van belang zijn. 
9.3 De hoofdredactie wordt door de directie vertrouwelijk ingelicht over een voorgenomen ingrijpende wijziging in de samenstelling in de kring der eigenaren en van de raad van commissarissen en/of andere colleges van toezicht. Zo spoedig mogelijk na de hoofdredactie wordt ook de redactieraad vertrouwelijk ingelicht.

\section{Regeling meningsverschüllen/ontslag}

10.1. Wanneer tussen een hoofdredacteur en degene(n), tegenover wie hij krachtens artikel 5.1 .2 verantwoordelijk is voor de handhaving van de uitgangspunten van het redactionele beleid en/of de beginselen en/of de redactionele doelstellingen alsmede de eventueel daarop gebaseerde richilijnen; een onoverbrugbaar verschil van mening bestaat over het redactionele beleid voor zover dat de genoemde uitgangspunten, beginselen en/of doelstellingen alsmede de eventueel daarop gebaseerde richtlijnen betreft, heeft de hoofdredacteur evenals de directie het recht gehoord te worden. De in de vorige alinea bedoelde instantie zal binnen veertien dagen nadat zij de hoofdredacteur en de directie heeft gehoord haar conclusie schriftelijk geven. Wanneer de hoofdredacteur in het ongelijk wordt gesteld, zal hij zich binnen veertien dagen na ontvangst van bedoelde conclusie emaar richten of ontslag wragen.

10.2 Indien een hoofdredacteur op grond van gebeurtenissen als bedoeld in artikel 10.1 ontslag vraagt, zullen op verzoek van de meest gerede partij de voorwaarden van het ontslag worden geregeld door een Bijzondere Ontslagkamer voor Hoofdredacteurem van de Dagbladuitgeverij als bedoeld in artikel 10.3, tenzij het daartoe bevoegde orgaan van de uitgeverij en de betrokken hoofdredactetur binnen vijf weken na het tijdstip van de mededeling van de beoordeling respectievelijk de interpretatie, definitieve overeenstemming zouden hebben bereikt over de voorwaarden van het ontslag. In de periode tussen opzegging en het einde van het dienstverband is de betrokken hoofdredacteur op non-actief gesteld met behoud wan volledige bezoldiging.

10.3 De Bijzondere Ontslagkamer voor Hoofdredacteuren van de Dagbladuitgeverij, nader te noemen "de Kamer", zal een continu college zijn, dat bestaat uit drie leden en drie plaatsvervangende leden. De Kamer oordeelt met drie personen. Van deze zes personen zullen steeds éen lid en diens plaatsvervanger zijn benoemd door het bestuur van de vereniging De Nederlandse Dagbladpers en éen lid en diens plaatsvervanger door het bestuur van de Nederlandse Vereniging van Journalisten.. Beide leden zullen na overleg met ieders plaatsvervanger het derde lid en diens vervanger benoemen; bij gebreke hiervan zal op verzoek van de meest gerede partij de president van de rechtbank van Amsterdam het derde lid en diens plaatsvervanger benoemen. De (plaatsvervangende) leden van de Kamer zullen van vorengenoemde verenigingen onafhankelijke juristen-buitenstaanders dienen te zijn. De Kamer zal naar eigen inzicht en methodiek zo spoedig mogelijk, maar in ieder geval binnen zes maanden na opzegging door de hoofdredacteur, de voorwaarden van de beëindiging van het dienstverband bij bindend advies vaststellen. De in artikel 10.1 bedoelde beoordeling respectievelijk interpretatie op zich zelf is voor de Kamer een gegeven.

$10.4 \mathrm{Bij}$ gebreke van een schriftelijke verklaring van de betrokken loofdredacteur, dat deze zich zal richten naar de beoordeling rspectievelijk de interpretatie als bedoeld in artikel 10.2 binnen de daarvoor gestelde termijn, heeft het tot een ontslag van een hoofdredacteur bevoegde orgaan van de uitgeverij, met inachtneming van de wettelijke termen ter zake, het recht het dienstverband met de in gebreke blijvende betrokkene op te zeggen, in wellk gevall de $K$ amer de voorwaarden van het ontslag van die betrokkene vaststelt bimnen zes maanden.

10.5 Wanneer tussen een hoofdredacteur en de directie een onoverbrugbaar verschil van mening ontstat (bij voorbeeld over het financiële beheer, de algemene regels binnen het bedrijf of de doelmatigheid van de redactionele leiding) dat niet te maken heeft met de uitgangspunten, beginselen en/of doelstellingen van het blad alsmede de eventueel daarop gebaseerde richtlijnen, zal, indien een dergelijk geschil leidt tot ontslag van de hoofdredacteur, eveneens de Kamer de voorwaarden regelen van het ontslag.

10.6 Bij ontslag van een hoofdredacteur is de directie verplicht voorafgaand aan de besluitvorming in de daartoe aangewezen organen overeenkomstig het in artikel 3.7 bepaalde advies in te winmen bij de redactieraad, die mede het recht tot woordracht woor ontslag heeft; een en ander onverminderd de mogelijkheid van een ontslag op staande voet. 


\section{Slotbepaling}

11.1 Wijziging van dit statuut wordt vastgesteld door de dagbladonderneming en geschiedt in overleg tussen directie, hoofdredactie en redactieraad. De redactieraad behoeft, voordat hij in deze beslissingen neemt, de instemming van de redactievergadering.

\section{Bijlage 4}

\section{Entwurf eines Gesetzes über die allgemeinen Rechtsverhältnisse der Presse}

(Uittreksel. De tekst is ontleend aan Wolfgang Hoffmann-Riem/Harro Plander: Rechtsfragen der Pressereform, pag. 195 e.v. De tekst is eveneens te vinden in Edwin Kau Die Mitbestimmung in Presseunternihmen, pag. 339 e.v.)

N.B.: Het hieronder afgedrukte ontwerp is gedateerd 25 september 1974 . Het betreft een door ambtenaren van het ministerie van binnenlandse zaken aangepaste versie van het oorspronkelijke ontwerp, gedateerd 25 juli 1974, dat in hoofdstuk 6 behandeld is. Bij de versie van 25 september 1974 ontbreekt een "Begründung" ${ }^{\mathrm{B}}$, ondat pogingen om het ontwerp geschikt te maken voor parlementaire behandeling inmiddels waren gestakkt.

\section{Abschnitt}

Aufgabenabgrenzung zwischen Verleger und Redakteuren bei Zeitungen, Zeitschriften sowie in presseredaktionellen Hilfsunternehmen.

\section{$\$ 10$ Allgemeine publizistische Haltung}

(1) Der Verleger legt düe Grundsätze für die publizistische Haltung der Zeitung oder Zeitschrift schriftlich fest. Sie sollen insbesondere die für die Zeitung oder Zeitschrift maligebenden publizistischen Ziele sowie die allgemeine publizistische Einstellung zu politischen, wirtschaftlichen, gesellschaftlichen, kulturellen und sonstigen für die Meinungsbildung wichtigen Fragen wiedergeben. Diese Grundsätze sind den Redakteuren bekanntzugeben; sie werden Bestandteil der Arbeits verhölt tnisse aller Redakteure.

(2) Die Grundsătze sind bei Zeitungen sowie bei Zeitschriften, die regelmäßig mindestens einmal monatlich erscheinen, in der ersten Ausgabe jedes Kalendervierteljahres, bei den übrigen Zeitschriften in der ersten Ausgabe jedes Kalenderjahres zu veroffentlichen.

\section{$\$ 11$ Anderwng der allgemeinen publizistischen Haltung}

(1) Der Verleger kann im Benehmen mit dem Chefredakteur die Grundsătze für die publizistische Haltung ändern. Vor einer Anderung dieser Grundsätze ist die Redakteurvertretung zu hören. Die Änderung wird, wenn kein späterer Zeitpunkt festgelegt ist, mit Ablauf von drei Monaten nach Zugang der Mitteilung an der Redakteurvertretung wirksam.

(2) Die geảnderten Grundsätze sind in der ersten Ausgabe der Zeitung oder Zeitschrift, die nach Eintritt der Wirksamkeit der Anderung erscheint, zu veröffentlichen; $\$ 10 \mathrm{Abs}$. 2 bleibt unberührt.

(3) Die geänderten Grundsätze sind den Redakteuren schriftlich bekanntzugeben. Sie werden mit ihrer Wirksamkeit Bestandteil des Arbeitsverhältnisses aller Redakteure. Ist ein Redakteur mit der 
Anderung der allgemeinen publizistischen Haltung nicht einverstanden, so kamn er, wenn sich die Anderung auf den Inhalt seines Arbeitsverhaltnisses auswirkt, innerhalb eines Monats nuch Zugang der Mitteilung nach Satz 1 aus Anlas dieser Änderung kündigen. Ist die Kündigungsfrist bis zum Wirksamwerden der Änderung noch nicht abgelaufen, so enden mit diesem Zeitpunkt die Arbeitspflicht und der Beschäftigungsanspruch des Redakteurs. Der Redakteur muB sich jedoch auf das Arbeitsentgelt anrechnen lassen, was er in dieser Zeit durch anderweitige Verwertung seiner Arbeitskraft erwirbt oder zu erwerben böswillig unterläBt.

(4) Mit dem Ablauf der Kündigungsfrist erwirbt der Redakteur einen Anspruch auf Abfindung in Höhe von drie Monatsverdiensten. (.. )

(5) Wird ein Arbeitsverhältnis, das für eine bestimmte Zeit abgeschlossen worden ist, von der Anderung der allgemeinen publizistischen Haltung betroffen, so kann der Redakteur, der mit die. ser Anderung nicht einverstanden ist, das Abeitsverhältnis aus diesem AnlaB unter Einhaltung einer Kündigungsfrist von acht Monaten zum Monatsende kuindigen. ( ........) Soweit durch die Kündigung ein Arbeitsverhältnis nach Satz 1 vorzeitig endet, erwirbt der Redakteur einen Anspruch auf eine angemessene Abfindung.

(6) Die Absälze 1 bis 5 gelten entsprechend in den Fällen, in den der Verleger die Grundsätze für die publizistische Haltung einer bestehenden Zeitung oder Zeitschrift gemä $B \& 10$ erstmals festlegt. Absatz 3 Satz 3 bis 5, Absatz 4 und 5 jedoch mit der Maßgabe, daß diese Grundsätze von der bisher feststellbaren grundsätzlichen Haltung der Zeitung oder Zeitschrift erheblich abweichen.

\section{$\S 12$ Richtlinien}

(1) Treten Fragen von grundsätzlicher Bedeutung auf, die nicht der Festlegung nach $\$ \$ 10,11$ dieses Gesetzes unterliegen, so entscheidet, sofern zwischen Verleger, Chefredakteur und Redakteurvertretung nichts anderes vereinbart ist, unter Wahrung der allgemeinen publizistischen Haltung der Zeitung oder Zeitschrift der Chefredakteur im Benehmen mit dem Verleger und den zuständigen Ressortleitern (Richtlinie). Von grundsätzlicher Bedeuting ü Sinne von Satz 1 sind Fragen, die in ihrer Tragweite erheblich über die Tagesaktualität hinausgehen.

(2) Vor der Festlegung der Richtlinie ist die Redakteurvertretung zu hören.

(3) Der Chefredakteur teilt die getroffene Richtlinie dem Verleger und der Redakteurvertretung mit.

Der Verleger hebt eine wom Chefredakteur festgelegte Richtlinie auf, wenn sie gegen die Grundsätze für die publizistische Haltung verstößt. In diesem Falle hat er seine Entscheidung unverzüglich der Redakteurvertretung bekanntzugeben.

(4) Wiederspricht die Redakteurvertretung mit der Mehrheit von zwei Dritteln ihrer Mitglieder einer getroffenen Richtlinie, so kann der von der Richtlinie betroffene Redakteur innerhalb eines Monats nach Mitteilung der Richtlinie an die Redakteurvertretung kündigen. $\$ 11$ Abs. 3 Saiz 5, Abs 4 und 5 findet Anwendung.

\section{$\$ 13$ Rechte und Pflichten des Redakteurs}

(1) Der Redakteur hat im Rahmen der allgemeinen publizistischen Haltung der Zeitung oder Zeitschrift, der nach $\$ 12$ getroffenen Richtlinien und im Rahmen der Redaktionsorganisation Freiheit bei der inhaltlichen Gestaltung seiner Beiträge im einzelnen; Einzelanweisungen des Verlegers sind insoweit unzulässig. Namentlich gezeignete Beĭträge dürfen ohne Zustimmung des Verfassers in ihrem Wesensgehalt nicht geändert werden.

(2) Kein Redakteur braucht in einer Veröffentlichung eine Meinung zu vertreten, die er mach Abwägung aller persönlichen Umstannde für unvereinbar mit seinem Gewissen hält.. Aus geiner Weigerung darf ihm kein Nachteil erwachsen. Seine Plichten aus dem Arbeitsverirag, insbesondere seine Pflicht zur Einhaltung der allgemeinen publizistischen Haltung, bleiben unberulhrt. Die Verpflichtung zu umfassender Information und die Möglichkeit der Darstellung unterschiedlicher Auffassungen im Rahmen der allgemeinen publizistischen Haltung müssen gewährleistet bleiben. (3) Ist zu besorgen, daß ein beabsichtigter Beitrag unzumutbare Folgen für die Zeitung, den Verlag oder den Verleger haben könnte, so haben der Chefredakteur und der zuständige Ressortleiter mit dem Verleger Einvernehmen über die Veröffentlichung des Beitrags herzustellen. Der Verfasser ist, wenn er der Redaktion angehört und dies möglich ist, zu hören. 
Unzumubar sind insbesondere Veroffentlichungen, die geeignet sind, den Tatbestand einer zum Schudenersatz verpllichtenden Handlung zu ertullen oder die zu voraussehbaren erheblichen wirtschathichen Nachteilen fur den Verlag oder den Verleger führen. Bei Abwägung der móglichen Nachteile ist die Aufgabe der Presse (1) 4 ) zu beachten.

NB: \& 4 Lidt: Die Presse dient insbesondere der Informationsfreiheit des Burgers, indem sie Nachrichten beschaffi oder verbreitet, Stellung nimmt, Kritik wbt oder in anderer Weise bei der Bhdug der offentlichen Meinung mitwirkt.)

\section{$\$ 14$ Berufung des Chefredakteurs}

(1) Vor der Berufung des Chefredakteurs had der Verleger die Redakteurvertretung zu hören. Widerspricht die Redakteurvertretung der Berufung, so hat sie dies dem Verleger unter Aufgabe von Gründen und der Mehrheitsverhältmisse mitzuteilen; der Verleger gibt die Auffassung der Redakteurvertretung dem in Aussicht genommenen Chefredakteur schriftlich vor Abschluß des Anstellungsvertrages bekannt.

(2) Beruft der Verleger entgegen der Entscheidung der Mehrheit won zwei Dritteln der Redakteurvertretung den Chefredakteur, so kann der Redakteur innerhalb eines Monats nach der Mitteilung der Berufung kủndigen. Ist die Kündigungsfrist bis zum Dienstantritt des Chefredakteurs noch nicht abgelaufen, so enden mit diesem Zeitpunkt die Arbeitspflicht und der Beschaftigungsanspruch des Redakteurs, \&11 Abs. 3 Satz 5, Abs. 4 und 5 gilt entsprechend.

(3) Absatz 1 und 2 finden bei der Berufung eines Mitgliedes eines Chefredakteurkollegiums entsprechende Anwendung.

\section{$\$ 15$ Abberufung des Chefredakteurs}

(1) Vor der Kündigung des Chefredakteurs durch den Verleger aus Gründen, die in der Art der Wahrnehmung der publizistischen Aufgaben und Befugnisse des Chefredakteurs liegen, ist die Redakteurvertretung zu hören.

(2) Hat die Redakteurvertretung gegen eine Kündigung Bedenken, so hat sie diese unter Angabe der Gründe dem Verleger bei einer ordentlichen Kündigung spätestens innerhalb einer Woche, bei einer auBierordentlichen Kündigung unverzïglich, spätestens innerhalb von drei Tagen, schriftlich mitzuteillen.

(3) Hat die Redakteurvertretung einer ordentlichen Kündigung frist- und ordnungsgemäß widersprochen und hat der Chefredakteur Klage auf Feststellung erhoben, daß das Arbeitsverhältnis durch die Kündigung nicht aufgelöst ist, so muB der Verleger auf Verlangen des Chefredakteurs diesen bis zum rechtskräftigen $A$ bschluB des Rechtstreits bei unveränderten Arbeitsbedingungen weiterbeschafftigen. Auf Antrag des Verlegers kann das Gericht ihn durch einstweilige Verfugung von der Verpllichtung zur Weiterbeschättigung nach Satz 1 entbinden, wenn die Verweigerung der Zustimmung durch die Redakteurvertretung offensichtlich unbegründet war oder die Weiterbeschältigung des Chefredakteurs clem Verleger nicht zugemutet werden kann. Unzumutbar ist die Weiterbeschaftigung insbesondere dann, wenn zu befürchten ist, daß durch sie die Verfolgung der maBgebenden publizistischen Zwecke der Zeitung oder Zeitschrift erustlich beeintrachtigt wilrde.

(4) Absiatz I bis 3 finden bei der Abberuftung eines Mitglieds eines Chefredakteurkolleginms entsprechende Anwendung.

\section{$\$ 16$ Personelle Veränderungen der Redaktion}

Redakteure können nur im Einvernelmen mit dern Chefredakteur und nach Anhörung der Redakteurvertietung eingestellt oder versetzt werden. Der Betroffene ist zu hören.

(2) Fur die Kundigung eines Redakteurs gilt $\$ 15$ entsprechend mit der Maßgabe, daß die auBerordent]iche Kündigung von Mitgliedern der Redakteurvertretung der Zustimmung derRedakteurvertretung bedarf. Verweigert die Redakteurvertretung ihre Zustimmung, so kann das Gericht sic auf Antrag des Verlegers ersetzen, wenn die auBerordentliche Kündigung unter 
Berüicksichtigung aller Umstände gerechtertigt ist.

(3) Die Kündigung eines Redakteurs kann nur im Benehmen mit dem Chefredakteur erfolgen.

\section{$\$ 17$ Mitwirkung beim Redaktionsetat sowie in wirtschaftlichen Angelegenheiten des Unternehmens}

(1) Der Redaktionsetat wird im Benehmen mit dem Chefredakteur und der Redakteurvertretung atu-

(2) In wirtschaftichen Angelegenheiten des Verlages, die sich auf die maBgebenden publizistischen Zwecke der Zeitung oder Zeitschrift auswirken können, ist die Redakteurvertretung rechtzeitig unter Vorlage der erforderlichen Unterlagen und unter Hinzuziehung des Betriebsrats zu hören, so* weit dadurch nicht die Betriebs- und Geschäftsgeheimnisse des Verlages gefahlurdet werden. Dabei sind die sich daraus ergebenden Auswirkungen auf die Personalplanung der Redaktion darzustellen. $\mathrm{Zu}$ den wirtschaftlichen Angelegenheiten im Sinne des Satzes l gehören insbesondere

1. wesentliche Änderungen der Eigentumsverhältrisse am Verlag;

2. die Auflagenentwicklung der Zeitung oder Zeitschrift;

3. die Verlegung, Einschränkung oder Stillegung von Redaktionseinheiten oder Redaktionsteilen;

4. die Einstellung des Erscheinens der Zeitung oder Zeitschrift oder von Teilatssgaben;

5. das geplante Zusammenwirken mit anderen Verlagen zwecks gemeinsamer Herstellung redaktioneiler Teile;

6. Rationalisierungsworhaben im redaktionellen Bereich;

(3) Die Zahl der nach Absatz 2 hinzuzuziehenden Mitglieder des Betriebsrates soll die Zahl der Mitglieder der Redlakteurvertretung nicht übersteigen.

\section{$\$ 18$ Redakteurvertretung}

(1) Bei Zeitungen oder Zeitschriften werden Redakteurvertretungen gebildet. Bei Zeitungen oder Zeitschriften mit in der Regel mehr als zehn wahlberechtigten Redakteuren besteht die Redakteurvertretung aus einem AusschuB, dem mindestens drei, höchstens sieben Redakteure angehören. Bei Zeitungen oder Zeitschriften mit bis zu zehn wahlberechtigten Redakteuren werden die Aufgaben der Redakteurvertretung durch einen Redakteursprecher walhrgenommen.

(2) Die Redakteurvertretung wird aus dem Kreis der Redakteure gewählt. Mitglieder der Chefredaktion sind nich wählbar.

(3) An den Sitzungen der Redakteurvertretung kann außerdem mit beratender Stimme ein Vertreter der Journalisten teilnehmen, die an der redaktionellen Gestaltung der Zeitung oder Zeitschrift ständig beteiligt sind, ohne in einem Arbeitsverhältnis zum Verleger zu stehen.

(4) Bei Zeitungen oder Zeitschriften mit in der Regel bis zu zehn wahlberechtigten Redakteuren nimmt in den Fällen des $\$ 12$ Abs. 4 Satz 1 und des $\$ 14$ Abs. 2 Satz $\mathbb{1 1}$ die Vollversammlung der Redakteure die Aufgaben der Redakteurvertretung wahr.

(5) Die durch die Tatigkeit der Redakteurvertretung oder der Vollversammlung dier Redakteure entstehenden notwendigen Kosten trägt der Verleger.

(6) Das năhere über die Zusammensetzung, die WahJ, die Amtszeit und die Geschäfusführung der Redakteurvertretung ( ..................... ) wird durch Landesrecht geregelt. ( .......)

\section{\$ 19 Umfang der Mitwirkungsrechte}

(1) Die in diesem Abschnitt oder aufgrund dieses Abschnitts gewährten Mitwirkungsrechte bei personellen oder betrieblichen Maßnahmen können nur zur Erfullung der Aufgaben der Presse( $\$ 4)$ und zur Wahrung der Pressefreiheit der für die Zeitung täligen Redakteure wahrgenommen werden.

(2) Eine Maß3nahme, die der Beteiligung der Redakteurvertretung mach den Vorschriften dieses Abschnitts bedarf, ist ohne die erfolgte Beteiligung unwirksam. 


\section{Verhatuis zum Betriebsverfassungsgesetz}

(1) Die nach dem Betriebswerfassungsgesetz bestehenden Rechte der Belegschaft, ihrer Organe und einzelner Arbeitnehmer werden durch die Vorschriften dieses Abschnitts nicht berilhrt.

(2) Kann im Einzelfall zweifelhaft sein, ob die Redakteurvertretung oder der Betriebsrat zur Beteiligung berulen sind, so unterrichten sich beide gegenseitig über den Gegenstand der Beteiligung und das Ergebnis ihrer Beiratungen.

\section{Gehelimhaltungspflicht}

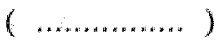

\section{\$21 Schutzbestimmungen}

Personen, die Aufgaben oder Befugnisse nach diesem Abschnitt wahrnehmen, dürfen darin nicht behindert oder wegen ihrer Tätigkeit nicht benachteiligt oder begünstigt werden; dies gilt auch für ihre berufliche Entwicklung.

\section{\$22 Redaktionsvereinbarungen (Redaktionsstatuten)}

(1) Der Verleger und die Redakteurvertretung können Vereinbarungen über den in diesem Abschnitt geregellten Gegenstancl treffen und dabei den Redakteuren über die $\$ \$ 11$ bis 21 hinausgehende Rechte eirräumen. Sie bedürfen der Schriftform. Arbeitsentgelte und sonstige Arbeitsbedingungen, die durch Tarifvertrag oder Betriebsvereinbarung geregelt sind oder üblicherweise geregelt werden, können nicht Gegenstand einer solchen Vereinbarung sein.

(2) In Vereinbarungen nach Absatz 1 soll tunlichst auch das Verfahren geregelt werden, das stattzufinden hat, wenn ein Einvernehmen unter den Beteiligten nach $\$ 13 \mathrm{Abs} 3, \& 16 \mathrm{Abs}$. 1 nicht erzielt werden kann.

(3) Die getroffenen Vereinbarungen gelten unmittelbar und zwingend. Redakteure können auf Rechte, die ihmen durch Vereinbarungen nach Abs. I eingeräumt wurden, nur mit Zustimmung der Redakteurvertretung verzichten.

(4) Vereinbarungen können, soweit nichts anderes vereinbart ist, milt einer Frist von dreil Monaten gekündigt werden.

\section{$\$ 23$ Herausgeber, Interessenkollision}

(1) Ist neben dem Verleger ein Ferausgeber (...... ) vorhanden, so hat der Verleger in den Fällen der $\$ 10,11,12, \$ 13$ Abs. $3, \$ 14$ und 15 Einvernehmen mit dem Herausgeber herzustellen.

(2) Ist der Verleger oder Herausgeber zugleich Chefredakteur, so ist ein Stellvertreter zu bestimmen, der in den Fällen des $\$ 1 \mathrm{LAbs}$. $1, \$ 13$ Abs. 3 und der $\$ \$ 16,17 \mathrm{Abs} .1$ an die Stelle des Chefredakteurs tritt.

\section{$\$ 24$ Geltung für presseredaktionelle Hilfsunternehmen}

Die Volschriften dieses Abschnitts gelten mit Ausnahme von $\$ 10$ Abs. $2, \$ 11$ Abs. 2 auch für presseredaktionelle Hilfsunternelmen. 


\section{Kurzfassung}

Ende der siebziger Jahre sind bei fast allen niederländischen Tageszeitungen Redaktionsstatuten in Kraft getreten. In solchen Vereinbarungen wird das wechselseitige Verhältnis zwischen Verleger, Chefredaktion und Redaktion in allen redaktionellen Angelegenheiten geregelt. Die Regelung dieser Verhältnisse ist deshalb wichtig, weil es dabei um das Grundrecht der Meinungsfreiheit bei Zeitungen geht, denn Zeitungen unterscheiden sich diesbezüglich wesentlich von anderen industriellen Erzeugnissen. In der Bundesrepublik Deutschland sind seit 1969 insgesamt lediglich zwölf Statuten für Tageszeitungen zustande gekommen; davon hatten 1993 nur noch sechs Bestand.

Der Unterschied zwischen der Situation in den Niederlanden und der in Deutschland erscheint um so merkwürdiger, wenn man bedenkt, daß die Statutenbewegung in Deutschland viel früher einsetzte. Sie hat ihre Wurzeln in der Diskussion über die Kompetenzabgrenzung zwischen Verlegern und Redakteuren ("innere Pressefreiheit"), die bereits 1920 begann. An dieser Diskussion haben sich seitdem nicht nur deutsche Journalisten und Verleger beteiligt, sondern vor allem Juristen und Wissenschaftler aus dem sich bildenden Fachgebiet Publizistik. In Deutschland wurde das Verhältnis Verleger Redakteure vorrangig als eine Frage der Grundrechte debattiert. In der niederländischen juristischen Literatur ist das Verhältnis zwischen Verleger und Redaktion erst seit Ende der sechziger Jahre aufgegriffen worden, und zwar fast ausschließlich aus arbeitsrechtlicher Sicht.

In der hier vorgelegten rechtsvergleichenden Arbeit wird versucht, die Frage der "inneren Pressefreiheit" im Zusammenhang mit den Grundrechten in den Niederlanden im allgemeinen und dem Grundrecht der Meinungsfreiheit im besonderen zu behandeln. Im ersten Kapitel werden diesbeziglich die folgenden Fragen aufgeworfen, auf die das Schlußkapitel der Untersuchung eine Antwort gibt:

-. Ist eine generelle Regelung der Redaktionsstatuten grundrechtlich statthaft, bei der Richtlinien für ein Statut - z.B. durch Gesetz oder durch Tarifvertrag vorgegeben werden?

- Wie ist eine Regelung des Verhältnisses zwischen Verleger, Chefredaktion und Redaktion mit dem Grundrecht der Meinungsfreiheit zu vereinbaren?

- Inwiefern ist das Verhältnis des Verlegers zur Identität der Zeitung, z.B. in der Frage, ob er seine Grundrechtskompetenz tatsächlich ausübt, wichtig zur Beurteilung seiner Position als Träger eines Grundrechts?

- Welche Konsequenzen soll die Beurteilung des tatsächlichen Verhaltens des Verlegers für den Fall haben, daß er sein Verfügungsrecht in für die Redaktion wichtigen Entscheidungen einfordert? 
- Ist eine ausschließliche Verantwortlichkeit des Chefredakteurs für den redaktionellen Inhalt der Zeitung auf die Dauer glaubhaft ohne seine Bereitschaft. auch die zivilrechtliche Haftung zu übernehmen?

Gegenstand der Kapitel 2 und 3 sind die Tagespresse in den Niederlanden und in Deutschland zwischen den beiden Weltkriegen sowie die damaligen Versuche in beiden Staaten, die Position der Redaktion gegenüber dem Verleger zu verstärken. In Kapitel 2 steht ein Untersuchungsbericht aus dem Jahre 1924 über redaktionelle Mitbestimmung im Mittelpunkt ("Rapport der Commissie voor de Medezeggenschap"). Teil des Berichts ist eine theoretische Diskussion der kulturellen und kommerziellen Aspekte einer Zeitung. Bezüglich der Mitbestimmung der Redakteure wird ausführlich aus bestehenden deutschen und österreichischen Regelungen und Tarifvertragsentwürfen zitiert. Der Bericht schließt mit dem Entwurf eines ersten Tarifvertrags für Journalisten bei Tageszeitungen. Er fand jedoch kaum Widerhall, denn nachdem die Verleger die Arbeitsbedingungen der Journalisten verbessert hatten, hatten diese an Mitbestimmung kein Interesse mehr.

Eine ähnliche Entwicklung war in Deutschland zu verzeichnen. Auch hier bevorzugten die Redakteure schließlich die Verbesserung ihrer - sehr schlechten Arbeitsbedingungen und ihrer sozialen Absicherungen. Als wirksames Druckmittel erwies sich, daß ihre berufsständische Organisation, der "Reichsverband der deutschen Presse" (RDP), oft gemeinsam mit dem Reichsministerium des Innern, mehrere Entwürfe für Tarifverträge und Journalistengesetze ausarbeitete, die alle einen Schritt vorwärts auf dem Weg zur Anerkennung einer "inneren Pressefreiheit" bedeuteten. Die Verleger betrachteten dies jedoch als "geistige Expropriierung", In Kapitel 3 wird vor allem die besondere Bedeutung des Artikels 118 der Weimarer Reichsverfassung und des damals entstandenen Gedankens einer "öffentlichen Aufgabe der Presse" für das deutsche Presserecht beschrieben.

Kapitel 4 behandelt die Bestrebungen der organisierten niederländischen Journalistik, einen ersten Tarifvertrag mit dem Verband der Zeitungsverleger abzuschließen (1948) und "Modelle" für Redaktionsstatuten zu entwickeln. Ein erstes Modell arbeitete 1972 das Verhältnis Chefredaktion - Verleger heraus. Später (1976) kam ein "Modellstatut für Chefredaktion und Redaktion" zustande. Dieses "Modellstatut" fand 1976 Aufnahme in einem Artikel des Tarifvertrags. Dort verpflichteten sich alle Zeitungsunternehmen, ab 1.1.1977 für Zeitungen mit mehr als 15 Journalisten ein Statut abzuschließen, das die Kompetenzabgrenzung zwischen Verleger, Chefredaktion und Redaktion regeln sollte. Während der Abschlußverhandlungen über das "Modellstatut" war der Journalistenverband zu Konzessionen prinzipieller Art bereit, die dazu führten, daß im Endergebnis der Grundrechtsaspekt kaum noch zurückzufinden war. Ein früherer Entwurf des Modellstatuts und das Statut für die Chefredaktion 
schlossen eine Rolle für den Betriebsrat in redaktionellen Angelegenheiten ausdrücklich aus. Im endgültigen Modell ist der Betriebsrat das höchste Mitbestimmungsorgan, auch in redaktionellen Angelegenheiten.

Das fünfte Kapitel besteht aus einer artikelweisen Darstellung des Modellstatuts. Es wird Artikel für Artikel sowohl mit dem Statut für die Chefredaktion als auch mit dem Statutentwurf, den der Journalistenverband in die Verhandlungen mit dem Verlegerverband eingebracht hatte, sowie mit einer vom Journalistenverband veröffentlichten Erläuterung zum Modellstatut verglichen.

In Kapitel 6 wird die Entwicklung in der Bundesrepublik Deutschland seit Kriegende bis zum Scheitern des Entwurfs für ein Presserechtsrahmengesetz (EPRG) 1974 beschrieben. Wichtigste Themen sind dabei:

- die Diskussion um die institutionelle oder die individualrechtliche Natur der Pressefreiheit,

- die Bedeutung der "öffentlichen Aufgabe der Presse" für die Kompetenzabgrenzung zwischen Verleger und Redakteuren, und

- die Einschränkung der Mitbestimmung aufgrund von $\$ 118$ des Betriebsverfassungsgesetzes (Tendenzschutz).

Aus der Darstellung wird deutlich, weshalb die Statutenbewegung in der Bundesrepublik keinen Erfolg haben konnte.

Der Verfasser meint, daß bestimmte Ideen und Vorschläge aus den Arbeiten des Hamburger Medienjuristen Wolfgang Hoffmann-Riem auch für die niederländische Diskussion über redaktionelle Mitbestimmung brauchbar sind.

Das Kapitel schließ3t mit der Beschreibung der sechs noch bestehenden Redaktionsstatuten bei deutschen Tageszeitungen und mit der Erörterung der wichtigsten Paragraphen des EPRG.

Im siebten Kapitel werden die Redaktionsstatuten, die von niederländischen Tageszeitungen dem Verfasser zur Verfügung gestellt wurden, beschrieben und kommentiert.

Im achten und letzten Kapitel wird versucht, die niederländische Diskussion über das Verhältnis Verleger - Chefredaktion - Redaktion von den dominierenden arbeitsrechtlichen Gesichtspunkten zu lösen und in Richtung des Grundrechts der Meinungsfreiheit und der zugehörigen Jurisprudenz zu lenken. Zu diesem Zweck wird vorgeschlagen, für jede Zeitung zunächst zu untersuchen, ob der Verleger sich vorrangig als Herausgeber oder als Unternehmer betätigt. In letzterem Fall sollten Entscheidungen, die für die Redaktion schwerwiegenden Folgen haben, nur im Einvernehmen mit den redaktionellen Organen getroffen werden. Zum Schluß enthält das Kapitel ein Plädoyer für eine freiwillige zivilrechtliche Haftung der Chefredaktion bei denjenigen Zeitungen, bei denen der Verleger kaum auf die Identităt der Zeitung Einfluß nimmt. 


\section{Lijst van geraadpleegde literatuur}

Akkermans-Koekkoek (red.) De Grondwet, 2de druk, Zwolle (1992); Hubert Armbruster u.a. (Herausg.) Pressefreiheit. Entwurf eines Gesetzes zum Schutze freier Meinungsbildung und Dokumentation des Arbeitskreises Pressefreiheit Neuwied (1970);

idem Pressefreiheit. (II) Entwurf eines Gesetzes zum Schutze freier Meinungsbildung Tübingen (1972);

Asser - Hartkamp III Verbintenissenrecht - De verbintenis uit de wet Zwolle (1990);

Asser - Rutten Verbintenissenrecht - Tweede stuk: De overeenkomst en de verbintenis uit de wet Zwolle (1974);

P.C. Aubel Persoon en pers: over onrechtmatige aantasting van persoonsbelangen door perspublicaties Deventer (1968);

Joop Bartman De Kring: hoe eindelijk vakbelangen het wonnen van een autoritje in: De Journalist van 1 februari 1984 (herdenkingsnummer);

J.M. Bik Het Duitse schaduwkabinet in: NRC Handelsblad van 28 maart 1992;

Albert Bleckmann Allgemeine Grundrechtslehre Köln-Berlin-Bonn u. München (1979);

J. Boesjes De horizontale werking van grondrechten NJB 1973, pag. 905 e.v.

Erik Boogerman Een gezaghebbende krant met twee gezichten in: NRC Handelsblad van 7 januari 1991;

P.J. Boon Zonder voorafgaand verlof. De vrijheid van meningsuiting in het Nederlandse recht Nijmegen(1988);

H.J.M. Boukema Recht voor journalisten Zwolle (1984);

idem: Congresbundel Media en maatschappelijke verantwoordelijkheid (VU 1980);

P.J. Boukema Enkele aspecten van de vrijheid van meningsuiting in de Duitse Bondsrepubliek en in Nederland Amsterdam (1966);

id. Preadvies naar aanleiding van de Staatscie. Cals-Donner Geschriften van de VAR (1972);

Werner Breede Pressefreiheit und Redaktionsfreiheit im Fadenkreuz der streitbaren Demokratie (Verlag Volker Spiess) (1982);

Udo Branahl/Wolfgang Hoffmann-Riem Redaktionsstatute in der Bewährung Baden-Baden (1975);

Karl Bringmann Die Presse und ihr Recht - Reformentwiurfe als Dokument und Selbstzeugnis (1924-1933) in: Festschrift für Karl Betz Düsseldorf (1963);

R.E.M. van den Brink Informatie over informatie Leiden (1987);

Gerd Bucerius Die Freiheit des Journalisten in: Der Volkswirt van 4 juli 1969; 
M.A.B. Chao-Duivis Vergelding als schadevergoeding. Enkele opmerkingen over de nakoming van de verbintenis uit delict in: NJB van 7 april 1990;

Centrum voor christen-journalisten De media als handelswaar .... en hwn identiteit (brochure) 1989;

Dr. N. Cramer 75 jaar in het niewws: 1884 - 1959 (NJK - Amsterdam) (1959);

J.J. van Cuilenburg, K. Leeuw, G.W. te Pas, J.H.J. van den Heuvel, E.C.M. Jurgens De redactionele zelfstandigheid van dagbladen (Bedrijfsfonds voor de pers) (1990);

J.J. van Cuilenburg, J. Kleinnijenhuis, A. de Ridder Concentratie en persklimaat Amsterdam (1988);

D. Czajka Pressefreiheit und "öffentiche Aufgabe der Presse" (Stuttgart) (1968); M. van Delft-Baas en M. van Driel Reclame in F.W. Grosheide (red.) Hoofdstukken mediarecht Alphen aan den Rijn (1991);

Deutscher Journalisten Verband (DJV) Journalistengesetze und Pressegesetze die Entwürfe von 1924 bis 1954 - Eine Dokumentation (1969);

$\mathrm{E}$. Diemer en P. Mout Bescherming van het individu ten opzichte van de communicatiemedia. Preadviezen NJV; Handelingen NJV 1978 Zwolle (1978);

Karl Doehring Staatsrecht der Bundesrepublik Deutschland, 2. Aufl. (1980)

Wolfgang Donsbach Legitimationsprobleme des Journalismus FreiburgMünchen (1982);

Helmut Egloff Arbeits- und Berufsorganisation im deutschen Zeitungsgewerbe Berlin (1927);

Ernst Forsthoff Tagespresse und Grundgesetz in: Jürgen Wilke (Herausg.) Pressefreiheit Darmstadt (1984);

Klaus-Detlev Funke Innere Pressefreiheit - Zu Problemen der Organisation von Journalisten Pullach bei München (1972);

Peter Glotz/Klaus Faber Richtlinien und Grenzen des Grundgesetzes fur das Bildungswesen in: Benda-Maihofer-Vogel Handbuch des Verfassungsrechts der Bundesrepublik Deutschland Berlin-New York (1983);

F. de Graaf en M. de Haas Horizontale werking van grondrechten, een heilloos leerstuk NJB 1984, pag. 1353 e.v.

Meo-Michaela Hahne Das Drittwirkungsproblem in der europäischen Konvention zum Schutz der Menschenrechte und Grundfreiheiten (diss.) Heidelberg (1973);

D. Hazewinkel-Suringa (bew. Remmelink) Inleiding tot de studie van het Nederlandse strafrecht Alphen aan den Rijn (1983);

HBO-Raad Actuele en toekomstige journalistieke arbeidsmarkt (1992);

Joan Hemels De krant in bedrijf: 75 jaar samenwerking en samenleving Baarn (1983); 
Joan Hemels De emancipatie van een dagblad - Geschiedenis van De Volkskrant Baarn (1981);

A.W. Heringa-T. Zwart De Nederlandse grondwet Zwolle (1991)

A.W. Heringa - R. de Winter Plakwerordening Dordrecht - een reactie in: Ars Aequi 30 (1981);

idem: De kleefkracht van de vrijheid van meningsuiting in: NJB 57 (1982) nr. 12 ;

J.H.J. van den Heuvel De vrijheid van de pers. De overheid en het commerciële karakter van de pers 1944 - 1949 Baarn (1981);

J. van der Hoeven, P.J. Boukema, M.C. Burkens advies TK 1989/1990 - 20 984, nir. 6

Wolfgang Hoffmann-Riem Massenmedien in: Benda-Maihofer-Vogel Handbuch des Verfassungsrechts der Bundesrepublik Deutschland. 6. Abschnitt Berlin-New York (1983);

idem: Innere Pressefreiheit als politische Aufgabe. Über die Bedingungen und Möglichkeiten arbeitsteiliger Aufgabenwahrnehmung in der Presse NeuwiedDarmstadt (1979);

idem (met Harro Plander): Rechtsfragen der Pressereform Baden-Baden (1977); H.J.A. Hofland Uit de memoires van een journalist in: NRC Handelsblad van 24 juni 1989 ;

Christina Holtz-Bacha Mitspracherechte für Journalisten-Redaktionsstatuten in Presse und Rundfunk Köln (1986);

idem: Tendenz lustlos - Flaute in der Statutenbewegung in: Der Journalist 9/1989;

idem: Goodwill des Verlegers in: Der Journalist 10/1986;

Jaarverslag NVJ 1977;

Jaarverslag NVJ 1978;

Jaarverslag NVJ 1979;

Walter Jänecke Verleger - Redakteur - Die Rechtslage und die Wirklichkeit in: Festschrift für Anton Betz Dủsseldorf (1963);

Jubileumboek Fries Dagblad Leeuwarden (1979);

E.C.M. Jurgens Een journalistiek verschoningsrecht in: Mediaforum 1991-2; idem: Nogmaals: journalistiek "verschoningsrecht" in: Mediaforum 1991-11/12; E.C.M. Jurgens en N. van Lingen Omreprecht en auteursrecht. Nieuwe ontwikkelingen in informatie- en communicatierecht Zwolle (1986);

J.J.C. Kabel Reclameverbod - Methode en Motieven in NJB (30);

idem: Uitingsvrijheid en absolute beperkingen op handelsreclame Deventer 1981);

Edwin Kau Die Mitbestimmung in Presseunternehmen Hamburg (1980);

F.H. Kistenkas Vrije straatcommunicatie Arnhem-Deventer (1989);

Horst Peter Klein Die öffentliche Aufgabe der Presse - Eine verfassungsrechtli- 
che und rechtspolitische Untersuchung der Presse in der Demokratie Düsseldorf (1973);

Wolfram Klein Der Tendenzschutz von Presseunternehnen und die Reform ihrer Binnenstruktur durch Redaktionsstatute (diss.) Göttingen (1976);

A.K. Koekkoek Partijleiders en kabinetsformatie (diss.) Deventer (1978);

A.K. Koekkoek-Willem Konijnenbelt-F.C.L.M. Crijns (red.) Grondrechten (Jeukensbundel) Nijmegen (1982)

Danielle Kool Het programmastatuut - noodzaak of formaliteit? Afstudeerscriptie AJV-Tilburg (1992);

C.A.J.M. Kortmann Constitutioneel recht Deventer (1990)

Edgar Kull Mäzen oder Publizist? Zur Rolle und Rechtsstellung des Herausgebers in: Die Öffentliche Verwaltung (DÖV), (1972);

idem Redaktionsstatut und Pressefreiheit in: Archiv für Presserecht (AfP) (1970);

idem Medien in Verfassungsrahmen in: Kurt Koszyk und Volker Schulze (Herausg.) Festschrift für Karl Bringmann Düsseldorf (1982);

Martin Löffler und Reinart Ricker Handbuch des Presserechts 2. Auflage München (1986);

Martin Löffler Presserecht Band I, 2. Auflage München (1969);

Walter Mallmann Pressefreiheit und Journalistenrecht in: Otto Wilfert (Herausg.) Es geht nicht nur um Springer - Material und Meinungen zur inneren Pressefreiheit Mainz (1968);

idem Diskussionsbeitrag Verhandlungen des 49. Deutschen Juristentages Empfiehlt es sich zum Schutz der Pressefreiheit gesetzliche Vorschriften über die innere Ordnung von Presseunternehmen zu erlassen? (1972)

von Mangold-Klein-Starck Das Bonner Grundgesetz Band 1, 3. Auflage München (1985);

A.G. Maris en J.M. Polak Preadviezen NJV (1969)

Marie Matthies Journalisten in eigener Sache - Zur Geschichte des Reichsverbandes der deutschen Presse Berlin (1969);

Maunz-Dürig-Herzog-Scholz Grundgesetz, Kommentar 5. Auflage, München (1978);

Theo Mayer-Maly Das Redaktionsstatut als Mitbestimmungsinstrument in AfP (Archiv für Presserecht) (1971);

L. Metzemaekers Wat is dat, die "identiteit"? in: De Journalist 15 september 1972 ;

D.H.M. Meuwissen De Europese Conventie en het Nederlandse recht Leiden (1968);

id.: Minderheidsnota II in: Staatscie. Cals-Donner, tweede rapport (1969);

id.: Grondrechten Utrecht-Antwerpen (1984);

J.M. de Meij Uitingsvrijheid - De vrije informatiestroom in grondrechtelijk perspectief Amsterdam (1989); 
J.M. de Meij De vrijheid en de verantwoordelijkheid wan de pers Utrecht (1975); idem Overheid en uitingsvrijheid Wetenschapp. Raad voor het Regeringsbeleid Den Haag (1982);

idemToch een persfusieregeling? in: Informatierecht/AMI oktober 1990;

idem De nieuwe media en artikel 7 van de grondwet in: Informatierecht/AMI november 1985 ;

idem Persfusies en persvrijhetd in: NJB (afl. 6) 11 februari 1989;

G.J.H.M. Mom en P.J. Keuchenius (red.) Het werkgeversauteursrecht - kan de werkgever het maken? Deventer (1992);

Aernout J. Nieuwenhuis Perswrijheid en persbeleid Amsterdam (1991);

Kurt Nuspriger Pressefreiheit und Pressevielfalt (diss. Bern) CH-8253 Diessenhofen (1980);

Reinhold Oertel Das Verhältnis Verleger - Redakteur im Hinblick auf die Sicherung der "inneren Pressefreiheit" diss. Würzburg (1971);

F.T. Oldenhuis Onrechtmatige daad: aansprakelijkheid voor personen Deventer (1984);

Guus Pikkemaat Aangaande het redactiestatuut in: Massacommunicatie 1978/6;

M.J. Plemp van Duiveland Joumalistiek in Nederland Den Haag (1924);

Martijn Polak Het recht van plakken in: Ars Aequi 32 (1983) 1;

C.W. van der Pot - A.M. Donner Handboek van het Nederlandse staatsrecht Zwolle (1972), (1977), (1983); id. bew. door Prakke (1989);

Hanns-Paul Prümm Pressefreiheit und Verlegerfreiheit in: Hans Popper/Erich Wolny (Herausg.) Beiträge zum Medienrecht Wien/New York (1979);

Rapport der Commissie voor de Medezeggenschap (Commissie-Van Blom) Ned. Journalistenkring (1924);

Rapport van de Werkgroep Redactionele Medezeggenschap, Instituut voor Perswetenschap Universiteit van Amsterdam (twee delen) Amsterdam (1975);

Rapport van de Studiecommissie Dagbladconcentraties, NVJ (1970);

Bernd Rebe Die Träger der Pressefreiheit nach dem Grundgesetz (diss.) Berlin (1969);

Manfred Rehbinder Die offentliche Aufgabe und rechtliche Verantwortlichkeit der Presse Berlin (1962);

id. Presserecht Herne/Berlin (1966);

Hans J. Reinowski Innere Pressefreiheit - ein Grundrecht für Verleger und Redakteure Darmstadt (1968);

Rolf Richter Kommunikationsfreiheit $=$ Verlegerfreiheit? Zur Kommunikationspolitik der Zeitungsverleger in der Bundesrepublik Deutschland 1945 - 1969 Pullach bei München (1973);

Helmut K.J. Ridder Meinungsfreiheit in: Bettermann/Neumann/Nipperdey Die Grundrechte (Band II) Berlin (1968); 
L.J. Rogier De Nederlandse pers van gisteren en heden Nijmegen-Utrecht (1954);

Franz Ronneberger; bespreking van Christina Holtz-Bacha Mitspracherechte fur Journalisten in: Publizistik Heft 3 (1987);

M. Rooij Het dagbladbedrijf in Nederland - Een economisch-sociaal beeld Leiden (1956);

id. Kranten - Dagbladpers en maatschappij Amsterdam (1974);

A.B. van Rijn De functie van de vrijheid van meningsuiting in beide Duitse staten Zwolle (1985);

H.J. Scheffer Henry Tindal - Een ongewoon heer met ongewone besognes Bussum (1976);

idem De Dagbladonderneming - Historische verkenningen Den Haag (1985);

Maarten Schneider i.s.m. Joan Hemels De Nederlandse krant 1618 - 1978: van 'nieuwstydinghe' tot dagblad Baarn (1979);

F. Schneider Presse- und Meinungsfreiheit nach dem Grundgesetz München (1962);

G.A.I. Schuijt Werkers van het woord - Media en arbeidsverhoudingen in de joumalistiek Deventer (1987);

idem Redactiestatuut: instrument voor journalistieke onafhankelijkheid in: J.P.M. van Beek (red.) Is de klant of de krant koning? Amsterdam (1990);

idem De Januskop van de NVJ houdt ons overeind in: De Journalist van 2 februari 1984;

idem Overheid en media: de klaagzang van Van Vollenhoven in: Informatierecht/AMI januari 1991

idem Onrechtmatige publicaties naar Nieuw BW in: Informatierecht/AMI januari 1992;

Ansgar Skriver Schreiben und schreiben lassen. Innere Pressefreiheit Redaktionsstatute Karlsruhe (1970);

Max Snijders Het redactiestatuut - Geschiedenis en bedoelingen in: J.P.M. van Beek (red.) Is de klant of de krant koning? Amsterdam (1990);

Kees Spaan De praktijk van alle dag in: J.P.M. van Beek (red.) Is de klant of de krant koning? Amsterdam (1990)

Rudolf Stöber Kontroversen um ein Journalistengesetz in: Publizistik Heft 3 (1990);

Connie Strauch Götterdämmerung in: Der Journalist sept. 1988;

Theo van Tienen De dagbladjournalist en artikel 7 Auteurswet in: Ars Aequi XXV (1976) 2;

R.A. Torringa De rechtspersoon als dader - strafbaar leidinggeven aan rechtspersonen Arnhem (1984);

M.J.P. Verburg Massamedia en persoonsbescherming in: NJB van 3 juni 1978; L. van Vollenhoven Overheid en media (inaug. rede) Amsterdam (1990); 
L. van Vollenhoven Omroep en pers in: F.W. Grosheid (red.) Hoofdstukken mediarecht Alphen aan den Rijn (1991);

idem Versterkt het statuut de uitgeverij of krant? in: J.P.M. van Beek (red.) Is de klant of de krant koning? Amsterdam (1990);

Werner Weber Innere Pressefreiheit als Verfassungsproblem Berlin (1973);

Susanne Welzel Redaktionsstatuten. Zum Problem der inneren Pressefreiheit in der Bundesrepublik Deutschland (manuseript) München (1972);

Wiardi Beckman Stichting De vrijheid van drukpers - Het recht op antwoord (1956);

Reiner de Winter De heersende leer - 100 jaar verspreidingsjurisprudentie 1892 1992 Den Haag (1993);

G.J.M. van Wissen Grondrechten Zwolle (1992)

Robert Zaal Commissariaat moet statuten inhoudelijk toetsen in: De Journalist van 12 februari 1993 ;

Annejet van Zijl Hoofdredacteur in Nederland doctoraalscriptie UvA (1987). 


\section{Curriculum vitae van de auteur}

Wim Teeuwen werd geboren op 10 oktober 1938 in Budel. Na het behalen van het gymnasium- (alpha)-diploma aan het Bisschoppelijk College te Weert in 1958 werkte hij enige jaren in het bedrijfsleven.

In 1962 trad hij als leerling-journalist in dienst van de Nieuwe Eindhovense Krant (Oost-Brabant). Tot 1.981 was hij, met onderbrekingen voor onder andere een verblijf van een jaar in Australië, verslaggever en redacteur bij het Eindhovens Dagblad-Helmonds Dagblad en Brabant Pers.

Tussen 1972 en 1981 combineerde hij zijn journalistieke werk met een rechtenstudie aan de Katholieke Hogeschool Tilburg, thans Katholieke Universiteit Brabant. In 1981 legde hij zijn doctoraalexamen (vrije studierichting Staatsrecht) af, met als afstudeerscripties "Het redactiestatuut en artikel 7 Grondwet" en "Constitutionele crisis van 1975 in Australië".

Sinds 1981 is hij werkzaam als docent journalistieke technieken en recht aan de Academie voor Journalistiek en Voorlichting in Tilburg. 